Prepared in cooperation with the Wyoming State Engineer's Office

Geologic and Hydrogeologic Characteristics of the White River Formation, Lance Formation, and Fox Hills Sandstone, Northern Greater Denver Basin, Southeastern Laramie County, Wyoming

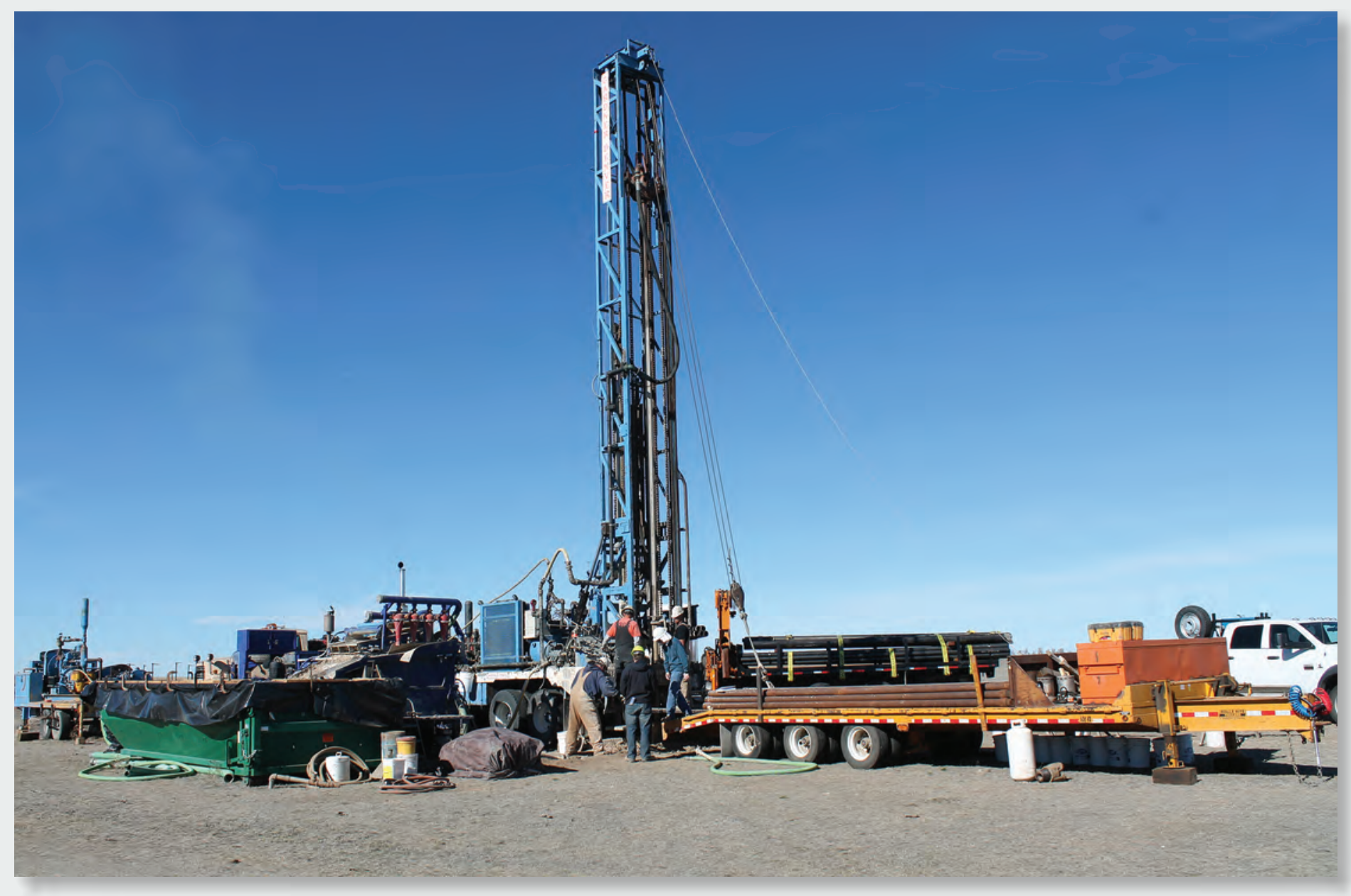

Scientific Investigations Report 2021-5020 
Cover. Photograph showing drilling and coring of exploratory borehole LC-F1, taken on November 6, 2012, by Laura Hallberg, U.S. Geological Survey. 


\section{Geologic and Hydrogeologic Characteristics of the White River Formation, Lance Formation, and Fox Hills Sandstone, Northern Greater Denver Basin, Southeastern Laramie County, Wyoming}

By Timothy T. Bartos, Devin L. Galloway, Laura L. Hallberg, Marieke Dechesne, Sharon F. Diehl, and Seth L. Davidson

Prepared in cooperation with the Wyoming State Engineer's Office

Scientific Investigations Report 2021-5020 


\section{U.S. Geological Survey, Reston, Virginia: 2021}

For more information on the USGS — the Federal source for science about the Earth, its natural and living resources, natural hazards, and the environment-visit https://www.usgs.gov or call 1-888-ASK-USGS.

For an overview of USGS information products, including maps, imagery, and publications, visit https://store.usgs.gov.

Any use of trade, firm, or product names is for descriptive purposes only and does not imply endorsement by the U.S. Government.

Although this information product, for the most part, is in the public domain, it also may contain copyrighted materials as noted in the text. Permission to reproduce copyrighted items must be secured from the copyright owner.

Suggested citation:

Bartos, T.T., Galloway, D.L., Hallberg, L.L., Dechesne, M., Diehl, S.F., and Davidson, S.L., 2021, Geologic and hydrogeologic characteristics of the White River Formation, Lance Formation, and Fox Hills Sandstone, northern greater Denver Basin, southeastern Laramie County, Wyoming: U.S. Geological Survey Scientific Investigations Report 2021-5020, 219 p., 1 pl., https://doi.org/10.3133/sir20215020.

Associated data for this publication:

Galloway, D.L., and Bartos, T.T., 2021, Atmospheric-loading frequency response functions and groundwater levels filtered for the effects of atmospheric loading and solid Earth tides for three USGS monitoring wells, southeastern Laramie County, Wyoming, 2014-2017: U.S. Geological Survey data release, https://doi.org/10.5066/P9PPLA74.

U.S. Geological Survey, 2019, USGS groundwater data for Wyoming, in USGS water data for the Nation: U.S. Geological Survey National Water Information System database, https://doi.org/10.5066/F7P55KJN.

ISSN 2328-0328 (online) 


\section{Acknowledgments}

The authors are grateful to all the people who supported this study and assisted with preparation of the report. Pat Tyrell and Lisa Lindemann of the Wyoming State Engineer's Office generously and enthusiastically supported this study. George Moser (Wyoming State Engineer's Office) assisted with site access and provided useful study assistance. Emmett Evanoff (University of Northern Colorado) shared his extensive knowledge of the White River Formation. Brent Breithaupt (Bureau of Land Management), Robert Hunt (University of Nebraska-Lincoln), Kent Sundell (Casper College), Jason Lillegraven (University of Wyoming), and Laura Vietti (University of Wyoming) assisted with the identification of a fossil jawbone recovered from collected core.

Numerous current and former U.S. Geological Survey colleagues assisted with various aspects of this study. Cheryl Eddy-Miller and Scott Edmiston installed the instrumentation used to continuously measure groundwater levels in three monitoring wells installed for this study. Cheryl Eddy-Miller, Greg Boughton, Peter Wright, and Scott Edmiston assisted with groundwater-quality sampling. Greg Stanton and Jonathan Thomas completed the borehole geophysical surveys. Colleague reviews of the full report by Janet Carter and Kent Becher and of parts of the report section "Response of Groundwater Levels to Atmospheric Loading and Earth Tides" by Fred Day-Lewis and Paul Hsieh improved the quality of the report. Suzanne Roberts created the illustrations. 



\section{Contents}

Acknowledgments ……...................................................................................................................

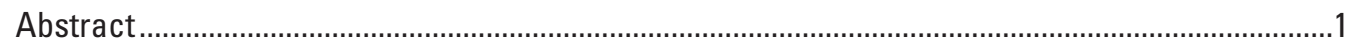

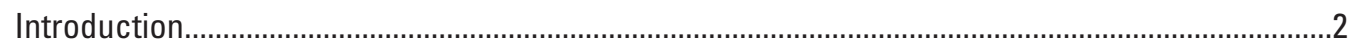

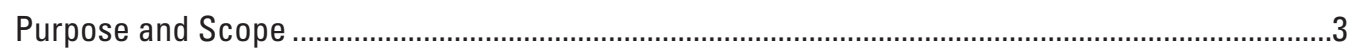

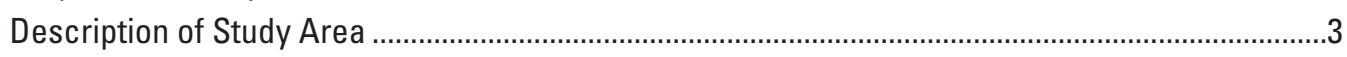

Geographic and Physiographic Setting ........................................................................

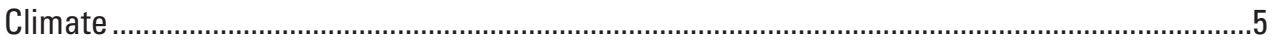

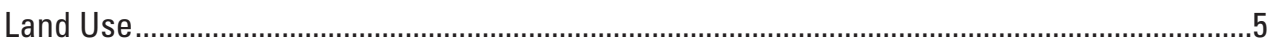

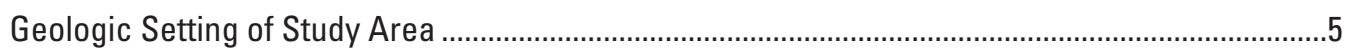

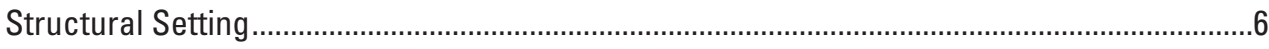

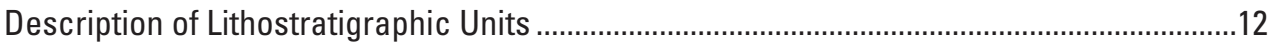

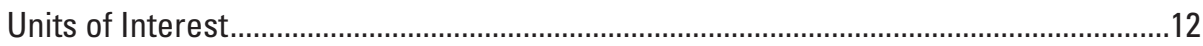

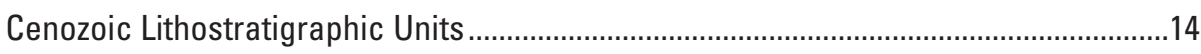

Quaternary Unconsolidated Deposits ...............................................................16

Ogallala Formation..............................................................................................

Arikaree Formation ...............................................................................................

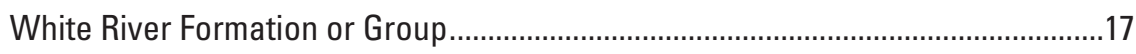

Upper Cretaceous Lithostratigraphic Units...............................................................18

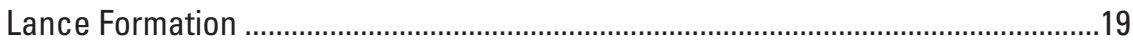

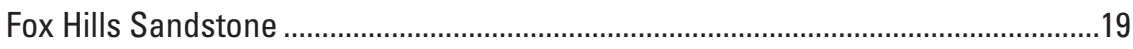

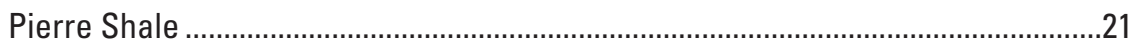

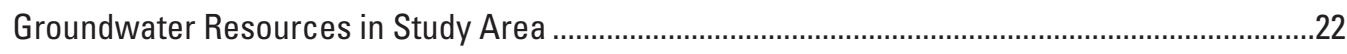

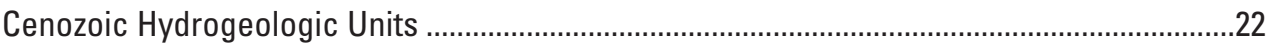

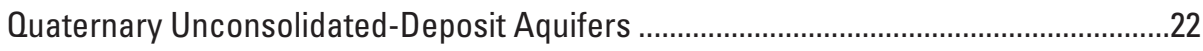

Ogallala and Arikaree Aquifers ..................................................................................23

White River Hydrogeologic Unit..............................................................................25

Relation of Cenozoic Hydrogeologic Units in Pine Bluffs Lowland to High Plains

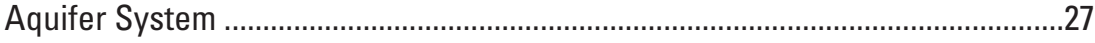

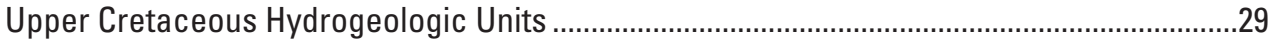

Lance Hydrogeologic Unit.....................................................................................29

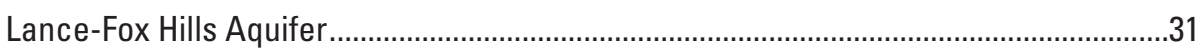

Upper Cretaceous Confining Units, Including Pierre Confining Unit ..............................32

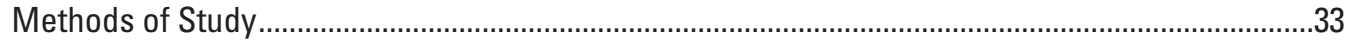

Drilling, Coring, and Monitoring Well Installation ..............................................................33

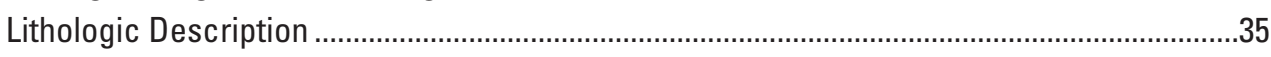

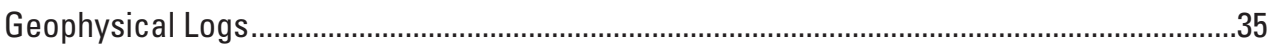

Collection, Processing, and Storage of Groundwater-Level Measurements...........................37

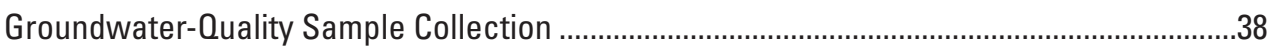

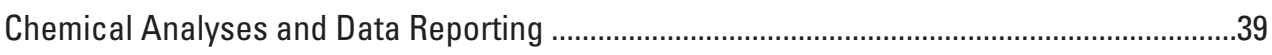

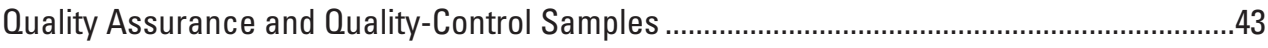

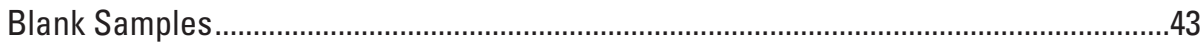

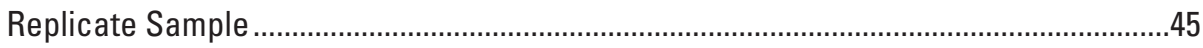

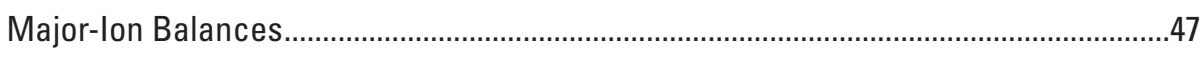


Guidelines and Regulatory Standards Used to Evaluate Groundwater Quality in Relation to Potential Uses

Geologic Characteristics of Study Site Strata .................................................................................

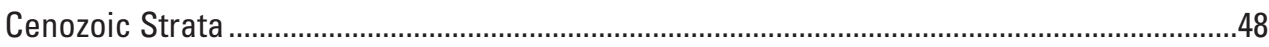

Quaternary Older Alluvial Fan Deposits ........................................................................48

White River Formation ..............................................................................................52

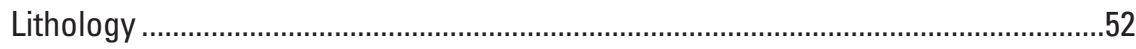

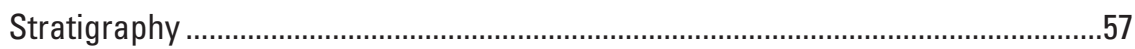

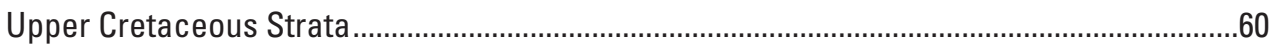

Identification of Upper Cretaceous Lithostratigraphic Units in the Subsurface.............60

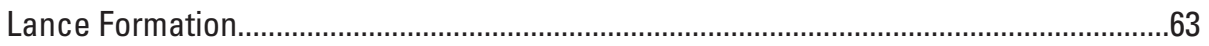

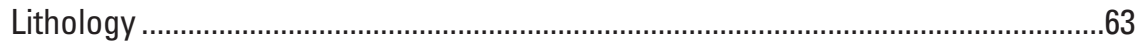

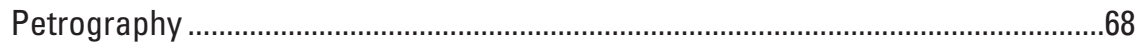

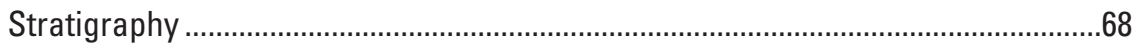

Fox Hills Sandstone and Upper Transition Member of the Pierre Shale .........................73

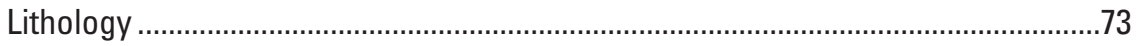

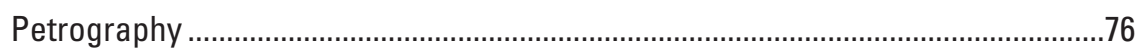

Occurrence in Laramie County Subsurface ................................................................84

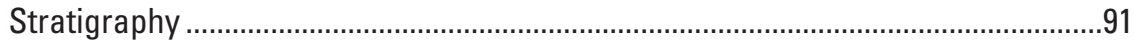

Hydrogeologic Characteristics of Study Site Strata ................................................................

Groundwater-Quality Characteristics ...............................................................................92

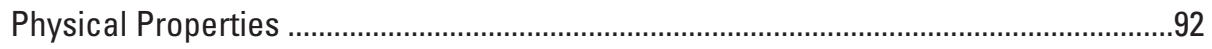

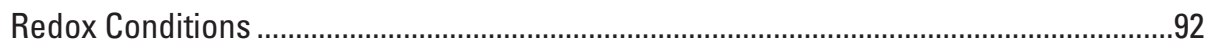

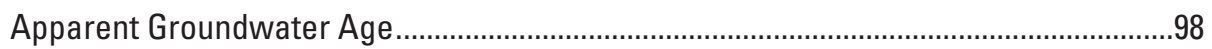

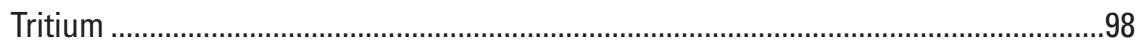

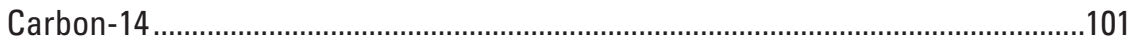

Major Ions and Related Groundwater-Quality Characteristics .....................................103

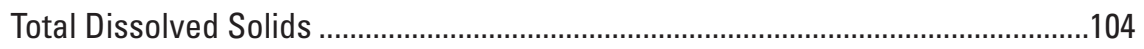

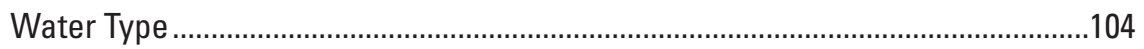

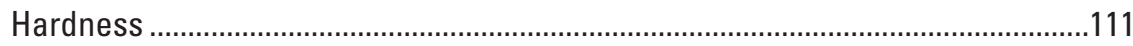

Comparison to Domestic and Livestock Standards and Guidelines .....................112

Comparison to Irrigation Standards and Guidelines...............................................112

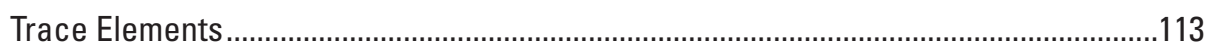

Nutrients and Dissolved Organic Carbon .................................................................115

Radiochemical Constituents ................................................................................116

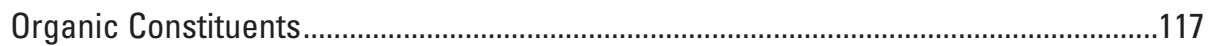

Volatile Organic Compounds...........................................................................117

Gasoline-Range Organics and Diesel-Range Organics ......................................119

Dissolved Hydrocarbon Gases ..........................................................................119

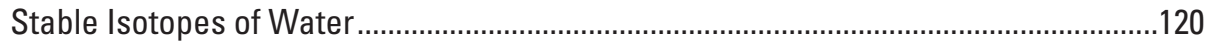

Summary of Groundwater Levels in Study Site Monitoring Wells .....................................122

Response of Groundwater Levels to Atmospheric Loading and Earth Tides ........................127

Water-Level Response to Atmospheric Loading —Constant Barometric Efficiency ...133 
Water-Level Responses to the Solid Earth Tide. 136

Preliminary Earth-Tide Analysis of Detrended, Parsed Water-Level Time Series .138

Earth-Tide Analysis of Discrete Segments of Select Detrended, Parsed Water-Level Time Series .141

Digital Earth-Tide Filters for Wells BR-1, LN-1, and FH-1 Detrended, Parsed Water-Level Time Series .............................................................................141

Frequency Responses of Water Levels to Atmospheric Loading ..................................148

Idealized Well/Aquifer Response to Atmospheric Loading .....................................148

Computed Frequency Responses ......................................................................151

Filtered Water-Level Time Series ........................................................................158

Interpretations and Summary of Results of the Water-Level Responses to Earth Tides and Atmospheric Loading, Filtered Water-Level Responses to Other Hydrologic Stresses and Computed Vertical Hydraulic Gradients .........164

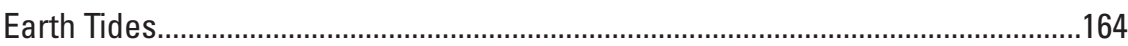

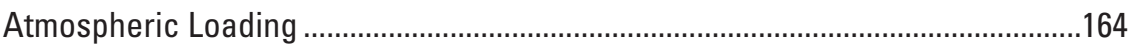

Constant Barometric Efficiency ...................................................................164

Frequency Dependent Barometric Efficiency..............................................165

Estimates of Hydraulic Properties Based on Well Responses to Atmospheric Loading and Earth Tides.......................................................................165

Specific Storage, Porosity, and Matrix Compressibility Formulations..........166

Estimates of Specific Storage, Porosity, and Matrix Compressibility

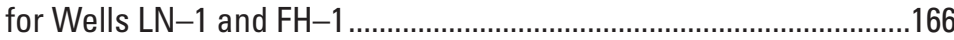

Estimates of Transmissivity, Hydraulic Conductivity, Specific Storage, Porosity, and Matrix Compressibility for Well BR-1.

Lower Bounding Estimates of Transmissivity and Hydraulic Conductivity for Wells LN-1 and FH-1 ................................................................169

Comparison of Hydraulic Properties Estimated for Wells BR-1, LN-1, and $\mathrm{FH}-1$ with Properties Determined in Other Studies....................169

Responses to Other Hydrologic Stresses Retained in the Filtered Water

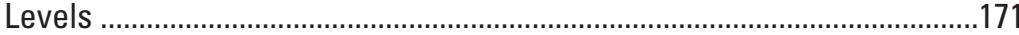

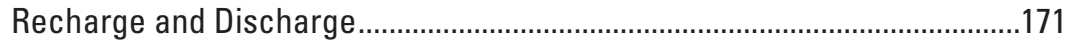

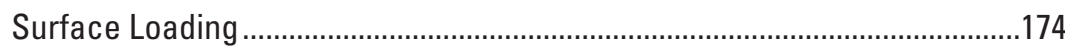

Vertical Hydraulic Gradients...........................................................................174

Interpretation of the Groundwater System at the Study Site ...............................................176

Quaternary Older Alluvial Fan Deposits .........................................................................176

White River Hydrogeologic Unit................................................................................176

Lance Hydrogeologic Unit.......................................................................................177

Lance-Fox Hills Aquifer...........................................................................................

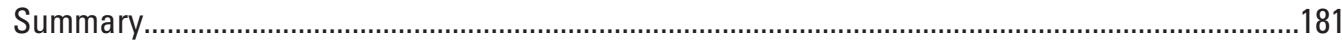

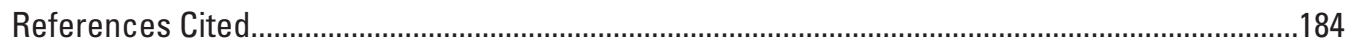

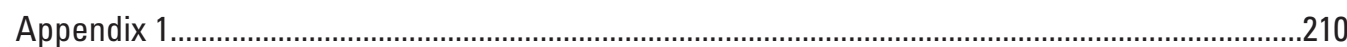

Appendix 2

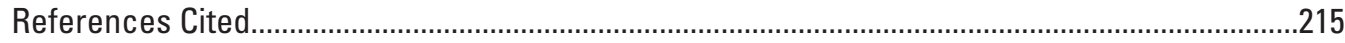

Appendix 3 


\section{Plate}

1. Construction of monitoring wells $B R-1, L N-1$, and $F H-1$, and geophysical logs, generalized lithology, and interpreted lithostratigraphy for exploratory borehole LC-F1, southeastern Laramie County, Wyoming

\section{Figures}

1. Map showing location of study site and lithostratigraphic units in Laramie County, Wyoming.

2. Map showing location and generalized basement structure of the greater Denver Basin, Wyoming, Nebraska, Colorado, and Kansas .......................................................7

3. Graphs showing cross sections through the northern subbasin of the greater Denver Basin, Wyoming and Colorado

4. Map showing estimated surface and subsurface extent of the Upper Cretaceous Lance/Laramie Formation and Fox Hills Sandstone, southeastern Wyoming, southwestern Nebraska, and northeastern Colorado.

5. Graphs showing cross section and comparison of lithostratigraphic units for the Cheyenne and Denver Basins

6. Chart showing lithostratigraphic units and informal subdivisions of the Cheyenne Basin

7. Map showing areal extent of lithostratigraphic units and the High Plains aquifer system in southeastern Wyoming

8. Maps showing paleogeography during Late Cretaceous time and progradational setting of Upper Cretaceous rocks.

9. Chart showing relation of Cenozoic lithostratigraphic units to hydrogeologic units composing or underlying the High Plains aquifer system, southeastern Wyoming........24

10. Graphs and tables showing classification system used to describe and name unconsolidated and consolidated sediments collected from coring of exploratory borehole LC-F1.

11. Graphs showing well construction for monitoring wells $B R-1, L N-1$, and $F H-1$ and sediment grain size, selected geophysical logs, and interpreted lithostratigraphy $f$ or exploratory borehole LC-F1, southeastern Laramie County, Wyoming.

12. Photographs showing cuttings and core from Quaternary older alluvial fan deposits, exploratory borehole LC-F1, southeastern Laramie County, Wyoming..

13. Photographs showing core and various characteristics of the White River Formation, exploratory borehole LC-F1, southeastern Laramie County, Wyoming..

14. Photographs showing various aspects of core in the White River Formation, borehole LC-F1, southeastern Laramie County, Wyoming

15. Cross section showing depositional environments and facies relation for the Lance/Laramie Formation, Fox Hills Sandstone, and Pierre Shale

16. Graphs showing typical character of the Upper Cretaceous Lance Formation, Fox Hills Sandstone, and upper transition member of the Pierre Shale.

17. Photographs showing core and various characteristics of the Lance Formation, exploratory borehole LC-F1, southeastern Laramie County, Wyoming.

18. Photographs showing core and various characteristics of parts of the Lance Formation muddy sandstone in which monitoring well $\mathrm{LN}-1$ was completed, exploratory borehole LC-F1, southeastern Laramie County, Wyoming 
19. Photographs showing muddy sandstone from the Lance Formation, 473.9 to

474.0 feet below land surface, exploratory borehole LC-F1, southeastern Laramie County, Wyoming.....

20. Photographs showing muddy sandstone from the Lance Formation, 485.1 to

485.3 feet below land surface, exploratory borehole LC-F1, southeastern Laramie County, Wyoming

21. Photographs showing core and various characteristics of the upper Fox Hills Sandstone, exploratory borehole LC-F1, southeastern Laramie County, Wyoming .......75

22. Photographs showing core and various characteristics of the lower Fox Hills Sandstone and upper transition member of the Pierre Shale, exploratory borehole LC-F1, southeastern Laramie County, Wyoming

23. Photographs showing muddy sandstone from upper sandstone bed of the upper Fox Hills Sandstone, 781.8 to 782.0 feet below land surface, exploratory borehole LC-F1, southeastern Laramie County, Wyoming

24. Photographs showing muddy sandstone from upper Fox Hills Sandstone, 813.7 to 813.9 feet below land surface, exploratory borehole LC-F1, southeastern Laramie County, Wyoming

25. Photographs showing samples from Fox Hills Sandstone, 824.4-824.6 feet below land surface, exploratory borehole LC-F1, southeastern Laramie County, Wyoming ....82

26. Photographs showing samples from Fox Hills Sandstone, 839.0-839.2 feet below land surface, exploratory borehole LC-F1, southeastern Laramie County, Wyoming ....83

27. Photographs showing samples from Fox Hills Sandstone, 897.0-897.2 feet below land surface, exploratory borehole LC-F1, southeastern Laramie County, Wyoming ....85

28. Photographs showing samples from Fox Hills Sandstone, 920.8-921.0 feet below land surface, exploratory borehole LC-F1, southeastern Laramie County, Wyoming ....87

29. Geologic cross section A-A' showing subsurface occurrence of Fox Hills Sandstone in relation to the Lance Formation and upper transition member of the Pierre Shale through part of southern Laramie County, southeastern Wyoming............88

30. Map showing location of geologic cross section $A-A^{\prime}$, wells with groundwaterquality sample data, Wyoming State Engineer's Office groundwater-level monitoring wells, and surficial lithostratigraphic units, Cheyenne Basin, Wyoming......89

31. Trilinear diagram showing major-ion composition for groundwater samples from aquifers in Tertiary and Upper Cretaceous hydrogeologic units in eastern Laramie County, Cheyenne Basin, southeastern Wyoming .....

32. Trilinear diagram showing major-ion composition for groundwater samples from aquifers in Tertiary and Upper Cretaceous hydrogeologic units in central and western Laramie County, Cheyenne Basin, southeastern Wyoming....

33. Trilinear diagram showing major-ion composition for groundwater samples from aquifers in Tertiary and Upper Cretaceous hydrogeologic units in southern oshen Hole, Laramie and Goshen Counties, Cheyenne Basin, southeastern Wyoming. 107

34. Trilinear diagram showing major-ion composition for groundwater samples from aquifers in Tertiary and Upper Cretaceous hydrogeologic units in central and northern Goshen Hole, Goshen County, Cheyenne Basin, southeastern Wyoming......108

35. Trilinear diagram showing major-ion composition for groundwater samples from aquifers in Tertiary hydrogeologic units in Platte County, Cheyenne Basin, southeastern Wyoming.

36. Trilinear diagram showing major-ion composition for groundwater samples from aquifers in Upper Cretaceous hydrogeologic units in Laramie, Goshen, and Platte Counties, Cheyenne Basin, southeastern Wyoming. 
37. Map showing suitability of water for use in irrigation based on analyses of water from wells, Cheyenne Basin, southeastern Wyoming.

38. Graph showing relation between oxygen-18/oxygen-16 isotopic ratio and deuterium/protium isotopic ratio for groundwater samples collected from wells in the Cheyenne Basin, southeastern Wyoming

39. Graphs showing groundwater levels for June 2013-September 2017, southeastern Laramie County, Wyoming.

40. Hydrographs showing three Wyoming State Engineer's Office groundwater-level monitoring wells in relation to hydrograph for monitoring well BR-1, September 2014-September 2017, southeastern Laramie County, Wyoming.

41. Flowchart showing the workflow process used to develop the digital atmosphericloading and Earth-tide filters for water levels from monitoring wells BR-1, LN-1, and FH-1, southeastern Laramie County, Wyoming

42. Graphs showing continuous time-series pieces for wells BR-1, LN-1, and FH-1, southeastern Laramie County, Wyoming

43. Graphs showing parsed, coincident water-level and barometric-pressure time series for wells BR-1, LN-1, and FH-1, southeastern Laramie County, Wyoming ........130

44. Graphs showing trended and detrended water-level and barometric-pressure parsed time series BR-1_4, October 20, 2015-March 23, 2016; LN-1_5, February 1-May 18, 2017; and FH-1_5, July 20, 2016-January 31, 2017, from wells BR-1, LN-1, and FH-1, southeastern Laramie County, Wyoming

45. Graphs showing estimates of constant barometric efficiency for detrended, parsed time series FH-1_5, July 20, 2016-January 31, 2017, from well FH-1, southeastern Laramie County, Wyoming, based on linear least-squares regression of water level on barometric pressure using methods 1, 2a, 2b, and 3.......135

46. Graphs showing digitally filtered water levels fWL:BE2a and fWL:BE2b for detrended, parsed water-level and barometric-pressure time series, February 1May 18, 2017, from wells BR-1, LN-1, and FH-1, southeastern Laramie County, Wyoming, using the constant barometric-efficiency estimates determined from methods $2 \mathrm{a}$ and $2 \mathrm{~b}$.

47. Graphs showing predicted fits for predicted water level and predicted tides to the high-pass, detrended, parsed water-level and theoretical areal-strain tide time series, respectively, for parsed series FH-1_8 for August 24-September 30, 2017, from well FH-1, southeastern Laramie County, Wyoming

48. Graphs showing predicted discrete amplitudes of the six principal Earth tides shown in table 13 computed for the high-pass, detrended theoretical areal-strain tide and unscaled and M2-scaled water levels for parsed series FH-1_8, August 24-September 30, 2017, from well FH-1, southeastern Laramie County, Wyoming.

49. Graphs showing predicted unscaled and M2-scaled water-level responses to the six principal Earth tides shown in table 13 for the high-pass, detrended water levels; and the tidally filtered, unscaled and M2-scaled, high-pass water levels for parsed series FH-1_8, August 24-September 30, 2017, from well FH-1, southeastern Laramie County, Wyoming.

50. Graph showing tidally filtered unscaled and M2-scaled water levels for the detrended, parsed time series FH-1_8, August 24-September 30, 2017, from well FH-1, southeastern Laramie County, Wyoming, shown with detrended water levels and barometric pressure

51. Graphs showing cross sections of idealized aquifers showing idealized well responses to atmospheric loading with principal sources of attenuation caused by drainage effects and idealized water-level responses to a step increase in barometric pressure or load. 
52. Graphs showing power spectral densities computed for the parameters listed in table 16 for the nontidally filtered, detrended, parsed series BR-1_4, October 20, 2015-March 23, 2016; LN-1_6, May 18-September 30, 2017; and FH-1_6, February 15-May 24, 2017, from wells BR-1, LN-1, and FH-1, respectively, southeastern Laramie County, Wyoming

53. Graphs showing computed atmospheric-loading frequency responses: frequency response for original sample rate without tidal filtering, frequency response for original sample rate with tidal filtering, and frequency response for resampled sample rate with tidal filtering of water levels in terms of barometric efficiency or gain, phase shift, and squared coherences for parsed time series BR-1_4, October 20, 2015-March 23, 2016; LN-1_6, May 18-September 30, 2017; and FH-1_6, February 15-May 24, 2017, from wells BR-1, LN-1, and FH-1, respectively, southeastern Laramie County, Wyoming..

54. Graphs showing computed, atmospheric-loading frequency responses with prior, M2-scaled filtered water levels, in terms of gain and phase shift, at frequencies in which squared coherences were greater than or equal to 0.85 , shown as FRF:Coh2:ETM2 for each of the detrended, parsed series for wells BR-1, LN-1, and $\mathrm{FH}-1$, southeastern Laramie County, Wyoming...

55. Graphs showing predicted water levels computed using the reFRF:ETM2 and barometric efficiency method 1 models, and the respective "observed" water levels, for the detrended, parsed series BR-1_4, October 20, 2015-March 23, 2016; LN-1_6, May 18-September 30, 2017; and FH-1_6, February 15-May 24, 2017, shown with the detrended, parsed barometric pressure, for wells BR-1, LN-1, | and $\mathrm{FH}-1$, respectively, southeastern Laramie County, Wyoming .

56. Graphs showing filtered, detrended, parsed water-level time series fWL:reFRF:ETM2 and fWL:BE1, computed using the frequency response function model, reFRF:ETM2, and the linear regression model, BE1, respectively, shown with detrended water level and barometric pressure for parsed series BR-1_4, October 20, 2015-March 23, 2016; LN-1_6, May 18-September 30, 2017; and FH-1_6, February 15-May 24, 2017, from wells BR-1, LN-1, and FH-1, southeastern Laramie County, Wyoming...

57. Graphs showing reconstructed, filtered water-levels trfWL:reFRF:ETM2 and trfWL:BE1 shown with water level and barometric pressure for the detrended, parsed time series BR-1_4, October 20, 2015-March 23, 2016; LN-1_6, May 18September 30, 2017; and FH-1_6, February 15-May 24, 2017, from wells $\mathrm{BR}-1, \mathrm{LN}-1$, and $\mathrm{FH}-1$, southeastern Laramie County, Wyoming

58. Graphs showing reconstructed, filtered water-levels trfWL:reFRF:ETM2 shown with water level and barometric pressure for parsed time series from wells BR-1, $\mathrm{LN}-1$, and $\mathrm{FH}-1$, southeastern Laramie County, Wyoming.

59. Graphs showing amplitude and phase shift computed using the Hsieh solution for the response of water level in an open well completed in a confined aquifer to the head disturbance in the aquifer caused by Earth tide dilatation of the aquifer...

60. Graphs showing predicted annual water-level responses to annual recharge pulses computed using the detrended, daily sampled, reassembled, filtered time series for wells BR-1, LN-1, and FH-1, January 21, 2015, to September 30, 2017, southeastern Laramie County, Wyoming...

61. Graphs showing measured, predicted, and filtered detrended water-level responses to two precipitation loading episodes, May 8-9, 2015, and June 12, 2016, in parsed series for wells BR-1, LN-1, and FH-1, southeastern Laramie County, Wyoming, shown with detrended barometric pressure 


\section{Tables}

1. Construction of monitoring wells installed and sampled for this study and production wells sampled for this study, southeastern Laramie County, Wyoming. ......34

2. Analyses for organic constituents in quality-control and environmental samples collected for this study.

3. Summary of major ions and related water-quality characteristics, trace elements, nutrients, and dissolved organic carbon in equipment blank sample in relation to groundwater-quality samples collected from monitoring wells BR-1, LN-1, and FH-1, southeastern Laramie County, Wyoming.

4. Replicate data for major ions and related water-quality characteristics, trace elements, nutrients, dissolved organic carbon, radioisotopes, and stable isotopes in groundwater-quality samples collected from monitoring well LN-1, southeastern Laramie County, Wyoming.

5. Summary of physical properties and inorganic constituents in groundwater-quality samples collected from monitoring wells $\mathrm{BR}-1, \mathrm{LN}-1$, and $\mathrm{FH}-1$ and production wells $\mathrm{FH}-2$ and $\mathrm{FH}-3$, southeastern Laramie County, Wyoming.

6. Assignment of redox categories and processes for groundwater-quality samples collected from monitoring wells $\mathrm{LN}-1$ and $\mathrm{FH}-1$ and production wells $\mathrm{FH}-2$ and FH-3, southeastern Laramie County, Wyoming.

7. Analyses for dissolved gases in groundwater-quality samples collected from monitoring wells $\mathrm{LN}-1$ and $\mathrm{FH}-1$ and production wells $\mathrm{FH}-2$ and $\mathrm{FH}-3$, southeastern Laramie County, Wyoming.

8. Salinity hazard and specific conductance, and sodium hazard and sodium adsorption ratio

9. Summary of organic constituents detected in environmental and quality-control samples collected for this study

10. Summary of discrete and continuously recorded groundwater-level data for monitoring wells BR-1, LN-1, and FH-1, June 2013-September 2017, southeastern Laramie County, Wyoming.

11. Parsed time-series parameters for wells BR-1, September 5, 2014-September 30, 2017; LN-1, November 8, 2014-September 30, 2017; and FH-1, December 19, 2014 September 30, 2017, southeastern Laramie County, Wyoming

12. Estimates of constant barometric efficiency determined using methods 1, 2a, 2b, and 3 for each of the parsed time series shown in table 11, for wells BR-1, LN-1, and FH-1, southeastern Laramie County, Wyoming

13. Frequencies, periods, and indices used in the analysis of the six principal Earth tides (Godin, 1972).

14. Results of tidal harmonic analysis of detrended, parsed time series for wells BR-1, September 5, 2014-September 30, 2017; LN-1, November 8, 2014-September 30, 2017; and FH-1, December 19, 2014-September 30, 2017, southeastern Laramie County, Wyoming

15. Results of tidal analysis of six principal Earth tides of discrete segments of selected detrended, parsed time series for wells BR-1, September 5, 2014September 23, 2017; LN-1, November 8, 2014-September 23, 2017; and FH-1, December 3, 2015-September 25, 2017, southeastern Laramie County, Wyoming 
16. Parameters used to compute atmospheric loading frequency-response functions for the parsed water-level and barometric-pressure time series from wells BR-1, September 5, 2014-September 30, 2017; LN-1, November 8, 2014September 30, 2017; and FH-1, December 19, 2014-September 30, 2017, southeastern Laramie County, Wyoming...

17. Root mean square errors for the fit of predicted water-level responses to atmospheric loading using the FRF, FRF:ETM2, and reFRF:ETM2 frequency response function models and the constant $B E$ method 1 linear least-squares regression model of detrended water level on detrended barometric pressure, to the observed detrended water levels, for the detrended, parsed time series analyzed for wells BR-1, September 5, 2014-September 30, 2017; LN-1, November 8, 2014September 30, 2017; and FH-1, December 19, 2014-September 30, 2017, outheastern Laramie County, Wyoming.

18. Groundwater-storage-related property values computed for wells $B R-1, L N-1$, and

FH-1, southeastern Laramie County, Wyoming.

\section{Conversion Factors}

U.S. customary units to International System of Units

\begin{tabular}{|c|c|c|}
\hline Multiply & By & To obtain \\
\hline \multicolumn{3}{|c|}{ Length } \\
\hline inch (in.) & 2.54 & centimeter $(\mathrm{cm})$ \\
\hline inch (in.) & 25.4 & millimeter $(\mathrm{mm})$ \\
\hline foot $(\mathrm{ft})$ & 0.3048 & meter $(\mathrm{m})$ \\
\hline mile (mi) & 1.609 & kilometer $(\mathrm{km})$ \\
\hline \multicolumn{3}{|c|}{ Area } \\
\hline square mile $\left(\mathrm{mi}^{2}\right)$ & 2.590 & square kilometer $\left(\mathrm{km}^{2}\right)$ \\
\hline \multicolumn{3}{|c|}{ Volume } \\
\hline gallon (gal) & 3.785 & liter $(\mathrm{L})$ \\
\hline acre-foot (acre-ft) & 1,233 & cubic meter $\left(\mathrm{m}^{3}\right)$ \\
\hline \multicolumn{3}{|c|}{ Flow rate } \\
\hline foot per second $(\mathrm{ft} / \mathrm{s})$ & 0.3048 & meter per second $(\mathrm{m} / \mathrm{s})$ \\
\hline foot per day (ft/d) & 0.3048 & meter per day $(\mathrm{m} / \mathrm{d})$ \\
\hline foot per year (ft/yr) & 0.3048 & meter per year $(\mathrm{m} / \mathrm{yr})$ \\
\hline gallon per minute (gal/min) & 0.06309 & liter per second $(\mathrm{L} / \mathrm{s})$ \\
\hline \multicolumn{3}{|c|}{ Radioactivity } \\
\hline picocurie per liter (pCi/L) & 0.037 & becquerel per liter $(\mathrm{Bq} / \mathrm{L})$ \\
\hline \multicolumn{3}{|c|}{ Pressure } \\
\hline pound per square inch $\left(\mathrm{lb} / \mathrm{in}^{2}\right)$ & 6.895 & kilopascal $(\mathrm{kPa})$ \\
\hline \multicolumn{3}{|c|}{ Transmissivity* } \\
\hline foot squared per day $\left(\mathrm{ft}^{2} / \mathrm{d}\right)$ & 0.09290 & meter squared per day $\left(\mathrm{m}^{2} / \mathrm{d}\right)$ \\
\hline gallons per day per foot $[(\mathrm{gal} / \mathrm{d}) / \mathrm{ft}]$ & 12.42 & liters per day per meter $[(\mathrm{L} / \mathrm{d}) / \mathrm{m}]$ \\
\hline \multicolumn{3}{|c|}{ Permeability } \\
\hline darcy (D) & $9.869 \times 10^{-13}$ & square meter $\left(\mathrm{m}^{2}\right)$ \\
\hline millidarcy $(\mathrm{mD})$ & $9.869 \times 10^{-16}$ & square meter $\left(\mathrm{m}^{2}\right)$ \\
\hline
\end{tabular}


International System of Units to U.S. customary units

\begin{tabular}{lll}
\hline \multicolumn{1}{c}{ Multiply } & \multicolumn{1}{c}{ By } & \multicolumn{1}{c}{ To obtain } \\
\hline millimeter $(\mathrm{mm})$ & Length & \\
micrometer $($ micron; $\mu \mathrm{m})$ & 0.03937 & inch (in.) \\
meter $(\mathrm{m})$ & 0.00003937 & inch (in.) \\
kilometer $(\mathrm{km})$ & 3.281 & foot (ft) \\
\hline & 0.6214 & mile (mi) \\
\hline milliliter $(\mathrm{mL})$ & Volume & \\
liter $(\mathrm{L})$ & 0.03382 & ounce, fluid $(\mathrm{fl} . \mathrm{oz})$ \\
\hline & 0.2642 & gallon (gal) \\
\hline centimeter per second $(\mathrm{cm} / \mathrm{s})$ & Flow rate & \\
meter per day $(\mathrm{m} / \mathrm{d})$ & 0.03281 & foot per second $(\mathrm{ft} / \mathrm{s})$ \\
\hline & 3.281 & foot per day $(\mathrm{ft} / \mathrm{d})$ \\
\hline gram $(\mathrm{g})$ & Mass & \\
kilogram $(\mathrm{kg})$ & 0.03527 & ounce, avoirdupois $(\mathrm{oz})$ \\
\hline
\end{tabular}

Temperature in degrees Celsius $\left({ }^{\circ} \mathrm{C}\right)$ may be converted to degrees Fahrenheit $\left({ }^{\circ} \mathrm{F}\right)$ as follows:

$$
{ }^{\circ} \mathrm{F}=\left(1.8 x^{\circ} \mathrm{C}\right)+32
$$

Temperature in degrees Fahrenheit $\left({ }^{\circ} \mathrm{F}\right)$ may be converted to degrees Celsius $\left({ }^{\circ} \mathrm{C}\right)$ as follows:

$$
{ }^{\circ} \mathrm{C}=\left({ }^{\circ} \mathrm{F}-32\right) / 1.8
$$

\section{Datum}

Vertical coordinate information is referenced to the National Geodetic Vertical Datum of 1929 (NGVD 29) or North American Vertical Datum of 1988 (NAVD 88).

Horizontal coordinate information is referenced to the North American Datum of 1983 (NAD 83).

Elevation, as used in this report, refers to distance above the vertical datum.

\section{Supplemental Information}

*Transmissivity: The standard unit for transmissivity is cubic foot per day per square foot times foot of aquifer thickness [(ft $\left.\left.\mathrm{ft}^{3} \mathrm{~d}\right) / \mathrm{ft}^{2}\right] \mathrm{ft}$. In this report, the mathematically reduced form, foot squared per day $\left(\mathrm{ft}^{2} / \mathrm{d}\right)$, is used for convenience.

Specific conductance is given in microsiemens per centimeter at 25 degrees Celsius $(\mu \mathrm{S} / \mathrm{cm}$ at $\left.25^{\circ} \mathrm{C}\right)$.

Concentrations of chemical constituents in water are given either in milligrams per liter (mg/L) or micrograms per liter $(\mu \mathrm{g} / \mathrm{L})$.

Activities for radioactive constituents in water are given in picocuries per liter (pCi/L).

Results for measurements of stable isotopes of an element (with symbol E) in water, solids, and dissolved constituents commonly are expressed as the relative difference in the ratio of the number of the less abundant isotope ( $\mathrm{E}$ ) to the number of the more abundant isotope of a sample with respect to a measurement standard. 


\section{Abbreviated Water-Quality Units}

$\mu \mathrm{g} / \mathrm{L} \quad$ microgram per liter

$\mu \mathrm{S} / \mathrm{cm}$ microsiemens per centimeter at 25 degrees Celsius

$\mathrm{mg} / \mathrm{L} \quad$ milligram per liter

$\mathrm{pCi} / \mathrm{L} \quad$ picocurie per liter

TU tritium unit

\section{Chemical Abbreviations}

$\delta^{13} \mathrm{C} \quad$ carbon-13/carbon-12 isotopic ratio

$\delta^{2} \mathrm{H} \quad$ deuterium/protium isotopic ratio

$\delta^{18} 0 \quad$ oxygen-18/oxygen-16 isotopic ratio

\section{Symbols and Abbreviations}

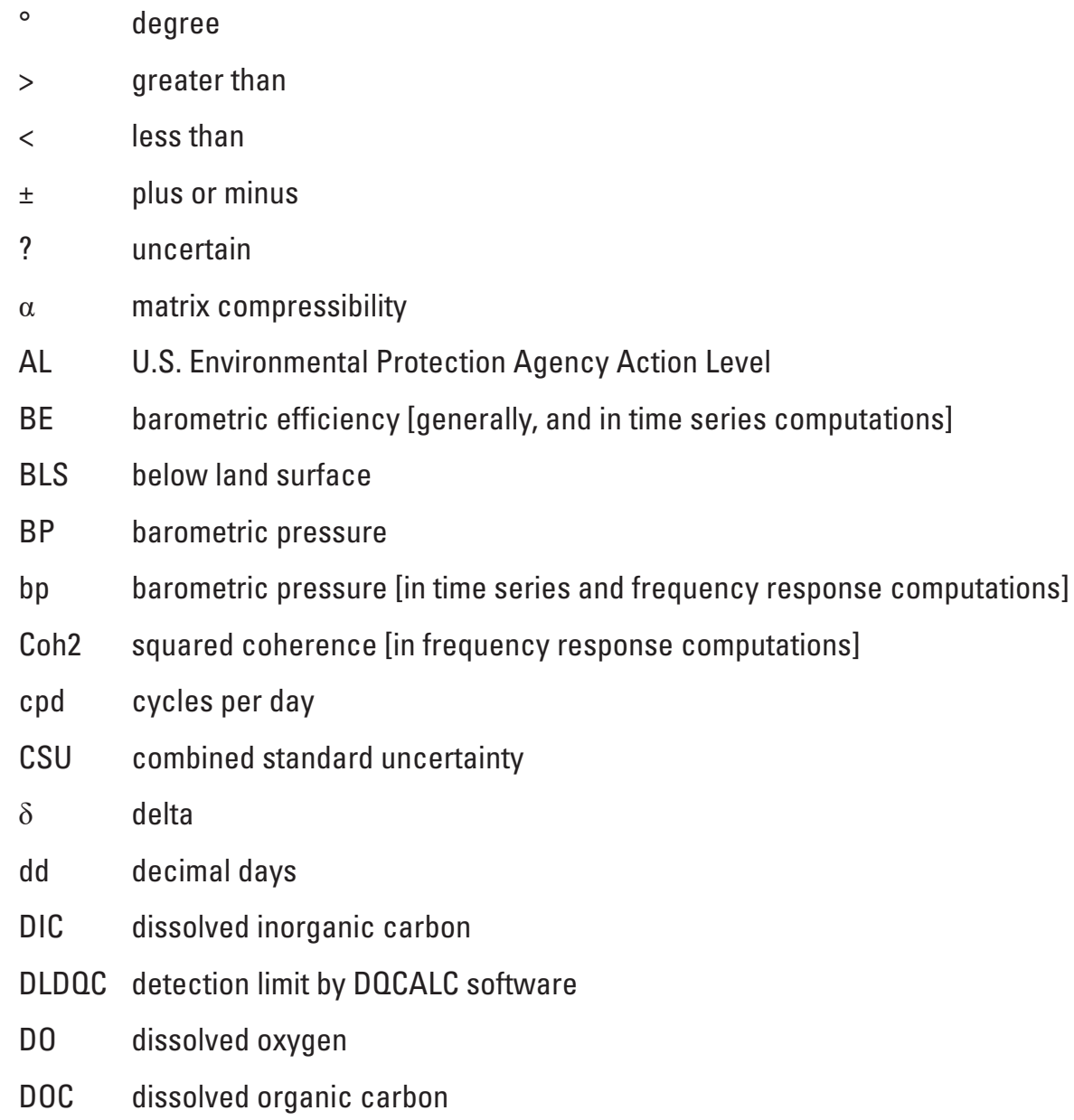




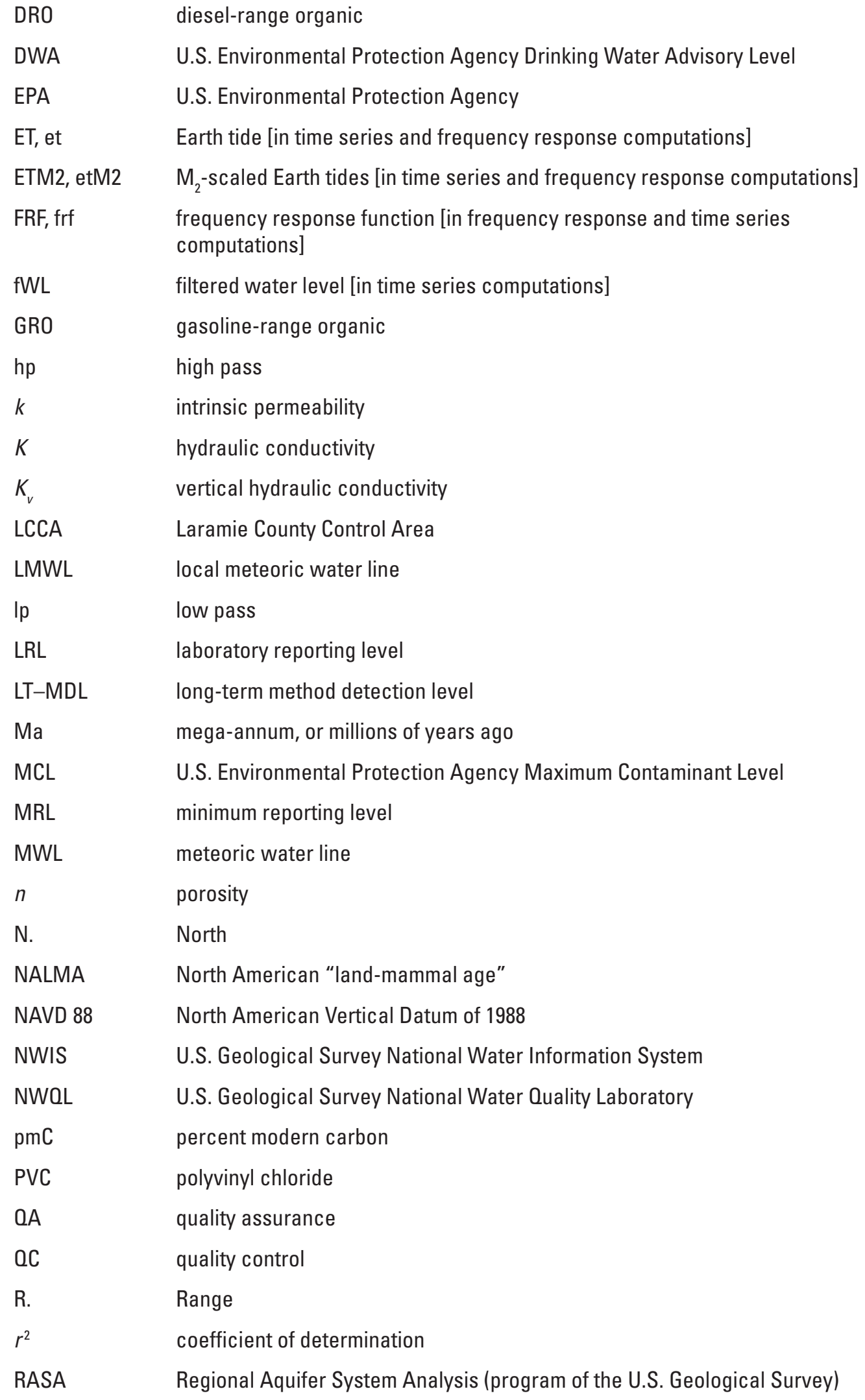




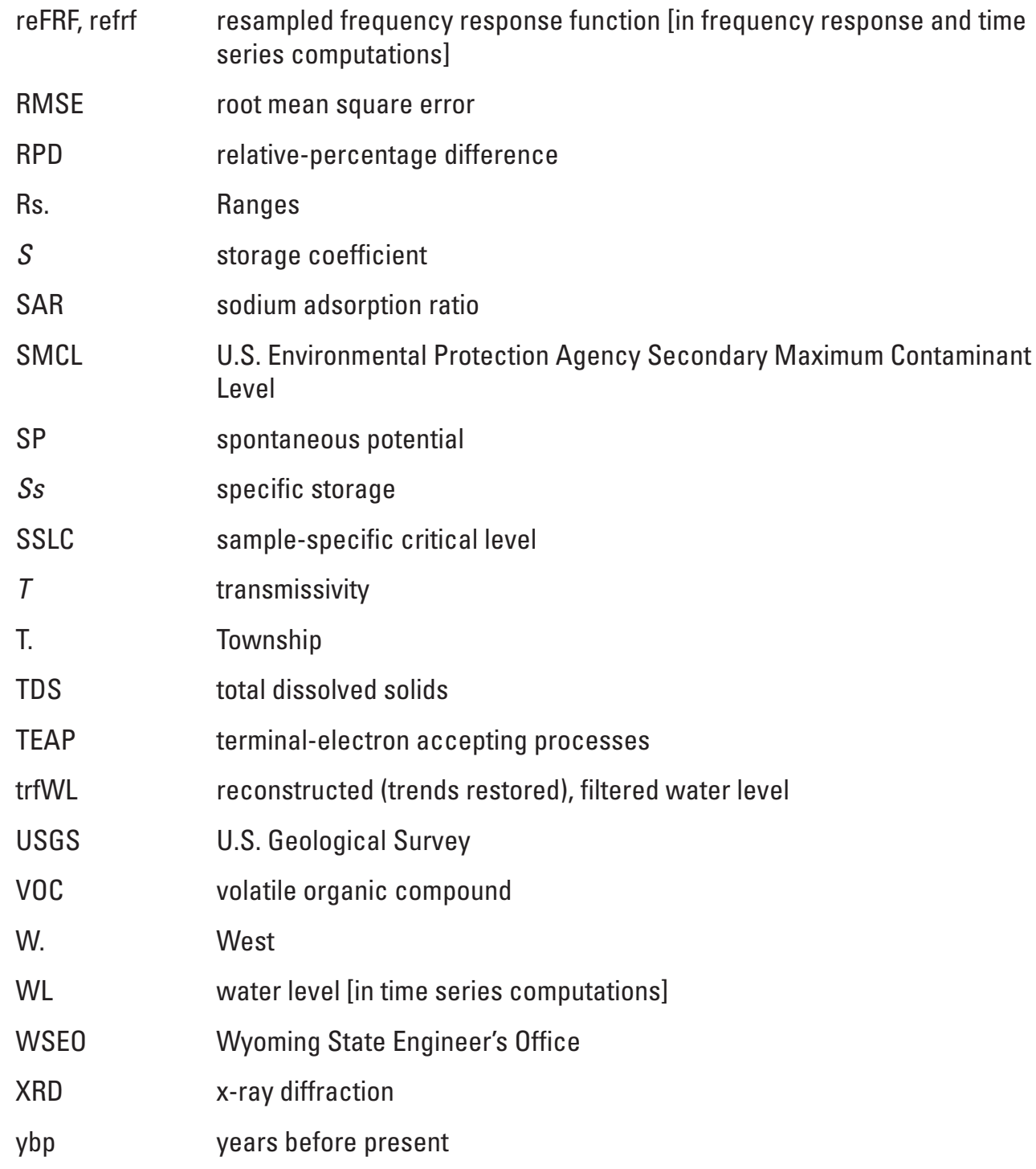





\title{
Geologic and Hydrogeologic Characteristics of the White River Formation, Lance Formation, and Fox Hills Sandstone, Northern Greater Denver Basin, Southeastern Laramie County, Wyoming
}

\author{
By Timothy T. Bartos, Devin L. Galloway, Laura L. Hallberg, Marieke Deschene, Sharon F. Diehl, and \\ Seth L. Davidson
}

\section{Abstract}

In cooperation with the Wyoming State Engineer's Office, the U.S. Geological Survey studied the geologic and hydrogeologic characteristics of Cenozoic and Upper Cretaceous strata at a location in southeastern Laramie County within the Wyoming part of the Cheyenne Basin, the northern subbasin of the greater Denver Basin. The study aimed to improve understanding of the aquifers/aquifer systems in these strata, motivated in part by declining groundwater levels and interest in exploring future groundwater supplies. Based on detailed geologic characterization using information obtained by drilling and coring a 960-foot-(ft) deep exploratory borehole, and comparisons with previously published descriptions, identified Cenozoic lithostratigraphic units included $40 \mathrm{ft}$ of Quaternary older alluvial fan deposits consisting of an unconsolidated mixture of sand and gravel with lesser quantities of silt and clay in varying proportions and the underlying 407.3-ft-thick White River Formation of late Eocene-Oligocene age consisting largely of mudrocks with sparse thin beds of sandstone, muddy gravel, and conglomeratic mudrocks. Identified Upper Cretaceous lithostratigraphic units included the 351.6-ft-thick Lance Formation, consisting of terrestrial sedimentary rocks including mudrocks (muddy shale and silty and sandy shale, siltstone, claystone, and mudstone) interbedded with much smaller quantities of very fine- to medium-grained muddy and silty sandstone and coal; the 79.6-ft-thick Fox Hills Sandstone, consisting of a transitional marine sequence of muddy or silty sandstone present in five individual beds; and $86.7 \mathrm{ft}$ of the upper transition member of the Pierre Shale, consisting largely of marine sedimentary rocks such as muddy shale. Beds of the upper and lower Fox Hills Sandstone were separated by tongues of the Lance Formation and upper transition member of the Pierre Shale, respectively.

The White River hydrogeologic unit, consisting of the entire White River Formation or Group at the study site, did not contain any substantial secondary permeability features in the mudrocks that composed almost all the unit. A monitoring well (BR-1) was completed in the White River aquifer with the well screen open to the only coarse-grained unit (muddy sandstone) that had sufficient thickness and permeability to be considered as an aquifer. Sampling of the well for a broad suite of constituents indicated groundwater generally was of excellent quality except dissolved arsenic was detected at a concentration greater than the U.S. Environmental Protection Agency (EPA) Maximum Contaminant Level, and dissolved sodium was measured at a concentration greater than several EPA Drinking Water Advisory Levels (DWAs) for the constituent. Well development, well purging for groundwater sampling, and calculated aquifer properties indicated the sandstone aquifer screened by monitoring well BR-1 was not very productive. Analysis of the well water-level responses in BR-1 to atmospheric loading and Earth tides indicated the responses were consistent with a confined-aquifer response with wellbore-storage effects. Hydraulic properties estimated based on these responses yielded values of hydraulic conductivity $(K, 0.057$ foot per day $[\mathrm{ft} / \mathrm{d}])$, specific storage $\left(S s, 1.6 \times 10^{-6}\right.$ per foot $\left.\left[\mathrm{ft}^{-1}\right]\right)$ and porosity $(n, 0.43)$. Water levels filtered to remove the effects of atmospheric loading and Earth tides indicated an upward trend $(+1.13$ foot per year [ft/yr]) during the period analyzed, September 5, 2014, to September 30, 2017.

Lithologic characteristics of the Lance hydrogeologic unit, consisting of the entire Lance Formation at the study site, indicated a potential aquifer in a "sandy" interval in the upper part of the unit. Most of the Lance hydrogeologic unit below the "sandy" interval consisted of various low-permeability lithologies unlikely to yield substantial quantities of water. This lower part of the hydrogeologic unit likely functions as a confining unit separating the underlying Lance-Fox Hills aquifer. A geologic cross section constructed for this study indicated fine-grained sediments composed most of the Lance Formation/hydrogeologic unit not only at the study location, but also throughout southern Laramie County along the line of section and throughout the Wyoming and Colorado parts of the Cheyenne Basin. A monitoring well (LN-1) completed in 
a sandstone bed in the "sandy" interval of the Lance hydrogeologic unit produced a mean of about 23 gallons per minute (gal/min) during well development, indicating sandstone beds can form moderately productive confined subaquifers in this part of the hydrogeologic unit. Analysis of the well water-level responses in well $\mathrm{LN}-1$ to atmospheric loading and Earth tides indicated the responses were consistent with a confined-aquifer response. Hydraulic properties estimated based on these responses yielded values for a lower bounding $K$ of $0.60 \mathrm{ft} / \mathrm{d}, S s$ of $1.6 \times 10^{-6} \mathrm{ft}^{-1}$, and $n$ of 0.38 . Water levels filtered to remove the effects of atmospheric loading and Earth tides indicated a downward trend $(-0.86 \mathrm{ft} / \mathrm{yr})$ during the period analyzed (November 8, 2014, to September 30, 2017). Analyses for a broad suite of constituents in samples from well $\mathrm{LN}-1$ indicated groundwater quality generally was excellent, although dissolved sodium was measured at a concentration greater than two EPA DWA levels for the constituent.

Because of the absence of any overlying or intertonguing sandstone beds belonging to the lower/basal part of the Lance Formation, the Lance-Fox Hills aquifer at the study site consisted only of the five sandstone beds of the Fox Hills Sandstone. The cross section constructed for this study illustrated how the Fox Hills Sandstone, and thus, most of the Lance-Fox Hills aquifer, consists of a series of sandstone bodies that overlap (shingle) upward to the east across southern Laramie County. These bodies collectively form a fairly continuous body of sandstone, thus potentially forming an areally extensive aquifer across southern Laramie County, and by extension, throughout most of the formation's extent in the Wyoming part of the Cheyenne Basin, as is the case in the Colorado part of the basin. A monitoring well (FH-1) completed in part of the thickest sandstone bed of the Lance-Fox Hills aquifer was moderately to highly productive and easily produced 25 to $30 \mathrm{gal} / \mathrm{min}$ after development. Substantially larger water production rates likely could be obtained by penetrating the full thickness of this bed and by completing a well open to the other overlying and underlying sandstone beds of the aquifer. Analysis of the water-level responses in well FH-1 to atmospheric loading and Earth tides indicated the responses were consistent with a confined-aquifer response. Hydraulic properties computed based on these responses yielded values for a lower bounding estimate for $K$ of $0.26 \mathrm{ft} / \mathrm{d}$, for $S s$ of $1.0 \times 10^{-6} \mathrm{ft}^{-1}$, and for $n$ of 0.41 . Water levels filtered to remove the effects of atmospheric loading and Earth tides indicated a downward trend $(-1.74 \mathrm{ft} / \mathrm{yr})$ during the period analyzed, December 19, 2014, to September 30, 2017. Sampling of monitoring well FH-1 and two production wells completed in the Fox Hills Sandstone in other parts of Laramie County indicated groundwater quality generally is excellent, although $\mathrm{pH}$ exceeded a recommended EPA aesthetic drinking-water standard (Secondary Maximum Contaminant Level) in two of three sampled wells, total dissolved solids concentrations exceeded the Secondary Maximum Contaminant Level in one of the two sampled production wells, and dissolved sodium was measured in all three sampled wells at a concentration greater than two EPA DWA levels for the constituent. The
Wyoming Class II agricultural (irrigation) sodium adsorption ratio standard of 8 was exceeded in all three sampled wells, indicating these waters are not suitable for irrigation use.

Computed vertical hydraulic gradients indicated a strong potential for downward flow throughout the groundwater system at the study site, including from the low-yielding aquifer in the upper White River Formation/hydrogeologic unit (monitoring well BR-1) to the sandstone subaquifer in the Lance Formation/hydrogeologic unit (monitoring well LN-1), and from the Lance subaquifer (monitoring well LN-1) to the sandstone bed/aquifer that composes much of the LanceFox Hills aquifer thickness at the study site (monitoring well FH-1). However, large hydraulic-head differences between wells indicated high resistance to vertical flow attributable to the low vertical hydraulic conductivity of intervening strata, which consisted almost entirely of low-permeability mudrocks. The confined nature of the sandstone aquifers monitored by the various wells coupled with dissimilarities between groundwater-level fluctuations and trends in groundwater levels indicated downward flow through the intervening strata (primarily mudrocks in the various lithostratigraphic/ hydrogeologic units) between the examined sets of wells likely was small.

\section{Introduction}

Located in southeastern Wyoming, most of Laramie County is underlain by Cenozoic (Quaternary and Tertiary) and Upper Cretaceous lithostratigraphic units. Aquifers in the Tertiary lithostratigraphic units, in combination with locally present Quaternary-age unconsolidated deposits, compose the locally and regionally important High Plains aquifer system. These aquifers have been the primary sources of groundwater for most uses in Laramie County, as well as for much of the High Plains area in southeastern Wyoming, including the area underlain by the Cheyenne Basin, the northern subbasin of the greater Denver Basin. Localized groundwater-level declines in these aquifers in Laramie County have been observed since the late 1940s (Lowry and Crist, 1967). The main areas with historically documented groundwater-level declines are near and west of Cheyenne, in southeastern Laramie County within an area known as the Pine Bluffs lowland (includes Carpenter and Pine Bluffs areas), and near Albin (for example, Lowry and Crist, 1967; Crist and Borchert, 1972; States West Water Resources Corporation and ESA Consultants, 1990; AMEC Environment and Infrastructure, Inc., and others, 2014). In response to these declines in parts of Laramie County, special "areas" ("Control Areas") were created for increased groundwater regulation. Control Areas are special groundwater management districts established through Wyoming Statute. Control Areas may be established for various reasons, including areas where groundwater levels have declined or conflicts have occurred between water users (Wyoming Statute $\S \S 41-3-912)$. Special groundwater production permitting 
procedures apply in Groundwater Control Areas (Wyoming Statutes §§ 41-3-912 and 41-3-932).

Between 1970 and 1973, concerns regarding declining groundwater levels led to creation of two Control Areas (then known as "Critical Areas") around Carpenter and Pine Bluffs in the Pine Bluffs lowland. In late 1976, the Wyoming State Engineer's Office (WSEO) received comments from groundwater appropriators near Albin about declining groundwater levels (the State Engineer is the chief administrator of Wyoming waters). As a result, the Laramie County Control Area (LCCA) was established by the Wyoming Board of Control on September 2, 1981. The LCCA merged the former Carpenter and Pine Bluffs Control Areas and expanded the boundaries. The current (2020) configuration of the LCCA generally includes the eastern two-thirds of Laramie County from Cheyenne east to the Nebraska border, south to the Colorado border, and north to Platte and Goshen Counties. Since creation of the LCCA, groundwater levels have continued to decline locally because of water demand from high production irrigation and municipal wells (AMEC Environment and Infrastructure, Inc., and others, 2014).

Responding to concerns over increasing development and use of groundwater resources from the High Plains aquifer system in southeastern Wyoming, the State Engineer issued the "Order of the State Engineer, Laramie County Control Area" on April 1, 2015 (Wyoming State Engineer's Office, 2015). Among other restrictions, the 2015 order requires lateral and sometimes vertical spacing for new groundwater production wells within the LCCA. Because of competition for water from the High Plains aquifer system and restrictions of the 2015 order, groundwater users within the LCCA are exploring or considering exploring potential sources of groundwater supply in the Tertiary and Upper Cretaceous lithostratigraphic units/aquifers beneath the High Plains aquifer system. In addition, groundwater users within parts of the Cheyenne Basin outside of the LCCA also are exploring or considering exploring groundwater resources in these units. Increased understanding of the characteristics of and groundwater availability from these units and degree of hydraulic connection with overlying units of the High Plains aquifer system will assist management of these resources. Consequently, the U.S. Geological Survey (USGS), in cooperation with the WSEO, studied the Tertiary and Upper Cretaceous units and the overlying High Plains aquifer system at a location in the Pine Bluffs lowland of southeastern Laramie County to better understand their geologic and hydrogeologic characteristics.

\section{Purpose and Scope}

The purpose of this report is to provide a description of the geologic and hydrogeologic characteristics of Tertiary and Upper Cretaceous units at a location within the Wyoming part of the Cheyenne Basin, the northern subbasin of the greater Denver Basin in southeastern Wyoming. Drilling, coring, and geophysical logging of a deep exploratory borehole were used to characterize and interpret subsurface physical and chemical geologic characteristics at the study location ("study site"), including identification of lithostratigraphic and hydrogeologic units. Three monitoring wells were installed at the study site, each completed in a different bedrock aquifer. These three monitoring wells and two other wells elsewhere in Laramie County were sampled for an extensive suite of water-quality constituents to provide information on the overall groundwater quality of the sampled aquifers. All three monitoring wells were instrumented to collect water levels continuously to understand the variability of groundwater-level elevations (hydraulic heads) among the bedrock aquifers, as well as the degrees of vertical hydraulic connection between the aquifers and confinement (confined flow to unconfined flow condi tions) of the aquifers in the groundwater system at the study site. Groundwater-level data also were used to evaluate the poroelastic responses of the monitored formations to solid Earth tides and atmospheric loading and to estimate hydraulic properties of groundwater storage and transmission of the monitored formations. Resulting descriptions of the physical and chemical characteristics of the various lithostratigraphic/ hydrogeologic units as part of this study were evaluated in relation to characteristics described in previous studies and, combined, were used to interpret the stratigraphy and groundwater system at the study site. Interpretation of subsurface stratigraphy was extended beyond the study site through construction of a geologic cross section using geophysical logs from other wellbores in southern Laramie County. Study results also are interpreted within a broader context of equivalent lithostratigraphic/hydrogeologic units throughout the Cheyenne Basin.

\section{Description of Study Area}

The study site and broader surrounding area are described in this section of the report. Because the geologic setting and groundwater resources of the study site and surrounding area warrant substantial discussion to place the results of this study in proper context, these topics are discussed in greater detail in subsequent report sections.

\section{Geographic and Physiographic Setting}

The site selected to drill, core, and install three monitoring wells for this study is in southeastern Laramie County, about 11 miles (mi) east of the unincorporated community of Carpenter and about $11 \mathrm{mi}$ southwest of the town of Pine Bluffs (fig. 1). The populations of Carpenter and Pine Bluffs in 2010 were 94 and 1,129, respectively (U.S. Census Bureau, 2020).

Laramie County and the Cheyenne Basin include parts of the southern Rocky Mountains physiographic province (Laramie Mountains that extend along the western edge of the 

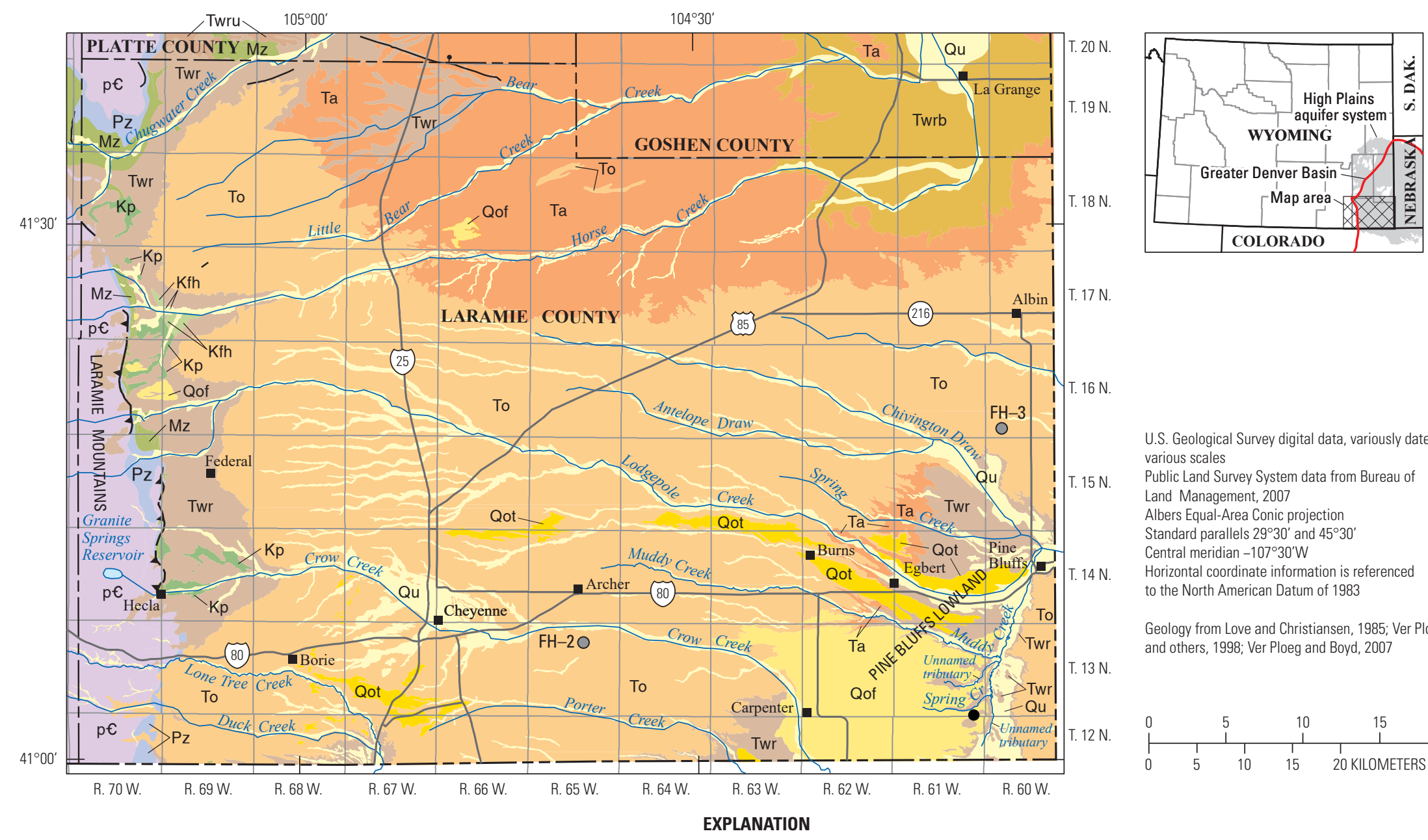

U.S. Geological Survey digital data, variously dated various scales

Public Land Survey System data from Bureau of

Land Management, 2007

Albers Equal-Area Conic projection

Standard parallels $29^{\circ} 30^{\prime}$ and $45^{\circ} 30^{\prime}$

Central meridian $-107^{\circ} 30^{\prime} \mathrm{W}$

Horizontal coordinate information is referenced

to the North American Datum of 1983

Geology from Love and Christiansen, 1985; Ver Ploeg and others, 1998; Ver Ploeg and Boyd, 2007

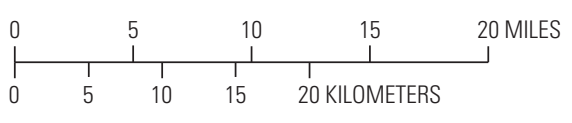

\section{Quaternary unconsolidated deposits} Holocene

Qu Alluvium, terrace deposits, and colluvium Pleistocene

Qof Older alluvial fan deposits

Qot Older terrace deposits

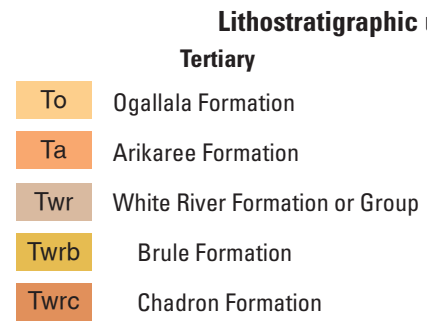

\section{Mesozoi}

KI Lance Formation

Kfh Fox Hills Sandstone

Kp

$\mathrm{Mz}$ Mesozoic sedimentary rocks (undivided) older than Pierre Shale

\section{Paleozoic and Precambrian}

$\mathrm{Pz}$ Paleozoic sedimentary rocks

pe Precambrian igneous and metamorphic rocks

- $\quad$ Fault-Bar and ball on downthrown side - $\boldsymbol{\Lambda} \boldsymbol{\Lambda}$ - Thrust fault-Sawteeth on upper plate

- Study site-Exploratory borehole LC-F1 and FH-3 monitoring wells $\mathrm{BR}-1, \mathrm{LN}-1$, and $\mathrm{FH}-1$ Fox Hills aquifer well sampled for this study

Figure 1. Location of study site and lithostratigraphic units in Laramie County, Wyoming. 
county west of the study area; fig. 1) and Great Plains physiographic province of the Interior Plains (rest of the county) as described by Fenneman and Johnson (1946). The topography of the area east of the Laramie Mountains within the Great Plains physiographic province, which is most of Laramie County and includes the southeastern parts of the county surrounding the study area, has been described as a "high eastward-sloping" and "gently rolling surface of only moderate relief" underlain by Tertiary sedimentary rocks (Lowry and Crist, 1967, p. 6). Laramie County east of the Laramie Mountains also has been described as being on a broad tableland or series of tablelands (Cheyenne tablelands) that forms part of the High Plains (physiographic feature, not aquifer system) that is underlain by the Miocene-age Ogallala Formation (fig. 1) deposited as an alluvial apron east of the Rocky Mountains (Cooley, 1991; Cooley and Crist, 1994, sheet 2; Mears, 1991). Erosion subsequent to Ogallala Formation deposition, primarily by dissection from generally eastwardflowing streams and rivers that drain the area, formed "broad gravel-capped terraces and benches and shallow valleys of moderate relief that characterize the High Plains in southeastern Wyoming" (Cooley and Crist, 1991, sheet 2).

The study site is located on a broad gently eastward and southeastward sloping alluvial fan/terrace (Rapp and others, 1953; Kirkham and Rold, 1986; Ver Ploeg, 1995; Hallberg and Case, 1998; Ver Ploeg and others, 1998) that is part of a broader lowland area in southeastern Laramie County identified by Rapp and others (1953) as the Pine Bluffs lowland (fig. 1). The Pine Bluffs lowland is a gently undulating erosional lowland that includes the lower valley of Lodgepole Creek; the lower parts of the valleys of three tributaries to Lodgepole Creek (Chivington Draw [identified as Chevington Draw in many earlier maps and publications], Muddy Creek, and Spring Creek [northwest of the town of Pine Bluffs]); and Crow Creek where it flows onto and incises into the alluvial fan/terrace that includes the study location (fig. 1; Rapp and others, 1953). All the streams draining the Pine Bluffs lowland are tributary to the South Platte River in Nebraska.

Created by former courses of eastward-flowing streams, the alluvial fan (identified as a terrace in older studies) upon which the study site is located extends from about $2 \mathrm{mi}$ west of and about $11 \mathrm{mi}$ east of Carpenter to the valley of Spring Creek and an unnamed tributary to Spring Creek (different Spring Creek than discussed previously; located in Townships 12 and 13 North [N.], and Ranges [Rs.] 60 and 61 West [W.]; fig. 1), and extends southward from Muddy Creek to as much as 4 mi south of the Wyoming-Colorado border into northeastern Colorado (not shown on fig. 1). The geographic extent of the alluvial fan/terrace in Wyoming coincides with the area shaded in yellow and identified as Quaternary older alluvial fan deposits (abbreviated as Qof) in figure 1 south of Township (T.) 14 N., east of Range (R.) 64 W., and west of Muddy Creek, Spring Creek, and an unnamed tributary to Spring Creek.

\section{Climate}

The climate in Laramie County, characteristic of the northern Great Plains, is semiarid with large temperature variations, cold winters, low precipitation, frequent winds, low humidity, and high evaporation. Mean annual precipitation (snow and rain) ranges from about 14 to 18 inches (in.) in the central and eastern parts of the county, including the study area in the Pine Bluffs lowland, to as much as 24 in. in the Laramie Mountains on the western edge of the county (JR Engineering and others, 2008, unnumbered figure, p. 4-1; period of record not identified). At Carpenter, Wyoming, the mean annual maximum temperature is 61.5 degrees Fahrenheit $\left({ }^{\circ} \mathrm{F}\right)$, mean annual temperature is $46.8^{\circ} \mathrm{F}$, and mean annual minimum temperature is $32.1^{\circ} \mathrm{F}$ (period of record is January 1, 1981, to December 31, 2010; Western Regional Climate Center, 2019). Mean annual precipitation for Carpenter, Wyo., is 14.93 in. (period of record is January 1, 1981, to December 31, 2010; Western Regional Climate Center, 2019).

\section{Land Use}

Except for small urbanized areas near Carpenter, Egbert, and Pine Bluffs, land use in the Pine Bluffs lowland is almost entirely agricultural and includes dryland and irrigated farming, pastureland, and rangeland. Dryland farming is the predominant land use on the alluvial fan/terrace upon which the study site is located, and pastureland and irrigated land are less common (U.S. Department of Agriculture, 2015). Dryland crops planted on the alluvial fan/terrace in 2014 consisted predominantly of winter wheat and much less commonly of sunflowers, oats, and millet (U.S. Department of Agriculture, 2015). Irrigated crops planted on the alluvial fan/terrace in 2014 consisted of alfalfa, corn, nonalfalfa hay, dry beans, oats, barley, and rye (U.S. Department of Agriculture, 2015). Water for crops that are irrigated on the alluvial fan/terrace is obtained from irrigation wells completed in the upper part of the High Plains aquifer system (consisting of Quaternary older alluvial fan deposits and the late Eocene to Oligocene White River Formation). Most water applied to irrigated crops is through use of large center-pivot sprinklers (Dahlgren Consulting, Inc., and others, 2018, figs. B4-11, B4-12). Within a 1-mi radius of the study site, dryland farming (winter wheat) and livestock grazing on pastureland are the predominant land uses; the study site is on pastureland.

\section{Geologic Setting of Study Area}

Geologic aspects of the study area, including structural setting and lithostratigraphic units, are described in this section of the report. The relations between the greater Denver Basin and its two subbasins, the Cheyenne Basin and the Denver Basin are described. Descriptions of lithostratigraphic 
Geologic and Hydrogeologic Characteristics, White River Formation, Lance Formation, and Fox Hills Sandstone, Wyo.

units of interest focus on the Cenozoic and Upper Cretaceous lithostratigraphic units of the Cheyenne Basin.

\section{Structural Setting}

Most of southeastern Wyoming east of the Laramie Mountains and south of the Hartville Uplift, including the Pine Bluffs lowland area, is within part of a large (multistate), asymmetric structural (synclinal or bowl-shaped depression) and sedimentary basin filled with layered sedimentary rocks known as the Denver Basin, Denver-Julesburg Basin (commonly abbreviated to "DJ Basin"), or Denver-Cheyenne Basin (fig. 2). The Denver Basin is divided into two subbasins in many studies (explained later in this report section), and when subdivided, the southernmost subbasin also is identified as the Denver Basin. To prevent confusion, in this report, the word "greater" is placed before "Denver" hereinafter whenever referencing the entire structural basin (greater Denver Basin) to differentiate it from the smaller subbasin (Denver Basin). The boundary of the greater Denver Basin is broadly defined by surrounding tectonic structures - on the south by the Apishapa uplift in Colorado, on the southwest by the Wet Mountains in Colorado, on the west by the Front Range in Colorado and Laramie Mountains in Wyoming, on the northwest by the Hartville Uplift in Wyoming, on the north by the Black Hills uplift in Wyoming and South Dakota, on the northeast by the Chadron and Cambridge arches in Nebraska (or alternatively, grouped together and identified as the Chadron-Cambridge arch or simply as the Cambridge arch), on the east by gentle onlap onto the stable midcontinent craton, and on the southeast by the Las Animas arch in southern Colorado (fig. 2; Anderman and Ackman, 1963; Martin, 1965; Tweto, 1975; Sonnenberg and Weimer, 1981; Sonnenberg, 1985; Weimer, 1996). Curtis (1988, p. 182) noted the unique asymmetry of the structural basin, observing that the "basin is unusual because its western flank involves Cordilleran foreland structure, whereas its eastern border is structurally similar to the stable craton of the midcontinent." Geographic extent of the greater Denver Basin within the region bordered by the surrounding tectonic structures is defined imprecisely and differs among many studies because the basin has no well-defined eastern structural boundary where it meets the adjacent midcontinent craton/ platform (for example, Kirkham and Ladwig, 1980; Curtis, 1988; Weimer, 1996). Nevertheless, all studies document the basin encompassing parts of at least three States (southeastern Wyoming, northeastern Colorado, and southwestern Nebraska), although the area within each State included as part of the basin may differ among studies. Many studies also extend the basin into a small part of northwestern Kansas (fig. 2; for example, Matuszczak, 1973; Curtis, 1988); consequently, estimates of the areal extent of the greater Denver Basin vary among studies, generally ranging from 50,000 to 70,000 square miles $\left(\mathrm{mi}^{2}\right)$.

Although the greater Denver Basin inherited structural trends from the development and subsequent erosion of the ancestral Rocky Mountains in the Paleozoic, the present-day structural configuration was formed largely because of deformation associated with the Laramide orogeny (Anderman and Ackman, 1963; Tweto, 1975, 1980; Sonnenberg and Weimer, 1981; Dickinson and others, 1988; Snoke, 1993; Weimer, 1996). In the Jurassic and Cretaceous, the Rocky Mountain area, including the greater Denver Basin area, was at or near sea level (Dickinson and others, 1988; Snoke, 1993; Weimer, 1996). The Laramide orogeny fragmented the Rocky Mountain area into a series of basement-cored uplifts and local adjacent peripheral downwarped/subsided basins beginning in the Late Cretaceous (Maastrichtian) and ending in early Tertiary (early to middle Eocene) time (Dickinson and others, 1988; Snoke, 1993). Clastic sediments eroded from the uplifts accumulated in the peripheral basins. Low-angle subduction of the Farallon oceanic plate beneath the North American continental plate along the western United States generally is accepted as the cause of the Laramide orogeny, but the mechanism of crustal deformation in response to the subduction during the period of the orogeny remains controversial (for example, Gao, 2017).

The greater Denver Basin is an example of a peripheral basin produced by the Laramide orogeny. It is a foreland basin formed by compressional downwarping and associated basinal subsidence/sedimentary accumulation that occurred simultaneously with uplift and erosion of the Front Range and Laramie Mountains of the southern Rocky Mountains. The Laramie Mountains and Front Range bordering the western greater Denver Basin have been uplifted relative to the Great Plains during the Laramide orogeny; these uplifts are attributed at least in part to horizontal compressive forces via basement shortening on a series of thrust and reverse faults along the sides of both uplifts (Johnson and Smithson, 1985; Blackstone, 1996; Karlstrom and others, 2005). The Laramie Mountains bordering the greater Denver Basin to the west in Wyoming are a northern extension of the Colorado Front Range. Blackstone (1996) described the Laramie Mountains as a large, vaulted, eastward verging, doubly plunging asymmetric foreland uplift with Archean and Proterozoic crystalline rocks exposed in the core. Much of the greater Denver Basin Laramide-age sediments and topography subsequently were eroded (Scott, 1975; Weimer, 1996; Raynolds, 2002; Raynolds and Johnson, 2003).

Two post-Laramide tectonic events affected the southern Rocky Mountains area during the middle to late Cenozoic, including the Laramie Mountains/Front Range and the Great Plains areas constituting the greater Denver Basin-(1) regional tilting of the southern Rocky Mountains/ Great Plains area during the middle Cenozoic (middle to late Miocene), possibly because of subduction-related dynamic mantle rebound, and (2) regional epeirogenic uplift of the Rocky Mountain region/Great Plains beginning in the late Tertiary (middle to late Miocene/early Pliocene) and continuing through to the Quaternary or present time (interpreted beginning and ending time differs among studies). The first event led to erosion of the Laramie Mountains/Front Range and 


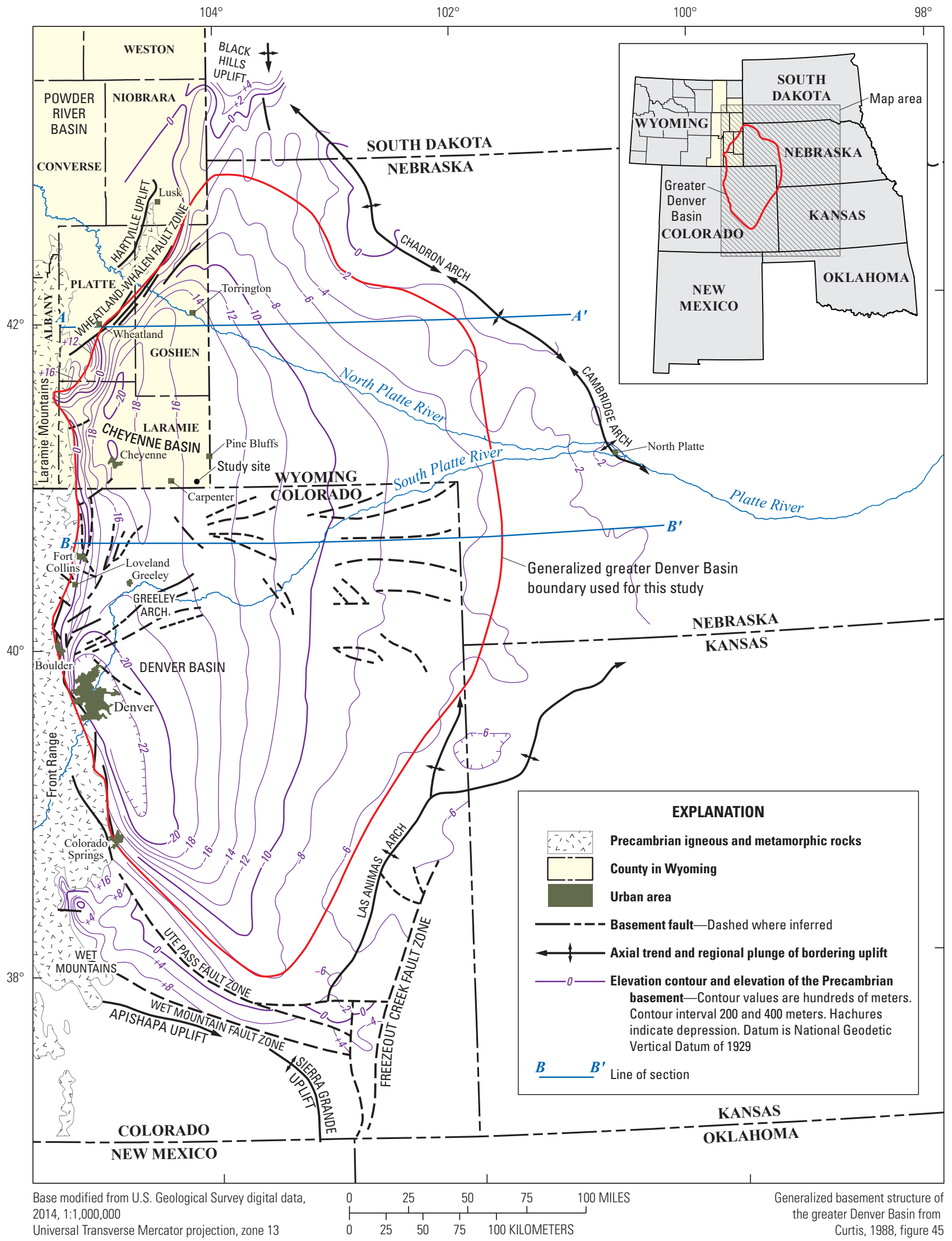

Figure 2. Location and generalized basement structure of the greater Denver Basin, Wyoming, Nebraska, Colorado, and Kansas. 
Geologic and Hydrogeologic Characteristics, White River Formation, Lance Formation, and Fox Hills Sandstone, Wyo.

deposition of the resulting eroded sediments (as the cut-andfill deposits of the Ogallala Formation), and the second event ended deposition of the Ogallala Formation and reactivated drainage networks across the area, resulting in widespread downcutting and erosion of the Tertiary sedimentary fill of the greater Denver Basin and ultimately, the present-day topography (Izett, 1975; Trimble, 1980; Steven and others, 1997; Raynolds, 2002; McMillan and others, 2002, 2006; Heller and others, 2003; Raynolds and Johnson, 2003; Chapin, 2008; Cather and others, 2012; Duller and others, 2012; Karlstrom and others, 2012; Liu, 2015).

Configuration of the greater Denver Basin structure in southeastern Wyoming and northeastern Colorado is shown by a generalized map of the Precambrian basement underlying all Phanerozoic sedimentary rocks and two corresponding cross sections (Curtis, 1988, figs. 45 and 46; reproduced herein as fig. $3 A, B$ ). Contours on the Precambrian basement (fig. 2) and both cross sections (fig. $3 A, B$ ) show the greater Denver Basin is highly asymmetric, with the basin trough (deepest parts of the basin; assumed to be approximately equivalent to the location of the synclinal axis) generally near and parallel to the geologic structures bordering the southwestern, western, and northwestern basin margins. Throughout much of Colorado and Wyoming, the basin trough generally trends north-south and parallel to much of the lengths of the Front Range and Laramie Mountains in Colorado and Wyoming, respectively, and is northeast trending near the Hartville uplift and Wheatland-Whalen fault system in Wyoming (fig. 2). Pre-Tertiary sedimentary rocks in the western flank near the mountain fronts dip moderately to steeply eastward toward the basin axis and are commonly complexly faulted (fig. $3 A, B$ ), and in some places overturned (also see Blackstone [1996] for many cross sections along the western and northwestern flanks of the basin in Wyoming), whereas rocks in the areally extensive eastern flank gently dip westward from the bordering eastern margin structures (Chadron-Cambridge and Las Animas arches) toward the basin axis over a broad area (fig. $3 A, B$ ). In Wyoming, the deepest part of the greater Denver Basin is near the city of Cheyenne and areas to the north (fig. 2).

As noted previously, many studies divide the greater Denver Basin into northern and southern subbasins (Cheyenne and Denver Basins, respectively). Identification of which parts of the greater Denver Basin constitute the two subbasins differs among studies/publications. Many studies simply include the entire areal extent of the greater Denver Basin north of a geologic structure (Greeley arch; location approximated in fig. 2) within the Cheyenne Basin and the entire areal extent of the basin to the south within the Denver Basin (for example, Dechesne and others, 2011a, b), and that interpretation is used herein. Alternatively, some greater Denver Basin studies, especially those with an emphasis on evaluation of the groundwater or energy resources (primarily coal and uranium) contained in Tertiary and Late Cretaceous rocks younger than the Pierre Shale, divide the larger structural basin or parts of the basin into two smaller "nested" subbasins (for example, Romero, 1976; Kirkham and Ladwig, 1979, 1980; Robson, 1987, 1989;
Robson and Banta, 1987; Paschke, 2011; Jehn-Dellaport and Renninger, 2017). As defined by Kirkham and Ladwig (1979, p. 13), each subbasin (Cheyenne or Denver Basin) coincides with a structural depression in Cretaceous rocks described as "distinct, doubly plunging synclines within the larger DenverCheyenne Basin [greater Denver Basin]." The areal extent of the two subbasins in these studies generally coincides with the areal extent of the base of the Fox Hills Sandstone and most overlying strata (areal extent of Fox Hills Sandstone and Lance/Laramie Formation shown on figure 4 [Lance Formation in southeastern Wyoming is stratigraphically equivalent to Laramie Formation in northeastern Colorado]; for example, Romero, 1976; Kirkham and Ladwig, 1979, 1980; Robson and others, 1981; Robson, 1987, 1989; Robson and Banta, 1987; Paschke, 2011; Jehn-Dellaport and Renninger, 2017). As described by Robson (1987, p. 7), "these formations occur in a sequence of layers that form an ellipsoidal, bowl-shaped groundwater basin having structural features similar to those in the underlying structural depression."

Separating the Cheyenne and Denver Basins, the Greeley arch is an east-trending, intrabasin structural high (saddle) extending from near Loveland or Fort Collins where it is poorly defined to Greeley (location approximated in fig. 2; north-south cross section through arch shown on fig. $5 \mathrm{~A}$; Kirkham and Ladwig, 1979, 1980). Some studies have indicated that the two subbasins were separated before development of the arch (Kirkham and Ladwig, 1979, 1980), and thus, depositional environments in the two subbasins differed. More recent study (Wilson and others, 2010) indicated the two subbasins likely became separated from each other only after formation of the Greeley arch, which must have occurred during or after the onset of the Laramide orogeny. Stratigraphic evidence indicates that there was about $1,000 \mathrm{ft}$ of structural relief on the Greeley arch relative to the adjacent Denver and Cheyenne Basins. A thick (1,800-4,700 ft) section of Upper Cretaceous through Eocene strata (identified as consisting of the Arapahoe Formation, Denver Formation, Dawson Arkose, and Castle Rock Conglomerate) present in the southern subbasin (Denver Basin) is absent north of the Greeley arch (Cheyenne Basin) because of erosion or nondeposition (fig. 5A, $B$ ). The Laramie and Lance Formations north of the arch are unconformably overlain by the Eocene and Oligocene White River Formation, whereas south of the arch, the formations are unconformably overlain by the Upper Cretaceous Arapahoe Formation or by equivalent strata included in the D1 synorogenic sequence of Raynolds (1997, 2002; fig. 5A, B). The entire sequence of rocks overlying the Pierre Shale in the Denver Basin (Laramie Formation to Dawson Arkose, or alternatively, to the top of the D2 synorogenic sequence) compose an important aquifer system (Denver Basin aquifer system; fig. $5 B$ ) that is one of the primary sources of freshwater for the entire basin (Romero, 1976; Robson, 1987, 1989; Paschke and others, 2011). Similarly, part of the sequence of Upper Cretaceous rocks overlying the Pierre Shale in the Cheyenne Basin in northeastern Colorado has been considered to compose an equivalent aquifer system (Robson and Banta, 1987), although 

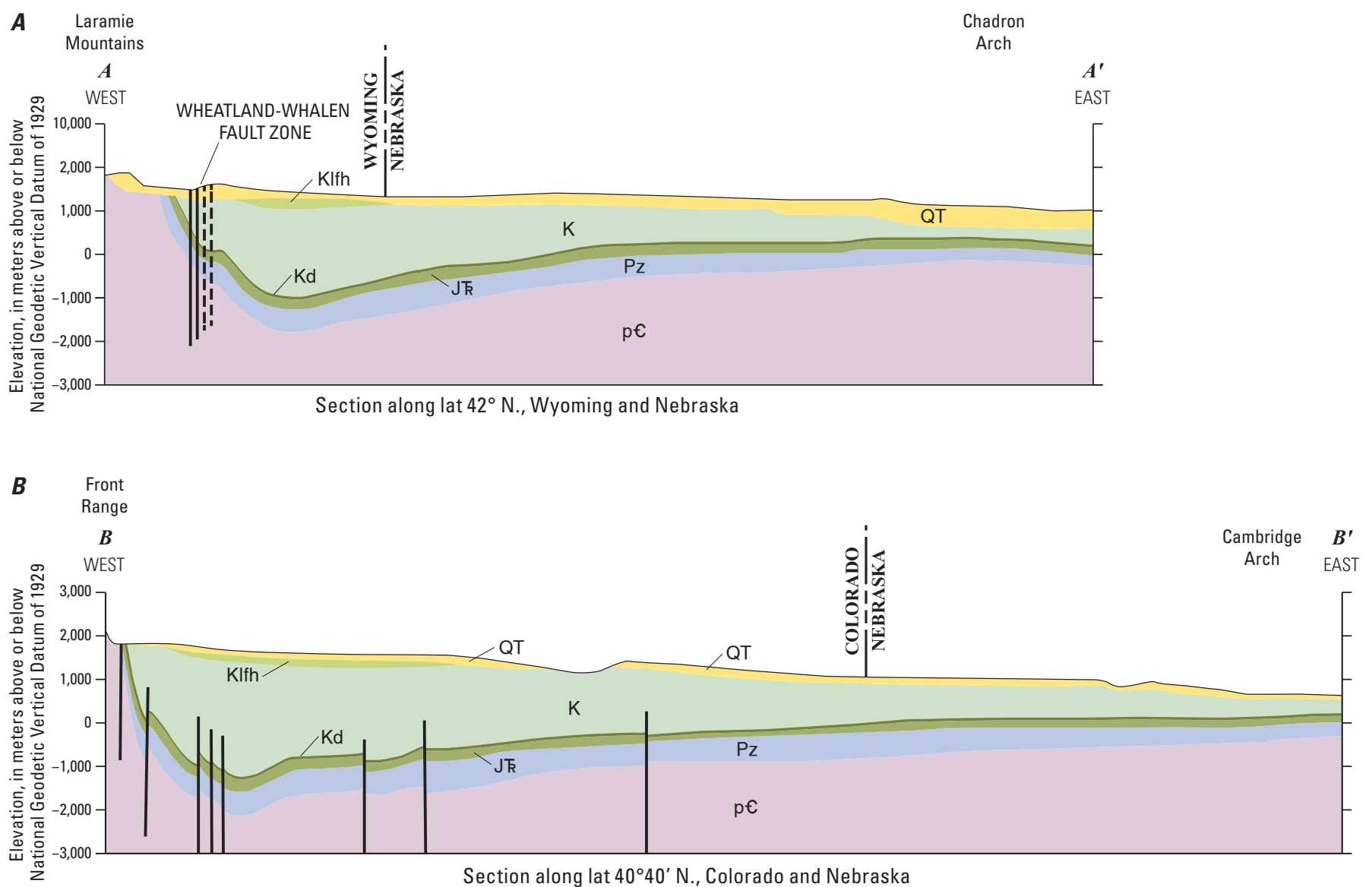

Section along lat $40^{\circ} 40^{\prime} \mathrm{N}$. , Colorado and Nebraska

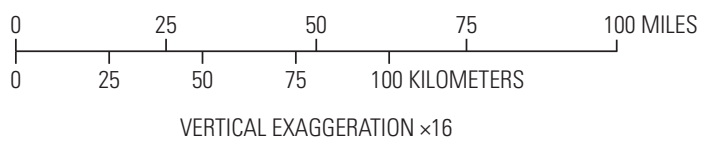

\section{EXPLANATION}

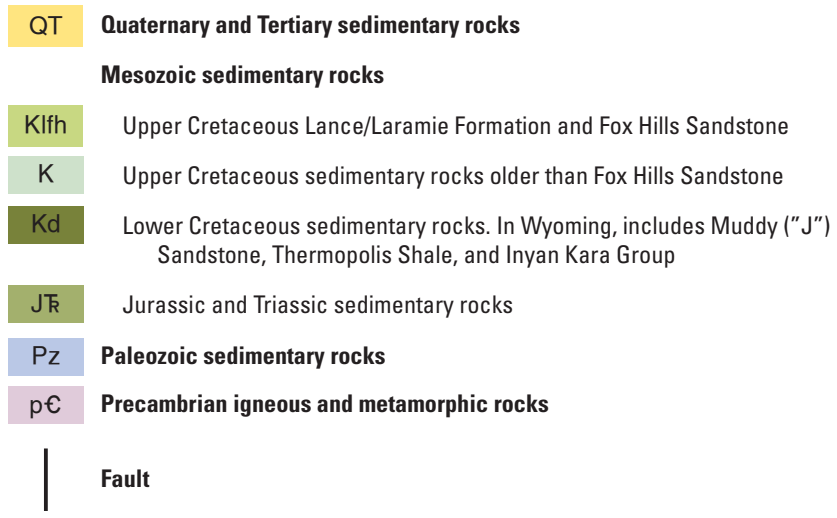

Figure 3. Cross sections through the northern subbasin (Cheyenne Basin) of the greater Denver Basin, Wyoming and Colorado (modified from Curtis, 1988, figures 45 and 46). $A$, cross section along lat $42^{\circ} \mathrm{N}$. , Wyoming and Nebraska; $B$, cross section along lat $40^{\circ} 40^{\prime} \mathrm{N}$., Colorado and Nebraska. Lines of section shown in figure 2. 

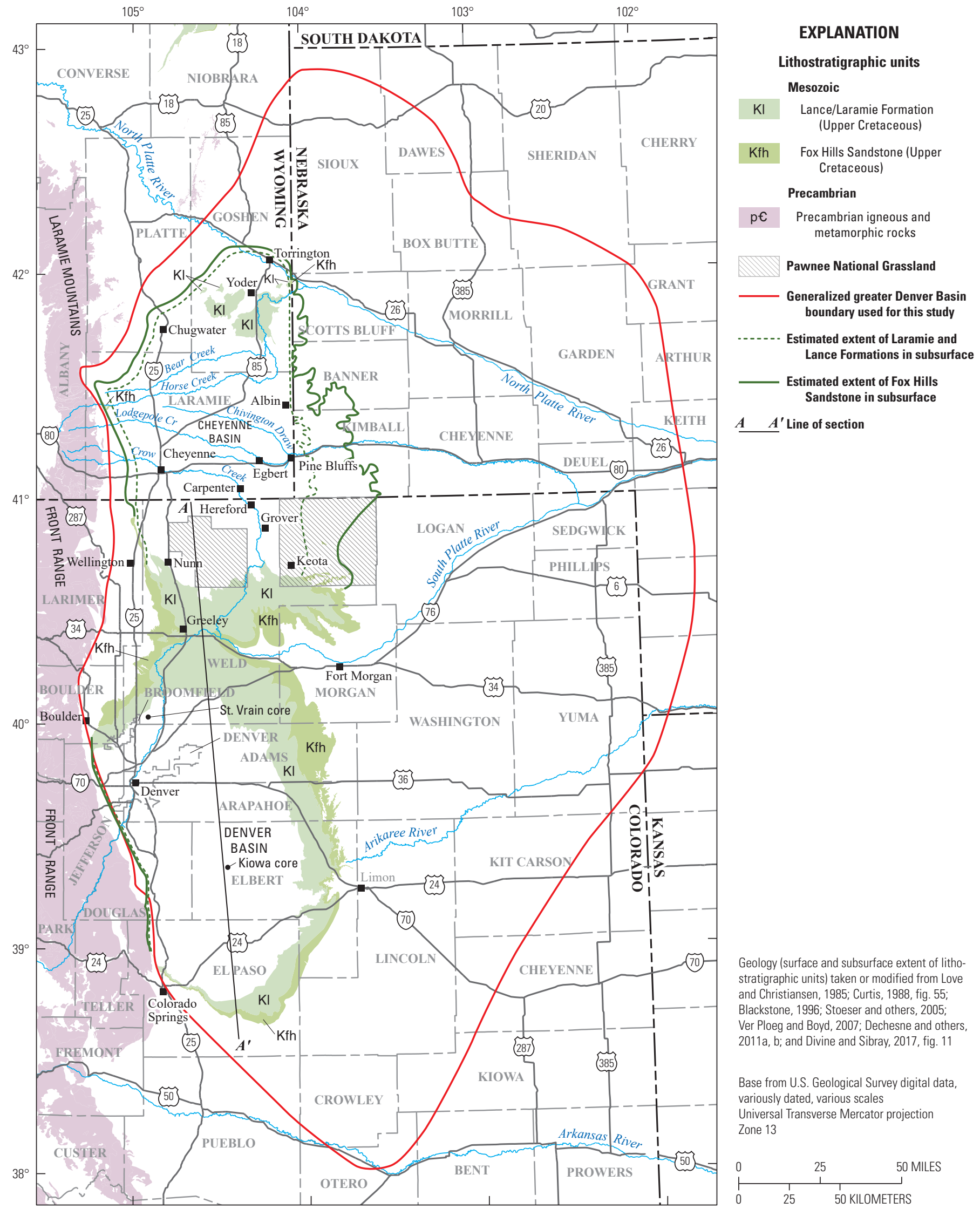

Geology (surface and subsurface extent of lithostratigraphic units) taken or modified from Love and Christiansen, 1985; Curtis, 1988, fig. 55; Blackstone, 1996; Stoeser and others, 2005; Ver Ploeg and Boyd, 2007; Dechesne and others, 2011a, b; and Divine and Sibray, 2017, fig. 11

Base from U.S. Geological Survey digital data, variously dated, various scales

Universal Transverse Mercator projection Zone 13

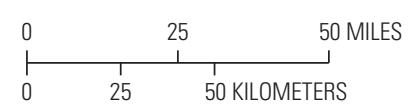

Figure 4. Estimated surface and subsurface extent of the Upper Cretaceous Lance/Laramie Formation and Fox Hills Sandstone, southeastern Wyoming, southwestern Nebraska, and northeastern Colorado. 


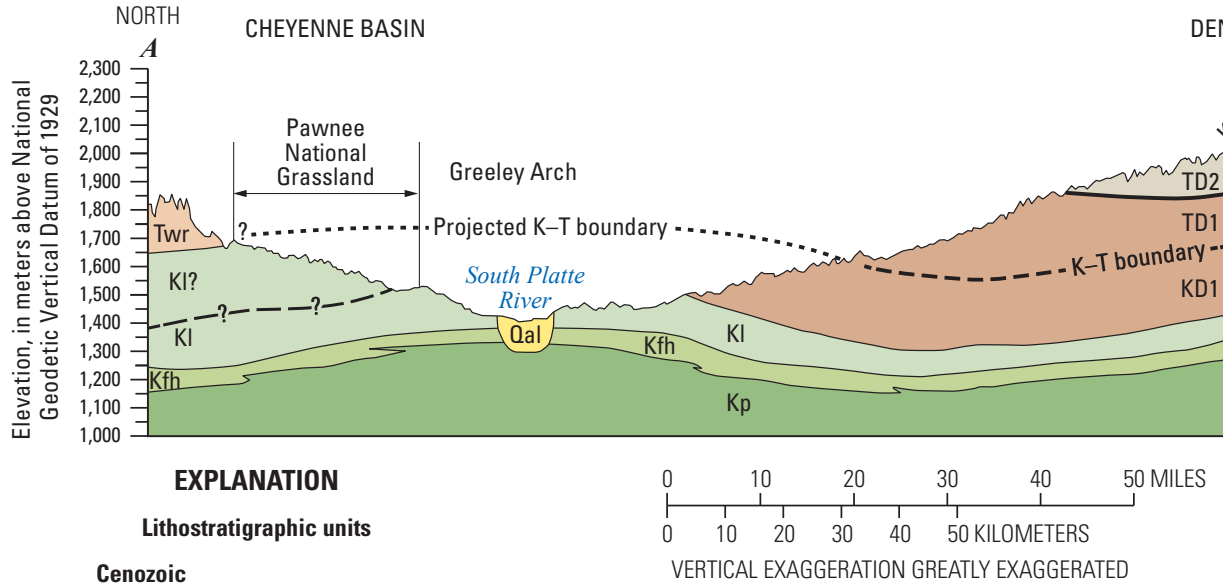

DENVER BASIN

Cenozoic

VERTICAL EXAGGERATION GREATLY EXAGGERATED

EXPLANATION

K-T Cretaceous-Tertiary (Paleogene

\section{Qal \\ CRcgl \\ Twr \\ TD2}

$\begin{array}{cl}\text { KI } & \text { Laramie Formation } \\ \text { Kfh } & \text { Fox Hills Sandstone } \\ \text { Kp } & \text { Pierre Shale }\end{array}$
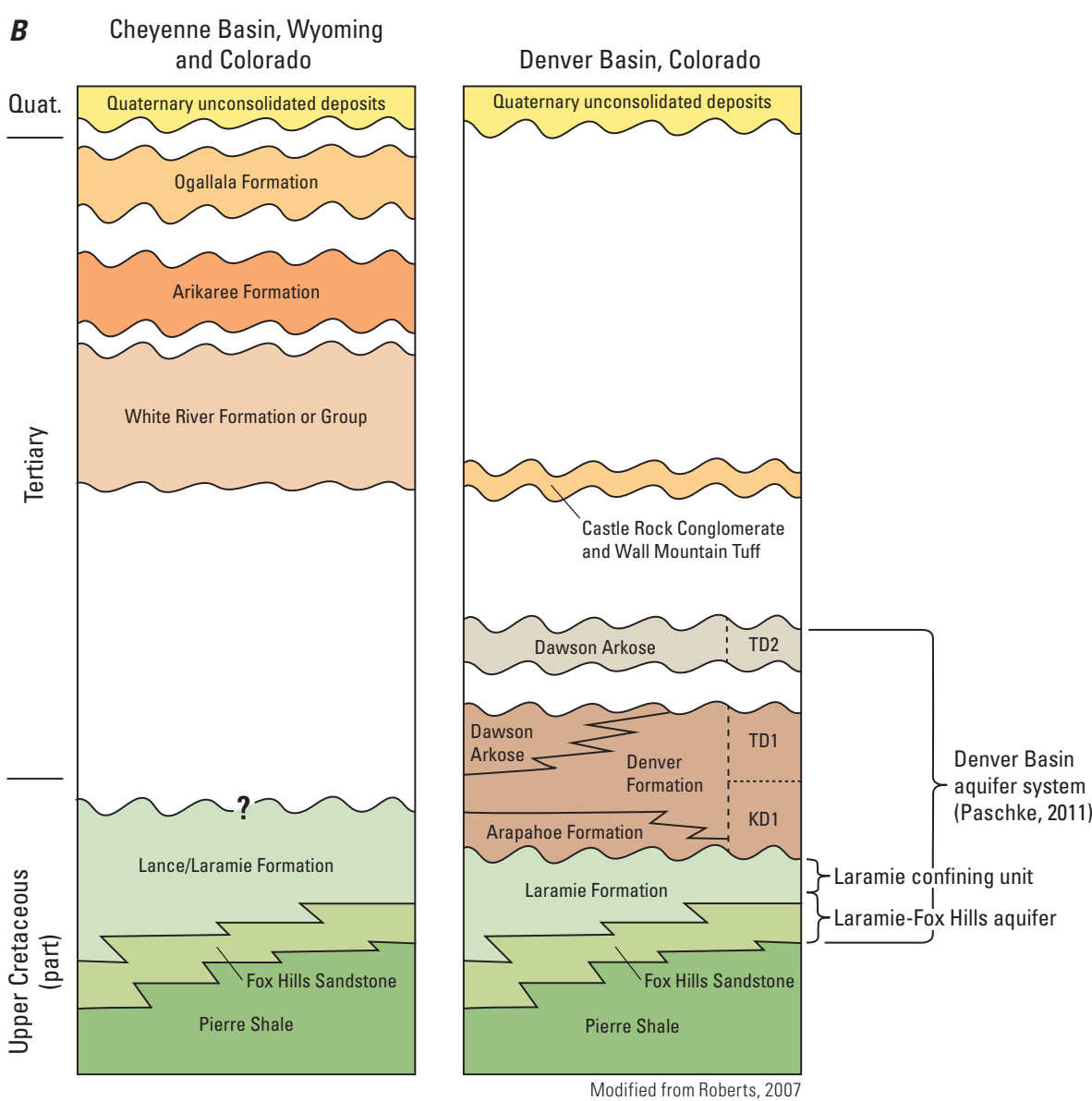

Greater Denver Basin, Colorado and Wyoming

EXPLANATION

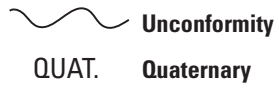

Figure 5. Cross section and comparison of lithostratigraphic units for the Cheyenne and Denver Basins. $A$, north-south cross section through the Cheyenne and Denver Basins, northeastern Colorado; $B$, comparison of Upper Cretaceous and Tertiary lithostratigraphic units in the Cheyenne Basin, southeastern Wyoming and northeastern Colorado, with the Denver Basin, northeastern Colorado. Line of section shown in figure 4. 
because only the lower part of the section is preserved, aquifer qualities will resemble the Laramie-Fox Hills aquifer (fig. $5 \mathrm{~A}$, $B$; also see "Groundwater Resources in Study Area" report section).

The Wyoming part of the greater Denver Basin of interest for this study, including Laramie County and the Pine Bluffs lowland study area, is in the Cheyenne Basin (figs. 2, 4). As described previously, the northern greater Denver Basin ("Cheyenne Basin" hereinafter) boundary in Wyoming is generally defined by the Hartville uplift, a geologic structure that separates the Cheyenne Basin from another structural basin (Powder River Basin; fig. 2). Droullard (1963) reported that as much as $12,000 \mathrm{ft}$ of structural relief occurs between the Hartville uplift and the trough of the Cheyenne Basin. In practice, the northern boundary of the Cheyenne Basin in Wyoming usually is placed at or near the Wheatland-Whalen fault zone (for example, Blackstone, 1996), and that convention is used herein (fig. 2). This fault zone disrupts lithostratigraphic unit/ aquifer continuity between the Hartville uplift and the Cheyenne Basin (Blackstone, 1996). In Laramie County, the Cheyenne Basin trough (approximately equivalent to basin axis) is near the city of Cheyenne and is generally oriented northsouth and parallel to the north-south-trending Laramie Mountains (fig. 2). Contours showing elevation of the Precambrian basement in the Cheyenne Basin in Wyoming indicate basin depth is greatest in western Laramie County, near Cheyenne (fig. 2), where more than 12,000 ft of Phanerozoic sedimentary rocks (Devonian to Quaternary age) overlie Precambrian basement rocks (Kirkham and Ladwig, 1979, 1980; Curtis, 1988, fig. 45; Love and others, 1993; Blackstone, 1996). Along the western basin margin near the eastern flank of the Laramie Mountains, Late Cretaceous and older sedimentary rocks are upturned moderately to steeply, or are faulted or folded, but the unconformably overlying Tertiary rocks (late Eocene-early Oligocene-age White River Formation or Group and Mioceneage Ogallala Formation) are nearly flat or upturned gently near the mountains (Morgan, 1946; Brady, 1949; Hammond, 1949; Haun, 1949; Cooley and Crist, 1981, 1994, sheet 1, fig. 4; Copland, 1984; Wiersma,1989; Blackstone, 1996; Lidstone and Associates, Inc., 2012). This configuration is illustrated by east-west cross sections constructed for the Cheyenne Basin in Wyoming, north of Laramie County in Platte and Goshen Counties and continuing eastward into Nebraska (fig. $3 A$ ) and south of the county in northeastern Colorado and continuing eastward into southwestern Nebraska (fig. 3B).

\section{Description of Lithostratigraphic Units}

Lithostratigraphic units of interest are identified and described in this section of the report.

\section{Units of Interest}

The units of interest are the lithostratigraphic units that are known or are likely to contain sufficient saturated deposits that provide or potentially can provide freshwater for nonindustrial uses such as irrigation and drinking water and industrial uses such as petroleum exploration and development. In this report, units are referred to as lithostratigraphic units for discussions of lithology, geology, and structure, whereas units are referred to as hydrogeologic units (or aquifers) for discussions of groundwater resources, hydrogeologic characteristics, and aquifer properties.

Thousands of feet of Phanerozoic sedimentary bedrock ranging from Cenozoic to Paleozoic in age overlie the Precambrian basement of the Cheyenne Basin (Love and others, 1993, column M; Blackstone, 1996; Wyoming Geological Association, 2014, column 18). Surficial unconsolidated deposits of Quaternary age locally overlie the Phanerozoic bedrock, primarily within and along the various surface drainages in the basin (Love and Christiansen, 1985; Ver Ploeg, 1995; Ver Ploeg and others, 1998; McLaughlin and Harris, 2005; Ver Ploeg and Boyd, 2007; McLaughlin and others, 2011). The lithostratigraphic and hydrogeologic units of interest for this study include terrestrial (nonmarine) Cenozoic and nonmarine, transitional marine, and marine Upper Cretaceous units (Quaternary unconsolidated deposits through Fox Hills Sandstone; fig. 6A). These strata occupy the part of the Cheyenne Basin located above thousands of feet of primarily fine-grained marine strata deposited in the Western Interior Seaway during Late Cretaceous time (Pierre Shale; fig. 6A). Based on available data, the Pierre Shale is unlikely to yield water of sufficient quantity and (or) quality for most uses in Wyoming, especially at economical drilling depths; thus, the top of the Pierre Shale chiefly defines the lower stratigraphic limit of freshwater-bearing lithostratigraphic units/aquifers in the Cheyenne Basin in Wyoming for nonindustrial and industrial (hydrocarbon exploration and development) uses (Libra and others, 1981; Dahlgren Consulting, Inc., and others, 2005; Bartos and others, 2013). Consequently, except for some older Paleozoic units with scanty outcrop/subcrop adjacent to the Laramie Mountains (Casper Formation; Lidstone and Associates, Inc., 2012), aquifers in Cenozoic (Quaternary and Tertiary) and Upper Cretaceous lithostratigraphic units above the Pierre Shale are the primary sources or potential sources of groundwater in most of the Cheyenne Basin in Wyoming. Parts of these units are known to contain aquifers at economical drilling depths capable of producing groundwater of sufficient quantity and quality for many uses, although waterbearing characteristics are highly spatially variable (Libra and others, 1981; Bartos and others, 2013).

Cenozoic and Upper Cretaceous lithostratigraphic units above the Pierre Shale known to contain aquifers include, from youngest to oldest, various types of Quaternary unconsolidated deposits; Tertiary White River Formation or Group, Arikaree Formation, and Ogallala Formation; and the Upper Cretaceous Lance Formation and Fox Hills Sandstone (lithostratigraphic units shown in fig. 6A). Aquifers in these lithostratigraphic units commonly contain freshwaters (dissolved-solids concentration less than 1,000 milligrams per liter $[\mathrm{mg} / \mathrm{L}]$ ) and supply most of the groundwater used in the 


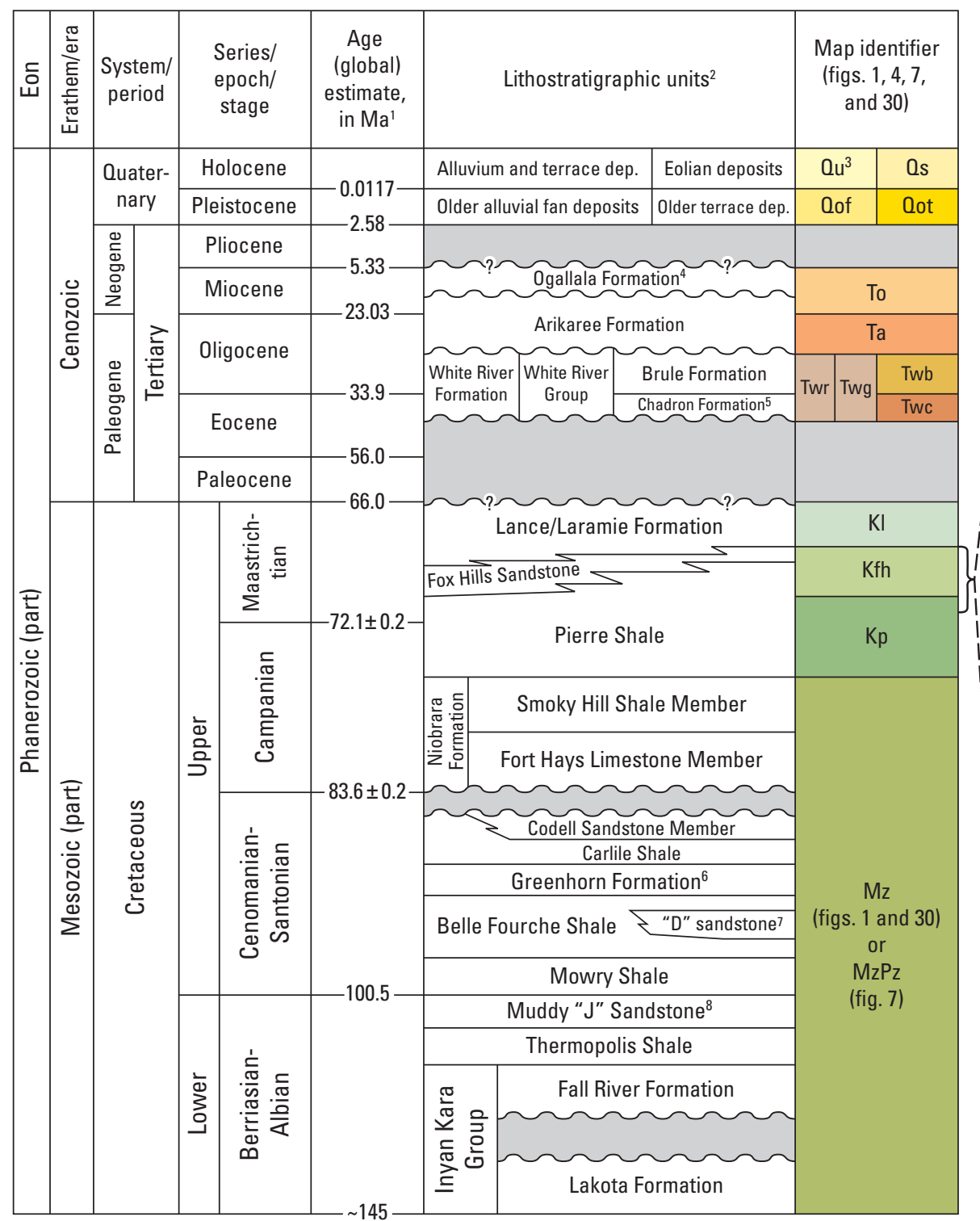

Diagram is not to scale relative to geologic time and stratigraphic thickness.
B

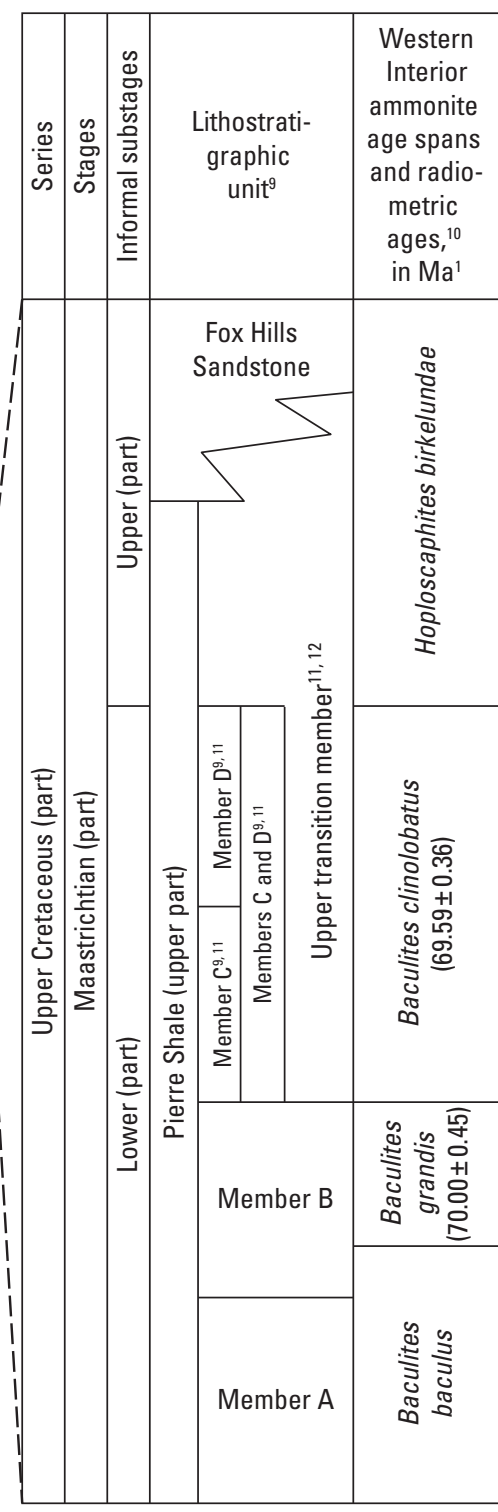

EXPLANATION

[ \pm , plus or minus; $\sim$, approximately]
Rocks absent because of erosion or nondeposition

\section{$\sim$ Unconformity}

'Global age estimates of boundaries in mega-annum ( $\mathrm{Ma}$, million years) before present. Age estimates are boundary estimates from the International Commission on Stratigraphy (Cohen and others, 2018).

2Lithostratigraphic units are from or modified from McGrew (1963); Love and Christiansen (1985); Lillegraven (1993); Love and others (1993), Ver Ploeg and others (19s8), Ver Ploeg and Boyd (201); andian

${ }^{3}$ " $\mathrm{Ou}$ " consists of Quaternary alluvium, terrace deposits, and colluvium in figs. 1 and 30 . Unit consists of all Quaternary unconsolidated deposits except for Quaternary (Pleistocene) older alluvial fan deposits (identified as Qof) in figs. 1 and 7. ${ }^{4}$ Some studies/stratigraphic charts consider age of the ${ }^{4}$ Some studies/stratigraphic charts consider age of the Wyallala Formation in Cheyenne Basin of southeastern Wyoming to range from Miocene to early Pliocene (for
example, Wyoming Geological Association, 2014, column 18). Includes the "Yoder beds"/"Yoder Formation" of Schlaikjer (1935b) and Kihm (1987). The "Yoder beds" are "areally restricted within a few miles of Yoder and Veteran, Wyoming, area (Goshen Hole) within a paleovalley found in the underlying Cretaceous Lance Formation" (Terry, 1998, p. 32). ${ }^{6}$ Also known as Greenhorn Limestone (Wyoming Geological Association, 2014).

7Informal economic subsurface stratigraphic term widely used by the oil and gas exploration and development industry (Higley and Cox, 2007).

${ }^{8}$ " $\mathrm{Jl}$ sandstone is an informal economic subsurface stratigraphic term (Colorado terminology) widely used by the oil and gas exploration and development industry to identify the Muddy Sandstone (formal stratigraphic term) in the subsurface (Love and others, 1993, reference citation 52; Higley and Cox, 2007).

Informal divisions and subdivisions of upper part of the Pierre Shale from Kiteley $(1976,1977,1978)$. Assignment of Kiteley's upper Pierre Shale divisions and subdivisions to lower and upper Maastrichtian substages inferred from Landman and Cobban (2003) and Merewether and others (2011).

${ }^{10}$ Western Interior ammonite age spans and radiometric ages are from Merero

"Kiteley $(1976,1977,1978)$ correlated her informal "members C and D" and all overlying unnamed Pierre Shale strata to the transitional uppermost part of the Pierre Shale assigned different names by various investigators, including "transitio "upper transition zone," or "upper transition member" herein; see discussion in text).

12The transitional nature of the contact between the upper Pierre Shale and the Fox Hills Sandstone in the greater discussion by Landman and Cobban, 2003).

Figure 6. Lithostratigraphic units and informal subdivisions of the Cheyenne Basin. $A$, Cenozoic and Cretaceous lithostratigraphic units of the Cheyenne Basin, Wyoming;

$B$, informal subdivisions of the upper part of the Pierre Shale and Fox Hills Sandstone in relation to Western Interior ammonite age spans and radiometric ages, Cheyenne Basin, Wyoming and northeastern Colorado. 
Cheyenne Basin in Wyoming, although most produced to date $(2020)$ is from aquifers in the Cenozoic units (Bartos and others, 2013; Taucher and others, 2013). The water-bearing characteristics of the Cenozoic lithostratigraphic units containing aquifers generally are well understood because all have been explored and developed extensively throughout much of the Cheyenne Basin. In contrast, exploration and development of Upper Cretaceous lithostratigraphic units as sources of water supply have been meager to date (2020) because water of sufficient quantity and generally excellent quality can be obtained throughout much of the Cheyenne Basin from the shallower and widely exposed aquifers in the Cenozoic lithostratigraphic units; consequently, the water-bearing characteristics of these units are poorly known and largely unexplored throughout most of the Cheyenne Basin, providing impetus for this study. The geologic characteristics of these lithostratigraphic units of interest, and the underlying Pierre Shale, are described in this report section, whereas groundwater resources in these units are described in the next report section ("Groundwater Resources in Study Area").

\section{Cenozoic Lithostratigraphic Units}

Alternating episodes of erosion and fluvial (stream-laid) and eolian (windborne) deposition created the sedimentary strata composing the Cenozoic (Quaternary and Tertiary) lithostratigraphic units in the Cheyenne Basin, including the Pine Bluffs lowland and adjacent areas. Cenozoic-age lithostratigraphic units in the Cheyenne Basin consist of various types of surficial unconsolidated deposits of Quaternary age (Quaternary unconsolidated deposits) and mostly flatlying (dips typically less than 3 degrees [ $\left.{ }^{\circ}\right]$; Ver Ploeg, 1995) sedimentary bedrock of Tertiary age. Tertiary sedimentary rocks range from late Eocene to Miocene (possibly Pliocene) in age (fig. 6A; Swinehart and others, 1985; Lillegraven, 1993; Swinehart and Diffendal, 1997; LaGarry, 1998; Prothero and Whittlesey, 1998; Terry, 1998). Older Tertiary (pre-late Eocene) rocks are absent from the Cheyenne Basin in southeastern Wyoming and northeastern Colorado largely because of earlier Cenozoic erosion (Lillegraven and Ostresh, 1988; Lillegraven, 1993; Condon, 2005; Cather and others, 2012).

Quaternary-age unconsolidated deposits consist of poorly consolidated mixtures of silt, clay, sand, and gravel, of generally local/modest areal extent in the Cheyenne Basin (fig. 7). In contrast, the Tertiary-age lithostratigraphic units are widely exposed throughout the Cheyenne Basin and much of the rest of southeastern Wyoming or are locally buried (subcrop) below various Quaternary unconsolidated deposits of slight extent (fig. 7). Tertiary strata consist largely of semiconsolidated to consolidated mudrocks (siltstone, mudstone, and claystone), sandstones, and conglomerates deposited in different paleoenvironments. Rocks composing the Tertiary units commonly are volcaniclastic, reflecting sediment (pyroclastic material) contribution by distant (outside Wyoming) regional volcanic activity in the western United States. Volcaniclastic rocks are "composed in part, of, or entirely of volcanic fragments," and this includes "the entire spectrum of volcanic rocks formed by any mechanism or origin, and placed in any physiographic environment (on land, underwater or under ice) or mixed with any other volcaniclastic type or with any nonvolcanic fragment types in any proportion" (Fischer, 1966, p. 289-290). Sediments composing the volcaniclastic rocks in the Cheyenne Basin were derived largely from pyroclastic material (sediment/fragments produced by a volcanic process; Fischer, 1966), and these Tertiary rocks also are commonly described as and considered equivalent to "tuffaceous" or "vitric" in many geologic publications (Denson and Bergendahl, 1961; Stanley, 1976; Swinehart and others, 1985; Bartos and others, 2014).

Tertiary (Paleogene and Neogene) strata in the Cheyenne Basin can be divided into two broadly defined groups: (1) a younger, coarser grained and more heterogeneous group of Miocene (and possibly younger) rocks composed mostly of sedimentary rocks such as sandstone and conglomerate deposited by streams (fluvial/alluvial origin), assigned to the Ogallala Formation, and (2) an older, more homogenous group composed largely of very fine- to fine-grained volcaniclastic rocks of eolian and fluvial origin, assigned to the Oligoceneand Miocene-age Arikaree Formation, and the late Eocene- to Oligocene-age White River Formation or Group (figs. 6, 7) (Denson and Bergendahl, 1961; Denson and Chisholm, 1971; Bart, 1974, 1975; Stanley, 1976; Diffendal, 1982; Hunt, 1985, 1990; Swinehart and others, 1985; Evanoff, 1990a, b, 1993; Swinehart and Diffendal, 1997; Rowley and Fan, 2016). Deposition of the White River Formation or Group and the Arikaree Formation reflected a period of deposition (aggradation) after the Late Cretaceous-middle Eocene Laramide orogeny and subsequent widespread middle-to-late Eocene erosion. Subsequently, the Ogallala Formation reflected the end of aggradation and the beginning of a "cut-and-fill" depositional sequence and eventually transitioned to incision as the dominant process (Diffendal, 1982; Swinehart and others, 1985; Lillegraven and Ostresh, 1988; Cather and others, 2012). All units are exposed throughout the Cheyenne Basin and larger southeastern Wyoming area (fig. 7). Paleosols (fossil soils) occur in all three Tertiary lithostratigraphic units (Retallack, 1983; Swinehart and others, 1985; Swinehart and Diffendal, 1997; LaGarry, 1998; Terry, 1998; Hembree and Hasiotis, 2007). The lithostratigraphic terminology applied to these late Eocene-Miocene strata in southeastern Wyoming is complex and controversial (for example, Flanagan and Montagne, 1993; Lillegraven, 1993; Boyd, 1999). These late Eocene-Miocene strata are described in greater detail in this report section. Discussion/description of strata assigned to the White River Formation or Group is more extensive because the unit is widely exposed (or subcrops below Quaternary unconsolidated deposits) and serves as the principal bedrock aquifer throughout the Pine Bluffs lowland, and the younger Arikaree and Ogallala Formations largely are absent in or only border most of the lowland because of erosion and (or) nondeposition. 

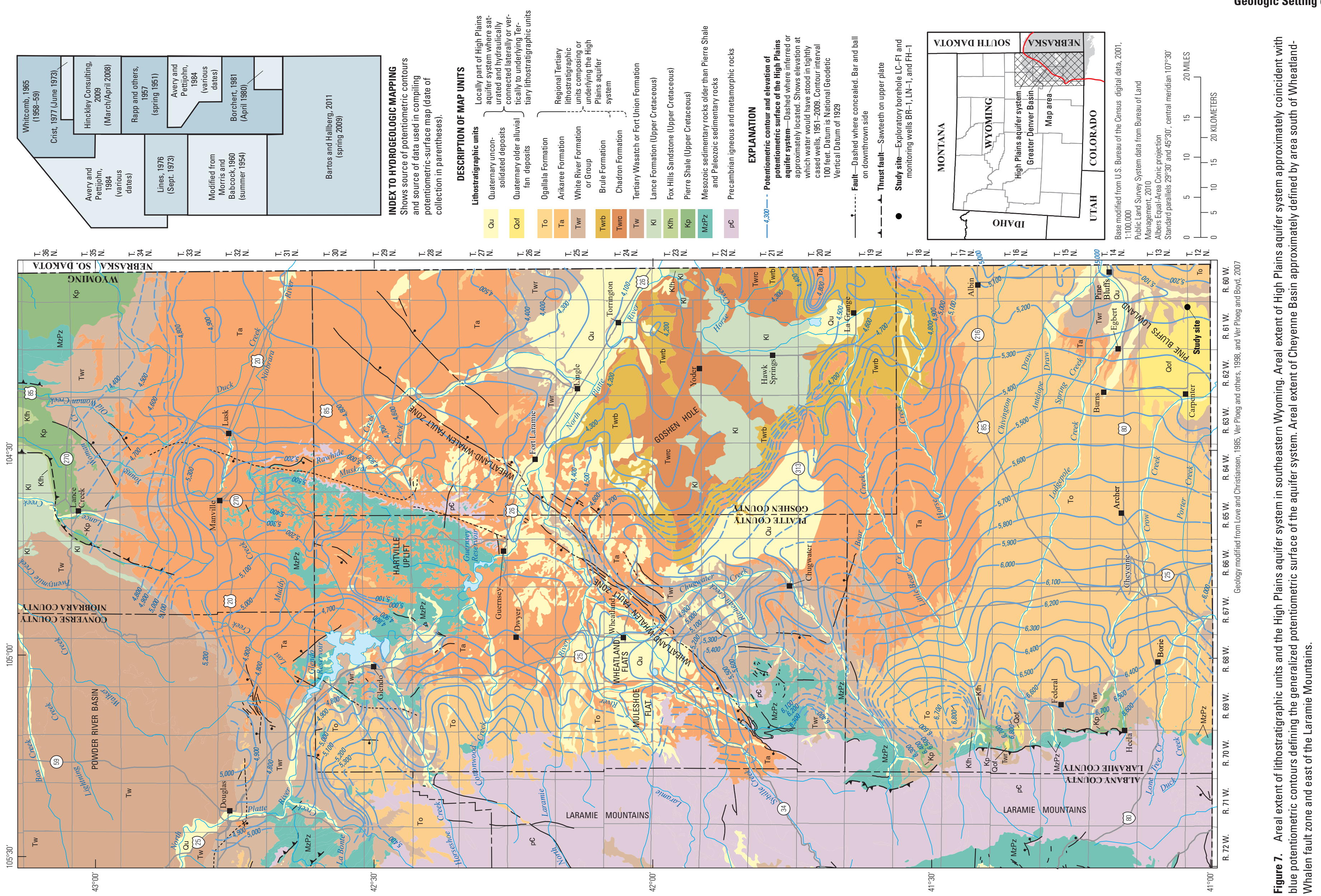
Geologic and Hydrogeologic Characteristics, White River Formation, Lance Formation, and Fox Hills Sandstone, Wyo.

\section{Quaternary Unconsolidated Deposits}

Several types of surficial Quaternary-age (Holocene and Pleistocene) unconsolidated deposits are exposed in the Pine Bluffs lowland area, including various stream-laid deposits mapped as alluvium, colluvium, terrace deposits, and alluvial fan deposits along or above the various drainages in the area (fig. 1; Ver Ploeg, 1995; Ver Ploeg and others, 1998). Deposits in and along current (2020) drainages and associated floodplains and low-level terraces are younger (Holocene age) than deposits located substantially above current or former drainages (Pleistocene age; fig. 1). At the study site, these surficial deposits cover and form the broad gently eastward and southeastward sloping alluvial fan/terrace south of Muddy Creek and east of Carpenter, described previously in the "Geographic and Physiographic Setting" section of this report. Identified as Pleistocene in age, these deposits are composed primarily of poorly sorted, bedded to nonbedded, unconsolidated to poorly consolidated mixtures of silt, clay, sand, and gravel deposited by streams flowing eastward from uplifts to the west (Laramie Mountains and Front Range) (Rapp and others, 1953; Babcock and Bjorklund, 1956; Lowry and Crist, 1967; Kirkham and Rold, 1986; Ver Ploeg, 1995; Ver Ploeg and others, 1998). Quaternary-age deposits covering the alluvial fan/terrace at the study site are mapped as terrace deposits in older studies (Rapp and others, 1953; Babcock and Bjorklund, 1956; Bjorklund, 1959; Lowry and Crist, 1967; Crist and Borchert, 1972) and as older alluvial fan deposits in recent studies (Kirkham and Rold, 1986; Ver Ploeg, 1995; Hallberg and Case, 1998; Ver Ploeg and others, 1998). The most recent mapping is adopted herein, and the deposits are identified as Quaternary older alluvial fan deposits (identified as Qof in figs. 1,7). The placement of the word "older" before "alluvial fan deposits" on recent geologic maps distinguishes these and other older Pleistocene surficial deposits from younger Holocene surficial deposits in the Pine Bluffs lowland area (Ver Ploeg, 1995; Hallberg and Case, 1998; Ver Ploeg and others, 1998). Thickness of the Quaternary older alluvial fan deposits in the Pine Bluffs lowland area ranges from a few feet around the edges of the deposits to as much as $150 \mathrm{ft}$ (Rapp and others, 1953; Crist and Borchert, 1972).

\section{Ogallala Formation}

Much of the areal extent of the Ogallala Formation in the Wyoming part of the Cheyenne Basin is within Laramie County (fig. 7). The Ogallala Formation is absent in much of the Pine Bluffs lowland because of erosion, but formation outcrops border much of the lowland area (fig. 1). Within Laramie County, the Ogallala Formation unconformably overlies either the Oligocene-Miocene Arikaree Formation or the late Eocene-Oligocene White River Formation or Group (fig. 1). Where present in the Pine Bluffs lowland area, the Ogallala Formation unconformably overlies the White River Formation in an area generally south of the boundary between T. $14 \mathrm{~N}$. and T. $13 \mathrm{~N}$. and east of the south-north flowing reaches of Spring and Muddy Creeks (fig. 1) and overlies the Arikaree Formation elsewhere (figs. 1, 7). In adjacent western Nebraska, the Ogallala Formation has been divided into additional lithostratigraphic units (formations) and elevated to group rank, including areas contiguous with the Ogallala Formation in the Pine Bluffs lowland area (Swinehart and others, 1985; Swinehart and Diffendal, 1997).

Strata composing the Ogallala Formation in southeastern Wyoming typically are considered Miocene in age (fig. 6A; Love and Christiansen, 1985; Swinehart and others, 1985; Flanagan and Montagne, 1993; Love and others, 1993). Flanagan and Montagne (1993, p. 581) speculated that "the age of the Ogallala Formation in eastern Wyoming is probably time transgressive from west to east, from mid-to-late Miocene." Some parts of the formation may contain younger strata in some areas. Fossils collected from a location in central Laramie County (Trail Creek Quarry [not shown]; Cassiliano, 1980 ) indicate that the Ogallala Formation is Barstovian to Clarendonian in age, but a mammoth (Mammut) tooth indicates the uppermost part of the formation could be younger (Voorhies, 1965; Cassiliano, 1980). Similarly, fossil seeds collected in eastern Laramie County at Pine Bluffs have been interpreted to indicate the Ogallala Formation is late Clarendonian to Hemphillian in age (Minick, 1951). The Hemphillian North American "land-mammal age" (NALMA; Wood and others, 1941) spans late Miocene and early Pliocene time; thus, age of the Ogallala Formation may extend into the lower Pliocene where the formation contains strata of late Hemphillian age. The most recent stratigraphic column produced for the Cheyenne Basin (identified as northern Denver Basin) by the Wyoming Geological Association identified the Ogallala Formation as middle Miocene to Pliocene in age (Wyoming Geological Association, 2014, column 18). Similarly, the Colorado Geological Survey's recent stratigraphic column for the greater Denver Basin (Cheyenne and Denver Basins) indicated the same age range (Raynolds and Hagadorn, 2016).

The Ogallala Formation is a complex sequence of superposed cuts and fills composed mostly of stream-laid (fluvial) sediments with minor amounts of volcanic ash (Diffendal, 1984; Swinehart and others, 1985; Swinehart and Diffendal, 1997). This complex sequence of cuts and fills is composed of a heterogeneous mixture of unconsolidated or poorly to well-cemented gravel, sand, silt, and clay (when consolidated/ cemented, these lithologies are equivalent to conglomerate, sandstone, siltstone, and mudstone, respectively) with minor amounts of volcanic ash (Foley, 1942; Morgan, 1946; Minick, 1951; Bjorklund, 1959; Moore, 1959, 1963; Denson and Bergendahl, 1961; Lowry and Crist, 1967; Stanley, 1971, 1976; Cassiliano, 1980; Cooley and Crist, 1981, 1994; Diffendal, 1984; Swinehart and others, 1985; Swinehart and Diffendal, 1997). In general, the formation is coarser grained near the Laramie Mountains and becomes finer grained to the east (Minick, 1951; Moore, 1959, 1963; Stanley, 1976; Cassiliano, 1980; Cooley and Crist, 1981). Thin lenses of well-cemented gravel, sand, and silt cemented primarily with calcium 
carbonate (caliche or calcrete) and less commonly with silica (silcrete) occur locally, and these lenses or beds are referred to as "mortar beds" in many publications; these cemented lenses or beds are resistant to erosion and commonly form ledges or caprocks such as those bordering the eastern boundary of the Pine Bluffs lowland. Lowry and Crist (1967, table 1) reported a maximum thickness of about $330 \mathrm{ft}$ for the Ogallala Formation in Laramie County.

\section{Arikaree Formation}

The Arikaree Formation is present at the surface and in the subsurface throughout much of the Wyoming part of the Cheyenne Basin (fig. 7). In the Pine Bluffs lowland area, the Arikaree Formation is north of the boundary between T. $14 \mathrm{~N}$. and T. $13 \mathrm{~N}$. and west of the south-north flowing reaches of Spring and Muddy Creeks (fig. 1). Where present in the Cheyenne Basin, the formation is unconformably overlain by the Ogallala Formation (in areas where not exposed) and underlain by the White River Formation or Group. Strata composing the Arikaree Formation are Oligocene and Miocene (Arikareean) in age (fig. 6A; Hunt, 1985, 1990, 2002; Swinehart and others, 1985; Lillegraven, 1993). In adjacent western Nebraska, the unit has been divided into additional lithostratigraphic units (formations) and elevated to group rank (Swinehart and others, 1985; Swinehart and Diffendal, 1997). Some investigators have applied this western Nebraska nomenclature to the unit in the Wyoming part of the Cheyenne Basin (for example, Cassiliano, 1980; Hunt, 1985, 1990, 2002; Swinehart, and others, 1985, fig. 5D).

The Arikaree Formation is composed primarily of semiconsolidated to consolidated volcaniclastic, calcareous, very fine- to fine-grained sandstone or silty sandstone; interbedded beds of siltstone, tabular limestone, carbonate mudrocks, diatomite, and volcanic ash/tuff are much less common (Minick, 1951; Babcock and Bjorklund, 1956; Bjorklund, 1959; Moore, 1959; Denson and Bergendahl, 1961; McGrew, 1963; Lowry and Crist, 1967; Sato and Denson, 1967; Denson and Chisholm, 1971; Bart, 1974, 1975; Stanley, 1976; Cassiliano, 1980; Cooley and Crist, 1981, 1994; Hunt, 1985, 1990, 2002; Swinehart and others, 1985). The Arikaree Formation in the Cheyenne Basin consists mainly of air-fall deposits of pyroclastic material derived from distant volcanism; however, eolian, alluvial, fluvial, and lacustrine environments are recorded as well. The air-fall deposits were deposited directly in place or were subsequently locally reworked and retransported by fluvial and (or) eolian processes (Denson and Chisholm, 1971; Bart, 1974, 1975; Cassiliano, 1980; Hunt, 1985, 1990; Rowley and Fan, 2016). Lowry and Crist (1967, table 1) reported a maximum thickness of about $450 \mathrm{ft}$ for the Arikaree Formation in Laramie County. Cassiliano (1980) reported a thickness of $262 \mathrm{ft}$ in north-central Laramie County, but the investigator did not include some "middle Miocene rocks" that Flanagan and Montagne (1993) subsequently assigned to the formation.

\section{White River Formation or Group}

The White River Formation, or Group where divided, is present at the surface and in the subsurface throughout much of the Wyoming part of the Cheyenne Basin (fig. 7). The unit crops out along the eastern flank of the Laramie Mountains, south of the Wheatland-Whalen fault zone in Platte County and northwestern Laramie County, within the Goshen Hole area, and throughout much of the Pine Bluffs lowland area (figs. 1, 7). Quaternary older alluvial fan deposits cover/overlie the White River Formation or Group at the study site, and other types of Quaternary unconsolidated deposits overlie the unit in other parts of the Pine Bluffs lowland (fig. 1). The White River Formation or Group disconformably overlies Upper Cretaceous strata throughout much of the Cheyenne Basin, including Laramie County and the Pine Bluffs lowland area (figs. 6A, 7; Minick, 1951; Love and Christiansen, 1985; Love and others, 1993; Ver Ploeg, 1995; Ver Ploeg and others, 1998). Near the Laramie Mountains, the unit overlies older pre-Tertiary strata (figs. 1, 7). Lowry and Crist (1967, table 1) reported a maximum thickness of about $500 \mathrm{ft}$ for the White River Formation or Group in Laramie County. Cooley and Crist (1981) determined a maximum thickness of about $600 \mathrm{ft}$ for the White River Formation or Group west of the city of Cheyenne near the Laramie Mountains (scaled from fence diagram, well location 22).

Strata composing the White River Formation or Group in southeastern and east-central Wyoming and adjacent parts of western Nebraska (including parts within the Cheyenne Basin) range from late Eocene (Chadronian) to Oligocene (Orellan and Whitneyan) in age (fig. 6A; Swinehart and others, 1985; Kihm, 1987; Evanoff, 1990a, b, 1993; Emry, 1992; Lillegraven, 1993; Swinehart and Diffendal, 1997; Prothero and Whittlesey, 1998; Terry, 1998; ). The lowest (oldest) strata in the White River Formation or Group (Chadronian age) in southeastern and east-central Wyoming, western Nebraska, and northeastern Colorado were long considered Oligocene in age (for example, Tweto, 1979; Love and Christiansen, 1985; Swinehart and others, 1985; Swinehart and Diffendal, 1997; Love and others, 1993). Revision of the Eocene-Oligocene boundary to about 34 mega-annum, or million years ago (Ma; Berggren and others, 1992; Obradovich and others, 1995), and radiometric age dating of ash beds in the White River Formation in east-central Wyoming indicating an age older than $34 \mathrm{Ma}$ (Prothero and Swisher, 1992), placed the lower White River Formation strata of Chadronian age (approximately corresponds to Chadron Formation or Member where unit is divided, or lower White River Formation where unit is undivided) into late Eocene time (for example, Swinehart and Diffendal, 1997; Prothero and Whittlesey, 1998).

Deposition of the White River Formation or Group represented the end to a prior period of intense and areally extensive late middle to late Eocene weathering and erosion that affected parts of Wyoming and several adjacent States (Epis and Chapin, 1975; Trimble, 1980; Swinehart and others, 
1985; Lillegraven, 1993; Cather and others, 2012). Unlike the Laramide orogeny, where erosion was localized on uplifts, this erosional event "involved both uplifts and basins of the preceding Laramide deformation" (Cather and others, 2012, p. 1,181). Regional erosional events may be caused by climate change, tectonic uplift, or a combination of these two mechanisms. Although the relative contributions of these mechanisms to this erosional event have been debated, recent studies have concluded differential tectonic uplift of the central Rocky Mountains with respect to the adjacent Great Plains likely caused this erosional episode (Cather and others, 2012; Fan and others, 2014a, b). This period of erosion resulted in a widespread erosional surface (late Eocene surface of Epis and Chapin [1975]; Rocky Mountain erosion surface of Evanoff and Chapin [1994], Chapin and Kelley [1997], and Cather and others [2012], and used hereinafter) that beveled parts of Laramide uplifts in Colorado and Wyoming before White River deposition. Steven and others (1997, p. 117) concluded that the character of this erosional surface in the Cheyenne Basin in northeastern Colorado (and likely everywhere present) varied "widely from one area to another" and "from very low relief, through moderately hilly, to mountainous." The resulting Rocky Mountain erosion surface upon which the White River Formation strata in Wyoming began to be deposited during the late Eocene (Chadronian age) consisted of relief that was "as great, if not greater, than at present" (Snoke, 1993, p. 35). This surface was incised by valleys (paleovalleys) formed by eastward and southward flowing rivers in parts of Wyoming, Colorado, and Montana (Clark, 1975; Seeland, 1985; Swinehart and others, 1985; Lillegraven and Ostresh, 1988) between $37 \mathrm{Ma}$ (approximate age of the earliest fill in the paleovalleys) and $50 \mathrm{Ma}$ (age of initial development of the Rocky Mountain erosion surface) (largely late Uintan-Duchesnean age; Cather and others, 2012). In places, these paleovalleys cut deeply into exposed Laramide uplifts, including the Precambrian crystalline core of the Laramie Mountains in Wyoming (Evanoff, 1990a). The lowest parts of the paleovalleys cut into the Laramie Mountains are filled with undeformed conglomeratic and volcaniclastic sedimentary rocks of the lower/older (Chadronian) part of the White River Formation or Group, including areas immediately west of Cheyenne (Moore, 1959, 1963; Evanoff, 1990a; Bartos and others, 2014). Deposition of these lower White River (Chadronian) deposits indicates the approximate time when widespread erosion that produced the Rocky Mountain erosional surface ended and the transition to deposition in the area began (Swinehart and others, 1985; Evanoff, 1990a, b; Cather and others, 2012).

The White River Formation or Group in southeastern Wyoming and adjacent western Nebraska and northeastern Colorado consists primarily of semiconsolidated to consolidated, argillaceous (clayey) volcaniclastic mudrocks, including siltstone, mudstone, and claystone (and various combinations of these three mudrock types) (Darton, 1899, 1903, 1905; Darton and others, 1910; Foley, 1942; Morgan, 1946; Gray, 1947; Brady, 1949; Minick, 1951; McGrew, 1953, 1963; Rapp and others, 1953; Babcock and Bjorklund, 1956; Bjorklund, 1959; Moore, 1959, 1963; Denson and Bergendahl, 1961; Lowry and Crist, 1967; Sato and Denson, 1967; Denson and Chisholm, 1971; Crist and Borchert, 1972; Stanley, 1976; Singler and Picard, 1979a, b; Stanley and Benson, 1979; Cassiliano, 1980; Cooley and Crist, 1981, 1994; Swinehart and others, 1985; Evanoff, 1990b, 1993; Swinehart and Diffendal, 1997; Bartos and others, 2014). Throughout much of the unit, diagenesis has devitrified the ash-rich volcaniclastic sediments, producing clays consisting substantially of montmorillonite and kaolinite (Denson and Bergendahl, 1961; Sato and Denson, 1967; Denson and Chisholm, 1971; Stanley, 1976; Stanley and Benson, 1979; Bartos and others, 2014). Thin volcanic ash beds occur throughout the sequence. Locally present fluvial deposits and sedimentary paleovalley fills consisting of coarse-grained stream channel deposits (sandstone and conglomerate, primarily arkosic) derived primarily from eroded Laramide uplifts and reworked fine-grained material (volcaniclastic sediments) are interbedded with the mudrocks. The coarse-grained stream channel deposits, consisting largely of sandstone, conglomeratic sandstone/sandy conglomerate, and conglomerate, generally are a volumetrically minor component of the White River Formation strata. Locally derived coarse-grained deposits (arkosic conglomerate with clasts as large as cobble size) of the White River Formation or Group are found along the eastern and northeastern flanks of the Laramie Mountains (Moore, 1959; McGrew, 1963; Stanley, 1976; Evanoff, 1990a; Bartos and others, 2014).

Distant explosive volcanism west of Wyoming in the Great Basin (Nevada and Utah) and possibly elsewhere in the western United States produced the pyroclastic material that is the source of the volcaniclastic sediments that compose much of the White River Formation or Group (and overlying Arikaree Formation, where present) throughout its geographic extent (Sato and Denson, 1967; Denson and Chisholm, 1971; Stanley, 1976; Singler and Picard, 1979a, b; Swinehart and others, 1985; Swinehart and Diffendal, 1997; Larson and Evanoff, 1998). This volcanism repeatedly produced large quantities of airborne pyroclastic material (ash) that blanketed parts of Wyoming and adjacent areas that compose most of the White River Formation or Group. Subsequently, this material was (1) deposited directly as air-fall deposits that remained largely in place (volcaniclastic loess deposits) or (2) washed off highland/uplifted areas, reworked locally by fluvial and eolian processes, and redeposited by eolian processes and periodic flooding of sediment-rich streams of varying size (Seeland, 1985; Swinehart and others, 1985; Lillegraven and Ostresh, 1988; Evanoff, 1990a, b, 1993; Rowley and Fan, 2016).

\section{Upper Cretaceous Lithostratigraphic Units}

An unconformity separates all Upper Cretaceous lithostratigraphic units from all overlying Tertiary lithostratigraphic units in the Cheyenne Basin, including the Pine Bluffs lowland (fig. 6A). Upper Cretaceous units of interest for this 
study included the Lance/Laramie Formation, Fox Hills Sandstone, and the uppermost part of the Pierre Shale (fig. 6A). In contrast to Tertiary lithostratigraphic units, areal extent of these units is defined by the structural depression of the Cheyenne Basin. Sediments of these three lithostratigraphic units form a depositional sequence that records the transition from an open marine environment (offshore shallow marine deposits of the upper Pierre Shale) to transitional marine environment (nearshore and shoreface [beach] deposits of the Fox Hills Sandstone), and finally to a terrestrial (nonmarine) depositional environment (Lance Formation in Wyoming and stratigraphically equivalent Laramie Formation in northeastern Colorado) as the Western Interior Seaway that extended from the Gulf of Mexico to the Arctic Ocean retreated toward the northeast at the end of the Late Cretaceous (fig. 8A, $B$; Kiteley, 1976, 1977, 1978; Weimer, 1977, 1996; Lillegraven and Ostresh, 1990; Roberts and Kirschbaum, 1995; Raynolds, 2002, 2003; Raynolds and Johnson, 2003; Dechesne and Raynolds, 2005, 2010; Raynolds and Dechesne, 2007; Dechesne and others, 2011a, b).

\section{Lance Formation}

The Lance Formation of Late Cretaceous (late Maastrichtian) age unconformably underlies the late Eocene- to Oligocene-age White River Formation or Group and conformably overlies and intertongues with the Fox Hills Sandstone in much of the Cheyenne Basin of Wyoming and northeastern Colorado (figs. $4 ; 5 A, B ; 6$ ). The surface and estimated subsurface extent of the formation in the Denver and Cheyenne Basins are shown on figure 4 . The formation is buried throughout most of the Wyoming part of the Cheyenne Basin except where exposed in the Goshen Hole area (fig. 7). The Lance Formation consists of terrestrial (nonmarine) deposits of interbedded fissile, yellowish, dark gray, and brown/black shale and silty and sandy shale (commonly carbonaceous), siltstone, claystone, and mudstone; interbedded brown to light brown, grayish, very fine- to medium-grained, clayey, calcareous sandstone; coal; and lignite (Cady, 1935 [lithologic descriptions and other information in this report are useful, but note lithostratigraphic unit assignments in this report are either incorrect or no longer valid for some of the strata]; Schlaikjer, 1935c; Rapp and others, 1957; Morris and Babcock, 1960; McGrew, 1963; Lowry and Crist, 1967; Libra and others, 1981; Trihydro Corporation, 1996; Lidstone and Associates, Inc., 2003; Dahlgren Consulting, Inc., and others, 2005; this study).

Upper Cretaceous strata assigned to the Lance Formation in the Wyoming part of the Cheyenne Basin extend uninterrupted into the Colorado and Nebraska parts of the basin (figs. $4 ; 5 A, B$ ). The equivalent strata in the Colorado part of the Cheyenne Basin have been given a different lithostratigraphic name (Laramie Formation), resulting in two names applied to the same strata on either side of the Wyoming-Colorado border (discussed in greater detail in the "Lance Formation" report section) for which lithologies and depositional environments are the same (Ethridge and others, 1979; Kirkham and Ladwig, 1979; Kirkham and others, 1980; Nibbelink, 1983; Kirkham and Rold, 1986; Wilson and others, 2010). In practice, strata assigned to the two units in the Cheyenne Basin are contiguous across the Colorado-Wyoming border, so geologists typically consider the units stratigraphically equivalent and identify the strata as "Laramie" in northeastern Colorado and "Lance" in southeastern Wyoming. This convention is used hereinafter except that "Lance/Laramie" will be used when collectively identifying and describing the strata extent throughout the Cheyenne Basin in Wyoming and Colorado.

Sediments composing the rocks of the Lance/Laramie Formation in the greater Denver Basin typically are interpreted as accumulating in paludal (swamp/marsh/lagoon), estuary, and fluvial-coastal/delta plain environments along the western margin of the retreating Western Interior Seaway (fig. 8A, $B$; Reade, 1976; Ethridge and others, 1979; Kirkham and Ladwig, 1979; Shepherd and Summer, 1979; Kirkham and others, 1980; Nibbelink, 1983; Roberts and Kirschbaum, 1995; Raynolds, 2002, 2003; Raynolds and Johnson, 2003; Dechesne and others, 2011a). The lower part of the formation conformably overlies and intertongues with the Fox Hills Sandstone (figs. 5A, $B ; 6 A, B ; 8 A, B$ ). Coal and lignite are present in the Lance/Laramie Formation, especially in the lower part of the formation (Schlaikjer, 1935c; Rapp and others, 1957; McGrew, 1963; Kirkham and Ladwig, 1979; Kirkham and others, 1980; Roberts and Kirschbaum, 1995; Lidstone and Associates, Inc., 2003; Dahlgren Consulting, Inc., and others, 2005; Wyoming Groundwater, LLC, and others, 2011; this study). Coal and lignite were formed from peat deposited in coastal plain mires (Roberts and Kirschbaum, 1995).

Few thickness estimates are available for the Lance Formation in the Wyoming part of the Cheyenne Basin. Lowry and Crist (1967, table 1, p. 8) estimated thickness ranged from 200 to $1,500 \mathrm{ft}$ or more in Laramie County. Rapp and others (1957, unnumbered table, p. 22) reported thickness ranged from 0 to $1,400 \mathrm{ft}$ or more in Goshen County. Wilson and others (2010) estimated a maximum thickness of 1,475 ft for the Laramie Formation in the Colorado part of the Cheyenne Basin.

\section{Fox Hills Sandstone}

Created by the episodic but overall eastward regression of the Western Interior Seaway during the Late Cretaceous (late Maastrichtian age; figs. $6 A, B ; 8 A, B)$, the Fox Hills Sandstone (also known as the Fox Hills Formation) in the greater Denver Basin consists of a series of one or more very fine- to mediumgrained generally upward-coarsening sandstone beds deposited in a shoreface to beach or other nearshore (barrier-bar, delta, or shallow marine) environment described in some studies as littoral or transitional/marginal marine (Rapp and others, 1957; Weimer, 1977, 1996; Kiteley, 1978; Kirkham and Ladwig, 1979, 1980; Shepherd and Summer, 1979; Kirkham and others, 1980; Nibbelink, 1983; Roberts and Kirschbaum, 1995; 


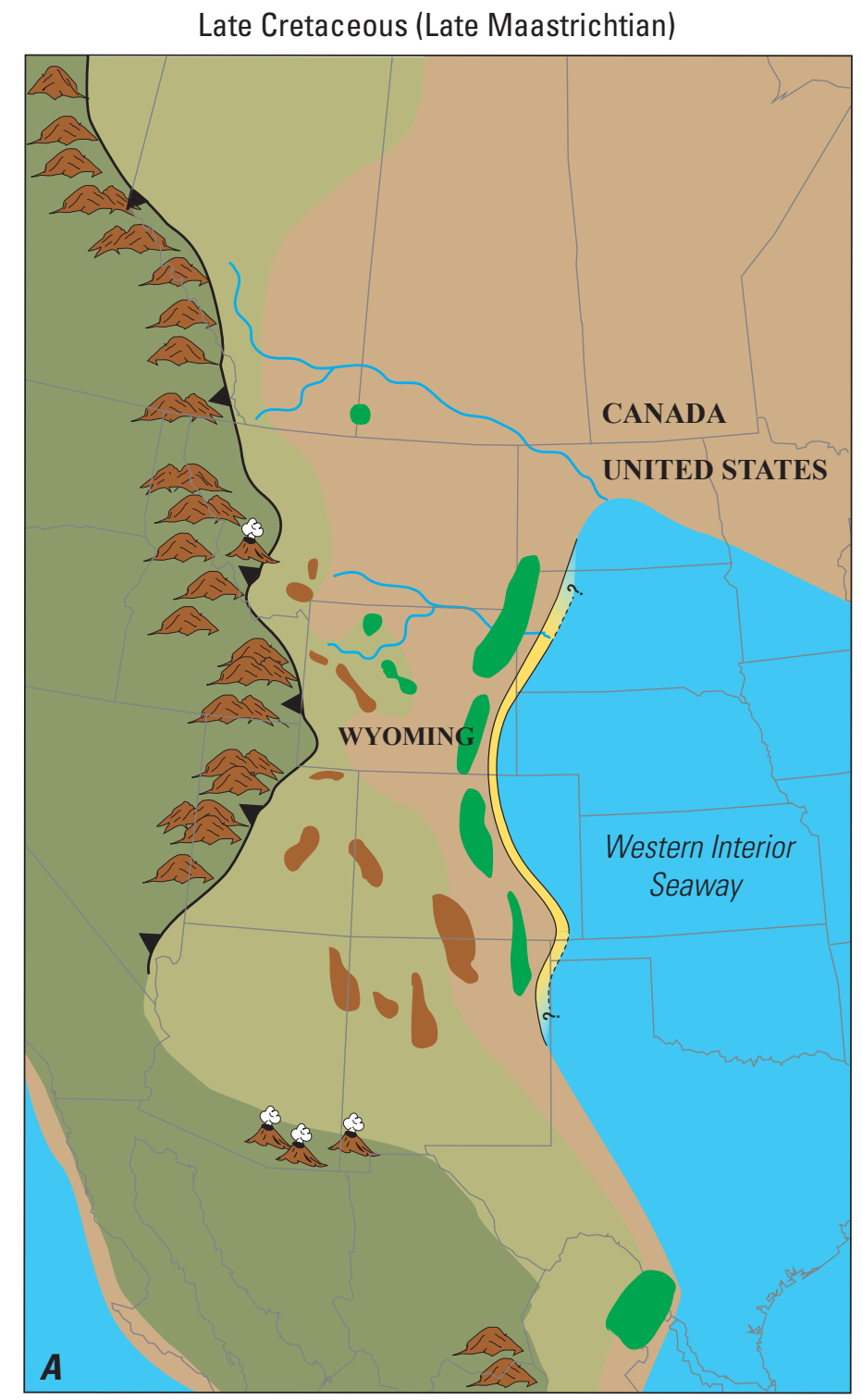

\section{EXPLANATION}
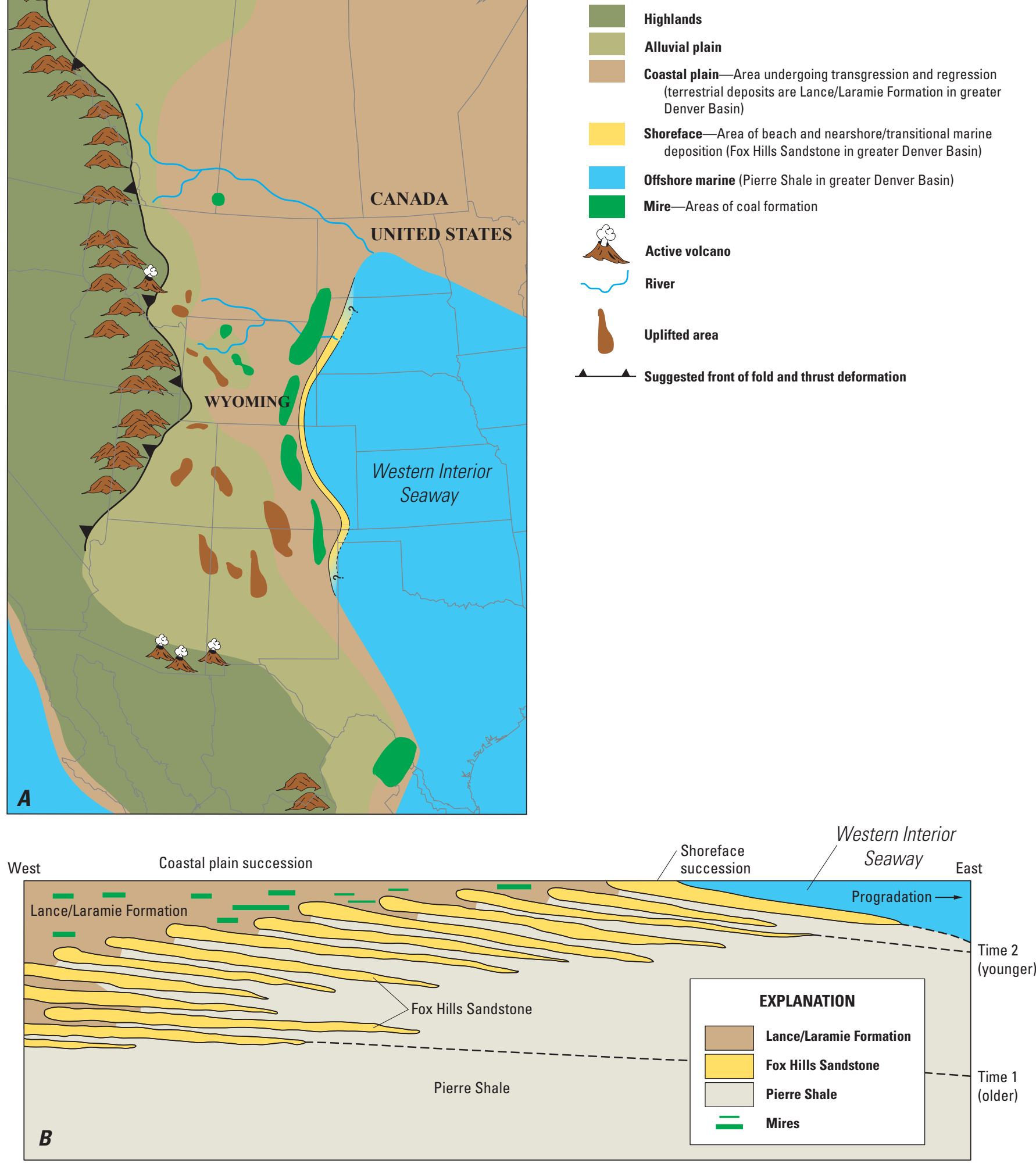

Figure 8. Paleogeography during Late Cretaceous time and progradational setting of Upper Cretaceous rocks (diagrams modified from Roberts [2007] and Dechesne and others [2011a]). A, paleogeography during Late Cretaceous (late Maastrichtian) time; $B$, progradational setting of Upper Cretaceous rocks in the upper part of the Pierre Shale, Fox Hills Sandstone, and Lance/Laramie Formation in the Cheyenne and Denver Basins, Wyoming and Colorado. 
Raynolds, 2002, 2003; Raynolds and Johnson, 2003; Dechesne and Raynolds, 2005; Raynolds and Dechesne, 2007; Dechesne and others, 2011a, b). The formation conformably underlies and intertongues with the terrestrial (nonmarine) deposits of the Lance/Laramie Formation and conformably overlies and intertongues with the offshore shallow marine deposits of the upper Pierre Shale (figs. $5 A, B ; 6 A, B ; 8 A, B$ ). Regression of the Western Interior Seaway formed the series of seaward (eastward) stepping sandstone bed/bodies that compose the Fox Hills Sandstone; these beds/bodies climb upsection and become progressively younger eastward throughout the greater Denver Basin (fig. 8A, B; Raynolds, 2002, 2003; Dechesne and Raynolds, 2005; Raynolds and Dechesne, 2007; Dechesne and others, 2011a, b). The surface and estimated subsurface extent of the Fox Hills Sandstone throughout the Cheyenne and Denver Basins is shown on figure 4. The formation is buried throughout most of the Wyoming part of the Cheyenne Basin except where exposed in a small area in the Horse Creek drainage (T. 17 N., Rs. 69 and 70 W.; figs. 1, 4, 7) and in a small area in Goshen Hole south of the North Platte River near the Nebraska-Wyoming border (T. 23 N., R. 60 W.; figs. 4, 7).

Thickness of the Fox Hills Sandstone in the Cheyenne Basin in Wyoming has been estimated to range from 0 to $190 \mathrm{ft}$ in Goshen County (Rapp and others, 1957, unnumbered table, p. 22), 0 to $250 \mathrm{ft}$ or more in Laramie County (Lowry and Crist, 1967, table 1, p. 9), and 0 to $550 \mathrm{ft}$ for the entire basin (Libra and others, 1981, table IV-1, p. 40). Published thickness estimates or scaled geologic cross sections showing thicknesses are available only for a few locations in Laramie County. Dockery (1940) reported a thickness of about $375 \mathrm{ft}$ where exposed along the upper Horse Creek drainage in western Laramie County. Kiteley (1978, sheet 2) determined thicknesses of 215, 335, and $350 \mathrm{ft}$ for three wells in southeastern Laramie County (scaled from columns 17, 18, and 19 on sheet 2). Illustrations in Jordan (1998) show thicknesses ranging from 150 to $200 \mathrm{ft}$ for wells that penetrated the Fox Hills Sandstone in the various public water-supply well fields west of Cheyenne. Dahlgren Consulting, Inc., and others (2005) reported a thickness of about $38 \mathrm{ft}$ for the Fox Hills Sandstone in an exploratory well less than $1 \mathrm{mi}$ northwest of Pine Bluffs. Wyoming Groundwater, LLC, and others (2011) reported a thickness of $127 \mathrm{ft}$ in a test well near Yoder. Reported Fox Hills Sandstone thickness varies substantially in these and other studies in the Cheyenne Basin, primarily reflecting different interpretations of what strata are assigned to the unit at a given location. In particular, stratigraphic assignment of sandstone beds near the upper formation contact with the Lance Formation and the lower formation contact with the Pierre Shale are interpreted differently by investigators. Importantly, some investigators include only sandstone beds when estimating formation thickness, whereas other investigators include not only the sandstone beds, but also intertonguing/ interfingering fine-grained rocks/facies (primarily shale and silty shale) that likely are part of the Lance Formation or underlying Pierre Shale rather than the Fox Hills Sandstone (see "Identification of Upper Cretaceous Lithostratigraphic Units in the Subsurface" report section).

\section{Pierre Shale}

The Late Cretaceous (early Campanian-early Maastrichtian age) Pierre Shale conformably underlies and interfingers with the Fox Hills Sandstone (figs. 5A, $B ; 6 A, B ; 8 A, B$ ) and conformably overlies the Late Cretaceous (Maastrichtian and Campanian age) Niobrara Formation (fig. 6A). The Pierre Shale represents the marine deposits of the Western Interior Seaway during Late Cretaceous time, whereas the Fox Hills Sandstone and Lance/Laramie Formation represent the shallow marine to beach and coastal plain deposits, respectively (fig. 8A, B). Much of the formation consists of fine-grained mudrocks such as dark gray shale, sandy shale, and siltstone, but several areally extensive sandstone beds separated by the fine-grained lithologies are present in the formation in parts of southeastern Wyoming and northeastern Colorado in the greater Denver Basin (Kiteley, 1976, 1977, 1978). The formation is thick, averaging 6,000 to $8,000 \mathrm{ft}$ in thickness within the greater Denver Basin (Higley and Cox, 2007). Immediately south of the Pine Bluffs lowland in northeastern Colorado, the Pierre Shale is more than 5,500 ft thick (scaled from Kiteley, 1978, sheet 1, columns 7-9).

The Pierre Shale has been divided into numerous informal and formal members correlative with well-defined biostratigraphic zones (Western Interior Upper Cretaceous ammonite and inoceramid taxon range zones [biozones/ biochrons]; Scott and Cobban, 1965, 1986; Kiteley, 1976, 1977, 1978; Weimer, 1977, 1996; Courtright and Braddock, 1989; Landman and Cobban, 2003; Cobban and others, 2006; Merewether and others, 2011). From youngest to oldest (shallowest to deepest), the Pierre Shale in southeastern Wyoming and northeastern Colorado contains the following informal and formal units grouped into three general "parts": (1) an upper part composed of a sequence of shales and sandstones that includes informal members A-D and overlying unnamed strata; (2) a middle part consisting of a sequence of shales and sandstones that includes the Richard, Larimer, Rocky Ridge, Terry, and Hygiene Sandstone Members; (3) and a lower part consisting of the Mitten Shale Member (also known in some studies as Mitten Black Shale Member), Sharon Springs Member, and Gammon Ferruginous Member (upper part, including informal members A-D, is shown in relation to ammonite age spans [biozones] and radiometric ages in fig. $6 B$; Kiteley, 1976, 1977, 1978; Merewether and others, 2011).

The Pierre Shale and several underlying Cretaceous units are the target of oil and gas exploration and production in the Cheyenne Basin in northeastern Colorado and southeastern Wyoming (Sonnenberg and Weimer, 1993; Higley and Cox, 2007; Sonnenberg, 2011; Toner and others, 2016; Toner and Campbell, 2017). To date (2020), hydrocarbon production from the Pierre Shale has been limited to the Colorado part of the basin. In the Wyoming part of the basin, current (2020) hydrocarbon production is from Cretaceous units below 
Geologic and Hydrogeologic Characteristics, White River Formation, Lance Formation, and Fox Hills Sandstone, Wyo.

the Pierre Shale, including the Niobrara Formation, Codell Sandstone Member of the Carlile Shale, "D" sandstone, and the Muddy "J" Sandstone (units shown in fig. 6A; Toner and others, 2016; Toner and Campbell, 2017).

\section{Groundwater Resources in Study Area}

Most groundwater used in the Cheyenne Basin in Wyoming is obtained from aquifers consisting of the watersaturated and permeable parts of the Cenozoic and Upper Cretaceous lithostratigraphic units (referred to as Cenozoic and Upper Cretaceous hydrogeologic units for discussions of groundwater resources) overlying the Pierre Shale (described in the previous report sections). The Cenozoic and Upper Cretaceous hydrogeologic units used in the Cheyenne Basin vary by location, reflecting differing areal and vertical extents and locally varying chemical and physical hydrogeologic (water-bearing) characteristics of the lithostratigraphic units containing the aquifers, as well as regulatory and economic considerations (for example, well-drilling depths).

Aquifers in Cenozoic hydrogeologic units composing the High Plains aquifer system are the primary sources of groundwater used throughout the Wyoming part of the Cheyenne Basin, including areas within and adjacent to the Pine Bluffs lowland (Bartos and others, 2013, 2014; Taucher and others, 2013). Use of groundwater from Upper Cretaceous hydrogeologic units in the Wyoming part of the Cheyenne Basin area has been small to date (2020), with almost all development limited to the Goshen Hole area (fig. 7; Bartos and others, 2013; Taucher and others, 2013). Cenozoic and Upper Cretaceous hydrogeologic units present in the Cheyenne Basin, including the Pine Bluffs lowland area, are identified and briefly described in this section of the report. In addition, the High Plains aquifer system is described, and Cenozoic lithostratigraphic/hydrogeologic units composing or underlying the aquifer system in the Pine Bluffs lowland area and throughout the Cheyenne Basin are identified.

\section{Cenozoic Hydrogeologic Units}

Most groundwater used in the Cheyenne Basin is withdrawn from aquifers contained within the water-saturated and permeable parts of Cenozoic lithostratigraphic units (Cenozoic hydrogeologic units), including several types of Quaternary unconsolidated deposits and three Tertiary lithostratigraphic units composed of semiconsolidated to consolidated sediments described previously (Ogallala and Arikaree Formations and White River Formation or Group) (Lowry and Crist, 1967; Crist, 1980; Cooley and Crist, 1981; Libra and others, 1981; JR Engineering and others, 2008; Taucher and others, 2013; Bartos and others, 2013, 2014). Groundwater wells in Laramie County outside of and adjacent to the Pine Bluffs lowland withdraw groundwater from aquifers in Cenozoic hydrogeologic units consisting of all or parts of these units, depending upon which is present and local hydrogeologic characteristics. In some cases, wells are constructed with open intervals in more than one of these units.

Because the Ogallala and Arikaree Formations have been removed by erosion throughout much of the Pine Bluffs lowland (fig. 1), groundwater wells completed in Cenozoic hydrogeologic units consisting of water-saturated and permeable surficial Quaternary alluvium, terrace deposits, and older alluvial fan deposits (Quaternary unconsolidated-deposit aquifers) and the water-saturated and locally permeable upper part of the late Eocene-Oligocene (Tertiary) White River Formation (identified as the Brule or White River aquifer in many studies) provide most groundwater used in the area (Lowry and Crist, 1967; Crist and Borchert, 1972; States West Water Resources Corporation and ESA Consultants, 1990; Lidstone and Anderson, Inc., and AVI Professional Corporation 1995; Dahlgren Consulting, Inc., and others, 2001; Lidstone and Associates, Inc., 2003; AMEC Environment and Infrastructure, Inc., and others, 2014; Dahlgren Consulting, Inc., and others, 2018). Groundwater withdrawn from these aquifers is used primarily for domestic, stock, public-supply, and irrigation purposes in the Pine Bluffs lowland area.

A brief description of all Cenozoic hydrogeologic units within and adjacent to the Pine Bluffs lowland area is provided in this section of the report, including the Ogallala and Arikaree aquifers (consisting of the water-bearing and permeable parts of the Ogallala and Arikaree Formations, respectively) within and near the Pine Bluffs lowland area. Both aquifers are part of the High Plains aquifer system, and groundwater flowing in these aquifers is hydraulically connected to the aquifers composing the aquifer system in the Pine Bluffs lowland.

\section{Quaternary Unconsolidated-Deposit Aquifers}

In the Pine Bluffs lowland area, several types of surficial Quaternary unconsolidated deposits contain unconfined aquifers where sufficiently water saturated and permeable, including alluvium and floodplain deposits (alluvial aquifers), terrace deposits (terrace-deposit aquifers), and older alluvial fan deposits (fan aquifers; Rapp and others, 1953; Bjorklund, 1959; Lowry and Crist, 1967; Crist and Borchert, 1972;

Kirkham and Rold, 1986). Few wells are completed exclusively in most of the Quaternary unconsolidated-deposit aquifers in the Pine Bluffs lowland area because the geographic extent of most deposits is restricted to localized areas within or adjacent to the primary streams, and saturated thicknesses typically are small and (or) vary substantially in response to highly variable groundwater recharge. Consequently, wells penetrating the deposits where saturated also are commonly completed in the underlying Tertiary strata to obtain a larger and more reliable water supply.

In contrast to other saturated Quaternary unconsolidated deposits with meager extent in the Pine Bluffs lowland, older alluvial fan deposits south of west-east flowing reaches of Muddy Creek covering the eastward and southeastward sloping alluvial fan/terrace near Carpenter and the study site 
(described previously in the "Cenozoic Lithostratigraphic Units" section of the report) are areally extensive and water saturated over a relatively large area. Where sufficiently saturated and permeable, the Quaternary older alluvial fan deposits contain a productive unconfined aquifer (Lowry and Crist, 1967; Crist and Borchert, 1972). Identified informally herein as the "fan aquifer" following Kirkham and Rold (1986), this aquifer supplies a substantial amount of the groundwater used in the Carpenter area east of Crow Creek (Lowry and Crist, 1967; Crist and Borchert, 1972) and in areas south of the Wyoming-Colorado State line where the aquifer also is present (Kirkham and Rold, 1986). Groundwater wells completed in the fan aquifer yield quantities of water sufficient for domestic and stock use, and locally, for irrigation use. Irrigation wells completed in the fan aquifer yield less than 100 to as much as 1,000 gallons per minute (gal/min) (Lowry and Crist, 1967; Crist and Borchert, 1972).

Lowry and Crist (1967) presented results from two separate multiple-well aquifer tests using pumped well 12-62$2 \mathrm{bcb}$ with an observation well $745 \mathrm{ft}$ distant, and 12-62-22abb with an observation well $305 \mathrm{ft}$ distant, near Carpenter (about $11 \mathrm{mi}$ west of the study site), penetrating older alluvial fan deposits with saturated thicknesses of 33 and $85 \mathrm{ft}$, respectively. Reported transmissivity $(T)$ and storage coefficient $(S)$ values of the fan aquifer were 19,420 feet squared per day $\left(\mathrm{ft}^{2} / \mathrm{d} ; 146,000\right.$ gallons per day per foot $\left.[(\mathrm{gal} / \mathrm{d}) / \mathrm{ft}]\right)$ and $5.43 \times 10^{-2}$ for the multiple-well test using pumped well 12-62$2 \mathrm{bcb}$ and $2,810 \mathrm{ft}^{2} / \mathrm{d}[44,800(\mathrm{gal} / \mathrm{d}) / \mathrm{ft}]$ and $4.65 \times 10^{-3}$ for the multiple-well test using pumped well 12-62-22abb (Lowry and Crist, 1967, unnumbered table, p. 39). The corresponding hydraulic conductivities ( $K$, computed for each well using $T$ divided by the saturated thickness) are $5.88 \times 10^{2}$ feet per day (ft/d) for the multiple-well test using pumped well 12-62$2 \mathrm{bcb}$ and $3.31 \times 10^{1} \mathrm{ft} / \mathrm{d}$ for the multiple-well test using pumped well 12-62-22abb (Lowry and Crist, 1967, unnumbered table, p. 39; note, the coefficient of permeabilities reported by Lowry and Crist [1967] are the $K$ values computed using the $T$ values reported from an apparent single-well analysis of the pumping-well responses rather than the reported $T$ values from the multiple-well analysis using the observation-well response). Using the $S$ values reported for the multiple-well tests, the corresponding specific storage $(S s)$ values (computed for each well using $S$ divided by the saturated thickness) are $1.65 \times 10^{-3} \mathrm{ft}^{-1}$ for the multiple-well test using pumped well $12-62-2 \mathrm{bcb}$ and $5.47 \times 10^{-5} \mathrm{ft}^{-1}$ for the multiple-well test using pumped well 12-62-22abb. The computed $K$ values and $S s$ values indicate more than an order of magnitude of variability in the hydraulic properties of the fan aquifer.

Mapping by Lowry and Crist (1967, fig. 12) indicated that maximum saturated thickness of the fan aquifer in 1965 was $80 \mathrm{ft}$ or more. Subsequently, Crist and Borchert (1972, fig. 6) mapped saturated thickness of the aquifer for the same general area in 1971, and maximum saturated thickness was as much as $110 \mathrm{ft}$. Where water saturated and permeable, the older alluvial fan deposits (fan aquifer) represent the uppermost individual lithostratigraphic/hydrogeologic unit composing the High Plains aquifer system in the Pine Bluffs lowland (fig. 9; also see "Relation of Cenozoic Hydrogeologic Units in Pine Bluffs Lowland to High Plains Aquifer System" report section). Throughout most of its areal extent, the fan aquifer is hydraulically connected to the underlying White River Formation (aquifer) (Lowry and Crist, 1967; Crist and Borchert, 1972). In these areas, the two aquifers collectively form the High Plains aquifer system.

\section{Ogallala and Arikaree Aquifers}

The Ogallala aquifer, composed of the water-saturated and permeable parts of the Ogallala Formation (fig. 9), is present in parts of four counties in Wyoming (figs. 1, 7), but the aquifer primarily is used in Laramie County in southeastern Wyoming. In Laramie County, the aquifer is used widely as a source of water for domestic, stock, industrial, public-supply, and irrigation purposes (AMEC Environment and Infrastructure, Inc., and others, 2014). The relation of the Ogallala aquifer to other underlying and overlying hydrogeologic units of the High Plains aquifer system is shown in figure 9.

Because of the heterogeneous nature of the Ogallala Formation, physical characteristics of the Ogallala aquifer are highly variable (Bartos and others, 2013, 2014). Permeability of the Ogallala aquifer is primary (intergranular) and highly variable in southeastern Wyoming because of lithologic heterogeneity of the Ogallala Formation; $T$ and well yields are highest where coarse-grained unconsolidated or poorly consolidated sand and gravel beds are present. Fine-grained sediments (clay, silt, and very fine sand) are common within the Ogallala Formation, and wells completed in these sediments can be unsuccessful because of negligible or low well yield (Knight and Morgan, 1937; Foley, 1942; Morgan, 1946; Lowry and Crist, 1967; Cooley and Crist, 1994). In addition, fine-grained sediments and zones of well-cemented sediments interbedded with coarse-grained water-bearing zones can result in widely varying hydraulic heads over short distances and locally confined or semiconfined groundwater-flow conditions (for example, Cooley and Crist, 1994).

The Arikaree aquifer, composed of the water-saturated and permeable parts of the Arikaree Formation (fig. 9), is present in parts of as many as five counties in southeastern Wyoming, and the aquifer is present at land surface throughout much of the High Plains aquifer-system areal extent (the extent is coincident with potentiometric-surface contours shown in fig. 7). The relation of the Arikaree aquifer to underlying and overlying hydrogeologic units of the High Plains aquifer system is shown in figure 9 . The aquifer primarily is used as a source of water for domestic and stock use, and less commonly for public-supply and irrigation use (Trihydro Corporation, 2006). The Arikaree Formation (aquifer) is absent in many parts of Laramie County, including areas west and south of Cheyenne and much of the Pine Bluffs lowland area, because of erosion or nondeposition (fig. 1; Denson and Bergendahl, 1961; Bart, 1974, 1975; Cooley and Crist, 1981; Cooley and Crist, 1994). 


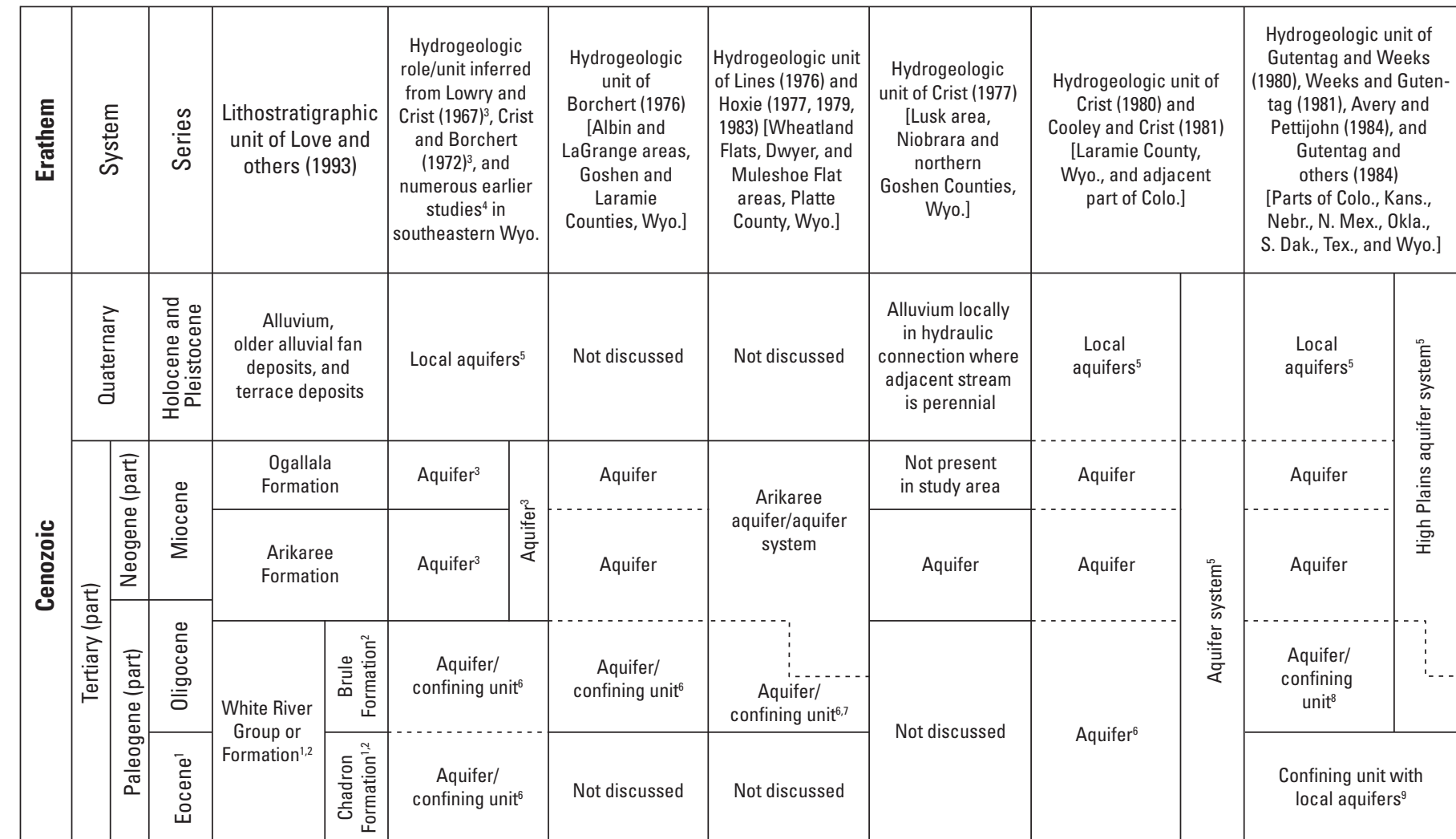

Dashed line indicates possible hydraulic connection with underlying or overlying hydrogeologic unit

'Historically, the Chadron Formation has been considered Oligocene in age (Love and others, 1993, and references therein). Revision of the Eocene-Oligocene boundary stratotype to about 34 million years before present or mega-annum (34 Ma) (for example, Berggren and others, 1992; Obradovich and others, 1995), and radiometric age
dating of ash beds in the White River Group or Formation in Wyoming indicating an age older than 34 Ma (Prothero and Swisher, 1992), indicates the Chadron Formation is late Eocene in age (Swinehart and Diffendal, 1997).

${ }^{2 " W h i t e ~ R i v e r " ~ n o t ~ e l e v a t e d ~ t o ~ G r o u p ~ r a n k ~(a n d ~ n o t ~ d i v i d e d ~ i n t o ~ B r u l e ~ a n d ~ C h a d r o n ~ F o r m a t i o n s) ~ a n d ~ t h e ~ u n i t ~ i s ~ d e f i n e d ~ a s ~ a ~ f o r m a t i o n ~ i n ~ p a r t s ~ o f ~ s o u t h e a s t e r n ~ W y o m i n g ~}$ including much of Laramie County (Love and Christiansen, 1985; Love and others, 1993; Ver Ploeg and others, 1998, and references therein).

3Hydrogeologic role of lithostratigraphic units defined for Laramie County (Lowry and Crist, 1967) and southeastern Laramie County (Crist and Borchert, 1972). Lowry and Crist 1967) noted it was difficult to differentiate the 0 .
considered as a single aquifer (where water bearing).

4See Knight and Morgan (1937), Burleigh and others (1938), Dockery (1940), Foley (1942), Morgan (1946), Babcock and Rapp (1952), Visher and Babcock (1953), Rapp and others $(1953,1957)$, Vher
and Herrmann (1972).

sLocal aquifers in Quaternary unconsolidated deposits can be hydraulically connected laterally or vertically to underlying Tertiary aquifers of the High Plains aquifer system; where hydratinally connected, they are part of the aquifer system.

BBrule or Chadron Formations (all or upper part), or both, may be considered aquifers and in hydraulic connection with overlying Tertiary and Quatermary aquifers where water saturated and permeable (coarse

'Brule Formation of White River Group considered part of Arikaree aquifer/aquifer system in western part of study area where permeable.

\begin{tabular}{|c|c|c|c|c|c|c|c|c|c|c|}
\hline 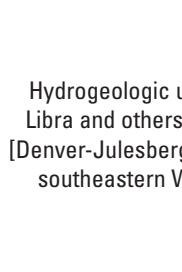 & & 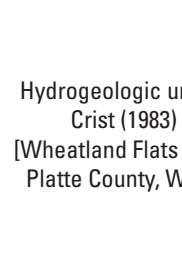 & & $\begin{array}{r}\text { Hydrogeologic u } \\
\text { Borchert (198 } \\
\text { [LaGrange area, G } \\
\text { and Laramie Cou } \\
\text { Wyo., and small a } \\
\text { western Neb }\end{array}$ & & 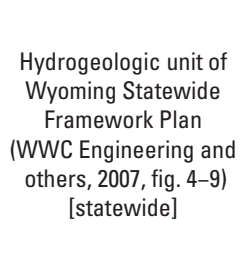 & $\begin{array}{l}\text { Hydrogeologic un } \\
\text { in this report (w口 } \\
\text { White River Grot } \\
\text { Formation is undi } \\
\text { (modified from Bart } \\
\text { others, 2014 } \\
\text { [southeastern V } \\
\text { including Laramie }\end{array}$ & & $\begin{array}{l}\text { Hydrogeologic un } \\
\text { in this report (wh } \\
\text { White River Gro } \\
\text { divided into Brul } \\
\text { Chadron Format } \\
\text { (modified from Bar } \\
\text { others, 2014 } \\
\text { [southeastern V } \\
\text { including Laramie }\end{array}$ & \\
\hline $\begin{array}{c}\text { Quaternar } \\
\text { aquifers }\end{array}$ & & $\begin{array}{l}\text { Local } \\
\text { aquifers }\end{array}$ & & $\begin{array}{l}\text { Local } \\
\text { aquifers }\end{array}$ & & Major aquifer-alluvial & $\begin{array}{c}\text { Quaternary } \\
\text { unconsololdated- } \\
\text { deposite } \\
\text { anuifers }\end{array}$ & 童 & $\begin{array}{c}\text { Quaternary } \\
\text { unconsolidated. } \\
\text { deposite } \\
\text { anuifers }\end{array}$ & 鄫 \\
\hline & & $\begin{array}{l}\text { Not present } \\
\text { in study area }\end{array}$ & 言 & $\begin{array}{l}\text { Not present } \\
\text { in study area }\end{array}$ & & $\begin{array}{l}\text { Major aquifer- } \\
\text { sandstone }\end{array}$ & $\begin{array}{l}\text { Ogallala } \\
\text { aquifer }\end{array}$ & 咨 & $\begin{array}{l}\text { Ogallalala } \\
\text { aquifer }\end{array}$ & \\
\hline aquifer & $\frac{5}{\frac{5}{5}}$ & Aquuifer & & $\begin{array}{l}\text { Not present or } \\
\text { not part of } \\
\text { LaGrange aquifer }\end{array}$ & $\begin{array}{l}\text { 言 } \\
\text { 兽 } \\
\text { 幽 }\end{array}$ & 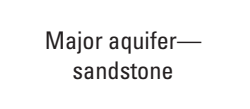 & $\begin{array}{l}\text { Arikaree } \\
\text { aquiterer }\end{array}$ & 嵩 & $\begin{array}{l}\text { Arikaree } \\
\text { aquifer }\end{array}$ & 产 \\
\hline $\begin{array}{c}\text { Confining unit } \\
\text { with } \\
\text { discontinuous } \\
\text { aquiferss }\end{array}$ & 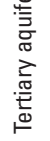 & Not discusse & & Aquifer & & Marginal anuifer & $\begin{array}{c}\text { White River } \\
\text { hydrogeologic unit }\end{array}$ & & 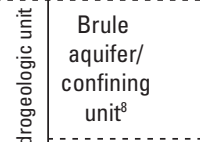 & \\
\hline $\begin{array}{l}\text { Confiningu unit } \\
\text { with } \\
\text { discontinuous } \\
\text { aquifers }\end{array}$ & & & & & & 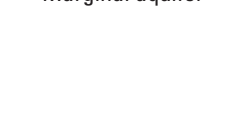 & 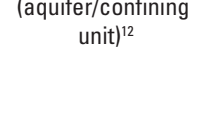 & & 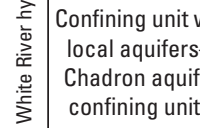 & \\
\hline
\end{tabular}

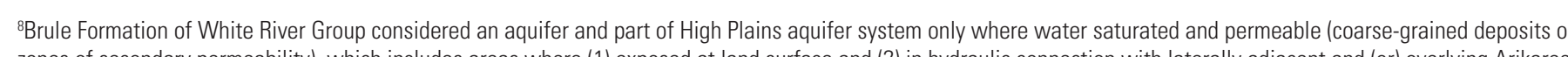

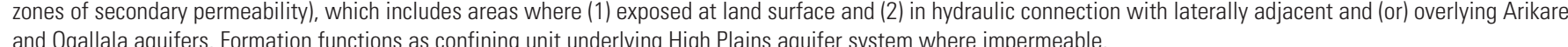

SRegionally, the U.S. Geological Survey does not consider the Chadron Formation to be part of the High Plains aquifer system, and the unit is classified as a confining unit include the forotion where exposed at tand sufree in the Goshen Hole area in southeastern Wyoming G Gutentag and Weeks, 1980; Weeks and Gutentag. 1981: Avery and Pettijohn, 1984; and Gutentag and others, 1984).

"Aquifer divided into an "upper aquifer" composed of "saturated terrace deposits and the upper part of the Arikaree where the Arikaree is exposed in Wheatland Flats" and

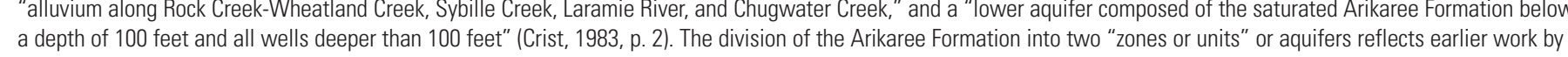
Morris and Babcock (1960) and Weeks (1964).

"LaGrange aquifer composed of saturated alluvium and both the Brule and Chadron Formations of the White River Group. Ogallala Formation not present in study area.

"2Undivided White River Group or Formation and Brule and Chadron Formations of the White River Group considered aquifers and part of the High Plains aquifer system only

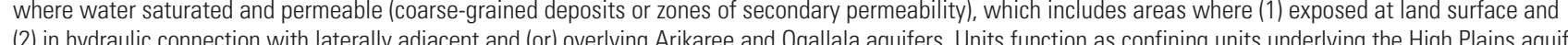
(2) in hydraulic connection with laterally adjacent and (or) overlying Arikaree and Ogallala aquifers. Units function as confing

IsChadron Formation (or parts of Chadron Formation) considered to be in hydraulic connection with and over part of the High Plains aquifer system in some areas in southeastern Wyoming by some investigators, most commonily where the tormation is exposed at land surface and located laterally or vertically adjacent to other Tertian
lithostratigraphic units ( (Daallala, Arikaree, and Brule Formations) (for example, Rapp and others, 1957; Borchert, 1985).

Figure 9. Relation of Cenozoic lithostratigraphic units to hydrogeologic units composing or underlying the High Plains aquifer system, southeastern Wyoming. 
Although Ogallala aquifer properties are highly variable primarily because of lithologic heterogeneity, Arikaree aquifer properties may be highly variable because of differences in the type of permeability present. The lithology of the Arikaree Formation (excluding the basal conglomerate reported in some areas) primarily is poorly to moderately cemented very fine- to fine-grained sandstone and generally is relatively homogenous (Morris and Babcock, 1960; Whitcomb, 1965; Borchert, 1976; Stanley, 1976), especially when compared to the overlying Ogallala Formation (Borchert, 1976). Because of predominantly fine-grained aquifer sediments in the Arikaree Formation, well yields in the Arikaree aquifer generally are small to moderate at most locations; consequently, large well yields typically are obtained by penetrating large thicknesses of the aquifer (Rapp and others, 1957; Morris and Babcock, 1960; Weeks, 1964; Whitcomb, 1965). In most areas, secondary permeability is absent. Areas of high permeability and $T$ reported in some studies may be attributable to secondary permeability derived from localized fractures (Rapp and others, 1957; Morris and Babcock, 1960; Whitcomb, 1965) or concretionary zones (Whitcomb, 1965). Morris and Babcock (1960, p. 37) noted that the basal conglomerate in Platte County, where present, saturated, and poorly cemented, "may yield large quantities of water to wells"; however, the investigators also noted that "the basal conglomerate is well cemented in most places, and it is doubtful that much greater yield could be obtained from it than from the upper part of the formation."

In some areas within Laramie County, lithologic and hydrologic characteristics of the Ogallala and Arikaree aquifers can be similar. Lowry and Crist (1967, p. 28) noted that the Arikaree Formation in Laramie County could be lithologically similar to the Ogallala Formation in places and that "it is difficult to distinguish the contact between the two formations in many wells"; the investigators also noted that in areas where both units were lithologically "similar in appearance," water-bearing properties of both units were similar enough that the two formations may be considered as a single hydrogeologic unit. Similarly, Cooley and Crist (1981, pl. 1) also noted the difficulty in separating the two formations and noted that the contact between the Ogallala and Arikaree Formations in their fence diagrams for southeastern Wyoming "generally was determined rather arbitrarily."

\section{White River Hydrogeologic Unit}

Water-bearing characteristics of the White River Formation or Group are highly spatially variable in the Cheyenne Basin and larger southeastern Wyoming area (Lowry and Crist, 1967; Bartos and others, 2013, 2014). Where sufficiently saturated and permeable to produce useful quantities of water, the lithostratigraphic unit or parts of the unit are classified as an aquifer (White River aquifer, or alternatively, Brule or Chadron aquifers where the unit is divided; fig. 9; Bartos and others, 2014). Where poorly permeable or nonwater bearing/ impermeable, the unit or parts of the unit are classified as a confining unit or nonaquifer (White River confining unit, or alternatively, Brule or Chadron confining units where the unit is divided; fig. 9; Bartos and others, 2014). Because of its function as an aquifer and (or) confining unit, depending on location, the White River Formation or Group is identified hereinafter as a "hydrogeologic unit" when broadly describing the entire lithostratigraphic unit in a hydrogeologic context.

Water-bearing parts of the White River Formation or Group (simplified to "White River Formation" hereinafter in this report section) in the Cheyenne Basin typically are discontinuous, consisting mainly of zones/areas in the upper part of the unit where secondary porosity and permeability have developed locally in the semiconsolidated to consolidated fine-grained mudrocks that volumetrically compose most of the unit, and much less commonly of locally present fluvially deposited coarse-grained rocks of slight areal extent (Knight and Morgan, 1937; Burleigh and others, 1938; Dockery, 1940; Warner, 1947; Babcock and Rapp, 1952; Rapp and others, 1953, 1957; Babcock and Bjorklund, 1956; Bjorklund, 1959; Morris and Babcock, 1960; Lowry, 1966; Lowry and Crist, 1967; Lidstone and Associates, Inc., 2005; Wyoming Groundwater, LLC, and others, 2011). The coarse-grained rocks typically consist of thin channel deposits/fills of muddy (silty and clayey) sandstone and conglomerate deposited in locally present paleovalleys incised into underlying and adjacent fine-grained mudrocks of the White River Formation or Upper Cretaceous rocks near the base of the White River Formation (for example, Schlaikjer, 1935a, b; Rapp and others, 1957; Lowry and Crist, 1967; Evanoff, 1990a; Lidstone and Associates, Inc., 2005; AVI Professional Corporation and others, 2008; Wyoming Groundwater, LLC, and others, 2011; Bartos and others, 2014; this study).

Groundwater wells successfully completed in the White River Formation in the Cheyenne Basin in southeastern Wyoming yield small to large quantities of water, although well yields typically are sufficient only for domestic or stock use (Bartos and others, 2013). However, some groundwater wells completed in the most permeable parts of the White River Formation locally are capable of producing quantities of water sufficient for public-supply, industrial, or irrigation use, with well yields ranging from hundreds to as much as 2,000 $\mathrm{gal} / \mathrm{min}$, but this productivity is not typical of most of the unit (Lowry, 1966; Lowry and Crist, 1967; Crist and Borchert, 1972; Lidstone and Anderson, Inc., and AVI Professional Corporation, 1995; Lidstone and Associates, Inc., 2003; AMEC Environment and Infrastructure, Inc., and others, 2014). In fact, much of the White River Formation yields only small quantities of water or no water to groundwater wells where water saturated because the mudrocks composing most of the unit typically have low primary (matrix or intergranular) permeability or are principally impermeable (for example, Rapp and others, 1957; Lowry, 1966; Lowry and Crist, 1967; Crist and Borchert, 1972; Borchert, 1976; Lidstone and Associates, Inc., 2003). Consequently, despite its substantial watersaturated thickness in Laramie County (Bartos and Hallberg, 2011, fig. 5), including the Pine Bluffs lowland area, only part of the total saturated volume of the White River Formation 
Geologic and Hydrogeologic Characteristics, White River Formation, Lance Formation, and Fox Hills Sandstone, Wyo.

typically is sufficiently permeable to yield useful quantities of water to wells (and thus, be considered an aquifer).

In the Pine Bluffs lowland area, yields tend to be largest in areas where wells are completed in the upper part of the White River Formation where productivity has been enhanced locally by secondary processes (secondary porosity and permeability development) and (or) where the unit is hydraulically connected with (and receives recharge from) overlying saturated permeable Quaternary unconsolidated deposits (Knight and Morgan, 1937; Bjorklund, 1959; Lowry, 1966; Lowry and Crist, 1967; Crist and Borchert, 1972; Crist, 1980; Dahlgren Consulting, Inc., and others, 2001). Recharge to the White River Formation from these overlying Quaternary unconsolidated deposits has been speculated to be larger in some topographically low areas and in floodplains associated with various drainages than in upland terranes because recharge may be more focused in these lowland areas (Knight and Morgan, 1937; Dahlgren Consulting, Inc., and others, 2001). In these areas, the saturated unconsolidated deposits likely provide a substantial amount of the water to wells completed in the upper part of the White River Formation.

Because of highly varying and often poor success in siting wells with yields sufficient for intended uses, the waterbearing characteristics of the White River hydrogeologic unit have been the source of much speculation, discussion, and investigation over the years. Numerous early studies attributed productivity of wells completed in mudrocks composing most of the White River Formation in southeastern Wyoming to secondary porosity and permeability development by joints, fissures, voids, and (or) fractures formed after the unit was deposited (Knight and Morgan, 1937; Burleigh and others, 1938; Dockery, 1940; Warner, 1947; Babcock and Rapp, 1952; Rapp and others, 1953, 1957; Babcock and Bjorklund, 1956; Bjorklund, 1959; Morris and Babcock, 1960). Most of these studies concluded that fractures (or fracture zones) were responsible for most water production from the unit, especially in areas where wells completed in the mudrocks provide quantities of water sufficient for irrigation use (hundreds to thousands of gallons per minute). Lowry (1966) and Lowry and Crist (1967) reevaluated the conclusion of many of these earlier studies that fractures alone were responsible for locally large well yields where the White River Formation was composed primarily of mudrocks; much of their reevaluation included study of the White River Formation in the Pine Bluffs lowland area. The investigators acknowledged that fractures likely were responsible for much of the water transmitted to wells with small yields (sufficient for stock or domestic use) completed in the White River Formation. The investigators observed that many of the wells with large yields sufficient for irrigation use in southeastern Wyoming were in valleys of major drainages; more detailed study led them to conclude that many of the large-yield wells also were likely completed in deposits composed of material eroded and reworked from the White River Formation and subsequently deposited as alluvium rather than the formation itself. Consequently, because the wells with large yields also were screened partially or completely in more permeable deposits eroded from the unit, "difficulty in differentiating the two has left the impression that the White River Formation is a much better aquifer than it really is" (Lowry, 1966, p. D219). This interpretation is similar to an earlier conclusion by Bjorklund (1959, p. 11), who observed that "where it is overlain by the protective cover of younger deposits, the top of the Brule [upper part/unit of White River Formation or Group] consists of rounded pebbles of reworked siltstone," and "this zone generally is very permeable and where saturated will readily transmit water to wells." In wells where a more detailed examination indicated that large yields clearly were not attributable to more permeable hydraulically connected overlying deposits eroded from the unit, Lowry (1966) and Lowry and Crist (1967) concluded that "tubes" formed by piping and (or) solutional activity, rather than fracturing alone, likely contributed substantially to much of the high permeability/productivity found locally in parts of the upper White River Formation in southeastern Wyoming, including the Pine Bluffs lowland area. The investigators speculated that the piping likely occurred before deposition of the overlying Quaternary unconsolidated deposits (alluvium or older alluvial fan deposits) or Ogallala Formation (favorable paleotopography) where present and that other conditions favorable to the development of piping include favorable grain-size distribution, mineralogy, and geochemistry; some of these conditions also were considered favorable to piping development in the upper part of the White River Formation of southeastern Wyoming in subsequent studies by Crist and Borchert (1972) and Borchert (1976).

Several other studies also examined secondary porosity and permeability in the White River Formation in southeastern Wyoming. Crist and Borchert (1972) used televiewer logs to examine boreholes open to the White River Formation in the Pine Bluffs lowland. The investigators reported openings resembling caverns or tubes of various sizes, but this interpretation also has been alternatively interpreted as asymmetric spalling of the borehole from the drilling process (Barrash and Morin, 1987). The investigators speculated that solutional activity also is likely a substantial contributor to secondary permeability development in the unit. Borchert (1976) used televiewer logs from wells to examine boreholes open to the White River Formation in the Albin and La Grange areas of southeastern Wyoming. Dark regions were reported from examination of the televiewer logs, and these regions were interpreted as irregular cavities. In addition, the investigators did not observe any features considered to be fractures other than possibly bedding plane fractures. Examination of the same dark regions in televiewer logs from another and more detailed study of the upper part of the White River Group (Brule Formation) near Sidney, Nebraska, led Barrash and Morin (1987, p. 452) to conclude that these regions also could be "artifacts because of drilling disturbance and/ or removal of lateral support from structurally weak, intensely fractured material." Two studies used a downhole camera to examine the uncased part (open borehole) of several publicsupply wells completed in the upper part of the White River 
Formation or Group (identified as Brule Formation) near the town of Pine Bluffs in the Pine Bluffs lowland (Lidstone and Anderson, Inc., and AVI Professional Corporation, 1995; Lidstone and Associates, Inc., 2003). Minor and highly fractured zones were visually observed in the wells and a large "cavity" was observed in one well.

At a study location near Sidney Draw, west of Sidney, Nebr., Barrash and Morin (1987) completed a detailed study of permeability of mudrocks in the upper part of the White River Group (Brule Formation). These rocks are virtually equivalent to those present in the Pine Bluffs lowland area. Using many geological, geophysical, and hydrogeological methods, the investigators concluded that (1) permeability is enhanced locally through fractures; (2) in the unfractured part of the Brule Formation, vertical hydraulic conductivity $\left(K_{v}\right)$ is enhanced at some locations by several types of features, including abundant pedotubules (vertical features in the rocks such as preserved animal burrows), and horizontal hydraulic conductivity could be enhanced by subhorizontal parting planes; (3) acoustic televiewer logs can be used to identify localized zones of secondary permeability (fracture zones) in open boreholes, and fracture zones correlate with locations of enlarged borehole diameter; and (4) televiewer images of fracture zones indicate fracture networks and voids (similar to some conclusions reached by Crist and Borchert, 1972, and Borchert, 1976), but the study could neither clearly support nor refute interpretation of piping for the origin or nature of the zones with the highest productivity (secondary permeability development) as proposed in earlier studies (Lowry, 1966; Lowry and Crist, 1967; Crist and Borchert, 1972; Borchert, 1976). Regardless of the different interpretations of the origins/mechanisms of permeability, all studies agree that in the absence of secondary features/processes that enhance permeability, permeability generally is low in the mudrocks that compose much of the White River Formation.

\section{Relation of Cenozoic Hydrogeologic Units in Pine Bluffs Lowland to High Plains Aquifer System}

The High Plains aquifer system (commonly shortened to "High Plains aquifer") is a nationally important water resource that underlies about 175,000 $\mathrm{mi}^{2}$ in parts of eight StatesColorado, Kansas, Nebraska, New Mexico, Oklahoma, South Dakota, Texas, and Wyoming (Qi, 2010). Because crops are irrigated with groundwater from the High Plains aquifer system, the area that overlies the aquifer system has become one of the major agricultural regions in the world (McGuire and others, 2003; McGuire, 2017). The High Plains aquifer system also serves as the primary source of drinking water for most residents of the region. In 2015, the High Plains aquifer system had an estimated 2.91 billion acre-feet of recoverable water in storage, making it one of the largest aquifers or aquifer systems in the world (McGuire and others, 2003; McGuire, 2017).
Present in parts of five counties in southeastern Wyoming, the High Plains aquifer system overlies an area of $8,190 \mathrm{mi}^{2}$ in southeastern Wyoming (Gutentag and Weeks, 1980). Aquifer-system areal extent in southeastern Wyoming includes and extends beyond the Cheyenne Basin and Pine Bluffs lowland area (extent coincident with potentiometricsurface contours shown in fig. 7). Regional groundwater flow in the High Plains aquifer system in the Pine Bluffs lowland area generally is from the west to the east (Bartos and Hallberg, 2011; fig. 7 [assuming groundwater flow is perpendicular to potentiometric contours]). Near Carpenter, groundwater flows south-southeast from the west (fig. 7). Based on withdrawals for irrigation, public-supply, and industrial use, the High Plains aquifer system is the most used source of groundwater in Wyoming (Boughton and others, 2006, fig. 4). Throughout much of southeastern Wyoming, including the Pine Bluffs lowland area, the High Plains aquifer system is the predominant groundwater resource for stock, domestic, municipal, agricultural (irrigation), and industrial uses (Trihydro Corporation, 2006; AMEC Environment and Infrastructure, Inc., and others, 2014; Dahlgren Consulting, Inc., and others, 2018). Withdrawal of groundwater for irrigation is the largest use of water from the High Plains aquifer system in southeastern Wyoming, including the Pine Bluffs lowland area (Trihydro Corporation, 2006; AMEC Environment and Infrastructure, Inc., and others, 2014; Dahlgren Consulting, Inc., and others, 2018).

Aquifers in as many as four Cenozoic lithostratigraphic units - Quaternary unconsolidated deposits [alluvium, terrace, and alluvial fan deposits], Ogallala Formation, Arikaree Formation, and the White River Formation or Group - may compose the regional High Plains aquifer system in southeastern Wyoming (fig. 9). An aquifer system consists of two or more aquifers, commonly vertically stacked, that are grouped together because of physical connection and (or) sharing of similar geologic and hydrologic characteristics that are best described and studied together. Although considered part of the aquifer system or units that underlie the aquifer system, depending on location, each of the four Cenozoic lithostratigraphic units also have been broadly defined as an individual hydrogeologic unit (aquifer or confining unit) or hydrostratigraphic unit within or below the larger High Plains aquifer system (see the last two columns in fig. 9), as described previously. The individual lithostratigraphic/hydrogeologic units that compose the High Plains aquifer system can be connected hydraulically to varying degrees, depending on local hydrogeologic conditions. Although hydraulic connection between the hydrogeologic units varies locally, regionally the Tertiary units are conceptually interpreted to be in sufficient hydraulic connection to compose a regional aquifer system (fig. 9; Crist, 1980; Gutentag and Weeks, 1980; Cooley and Crist, 1981, 1994; Libra and others, 1981; Weeks and Gutentag, 1981; Avery and Pettijohn, 1984; Gutentag and others, 1984). However, this idealized regional aquifer-system conceptualization warrants examination in relation to the location and scale of study because of spatially variable hydrogeologic 
characteristics and variable horizontal/vertical hydraulic connection within and between the different Tertiary hydrogeologic units (Wyoming State Engineer's Office, 2008; Bartos and others, 2014). Conceptually, it is perhaps best to think of the High Plains aquifer system in southeastern Wyoming as a complex system of multiple water-bearing zones of varying geometry in one or more lithostratigraphic/hydrogeologic units (or parts of units), with varying amounts of hydraulic interconnection, and with primary and secondary permeability (Wyoming State Engineer's Office, 2008; Bartos and others, 2014).

Historically, many combinations or groupings of the four Cenozoic lithostratigraphic units composing the High Plains aquifer system have been used by many investigators to define various aquifers and aquifer systems at different locations in southeastern Wyoming (fig. 9); the definition of the aquifers and aquifer systems varies because of the different Cenozoic lithostratigraphic units present at a given location, as well as different hydrogeologic characteristics of the units in the area evaluated and different interpretations of the degree of hydraulic interconnection between the units by different investigators. In many earlier studies, the degree of regional hydraulic interconnection between the different Tertiary hydrogeologic units composing the High Plains aquifer system generally went unrecognized but some earlier studies did recognize hydraulic connection between the units, especially in Laramie County. Lowry and Crist (1967, p. 28) noted that in areas where the Ogallala and Arikaree Formations were lithologically similar in Laramie County, "the water-bearing properties of the Ogallala and of the Arikaree are similar enough that the two formations may be considered as a [single] hydrologic unit." In addition, the investigators indirectly noted the existence of an aquifer system in Laramie County, stating that "hydraulic connection between the Tertiary formations [in Laramie County] is sufficient to permit contouring a common water table" (Lowry and Crist, 1967, p. 39). Similarly, Crist and Borchert (1972) indicated that hydraulic connection between different Tertiary lithostratigraphic units, as well as between Tertiary lithostratigraphic units and extensive alluvial and older alluvial fan deposits (identified as terrace deposits in their report), in the Pine Bluffs lowland area was sufficient to permit contouring a common water table. Crist (1980) was the first investigator to formally identify and propose a regional "aquifer" or "aquifer system" composed of all the Tertiary lithostratigraphic units in southeastern Wyoming, although his study was limited to Laramie County and the aquifer system was unnamed; however, Crist (1980) states that part of the reason the Tertiary lithostratigraphic units were "grouped" together into an aquifer system for modeling purposes was because of the difficulty in differentiating the individual lithostratigraphic units throughout the county. Subsequently, Cooley and Crist (1981) and Libra and others (1981) also recognized a regional aquifer system composed of all Tertiary lithostratigraphic units in southeastern Wyoming; the aquifer system was unnamed in Cooley and Crist (1981) but was informally defined as the "Tertiary aquifer system" in Libra and others (1981, fig. II-5; see "Hydrogeologic unit of Libra and others (1981)" column in fig. 9). Identification of the High Plains aquifer system as the "Tertiary aquifer system" or some variation of this nomenclature ("Tertiary aquifer" or "upper Tertiary aquifer") is relatively common in southeastern Wyoming. Regional studies of the aquifer system in Cenozoic lithostratigraphic units in southeastern Wyoming and equivalent lithostratigraphic units in adjacent States by the USGS Regional Aquifer System Analysis (RASA) program led to formal naming and definition of the High Plains aquifer system (Gutentag and Weeks, 1980; Weeks and Gutentag, 1981; Avery and Pettijohn, 1984; Gutentag and others, 1984; Weeks and others, 1988).

Modified from Bartos and others (2014, fig. 4), figure 9 summarizes and synthesizes previous studies and unifies regional aquifer and aquifer-system nomenclature in southeastern Wyoming while chiefly reflecting the formal definition of the regional High Plains aquifer system by the USGS RASA program (Gutentag and Weeks, 1980; Weeks and Gutentag, 1981; Avery and Pettijohn, 1984; Gutentag and others, 1984; Weeks and others, 1988); however, there are some notable discrepancies and contradictions between the USGS definition of the regional aquifer system and local definitions. Discrepancies in regional aquifer and aquifer-system nomenclature (hydrostratigraphy) arise primarily as a result of different interpretations of the hydrogeologic role of the White River Formation or Group in southeastern Wyoming, including the Pine Bluffs lowland area. Although the Arikaree and Ogallala Formations are broadly defined as aquifers within the High Plains aquifer system throughout their areal extent in southeastern Wyoming and adjacent States by all investigators, the White River Formation or Group (or parts of the unit) is classified as either an aquifer or confining unit, depending upon local hydrogeologic characteristics (fig. 9). As described previously, permeability of the White River Formation or Group is highly variable, and thus, the lithostratigraphic unit or parts of the unit are classified as either an aquifer where sufficiently water saturated and permeable to produce economic quantities of water (White River aquifer) or as a confining unit/nonaquifer where poorly permeable or impermeable (White River confining unit; fig. 9).

Most studies, including the USGS RASA program, defined the upper part of the White River Formation or Group (Brule Formation) as an aquifer and part of the High Plains aquifer system only where it is sufficiently permeable and (or) in hydraulic connection with the overlying Ogallala or Arikaree aquifers where present. Where the permeability is low, the White River Formation or Group was defined as a nonwater-bearing unit or confining unit (where present at land surface) or confining unit underlying the High Plains aquifer system (where underlying the Ogallala and [or] Arikaree Formations and not in hydraulic connection with either unit). In some areas, water-saturated and permeable coarse-grained sediments in the lower part of the White River Formation or Group constitute local aquifers that likely are not in hydraulic connection with the overlying High Plains aquifer system 
(Bartos and others, 2014). Regionally, the USGS does not consider the Chadron Formation (or equivalently, the lower part of the White River Formation where undivided) where buried below the overlying Brule Formation (or equivalently, the upper part of the White River Formation where undivided) to be part of the High Plains aquifer system, and the unit is classified as a confining unit, a confining unit with local aqui fers, or an aquifer underlying the High Plains aquifer system (fig. 9). However, regional USGS potentiometric-surface maps group the Chadron Formation with the Brule Formation (or the upper part of White River Formation, where undivided) and show both units as part of the aquifer system where these units are exposed in southeastern Wyoming, including where the Chadron Formation is exposed in the Goshen Hole area and the upper White River Formation is exposed in the Pine Bluffs lowland area (fig. 9), inferring hydraulic connection with the rest of the aquifer system (see Chadron Formation outcrop area in Goshen Hole in fig. 7) and somewhat contradicting the USGS RASA regional definition of the aquifer system (Gutentag and Weeks, 1980; Weeks and Gutentag, 1981; Avery and Pettijohn, 1984; Gutentag and others, 1984; Weeks and others, 1988). In addition, some local studies (most of which were done by the USGS and are shown in fig. 9) consider the Chadron Formation (or the upper parts of the Chadron Formation), where locally permeable, to be in hydraulic connection with adjacent members of the aquifer system in Goshen Hole where the formation is exposed at land surface and located laterally or vertically adjacent to other Tertiary lithostratigraphic units (Rapp and others, 1957; Borchert, 1985). Consequently, the definition of the High Plains aquifer system of Bartos and others (2014; last two columns in fig. 9) acknowledged the regional definition of the system by the USGS RASA program but also acknowledged potential areas of local hydraulic connection of the upper parts of the White River Formation or Group or lower parts of the White River Formation or Group where exposed (including Chadron Formation in Goshen Hole) with other Cenozoic lithostratigraphic units commonly considered part of the aquifer system in southeastern Wyoming. In addition, this definition acknowledged that lower parts of the White River Formation in some areas may contain aquifers of local/slight areal extent that likely are hydraulically isolated from the overlying High Plains aquifer system, including some areas where the upper part of the White River Formation or Group overlying the local lower White River aquifers constitutes all or part of the High Plains aquifer system (fig. 9).

Where Quaternary unconsolidated deposits are in hydraulic connection laterally or vertically to the underlying Tertiary aquifers, as is the case with the Quaternary older alluvial fan deposits and the upper part of the White River Formation or Group (Brule Formation) in parts of the Pine Bluffs lowland, the deposits generally are considered locally part of the High Plains aquifer system by many investigators (fig. 9; Lowry and Crist, 1967; Crist and Borchert, 1972; Crist, 1980; Gutentag and Weeks, 1980; Libra and others, 1981; Weeks and Gutentag, 1981; Avery and Pettijohn, 1984; Gutentag and others, 1984; Bartos and Hallberg, 2011). Consequently, wells completed in the High Plains aquifer system in the Pine Bluffs lowland withdraw water from water-saturated and permeable parts of the Quaternary older alluvial fan and alluvial deposits and (or) the upper part of the White River Formation (some wells are completed in more than one lithostratigraphic unit).

\section{Upper Cretaceous Hydrogeologic Units}

Upper Cretaceous hydrogeologic units are identified and described in this report section.

\section{Lance Hydrogeologic Unit}

The Lance Formation in the Wyoming part of the Cheyenne Basin has been broadly defined as a potential aquifer, aquifer, or minor aquifer, primarily based on hydrogeologic characteristics determined from wells completed in individual water-saturated and permeable sandstone beds at relatively shallow depths in the Goshen Hole area where the formation crops out or subcrops at shallow depths; these wells primarily are used as a source of water for stock and domestic purposes (Dockery, 1940; Rapp and others, 1957; Morris and Babcock, 1960; Lowry and Crist, 1967; Libra and others, 1981; BRS, Inc., and Lidstone and Anderson, Inc., 1996; WWC Engineering and others, 2007, figs. 4-9; Wyoming Groundwater, LLC, and others, 2011). Most water produced from the Lance Formation in the Wyoming part of the Cheyenne Basin is from the Goshen Hole area. For a variety of reasons, the formation is rarely used for public-supply, irrigation, or industrial purposes in the Wyoming part of the Cheyenne Basin. Availability of water from shallower or more productive aquifers (primarily of the High Plains aquifer system), absence of water-bearing sandstone beds or sufficient cumulative water-saturated sandstone thickness at many locations, small to moderate well yields, deep burial at many locations, inadequate water quality for intended uses, or large distances from towns or cities has limited development of the formation for these and other water uses (Dockery, 1940; Rapp and others, 1957; Morris and Babcock, 1960; Libra and others, 1981; Borchert, 1985; BRS, Inc., and Lidstone and Anderson, Inc., 1996; Wyoming Groundwater, LLC, and others, 2011). In the Colorado part of the Cheyenne Basin, sandstone beds in the equivalent Laramie Formation are developed more extensively as sources of water, most commonly for stock and domestic use and less commonly for industrial use (Weist, 1964, 1965; Kirkham and others, 1980; Thompson and others, 1980; Kirkham and Rold, 1986).

As described previously, the Lance/Laramie Formation is composed of alternating layers of sandstone, various types of mudrocks, and coal. Very fine- to medium-grained, poorly to moderately consolidated water-bearing sandstone beds compose the individual aquifers in the Lance/Laramie Formation in the Cheyenne Basin of southeastern Wyoming and northeastern Colorado (Dockery, 1940; Rapp and others, 
Geologic and Hydrogeologic Characteristics, White River Formation, Lance Formation, and Fox Hills Sandstone, Wyo.

1957; Morris and Babcock, 1960; Weist, 1965; Wacinski, 1979; Kirkham and others, 1980; Wade, 1981; Kirkham and Rold, 1986; Wyoming Groundwater, LLC, and others, 2011). Sandstone beds in the Lance/Laramie Formation are highly irregular in thickness and areal distribution in the Cheyenne Basin of southeastern Wyoming and northeastern Colorado (Rapp and others, 1957; Morris and Babcock, 1960; Ethridge and others, 1979; Kirkham and Ladwig, 1979, 1980; Wacinski, 1979; Kirkham and others, 1980; Wade, 1981; Nibbelink, 1983; Borchert, 1985; Kirkham and Rold, 1986; Lidstone and Associates, Inc., 2003; Wyoming Groundwater, LLC, and others, 2011). Sandstone beds that function as aquifers in the Lance/Laramie Formation typically are small in extent, lenticular, discontinuous, and interpreted to be isolated meandering channels in a coastal plain environment (Wilson and others, 2010), and thus are confined laterally and vertically by low-permeability, fine-grained mudrocks such as shale. This results in a series of individual, spatially scant, confined sandstone aquifers (identified as "subaquifers" in this report) within the formation (Rapp and others, 1957; Morris and Babcock, 1960; Kirkham and others, 1980; Libra and others, 1981; Kirkham and Rold, 1986; Wyoming Groundwater, LLC, and others, 2011). However, some sandstone beds/aquifers in the Colorado part of the Cheyenne Basin are more extensive and thicker than likely is typical for the formation in many areas (for example, Reade, 1976; Ethridge and others, 1979; Nibbelink, 1983). Some Laramie Formation sandstone beds (and some Fox Hills Sandstone beds) are uranium bearing (in the form of roll-front deposits) in the Colorado part of the Cheyenne Basin (Weld County, fig. 4; Reade, 1976; Thompson and others, 1980; Wade, 1981; Yoshino, 2011). In some areas in the Wyoming part of the Cheyenne Basin, the Lance Formation contains few or only thin water-bearing sandstone beds (Babcock and Rapp, 1952; Borchert, 1985), and thus, the formation (or most of the formation) may function as a confining unit in these areas.

Although sandstone beds composing the water-bearing parts of the Lance Formation are confined by fine-grained mudrocks at most locations, unconfined (water-table) conditions may be present in shallow sandstone beds in Goshen Hole where the Lance Formation is exposed at land surface or buried at shallow depths below overlying strata (Dockery, 1940; Wyoming Groundwater, LLC, and others, 2011). Yields from wells completed in the Lance Formation in the Cheyenne Basin in Wyoming are highly dependent on the number and (or) thickness of the saturated sandstone beds penetrated, as well as hydraulic properties of the individual sandstone beds (Rapp and others, 1957; Libra and others, 1981; Lidstone and Associates, Inc., 2003; Wyoming Groundwater, LLC, and others, 2011). Different strata within the Lance Formation can yield groundwater of different quality (Dockery, 1940; Wyoming Groundwater, LLC, and others, 2011; this study, see "Groundwater-Quality Characteristics" report section and appendix 2, table 2.1).

In a study broadly summarizing the known or potential water-bearing characteristics of lithostratigraphic units throughout the Cheyenne Basin of Wyoming, Libra and others (1981) grouped the entire combined thickness of the Lance Formation and Fox Hills Sandstone into a single regional (basinwide) hydrogeologic unit identified as the "Lance-Fox Hills aquifer." This hydrogeologic unit name was from thencurrent hydrogeologic studies of these and overlying formations in the Denver Basin composing the heavily developed and productive multiaquifer Denver Basin aquifer system in northeastern Colorado (strata composing the Denver Basin aquifer system are shown in fig. $5 B$; the Laramie-Fox Hills aquifer is the basal aquifer of the Denver Basin aquifer system). However, whether intentional or not, the investigators used the name in a different manner than used in all thencurrent and later hydrogeologic studies of these strata in the Denver Basin of northeastern Colorado beginning in the early to mid-1970s. These and later studies defined the Laramie-Fox Hills aquifer in the Denver Basin (and later, Cheyenne Basin) of northeastern Colorado as a multilayered aquifer consisting of the water-saturated and permeable sandstone beds of the Fox Hills Sandstone, overlying or intertonguing water-bearing sandstone beds located only in the lowermost/basal part of the Laramie Formation (where present) and intervening mudrock layers; thus, most of the Laramie Formation thickness is not included in the Laramie-Fox Hills aquifer (for example, Romero and Hampton, 1972; Romero, 1976; Schneider, 1980; Robson and others, 1981, 1998; Colorado Division of Water Resources, 1985; Robson, 1987, 1989; Paschke, 2011). In addition, some locally present water-saturated and permeable sandstone or siltstone beds in the upper transition member of the Pierre Shale (above members C and D; fig. 6B) also are included as part of the aquifer in some areas, if suspected to be in hydraulic connection with the overlying sandstone beds of the Fox Hills Sandstone. In the Denver Basin, all Laramie Formation strata above the Laramie-Fox Hills aquifer (most of the formation) and below the Arapahoe Formation (or equivalently, the bottom of the D1 sequence; fig. $5 B$ ) are assigned to a basinwide confining unit identified as the Laramie confining unit (for example, Robson, 1987, 1989; Paschke, 2011; fig. 5B); the confining unit primarily composes the fine-grained mudrocks (most of the Lance Formation thickness) above the Laramie-Fox Hills aquifer. In the Denver Basin aquifer system, the Laramie confining unit separates the Laramie-Fox Hills aquifer from the lower Arapahoe aquifer consisting of the lower 200 to $600 \mathrm{ft}$ of the Arapahoe Formation (Paschke, 2011). Although defined as a confining unit, locally present sandstone beds in the Laramie confining unit can contain productive aquifers of small areal extent.

Subsequent studies applied the Denver Basin LaramieFox Hills aquifer name to the equivalent parts of the Laramie Formation and Fox Hills Sandstone in the Cheyenne Basin of northeastern Colorado because of similar formational characteristics (Wacinski, 1979; Kirkham and Rold, 1986; Robson and Banta, 1987; Robson, 1989; Robson and others, 1998, 2000a, b); however, the hydrogeologic/hydrostratigraphic name applied to the part of the Laramie Formation located above and not considered part of the Laramie-Fox Hills 
aquifer differs between studies. Several studies concluded that the Laramie Formation is thicker and may contain more and thicker sandstone beds in the Cheyenne Basin than in the Denver Basin (Kirkham and Ladwig, 1980; Kirkham and others, 1980; Kirkham and Rold, 1986). Consequently, Kirkham and Rold (1986) identified the part of the Laramie Formation (and equivalent Lance Formation in the Crow Creek drainage in Wyoming) above the Laramie-Fox Hills aquifer in the upper Crow Creek drainage of northeastern Colorado and Wyoming as the "upper Laramie aquifer." However, the investigators infer this aquifer name was adopted to simply apply a name to the part of the Laramie Formation above the Laramie-Fox Hills aquifer in which various discontinuous water-bearing sandstone beds occur and in which numerous wells in the Colorado part of the Cheyenne Basin were completed (the formation underlies much of the Cheyenne Basin in Colorado at shallow depths). Furthermore, the investigators indicate it does not imply that all Lance/Laramie Formation strata or even most of the strata above the Laramie-Fox Hills aquifer (entire upper Laramie aquifer interval) are composed of water-bearing strata/sandstone (Kirkham and Rold, 1986). In addition, it should be noted that the Laramie Formation in the Colorado part of the upper Crow Creek drainage contains several locally present thick and laterally extensive sandstone beds (several of which have been given local names, some of which are uranium bearing; Reade, 1976; Ethridge and others, 1979; Thompson and others, 1980; Wade, 1981; Nibbelink, 1983; Kirkham and Rold, 1986) that likely are not typical of the formation at all locations. In contrast to Kirkham and Rold (1986), other investigators applied the Denver Basin "Laramie confining unit" designation to the Laramie Formation strata above the Laramie-Fox Hills aquifer throughout the Cheyenne Basin of northeastern Colorado because most of the formation in this subbasin was interpreted to be composed largely of low-permeability mudrocks, and sandstone beds likely represented a minority of total formation thickness, just as in the Denver Basin (Robson, 1989; Robson and others, 1998, 2000a, b).

Unfortunately, use of the regional "Lance-Fox Hills aquifer," as a term defined and misapplied by Libra and others (1981) with respect to inclusion of all strata of the Lance Formation and Fox Hills Sandstone, has been retained in subsequent reports examining the water-bearing characteristics or potential water-bearing characteristics of the Lance Formation and Fox Hills Sandstone in the Wyoming part of the Cheyenne Basin. If this definition of the Lance-Fox Hills aquifer is accepted, designation of the combined thickness of the Lance Formation and Fox Hills Sandstone as a single aquifer would imply substantial regional vertical hydraulic connection between and within the two lithostratigraphic units and the presumed absence of a regional confining unit between them. However, no regional or local evidence was provided by Libra and others (1981) for this interpretation and, more broadly, their alternative definition of the "Lance-Fox Hills aquifer." In addition, the authors of this study are not aware of any subsequent studies to date (2020) that support this interpretation/ definition of the Lance-Fox Hills aquifer in either the Wyoming or Colorado parts of the Cheyenne Basin.

This study adopts the Lance-Fox Hills aquifer (or alternatively, Laramie-Fox Hills aquifer in Colorado) name as used by most studies in the Cheyenne and Denver Basins in northeastern Colorado, as described previously. Consequently, the Lance-Fox Hills aquifer in this study is defined as a multilayered aquifer consisting of the water-bearing sandstone beds of the Fox Hills Sandstone and overlying or intertonguing waterbearing sandstone beds located only in the lowermost/basal part of the Lance Formation (where present). Additionally, this study groups all strata above the Lance-Fox Hills aquifer into a broad generalized hydrogeologic unit identified as the "Lance hydrogeologic unit" when broadly describing these strata (or the entire formation where basal Lance Formation sandstones immediately above or intertonguing with the Fox Hills Sandstone are not present) as a hydrogeologic unit. This generalized hydrogeologic unit name acknowledges that the lithology of the Lance/Laramie Formation is highly spatially variable, and consequently, the Lance/Laramie Formation or parts of the formation may act as a confining unit or leaky confining unit in some areas and as an aquifer in other areas. Using this approach, the water-bearing sandstone beds of the Lance Formation can be individually or collectively identified as a subaquifer or aquifer (Lance aquifer) within the larger hydrogeologic unit ("Lance hydrogeologic unit").

\section{Lance-Fox Hills Aquifer}

As described in the previous report section ("Lance Hydrogeologic Unit"), this study adopts the Laramie-Fox Hills aquifer definition as used by most studies of the equivalent strata in the Cheyenne and Denver Basins of northeastern Colorado, except the name "Laramie" is replaced with the equivalent "Lance" when discussing the Wyoming part of the aquifer. The Lance-Fox Hills aquifer in this study is defined as a multilayered aquifer consisting of the water-bearing sandstone beds of the Fox Hills Sandstone and overlying or intertonguing water-bearing sandstone beds located only in the lowermost/basal part of the Lance Formation (where present). However, the terms "Lance aquifer" and "Fox Hills aquifer" are used in the water-quality sections of this report to facilitate comparisons between the chemical (water-quality) characteristics of the Lance Formation and Fox Hills Sandstone, even though it is recognized that all wells completed in the Fox Hills Sandstone are completed in the "Lance-Fox Hills aquifer."

Because the Fox Hills Sandstone consists primarily of very fine- to medium-grained sandstone beds, the formation in the Cheyenne Basin in Wyoming was identified by earlier investigators as a potential aquifer (Dockery, 1940; Rapp and others, 1957), an aquifer (Morris and Babcock, 1960; Lowry and Crist, 1967) or a "minor aquifer" (Libra and others, 1981). The Fox Hills Sandstone is an aquifer in the Powder River Basin north of the Cheyenne Basin, and wells completed in the formation supply water to the cities of Midwest, Edgerton, and 
Geologic and Hydrogeologic Characteristics, White River Formation, Lance Formation, and Fox Hills Sandstone, Wyo.

Gillette (not shown) (Taboga and others, 2019). Until recently, the Fox Hills Sandstone was undeveloped in the Wyoming part of the Cheyenne Basin, primarily because water was available from shallower aquifers of the High Plains aquifer system. Availability of water from these shallower aquifers limited the need to explore the water-supply potential of underlying deeper lithostratigraphic/hydrogeologic units, including the Fox Hills Sandstone. In the Colorado part of the Cheyenne Basin, the Laramie-Fox Hills aquifer is developed as a source of water, most commonly for stock and domestic use and rarely for industrial use (Weist, 1964, 1965; Kirkham and others, 1980; Kirkham and Rold, 1986). Farther south in the Denver Basin, the Fox Hills Sandstone (as part of the Laramie-Fox Hills aquifer; fig. $5 B$ ) is developed much more extensively for domestic, stock, municipal, irrigation, and industrial/commercial use (Paschke and others, 2011).

Only a few exploratory or production (water-supply) wells have been completed in the Fox Hills Sandstone in the Wyoming part of the Cheyenne Basin. An exploratory well was successfully completed in the Fox Hills Sandstone as part of a study to evaluate potential development of the formation as an additional source of water in the Pine Bluffs lowland in southeastern Laramie County (Dahlgren Consulting, Inc., and others, 2005). This well (identified as FH-4 herein) was subsequently converted to a production well (JR Engineering and Lidstone and Associates, Inc., 2009). Similarly, an exploratory well (FH-7 in this report) was successfully completed in the Fox Hills Sandstone in Goshen Hole as part of a study to evaluate potential development of the formation as a source of water (Wyoming Groundwater, LLC, and others, 2011). Success in obtaining well yields and water quality sufficient for public-supply use and presence at economical drilling depths in these two studies indicated the Fox Hills Sandstone could be successfully developed for public supply and likely many other uses in parts of the Cheyenne Basin in Wyoming. Recently, the WSEO also has permitted two industrial wells in the Fox Hills Sandstone in Laramie County as a source of water to support petroleum exploration and production from the Niobrara Formation underlying the Pierre Shale (George Moser, Wyoming State Engineer's Office, oral commun., 2015; identified as wells FH-2 and FH-3 in this study).

\section{Upper Cretaceous Confining Units, Including Pierre Confining Unit}

Sedimentary rocks composing the thick (thousands of feet) sequence of fine-grained marine strata (Pierre Shale to Mowry Shale; fig. 6A) underlying the Fox Hills Sandstone consist largely of shale, marlstone, and chalks/limestone, although parts of the uppermost unit (Pierre Shale) contain laterally extensive very fine- to medium-grained sandstone or muddy (silty and clayey) sandstone beds (Kiteley, 1976, 1977, 1978; Love and Christiansen, 1985). Permeability of most of these lithologies generally is low unless enhanced by secondary processes (Belitz and Bredehoeft, 1988; Sonnenberg,
2011). Consisting largely of low-permeability rocks, formations containing these fine-grained rocks (Pierre Shale to Mowry Shale; fig. $6 A$ ) have been classified as confining units in the greater Denver Basin in Wyoming (Libra and others, 1981; Bartos and others, 2013). Collectively, this series of stacked confining units forms a thick, regionally extensive confining unit that restricts groundwater flow between all overlying aquifers/aquifer systems in the Upper Cretaceous and Cenozoic lithostratigraphic units and all underlying aquifers/aquifer systems contained in stratigraphically older lithostratigraphic units (Libra and others, 1981; Belitz and Bredehoeft, 1988; Robson, 1987; Robson and Banta, 1987; Jorgensen and others, 1996; Nelson and others, 2015; Umari and others, 2018). This confining unit extends throughout the greater Denver Basin and across the adjacent midcontinent craton in multiple States to the east (Belitz and Bredehoeft, 1988; Jorgensen and others, 1996; Nelson and others, 2015; Umari and others, 2018). Jorgensen and others (1996) identified this regional confining unit as the Great Plains confining system, and Bartos and others (2013) identified the unit as the Upper Cretaceous confining unit for an area coinciding with the North Platte River Basin in Wyoming.

Despite being classified as a confining unit (Pierre confining unit), parts of the upper Pierre Shale yield, or have been speculated to yield, small quantities of groundwater from local water-bearing zones/minor aquifers consisting of thin to moderately thick sandstone beds of varying lateral extent or zones of fractured shale (Lowry and Crist, 1967; Libra and others, 1981, table IV-1; Dahlgren Consulting, Inc., and others, 2005; Jehn-Dellaport and Renninger, 2017). Deep burial below economical drilling depths throughout most of its geographic extent, poor groundwater quality, and generally low well yields have led investigators to conclude the Pierre Shale has little or no potential for development as a water supply in the Wyoming part of the Cheyenne Basin (Lowry and Crist, 1967; Libra and others, 1981; Dahlgren Consulting, Inc., and others, 2005; Bartos and others, 2013). However, studies in the Colorado part of the Cheyenne Basin indicate some sandstones in the upper part of the Pierre Shale are sources or potential sources of small to moderate quantities of slightly saline/ brackish groundwater (Weist, 1964, 1965; Wacinski, 1979; Kirkham and others, 1980; Kirkham and Rold, 1986; JehnDellaport and Renninger, 2017; Topper and others, 2017). Where these sandstone beds occur above members C and D within the part of the uppermost Pierre Shale transitional with the Fox Hills Sandstone (upper transition member; fig. 6B) in the Cheyenne and Denver Basins in northeastern Colorado, they may in some cases be considered part of the Laramie-Fox Hills aquifer (Romero and Hampton, 1972; Romero, 1976; Schneider, 1980; Robson and others, 1981, 1998; Colorado Division of Water Resources, 1985; Kirkham and Rold, 1986; Robson, 1987, 1989; Paschke, 2011). Some sandstone beds in members $\mathrm{C}$ and $\mathrm{D}$ and parts of the overlying unnamed strata of the upper Pierre Shale (fig. $6 B$ ) below the Laramie-Fox Hills aquifer produce small to moderate quantities of water in the Colorado part of the Cheyenne Basin, and these beds 
are recognized as aquifers or potential aquifers (Kirkham and others, 1980; Kirkham and Rold, 1986; Jehn-Dellaport and Renninger, 2017; Topper and others, 2017). These sandstone aquifers have been grouped into a hydrogeologic unit identified as the "upper Pierre aquifer" (Kirkham and others, 1980; Kirkham and Rold, 1986; Topper and others, 2017) or alternatively, the "Pawnee aquifer" (Jehn-Dellaport and Renninger, 2017).

\section{Methods of Study}

Methods used for collection, storage, and analysis of geologic, hydrogeologic, and groundwater-quality data are described in this section. Quality-assurance (QA) methods and quality-control $(\mathrm{QC})$ data associated with groundwater-quality samples are described in this section. Finally, a brief description of the groundwater-quality criteria used herein to evaluate water samples in relation to potential uses is provided.

\section{Drilling, Coring, and Monitoring Well Installation}

All drilling, coring, and monitoring well installation were completed by the USGS Research Drilling Program. Characterization of the study site subsurface began by drilling and continuously coring a deep (960 feet [ft] below land surface [BLS]) exploratory borehole (designated exploratory borehole LC-F1) (plate 1, available for download at https://doi.org/10.3133/sir20215020) using a hydraulic mud rotary drilling rig and procedures described in Lapham and others (1995). Immediately after collection, core samples were wiped to remove drilling mud, measured, and photographed. In depth intervals where core could not be collected, cuttings were collected in plastic bags. Cores and cuttings then were described briefly onsite as drilling/coring progressed; these field descriptions were used to construct a preliminary description of subsurface lithology and stratigraphy (litho$\operatorname{logic} \log$ ) that later was substantially refined through more detailed examination in the office. After field descriptions were complete, core samples were tightly wrapped and sealed in multiple layers of heavy-duty aluminum foil. Depth intervals from which core and cuttings were collected were measured carefully and recorded in photographs and a field notebook, and then depth information was recorded directly on the tightly wrapped aluminum foil using black permanent ink markers. Core and cuttings then were placed into labeled core boxes. All boxed core and cuttings collected as part of this study will be permanently archived at the USGS core laboratory in Denver, Colorado.

Drilling and coring of exploratory borehole LC-F1 was discontinued in the upper transition member of the Pierre Shale at a depth of $960 \mathrm{ft}$ BLS. Downhole drilling equipment then was removed, and an extensive suite of wireline geophysical logs were made in the uncased borehole (plate 1).
After geophysical logging was complete, the borehole was sealed with bentonite grout. Lithologic and geophysical logs were used to identify the contacts between lithostratigraphic/ hydrogeologic units and to select the length and location of well screen intervals for completion of monitoring wells.

Three monitoring wells were installed at the study site in June 2013 -well BR-1 (USGS site 410233104093203), completed in the White River Formation; well LN-1 (USGS site 410233104093202), completed in the Lance Formation; and well FH-1 (USGS site 410233104093201), completed in the Fox Hills Sandstone (fig. 1). Monitoring wells were installed with a hydraulic mud rotary rig using procedures described in Lapham and others (1995). All three monitoring wells were near exploratory borehole LC-F1.

Construction information for all three monitoring wells is summarized in table 1 and shown in greater detail and graphically in relation to lithology and interpreted stratigraphy on plate 1 . Steel surface casing was installed in all three monitoring wells to a depth of about $40 \mathrm{ft}$ BLS to stabilize and seal the boreholes through the unconsolidated Quaternary older alluvial fan deposits. Monitoring well BR-1 was installed to a depth of $132.1 \mathrm{ft}$ BLS with a 20 -ft-long well screen from 109.5 to $129.5 \mathrm{ft}$ BLS. Monitoring well LN-1 was installed to a depth of $485.2 \mathrm{ft}$ BLS with a 20-ft-long well screen from 463.6 to $483.6 \mathrm{ft}$ BLS. Monitoring wells BR-1 and LN-1 were constructed with factory cleaned and sealed, 4-in. diameter, threaded, flush-jointed, schedule 80 polyvinyl chloride (PVC) well casing and 4-in. diameter perforated, PVC-slotted, nonmetallic well screen (0.020-in. slot size). O-rings were placed at each casing joint to help maintain a good seal. Monitoring well FH-1 was constructed with 4-in. steel, welded well casing to $792 \mathrm{ft}$ BLS; factory cleaned and sealed, 4-in. diameter, threaded, stainless-steel well casing from 792 to $812 \mathrm{ft}$ BLS; and factory cleaned and sealed, 4-in. diameter, threaded, stainless-steel well screen (0.020-in. slot size) from 812 to $832 \mathrm{ft}$ BLS. O-rings were placed at each threaded casing joint to help maintain a good seal. Filter packs composed of 10/20 silica sand were installed with tremie pipes from the bottom of the wells to about 8 to $17 \mathrm{ft}$ above the screened intervals; about 19 to $21 \mathrm{ft}$ of hydrated bentonite pellets were installed above the filter packs to prevent the environmental seal from entering the filter pack. An environmental seal consisting of bentonite grout mixed onsite was installed with tremie pipes from the top of the hydrated bentonite pellets in the wells to within about $3 \mathrm{ft}$ BLS. Cement was placed from the top of the environmental seal to land surface.

After installation was complete, wells were developed using procedures described in Lapham and others (1995). The shallow monitoring well (BR-1) was developed using bailing, whereas the deeper monitoring wells $(\mathrm{LN}-1$ and $\mathrm{FH}-1)$ were developed using an airlift method (Driscoll, 1986). All three monitoring wells were developed until water removed from each was visibly "clear" in appearance. Lockable outer steel protective shelters were set on concrete bases poured around all three wells to protect the well casing protruding above the land surface and to allow for protection of continuous 
[USGS, U.S. Geological Survey; DMS, degree, minute, second; NAVD 88, North American Vertical Datum of 1988; ft, foot; BLS, below land surface; PVC, polyvinyl chloride; in., inch; NA, not available

\begin{tabular}{|c|c|c|c|c|c|c|c|c|c|c|c|c|c|c|c|c|}
\hline 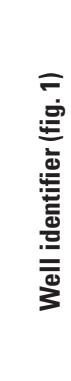 & 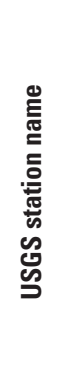 & 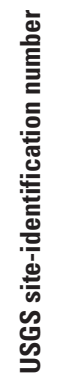 & 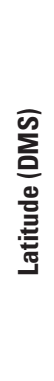 & 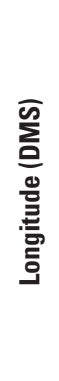 & 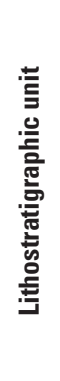 & 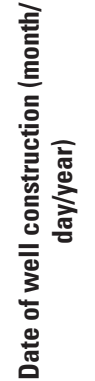 & 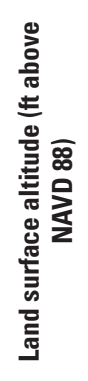 & 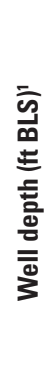 & 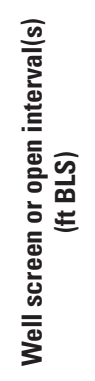 & 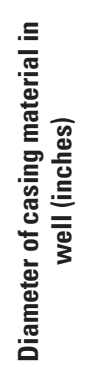 & 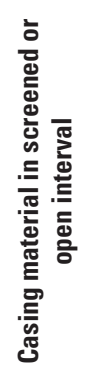 & 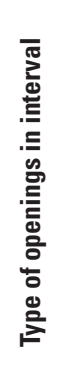 & 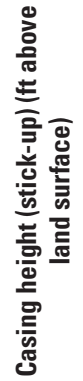 & 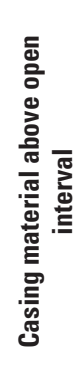 & 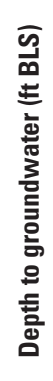 & 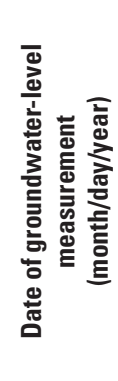 \\
\hline
\end{tabular}

\begin{tabular}{|c|c|c|c|c|c|c|c|c|c|c|c|c|c|c|c|c|}
\hline \multicolumn{17}{|c|}{ Monitoring wells installed and sampled for this study ${ }^{2}$} \\
\hline BR-1 & $13-061-36 \operatorname{ccc} 04$ & 410233104093203 & $41^{\circ} 02^{\prime} 33.2^{\prime \prime}$ & $104^{\circ} 09^{\prime} 32.1^{\prime \prime}$ & $\begin{array}{c}\text { White } \\
\text { River } \\
\text { Formation }\end{array}$ & $6 / 17 / 2013$ & 5,229 & 132.1 & $109.5-129.5$ & 4 & PVC & $\begin{array}{l}\text { 0.020-in. } \\
\text { slot screen }\end{array}$ & 2.73 & PVC & $\begin{array}{c}{ }^{3} 54.22- \\
60.07\end{array}$ & $\begin{array}{c}6 / 20 / 2013- \\
5 / 25 / 17\end{array}$ \\
\hline $\mathrm{LN}-1$ & $13-061-36 \mathrm{ccc} 03$ & 410233104093202 & $41^{\circ} 02^{\prime} 33.0^{\prime \prime}$ & $104^{\circ} 09^{\prime} 32.0^{\prime \prime}$ & $\begin{array}{c}\text { Lance } \\
\text { Formation }\end{array}$ & $6 / 13 / 2013$ & 5,229 & 485.2 & $463.6-483.6$ & 4 & PVC & $\begin{array}{l}\text { 0.020-in. } \\
\text { slot screen }\end{array}$ & 2.23 & PVC & $\begin{array}{c}{ }^{3} 120.42- \\
127.42\end{array}$ & $\begin{array}{c}\text { 6/20/2013- } \\
9 / 28 / 17\end{array}$ \\
\hline $\mathrm{FH}-1$ & $13-061-36 \mathrm{ccc} 02$ & 410233104093201 & $41^{\circ} 02^{\prime} 32.8^{\prime \prime}$ & $104^{\circ} 09^{\prime} 32.1^{\prime \prime}$ & $\begin{array}{l}\text { Fox Hills } \\
\text { Sandstone }\end{array}$ & $6 / 5 / 2013$ & 5,229 & 837 & $812-832$ & 4 & $\begin{array}{c}\text { Stainless } \\
\text { steel }\end{array}$ & $\begin{array}{l}\text { 0.020-in. } \\
\text { slot screen }\end{array}$ & 2.72 & Stee $^{4}$ & $\begin{array}{c}3431.94 \\
439.39\end{array}$ & $\begin{array}{c}6 / 20 / 2013- \\
9 / 28 / 17\end{array}$ \\
\hline \multicolumn{17}{|c|}{ Production wells sampled for this study ${ }^{5,6}$} \\
\hline FH-2 & 13-065-10abc01 & 410651104384601 & $41^{\circ} 06^{\prime} 51.3^{\prime \prime}$ & $104^{\circ} 38^{\prime} 46.2^{\prime \prime}$ & $\begin{array}{l}\text { Fox Hills } \\
\text { Sandstone }\end{array}$ & $8 / 21 / 2014$ & 5,867 & 2,000 & $\begin{array}{l}1,702-1,752, \\
1,758-1,768, \\
1,796-1,826, \\
1,836-1,846, \\
1,874-1,884, \\
1,901-1,916\end{array}$ & 10 & $\begin{array}{c}\text { Stainless } \\
\text { steel }\end{array}$ & $\begin{array}{c}\text { 0.030-in. } \\
\text { wire- } \\
\text { wound } \\
\text { screen }\end{array}$ & 2 & Steel & ${ }^{79} 982$ & NA \\
\hline FH-3 & $16-060-32 \mathrm{dc} 01$ & 411814104062601 & $41^{\circ} 18^{\prime} 14.69^{\prime \prime}$ & $104^{\circ} 06^{\prime} 25.85^{\prime \prime}$ & $\begin{array}{l}\text { Fox Hills } \\
\text { Sandstone }\end{array}$ & $9 / 28 / 2015$ & 5,277 & 1,012 & $\begin{array}{l}{ }^{8} 927-942, \\
{ }^{8} 955-965\end{array}$ & 8.62 & Steel & $\begin{array}{c}\text { 0.38-in. x } \\
24 \text {-in. jet } \\
\text { charge }\end{array}$ & 1 & Steel & ${ }^{7} 533$ & NA \\
\hline
\end{tabular}

${ }^{1}$ All wells are cased to total depth.

${ }^{2}$ Additional construction information for three monitoring wells installed and sampled for this study provided on plate 1.

${ }^{3}$ Highest and lowest depth to groundwater measured or recorded for period of measurement indicated in adjacent column.

${ }^{4}$ Regular steel casing to 792 feet; stainless steel casing from 792 to 837 feet.

${ }^{5}$ Construction information for well FH-2 from Wyoming State Engineer's Office well permit P202090W.

${ }^{6}$ Construction information for well FH-3 from Wyoming State Engineer's Office well permit P203406W and Wyoming Oil and Gas Conservation Commission reports for API number 49-021-20914. This well was originally drilled to a depth of 7,704 feet as an oil well; the upper 8.625-inch steel casing was installed to 1,050 feet and cemented in place.

${ }^{7}$ Static water level reported on Wyoming State Engineer's Office well permit.

${ }^{8}$ Wyoming State Engineer's Office well permit also indicates a 7-inch diameter, 0.005-inch slot well screen from 920 to 970 feet. One of the Wyoming Oil and Gas Conservation Commission sundry notices for the well recorded that a "poly screen will be run and set with a packer." 
water-level recorders installed in all three monitoring wells. Detailed information describing well installation and construction for all three wells was recorded and entered into the USGS National Water Information System (NWIS) Groundwater Site Inventory database (https://waterdata.usgs.gov/wy/ nwis/gw/; U.S. Geological Survey, 2019).

\section{Lithologic Description}

Sediment characteristics from collected core and cuttings were described visually by viewing the core and cuttings in the office with a binocular microscope. Grain size was described using a binocular microscope and the Wentworth scale (Ingram and Johnson, 2006, p. 161); the relative proportions of different grain sizes composing the sediments for a given depth interval were estimated visually (ocular estimates) using a binocular microscope and American Geological Institute comparison charts (Powers and Johnson, 2006, p. 167). Sediment rounding and sphericity were described using a binocular microscope and American Geological Institute comparison charts (Powers and Johnson, 2006, p. 167). Color and hue were described using the alpha-numerical color designations in Munsell soil color charts (Munsell, 2000). The entire Munsell alpha-numerical color designations are used in the detailed lithologic descriptions in appendix 1, but these designations are simplified to only the color "name" in the text of this document. Other physical sediment characteristics described visually included mineralogical and lithological composition, sorting, layering, cementation, calcium carbonate content, sedimentary structures, occurrence of vertebrate and invertebrate fossils or other biogenic material, and evidence of biological activities such as trace fossils or bioturbation. The relative amount of calcium carbonate (carbonate content) was estimated from the intensity of effervescence after application of a 10-percent solution of hydrochloric acid. Sediments also were routinely tested for magnetic grains using a magnet.

Classification of unconsolidated and consolidated sediments was based on sedimentary texture. Texture descriptions and associated names follow Folk's $(1954,1980)$ classification system (reproduced with modification herein as fig. 10). This classification system allows for correlation of grain-size terms such as "mud" or "sand" to the numerical grain-size limits (for example, millimeters) of the Wentworth scale (grain-size ranges/limits shown on plate 1).

Most of the subsurface sedimentary rocks cored in borehole LC-F1 were mudrocks (appendix 1; plate 1). Mudrocks, by Folk's definition, consist of at least 50-percent mud-sized particles (fig. 10). Specifically, mud is composed of silt-sized particles that are between 0.0625 (1/16 in.) and 0.0039 (1/256 in.) millimeter $(\mathrm{mm})$ in diameter, and claysized particles that are less than $0.0039 \mathrm{~mm}(1 / 256 \mathrm{in}$.) in diameter (fig. 10). Mudrocks are divided into classes (for example, siltstone, claystone, and mudstone for consolidated/ lithified sedimentary rocks, or alternatively, silt, clay, and mud if unconsolidated) based on the ratio of silt to clay in the fine-grained size fraction (defined as consisting of all silt- and clay-sized particles) of the sedimentary rock (fig. 10). Consolidated mudrocks that indicate fissility (ability to break parallel to stratification) are classified as shale (fig. 10).

Eight lithologic samples were subsampled from core to create thin sections for petrographic examination. Polished thin sections were examined under transmitted and reflected light microscopy to describe mineralogy and other sediment characteristics. In addition, selected thin sections, as well as three-dimensional core samples, were examined with a JEOL 5800LV scanning electron microscope equipped with an Oxford ISIS energy-dispersive $\mathrm{x}$-ray detector to determine basic mineralogy and identify textural features. Some samples also were examined for mineralogy using $\mathrm{x}$-ray diffraction (XRD) analysis.

\section{Geophysical Logs}

After drilling and coring of exploratory borehole LC-F1 were completed, wireline borehole geophysical logs were collected by USGS personnel in the uncased (open) 960-ft-deep borehole filled with drilling fluid (plate 1). Wireline geophysical logs provide information about the characteristics of the sediments and groundwater within and near the borehole. This information can be used to help identify aquifers and better understand the extent and lithology of aquifers and adjacent confining units. Wireline geophysical logs collected in the borehole included a combination of the following measurements: caliper, natural gamma, spontaneous potential (SP), electromagnetic induction, 16- and 64-in. normal resistivity, lateral resistivity, single-point resistance, neutron, full waveform sonic, temperature, and fluid resistivity. All tools were properly calibrated to manufacturer specifications before use. Information describing these geophysical tools and methods of interpretation is provided in Keys $(1990,1997)$ and Hearst and others (2000). Most of these geophysical logging methods are briefly described in this section by summarizing information in these three references and Anderson and others (2009). All wireline borehole geophysical logs and associated data files collected as part of this study are available through the online USGS "GeoLog" geophysical log database (available at https://webapps.usgs.gov/GeoLogLocator, accessed November 2020).

The caliper tool is a spring-loaded multiarm device that provides a mean measure of the inside diameter of the open borehole. Changes in borehole diameter may reflect drilling and construction procedures, relative consolidation of lithologic units, and other lithologic features such as fractures. Caliper logs are particularly useful for evaluating the integrity of the borehole and for identifying "wash-out zones" where sediments have been eroded away from the side of the borehole by the drilling process.

A natural gamma tool measures the total natural gammaray radiation emitted by sediments surrounding a borehole. Potassium-40 and the daughter products of the uranium- and 


\section{EXPLANATION}

- Wentworth scale to determine

- Specify median size of gravel wherever present.

- Specify median size of sand only in the stippled area.

- Specify composition of mud (whether silty, muddy, or clayey) wherever present

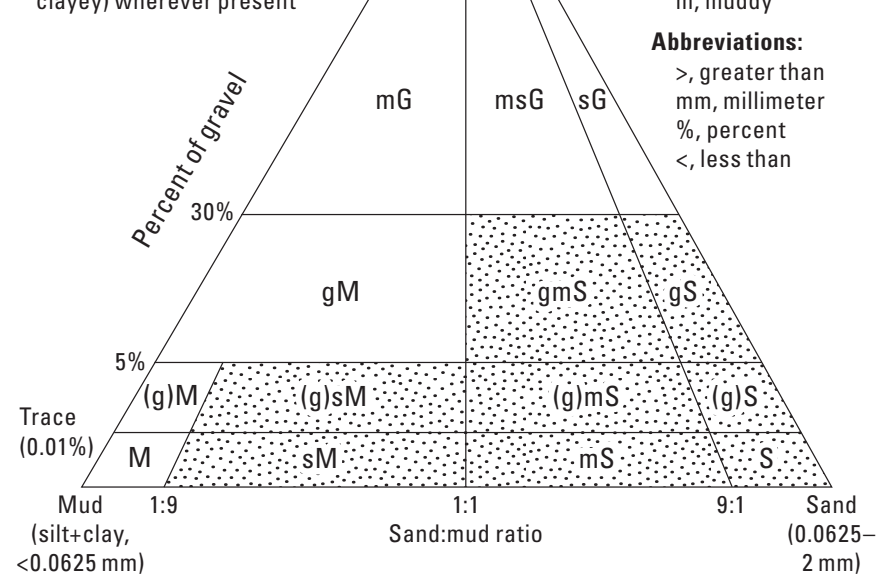

Samples with gravel

\begin{tabular}{|c|c|c|}
\hline \multicolumn{3}{|c|}{ For samples with gravel } \\
\hline \multirow{2}{*}{$\begin{array}{c}\text { Grain-size } \\
\text { (texture) class } \\
\text { abbreviation on } \\
\text { ternary diagram } \\
\text { shown above }\end{array}$} & \multicolumn{2}{|c|}{ Name of grain-size (texture) class } \\
\hline & $\begin{array}{l}\text { Unconsolidated } \\
\text { sediment }^{1}\end{array}$ & $\begin{array}{l}\text { Consolidated (lithified) } \\
\text { sediment (rock) }\end{array}$ \\
\hline G & Gravel & Conglomerate \\
\hline sG & Sandy gravel & Sandy conglomerate \\
\hline $\mathrm{msG}$ & Muddy sandy gravel & Muddy sandy conglomerate \\
\hline $\mathrm{mG}$ & Muddy gravel & Muddy conglomerate \\
\hline $\mathrm{gS}$ & Gravelly sand & Conglomeratic sandstone \\
\hline gmS & Gravelly muddy sand & Conglomeratic muddy sandstone \\
\hline $\mathrm{gM}$ & Gravelly mud & Conglomeratic mudstone \\
\hline (g)S & Slightly gravelly sand & Slightly conglomeratic sandstone \\
\hline$(\mathrm{g}) \mathrm{mS}$ & $\begin{array}{l}\text { Slightly gravelly muddy } \\
\text { sand }\end{array}$ & $\begin{array}{l}\text { Slightly conglomeratic muddy } \\
\text { sandstone }\end{array}$ \\
\hline (g)sM & Slightly gravelly sandy mud & $\begin{array}{l}\text { Slightly conglomeratic sandy } \\
\text { mudstone }\end{array}$ \\
\hline (g)M & Slightly gravelly mud & Slightly conglomeratic mudstone \\
\hline S & Sand & Sandstone \\
\hline $\mathrm{mS}$ & Muddy sand & Muddy sandstone \\
\hline $\mathrm{sM}$ & Sandy mud & Sandy mudstone \\
\hline M & Mud & Mudstone \\
\hline
\end{tabular}

${ }^{1}$ Specify additional characteristics describing gravel- and sand-sized sediments such as sorting and size as desired.
Grain-size (texture) terms

for samples with gravel:

G, gravel

g, gravelly

(g), slightly gravelly

$S$, sand

S, sandy

$\mathrm{M}$, mud

$\mathrm{m}$, muddy

$\mathrm{mm}$, millimeter

$\%$, percent

$<$, less tha (silt+clay,

$<0.0625 \mathrm{~mm}$ ) $\mathrm{mm}$ )

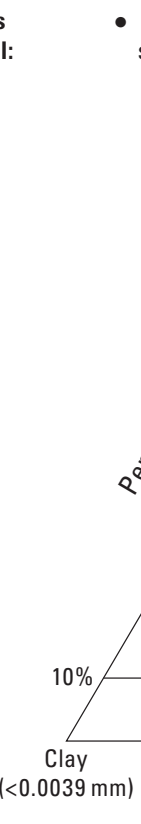

Clay
$0.0039 \mathrm{~mm}$
Specify median size of Sand sand throughout. $\quad(0.0625-2 \mathrm{~mm})$ without gravel:

$S$, sand

s, sandy

$Z$, silt

Z, silty

M, mud

m, muddy

C, clay

c, clayey

Abbreviations: $\mathrm{mm}$, millimeter $\%$, percent $<$, less than

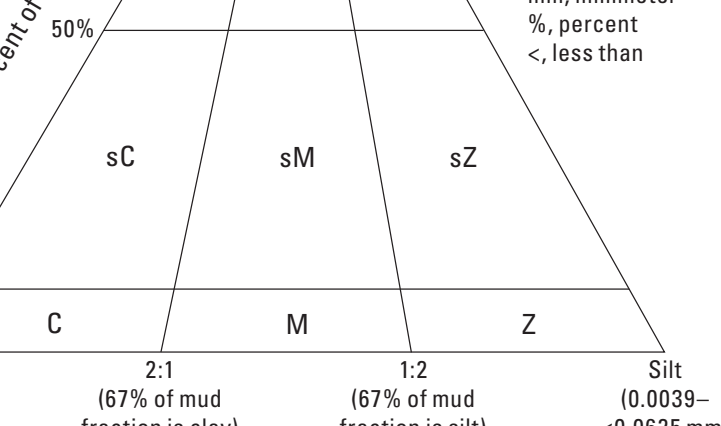

\begin{tabular}{|c|c|c|}
\hline \multicolumn{3}{|c|}{ For samples without gravel consisting of greater than $\mathbf{5 0}$ percent sand } \\
\hline \multirow{2}{*}{$\begin{array}{c}\text { Grain-size (texture) class } \\
\text { abbreviation on ternary } \\
\text { diagram shown above }\end{array}$} & \multicolumn{2}{|c|}{ Name of grain-size (texture) class } \\
\hline & $\begin{array}{l}\text { Unconsolidated } \\
\text { sediment }\end{array}$ & $\begin{array}{c}\text { Consolidated (lithified) } \\
\text { sediment (rock) }\end{array}$ \\
\hline $\mathrm{S}$ & Sand ${ }^{1}$ & Sandstone $^{1}$ \\
\hline $\mathrm{cS}$ & Clayey sand ${ }^{1}$ & Clayey sandstone $^{1}$ \\
\hline $\mathrm{mS}$ & Muddy sand ${ }^{1}$ & Muddy sandstone ${ }^{1}$ \\
\hline $\mathrm{zS}$ & Silty sand ${ }^{1}$ & Silty sandstone ${ }^{1}$ \\
\hline
\end{tabular}

${ }^{1}$ Specify additional characteristics describing sand grains such as sorting and size as desired.

\begin{tabular}{|c|c|c|c|}
\hline \multicolumn{4}{|c|}{ For samples without gravel consisting of less than 50 percent mud } \\
\hline \multirow{3}{*}{$\begin{array}{c}\text { Grain-size } \\
\text { (texture) class } \\
\text { abbreviation on } \\
\text { ternary diagram } \\
\text { shown above }\end{array}$} & \multicolumn{3}{|c|}{ Name of grain-size (texture) class } \\
\hline & \multirow{2}{*}{$\begin{array}{l}\text { Unconsolidated } \\
\text { sediment }\end{array}$} & \multicolumn{2}{|c|}{$\begin{array}{l}\text { Consolidated (lithified) } \\
\text { sediment (mudrock) }\end{array}$} \\
\hline & & Not fissile & Fissile \\
\hline $\mathrm{Z}$ & Silt $(>67 \% \text { silt })^{1}$ & Siltstone & Silty shale \\
\hline M & Mud (intermediate) & Mudstone & Muddy shale \\
\hline $\mathrm{C}$ & Clay $(>67 \% \text { clay })^{1}$ & Claystone & Clayey shale \\
\hline sZ & Sandy silt & Sandy siltstone & Sandy silty shale \\
\hline sM & Sandy mud & Sandy mudstone & Sandy muddy shale \\
\hline $\mathrm{sC}$ & Sandy clay & Sandy claystone & Sandy clayey shale \\
\hline
\end{tabular}

${ }^{1}$ Of total mud fraction only (not total of all grain sizes).

Figure 10. Classification system used to describe and name unconsolidated and consolidated sediments collected from coring of exploratory borehole LC-F1 (modified from Folk [1954, 1980]). 
thorium-decay series are the primary naturally occurring gamma-emitting radioisotopes. Clayey minerals tend to accumulate radioisotopes through adsorption and ion-exchange processes; consequently, zones of high natural gamma activity typically are interpreted as being clay or shale rich. In addition, higher gamma-ray activity in sedimentary rocks is associated with increasing potassium content, commonly reflecting the relative abundance of potassium-feldspar-rich sediments (for example, feldspathic sandstones and conglomerates). Quartz-rich sands/sandstones typically produce lower gamma activity than clay- or potassium-feldspar-rich sediments.

The electromagnetic induction tool measures the vertical electrical conductivity of sediments and water surrounding the borehole induced from electromagnetic fields created by the tool. Vertical changes in conductivity are used to infer lithology and the boundaries of individual beds. Conductivity measurements typically are converted to resistivity values for comparison with other resistivity logs. Conductivity and resistivity converted from conductivity are presented in this report on plate 1.

Several types of resistivity tools were used to measure the electrical resistivity of sediments and water surrounding the borehole. Resistivity tools measure the apparent resistivity of a volume of sample material under the direct application of an electrical current. SP logs measure electrical potentials that develop in boreholes at lithologic and water-quality interfaces. SP response largely is a function of chemical reactions that occur within the wellbore fluids and the type and amount of clay present. Electrochemical effects generally result from the migration of ions from more to less mineralized fluids. Shortnormal (16-in.) and long-normal (64-in.) resistivity tools have two volumes of investigation beyond the borehole. The longnormal measurement has a greater vertical and lateral volume of investigation beyond the borehole and is affected less by drilling fluid than is the short-normal measurement. Lateral resistivity logs are like normal resistivity logs but use a different electrode configuration to measure electrical resistivity farther beyond the borehole fluid invaded zone. In general, electrical resistivity measurements are affected by clay content, sediment porosity, and pore fluid dissolved-solids concentrations. In general, lower resistivities measured with resistivity tools generally correspond to higher porosity or smaller grain size because the surface area associated with small grain size promotes electrical current transmission. These characteristics can be used to infer lithology and the boundaries of individual beds. For example, in areas where subsurface sediments are saturated with freshwater such as the study site, coarse-grained sediments such as sandstone typically are indicated by a negative deflection (leftward deflection) on the SPlog and by a high resistivity response (rightward deflection) on the other resistivity logs.

The neutron tool records the continuous measurement of the induced radiation produced by bombarding the surrounding geologic formation and fluid with neutrons from a sealed neutron source, which interact with surrounding atomic nuclei until they are captured. In groundwater environments, most neutron interactions are in response to the amount of hydrogen present. Because the amount of hydrogen present largely is a function of the water content of surrounding borehole sediments, neutron logs reflect saturated porosity and commonly are used to qualitatively or quantitatively estimate saturated formation porosity; however, the matrix and the type of fluid present also can affect saturated porosity estimates. Neutron logs are strongly affected by clay because hydrogen occurs in clays within the clay molecule or adsorbed between clay mineral layers ("bound water"). In this study, neutron logs are presented in counts per second and in neutron porosity units (two different columns on plate 1). Neutron porosity units are converted directly from the hydrogen index, a measure of the amount of hydrogen in quantity per unit volume in surrounding borehole sediments. Neutron porosity is calibrated to limestone, so neutron porosity units must be converted for use with other lithologies such as sandstone.

The full waveform sonic logging tool measures the acoustic properties of surrounding borehole sediments. Sonic (acoustic) logging tools measure the travel time (velocity) it takes for acoustic energy (soundwaves) emitted from one end of a logging tool to travel through the surrounding borehole sediments and to the receivers at the other end of the tool. Travel times generally depend on the elastic properties of the sediments, which are related to lithology and porosity.

\section{Collection, Processing, and Storage of Groundwater-Level Measurements}

Discrete and continuous-record groundwater levels were collected in all three monitoring wells. The nested configuration of the monitoring wells provided information on vertical hydraulic-head (groundwater-level) gradients between the aquifers, and continuous monitoring of groundwater levels was used to establish water-level trends over time, establish the poroelastic responses of the monitored formations to solid Earth tides and atmospheric loading, and estimate hydraulic properties of groundwater storage and transmission of the monitored formations. Groundwater levels were measured manually with either a chalked, graduated steel tape or a calibrated electric tape from a measuring point of known elevation on the well casing (identified on plate 1) referenced to a landsurface datum established at the well or automatically from a submerged pressure transducer set below the water level in the well, at a known depth below the measuring point. The pressure transducers were sampled continuously at a specified frequency, and the output was digitally recorded automatically and stored on site by instrumentation installed in all three wells. Manual and automatic (continuous) depth-to-water measurements were made and documented in accordance with standard USGS procedures (Cunningham and Schalk, 2011). The accuracy of the manual depth-to-water-level measurements was $0.01 \mathrm{ft}$. Depth-to-water measurements were converted to groundwater-level elevation values by subtracting 
Geologic and Hydrogeologic Characteristics, White River Formation, Lance Formation, and Fox Hills Sandstone, Wyo.

the depth-to-water measurements from the measuring point elevation, referenced to the local land-surface datum.

Vented (gauge) submersible pressure transducers with a range of $0-30$ pounds per square inch $\left(\mathrm{lb} / \mathrm{in}^{2}\right)$ of pressure (or an equivalent water-level range of 0-69.2 ft of water) and associated data loggers were installed in all three wells and were programmed to measure and record groundwater levels. The stated accuracy of the pressure transducers was about $0.014 \mathrm{ft}$ of water $\left(0.006 \mathrm{lb} / \mathrm{in}^{2}\right)$. Generally, the specified sampling rate of the pressure transducer was hourly, though for some periods of record, smaller sampling rates were specified in minutes as factors of 60 minutes, for example, 1, 5, $10,15,20$, or 30 minutes. Recorded data were downloaded and corrected for instrument drift based on manual measurements of groundwater-level elevations that were made from the wellhead measuring points during periodic field inspections. Location, construction, well-completion information, and discrete groundwater-level measurements were entered into and stored in the USGS NWIS Groundwater Site Inventory database; continuous-record groundwater-level data were entered into and stored in the USGS AQUARIUS database, and these data are available at https://waterdata.usgs.gov/wy/ nwis/gw/ (U.S. Geological Survey, 2019).

\section{Groundwater-Quality Sample Collection}

Groundwater-quality samples were collected from the three monitoring wells installed as part of the study and two additional production wells. Monitoring well BR-1 was sampled on November 13, 2013; monitoring well LN-1 on December 17, 2013; and monitoring well FH-1 on November 14, 2013. The production wells were sampled on December 3, 2014 (FH-2), and on September 23, 2015 (FH-3). Samples from four of five wells ( $\mathrm{LN}-1, \mathrm{FH}-1, \mathrm{FH}-3$, and FH-3) were analyzed for a much larger suite of groundwaterquality constituents than samples collected from monitoring well BR-1. Low well yield and long water-level recovery times after purging/sampling made it difficult to collect substantial quantities of water from monitoring well BR-1, so the analytical list for this well was reduced compared to the other sampled wells. Samples were collected and processed in a mobile water-quality laboratory using groundwater sampling procedures described in Koterba and others (1995) and the USGS "National Field Manual for the Collection of WaterQuality Data" (U.S. Geological Survey, variously dated). Protocols for instrument calibration and equipment cleaning in the USGS "National Field Manual for the Collection of WaterQuality Data" (U.S. Geological Survey, variously dated) were followed to maintain proper QA and QC of groundwaterquality data associated with groundwater sampling. Physical characteristics measured during purging, pumping rates, purge volumes, and other pertinent ancillary information were recorded in the field on groundwater site forms for each well.

Several types of submersible groundwater sampling pumps were used to collect groundwater-quality samples.
The groundwater-quality sample from monitoring well BR-1 was collected using a stainless-steel, submersible positivedisplacement pump with Teflon impellers. Groundwaterquality samples from monitoring wells $\mathrm{LN}-1$ and $\mathrm{FH}-1$ were collected using an air-operated, stainless-steel, submersible double-acting piston-fluid pump. The groundwater-quality sample from production well FH-2 was collected using an existing submersible pump installed in the well to complete a 24-hour aquifer (pumping) test as part of a non-USGS study; the sample was collected near the end of the test.

Groundwater from all sampled wells was pumped into a sampling manifold and flow-through chamber in a mobile field laboratory until at least two or more well-casing volumes were purged and measurements of $\mathrm{pH}$, specific conductance, temperature, turbidity, and dissolved oxygen (DO) stabilized. This process was the same for the sample collected from production well FH-2 except that the well was pumped for a much longer time (nearly 24 hours) and at a high rate to induce waterlevel drawdown for the aquifer test. After field measurements stabilized, water was diverted to a sampling chamber consisting of a PVC frame enclosed in a plastic bag to minimize the potential of atmospheric contamination. Samples collected for most analyses were collected within the sampling chamber. All materials in contact with the water samples after being pumped out of the wells were either stainless steel or Teflon.

Different types of samples were collected from each well and each required different types of filtration, sampling containers, and preservation. Samples to determine alkalinity; major-ion, trace-element, dissolved organic carbon (DOC), and nutrient concentrations; stable isotopes of oxygen and hydrogen; and selected radiochemical constituents (gross alpha-particle and gross beta-particle activity, radium-226, radium-228) were filtered onsite using a 0.45 -micrometer $(\mu \mathrm{m})$ pore-size, disposable-capsule filter. Samples to determine the isotopic ratio of carbon (carbon-13/carbon-12) of dissolved inorganic carbon (DIC) in water (carbon-13/carbon-12 isotopic ratio $\left[\delta^{13} \mathrm{C}\right]$ ) and carbon-14 of DIC in water also were filtered onsite using a $0.45-\mu \mathrm{m}$ pore-size, disposable-capsule filter. Samples analyzed for alkalinity, major ions, and trace elements were collected in precleaned plastic or glass bottles that were rinsed onsite with filtered groundwater. Samples analyzed for DOC were collected in baked amber-colored glass bottles. Samples to be analyzed for major cations and trace elements were preserved to a $\mathrm{pH}$ of less than 2 standard units using ultrapure nitric acid. Samples to be analyzed for nutrients and DOC were preserved to a $\mathrm{pH}$ of less than 2 standard units using 4.5 normal sulfuric acid. Samples for major anions, tritium, stable isotopes of oxygen and hydrogen, dissolved gases, $\delta^{13} \mathrm{C}$, and carbon-14 did not require preservation.

Samples for radon-222 were collected using a glass syringe to withdraw 10 milliliters $(\mathrm{mL})$ of water from a special back-pressure valve attached to the sampling manifold. The water sample then was injected into a glass scintillation vial below a layer of mineral oil and shipped separately to a laboratory by overnight carrier to ensure the 48 -hour maximum holding time was met. 
Groundwater samples analyzed for volatile organic compounds (VOCs), diesel-range organics (DROs), and gasolinerange organics (GROs) were not filtered. Samples for VOCs and GROs were collected in three preacidified $40-\mathrm{mL}$ ambercolored glass vials with septa obtained from RTI Laboratories, Inc., and the vials were filled, leaving no headspace. When the three vials were filled, the flow rate was adjusted to about $100 \mathrm{~mL}$ per minute to minimize aeration of the samples. DRO samples were collected in 1-liter amber-colored glass bottles. The VOC, GRO, and DRO samples were chilled on ice immediately after collection and shipped to RTI Laboratories in Livonia, Michigan. The VOC, GRO, and DRO samples were preserved to a $\mathrm{pH}$ of less than 2 standard units using ultrapure hydrochloric acid.

Groundwater samples analyzed for major dissolved gases (argon, carbon dioxide, methane, nitrogen, and oxygen) were collected using procedures described by the USGS Groundwater Dating Laboratory (formerly known as the USGS Reston Chlorofluorocarbon Laboratory) in Reston, Virginia (U.S. Geological Survey, 2015), and analyzed at the same laboratory using gas chromatography (Busenberg and others, 2001). Samples collected for dissolved hydrocarbon gases (methane, ethene, and ethane) were analyzed at RTI Laboratories, Inc., using gas-chromatograph headspace equilibrium method RSKSOP-175 (Hudson, 2004).

Low-concentration range DO, sulfide, and ferrous iron were analyzed in the field laboratory using a HACH DR 2800 spectrophotometer (HACH, 2007). Methods of analyses included HACH method 8316, which is the indigo carmine method using AccuVac ampoules for low-range DO; $\mathrm{HACH}$ method 8146, which is the 1,10-phenanthroline method using AccuVac ampoules for ferrous iron; and HACH method 8131, which is a methylene blue method for sulfide (HACH, 2007).

Groundwater-quality data for the five wells sampled for this study are presented herein as described in subsequent sections. Results for environmental samples from the sampled wells are available from https://waterdata.usgs.gov/wy/nwis/ qw/ (U.S. Geological Survey, 2019).

\section{Chemical Analyses and Data Reporting}

Several physical characteristics (water temperature, $\mathrm{pH}$, specific conductance, turbidity, and DO) were measured in the field during collection of groundwater samples using methods described in the USGS "National Field Manual for the Collection of Water-Quality Data" (U.S. Geological Survey, variously dated). Alkalinity was determined onsite by incremental titration of a filtered water sample with sulfuric acid (U.S. Geological Survey, variously dated).

The USGS National Water Quality Laboratory (NWQL) in Lakewood, Colo., analyzed groundwater samples for major ions, trace elements, radon, nutrients, and DOC. Major ions and trace elements were analyzed using atomic-absorption spectrometry, colorimetry, ion-exchange chromatography, or inductively coupled plasma/mass spectrometry (Fishman and
Friedman, 1989; Faires, 1993; Fishman, 1993; McLain, 1993; Garbarino, 1999; Jones and Garbarino, 1999). Radon-222 was analyzed using liquid scintillation (American Society for Testing and Materials, 1996). Nutrients were analyzed using colorimetry (Fishman, 1993). DOC was analyzed using ultraviolet light-promoted persulfate oxidation and infrared spectrometry (Brenton and Arnett, 1993).

RTI Laboratories, Inc., in Livonia, Mich., was contracted by the NWQL to analyze groundwater samples for VOCs, GROs, and DROs (table 2) using U.S. Environmental Protection Agency (EPA) methods. VOC samples were analyzed using EPA method SW8260C (U.S. Environmental Protection Agency, 2006). Samples for GROs (C6-C10 carbon range) and DROs (C10-C36 carbon range) were analyzed using EPA methods SW8021/8015B (U.S. Environmental Protection Agency, 1996a, b) and SW8015B (U.S. Environmental Protection Agency, 1996a), respectively. TestAmerica Laboratories, Inc., in Richland, Washington, was contracted by the NWQL to analyze groundwater samples for gross alpha- and gross beta-particle activity using EPA method 900.0 (U.S. Environmental Protection Agency, 1980), radium-226 using EPA method 903.1 (U.S. Environmental Protection Agency, 1980), and radium-228 using EPA method 904.0 (U.S. Environmental Protection Agency, 1980).

The USGS Groundwater Dating Laboratory in Reston, Va., analyzed groundwater samples for dissolved gases (methane, carbon dioxide, nitrogen, oxygen, and argon) using gas chromatography (Busenberg and Plummer, 1992). RTI Laboratories, Inc., in Livonia, Mich., analyzed groundwater samples for dissolved hydrocarbon gases (methane, ethene, ethane).

In this report, standard nomenclature is used to describe the analyses of water samples for the isotopic ratio of carbon (ratio of carbon-13 to carbon-12) of dissolved inorganic carbon in water $\left(\delta^{13} \mathrm{C} \mathrm{DIC}\right)$ and stable isotopes of oxygen and hydrogen in water. The composition of isotopes is reported using delta $(\delta)$ notation, which indicates parts per thousand (per mil). The value for $\delta$ in per mil is calculated using the following equation:

$$
\delta=(R x / R s-1) \times 1,000,
$$

where

$R x \quad$ is the ratio of the heavy-to-light isotope of the sample and

$R s \quad$ is the ratio of the heavy-to-light isotope of the applicable reference standard (Clark and Fritz, 1997).

The Woods Hole Oceanographic Institution Accelerator Mass Spectroscopy Laboratory in Woods Hole, Massachusetts, analyzed samples for $\delta^{13} \mathrm{C}$ and carbon-14 (Woods Hole Oceanographic Institution 2015). Values of $\delta^{13} \mathrm{C}$ are reported in relation to the Vienna Pee Dee Belemnite (Mook and van der Plicht, 1999). Values of carbon-14 are reported relative to percent modern carbon (not normalized for carbon-13 
Table 2. Analyses for organic constituents in quality-control and environmental samples collected for this study.

[Detections in bold. Abbreviations: USGS, U.S. Geological Survey; NWIS, National Water Information System; LRL, laboratory reporting level; $\mu \mathrm{g} / \mathrm{L}$, microgram per liter; <, less than symbol indicates that constituent was not detected, and the value following the less than symbol was an LRL; E, estimated concentration, indicates value measured was below LRL but greater than established method detection limit (MDL); --, not analyzed for constituent or not applicable; CFC, chlorofluorocarbon; M, constituent detected, but not quantified]

\begin{tabular}{|c|c|c|c|c|c|c|c|c|c|}
\hline \multirow{3}{*}{ Organic constituent } & \multirow{3}{*}{$\begin{array}{c}\text { USGS } \\
\text { NWIS } \\
\text { parameter }\end{array}$} & \multirow{3}{*}{$\begin{array}{c}\text { Laboratory } \\
\text { reporting } \\
\text { level (LRL) } \\
(\mu \mathrm{g} / \mathrm{L})\end{array}$} & \multicolumn{3}{|c|}{ Quality-control samples } & \multirow{2}{*}{\multicolumn{4}{|c|}{$\begin{array}{c}\text { Environmental samples } \\
\text { Sampled well } \\
\end{array}$}} \\
\hline & & & \multirow{2}{*}{$\begin{array}{c}\text { Source solu- } \\
\text { tion blank } \\
(\mu \mathrm{g} / \mathrm{L})\end{array}$} & \multirow{2}{*}{$\begin{array}{c}\text { Trip } \\
\text { blank } \\
\text { ( } \mu \mathrm{g} / \mathrm{L})\end{array}$} & \multirow{2}{*}{$\begin{array}{l}\text { Equipment } \\
\text { blank } \\
\text { ( } \mu \mathrm{g} / \mathrm{L})\end{array}$} & & & & \\
\hline & & & & & & $\begin{array}{l}\mathrm{LN}-1 \\
(\mu \mathrm{g} / \mathrm{L})\end{array}$ & $\begin{array}{l}\mathrm{FH}-1 \\
(\mu \mathrm{g} / \mathrm{L})\end{array}$ & $\begin{array}{l}\text { FH-2 } \\
(\mu \mathrm{g} / \mathrm{L})\end{array}$ & $\begin{array}{l}\text { FH-3 } \\
(\mu \mathrm{g} / \mathrm{L})\end{array}$ \\
\hline $\begin{array}{c}\text { Gasoline-range organic } \\
\text { compounds (C6-10) }\end{array}$ & 49892 & 100 & $<100$ & -- & $<100$ & E24 & E18 & $\mathbf{E 3 2}$ & $\mathbf{E 5 4}$ \\
\hline $\begin{array}{l}\text { Diesel-range organic } \\
\text { compounds (C10-C36) }\end{array}$ & 63746 & 1210 & E25 & -- & E36 & ${ }^{2} \mathbf{E} 77$ & ${ }^{2} \mathbf{E} 31$ & ${ }^{2} \mathbf{E} 63$ & $<390$ \\
\hline \multicolumn{10}{|c|}{ Volatile organic compounds } \\
\hline Dibromomethane & 30217 & 1 & $<1$ & $<1$ & $<1$ & $<1$ & $<1$ & $<1$ & $<1$ \\
\hline Bromodichloromethane & 32101 & 1 & $<1$ & $<1$ & $<1$ & $<1$ & $<1$ & $<1$ & $<1$ \\
\hline Tribromomethane & 32104 & 1 & $<1$ & $<1$ & $<1$ & $<1$ & $<1$ & $<1$ & $<1$ \\
\hline Dibromochloromethane & 32105 & 1 & $<1$ & $<1$ & $<1$ & $<1$ & $<1$ & $<1$ & $<1$ \\
\hline Toluene & 34010 & 1 & $<1$ & $<1$ & E0.25 & $<1$ & $<1$ & $<1$ & $<1$ \\
\hline Chloroethane & 34311 & 2 & $<2$ & $<2$ & $<2$ & $<2$ & $<2$ & $<2$ & $<2$ \\
\hline Ethylbenzene & 34371 & 1 & $<1$ & $<1$ & $<1$ & $<1$ & $<1$ & $<1$ & $<1$ \\
\hline Bromomethane & 34413 & 5 & $<5$ & $<5$ & $<5$ & $<5$ & $<5$ & $<5$ & $<5$ \\
\hline Chloromethane & 34418 & 1 & $<1$ & $<1$ & $<1$ & $<1$ & $<1$ & $<1$ & $<1$ \\
\hline Methylene chloride ${ }^{3}$ & 34423 & 2 & $<2$ & $<2$ & $<2$ & $<2$ & $<2$ & 5.7 & $<2$ \\
\hline $\begin{array}{l}\text { Trichlorofluoromethane } \\
\qquad(C F C-11)\end{array}$ & 34488 & 1 & $<1$ & $<1$ & $<1$ & $<1$ & $<1$ & $<1$ & $<1$ \\
\hline 1,1-Dichloroethane & 34496 & 1 & $<1$ & $<1$ & $<1$ & $<1$ & $<1$ & $<1$ & $<1$ \\
\hline 1,1,1-Trichloroethane & 34506 & 1 & $<1$ & $<1$ & $<1$ & $<1$ & $<1$ & $<1$ & $<1$ \\
\hline 1,1,2-Trichloroethane & 34511 & 1 & $<1$ & $<1$ & $<1$ & $<1$ & $<1$ & $<1$ & $<1$ \\
\hline 1,1,2,2-Tetrachloroethane & 34516 & 1 & $<1$ & $<1$ & $<1$ & $<1$ & $<1$ & $<1$ & $<1$ \\
\hline 1,2-Dichlorobenzene & 34536 & 1 & $<1$ & $<1$ & $<1$ & $<1$ & $<1$ & $<1$ & $<1$ \\
\hline 1,2-Dichloropropane & 34541 & 1 & $<1$ & $<1$ & $<1$ & $<1$ & $<1$ & $<1$ & $<1$ \\
\hline trans-1,2-Dichloroethene & 34546 & 1 & $<1$ & $<1$ & $<1$ & $<1$ & $<1$ & $<1$ & $<1$ \\
\hline 1,2,4-Trichlorobenzene & 34551 & 1 & $<1$ & $<1$ & E0.4 & $<1$ & $<1$ & $<1$ & $<1$ \\
\hline 1,3-Dichlorobenzene & 34566 & 1 & $<1$ & $<1$ & $<1$ & $<1$ & $<1$ & $<1$ & $<1$ \\
\hline $\begin{array}{l}\text { Dichlorodifluoromethane } \\
\text { (CFC-12) }\end{array}$ & 34668 & 1 & $<1$ & $<1$ & $<1$ & $<1$ & $<1$ & $<1$ & $<1$ \\
\hline Naphthalene & 34696 & 1 & $<1$ & $<1$ & E0.3 & $<1$ & $<1$ & $<1$ & $<1$ \\
\hline $\begin{array}{l}\text { trans-1,3-Dichloropro- } \\
\text { pene }\end{array}$ & 34699 & 1 & $<1$ & $<1$ & $<1$ & $<1$ & $<1$ & $<1$ & $<1$ \\
\hline cis-1,3-Dichloropropene & 34704 & 1 & $<1$ & $<1$ & $<1$ & $<1$ & $<1$ & $<1$ & $<1$ \\
\hline Hexachlorobutadiene & 39702 & 5 & $<5$ & $<5$ & $<5$ & $<5$ & $<5$ & $<5$ & $<5$ \\
\hline Carbon disulfide & 77041 & 1 & $<1$ & $<1$ & $<1$ & $<1$ & $<1$ & $<1$ & $<1$ \\
\hline cis-1,2-Dichloroethene & 77093 & 1 & $<1$ & $<1$ & $<1$ & $<1$ & $<1$ & $<1$ & $<1$ \\
\hline$n$-Butyl methyl ketone & 77103 & 5 & $<5$ & $<5$ & $<5$ & $<5$ & $<5$ & $<5$ & $<5$ \\
\hline Styrene & 77128 & 1 & $<1$ & $<1$ & $<1$ & $<1$ & $<1$ & $<1$ & $<1$ \\
\hline
\end{tabular}


Table 2. Analyses for organic constituents in quality-control and environmental samples collected for this study.-Continued

[Detections in bold. Abbreviations: USGS, U.S. Geological Survey; NWIS, National Water Information System; LRL, laboratory reporting level; $\mu \mathrm{g} / \mathrm{L}$, microgram per liter; <, less than symbol indicates that constituent was not detected, and the value following the less than symbol was an LRL; E, estimated concentration, indicates value measured was below LRL but greater than established method detection limit (MDL); --, not analyzed for constituent or not applicable; CFC, chlorofluorocarbon; M, constituent detected, but not quantified]

\begin{tabular}{|c|c|c|c|c|c|c|c|c|c|}
\hline \multirow{3}{*}{ Organic constituent } & \multirow{3}{*}{$\begin{array}{c}\text { USGS } \\
\text { NWIS } \\
\text { parameter }\end{array}$} & \multirow{3}{*}{$\begin{array}{l}\text { Laboratory } \\
\text { reporting } \\
\text { level (LRL) } \\
\text { ( } \mu \mathrm{g} / \mathrm{L})\end{array}$} & \multicolumn{3}{|c|}{ Quality-control samples } & \multirow{2}{*}{\multicolumn{4}{|c|}{$\begin{array}{c}\text { Environmental samples } \\
\text { Sampled well }\end{array}$}} \\
\hline & & & \multirow{2}{*}{$\begin{array}{l}\text { Source solu- } \\
\text { tion blank } \\
\text { ( } \mu \mathrm{g} / \mathrm{L})\end{array}$} & \multirow{2}{*}{$\begin{array}{l}\text { Trip } \\
\text { blank } \\
\text { ( } \mu \mathrm{g} / \mathrm{L})\end{array}$} & \multirow{2}{*}{$\begin{array}{l}\text { Equipment } \\
\text { blank } \\
\text { ( } \mu \mathrm{g} / \mathrm{L})\end{array}$} & & & & \\
\hline & & & & & & $\begin{array}{l}\mathrm{LN}-1 \\
(\mu \mathrm{g} / \mathrm{L})\end{array}$ & $\begin{array}{c}\text { FH-1 } \\
(\mu \mathrm{g} / \mathrm{L})\end{array}$ & $\begin{array}{l}\text { FH-2 } \\
(\mu \mathrm{g} / \mathrm{L})\end{array}$ & $\begin{array}{l}\text { FH-3 } \\
(\mu g / L)\end{array}$ \\
\hline \multicolumn{10}{|c|}{ Volatile organic compounds-Continued } \\
\hline$o$-Xylene & 77135 & 1 & $<1$ & $<1$ & $<1$ & $<1$ & $<1$ & $<1$ & $<1$ \\
\hline 1,3-Dichloropropane & 77173 & 1 & $<1$ & $<1$ & $<1$ & $<1$ & $<1$ & $<1$ & $<1$ \\
\hline 1,2,4-Trimethylbenzene & 77222 & 1 & $<1$ & $<1$ & $<1$ & $<1$ & $<1$ & $<1$ & $<1$ \\
\hline Isopropylbenzene & 77223 & 1 & $<1$ & $<1$ & $<1$ & $<1$ & $<1$ & $<1$ & $<1$ \\
\hline$n$-Propylbenzene & 77224 & 1 & $<1$ & $<1$ & $<1$ & $<1$ & $<1$ & $<1$ & $<1$ \\
\hline Bromochloromethane & 77297 & 1 & $<1$ & $<1$ & $<1$ & $<1$ & $<1$ & $<1$ & $<1$ \\
\hline$n$-Butylbenzene & 77342 & 1 & $<1$ & $<1$ & E0.19 & $<1$ & $<1$ & $<1$ & $<1$ \\
\hline sec-Butylbenzene & 77350 & 1 & $<1$ & $<1$ & $<1$ & $<1$ & $<1$ & $<1$ & $<1$ \\
\hline tert-Butylbenzene & 77353 & 1 & $<1$ & $<1$ & $<1$ & $<1$ & $<1$ & $<1$ & $<1$ \\
\hline 4-Isopropyltoluene & 77356 & 1 & $<1$ & $<1$ & $<1$ & $<1$ & $<1$ & $<1$ & $<1$ \\
\hline 1,2,3-Trichloropropane & 77443 & 5 & $<5$ & $<5$ & $<5$ & $<5$ & $<5$ & $<5$ & $<5$ \\
\hline 1,1,1,2-Tetrachloroethane & 77562 & 1 & $<1$ & $<1$ & $<1$ & $<1$ & $<1$ & $<1$ & $<1$ \\
\hline 1,2,3-Trichlorobenzene & 77613 & 1 & $<1$ & $<1$ & $<1$ & $<1$ & $<1$ & $<1$ & $<1$ \\
\hline 1,2-Dibromoethane & 77651 & 1 & $<1$ & $<1$ & $<1$ & $<1$ & $<1$ & $<1$ & $<1$ \\
\hline Xylene (all isomers) & 81551 & 3 & $<3$ & $<3$ & $<3$ & $<3$ & $<3$ & $<3$ & $<3$ \\
\hline Acetone & 81552 & 10 & $<10$ & $<10$ & $<10$ & $<10$ & $<10$ & $\mathbf{M}$ & $<10$ \\
\hline Bromobenzene & 81555 & 1 & $<1$ & $<1$ & $<1$ & $<1$ & $<1$ & $<1$ & $<1$ \\
\hline $\begin{array}{l}\text { 1,2-Dibromo-3-chloro- } \\
\text { propane (Dibromo- } \\
\text { chloropropane) }\end{array}$ & 82625 & 1 & $<1$ & $<1$ & $<1$ & $<1$ & $<1$ & $<1$ & $<1$ \\
\hline$m$-Xylene plus $p$-xylene & 85795 & 2 & $<2$ & $<2$ & $<2$ & $<2$ & $<2$ & $<2$ & $<2$ \\
\hline 1,4-Dichlorobenzene & 34571 & 1 & $<1$ & $<1$ & $<1$ & $<1$ & $<1$ & $<1$ & $<1$ \\
\hline Benzene & 34030 & 1 & $<1$ & $<1$ & $<1$ & $<1$ & $<1$ & $<1$ & $<1$ \\
\hline $\begin{array}{l}\text { Methyl ethyl ketone } \\
\text { (MEK) }\end{array}$ & 81595 & 10 & $<10$ & $<10$ & $<10$ & $<10$ & $<10$ & $<10$ & $<10$ \\
\hline Tetrachloromethane & 32102 & 1 & $<1$ & $<1$ & $<1$ & $<1$ & $<1$ & $<1$ & $<1$ \\
\hline
\end{tabular}


Table 2. Analyses for organic constituents in quality-control and environmental samples collected for this study.-Continued

[Detections in bold. Abbreviations: USGS, U.S. Geological Survey; NWIS, National Water Information System; LRL, laboratory reporting level; $\mu$ g/L, microgram per liter; <, less than symbol indicates that constituent was not detected, and the value following the less than symbol was an LRL; E, estimated concentration, indicates value measured was below LRL but greater than established method detection limit (MDL); --, not analyzed for constituent or not applicable; CFC, chlorofluorocarbon; M, constituent detected, but not quantified]

\begin{tabular}{|c|c|c|c|c|c|c|c|c|c|}
\hline \multirow{3}{*}{ Organic constituent } & \multirow{3}{*}{$\begin{array}{c}\text { USGS } \\
\text { NWIS } \\
\text { parameter }\end{array}$} & \multirow{3}{*}{$\begin{array}{c}\text { Laboratory } \\
\text { reporting } \\
\text { level (LRL) } \\
(\mu \mathrm{g} / \mathrm{L})\end{array}$} & \multicolumn{3}{|c|}{ Quality-control samples } & \multirow{2}{*}{\multicolumn{4}{|c|}{$\begin{array}{c}\text { Environmental samples } \\
\text { Sampled well }\end{array}$}} \\
\hline & & & \multirow{2}{*}{$\begin{array}{c}\text { Source solu- } \\
\text { tion blank } \\
(\mu \mathrm{g} / \mathrm{L})\end{array}$} & \multirow{2}{*}{$\begin{array}{c}\text { Trip } \\
\text { blank } \\
\text { ( } \mu \mathrm{g} / \mathrm{L})\end{array}$} & \multirow{2}{*}{$\begin{array}{c}\text { Equipment } \\
\text { blank } \\
(\mu \mathrm{g} / \mathrm{L})\end{array}$} & & & & \\
\hline & & & & & & $\begin{array}{l}\mathrm{LN}-1 \\
(\mu \mathrm{g} / \mathrm{L})\end{array}$ & $\begin{array}{l}\mathrm{FH}-1 \\
(\mu \mathrm{g} / \mathrm{L})\end{array}$ & $\begin{array}{l}\text { FH-2 } \\
(\mu g / L)\end{array}$ & $\begin{array}{l}\text { FH-3 } \\
(\mu \mathrm{g} / \mathrm{L})\end{array}$ \\
\hline \multicolumn{10}{|c|}{ Volatile organic compounds-Continued } \\
\hline Chlorobenzene & 34301 & 1 & $<1$ & $<1$ & $<1$ & $<1$ & $<1$ & $<1$ & $<1$ \\
\hline 1,1-Dichloroethane & 34496 & 1 & $<1$ & $<1$ & $<1$ & $<1$ & $<1$ & $<1$ & $<1$ \\
\hline Tetrachloroethene & 34475 & 1 & $<1$ & $<1$ & $<1$ & $<1$ & $<1$ & $<1$ & $<1$ \\
\hline Trichloroethene & 39180 & 1 & $<1$ & $<1$ & $<1$ & $<1$ & $<1$ & $<1$ & $<1$ \\
\hline Vinyl chloride & 39175 & 1 & $<1$ & $<1$ & $<1$ & $<1$ & $<1$ & $<1$ & $<1$ \\
\hline
\end{tabular}

${ }^{1} \mathrm{LRL}$ for diesel-range organics (DRO) samples from LN-1 and FH-2 was $210 \mu \mathrm{g} / \mathrm{L}$. LRL for DRO samples from FH-1 and FH-3 were 190 and $390 \mu \mathrm{g} / \mathrm{L}$, respectively.

${ }^{2} \mathrm{DRO}$ detection attributed to sample contamination (see text).

${ }^{3}$ Also known as dichloromethane.

${ }^{4}$ Also known as trichloromethane.

fractionation; Mook and van der Plicht, 1999; Plummer and others, 2004).

The USGS Reston Stable Isotope Laboratory analyzed groundwater samples for stable isotopes of hydrogen (deuterium/protium isotopic ratio $\left.\left[\delta^{2} \mathrm{H}\right]\right)$ in water by hydrogen equilibration (Coplen and others, 1991; Révész and Coplen, 2008a) and oxygen (oxygen-18/oxygen-16 isotopic ratio $\left[\delta^{18} \mathrm{O}\right]$ ) in water by carbon-dioxide equilibration (Epstein and Mayeda, 1953; Révész and Coplen, 2008b). Both $\delta^{2} \mathrm{H}$ and $\delta^{18} \mathrm{O}$ are reported in relation to Vienna Standard Mean Ocean Water and normalized (Coplen, 1994) on scales such that the oxygen and hydrogen isotopic values of Standard Light Antarctic Precipitation are -55.5 per mil and -428 per mil, respectively.

Groundwater sampled from monitoring wells BR-1, LN-1, and FH-1 was analyzed for tritium at the USGS Menlo Park Tritium Laboratory using electrolytic enrichment (Ostlund and Dorsey, 1977). Groundwater sampled from wells FH-2 and FH-3 was analyzed for tritium at the University of Miami Tritium Laboratory in Miami, Florida, using the same analytical method.

Laboratory analytical results for constituents were reported relative to laboratory reporting levels (LRLs), long-term method detection levels (LT-MDLs), minimum reporting levels (MRLs), or to a detection limit determined by DQCALC software (DLDQC [Standard Practice D7510-10; ASTM International, 2010]). The LRLs are set by the NWQL to minimize false positive and false negative measurement errors (Oblinger Childress and others, 1999). The LRLs are calculated statistically on a continual basis using QC data for a given analytical method to determine LT-MDLs (Oblinger Childress and others, 1999). The LRLs are defined as twice the annual LT-MDLs. The MRLs are the minimum concentrations of a constituent that can be reported reliably using a given analytical method (Timme, 1995). The MRLs and LRLs can differ for the same constituent because of improvement in analytical methods or possible complications with individual analyses. The DLDQC is the lowest concentration that with 90-percent confidence will be exceeded no more than 1 percent of the time when a blank sample is measured (less than or equal to 1-percent false positive risk) (Williams and Foreman, 2015). The DLDQC is equal to the critical level "LC" of ASTM International's Standard Practice D6091-07 (ASTM International, 2007) and approximately equals the method detection limit (Williams and Foreman, 2015).

The NWQL reports some analytical results as estimated concentrations. Estimated concentrations are smaller than a minimum concentration that can be reported reliably by a given analytical method but generally larger than the LT-MDL (Oblinger Childress and others, 1999). Concentrations reported as estimated indicate that the constituent is present in the water sample but there is some type of quantitative analytical uncertainty associated with the reported concentration. In this report, estimated concentrations in tables are designated with the placement of the letter " $E$ " preceding the reported laboratory concentration. 
Analytical results for radiochemical constituents have unique specific reporting requirements related to each sample analyzed. Radiochemical constituents are reported in relation to a sample-specific critical level (SSLC) plus or minus a one-sigma combined standard uncertainty (CSU). The SSLC is the lowest concentration measured that indicates a significant statistical difference from the instrument background noise or the analytical blank sample (McCurdy and others, 2008). If the radiochemical constituent concentration is greater than of the SSLC, the radionuclide is considered present in a sample. Values less than the SSLC are reported as nondetections and are denoted with an "R" before the value. Some radiochemical analyses were reported as negative values; this indicated that the radiation count of the sample was less than the mean background radiation routinely reported by the instrument. The one-sigma CSU is the statistical standard deviation of an individual radiochemical measurement and is a function of several variables that can cause variances in measurement, one of which is the counting error associated with the random nature of radioactive decay with any given brief instant of time. The counting error imposes limitations on the precision of radioactive counting techniques. The one-sigma CSU is provided with the measured radionuclide concentration and defines upper and lower concentrations for a confidence interval of the true concentration (McCurdy and others, 2008).

\section{Quality Assurance and Quality-Control Samples}

In addition to collection of environmental groundwaterquality samples from 5 wells, 3 types of QC samples were collected as part of the QA program (Koterba and others, 1995). The QC samples included 1 equipment blank, 1 trip blank, and 1 replicate environmental sample. Analytical results from QC samples collected in the field and prepared in the laboratories were used to assess the quality of the data reported for environmental samples. The QC samples were collected, preserved, transported, and analyzed using the same methods and equipment as used for environmental samples. Data from QC samples collected during this study were used to evaluate the bias and variability that may have resulted from sample collection, processing, transport, and analysis. Collection and evaluation of QC samples, in addition to adherence to strict USGS sample collection, processing, and analysis procedures, composed the QA program.

\section{Blank Samples}

Three types of blank samples (equipment, trip, and source-solution blank samples) were collected as part of this study. The equipment blank sample was collected at the USGS Wyoming-Montana Water Science Center office in Cheyenne, Wyo., before sampling to evaluate bias, providing data used to determine if cleaning procedures removed constituents from sampling equipment and if sampling and laboratory methods were appropriate to prevent contamination of environmental samples. Upon completion of cleaning, the equipment blank sample was collected by passing specially prepared blank water through all sampling equipment and then collecting, preserving, and transporting the sample using the same procedures as for environmental samples. Specially prepared water for the equipment blank sample was provided by the NWQL before sampling of the three monitoring wells using portable sampling pumps and was certified to be free of inorganic (inorganic-free blank water) and organic (organic-free blank water) constituents to concentrations less than NWQL LRLs or MRLs. The one trip blank collected for this study consisted of VOC vials of laboratory blank water, filled and sealed by the analyzing laboratory. The trip blank accompanied environmental sample vials to verify that VOC contamination did not take place during storage, sampling, or shipment to or from the analyzing laboratory. No VOCs were detected in the trip blank (table 2).

The one source-solution blank sample was collected by pouring certified organic-free blank water directly into VOC sample vials in the field where groundwater-quality samples were collected. The source-solution blank was used to determine if the blank water, sample vials, preservation chemicals, or air in the mobile laboratory where VOC samples were collected was contaminated. A quantified result in any blank sample was considered evidence that contamination could have affected groundwater sample results. No VOCs were detected in the source-solution blank (table 2).

The equipment blank sample was analyzed for major ions, trace elements, nutrients, DOC (table 3), and VOCs (table 2). One major ion (calcium) and one uncharged species (silica) were detected, but concentrations were much smaller than measured in all three monitoring well samples (table 3). Nutrients and DOC were not detected in the equipment blank sample (table 3). Eight trace elements were detected in the equipment blank sample (barium, copper, manganese, nickel, silver, strontium, uranium, and zinc; table 3). Silver was detected in the equipment blank sample but not in any of the environmental samples (table 3 ). Concentrations of five trace elements (barium, manganese, nickel, strontium, and uranium), which were detected in the equipment blank sample and at least one environmental sample from monitoring wells $\mathrm{BR}-1, \mathrm{LN}-1$, and $\mathrm{FH}-1$, were smaller in the equipment blank sample than in the associated environmental samples with detections of the same constituents (table 3 ). The concentrations of copper and zinc in the equipment blank sample ( 67.0 and $8.4 \mathrm{mg} / \mathrm{L}$, respectively) were larger than the concentrations measured in the one monitoring well with detections of the same constituents (BR-1, 1.2 and $6.5 \mathrm{mg} / \mathrm{L}$, respectively; table 3), indicating high bias for these constituents. Consequently, the detection of copper and zinc in the environmental sample from well BR-1 and the measured concentrations are suspect because of the larger concentrations measured in the equipment blank sample; however, the concentrations of both constituents measured in the environmental sample are small and likely of little environmental concern. Overall, results of the equipment blank sample indicated that 
Table 3. Summary of major ions and related water-quality characteristics, trace elements, nutrients, and dissolved organic carbon in equipment blank sample in relation to groundwater-quality samples collected from monitoring wells BR-1, LN-1, and FH-1, southeastern Laramie County, Wyoming.

[USGS, U.S. Geological Survey; NWIS, National Water Information System; LRL, laboratory reporting level; <, less than; MRL, minimum reporting level; mg/L, milligram per liter; $\mathrm{CaCO}_{3}$, calcium carbonate; IRL, interim reporting level; --, not available]

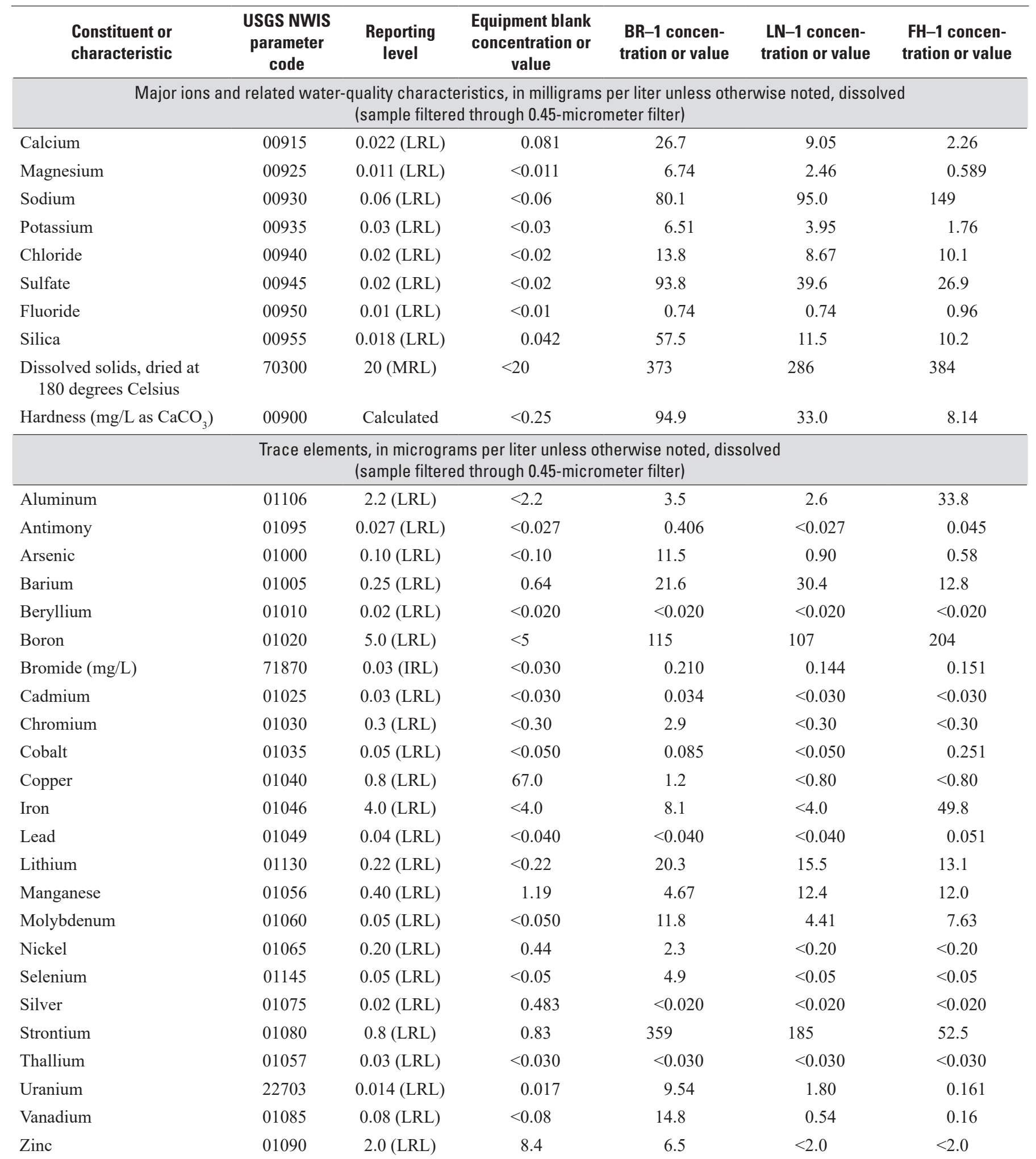


Table 3. Summary of major ions and related water-quality characteristics, trace elements, nutrients, and dissolved organic carbon in equipment blank sample in relation to groundwater-quality samples collected from monitoring wells BR-1, LN-1, and FH-1, southeastern Laramie County, Wyoming.-Continued

[USGS, U.S. Geological Survey; NWIS, National Water Information System; LRL, laboratory reporting level; <, less than; MRL, minimum reporting level; $\mathrm{mg} / \mathrm{L}$, milligram per liter; $\mathrm{CaCO}_{3}$, calcium carbonate; IRL, interim reporting level; --, not available]

\begin{tabular}{|c|c|c|c|c|c|c|}
\hline $\begin{array}{l}\text { Constituent or } \\
\text { characteristic }\end{array}$ & $\begin{array}{l}\text { USGS NWIS } \\
\text { parameter } \\
\text { code }\end{array}$ & $\begin{array}{l}\text { Reporting } \\
\text { level }\end{array}$ & $\begin{array}{c}\text { Equipment blank } \\
\text { concentration or } \\
\text { value }\end{array}$ & $\begin{array}{l}\text { BR-1 concen- } \\
\text { tration or value }\end{array}$ & $\begin{array}{l}\text { LN-1 concen- } \\
\text { tration or value }\end{array}$ & $\begin{array}{l}\text { FH-1 concen- } \\
\text { tration or value }\end{array}$ \\
\hline \multicolumn{7}{|c|}{$\begin{array}{l}\text { Nutrients, in milligrams per liter, dissolved, and dissolved organic carbon } \\
\text { (samples filtered through } 0.45 \text {-micrometer filter) }\end{array}$} \\
\hline Nitrate, as nitrogen & 00618 & Calculated & $<0.040$ & 1.91 & $<0.040$ & $<0.040$ \\
\hline Nitrite, as nitrogen & 00613 & 0.001 (IRL) & $<0.001$ & 0.016 & $<0.001$ & $<0.001$ \\
\hline Ammonia, as nitrogen & 00608 & $0.01(\mathrm{LRL})$ & 0.02 & 0.01 & 0.05 & 0.36 \\
\hline Organic nitrogen & 00607 & Calculated & $<0.03$ & 0.23 & -- & $<0.08$ \\
\hline Total nitrogen & 62854 & $0.05(\mathrm{LRL})$ & $<0.05$ & 2.18 & $<0.05$ & 0.43 \\
\hline Phosphorus, as phosphorus & 00666 & 0.003 (LRL) & $<0.003$ & 0.017 & 0.008 & 0.121 \\
\hline
\end{tabular}

decontamination procedures were adequate and that field and laboratory contamination of environmental samples by most inorganic constituents was minimal.

DROs were detected in the equipment and sourcesolution blanks at low (estimated) concentrations (E25 and E36 micrograms per liter $[\mu \mathrm{g} / \mathrm{L}]$, respectively) similar to those detected in environmental samples collected from wells $\mathrm{LN}-1$, FH-1, and FH-2 (E77, E31, and E63 $\mu \mathrm{g} / \mathrm{L}$, respectively; table 2). Because of similarity in concentration ranges, DRO detections in samples from these three wells were attributed to sample contamination and not actual detections for this study.

Four VOCs were detected at low (estimated) concentrations in the equipment blank sample: 1,2,4-trichlorobenzene, naphthalene, $n$-butylbenzene, and toluene (table 2). The source of these VOCs is unknown. None of these VOCs were detected in any environmental samples (table 2).

\section{Replicate Sample}

A replicate sample (also known as a duplicate sample) is a sample collected immediately after the primary groundwater sample (environmental sample); both samples are analyzed for the same constituents to assess combined effects of field and laboratory procedures on measurement variability (precision). The relative-percentage difference (RPD) was calculated to compare constituent concentrations measured in both samples using the following equation:

$$
R P D=\left|\frac{\frac{\text { sample } 1-\text { sample } 2}{\text { sample1 } 1 \text { sample } 2}}{2}\right| \times 100 .
$$

One replicate sample was collected and analyzed for major ions and related water-quality characteristics, trace elements, nutrients, DOC, radioisotopes, and stable isotopes (table 4). The RPDs were not calculated for inorganic sample pairs where one value was reported as less than the applicable reporting level (LRL, MRL, interim reporting level, or SSLC) and the other value was reported as greater than the applicable reporting level (LRL, MRL, interim reporting level, or SSLC); RPDs also were not calculated when both values were less than the applicable reporting level. For this study, RPD values greater than (>) 20 percent were considered indicative of analytical results that might be affected by high variability. The RPDs for all inorganic constituents except for gross alpha- and gross beta-particle activity were less than 5 percent and indicated good precision (reproducibility) for inorganic constituents (table 4). The calculated RPDs for gross alpha- and gross beta-particle activities (30.3 and 10.6 percent, respectively; table 4) indicated analytical results for these constituents might be affected by high variability. 
Table 4. Replicate data for major ions and related water-quality characteristics, trace elements, nutrients, dissolved organic carbon, radioisotopes, and stable isotopes in groundwater-quality samples collected from monitoring well LN-1, southeastern Laramie County, Wyoming.

[USGS, U.S. Geological Survey; NWIS, National Water Information System; L, long-term method detection limit; MRL, minimum reporting level; mg/L, milligram per liter; $\mathrm{CaCO}_{3}$, calcium carbonate; <, less than; $\mathrm{NC}$, not calculated; IRL, interim reporting level; --, no data; +, plus; C, carbon; SSLC, sample-specific critical level; R, nondetect, value below sample-specific critical level; per mil, parts per thousand]

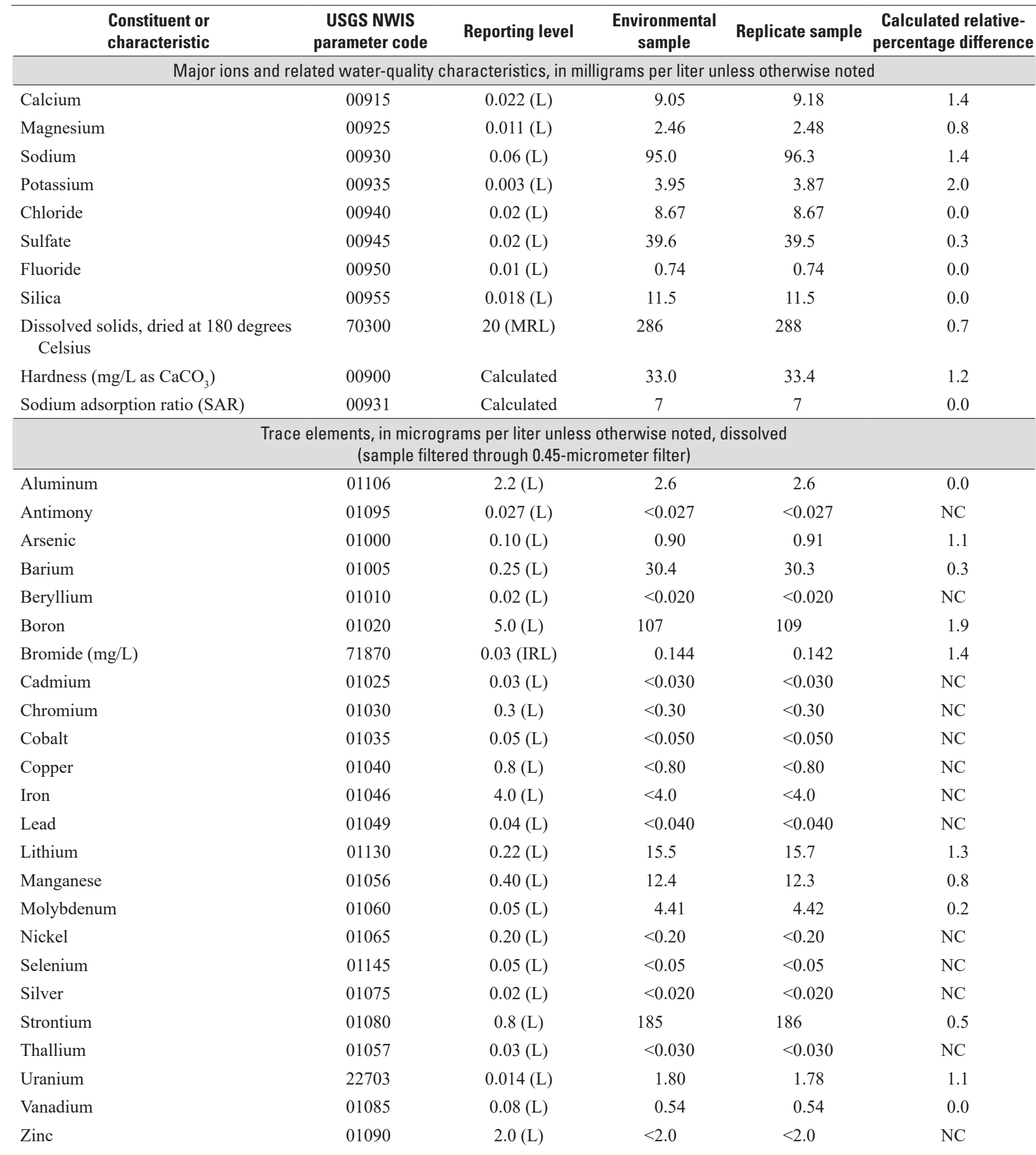


Table 4. Replicate data for major ions and related water-quality characteristics, trace elements, nutrients, dissolved organic carbon, radioisotopes, and stable isotopes in groundwater-quality samples collected from monitoring well LN-1, southeastern Laramie County, Wyoming.-Continued

[USGS, U.S. Geological Survey; NWIS, National Water Information System; L, long-term method detection limit; MRL, minimum reporting level; mg/L, milligram per liter; $\mathrm{CaCO}_{3}$, calcium carbonate; <, less than; $\mathrm{NC}$, not calculated; IRL, interim reporting level; --, no data; +, plus; C, carbon; SSLC, sample-specific critical level; R, nondetect, value below sample-specific critical level; per mil, parts per thousand]

\begin{tabular}{|c|c|c|c|c|c|}
\hline $\begin{array}{l}\text { Constituent or } \\
\text { characteristic }\end{array}$ & $\begin{array}{l}\text { USGS NWIS } \\
\text { parameter code }\end{array}$ & Reporting level & $\begin{array}{l}\text { Environmental } \\
\text { sample }\end{array}$ & Replicate sample & $\begin{array}{l}\text { Calculated relative- } \\
\text { percentage difference }\end{array}$ \\
\hline \multicolumn{6}{|c|}{$\begin{array}{l}\text { Nutrients, in milligrams per liter, and dissolved organic carbon, dissolved } \\
\text { (sample filtered through } 0.45 \text {-micrometer filter) }\end{array}$} \\
\hline Nitrate, as nitrogen & 00618 & Calculated & $<0.040$ & $<0.040$ & $\mathrm{NC}$ \\
\hline Nitrite, as nitrogen & 00613 & $0.001(\mathrm{~L})$ & $<0.001$ & $<0.001$ & $\mathrm{NC}$ \\
\hline Nitrate + nitrite, as nitrogen & 00631 & $0.04(\mathrm{~L})$ & $<0.040$ & $<0.040$ & $\mathrm{NC}$ \\
\hline Organic nitrogen & 00607 & Calculated & -- & $<0.002$ & $\mathrm{NC}$ \\
\hline $\begin{array}{l}\text { Total nitrogen (nitrate }+ \text { nitrite }+ \\
\text { ammonia }+ \text { organic nitrogen })\end{array}$ & 62854 & $0.05(\mathrm{~L})$ & $<0.05$ & $<0.05$ & $\mathrm{NC}$ \\
\hline Phosphorus, as phosphorus & 00666 & $0.003(\mathrm{~L})$ & 0.008 & 0.008 & 0.0 \\
\hline Tritium (picocuries per liter) & 07000 & $0.28-0.33$ (SSLC) & 0.41 & R0.00 & $\mathrm{NC}$ \\
\hline $\begin{array}{l}\left.\text { Radium-228 (dissolved }{ }^{1}\right) \\
\quad \text { (picocuries per liter) }\end{array}$ & 81366 & $0.195-0.262$ (SSLC) & 0.31 & $\mathrm{R} 0.06$ & $\mathrm{NC}$ \\
\hline $\begin{array}{l}\left.\text { Radium-226 (dissolved }{ }^{1}\right) \\
\quad \text { (picocuries per liter) }\end{array}$ & 09511 & $0.022-0.023$ (SSLC) & 0.09 & 0.09 & 0.0 \\
\hline $\begin{array}{l}\text { Gross alpha-particle activity } \\
\quad\left(\text { dissolved }^{1}\right) \text { (picocuries per liter) }\end{array}$ & 04126 & $1.26-1.46$ (SSLC) & 4.2 & 5.7 & 30.3 \\
\hline $\begin{array}{l}\text { Gross beta-particle activity } \\
\quad\left(\text { dissolved }^{1}\right) \text { (picocuries per liter) }\end{array}$ & 03515 & $1.37-1.54$ (SSLC) & 6.9 & 6.2 & 10.6 \\
\hline $\begin{array}{l}\delta \mathrm{H} \text { or deuterium (hydrogen-2)/ } \\
\text { protium (hydrogen-1) isotopic ratio } \\
\text { (per mil) }\end{array}$ & 82082 & -- & -99.2 & -100 & 0.8 \\
\hline
\end{tabular}

${ }^{1}$ Sample filtered through 0.45 -micrometer filter.

\section{Major-Ion Balances}

Major-ion data were quality assured by calculating ion balances. The ion balance was calculated (in milliequivalents per liter) as the total dissolved-cation equivalence minus the total dissolved-anion equivalence divided by the total equivalence of ions dissolved in solution. Calculated ion balances for all five groundwater samples were less than 3 percent. An ionic charge balance within plus or minus $( \pm) 5$ percent is considered acceptable (Clesceri and others, 1998).

\section{Guidelines and Regulatory Standards Used to Evaluate Groundwater Quality in Relation to Potential Uses}

To aid in the determination of suitability for potential uses, characteristic and constituent concentrations measured in groundwater samples collected for this study are compared to EPA drinking-water standards and health advisories for finished (treated) water established in the Safe Drinking Water Act (U.S. Environmental Protection Agency, 2018), State of Wyoming Class I drinking-water standards, Class II agricultural (irrigation) water standards, and Class III livestock water standards (Wyoming Department of Environmental Quality, 2005, table 1) and several additional commonly used 
Geologic and Hydrogeologic Characteristics, White River Formation, Lance Formation, and Fox Hills Sandstone, Wyo.

guidelines. Wyoming Class I drinking-water standards are the same as EPA drinking-water standards for most constituents. Although the EPA and Wyoming Class I drinking-water standards only apply to water supplied by public water-supply systems, not individual well owners, the concentrations are useful for comparison to evaluate the suitability of groundwater for drinking. The EPA has established standards for physical properties and chemical constituents in drinking water that may have adverse effects on human health or that may cause cosmetic or aesthetic effects. The Maximum Contaminant Level (MCL) is a legally enforceable, health-based standard and is the maximum permissible concentration for a constituent in drinking water that is delivered to any user of a public water-supply system that provides water to at least 15 connections and to at least 25 individuals (U.S. Environmental Protection Agency, 2018). A Lifetime Health Advisory Level is the concentration of a constituent in drinking water at or below which there is not expected to be any adverse, noncarcinogenic effects over a lifetime of exposure (U.S. Environmental Protection Agency, 2018). The Lifetime Health Advisory Level is based on toxicity (dose-response) information for the constituent and is not legally enforceable. It assumes lifetime consumption of 2 liters of water per day by a 70-kilogram (154-pound) adult and that 20 percent of total exposure to the constituent comes from drinking water whereas 80 percent comes from other sources. An EPA Action Level (AL) is the concentration of copper or lead in drinking water at or above which additional steps are required to reduce the constituent concentration (U.S. Environmental Protection Agency, 2018). For regulatory purposes, the AL is applied only to tap water samples and only if more than 10 percent of the samples exceeded the AL. A Drinking Water Advisory Level (DWA) is the concentration of a contaminant in water at or below which there are likely to be no adverse effects on health or aesthetic characteristics (taste or odor; U.S. Environmental Protection Agency, 2018). DWAs are not legally enforceable. Secondary Maximum Contaminant Levels (SMCLs) are unenforceable Secondary Drinking Water Regulations recommended to public water-supply systems (U.S. Environmental Protection Agency, 2018). An SMCL is a concentration in drinking water above which cosmetic effects (such as skin or tooth discoloration) or aesthetic effects (such as taste, odor, or color) may occur.

\section{Geologic Characteristics of Study Site Strata}

Cenozoic and Upper Cretaceous strata detected on the surface and in the subsurface during drilling and coring at the study site are identified and described in this section of the report. Physical characteristics are described, and various aspects of stratigraphy are discussed. Characterization of the strata was derived by use of drilling and coring of exploratory borehole LC-F1, through which visual lithologic descriptions, samples for petrographic analyses, geophysical logging, and lithostratigraphic descriptions were obtained. The term "lithology" herein refers to unconsolidated, semiconsolidated, or consolidated sediments collected during drilling and coring at the study site. Lithology is described at several scales: visual descriptions of core, including use of a binocular microscope (appendix 1; plate 1), supplemented with selected photographs; qualitative description of sediment grain size; and petrographic analysis of eight thin sections supplemented with scanning electron microscopy or XRD. In addition, the lithology and lithostratigraphy are selectively evaluated in relation to the types of responses given by various geophysical tools.

\section{Cenozoic Strata}

Surface and subsurface Cenozoic strata detected at the study site are identified and described in this section of the report.

\section{Quaternary Older Alluvial Fan Deposits}

Quaternary older alluvial fan deposits were present from land surface to about $40 \mathrm{ft} \mathrm{BLS} \mathrm{(fig.} \mathrm{11;} \mathrm{plate} \mathrm{1;} \mathrm{appendix} \mathrm{1).}$ Coring of this interval was difficult because of the prevalence of gravel-sized sediments, so little continuous core of the fan deposits was retrieved from exploratory borehole LC-F1. For intervals where core could not be obtained, sufficient quantities of cuttings were obtained for sediment description.

Subangular to subrounded sand- and gravel-sized sediments composed a much larger percentage of the unconsolidated deposits than mud-sized sediments (silt and clay), although some depth intervals had mud-sized sediments that composed most or a much larger percentage of the sedimentsize range (fig. 11; appendix 1; plate 1). A photograph showing typical coarse-grained deposits composed of sandy gravel is shown using cuttings from $29.5 \mathrm{ft}$ BLS (fig. 12A). Clay formed a matrix (provided some cementation) between coarse-grained sediments in some depth intervals; some weak carbonate cementation also was observed (appendix 1). Finer grained sediments not intermixed with gravel-sized sediments were present as several distinct layers within the overall sequence of coarse-grained unconsolidated deposits; an example of one of these finer grained layers composed of muddy sand with little to no gravel is shown in a photograph of core collected from the 16.5-18.0-ft depth interval (fig. 12B). Coarse-grained (sand- and gravel-sized) sediments were of variable composition; igneous rock fragments (primarily granite, commonly pink colored) and light- and dark-colored metamorphic rock fragments composed a substantial percentage of the sediments (appendix 1).

Composition of the unconsolidated fan deposits from the 29.5-40-ft depth interval differed from above. A substantial amount of the sediment clasts from this depth interval consisted of fragments of siltstone apparently derived from erosion of the upper part of the White River Formation 


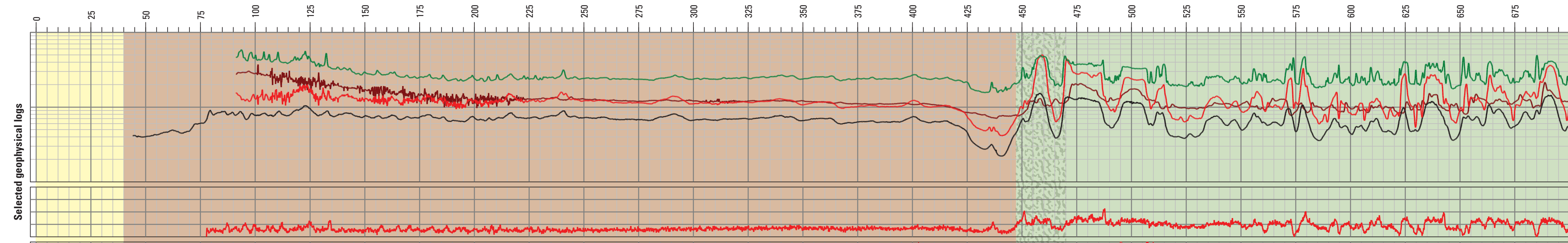

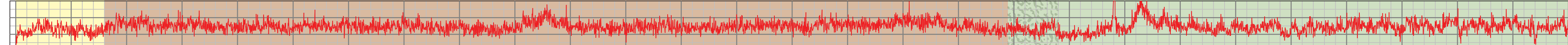

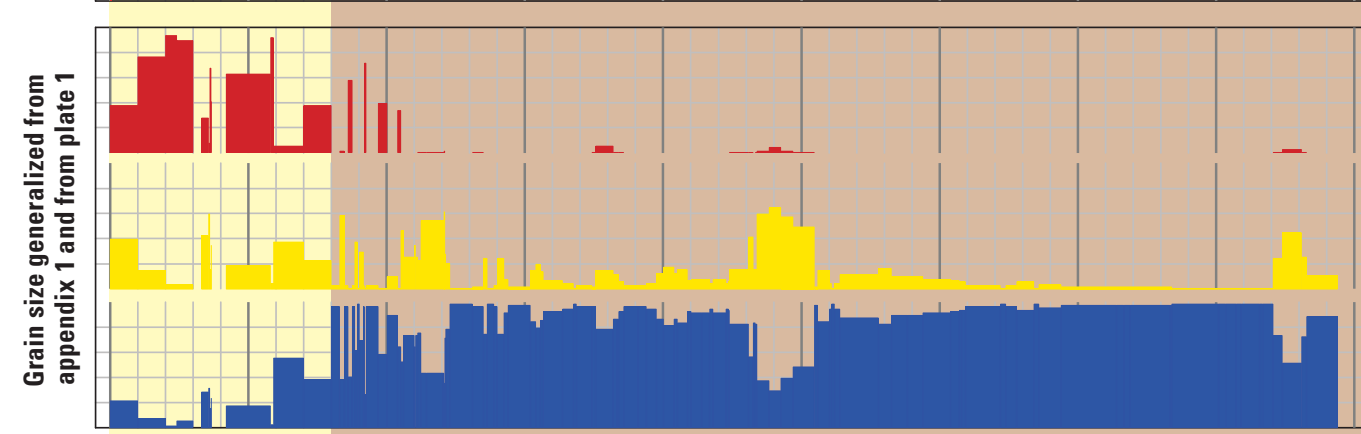

1. 1.

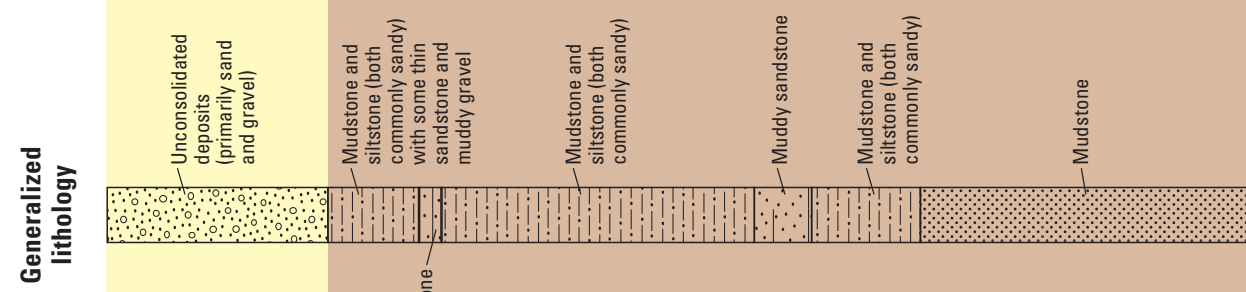

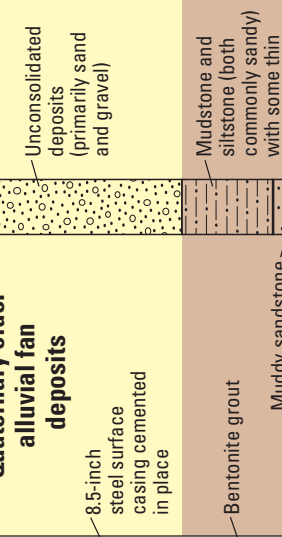

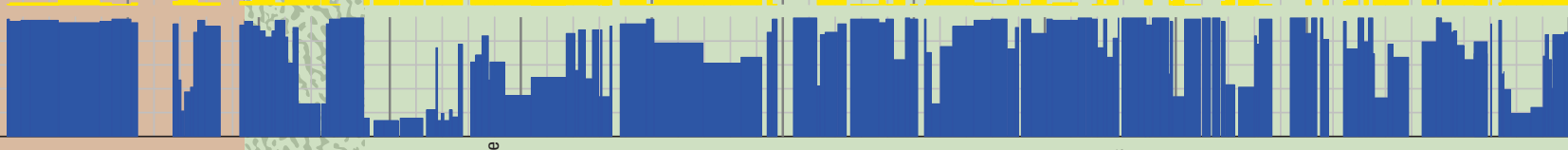

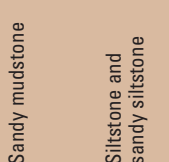
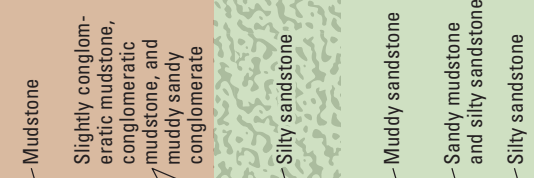

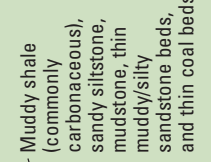
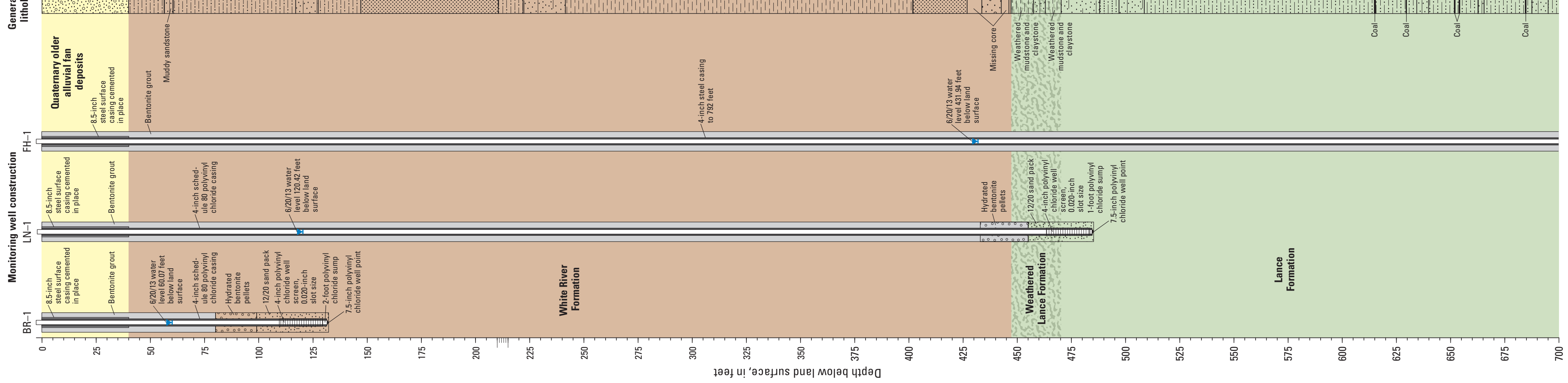


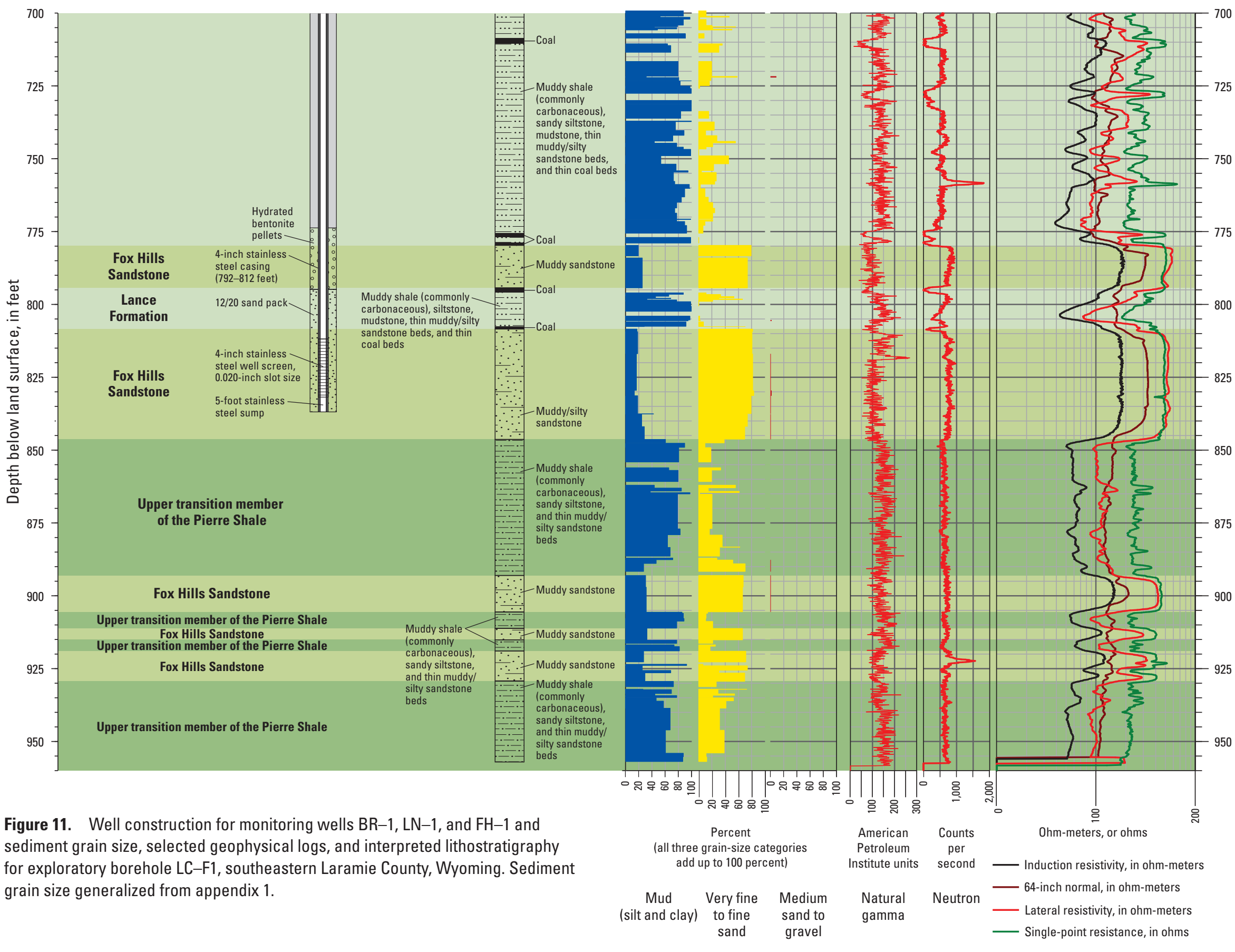



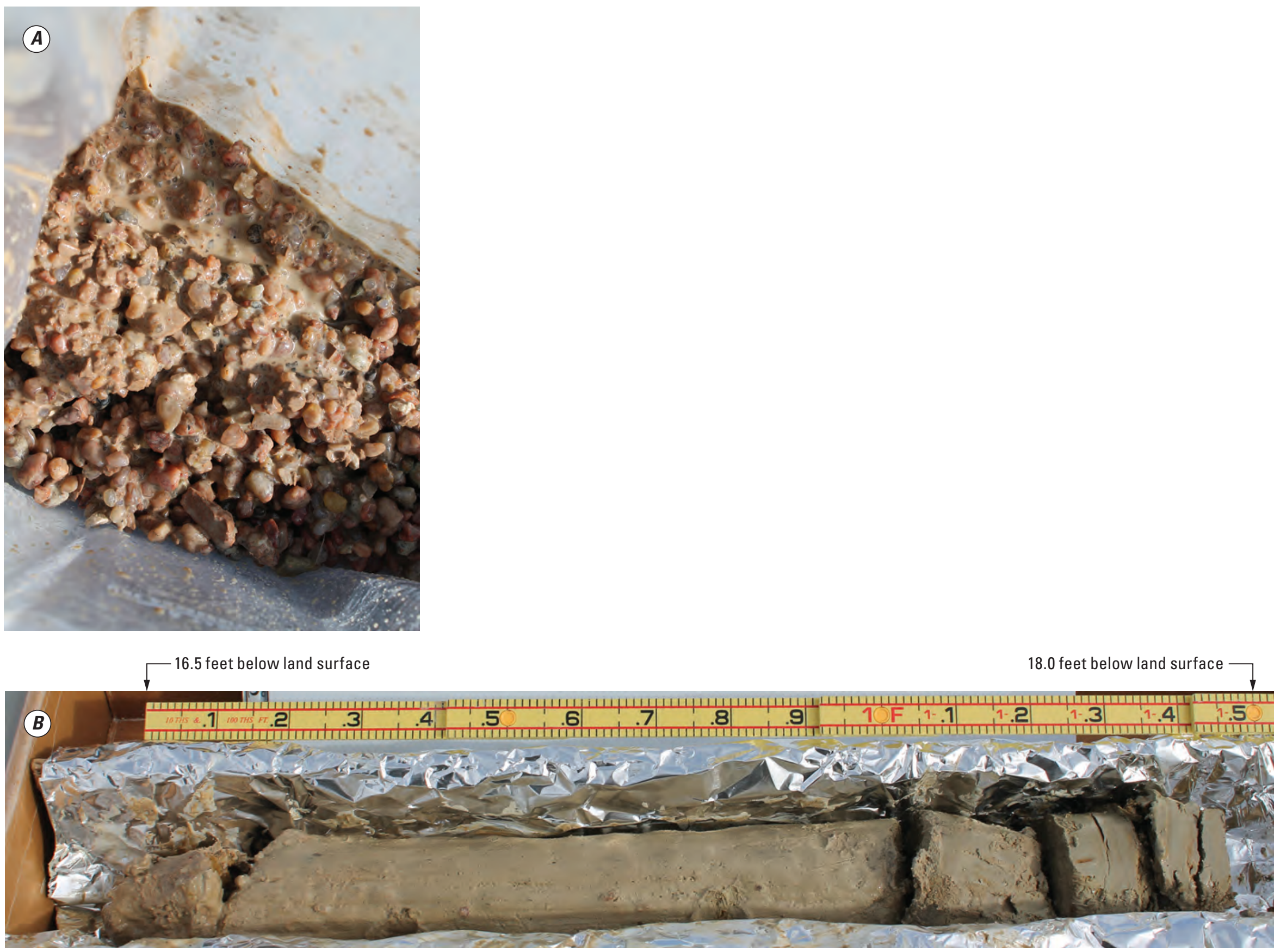

Figure 12. Cuttings and core from Quaternary older alluvial fan deposits, exploratory borehole LC-F1, southeastern Laramie County, Wyoming. $A$, cuttings from 29.5 feet below land surface (ft BLS) showing muddy sandy gravel; $B$, lateral view of core from 16.5 to $18.0 \mathrm{ft} \mathrm{BLS}$ showing muddy sand. 
(appendix 1); however, evaluation of sediments in this and other intervals throughout the full thickness of the fan deposits was limited primarily to descriptions of cuttings rather than core because of the coring difficulties noted previously. The siltstone fragments were intermixed with sand- and gravelsized clasts with composition the same as the overlying sediments. This depth interval conceptually is interpreted as transitional between the overlying Quaternary older alluvial fan deposits and the mudrock-dominated composition of the underlying upper part of the White River Formation. This "transitional zone" of reworked White River Formation strata has been noted in previous studies in the area (Bjorklund, 1959; Lowry, 1966; Lowry and Crist, 1967; Crist and Borchert, 1972).

\section{White River Formation}

Strata composing the late Eocene-Oligocene White River Formation at the study site are identified and described in this report section. Various aspects of White River Formation stratigraphy also are discussed, including comparisons of the formation in other parts of the Cheyenne Basin.

\section{Lithology}

In stark contrast to the overlying coarse-grained unconsolidated Quaternary alluvial fan deposits, the White River Formation consisted of a 407.3-ft-thick sequence of predominantly very fine-grained (mud-sized) sediments from 40 to $447.3 \mathrm{ft} \mathrm{BLS}$ (fig. 11; appendix 1; plate 1). Except for a few thin sandstone, muddy gravel, and conglomeratic beds, formation lithology was relatively homogenous and consisted almost entirely of mudrocks. Mudrocks were composed of differing proportions of mud-sized sediments (clay and silt) with variable but overall minor quantities of coarser very fine- to fine-grained sand-sized and gravel-sized sediments. Visual estimation of the relative percentage of clay-sized as compared to silt-sized sediments composing the mudrocks was difficult and subjective; more quantitative techniques would be required to provide a quantitative estimation of relative percentages of each size in any given mudrock. Consolidation of sediments varied throughout the formation, ranging from poorly to well consolidated, but overall sediments were poorly to moderately consolidated. Calcium carbonate, as indicated by effervescence upon application of hydrochloric acid, was observed throughout much of the formation (appendix 1). Two isolated small (less than $5 \mathrm{~mm}$ ) voids were detected in the 55.6-56-ft depth interval (fig. 13A). One void was partially filled with calcium carbonate (crystals fizzed upon application of hydrochloric acid), whereas the other was completely filled.

Sediment color throughout the White River Formation was primarily various shades of brown, but distinctive greenish-gray (Munsell soil color 5GY 6/1) mottling occurred throughout much of the 242-437-ft depth interval (fig. 13B-D; appendix 1). The mottling became more prevalent with increasing depth, and some depth intervals were almost entirely greenish gray (fig. 13D). Greenish-colored sediments (all lithologies, including mudrocks, sandstones, and conglomerate) are common in parts of the White River Formation or Group throughout southeastern Wyoming and adjacent western Nebraska and are reported in the stratigraphically middle to lower parts of the unit (for example, McGrew, 1953; Babcock and Bjorklund, 1956; Rapp and others, 1957; Morris and Babcock, 1960; Moore, 1963; Whitcomb, 1965; Lowry and Crist, 1967 [described as lower part of the White River Formation]; Singler and Picard, 1979a, b; Crist, 1980; Cooley and Crist, 1981; Swinehart and others, 1985; Swinehart and Diffendal, 1997; Bartos and others, 2014). Cored sediments became noticeably lighter in color upon drying (less brown and more white/tan) and, once dry, generally resembled the color of the White River Formation outcrops in the Pine Bluffs lowland area (not shown).

Sediments in the upper part of the White River Formation ("upper White River"; 40-242 ft BLS) were coarser (more silt- and sand-sized sediments) and consisted of more variable grain size than in the middle to lower part ("middle to lower White River"; 242-427 ft BLS), which was composed of a homogenous sequence of mudstone and claystone (fig. 11; plate 1; appendix 1). Upper White River rocks were mostly mudstone, siltstone, and claystone, and all three mudrock types commonly were sandy. Thin bedding/laminations were present in some depth intervals composed of fine-grained mudrocks, as well as depth intervals composed of coarser sediments such as muddy sandstone. Coarse-grained rocks included silty or muddy sandstone or muddy gravel, but these lithologies were uncommon and represented only a small percentage of upper White River and total formation thickness. Horizontal bar graphs showing grain size (created from ocular estimates in appendix 1) and (or) the various geophysical logs nicely illustrated the coarser grained nature of the upper White River in comparison to the middle to lower and lowermost parts of the White River ("lowermost White River," 427-447.3ft BLS; bar graphs not constructed for middle to lower White River; fig. 11; plate 1). Amongst the different types of geophysical logs collected, resistivity logs were perhaps the most useful for illustrating grain-size variation among different parts of the formation. In particular, the greater overall resistivity and frequent (and larger) variation (increases and decreases) in electrical resistivity (rightward or leftward deflections of the resistivity log traces, respectively) measured in the upper White River visually reflected the coarser and more variable grain size/lithology determined through core examination (appendix 1 and visualized with the horizontal bar graphs showing grain-size estimates; fig. 11; plate 1). Combined, the core description (including ocular grain-size estimates) and geophysical logs indicated sediment grain size decreased downward (fines downward) through the upper White River as it transitioned into the underlying even finer grained rocks (mudstone and claystone) of the middle to lower White River.

Sand grains in the upper White River ranged from very fine to medium in size, but most ranged from very fine to fine. 


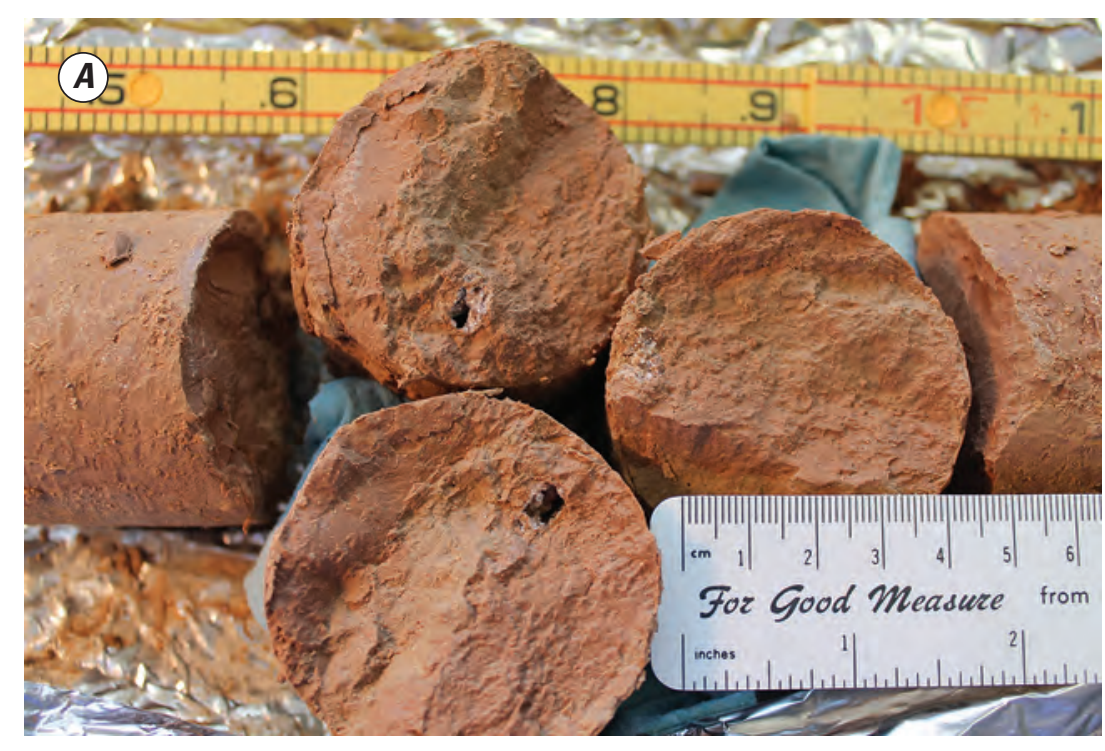

304.2 feet below land surface
Figure 13. Core and various characteristics of the White River Formation, exploratory borehole LC-F1, southeastern Laramie County, Wyoming. A, core from 55.6 to 56 feet below land surface ( $\mathrm{ft} \mathrm{BLS}$ ) showing voids in sandy mudstone; $B$, lateral view of core from 304.2 to $306.1 \mathrm{ft}$ BLS showing sparse greenish-gray mottling in moderate yellowish-brown mudstone and claystone; $C$, lateral view of core from 344.4 to $346.3 \mathrm{ft}$ BLS showing greenish-gray mottling in moderate yellowish-brown mudstone and claystone; $D$, lateral view of core from 394.6 to $396.5 \mathrm{ft}$ BLS showing greenish-gray mottling in moderate yellowish-brown mudstone and claystone. Note brown coloration on parts of greenish-gray core is drilling mud, not sediment color. Greenish-gray mottling is more prevalent in this depth interval than in overlying depth intervals (fig. 13C,D); $E$, view perpendicular to core at $121 \mathrm{ft} \mathrm{BLS} \mathrm{showing}$ part of muddy sandstone open to the well screen of monitoring well BR-1.

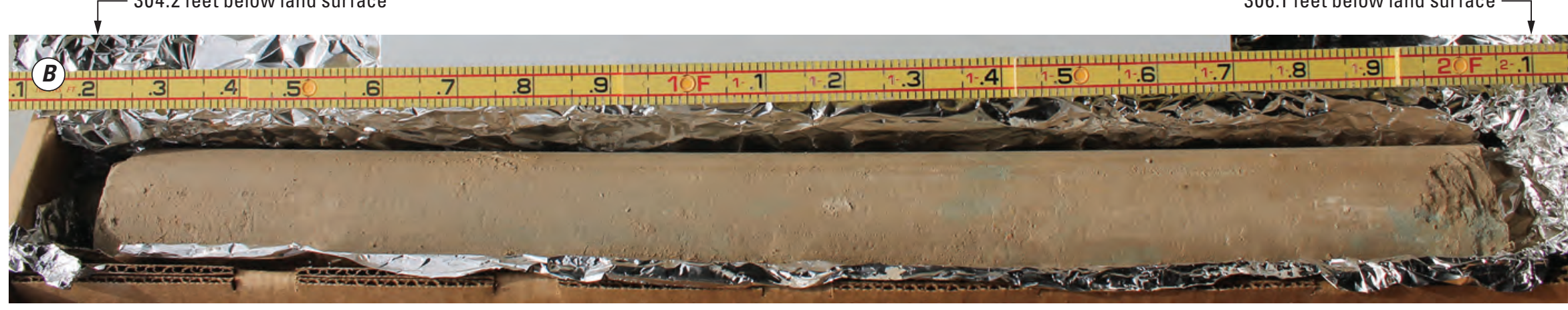

306.1 feet below land surface

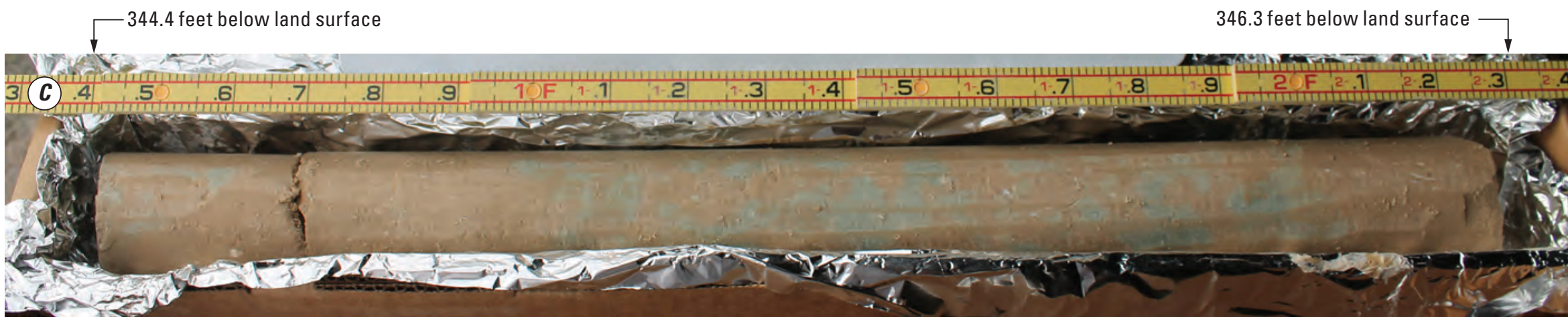



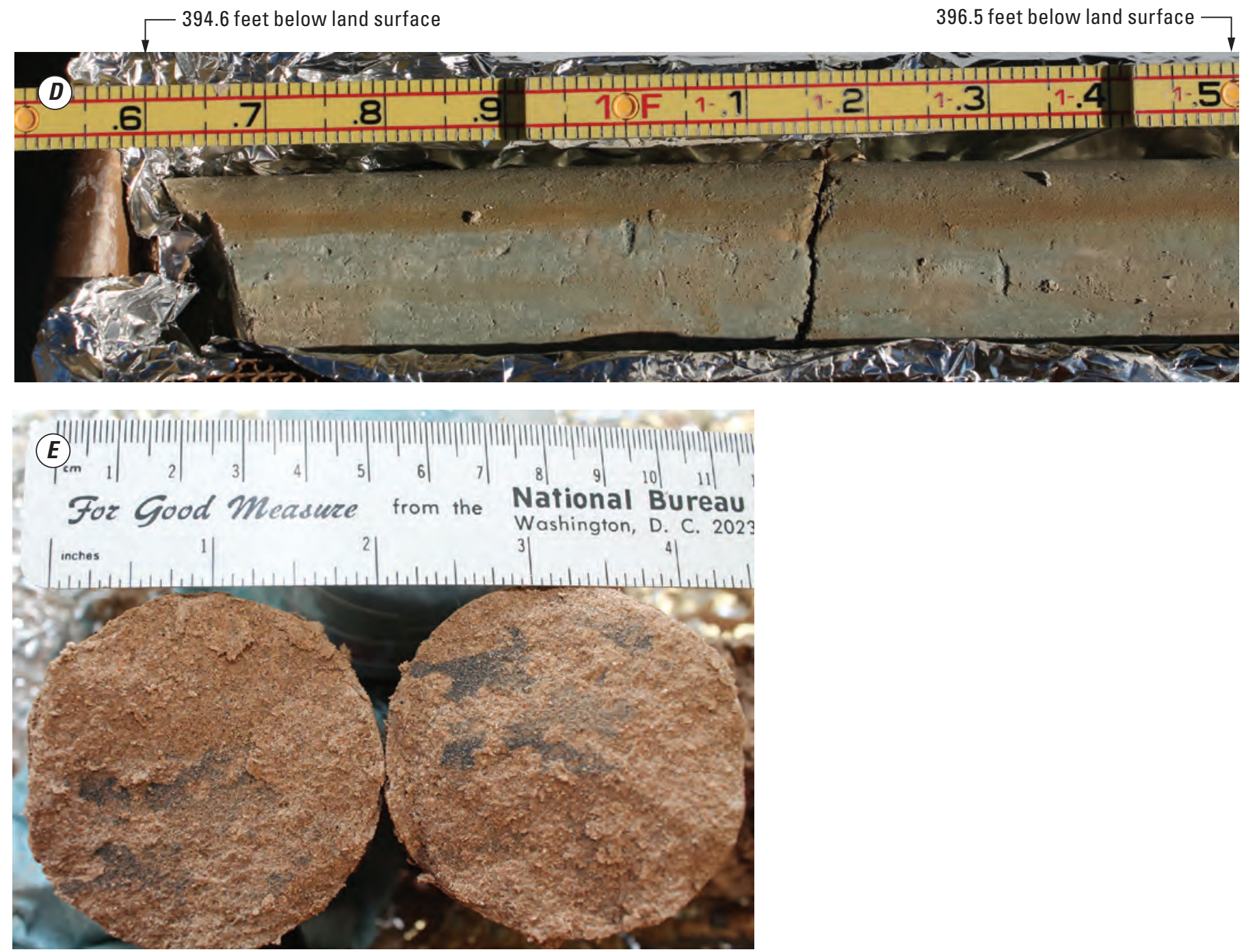

Figure 13. Core and various characteristics of the White River Formation, exploratory borehole LC-F1, southeastern Laramie County, Wyoming. $A$, core from 55.6 to 56 feet below land surface (ft BLS) showing voids in sandy mudstone; $B$, lateral view of core from 304.2 to $306.1 \mathrm{ft}$ BLS showing sparse greenish-gray mottling in moderate yellowish-brown mudstone and claystone; $C$, lateral view of core from 344.4 to $346.3 \mathrm{ft} \mathrm{BLS}$ showing greenish-gray mottling in moderate yellowish-brown mudstone and claystone; $D$, lateral view of core from 394.6 to $396.5 \mathrm{ft}$ BLS showing greenish-gray mottling in moderate yellowish-brown mudstone and claystone. Note brown coloration on parts of greenish-gray core is drilling mud, not sediment color. Greenish-gray mottling is more prevalent in this depth interval than in overlying depth intervals (fig. 13C,D); $E$, view perpendicular to core at $121 \mathrm{ft} \mathrm{BLS} \mathrm{showing} \mathrm{part} \mathrm{of} \mathrm{muddy} \mathrm{sandstone} \mathrm{open} \mathrm{to} \mathrm{the} \mathrm{well}$ screen of monitoring well BR-1.-Continued 
Grain rounding ranged from angular to well rounded, and sphericity ranged from subprismoidal to subdiscoidal, indicating relatively immature sediments. Sand-sized sediments occurred most commonly intermixed with the silt- and claysized sediments that composed most of the mudrock fabric throughout the upper White River (see percentage estimates of grain size on fig. 11 and plate 1); many upper White River mudrocks contained quantities of intermixed sand sufficiently large to be classified as sandy (sandy mudstone or sandy siltstone). Much less commonly, sand-sized sediments were present as thin layers interbedded/interlayered with mudrocks or surrounding intact mudstone rock fragments/clasts (rip-up clasts; appendix 1).

Four upper White River depth intervals (41.5-42.3, 52.6-53, 56.2-60.5, and 117-127.4 ft BLS) overall contained more sand-sized than mud-sized sediments, and thus, rocks in these intervals were classified as muddy sandstones (fig. 11; appendix 1; plate 1); however, parts of these three sandstone beds were highly clayey and silty, and these thin clayey and silty zones within the beds could be classified alternatively as sandy siltstones or sandy mudstones. The thickest of the four sandstone beds was a 10.4-ft-thick muddy (silty and clayey) sandstone present from 117 to $127.4 \mathrm{ft} \mathrm{BLS}$ (appendix 1; plate 1; fig. 11). A photograph of core from a discrete interval (121 ft BLS) within this sandstone bed is shown in figure $13 E$. This sandstone bed was water saturated, and a monitoring well (BR-1) was completed with the well screen open to the bed (and partly open to overlying/underlying mudrocks, many of which were sandy; fig. 11; plate 1). The percentage of mud-sized sediment (silt and clay) in comparison to sandsized sediment composing the 10.4-ft-thick sandstone varied throughout the 117-127.4 ft BLS depth interval, but silt- and clay-sized particles still composed a substantial percentage of the sediments (fig. 11; appendix 1; plate 1). Sand grains ranged in size from very fine to medium $(0.062-0.500 \mathrm{~mm}[0.002-$ $0.020 \mathrm{in}]$.$) , but most were very fine to fine (0.062-0.250 \mathrm{~mm}$ [0.002-0.010 in.]; plate 1; appendix 1; fig. 13E). Cooley and Crist (1981) reported a coarse-grained sequence similar to this sandstone bed in the middle to upper part of the White River Formation in some areas in southeastern Laramie County, including parts of the Pine Bluffs lowland. The investigators noted the sequence would yield water to wells in places.

Lithologic characteristics of the lowermost White River (427-447.3 ft BLS) differed from the overlying middle to lower and upper White River. Drilling and coring was difficult in parts of the lowermost White River, presumably because of the combination of relatively soft mudstone with varying amounts of gravel (described in this section). Large increases in borehole diameter (washout zones) were measured throughout this depth interval (see caliper log on plate 1). Similar washout zones also can be seen in other studies that penetrated the equivalent lower White River Formation strata elsewhere in the Pine Bluffs lowland (for example, Dahlgren Consulting, Inc., and others, 2005, caliper log shown on figs. 3-10 [location near the town of Pine Bluffs]). Core was not obtained from 427-433.7 and 442.7-446.4 ft BLS because of the coring difficulty (appendix 1). Cuttings from the shallower of these two depth intervals without core (427-433.7 ft BLS) indicated some sediments in this depth interval were gravel (appendix 1). Except for some clay and claystone in parts of the 438.4-442.7-ft depth interval, most of the lowermost White River that was successfully cored consisted of mudstone with varying amounts of gravel, including slightly conglomeratic mudstone, conglomeratic mudstone, and conglomeratic sandy mudstone (fig. 11; plate 1; appendix 1). Pebbles constituting the gravel-sized sediments within these three rock types ranged in size from very fine to medium (2-16 mm [0.08-0.63 in.]) but most were very fine to fine (2-8 mm [0.08-0.32 in.]; plate 1; appendix 1). Pebble rounding (and sand grains, where present) ranged from subangular to rounded, and sphericity ranged from subprismoidal to subdiscoidal (appendix 1). Characteristics of a coarse zone within one of the conglomeratic mudstones (434.7-435.2 ft BLS) are shown in a photograph taken perpendicular to collected core (fig. 14A). A 0.6-ft-thick muddy sandy conglomerate was present from 435.2 to $435.8 \mathrm{ft}$ BLS (fig. 11; plate 1; appendix 1). Two photographs of this muddy sandy conglomerate are shown in fig. 14B, $C$. This thin lithologic unit was the coarsest in the lowermost White River, as well as the entire formation. The conglomerate contained pebbles ranging in size from very fine to medium and sands ranging in size from very fine to very coarse (0.062-2 mm [0.002-0.080 in.]; fig. 11; plate 1; appendix 1; also see photographs in fig. $14 B, C$ ). Photographs taken lateral and perpendicular to collected core show the color and coarse-grained nature of the muddy sandy conglomerate (fig. 14B, C).

Sand- and gravel-sized clasts in the lowermost White River were composed of a substantially larger proportion of quartz (including quartzite and chert) than in the upper White River (appendix 1). Even though upper White River feldspar content was reported as "minor" (appendix 1), quantities still were sufficiently large enough that these rocks typically would be classified as "arkosic" (contained substantial quantities of feldspar). Because of minor feldspar content, lowermost White River rocks at the study site might not be considered arkosic in some sedimentary-rock classification schemes. Similar coarse-grained deposits consisting of clasts composed largely of quartz (including quartzite and chert) also are found at or near the base of the White River Formation immediately south of the Wyoming-Colorado border in northeastern Colorado (Emmett Evanoff, University of Northern Colorado, oral commun., 2019). These quartz-rich deposits have been interpreted as basal lag deposits at the bottom of the White River Formation or Group, and thus, the bottom of these deposits may represent the unconformity between the Tertiary (late Eoceneand Oligocene-age White River Formation or Group) and the Cretaceous (underlying Late Cretaceous- [late Maastrichtian] age Lance/Laramie Formation; Emmett Evanoff, University of Northern Colorado, oral commun., 2019). The lowermost White River at the study site with clasts composed substantially of quartz and chert likely is equivalent to this basal lag deposit (Emmett Evanoff, University of Northern Colorado, 

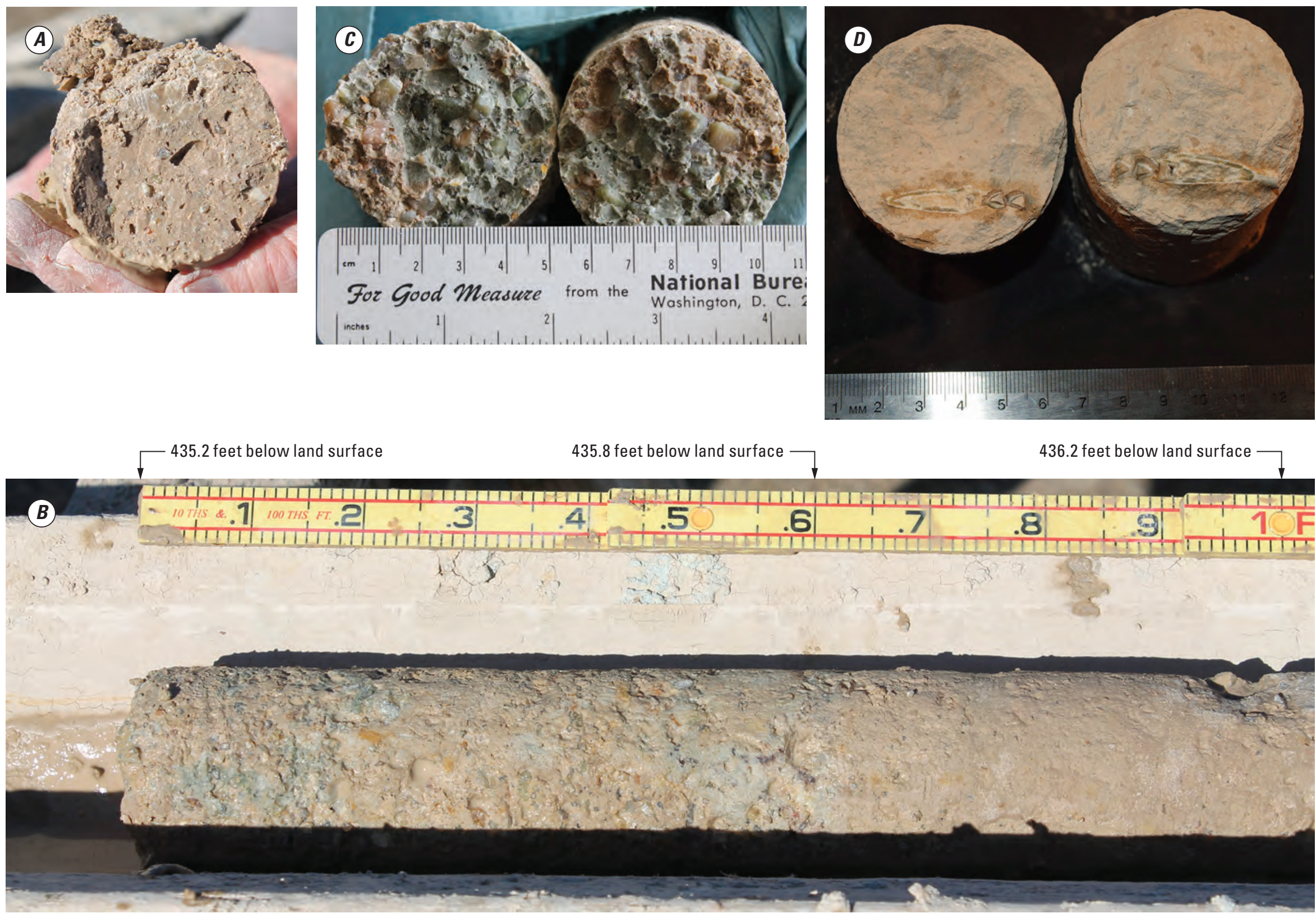

Figure 14. Various aspects of core in the White River Formation, borehole LC-F1, southeastern Laramie County, Wyoming. $A$, view perpendicular to core at about 435.1 feet below land surface (ft BLS) showing conglomeratic mudstone; $B$, lateral view of core showing muddy sandy conglomerate present from 435.2 to $435.8 \mathrm{ft} B L S$. This was the coarsest lithologic unit detected in the White River Formation; $C$, view perpendicular to core showing muddy sandy conglomerate at $435.4 \mathrm{ft} \mathrm{BLS}$; $D$, view of probable Poebrotherium (a camel) fossil jawbone recovered from core at about $202 \mathrm{ft}$ BLS. Photograph provided by Laura Vietti (University of Wyoming) used with permission. 
oral commun., 2019), and thus, the base of the White River Formation for this study was interpreted to be at the bottom (447.3 ft BLS) of this depth interval.

The lowermost White River corresponded to distinctive decreases (leftward deflections) in the natural gamma, SP, resistivity, and neutron logs that gradually began above in the 395405-ft depth interval and became increasingly sharper beginning in the 415-425-ft depth interval (depth where leftward decreases/deflections began and deflection "sharpness/steepness" increased differed by log type; fig. 11; plate 1). Except for natural gamma, these logs continued to decrease (leftward deflection) until about $440 \mathrm{ft}$, at which point they began to increase (inflection and then rightward deflection) until eventually returning to the approximate location (same measured values) where the leftward deflection began. The resistivity logs recorded the sharpest/steepest deflections amongst the various log types. Importantly, this lower White River resistivity "deflection" or "low-resistivity zone" is observable on many resistivity logs published as part of other studies in central and eastern Laramie County (for example, Lidstone and Associates, Inc., 2003; Dahlgren Consulting, Inc., and others, 2005; AVI Professional Corporation and others, 2008), as well as in other parts of the Cheyenne Basin in Wyoming, including Goshen Hole (for example, Borchert, 1985, fig. 5). On some logs, this low-resistivity zone can be seen even where coarsegrained (resistive) deposits composed a substantial part of the lowermost White River Formation or Group (for example, AVI Professional Corporation and others, 2008, appendix 7 [Archer area in south central Laramie County; fig. 1]). In this study, the thin muddy sandy conglomerate at 435.2-435.8 ft BLS and overlying/underlying conglomeratic mudrocks were identifiable as one or more small rightward resistivity deflections (best imaged with the single-point resistance $\log$ ), even though the overall deflection "trend" continued leftward (resistivity continued to decrease; fig. 11; plate 1).

Some studies have used the low-resistivity zone to locate the bottom of the White River Formation or Group and, equivalently, the top of the underlying Upper Cretaceous rocks over areally extensive parts of the Cheyenne Basin in Wyoming, western Nebraska, and northern Colorado - the bottom of the White River Formation typically was placed where the resistivity deflection had returned to its approximate original "location/measured resistivity value" with increasing depth before leftward deflection and subsequent rightward deflection, although exact placement varies among studies. Crist (1980) and Cooley and Crist (1981) used the low-resistivity zone to identify the top of Cretaceous rocks (Lance Formation) underlying the High Plains aquifer system (equivalent to bottom of Tertiary rocks) throughout Laramie County. Additionally, this low-resistivity zone has been used to determine the bottom of the White River Formation in areas south of the Wyoming-Colorado border (for example, Kirkham and Rold, 1986; Topper and others, 2017) and east of the WyomingNebraska border (Swinehart and others, 1985). Using ash layers in the White River Formation or Group as chronostratigraphic datums, Swinehart and others (1985, fig. 6) correlated this low-resistivity zone and additional overlying strata with the lower White River (Chadron Formation of the White River Group), and the investigators used the bottom of this zone to identify the boundary between the White River Formation and underlying Upper Cretaceous rocks in eastern Nebraska. Similarly, Kirkham and Rold (1986) considered the lowresistivity zone to be representative of the Chadron Formation of the White River Group in the Crow Creek drainage basin of Colorado and Wyoming (includes study site and part of Pine Bluffs lowland); these investigators also used this electrical log signature to identify the bottom of the White River Formation or Group (top of the underlying Lance/Laramie Formation) in numerous geologic cross sections.

\section{Stratigraphy}

The White River Formation at the study site, consisting primarily of mudrocks, is similar to petrologic and petrographic descriptions of the predominant fine-grained lithology of the White River Formation or Group in southeastern Wyoming and adjacent parts of western Nebraska and northeastern Colorado (Denson and Bergendahl, 1961; Sato and Denson, 1967; Denson and Chisholm, 1971; Stanley, 1976; Stanley and Benson, 1979; Swinehart and others, 1985; Kirkham and Rold, 1986; Swinehart and Diffendal, 1997). Based on lithologic characteristics and comparisons with equivalent strata (lithostratigraphic methods) in western Nebraska, division of the White River Formation or Group (members or formations, respectively) is recognized informally or formally throughout much of east-central, eastern, and southeastern Wyoming (Darton, 1905; Darton and others, 1910; Meinzer, 1917; Schlaikjer, 1935a, b; Knight and Morgan, 1937; Foley, 1942; Morgan, 1946; Gray, 1947; Brady, 1949; Minick, 1951; McGrew, 1953, 1963; Rapp and others, 1953; Babcock and Bjorklund, 1956; Bjorklund, 1959; Moore, 1959, 1963; McGrew, 1963; Van Houten, 1964; Emry, 1973; Stanley, 1976; Singler and Picard, 1979a, b; Swinehart and others, 1985; Evanoff, 1990b; Evanoff and others, 1992; Ver Ploeg and others, 1998; Bartos and others, 2014). Where formally divided, the upper part of the "White River" is identified as the "Brule" (Member or Formation) and the lower part is identified as the "Chadron" (Member or Formation). In addition to lithostratigraphic methods, biostratigraphic (where fossils were found), magnetostratigraphic, and chronostratigraphic (absolute age dating of volcanic ash in the Wyoming strata) methods also have been used to help divide the White River Formation or Group in parts of Wyoming north of the Cheyenne Basin and help relate the White River Formation strata stratigraphically to the Chadronian and Orellan NALMAs (for example, Emry and others, 1987; Berggren and Prothero, 1992; Emry, 1992; Terry and others, 1995; Prothero, 1996a; Prothero and Whittlesey, 1998; Prothero and Emry, 2004). In Wyoming, these stratigraphic methods have been applied to White River Formation deposits west, north, and northwest of the Pine Bluffs lowland (for example, Evanoff, 1993). At many locations, it is difficult to find stratigraphic characteristics useful for dividing the 
"White River" into different members or formations, including the study site.

Historically, lithology has commonly been combined with other physical characteristics such as color to informally or formally divide the White River Formation strata in some areas of Laramie County into upper and lower parts. The upper part typically is described as a brown to pink, massive, argillaceous, calcareous siltstone interbedded with locally present sandstone, conglomerate, and volcanic ash beds; the lower part typically is described as a red, green, or grayishgreen bentonitic claystone with locally present siltstone, sandstone, and conglomerate, with the coarse-grained deposits found most commonly near the bottom (Rapp and others, 1953; Babcock and Bjorklund, 1956; Bjorklund, 1959; Lowry and Crist, 1967; Cooley and Crist, 1981; Ver Ploeg and others, 1998; Bartos and others, 2014). Some of these studies examining White River Formation strata in Laramie County formally assigned these upper and lower parts of the unit to the Brule and Chadron Formations, respectively. The coarse-grained facies composed of fluvial deposits found in the lower/basal part of the unit at some locations commonly are assigned to or informally considered equivalent to the Chadron Formation (or to contain rocks of Chadronian age), and some or all of the overlying mudrocks are assigned to or informally considered equivalent to the Brule Formation, primarily in the western part of Laramie County near the Laramie Mountains (Knight and Morgan, 1937; Gray, 1947; Brady, 1949; Minick, 1951; Lowry and Crist, 1967; Evanoff, 1990a; Trihydro Corporation, 2009; Bartos and others, 2014). Detailed stratigraphic study of the White River Formation in the eastern and east-central part of Wyoming north of the Cheyenne Basin indicated that lithology can be similar or the same between upper and lower parts of the formation, and therefore, lithology should be used cautiously or not at all for division of the unit, and other methods should be considered for detailed stratigraphic study (for example, Evanoff and others, 1992).

In the Pine Bluffs lowland, stratigraphic rank (formation or group) applied to the White River Formation strata has differed among investigators and has changed over time because of various stratigraphic interpretations and presumably differing study purposes. In addition and perhaps most notably, attempts at detailed stratigraphic correlation (determination of stratigraphic position) of the White River Formation strata in the Pine Bluffs lowland with White River Formation strata to the west along the Laramie Mountains, to areas to the north (Goshen Hole area northward), to the northwest in east-central Wyoming, south into northeastern Colorado, and east into Nebraska have been few to date (2020), most likely because (1) with the exception of this study and an earlier study (Minick, 1951), few vertebrate fossils for biostratigraphic correlation have been found in the Pine Bluffs lowland deposits; (2) outcrop extent is small; (3) subsurface data are meager; and (4) access to outcrops on private lands cannot be obtained. Further complicating potential correlation are problems with the original stratigraphic nomenclature and lack of good stratigraphic control applied to White River deposits throughout the geographic extent in the northern Great Plains, including North and South Dakota, Nebraska, Wyoming, and northeastern Colorado (for example, Singler and Picard, 1979a, b; Emry and others, 1987; LaGarry, 1998; Prothero and Whittlesey, 1998; Prothero and Emry, 2004). Many of the problems with White River stratigraphy are attributable to lack of establishment of type sections when formation names (Brule Clay [Formation] and Chadron Formation) for the White River Group of Meek and Hayden $(1857,1861)$ were applied by Darton $(1899,1903)$ to rocks in northwestern Nebraska (LaGarry, 1998); consequently, "since Darton's work, controversy has surrounded the type localities and sections of the White River Group in Nebraska and South Dakota" (LaGarry, 1998, p. 65).

Early geologic mapping identified the White River deposits cropping out at the surface in the Pine Bluffs lowland as a geologic formation named the "Brule clay" of the White River Group (Darton, 1905; Meinzer, 1917). Subsequent geologic and hydrologic studies in the 1930s-1950s (Knight and Morgan, 1937; Burleigh and others, 1938; Dockery, 1940; U.S. Department of Agriculture, 1943; Minick, 1951; Rapp and others, 1953; Bjorklund, 1959) and earlier State of Wyoming geologic maps (Love and others, 1955) identified the White River Formation strata in the Pine Bluffs lowland as a geologic "group" divided into an upper unit (Brule Formation [mapped surface exposures]) and a lower unit (Chadron Formation; also identified as the Chadron Sandstone in some of these early studies). Minick (1951) examined the White River deposits at a location about 4 mi south of Pine Bluffs, and the investigator found two vertebrate fossils. Based on the then-current interpretations of the biostratigraphic age range of the two vertebrate fossils (identified as Hypertragulus calcaratus [small deer-like mammal] and Merycoidodon gracilis [camel-related mammal that was somewhat piglike in appearance]; unknown if these identifications are still valid for these fossils), the investigator identified the sediments as the "Orella equivalent" of the Brule Formation of the White River Group. The investigator's use of "Orella equivalent" refers to the faunal (vertebrate fossil) assemblage/collection associated with the Orellan NALMA (Wood and others, 1941) and Orella Member of the Brule Formation at the time of the study (the Orella Member of the Brule Formation is one of as many as three members of the Brule Formation recognized in western Nebraska [Schultz and Stout, 1938, 1955; Swinehart and others, 1985; Emry and others, 1987; Swinehart and Diffendal, 1997; Prothero and Emry, 2004]).

Geologic and hydrologic studies in the 1960s-1984 typically identified the exposed White River Formation strata in the Pine Bluffs lowland area as the White River Formation, despite the then most-current State of Wyoming geologic map (Love and others, 1955) identifying these deposits as the Brule Formation of the White River Group. Widely cited publications by Lowry (1966) and Lowry and Crist (1967) identified the deposits as the White River Formation. No explanation for abandonment of group rank and use of the "Brule Formation" was provided, and the investigators (Lowry and Crist, 1967, p. 13) noted that the "White River Formation has been given 
group rank in nearby areas and divided into the Chadron and Brule Formations" and "in this report, the Chadron and Brule are not differentiated." Crist and Borchert (1972) subsequently retained formation rank for the White River in a study of the hydrogeologic characteristics of the deposits in southeastern Laramie County, including the study area. A groundwaterflow model constructed for Laramie County (Crist, 1980) also retained formation rank. In contrast, a map consisting of a series of geologic fence diagrams showing Tertiary lithostratigraphic units throughout Laramie County readopted group rank for White River Formation strata in southeastern Laramie County near the study area (Cooley and Crist, 1981); however, the investigators did not show the division of the Brule and Chadron Formations on the fence diagrams. Because many of these studies had a groundwater emphasis, it is likely that the details of White River stratigraphy in Laramie County were likely of minor interest and it was simpler to classify the unit as a formation. In fact, the lead author of this study had conversations with one of the lead or coauthors of these three studies (Marvin Crist, USGS, retired), and the investigator in effect confirmed this interpretation.

The most recent State of Wyoming geologic map (Love and Christiansen, 1985) and the most recent 1:100,000scale geologic map that includes the study area (Ver Ploeg, 1995; Ver Ploeg and others, 1998) identified the White River Formation strata in the Pine Bluffs lowland as a formation. Assignment of formation rank to the White River Formation strata in the Pine Bluffs lowland and other parts of Laramie County was at least partly due to resource constraints that limited reevaluation of earlier studies/mapping/assignments of these strata and lack of consensus and inconsistent/differing approaches to division of the White River Formation amongst researchers (Alan Ver Ploeg, Wyoming State Geological Survey, oral commun., 2015). Since publication of these maps, numerous hydrogeologic studies evaluating potential sources of public water supply for communities in the Pine Bluffs lowland divided the White River Formation strata into the Brule and Chadron Formations, although stratigraphic criteria for the division typically were not provided in these studies (for example, AVI Professional Corporation and Lidstone and Anderson, Inc., 1994; Lidstone and Anderson, Inc., and AVI Professional Corporation, 1995; Lidstone and Associates, Inc., 2003; Dahlgren Consulting, Inc., and others, 2005).

During coring, a partial fossil jaw from an extinct camel (most likely Poebrotherium) from the family Camelidae (mammal family that includes camels and llamas and extinct relatives) was recovered at about $202 \mathrm{ft} \mathrm{BLS} \mathrm{(fig.} \mathrm{14E).} \mathrm{Poe-}$ brotherium fossils commonly are found in the White River Formation or Group throughout the Great Plains, including Wyoming (Prothero and Emry, 2004). Several species of Poebrotherium are recognized, although the number of recognized species differs among scientists (for example, Prothero, 1996a, b). Fossils of the animal have been found in deposits ranging from late Eocene to Oligocene in age (Chadronian, Orellan, and Whitneyan NALMAs, corresponding to about 30 to $37 \mathrm{Ma}$; Prothero and Whittlesey, 1998; Prothero and
Emry, 2004, fig. 5.2). Biostratigraphic age ranges have been established for the various species of Poebrotherium (Emry, 1992; Prothero, 1996a; Prothero and Emry, 2004); however, detailed fossil preparation and additional study would be required to determine the Poebrotherium species of the fossil found during this study. Different Poebrotherium species have overlapping age ranges (Chadronian and [or] Orellan), including where fossils of the animal are found in Wyoming (for example, Evanoff and others, 1992). The fossil has been donated to the University of Wyoming fossil collection (specimen UW-5059).

Extensive stratigraphic, biostratigraphic, and magnetostratigraphic studies coupled with absolute age dating of ash layers in the White River Formation and Group in central and east-central Wyoming to the north have been completed (Douglas area [fig. 7] and Flagstaff Rim area [not shown in report]) (for example, Emry, 1973; Evanoff, 1990b; Evanoff and others, 1992; Prothero and Swisher, 1992; Obradovich and others, 1995; Prothero and Whittlesey, 1998; Prothero and Emry, 2004). These and other studies from adjacent States have resulted in substantial revision of White River stratigraphy. Unfortunately, no studies to date (2020) have stratigraphically correlated (determined the stratigraphic position) the Pine Bluffs lowland White River Formation strata with the areas farther to the north or with other strata in Laramie County. The absence of a substantial fossil fauna/record from the White River Formation in the Pine Bluffs lowland area makes such correlation difficult.

White River Formation strata in the Pine Bluffs lowland area extend uninterrupted southward into northeastern Colorado and eastward into western Nebraska. In northeastern Colorado, the White River Formation strata have been identified differently, including the White River Formation composed of as many as three members (Galbreath, 1953; these members are no longer recognized in most studies), the Brule Formation of the White River Group (surficial exposures), or the White River Formation or Group (for example, Bjorklund, 1957b; Braddock and Cole, 1978; Scott, 1978, 1982; Tweto, 1979). Older studies identified the exposed upper White River Formation strata in Nebraska contiguous with the strata of the eastern Pine Bluffs lowland area as the Brule Formation of the White River Group (for example, Lugn, 1939; Bjorklund, 1957a; Weist, 1965). More recent mapping by Swinehart and others (1985) and Swinehart and Diffendal (1997) continued to identify the White River Formation strata along the Wyoming-Nebraska border as the White River Group, and the exposed White River Formation strata along Lodgepole Creek in Nebraska that are contiguous with strata in Wyoming were identified as the Brule Formation.

Studies in Nebraska and Colorado have assigned the lowermost White River Formation strata associated with the low-resistivity zone to the Chadron Formation of the White River Group (Swinehart and others, 1985; Kirkham and Rold, 1986). In southeastern Wyoming and adjacent western Nebraska, Chadron Formation deposition consisted of two phases (Swinehart and others, 1985; Swinehart and Diffendal, 
1997). The first phase was dominated by fluvial deposition, primarily in paleovalleys cut into Upper Cretaceous sedimentary rocks. This fluvial phase resulted in deposition of coarse-grained sediments in the lower part of the Chadron Formation, including fine- and coarse-grained sandstones and locally present conglomerates interbedded with fine-grained mudrocks such as claystone and mudstone. Less volcaniclastic sediment occurs in this fluvial phase of the Chadron Formation in southeastern Wyoming and adjacent western Nebraska than in the upper part of the Chadron Formation and the overlying Brule Formation (Swinehart and others, 1985; Swinehart and Diffendal, 1997), although volcaniclastic sediments may be present in greater quantities in areas to the north in eastcentral Wyoming (Douglas area; fig. 7) and the Flagstaff Rim area (not shown) (Emry, 1973; Evanoff, 1990b; Evanoff and others, 1992). Subsequent to the fluvial paleovalley filling phase, eolian deposition of rhyolitic volcanic ash from western volcanic eruptions contributed large quantities of volcaniclastic sediments to the upper Chadron Formation (and later, the overlying Brule Formation) throughout southeastern Wyoming and western Nebraska; this volcaniclastic phase is composed primarily of vitric (tuffaceous) mudrocks (claystones, mudstones, and siltstones) with less common coarse-grained sediments or facies (Swinehart and others, 1985; Swinehart and Diffendal, 1997).

\section{Upper Cretaceous Strata}

Subsurface Upper Cretaceous strata at the study site are identified and described in this report section.

\section{Identification of Upper Cretaceous Lithostratigraphic Units in the Subsurface}

The Late Cretaceous upper Pierre Shale, Fox Hills Sandstone, and Lance/Laramie Formation in the Cheyenne and Denver Basins are lithostratigraphic names for genetically related sedimentary strata reflecting the transition from marine to terrestrial deposition related to the retreat of the Cretaceous Western Interior Seaway in an eastward direction (figs. $6 A, B$; $8 A, B$; Raynolds, 2002, 2003; Landman and Cobban, 2003; Raynolds and Dechesne, 2007; Dechesne and Raynolds, 2010; Dechesne and others, 2011a). Timing of deposition of these units in the Cheyenne Basin generally was during the Baculites clinolobatus and Hoploscaphites birkelundae ammonite zones (fig. 6B; Landman and Cobban, 2003; Merewether and others, 2011). Depositional environments are connected at any point in time - the upper Pierre Shale (upper transition member) reflects the shallow marine deposits of the Western Interior Seaway; the Fox Hills Sandstone reflects the upper shoreface, deltaic, and beach deposits marking the coastline; and the Lance Formation reflects the fluvial and paludal (swampy) back barrier deposits of the coastal plain (gray shades, yellow, and brown, respectively, on fig. 15). The upward transition from the upper Pierre Shale to the Fox Hills
Sandstone is gradational and transitional. Alternating beds of marine shale and sandstone become increasingly sandier and increase in grain size upward in section. This "transitional zone" between the marine shales of the Pierre Shale and sandier shoreface and beach sandstones of the Fox Hills Sandstone has long been recognized in many Denver and Cheyenne Basin studies (Mather and others, 1928; Lovering and others, 1932; Lavington, 1933; LeRoy, 1946; Scott and Cobban, 1965, 1986; Landman and Cobban, 2003; Dechesne and others, 2011a; Merewether and others, 2011). However, stratigraphic placement of the approximated boundary between the two lithostratigraphic units within this zone commonly differs between investigators and is often controversial "due to the complex vertical and lateral variation in the lithology associated with repetitive interfingering of shales and sandstones in this part of the section" (Landman and Cobban, 2003, p. 3). This "zone" is identified informally with different names, including the "transition zone," "upper transition zone," or "upper transition member" of the Pierre Shale (upper transition member used herein; see review by Landman and Cobban, 2003). It is common that thin individual sandstone beds of distal shoreface deposits of the Fox Hills Sandstone are encased within the shallow marine upper transition member of the Pierre Shale, or that intertongued lagoonal or terrestrial deposits of the Lance Formation are "lumped in" with the Fox Hills Sandstone, depending on sea-level fluctuations (fig. 15). The top of the Fox Hills Sandstone typically is a very fine- to medium-grained sandstone bed that is in sharp contact with nonmarine carbonaceous mudrocks and coals of the Lance/ Laramie Formation. This sharp contact is a distinct marker on most well logs (fig. 16). Depending on local depositional setting, the lower part of the Lance/Laramie Formation may contain estuarine or fluvial sandstones that immediately overlie or interfinger/intertongue with the Fox Hills Sandstone. Where this occurs, the contact between the two formations can be difficult to determine (especially in the subsurface), and investigators commonly interpret the contact differently on geophysical logs; many investigators lump the Lance/Laramie Formation sandstones with the upper part of the Fox Hills Sandstone.

As part of the coastal plain, coastline-to-shallow marine system, littoral swamps and mires, beach sandstones, coastal bars, shorefaces, and shallow marine shales were deposited. As the Western Interior Seaway retreated eastward and northward off the continent, the general trend of linked swampto-beach to shallow marine system migrated in that direction as well. This is best marked by the position of the Fox Hills Sandstone that generally represented the coastline at the time; however, the large-scale retreat of the Western Interior Seaway was not uniform, and small-scale "minor" transgressions are superimposed on the overall regressive pattern (fig. 15). During times of short-term seaway expansion (minor transgression), sandstones and fine-grained rocks (marine shales and siltstones) of the upper transition member of the Pierre Shale were deposited directly on top of the sandy shoreface and beach deposits of the Fox Hills Sandstone. In some cases, the 


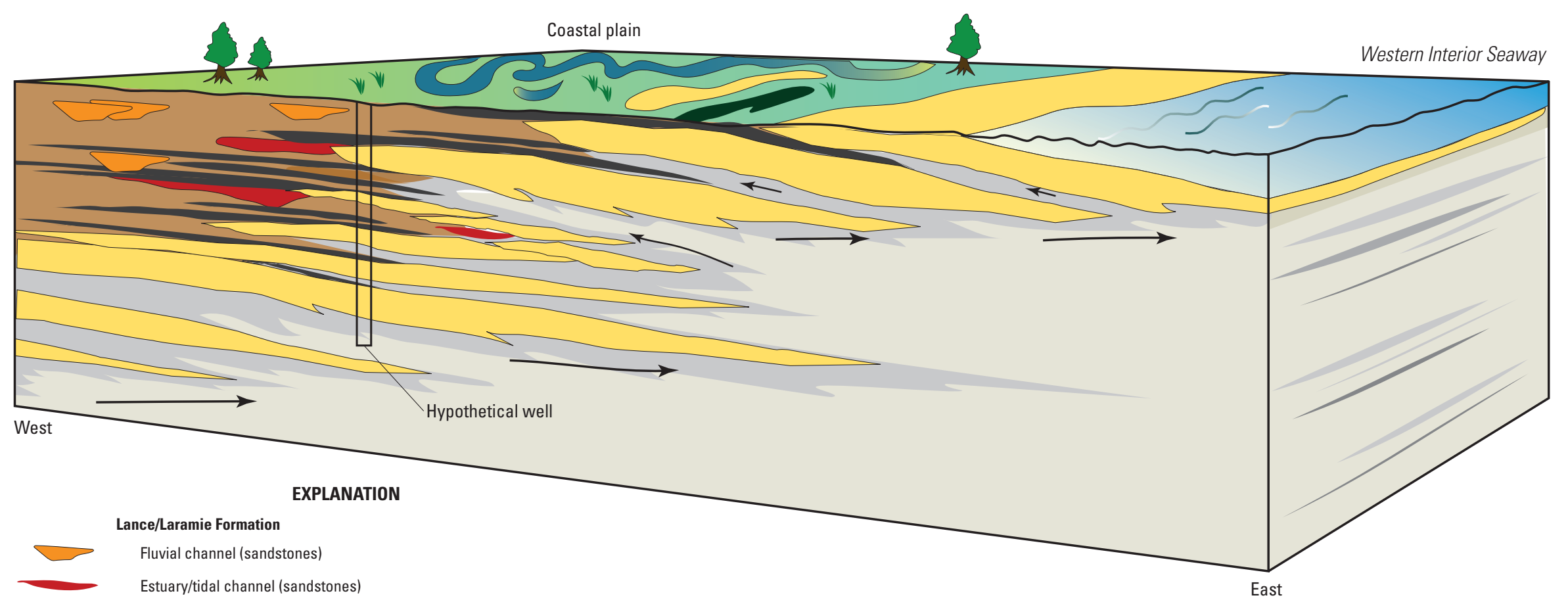

Estuary/tidal channel (sandstones)

Coal bed

Fluvial and paludal sediments (primarily mudrocks, including muddy shale/carbonaceous

shale, siltstone, mudstone, and claystone, but can include thin sandstones)

\section{Fox Hills Sandstone}

Beach and nearshore (transitional marine) sandstones

Pierre Shale (upper transition member)

Shallow and deeper marine shales

Direction of shoreline movement during regression of Western Interior Seaway during

the time of late Maastrichtian fossil (ammonite) Hoploscaphites birkelundae

Movement to the west (landward) indicates minor marine transgression and

movement to the east (seaward) indicates marine regression

Figure 15. Depositional environments and facies relation for the Lance/Laramie Formation, Fox Hills Sandstone, and Pierre Shale. Arrows show stacking pattern. Note that when the coastline (Fox Hills Sandstone) steps landward during short transgressions, marine deposits of the Pierre Shale can be found between the beach and upper shoreface deposits of the Fox Hills Sandstone. During seaward steps, swamp deposits form coals on top of beach deposits of the Fox Hills Sandstone. 


\section{$\boldsymbol{A}$}

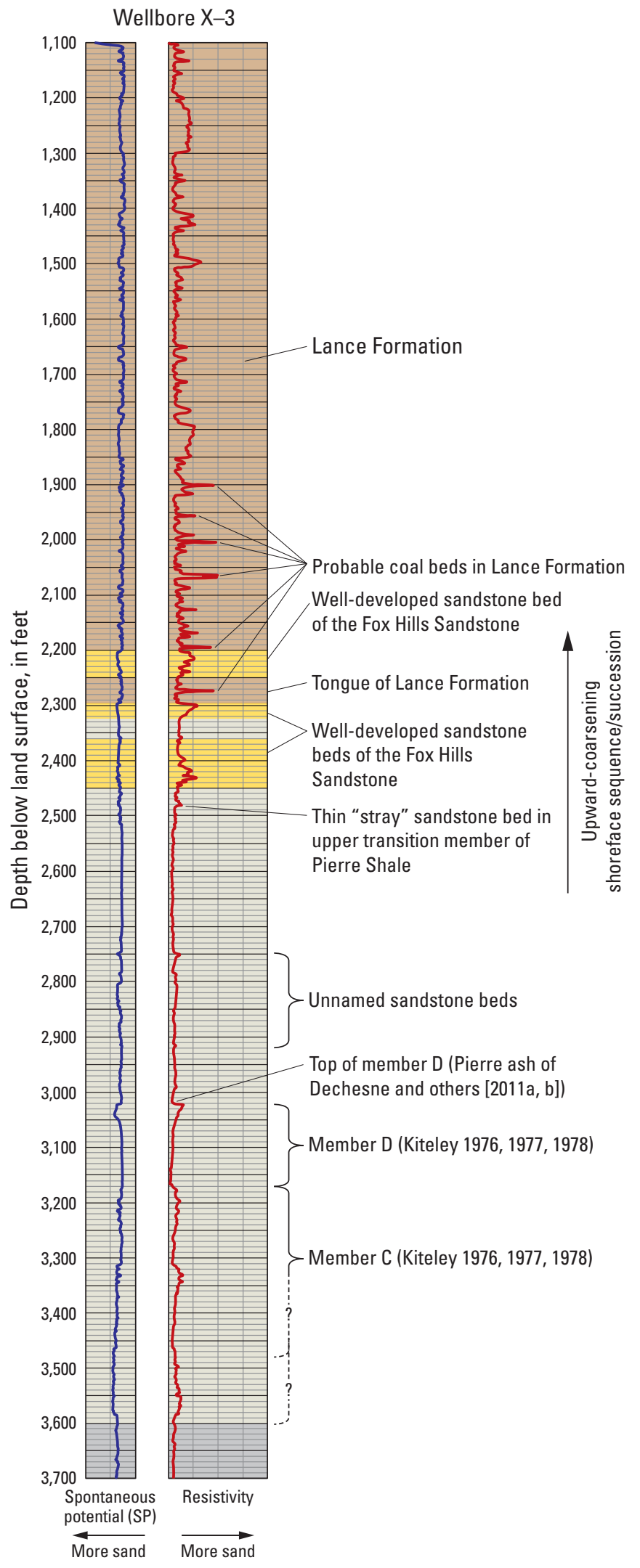

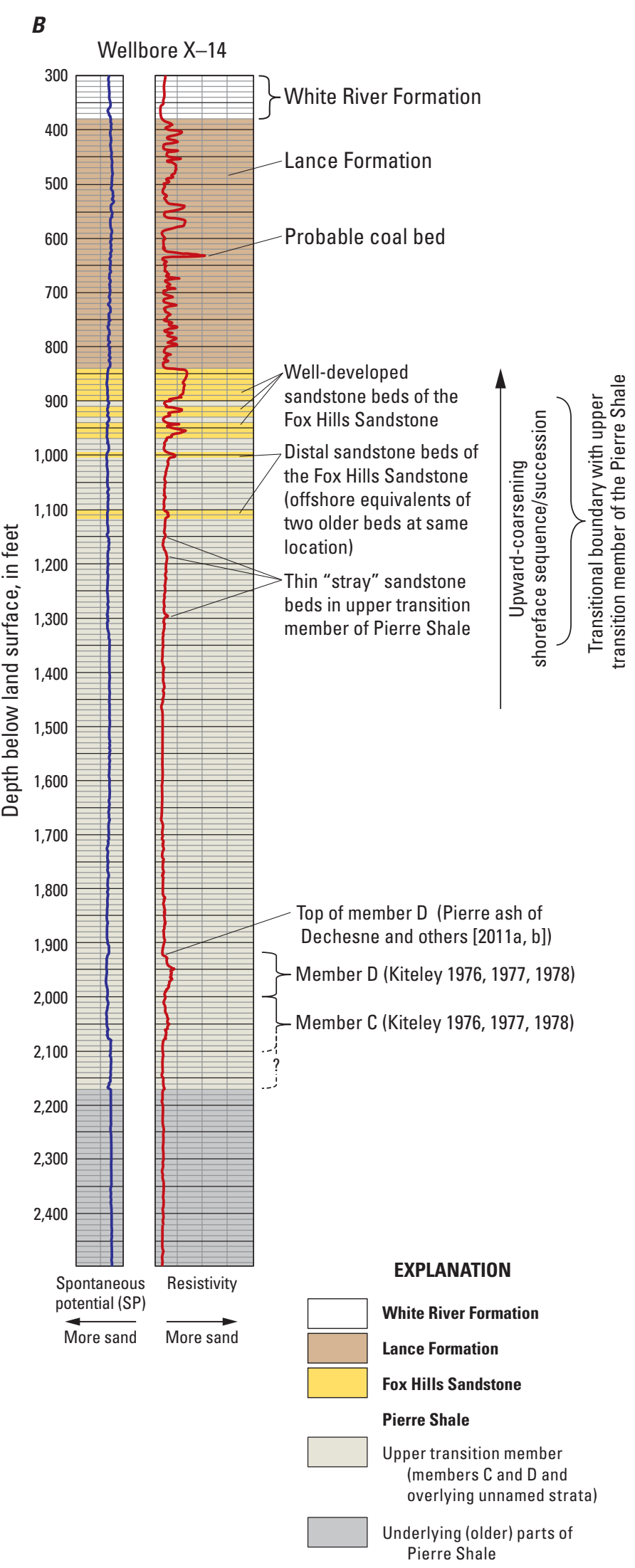

Figure 16. Typical character of the Upper Cretaceous Lance Formation, Fox Hills Sandstone, and upper transition member of the Pierre Shale. A, wellbore $\mathrm{X}-3$; $B$, wellbore $\mathrm{X}-14$. Location of both wellbores in Laramie County shown in figure 30. [Geophysical logs from Wyoming Oil and Gas Conservation Commission, 2018] 
marine incursions were more pronounced, and in those cases, marine deposits of the upper transition member of the Pierre Shale overlie proximal Fox Hills Sandstone deposits or even coaly swamp deposits of the Lance Formation. Depending on fluctuations in this landward and seaward stepping pattern, both vertical successions can be found in the Cheyenne and Denver Basins. These overall seaward and occasional landward movements of the coastline make the stratigraphic stacking pattern stepwise or "shingled" (example of hypothetical shoreface sequence/succession shown in fig. 15; Dechesne and Raynolds, 2005).

The overall regressive and minor transgressive shifts in facies of the upper Pierre Shale, Fox Hills Sandstone, and Lance Formation described previously are documented in the Colorado part of the Denver and Cheyenne Basin subsurface on geophysical logs (Dechesne and Raynolds, 2010; Dechesne and others, 2011a, b). Rock properties measured by various geophysical tools in wellbores allowed for identification of sandy versus shaly intervals, coal, and bentonite in these formations. In the Denver and Cheyenne Basins of Colorado, resistivity logs especially, but also SP and natural gamma logs, were determined to be good indicators of facies (sandy versus muddy/shaly intervals) throughout the stratigraphic interval. Because of little available outcrop, these logs were the primary tools used to identify facies and assign different facies to lithostratigraphic units. In the Denver Basin, these mapped subsurface facies were tied into surficial mapping and assigned to individual lithostratigraphic units (formations), ultimately leading to an understanding of the basinwide distribution and relations between these units (Dechesne and others, 2011a, b). The same approach used to interpret the geophysical log characteristics of Upper Cretaceous strata in the Denver and Cheyenne Basins in Colorado is described in the following paragraph using geophysical logs from the Wyoming part of the Cheyenne Basin.

Upper Cretaceous strata in the Wyoming part of the Cheyenne Basin have the same geophysical log characteristics as in the Denver and Cheyenne Basins in Colorado. Partial SP and resistivity logs for two deep wellbores in western and eastern Laramie County, respectively (obtained from the Wyoming Oil and Gas Conservation Commission, 2018), are shown in figure $16 A$ and $B$. Wellbore $\mathrm{X}-14$ is about $5 \mathrm{mi}$ from the study site. The log character of the shallow marine upper transition member of the Pierre Shale indicates an irregular to gradually upward-coarsening pattern (leftward deflection on the SP log and correlative rightward deflection on the resistivity $\log$ [Cant, 1992]) as it transitions into the Fox Hills Sandstone (identified with upward pointing arrow on fig. 16A, $B)$. Well-developed sandstone beds composing the main body of the Fox Hills Sandstone, separated by intervening mudrocks of the upper transition member of the Pierre Shale or Lance Formation, show a typical funnel-shaped pattern (subtle leftward deflection on the SP log and gradational to steep rightward deflection on the resistivity $\log$ ) caused by an upward coarsening in grain size related to progradation of the depositional system, which is typical for lower shoreface to beach ridge and delta (collectively, shoreface) successions like the Fox Hills Sandstone (Cant, 1992). Because of the subdued nature of the SP curves, resistivity logs generally were much more useful for identifying different lithologies/ facies and associated lithostratigraphic units. Thin sandstone beds below the lowermost well-developed sandstone beds of the Fox Hills Sandstone either are distal sandstone beds of the Fox Hills, which are the more marine equivalents of older Fox Hills Sandstone beds at the same location, or thin stray sandstone beds of the upper transition member of the Pierre Shale. Unfortunately, it is often difficult to determine which interpretation is correct. The top of the Fox Hills Sandstone is commonly a sharp contact with the finer grained shales, mudrocks, and coal deposits of the Lance Formation. Coal beds and lignites formed in mires in coastal swamps behind beach ridges commonly occur just landward of the Fox Hills Sandstone. The irregular to blocky and bell-shaped patterns in the Lance Formation are typical for fluvial floodplain and channel belt deposits (Cant, 1992). High resistivity "spikes" (rapid increase and subsequent rapid decrease in a given log trace) typically reflect coal beds in the Lance Formation (see discussion in the "Lance Formation" section of the report). These spikes often occur in the main body of the Lance Formation above the uppermost sandstone bed of the Fox Hills Sandstone (fig. 16A, $B$ ) and within a tongue of the Lance Formation between individual Fox Hills Sandstone beds (fig. 16A).

\section{Lance Formation}

Strata composing the Upper Cretaceous Lance Formation at the study site are identified and described in this report section.

\section{Lithology}

Present from 447.3 to 779.7 and 794.4 to $808.4 \mathrm{ft}$ BLS, the Lance Formation consisted of $346.4 \mathrm{ft}$ of many types of terrestrial sedimentary rocks (fig. 11; appendix 1; plate 1). Lance Formation lithology varied with depth, commonly over relatively short depth intervals/lengths of core (for example, see photograph in fig. 17A). Consequently, a different approach was used in appendix 1 and on plate 1 to describe lithology and grain size in a more "generalized manner" for Lance Formation (and Pierre Shale) depth intervals with many lithologic changes over a short depth interval/length of corelithologic descriptions begin with the word "interbedded" and continue with a subsequent listing of all lithologies present in the depth interval beginning with the most common. Where this approach was used, the visual grain-size estimates are presented as written descriptions and as bar graphs (fig. 11; appendix 1; plate 1) for the entire described interbedded interval rather than individual lithologic unit intervals (for example, compare photograph of core from 492.4 to $494.1 \mathrm{ft} \mathrm{BLS}$ in fig. $17 \mathrm{~A}$ with written description and bar graphs showing grain-size distribution for the same depth interval presented in fig. 11 and appendix 1, and on plate 1, respectively). 

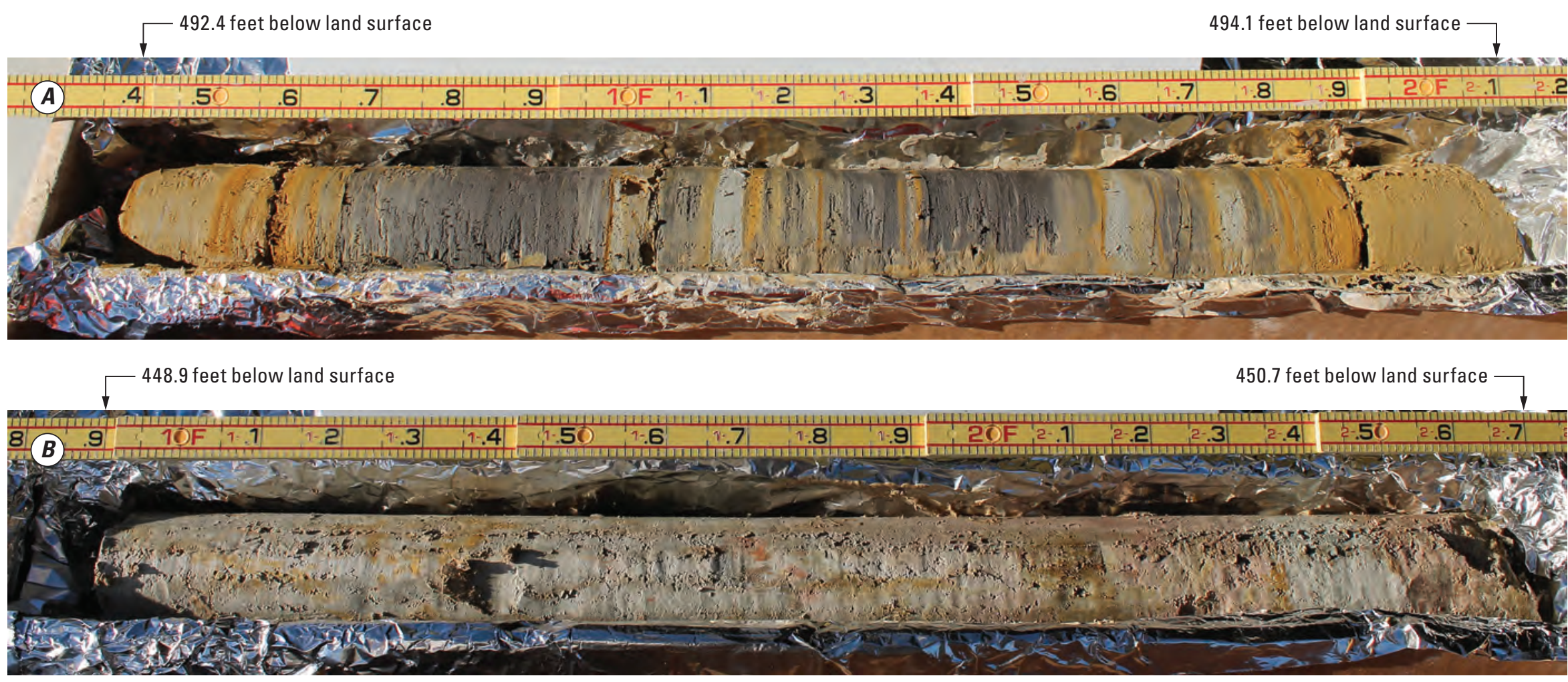

450.7 feet below land surface

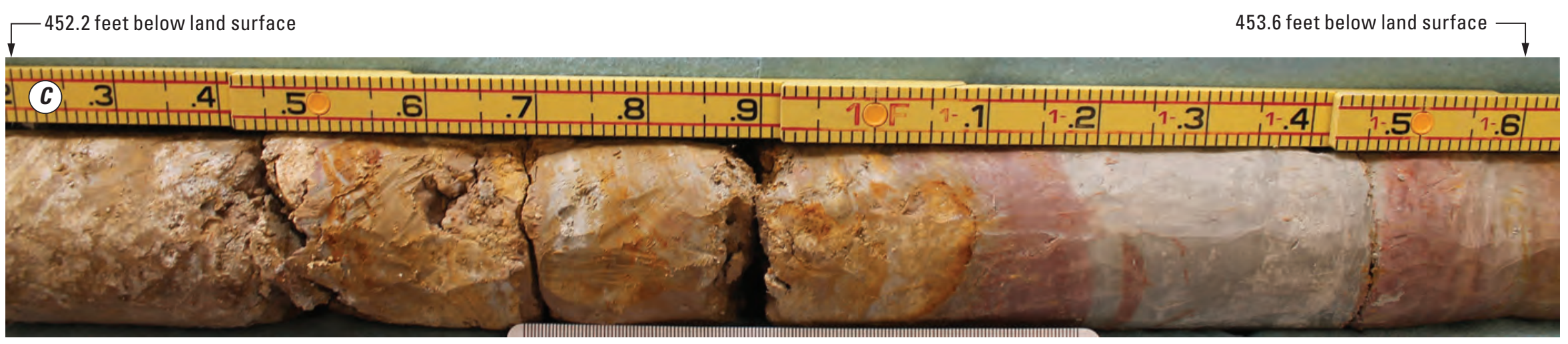



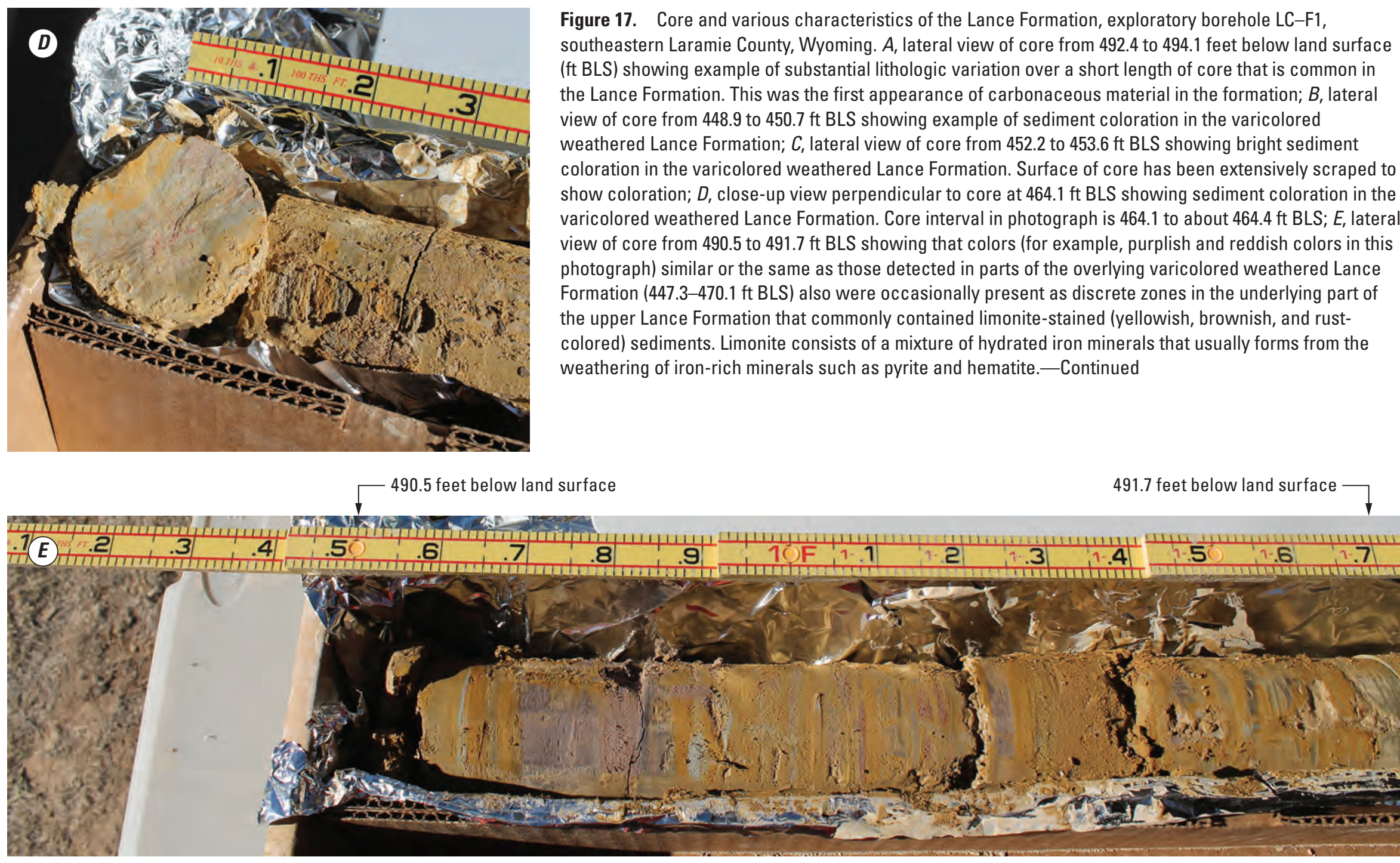

Figure 17. Core and various characteristics of the Lance Formation, exploratory borehole LC-F1, southeastern Laramie County, Wyoming. A, lateral view of core from 492.4 to 494.1 feet below land surface (ft BLS) showing example of substantial lithologic variation over a short length of core that is common in the Lance Formation. This was the first appearance of carbonaceous material in the formation; $B$, lateral view of core from 448.9 to $450.7 \mathrm{ft}$ BLS showing example of sediment coloration in the varicolored weathered Lance Formation; $C$, lateral view of core from 452.2 to $453.6 \mathrm{ft}$ BLS showing bright sediment coloration in the varicolored weathered Lance Formation. Surface of core has been extensively scraped to show coloration; $D$, close-up view perpendicular to core at $464.1 \mathrm{ft} B L S$ showing sediment coloration in the varicolored weathered Lance Formation. Core interval in photograph is 464.1 to about $464.4 \mathrm{ft} \mathrm{BLS}$; $E$, lateral view of core from 490.5 to $491.7 \mathrm{ft} \mathrm{BLS}$ showing that colors (for example, purplish and reddish colors in this photograph) similar or the same as those detected in parts of the overlying varicolored weathered Lance Formation (447.3-470.1 ft BLS) also were occasionally present as discrete zones in the underlying part of the upper Lance Formation that commonly contained limonite-stained (yellowish, brownish, and rustcolored) sediments. Limonite consists of a mixture of hydrated iron minerals that usually forms from the weathering of iron-rich minerals such as pyrite and hematite.-Continued 
Lance Formation sedimentary rocks at the study site included interbedded fissile, yellowish, dark gray, and brown/ gray/black muddy shale and silty and sandy shale, siltstone, claystone, and mudstone; interbedded brown, yellowishbrown, light brown, grayish-green, very fine- to mediumgrained, muddy and silty sandstone; and coal (appendix 1; plate 1). Mudrocks commonly were carbonaceous. Muddy shale and other mudrocks such as sandy siltstone and mudstone composed most of the total formation thickness (appendix 1; plate 1). Invertebrate mollusk fossils (bivalves, gastropods) commonly were found in mudrocks throughout the formation (appendix 1). Thin oyster beds were not uncommon in the mudrocks (appendix 1). The 14.0-ft-thick interval of the Lance Formation from 794.4 to $808.4 \mathrm{ft} \mathrm{BLS}$ is interpreted as a tongue overlain and underlain by two muddy sandstone beds of the Fox Hills Sandstone. Several rock types composed the tongue, including carbonaceous muddy shale and several thin coal beds indicative of a terrestrial (swampy) depositional environment. The presence of this tongue is attributable to the episodic eastward retreat and occasional westward advance of the Western Interior Seaway as was conceptually explained in the previous report section ("Identification of Upper Cretaceous Lithostratigraphic Units in the Subsurface").

Because of the wide range of lithologies, Lance Formation geophysical log responses were highly variable, and traces for all log types varied more with depth than in other formations (fig. 11; plate 1). These variable geophysical log responses contrasted substantially with the geophysical log responses of the overlying White River Formation that were relatively uniform (primarily vertical linear pattern) with minor deflections except for the log deflections characterizing the lowermost White River. Frequent variability, indicated by leftward and rightward geophysical log deflections, correlated well with frequent lithologic changes identified visually in the Lance Formation core (fig. 11; plate 1). Excellent correlation between changes in grain size and geophysical log response also was observed for most log types. Depth intervals with a higher proportion of coarse-grained sediments (sand/sandstone) generally were characterized by lower gamma counts (leftward deflection), lower SP (leftward deflection), higher resistivity (rightward deflection), lower conductivity (leftward deflection), and higher neutron counts (rightward deflection) in comparison with adjacent intervals with a higher proportion of fine-grained (mud-sized) sediments (mudrocks; fig. 11; plate 1).

Geophysical log variation, including "spikiness," was much greater in the coal-bearing part of the Lance Formation (below about $556.6 \mathrm{ft}$ BLS) than in the noncoal-bearing part (fig. 11; plate 1). Most of the sharp "spikes" corresponded to coal beds identified in the core. The "spikiness" is attributable to the unique petrophysical properties of coal that contrast with those of most other sedimentary rocks in a coal-bearing sequence. Specifically, coal in exploratory borehole LC-F1 had geophysical log characteristics/responses typical of most coals, including lower natural radioactivity (lower natural gamma response), high resistivity, lower neutron counts (and conversely, higher neutron porosity), and higher sonic porosity than adjacent lithologies (Wood and others, 1983).

Examination of collected core in relation to geophysical logs indicated that, overall, the various types of resistivity logs were the most useful tools for identifying and determining the thickness of Lance Formation sandstone beds. Of the various types of resistivity logs collected, single-point resistance logs were the most effective at identifying sandstone beds, determining sandstone bed thickness, and identifying fine-grained interbeds within sandstone beds. This is not surprising given single-point resistance logs have higher resolution than other resistivity logs (note scale of single-point resistance log in fig. 11 and on plate 1 is in ohms whereas scale of the other resistivity logs is in ohm-meters). In addition, single-point resistance logs have much higher vertical resolution because they do not have reversals due to bed-thickness effects like multielectrode resistivity logs (Keys, 1990, 1997). Caution is advised when relying exclusively upon resistivity logs to identify thin (less than $[<] 2.5$-ft) sandstone beds in the coalbearing part of the Lance Formation because coal beds also are highly resistive. In some cases, the shape of the resistivity signature of the coal beds is not spiky and resembles some thin sandstone beds; consequently, when possible, the resistivity logs should be examined in relation to other geophysical logs such as natural gamma to help differentiate lithologies in thin beds.

The upper part of the Lance Formation from 447.3 to $470.1 \mathrm{ft}$ BLS consisted of a unique sequence of variegated, mottled, and banded (collectively, varicolored) mudrocks, except for a 5.4-ft-thick light yellowish-brown to dark yellowish-brown silty sandstone in the 457.5-462.9-ft depth interval (fig. $17 B-D$; appendix 1; plate 1). Some mudrocks in this sequence were colorful (for example, fig. 17C). Identified herein as the "weathered Lance Formation," the upper part of this varicolored rock sequence represents a paleosol zone that developed on the top of the Lance Formation before deposition of the White River Formation or Group. A zone of ancient pedogenic modification below the White River Formation or Group has been recognized throughout much of the northern Great Plains, and many names have been applied to the zone (Schultz and Stout, 1955; Pettyjohn, 1966; Retallack, 1983; Swinehart and others, 1985; Terry, 1998; Sibray, 2011). Pettyjohn (1966) concluded this zone developed in the late Eocene. This "regional weathered zone" is commonly developed on Upper Cretaceous rocks, and development on the upper Pierre Shale often is reported because the Pierre Shale is prevalent throughout large parts of the northern Great Plains. Studies in parts of northwestern Nebraska and South Dakota indicate the zone may consist of more than one paleosol in some parts of the northern Great Plains (Terry, 1998; Sibray, 2011). Unfortunately, this sequence is rarely recognized when detected (typically as varicolored cuttings during well drilling) in the Wyoming part of the Cheyenne Basin. With few exceptions (Crist, 1980; Cooley and Crist, 1981; Borchert, 1985), most studies in the Wyoming part of the Cheyenne Basin (and many in the Colorado part) identify some or all of the rocks 
identified herein as the weathered Lance Formation as part of the lower White River Formation or Group. It should be noted that varicolored rocks are common in the Chadron Formation of the White River Group overlying the Lance Formation in parts of Goshen Hole (Schlaikjer, 1935c; Rapp and others, 1957; Kihm, 1987); these varicolored rocks are not equivalent to the weathered Lance Formation detected at the study site and elsewhere in the Cheyenne Basin.

The change from the regional weathered zone to the underlying part of the Lance Formation typically is transitional (Emmett Evanoff, University of Northern Colorado, oral commun., 2019). The bottom of the regional weathered zone typically is placed where the first undisturbed beds are detected (Emmett Evanoff, University of Northern Colorado, oral commun., 2019). Colors similar or the same as those detected in parts of the weathered Lance Formation also were occasionally present as discrete zones in the underlying part of the upper Lance Formation that commonly contained limonitestained (yellowish, brownish, and rust-colored) sediments (490.5-492.6-ft depth interval; for example, see photograph in fig. $17 \mathrm{E}$; appendix 1). Limonite consists of a mixture of hydrated iron minerals that usually forms from the weathering of iron-rich minerals such as pyrite and hematite. This and other evidence indicated some of the varicolored sediments below the uppermost part of the weathered zone likely are not equivalent to the regionally recognized weathered zone and, thus, may represent a different/earlier period of weathering/ coloring that is a characteristic of the upper Lance Formation below some undetermined thickness of the regional weathered zone. Notably, Lance Formation exposures in Goshen Hole consist of similar varicolored rocks (Schlaikjer, 1935c; Rapp and others, 1957), and these rocks contain vertebrate fossils (for example, Triceratops, Schlaikjer, 1935c) that are now recognized as Lancian (late Maastrichtian) in age. Alternatively, the occurrence of discrete zones of varicolored sediments within the limonite-stained sediments of the upper Lance Formation could indicate that the weathered zone at the study site continues to a greater depth than recognized. Regardless of how much of the upper part of the weathered Lance Formation sequence is correlative with the regional weathered zone, the top of this colorful sequence identified herein as the weathered Lance Formation serves as an easily identifiable marker bed/ zone for identification of the bottom of the White River Formation, and equivalently, the top of Upper Cretaceous rocks wherever detected in the subsurface.

Including the weathered zone, rocks in the upper part of the Lance Formation (all lithologies, including sandstone beds) were lighter in color and more colorful compared to rocks below, which were darker (grayer and blacker; appendix 1). The change from the lighter to darker colored part of the formation was transitional and generally reflected an increasing abundance of carbonaceous material with depth, including coal. The first carbonaceous material was detected in the 492.6-493.9-ft depth interval (see photograph in fig. 17A; appendix 1). Yellow and rust-colored staining caused by the presence of limonite was common throughout the light-colored interval (see photograph in fig. 17E). Rapp and others (1957) noted the same light-to-dark coloration sequence in Lance Formation rocks in Goshen Hole. The investigators informally divided the Lance Formation into an "upper unit" consisting of the colorful, light-colored part of the formation and a "lower unit" consisting of the darker colored (identified as grayish), more carbonaceous part of the formation. The color difference between the upper and lower units was attributed to weathering of the upper unit and partly to the greater abundance of carbonaceous material in the lower unit.

Thin beds of coal were present from 556.6 to $808.4 \mathrm{ft}$ BLS in the main body of the Lance Formation and in the tongue between two sandstone beds of the Fox Hills Sandstone (fig. 11; appendix 1; plate 1). Most coal beds were less than $1 \mathrm{ft}$ in thickness. Four beds in the lower part of the formation were thicker, and these beds ranged from 1.0 to $1.8 \mathrm{ft}$ in thickness (from shallowest to deepest, 708.7-710.5 [1.8 ft], $726.0-727.1[1.1 \mathrm{ft}], 775.6-776.6[1.0 \mathrm{ft}]$, and 794.4-796.0 $[1.6 \mathrm{ft}] \mathrm{ft}$ BLS). Thin beds of coal are found in the Lance/Laramie Formation throughout the Cheyenne and Denver Basins (Kirkham and Ladwig 1979, 1980; Kirkham and others, 1980; Roberts and Kirschbaum, 1995). Lance/Laramie Formation coal beds in the Wyoming part of the Cheyenne Basin generally are thinner than in the Colorado part of the basin (Roberts and Kirschbaum, 1995).

Sandstone beds, interbedded with fine-grained mudrocks composing most of the Lance Formation, represented only a small amount of total formation thickness. Excluding all thin sandstones interbedded with numerous other lithologies in a given depth interval that were not measured (lithologic descriptions beginning with "interbedded" in appendix 1), only about $57.4 \mathrm{ft}$ of $351.6 \mathrm{ft}$ of total formation thickness (16 percent) was sandstone. Assuming the thin sandstone beds interbedded with numerous other lithologies increased total sandstone thickness by an additional 20 percent $(11.5 \mathrm{ft})$, total sandstone thickness would only be about 20 percent of total formation thickness. Thickness of sandstone beds in the Lance Formation ranged from $<1$ to $18 \mathrm{ft}$, but most beds were thin ( $<2.5 \mathrm{ft}$; fig. 11; appendix 1; plate 1$)$. Only five sandstone beds were greater than $2.5 \mathrm{ft}$ in thickness - three were less than $10 \mathrm{ft}$ (5.4 ft [457.5-462.9 ft BLS], $5.5 \mathrm{ft}$ [634.5-640 ft BLS], and $6.1 \mathrm{ft}$ [689.0-695.1 ft BLS]) and two were between 10 and $20 \mathrm{ft}(11.7 \mathrm{ft}$ [497.0-508.7 ft BLS] and $18.0 \mathrm{ft}$ [470.1$488.1 \mathrm{ft}$ BLS]). Three of the five sandstone beds, including the two thickest, were from part of the upper Lance Formation (about 457-517 ft BLS) that overall was coarser (contained more sand) than the rest of the formation (fig. 11; appendix 1; plate 1). Sandstones throughout the formation were unconsolidated or poorly consolidated (friable) to moderately consolidated but mostly were unconsolidated or poorly consolidated (friable). Sandstone grain size ranged from very fine to medium, but most grains ranged from very fine to fine in size (fig. 11; appendix 1; plate 1). Grains composing the sandstones were angular to subrounded, and grain sphericity was subprismoidal to subdiscoidal (appendix 1). Clay and silt content within the sandstones varied, but quantities of both 
were sufficiently large to classify Lance Formation sandstones as either muddy or silty sandstones (appendix 1; plate 1). All sandstone beds appeared to be water saturated.

A monitoring well ( $\mathrm{LN}-1)$ was completed with the well screen open to $13.5 \mathrm{ft}$ (fig. 11; plate 1) of the thickest sandstone bed in the Lance Formation (18.0-ft thick; 470.1$488.1 \mathrm{ft}$ BLS). Photographs of core from five depth intervals (472.0-473.9, 473.25-473.85, 482.9-484.7, 482.9-483.5, and 484.9-485.7 ft BLS) within this sandstone bed are shown in figure $18 A-E$. Colors in the upper part of the sandstone bed included brownish yellow, greenish gray, and light olive brown (about 470.1-477.0 ft BLS), and colors below included greenish gray, light olive brown, and olive gray (appendix 1). Overall, this color succession led to a more brownish color in the uppermost part compared to a darker, more greenishgray color in the lower part (appendix 1). Many parts of the sandstone bed had a classic "salt-and-pepper" (mixture of light- and dark-colored grains) appearance (appendix 1). Color banding and black and limonite staining were present in some depth intervals (appendix 1; photographs showing examples of limonite staining shown in fig. 18A-E). Consolidation ranged from unconsolidated or very poorly consolidated (friable) to moderately consolidated, but much of the sandstone bed was unconsolidated or very poorly consolidated. Grain size ranged from very fine to medium, and grain size coarsened upward through the bed (fig. 11; appendix 1; plate 1). Visual grain-size estimates indicated that this sandstone bed was the coarsest in the entire Lance Formation, primarily because of the much larger medium-size sand content than other beds. Grain rounding ranged from subangular to rounded, and grain sphericity ranged from subprismoidal to subdiscoidal. A thin (0.4-ft thick), fine-grained interbed composed of sandy mudstone was present within the sandstone from 483.8 to $484.2 \mathrm{ft} \mathrm{BLS}$ (fig. 11; appendix 1; plate 1). Mud-sized sediment content was sufficiently large to classify the sandstone as a muddy sandstone.

\section{Petrography}

Petrographic thin sections were created from two depth intervals (473.9-474.0 and 485.1-485.3 ft BLS) within the muddy sandstone (470.1-488.1 ft BLS) in which monitoring well $\mathrm{LN}-1$ was installed. The petrographic thin section constructed from core collected from the 473.9-474.0-ft depth interval of exploratory borehole LC-F1 indicated the primary constituent grains of this interval of muddy sandstone included quartz, feldspars, and rock fragments (fig. 19A-D). Angular to subrounded quartz grains were the dominant constituent grain. Quartz grain boundaries were dissolution etched and commonly were outlined by clay (fig. 19D). Potassium feldspar was the predominant feldspar constituent grain. Rock fragments composed of quartz and feldspar were common. Finegrained rock fragments of indeterminate origin are altered to iron oxides and clays. Mica grains are crushed between harder constituent grains (fig. 19C), indicating a period of compaction. Mica grains commonly are deformed (compressed between constituent grains and exfoliated), resulting in alteration along cleavage planes. There is evidence for two distinct generations of intergranular clay (montmorillonite and kaolinite) formation; these clays partially occlude void (pore) space (fig. 19B, D). Montmorillonite (smectite) seems to be the result of the total alteration of feldspar grains and feldspar-rich rock fragments (possibly volcanic rock fragments [uncertain (?)]; fig. 19D). The kaolinite may have formed from the weathering of feldspar grains.

Overall, the muddy sandstone in this depth interval is immature, clayey, and highly altered. Pore-occluding clays, the result of substantial alteration/weathering of feldspar grains and feldspar-rich rock fragments, were common but "patchy" in occurrence (fig. 19B-D). Abundant secondary porosity is maintained by dissolution of labile (readily decomposed) grains and quartz overgrowths (fig. 19A, $C, D$ ). Skeletal remnants of constituent labile grains are common (fig. 19A,C).

The petrographic thin section constructed from core collected from the 485.1-485.3-ft depth interval of exploratory borehole LC-F1 indicated the primary constituent grains of this interval of muddy sandstone were quartz/chert and feldspars (fig. 20A, $B$ ). Sorting ranged from moderate to poor. Quartz grain rounding ranged from subrounded to highly angular (fig. 20A, B); grain shape/rounding may be attributable not only to provenance, but also to dissolution of quartz overgrowths. Many angular quartz grains have preserved their overgrowths. Many constituent grains are highly fractured and indicate compaction, including many quartz grains (fig. 20B). Quartz grains largely were monocrystalline, and polycrystalline quartz grains were uncommon. There is faint alignment of some high-aspect elongated angular quartz grains, but this is not as strongly defined as in the thin section constructed from the 473.9-474.0-ft BLS depth interval. Feldspars include orthoclase, anorthoclase, and plagioclase (albite). Minor constituent grains and accessory minerals included rock fragments, mica (commonly muscovite), ferromagnesium minerals (occasional altered amphibole [hornblende?] minerals), rare zircons, and possibly allanite (?). Mica grains commonly were altered to clays. Patchy calcite cementation encased and partially to totally replaced many constituent grains (fig. 20A). Clays partially occlude porosity (fig. 20B). As with the thin section from the 473.9-474.0-ft BLS depth interval in this sandstone, widespread dissolution and alteration of constituent grains indicates development of substantial secondary porosity.

\section{Stratigraphy}

As noted previously, many older geologic publications identify Upper Cretaceous strata in the Wyoming part of the Cheyenne Basin currently (2020) known as the Lance Formation in Wyoming as the Laramie Formation (for example, see summary in Nace, 1936, p. 9-13; Moore, 1959). Early investigators applied the name "Laramie Formation" to Upper Cretaceous strata throughout the Rocky Mountain region now assigned to numerous formations of differing origin, age, and 


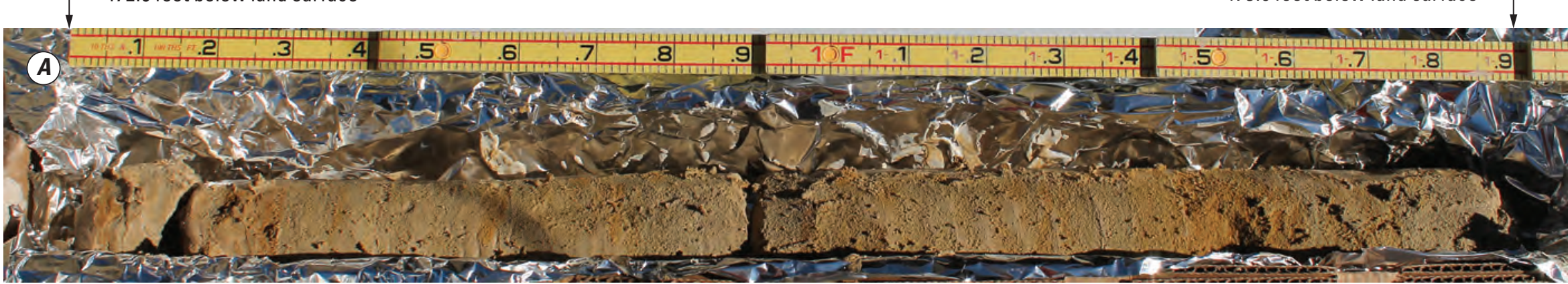

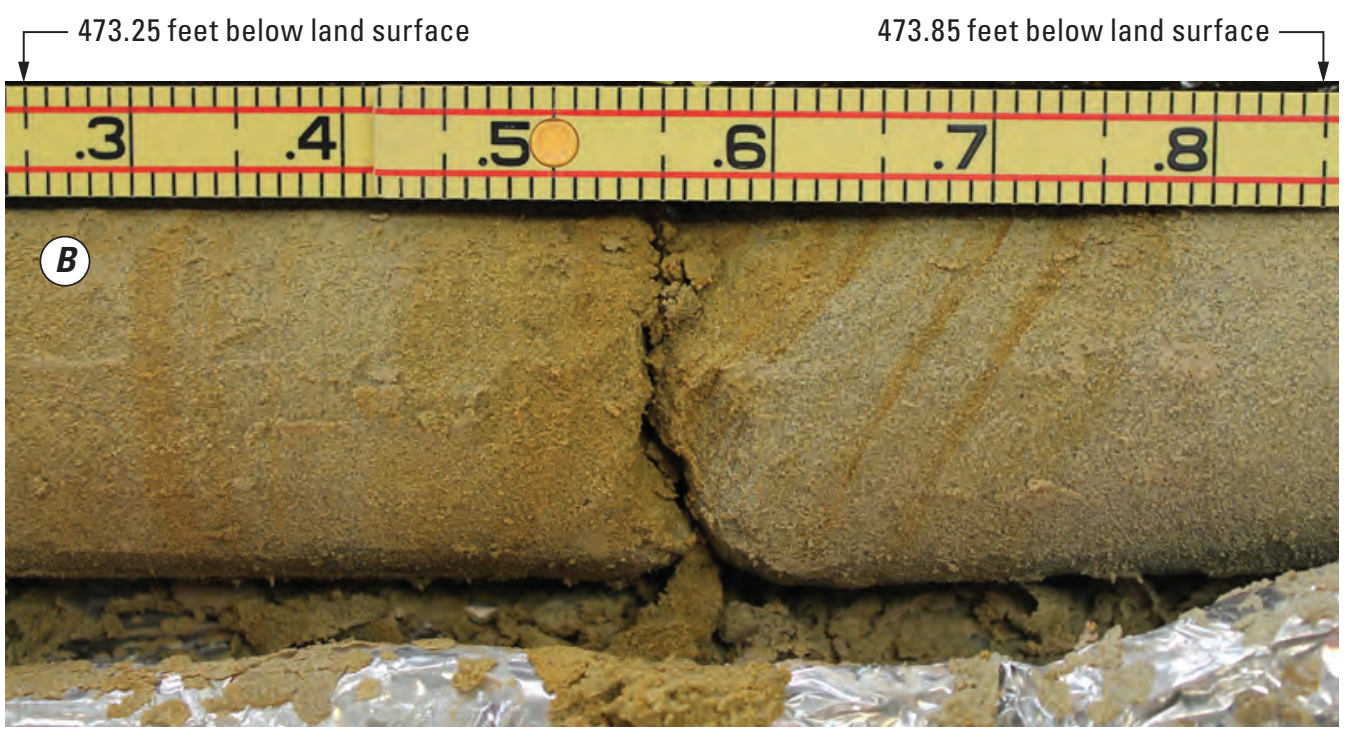

Figure 18. Core and various characteristics of parts of the Lance Formation muddy sandstone (470.1-488.1 feet below land surface [ft BLS]) in which monitoring well LN-1 was completed, exploratory borehole LC-F1, southeastern Laramie County, Wyoming. $A$, lateral view of core from 472.0 to $473.9 \mathrm{ft}$ BLS showing muddy sandstone. Colors and color banding shown in this photograph and photographs of underlying depth intervals in this sandstone bed (fig. 18B-E) are common to other sandstone beds in the "lighter-colored" part of the Lance Formation; $B$, close-up lateral view of core from 473.25 to $473.85 \mathrm{ft}$ BLS showing part of muddy sandstone interva shown in figure $18 A$. Surface of core has been carefully scraped to reveal sedimentary characteristics that were not easily seen in figure $18 A ; C$, lateral view of core from 482.9 to $484.7 \mathrm{ft} \mathrm{BLS}$ showing lateral view of muddy sandstone bed; $D$, close-up lateral view of core from 482.9 to $483.5 \mathrm{ft} \mathrm{BLS}$ showing part of muddy sandstone interval shown in figure $18 \mathrm{C}$. Surface of core has been carefully scraped to reveal sedimentary characteristics that were not easily seen in figure $18 C$; $E$, close-up lateral view of core from 484.9 to $485.7 \mathrm{ft} \mathrm{BLS}$ showing muddy sandstone. Surface of core has been carefully scraped to reveal sedimentary characteristics.

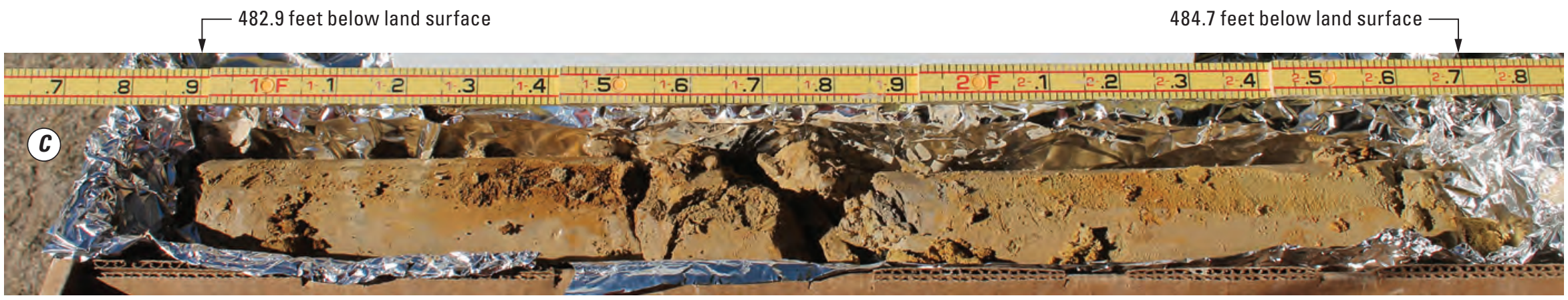



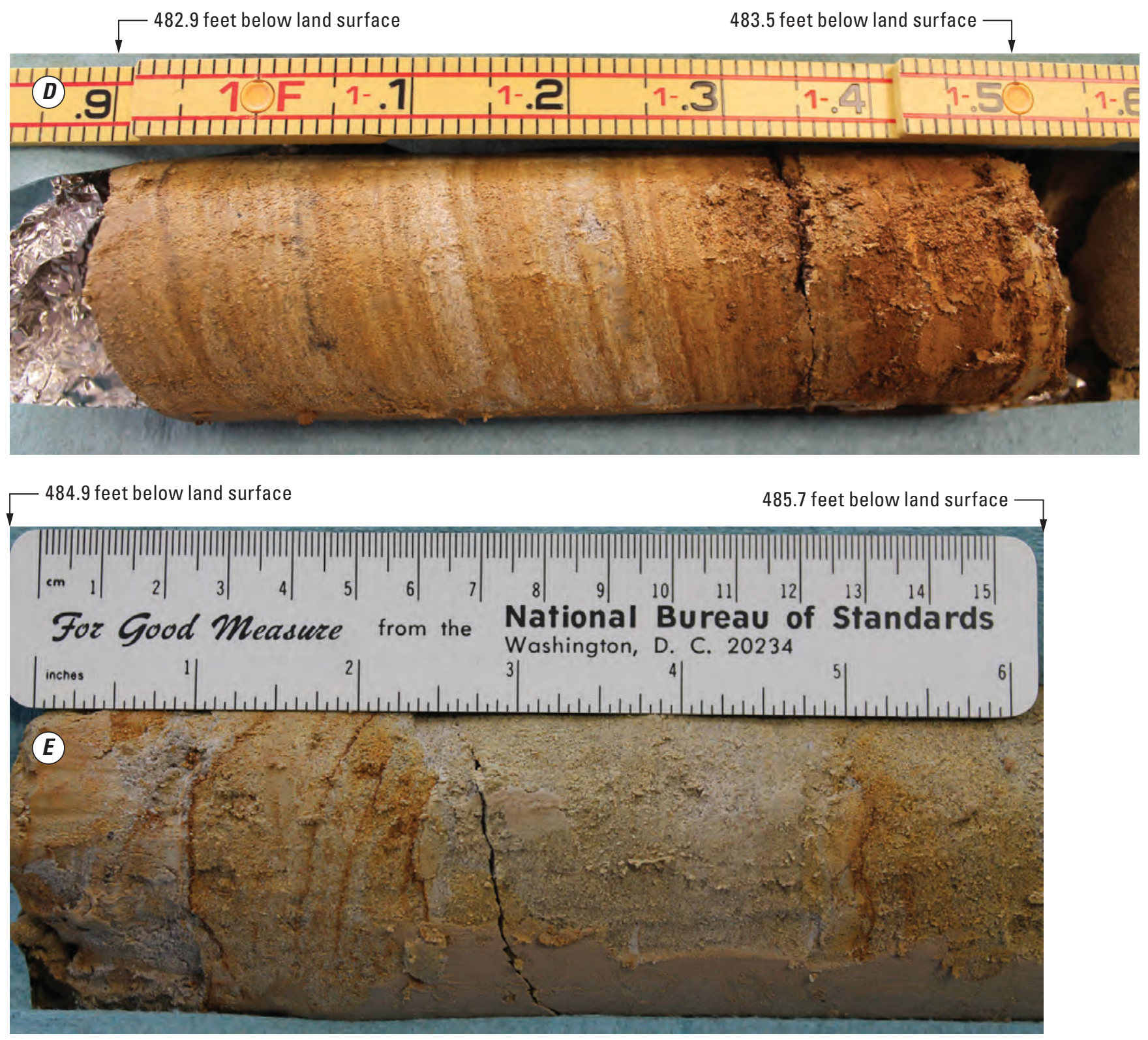

Figure 18. Core and various characteristics of parts of the Lance Formation muddy sandstone (470.1-488.1 feet below land surface [ft BLS]) in which monitoring well LN-1 was completed, exploratory borehole LC-F1, southeastern Laramie County, Wyoming. $A$, lateral view of core from 472.0 to $473.9 \mathrm{ft}$ BLS showing muddy sandstone. Colors and color banding shown in this photograph and photographs of underlying depth intervals in this sandstone bed (fig. 18B-E) are common to other sandstone beds in the "lighter-colored" part of the Lance Formation; $B$, close-up lateral view of core from 473.25 to $473.85 \mathrm{ft} B L S$ showing part of muddy sandstone interval shown in figure $18 \mathrm{~A}$. Surface of core has been carefully scraped to reveal sedimentary characteristics that were not easily seen in figure $18 A$; $C$, lateral view of core from 482.9 to $484.7 \mathrm{ft} \mathrm{BLS}$ showing lateral view of muddy sandstone bed; $D$, close-up lateral view of core from 482.9 to $483.5 \mathrm{ft}$ BLS showing part of muddy sandstone interval shown in figure $18 \mathrm{C}$. Surface of core has been carefully scraped to reveal sedimentary characteristics that were not easily seen in figure $18 C$; $E$, close-up lateral view of core from 484.9 to $485.7 \mathrm{ft} \mathrm{BLS} \mathrm{showing}$ muddy sandstone. Surface of core has been carefully scraped to reveal sedimentary characteristics. - Continued 

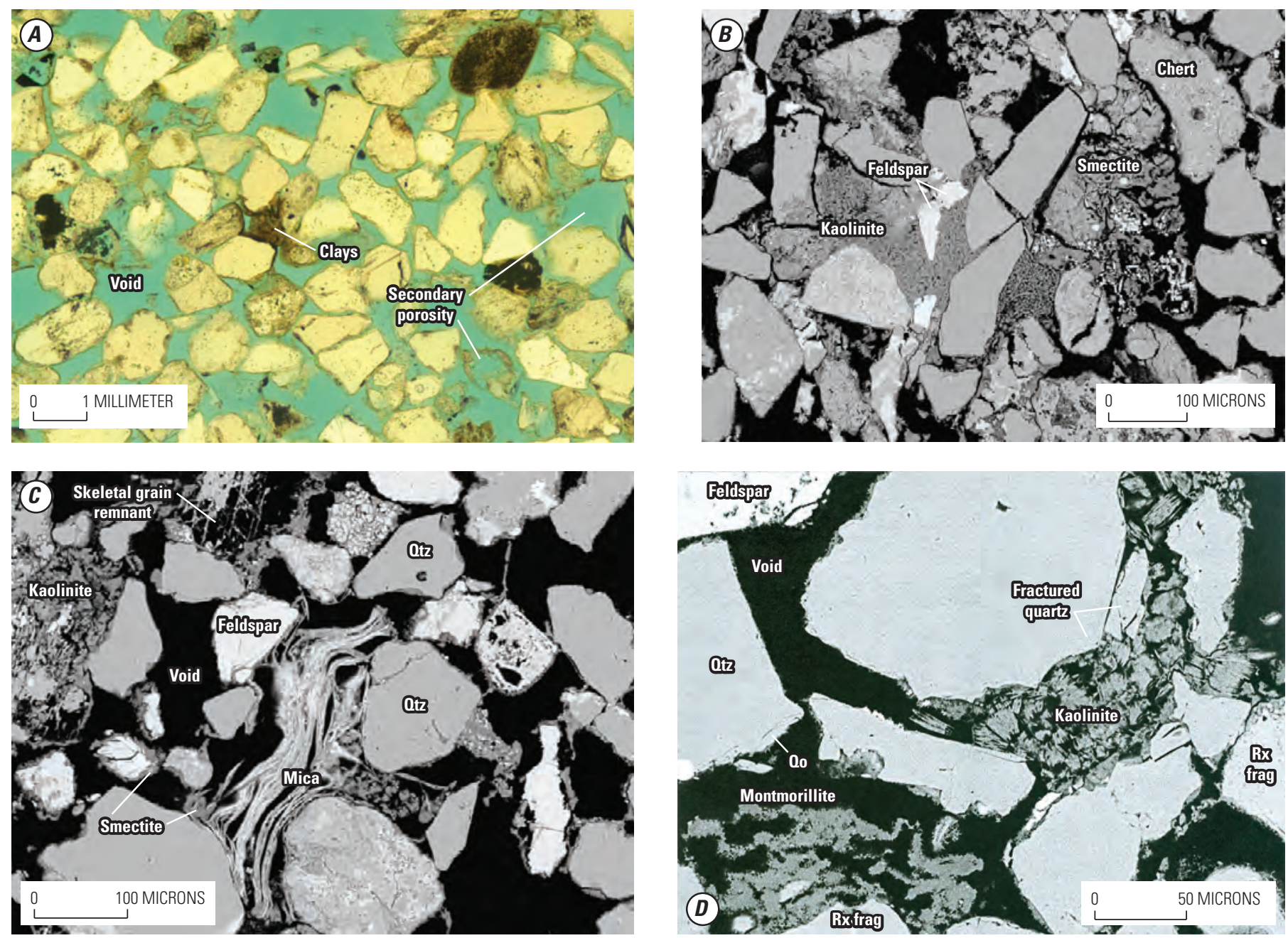

\section{EXPLANATION}

$\begin{array}{ll}\text { Ctz } & \text { Quartz } \\ \text { Co } & \text { Quartz with overgrowth } \\ \text { Bxy } & \text { Rock fragment } \\ \text { frag } & \end{array}$

Figure 19. Muddy sandstone from the Lance Formation, 473.9 to 474.0 feet below land surface, exploratory borehole LC-F1, southeastern Laramie County, Wyoming. A, plane light photomicrograph showing porosity (blue-green areas) between constituent grains and patchy areas of clay. Grain-sized areas of void space and remnant clay outlines (white lines) indicate complete alteration and (or) dissolution of labile grains; $B$, scanning electron microscope (SEM) photomicrograph showing labile rock fragments and feldspar are highly altered to clays (kaolinite and smectite). Most constituent grains are rimmed with clays; $C$, SEM photomicrograph showing clays (kaolinite and smectite) and constituent grains of quartz ( $\mathrm{Qtz}$ ) and feldspar. Mica is deformed (compressed between constituent grains and exfoliated), resulting in alteration along cleavage planes; $D$, SEM photomicrograph showing two types of intergranular clay (kaolinite and montmorillonite), which likely records two generations of clay formation that partially occlude void space. Quartz overgrowths on quartz grains have undergone dissolution etching, creating secondary porosity. 

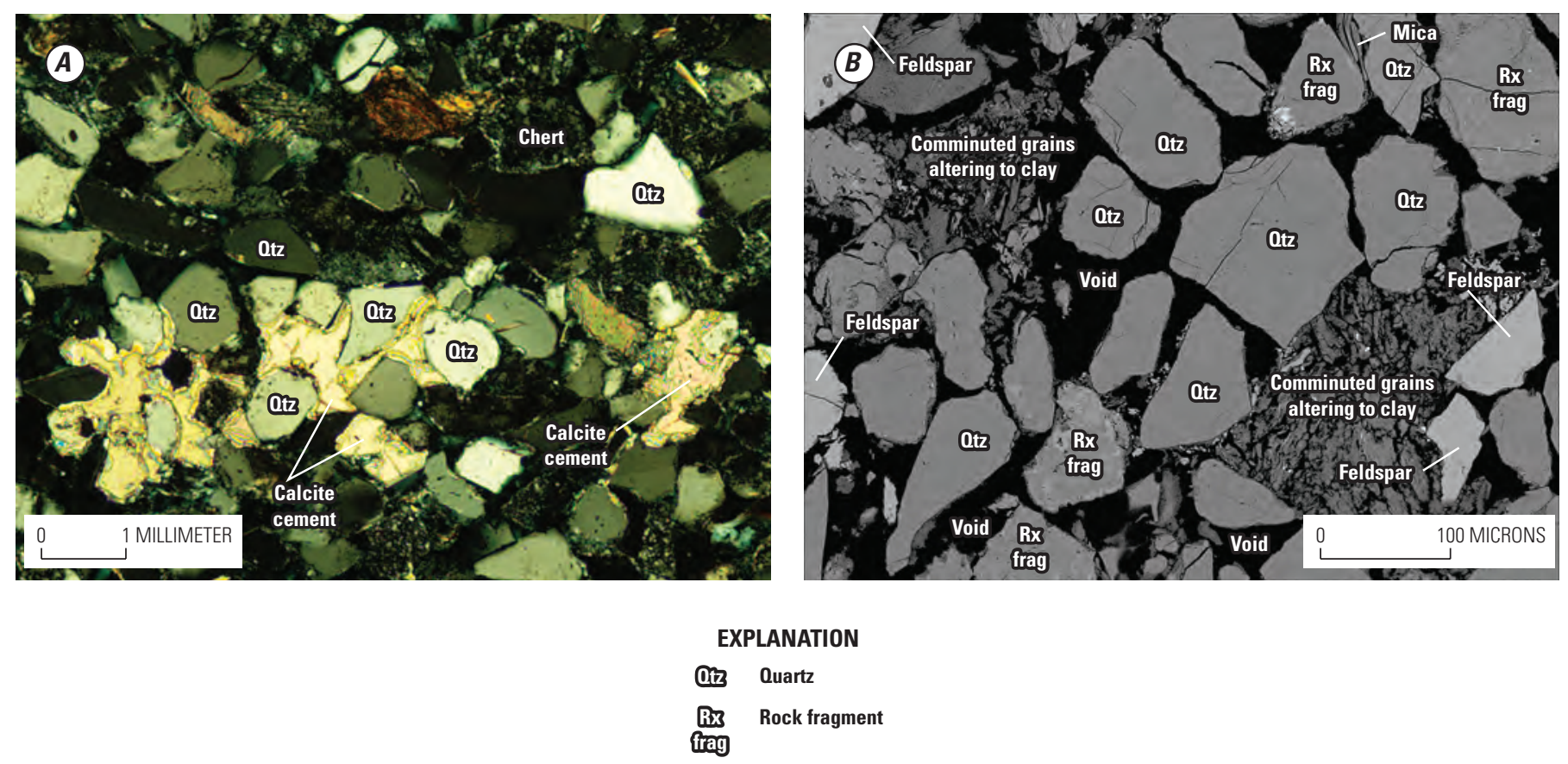

Figure 20. Muddy sandstone from the Lance Formation, 485.1 to 485.3 feet below land surface, exploratory borehole LC-F1, southeastern Laramie County, Wyoming. $A$, crossed-nicols photomicrograph showing primary constituent grains of quartz and patchy intergranular calcite cement ("pinkish" birefringent areas). Calcite has partially to totally replaced constituent grains. Black areas are voids between grains. Constituent grains commonly are outlined by clays; $B$, scanning electron microscope photomicrograph showing fractured constituent quartz grains, feldspar, mica, rock fragments, and the breakdown/alteration of labile constituent grains. Black areas are voids between grains.

areal extent (Knowlton, 1922; Willmarth, 1957, p. 1,151; Waage, 1975). Usage of "Laramie" in the greater Denver Basin currently (2020) is restricted by most to strata south of the Wyoming-Colorado border, reflecting the decision by the USGS Committee on Geologic Names to restrict the use of Laramie Formation to the Denver Basin in Colorado where the name was first applied in 1876 (Willmarth, 1957, p. 1,151).

Stratigraphic columns published in Wyoming Geological Association guidebooks beginning in 1969 identified the Upper Cretaceous strata assigned to the Lance Formation in the Cheyenne Basin (identified as Denver Basin) as the Laramie Formation (Wyoming Geological Association, 1969, p. 7). The authors of this report could not locate associated publications describing/supporting adoption of the name in the 1969 stratigraphic column, but it might reflect a study of the geology of the east flank of the Laramie Mountains along the Wyoming-Colorado border by Moore (1959). The investigator mapped the unit along the Laramie Mountains immediately south of the Wyoming-Colorado border and subsequently applied the name "Laramie Formation" to the contiguous surficial and subsurface strata on both sides of the border. The most recent greater Denver Basin stratigraphic chart produced by the Wyoming Geological Association (2014, column 18) continued this interpretation and identified the strata as the Laramie Formation. Identification of these strata as the Laramie Formation in the Wyoming part of the Cheyenne Basin has not been widely adopted, probably because statewide and larger scale geologic maps still identify the strata as the Lance Formation (for example, Love and Christiansen, 1985).

Examination of Lance Formation stratigraphy in the Wyoming part of the Cheyenne Basin is limited primarily to a study of outcrops in Goshen Hole by Schlaikjer (1935c). Examination of the rocks composing the outcrops in relation to the associated vertebrate and invertebrate fossils led to the investigator dividing the upper part of the Lance Formation in Goshen Hole into three informal units. The uppermost (stratigraphically youngest) unit was identified as a $60-100+$-ft-thick "continental deposit." Informally named by the investigator as the "Torrington member of the Lance," this unit contained numerous vertebrate fossils, including the ceratopsid (horned dinosaur) Triceratops, the hadrosaurid ("duckbill” dinosaur) "Trachodon" (genus no longer recognized; this material likely is referable to Edmontosaurus annectens; Derstler, 1994), crocodiles, and turtles. In the uppermost part of the "Torrington member," Schlaikjer (1935c, p. 65) recovered Triceratops material that he believed represented a new, "very advanced form/species" of the ceratopsian that "presents a combination of the main evolutionary trends in Triceratops development during Lance times" (identified as Triceratops eurycephalus; species no longer valid [Scannella and others, 2014] and is likely Triceratops horridus; [Derstler, 1994]). Below the upper unit, the middle unit was described as an 
80- to 125 -ft-thick brackish-water deposit because of the widespread occurrence of numerous invertebrate fossils including the aquatic bivalve mollusks Corbicula (clam) and Ostrea (oyster). The lower unit, described as a 100- to 200-ft-thick "continental deposit," contained ceratopsid and other vertebrate fossils described as "reptilian."

Vertebrate fossils found in the Laramie Formation in the Denver and Cheyenne Basins in Colorado also are found in the Lance Formation in northeastern Wyoming (Powder River Basin) and equivalent Hell Creek Formation in eastern Montana, indicating that the fauna and associated formations are the same or similar in age (Carpenter, 1979; Kirkham and others, 1980; Kirkham and Rold, 1986; Carpenter and Young, 2002; Wilson and others, 2010). Some studies have speculated the Laramie Formation in the Cheyenne Basin of Colorado may be more similar to (or equivalent to) the Lance Formation in Wyoming north of the Cheyenne Basin (primarily Powder River Basin) than the Laramie Formation in the Denver Basin because the units were deposited in different subbasins (Kirkham and others, 1980; Kirkham and Rold, 1986). However, this interpretation requires the Laramie/Lance strata to have been deposited after separation of the Cheyenne and Denver Basins by the Greeley arch. Wilson and others (2010) noted the Laramie Formation and the underlying Fox Hills Sandstone and upper Pierre Shale likely were deposited before separation of the two subbasins by the Greeley arch; therefore, if this were the case, the depositional patterns and setting for these units likely would be similar between the two subbasins.

Several studies have noted that thickness of the Laramie Formation in the Cheyenne Basin in northeastern Colorado is much greater than in the Denver Basin south of the Greeley arch (fig. 5A; for example, Kirkham and others, 1980; Wilson and others, 2010). These studies indicate Laramie Formation thickness may seem to be greater because the upper part of the thick sequence in the Cheyenne Basin currently (2020) assigned to or mapped as the Laramie Formation actually may be temporally equivalent to additional stratigraphically higher Late Cretaceous sediments identified in the Denver Basin as the Cretaceous part of the Denver Formation and Arapahoe Formation or the alternatively named "D1 synorogenic sedimentary sequence" (fig. 5A, B; Kirkham and others, 1980; Raynolds, 1997, 2002; Raynolds and Johnson, 2003; Wilson and others, 2010). Assuming this interpretation is applicable to the Cheyenne Basin in Wyoming, some of the sediments in the upper part of the wholly or partially stratigraphically equivalent Lance Formation also may be stratigraphically equivalent to the same "D1" sedimentary sequence. This is similar to earlier speculation by Schlaikjer (1935c, p. 51), who considered his "Torrington member" to be equivalent "to at least part of the Arapahoe-Denver beds [now known as Denver and Arapaho Formations, or alternatively Cretaceous part of the D1 sequence; fig. $5 B]$ in the Denver Basin" because of the "close affinity of the ceratopsians in both." The authors are not aware of any studies since Schlaikjer (1935c) that have compared Laramie Formation strata in northeastern Colorado to the exposed Lance Formation strata in Goshen Hole.

\section{Fox Hills Sandstone and Upper Transition Member of the Pierre Shale}

Strata composing the Upper Cretaceous Fox Hills Sandstone and Pierre Shale at the study site are identified and described in this report section.

\section{Lithology}

The Fox Hills Sandstone at the study site consisted not of a single massive sandstone bed, but as a sequence of five sandstone beds separated by generally much finer grained rocks attributable to either the Lance Formation or the upper transition member of the Pierre Shale (fig. 11; appendix 1; plate 1). Including all five sandstone beds, total formation thickness was $79.6 \mathrm{ft}$. The upper part of the Fox Hills Sandstone ("upper Fox Hills" or "upper Fox Hills Sandstone") consisted of two upward-coarsening sandstone beds separated by the 14-ft-thick Lance Formation tongue described previously ("Lance Formation" report section) — an upper 14.7-ft-thick bed from 779.7 to $794.4 \mathrm{ft}$ BLS and a lower 37.9-ft-thick bed from 808.4 to $846.3 \mathrm{ft}$ BLS. The top of the upper sandstone bed (779.7 ft BLS) was in sharp contact with an overlying Lance Formation coal bed, and the bottom of the bed (794.4 ft BLS) was in sharp contact with a coal bed forming the top of the Lance Formation tongue (fig. 11; see photographs in fig. 21A, $B$ ). The lower bed of the upper Fox Hills was the thickest sandstone bed detected in exploratory borehole LC-F1. A monitoring well (FH-1) was completed with the well screen open to much of this thick lower bed (fig. 11; plate 1). The lower part of the Fox Hills Sandstone ("lower Fox Hills" or "lower Fox Hills Sandstone") is separated from the upper Fox Hills by $46.7 \mathrm{ft}$ of intertonguing rocks belonging to the upper transition member of the Pierre Shale. The lower Fox Hills consisted of three sandstone beds, including a 12.6-ft-thick bed from 893.0 to 905.6 ft BLS, a 4-ft-thick bed from 911.2 to 915.2 ft BLS, and a 10.4-ft-thick bed from 919.0 to $929.4 \mathrm{ft}$ BLS. A cross section constructed for this study (see "Occurrence in Laramie County Subsurface" report section) illustrates how these three sandstone beds of the lower Fox Hills Sandstone are offshore (distal or "more marine") equivalents of older Fox Hills Sandstone bodies/beds farther to the east. The three sandstone beds of the lower Fox Hills Sandstone were separated from one another by intertonguing parts of the upper transition member of the Pierre Shale, which continued below the lowermost sandstone bed to the bottom of exploratory borehole LC-F1. Including all five sandstone beds and intervening strata of the Lance Formation and upper transition member of the Pierre Shale, the Fox Hills Sandstone spanned $149.7 \mathrm{ft}$ (779.7-929.4 ft BLS) of total stratigraphic section at the study site.

Composition and characteristics of the upper and lower beds of the upper Fox Hills Sandstone were similar, but numerous subtle differences were observed. Several photographs of core from different intervals within both sandstone beds (upper bed, 779.7-780.2 and 793.9-794.4 ft BLS; lower bed, 810.3-811.2, 829.0-829.6, and 842.7-843.7 ft BLS) are 
A)

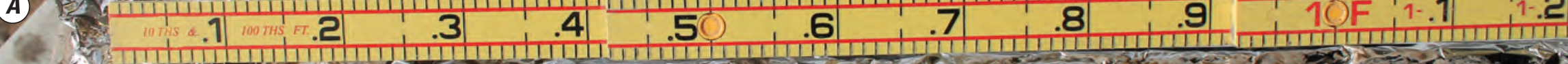

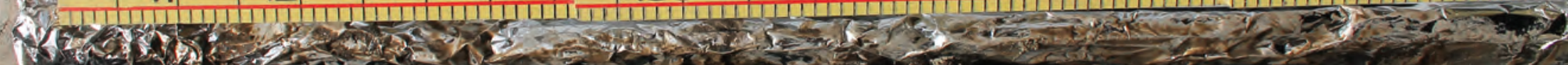

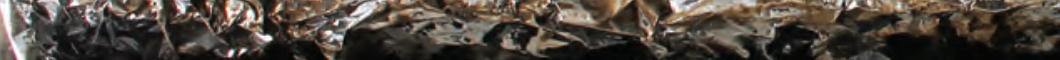
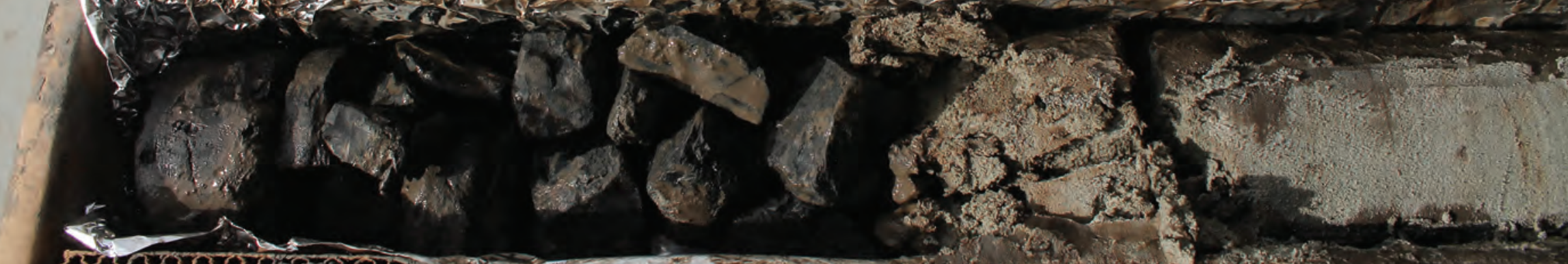

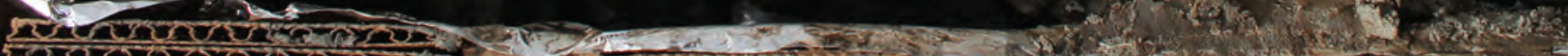

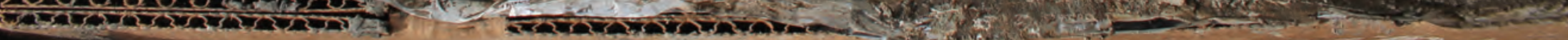

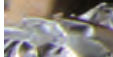

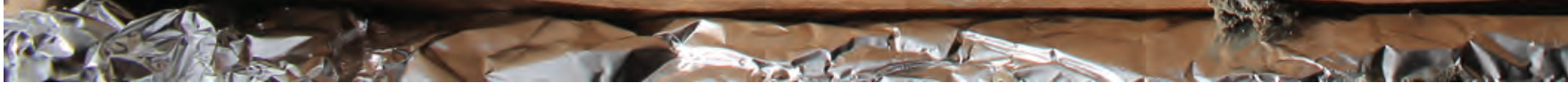

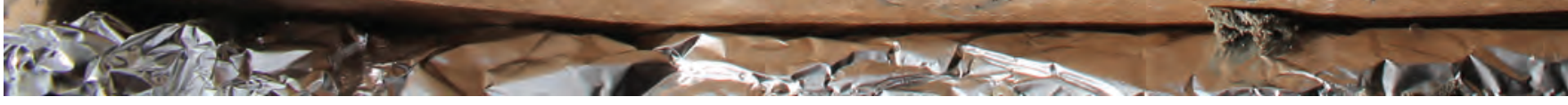
$2 \pi$

793.9 feet below land surface

795 feet below land surface

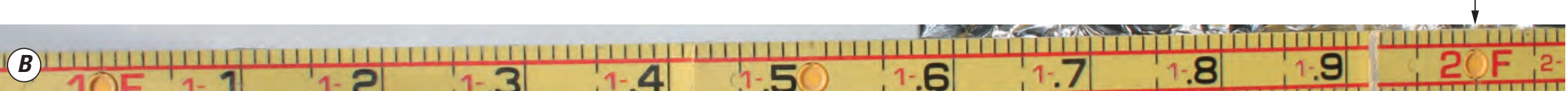

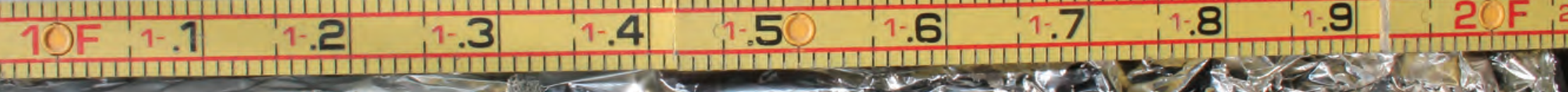

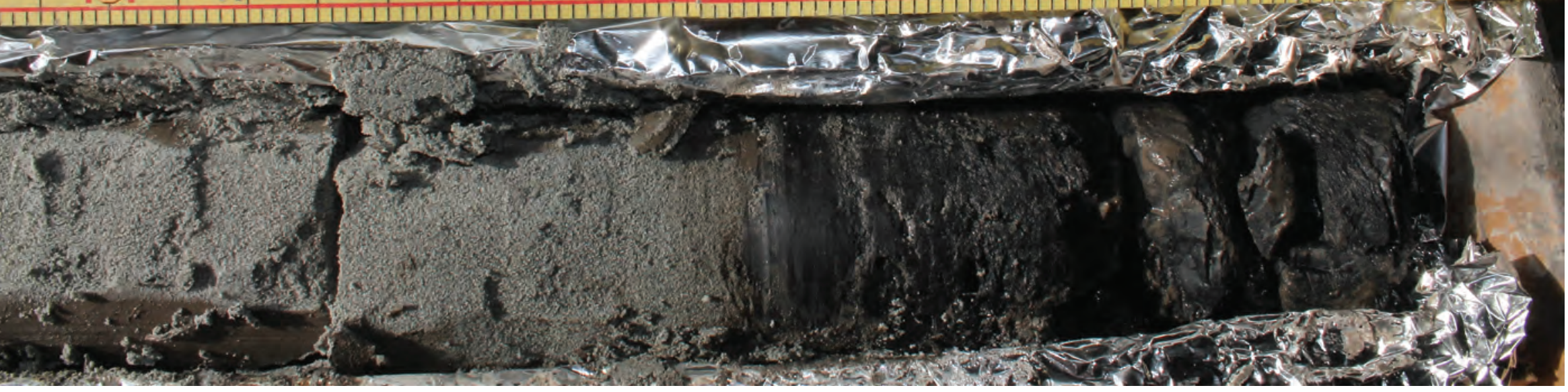



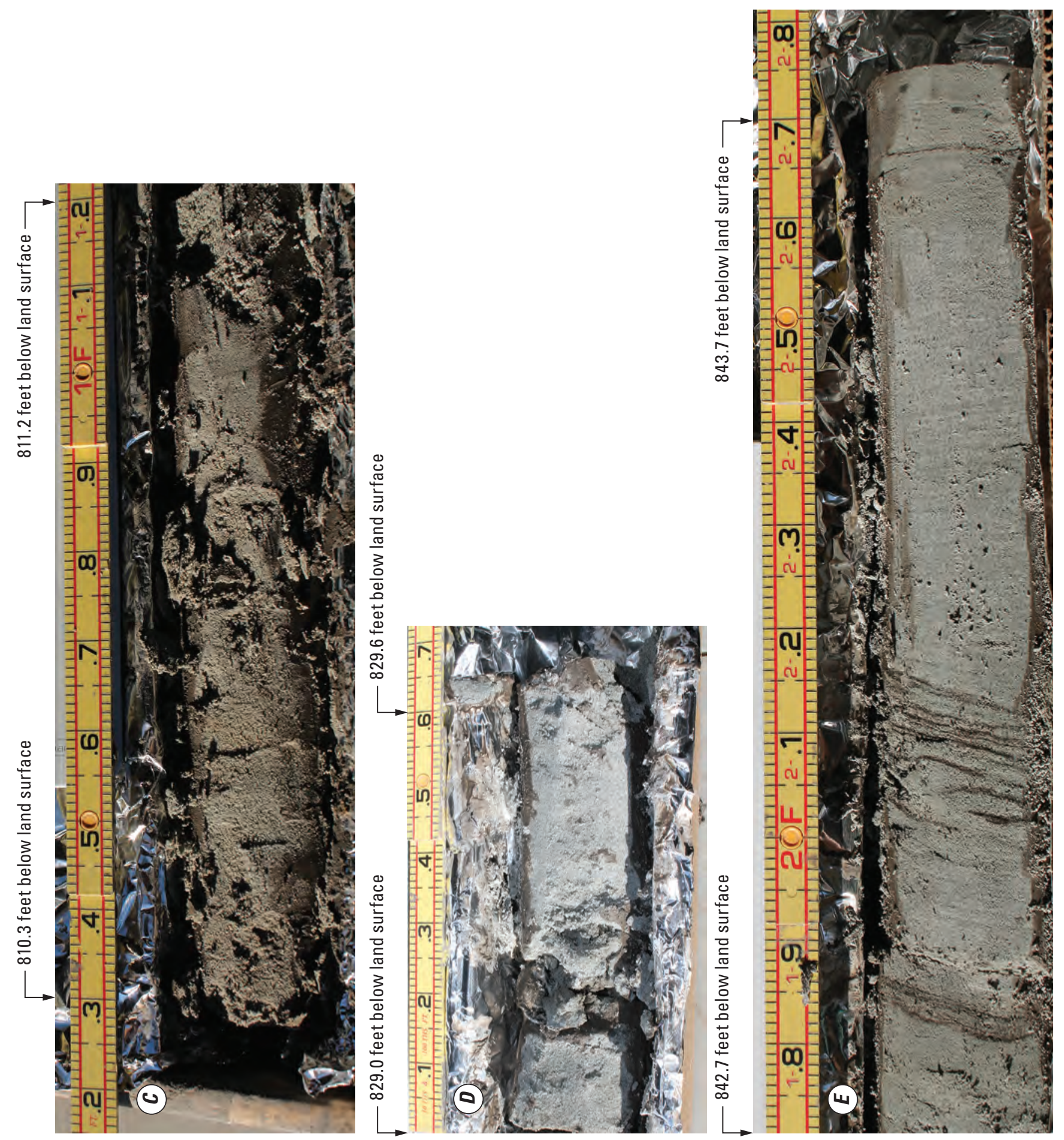

Figure 21. Core and various characteristics of the upper Fox Hills Sandstone, exploratory borehole LC-F1, southeastern Laramie County, Wyoming. $A$, lateral view of core from 779.0 to 780.2 feet below land surface (ft BLS) showing sharp contact between top of upper sandstone bed of the upper Fox Hills Sandstone and overlying Lance Formation coal bed. Note brown coloration on parts of olive-gray muddy sandstone of the Fox Hills Sandstone is drilling mud, not sediment color. Olive-gray color of Fox Hills Sandstone in this depth interval is typical of most sandstone beds in the formation, as well as thin sandstone beds in parts of the intertonguing upper transition member of the Pierre Shale; $B$, lateral view of core from 793.9 to $795.0 \mathrm{ft} \mathrm{BLS}$ showing sharp contact between bottom of upper sandstone bed of the upper Fox Hills Sandstone and underlying Lance Formation coal bed that defines the top of the Lance Formation tongue present from 794.4 to $809.3 \mathrm{ft} \mathrm{BLS}$; $C$, lateral view of core from 810.3 to $811.2 \mathrm{ft} \mathrm{BLS}$ showing the lower sandstone bed of the upper Fox Hills Sandstone. Photograph is near the top of the muddy sandstone bed; $D$, lateral view of core from 829.0 to $829.6 \mathrm{ft} B L S$ showing the lower sandstone bed of the upper Fox Hills Sandstone. Photograph is about in the middle of the muddy sandstone bed; $E$, lateral view of core from 842.7 to $843.7 \mathrm{ft} \mathrm{BLS}$ showing the lower sandstone bed of the upper Fox Hills Sandstone. Photograph is near the bottom of the muddy sandstone bed. 
shown in figure $21 A-E$. Both sandstone beds had a "salt-andpepper" (mixture of light- and dark-colored grains) appearance (fig. 21A-E). Carbonaceous streaks and carbonaceous material were present in varying quantities throughout both sandstones. Color throughout the upper sandstone bed and in 29.3 of $37.9 \mathrm{ft}$ of the underlying lower sandstone bed (817.0 to $846.3 \mathrm{ft} \mathrm{BLS}$ ) overall was olive gray to gray. Colors in the upper part of the lower bed from 808.4 to $817.0 \mathrm{ft}$ BLS overall were darker than in the lower part primarily because of greater carbonaceous material content, including black, dark brown, and olive brown in the 808.4-809.3-ft interval and grayish brown in the 809.3-817.0-ft depth interval. Consolidation of both beds ranged from unconsolidated or very poorly/poorly consolidated to moderately consolidated but both largely were unconsolidated or very poorly/poorly consolidated (collectively, friable). Both sandstone beds were composed primarily of very fine- to fine-grained sand, but the lower bed also contained small quantities (1-2 percent) of medium sand beginning at $817.0 \mathrm{ft}$ BLS. Compared to the lower bed, fine-grained sand in the upper bed overall composed a larger percentage of all sand-sized sediments as compared to very fine-grained sand (fig. 11; appendix 1; plate 1). Grain-size analyses and geophysical logs indicated the size of sand grains coarsened upward in the lower bed from the bottom $(846.3 \mathrm{ft})$ to about 829.6 ft BLS (fig. 11; appendix 1; plate 1). Grain rounding ranged from subangular to subrounded in the upper sandstone bed and from angular to subrounded in the lower bed. Grain sphericity ranged from subprismoidal to subdiscoidal in both sandstone beds. Mud-sized sediment content was sufficiently large to classify the upper sandstone as a muddy sandstone and the lower sandstone as a muddy and silty sandstone.

Composition and characteristics of the three sandstone beds of the lower Fox Hills Sandstone (uppermost, middle, and lowermost, respectively) were similar to the overlying upper Fox Hills but had several characteristics reflecting a more marine depositional environment. Photographs of core collected from the three sandstone beds are shown in figure $22 A-C$. Like the overlying upper Fox Hills, all three lower Fox Hills sandstone beds had a "salt-and-pepper" appearance, but the appearance was more subdued (less contrast between light- and dark-colored grains) in the two lower beds (fig. $22 A-C$ ). Carbonaceous streaks and carbonaceous material were present in varying quantities throughout all three beds. Color of the uppermost bed (12.6-ft-thick bed from 893.0-905.6 ft BLS) was olive gray, and color of the middle bed (911.2-915.2 ft BLS) was olive brown and olive gray. Color of the sandstone beds within the lowermost bed (919.0-929.4 ft BLS) was olive gray to gray, whereas color of two finer grained interbeds within the bed (described later in this section) ranged from gray to grayish brown (siltstone) to black to dark olive gray and olive gray to gray (interbedded series of rocks). Consolidation ranged from unconsolidated or very poorly consolidated (friable) to well consolidated, but sandstones composing all three beds largely were unconsolidated or very poorly consolidated (collectively, friable).
Qualitative grain-size analyses and geophysical logs indicated sediments composing the sandstone beds of the lower Fox Hills Sandstone were finer grained than sandstone beds composing the upper Fox Hills Sandstone. This difference was reflected not only by the actual size of the sand grains composing the beds, but also by the larger percentage of mud-sized sediments (silt and clay) as compared to sand-sized sediments within the lower Fox Hills beds. As is typical in an upward-coarsening shoreface succession like the Fox Hills Sandstone, sediment size generally increased upward (from deepest to shallowest shoreface/beach environment) through the lower Fox Hills beds and ultimately upward into the overlying sandstone beds composing the upper Fox Hills (fig. 11; plate 1). Sand grains composing the uppermost sandstone bed were the coarsest of the lower Fox Hills, ranging in size from very fine to medium, but most grains ranged from very fine to fine. Sand grains in the middle sandstone bed ranged in size from very fine to fine, but fine-sized sand content decreased in comparison with the overlying uppermost bed. The lowermost sandstone bed consisted not only of sandstone, but also two fine-grained interbeds, including a 0.5 -ft-thick siltstone from 923.5 to $924.0 \mathrm{ft}$ BLS and a 0.9-ft-thick sequence of interbedded rocks (muddy shale, sandy siltstone, and silty sandstone) from 925.6 to $926.5 \mathrm{ft}$ BLS (fig. 11; plate 1; appendix 1). Sand grains in the lowermost sandstone bed ranged in size from very fine to fine. In all three sandstone beds of the lower Fox Hills, grain rounding ranged from subangular to subrounded, and grain sphericity ranged from subprismoidal to subdiscoidal. Mud-sized sediment content was sufficiently large to classify the uppermost bed as a muddy sandstone and the middle and lower beds as silty sandstones.

All parts of the upper transition member of the Pierre Shale consisted largely of muddy shale and sandy siltstone with thin beds of silty sandstone (appendix 1; plate 1). Color of the unit was dark, and sediment colors included gray, light gray, olive gray, light olive gray, dark olive gray, and black. Muddy shale commonly contained small quantities of carbonaceous material (slightly carbonaceous), but some intervals contained much larger quantities (very carbonaceous). Consolidation ranged from unconsolidated or poorly consolidated to well consolidated. Some parts of the formation were bioturbated (for example, see photograph in fig. 22D; appendix 1). Sand grains composing the silty sandstone beds were primarily very fine in size. Sand grain rounding ranged from angular to subrounded, and grain sphericity ranged from subprismoidal to subdiscoidal. Visually, the sandstone beds possessed the same overall color (olive gray) and "salt-and-pepper" appearance as the sandstone beds composing the Fox Hills Sandstone.

\section{Petrography}

Six petrographic thin sections were created from the various sandstone beds composing the Fox Hills Sandstone-four from the upper Fox Hills Sandstone (one from the upper bed and three from the thick lower bed) and two from the lower Fox Hills Sandstone (one from the uppermost bed and one 

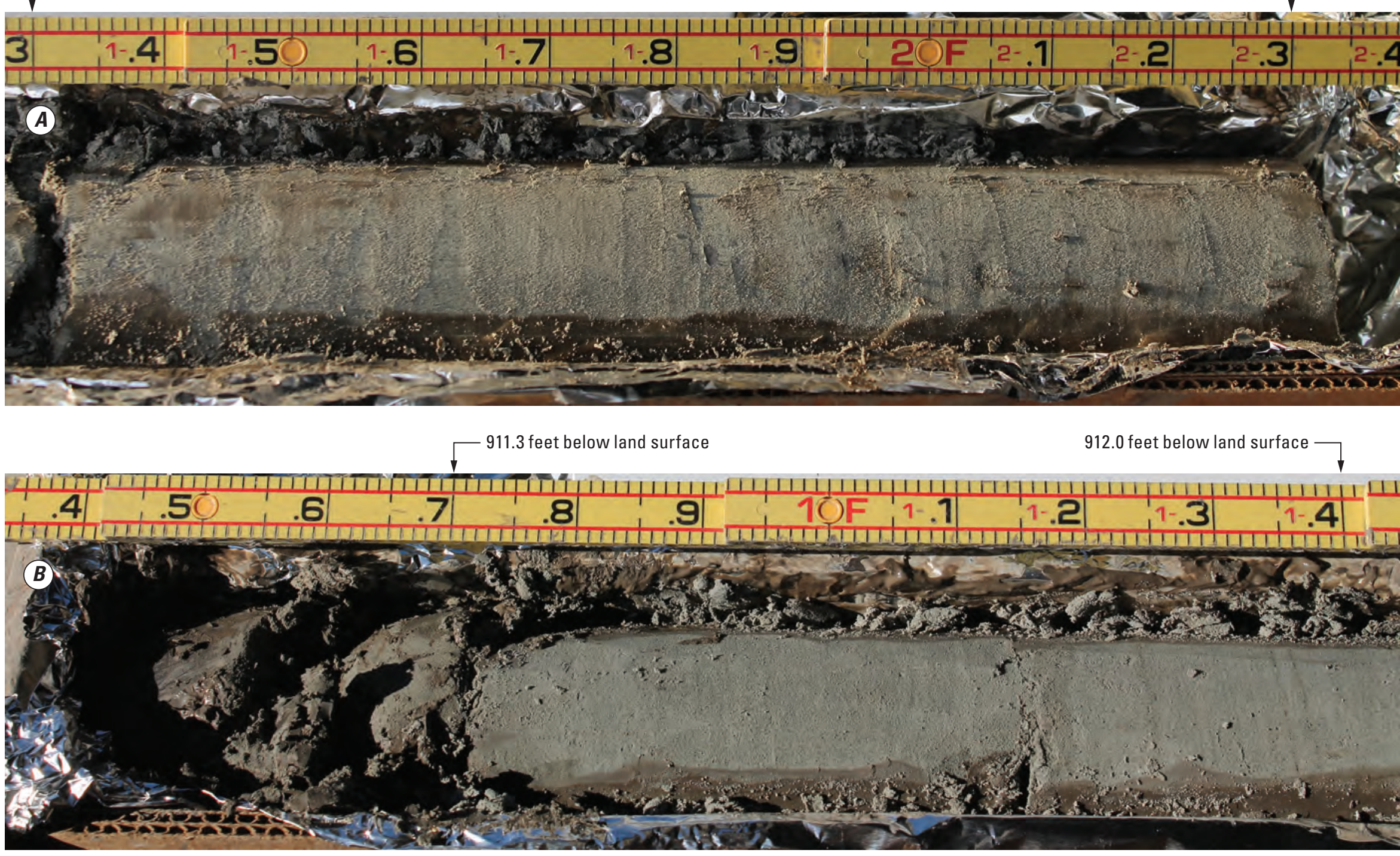

Figure 22. Core and various characteristics of the lower Fox Hills Sandstone and upper transition member of the Pierre Shale, exploratory borehole LC-F1, southeastern Laramie County, Wyoming. A, lateral view of core from 894.3 to 895.3 feet below land surface (ft BLS) showing uppermost sandstone bed of the lower Fox Hills Sandstone. Photograph is near the top of the muddy sandstone bed; $B$, lateral view of core from 911.3 to $912.0 \mathrm{ft} \mathrm{BLS}$ showing middle sandstone bed of the lower Fox Hills Sandstone. Photograph is near the top of the silty sandstone bed; $C$, lateral view of core from 927.8 to $928.8 \mathrm{ft} \mathrm{BLS}$ showing the lower sandstone bed of the lower Fox Hills Sandstone. Photograph is near the bottom of the silty sandstone bed; $D$, lateral view of core from 867.2 to $867.6 \mathrm{ft} B L S$ showing disturbed bedding presumed to be bioturbation in the upper transition member of the Pierre Shale. 


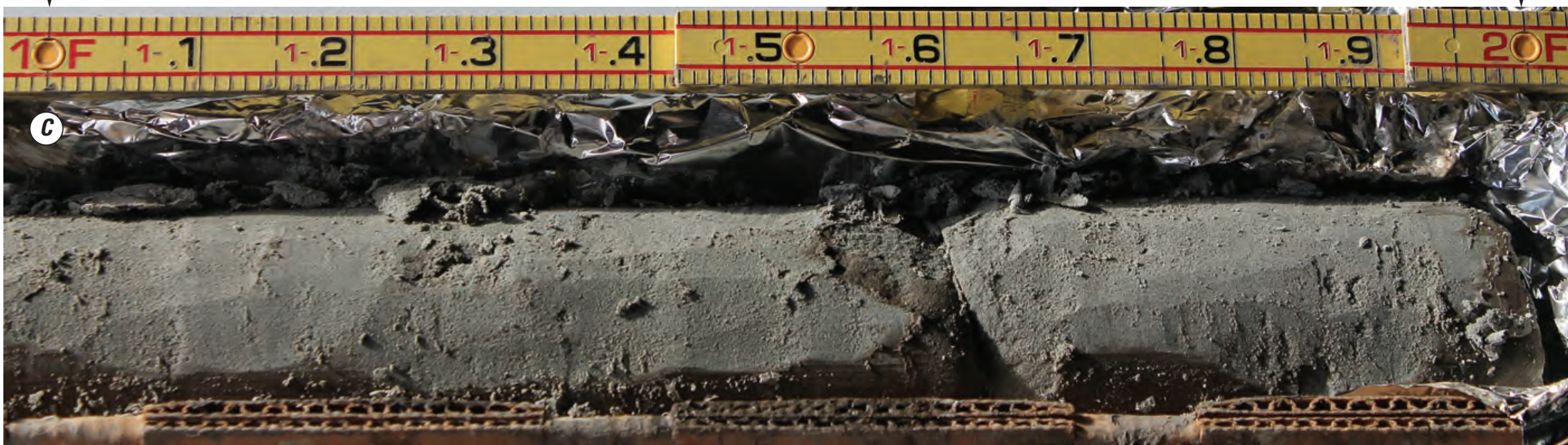

2. Core and various characteristics of the lower Fox Hills Sandstone and upper transition member of the Pierre Shale, exploratory borehole LC-F1, southeastern Laramie County, Wyoming. A, lateral view of core from 894.3 to 895.3 feet below land surface (ft BLS) showing uppermost sandstone bed of the lower Fox Hills Sandstone. Photograph is near the top of the muddy sandstone bed; $B$, lateral view of core from 911.3 to $912.0 \mathrm{ft} \mathrm{BLS}$ showing middle sandstone bed of the lower Fox Hills Sandstone. Photograph is near the top of the silty sandstone bed; $C$, lateral view of core from 927.8 to $928.8 \mathrm{ft} \mathrm{BLS}$ showing the lower sandstone bed of the lower Fox Hills Sandstone. Photograph is near the bottom of the silty sandstone bed; $D$, lateral view of core from 867.2 to $867.6 \mathrm{ft}$ BLS showing disturbed bedding presumed to be bioturbation in the upper

transition member of the Pierre Shale.-Continued

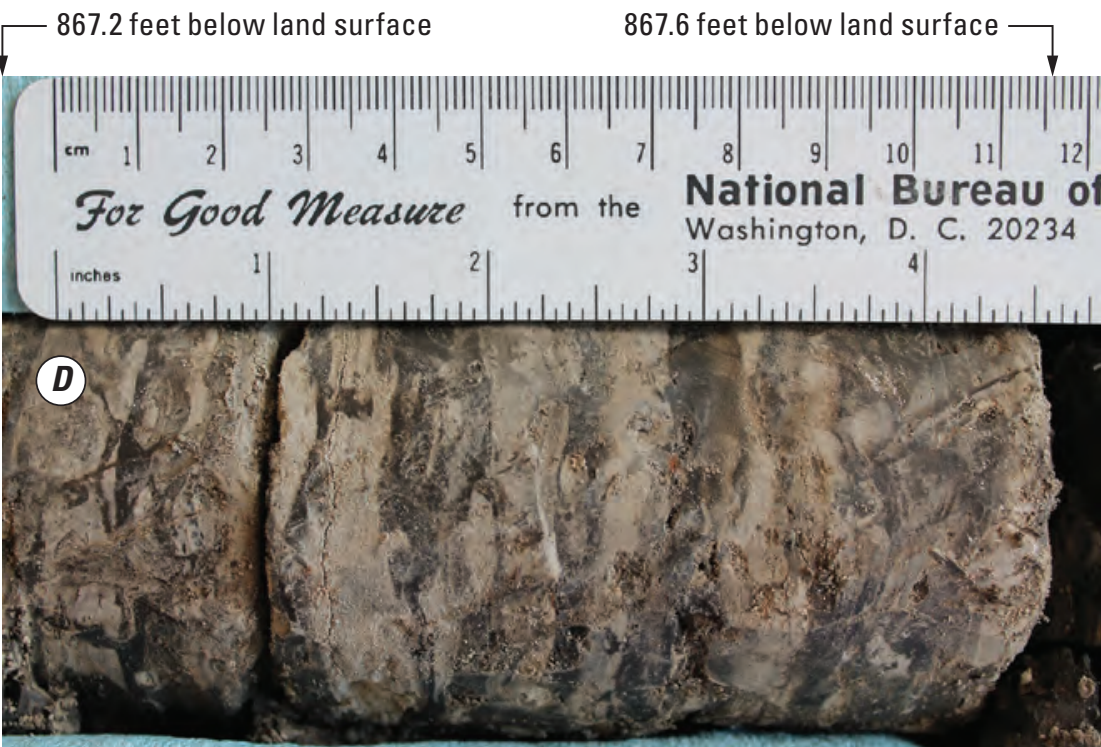


from the middle bed; no thin section was constructed from the lowermost bed). These six thin sections are described in this report section.

The one petrographic thin section from the upper bed of the upper Fox Hills Sandstone (fig. 23A-C) was from a depth interval (781.8-782.0 ft BLS) near the top of the bed (779.7$794.4 \mathrm{ft}$ BLS). Examination of the thin section indicated the muddy sandstone in this depth interval was moderately to well sorted. Constituent grains commonly are micron sized and indicated highly variable rounding (angular to rounded; fig. $23 A-C$ ). Primary constituent grains are monocrystalline igneous quartz grains, chert, feldspars, and rock fragments (fig. 23A-C). Minor (accessory) constituent grains included muscovite and altered biotite (?) grains, which are kinked, exfoliated, and deformed, indicating compaction and alteration (not shown). There are occasional altered hornblende grains, dolomite, opaque mineral grains, and rare igneous-sourced zircons. The most common rock fragments are igneous, with quartz and feldspars. Plagioclase in rock fragments commonly is altered to sericitic clays. Other rock fragments include volcanic rock fragments and schistose fragments of mica/clay and quartz. Volcanic rock fragments are varied, and some appear to be devitrified with faint alignment of feldspar phenocrysts.

A total of 3 petrographic thin sections were created from core collected from 3 intervals within the thick lower sandstone bed (808.4-846.3 ft BLS) of the upper Fox Hills Sandstone. The thin section from the shallowest depth was near the top of the lower bed, from the 813.7-813.9-ft BLS depth interval. The muddy sandstone in this depth interval is highly quartz rich, and monocrystalline quartz grains are the most abundant constituent grains (fig. $24 A-C$ ). Other primary constituent grains are chert, various feldspars (potassium feldspar [orthoclase], anorthoclase, plagioclase [identified as albite using XRD]), igneous rock fragments (quartz, feldspar, micas, and opaque minerals [iron and (or) titanium oxides]), and rarer metamorphic (micaceous schist) and sedimentary rock fragments. One rare sedimentary rock fragment consisted of a rounded carbonate (possible fossil; not shown). Identified accessory minerals include mica, dolomite, apatite, titanium oxides, glauconite (?), and rare zircon and monazite. Mean grain size of the main constituent grains is about $0.25 \mathrm{~mm}$, but smaller grains that have undergone alteration and fracturing act as matrix material between larger grains. Quartzgrain rounding ranges from angular to rounded or elongated (fig. 24A-C). Some quartz grains retain original detrital outlines with partially dissolved quartz overgrowths (fig. 24B); dissolution of quartz overgrowths created secondary porosity. Quartz grains commonly are strain shadowed. Chert grains are subrounded to rounded and have a microcrystalline texture. Feldspar grains are subangular to rounded, and some have altered to sericitic clays, especially in igneous rock fragments. Many constituent grains are highly fractured and indicate compaction, including many quartz and feldspar grains (fig. 24B, C). Mica grains commonly are compressed/bent/kinked and deformed between harder grains, another indication of compaction. Many mica grains were exfoliated (fig. 24B).
Exfoliated mica creates secondary porosity as opened "plates" are altered along cleavage after compaction.

Examination of this thin section indicated the muddy sandstone in this depth interval (813.7-813.9 ft BLS) was once well cemented and less permeable. Evidence for secondary permeability development includes long contacts between constituent grains; exfoliated mica; common skeletal remnants of grains and easily altered and broken rock fragments and feldspar grains indicating extensive dissolution, pitting, and etching; partially altered quartz overgrowths because of dissolution of minerals; and grain-sized void areas indicating total dissolution of grains.

The second petrographic thin section $(824.4-824.6 \mathrm{ft}$ BLS) constructed from core collected from the lower sandstone bed of the upper Fox Hills Sandstone indicated the predominant constituent grains of this interval of muddy sandstone were monocrystalline quartz and microcrystalline chert (fig. 25A-C). Other major constituent grains included various types of feldspar and rock fragments. Identified feldspars included microcline (identified by gridiron twinning), orthoclase (identified by XRD), anorthoclase, and plagioclase (identified by XRD). Accessory minerals included mica (muscovite and possibly biotite), dolomite, apatite, opaque minerals (titanium [ilmenite?] and iron oxides, sulfide minerals [sphalerite and pyrite]), glauconite (?), monazite, and rare zircons. Mica grains show exfoliation and alteration along cleavage (fig. 25C). Muscovite grains are kinked and deformed because of compaction (fig. 25C). Evidence for sulfide mineralization in this depth interval, an indicator of reduced conditions, is provided by the presence of sphalerite, pyrite, and iron oxides; these minerals were identified between the exfoliated sheets of a mica (biotite?) altered to chlorite (fig. 25C).

As with the other thin sections constructed from the Fox Hills Sandstone, there was evidence for secondary porosity development in this depth interval (824.4-824.6 ft BLS). Grain-sized areas of interstitial void (pore) space indicate dissolution of grains that are more readily susceptible to alteration such as potassium feldspar to kaolinitic clay. Exfoliated micas (fig. 25C) can create secondary porosity as "open plates" are altered along cleavage after compaction. Patchy filling of pores occurs through compaction of softer grains such as rock fragments of micaceous schist, through fracturing and comminution of "unstable" grains, and by clays (fig. $25 B$, C).

The third and last petrographic thin section (839.0$839.2 \mathrm{ft}$ BLS) constructed from core collected from the lower sandstone bed of the upper Fox Hills Sandstone indicated the most common constituent grains of this interval of muddy sandstone were quartz, chert, various types of feldspars and rock fragments, and dolomite (fig. 26A-C). Rock fragments include volcanic/igneous rock fragments with phenocrysts, rock fragments of feldspar and quartz, myrmekitic volcanic rock fragments ("wormy" intergrowth of quartz and feldspar; for example, see grain identified as "volcanic fragment" in center of fig. 26A, $B$ ), and seriticized (altered to clay) rock fragments (fig. 26A, $B$ ), which may be metamorphic in origin. 

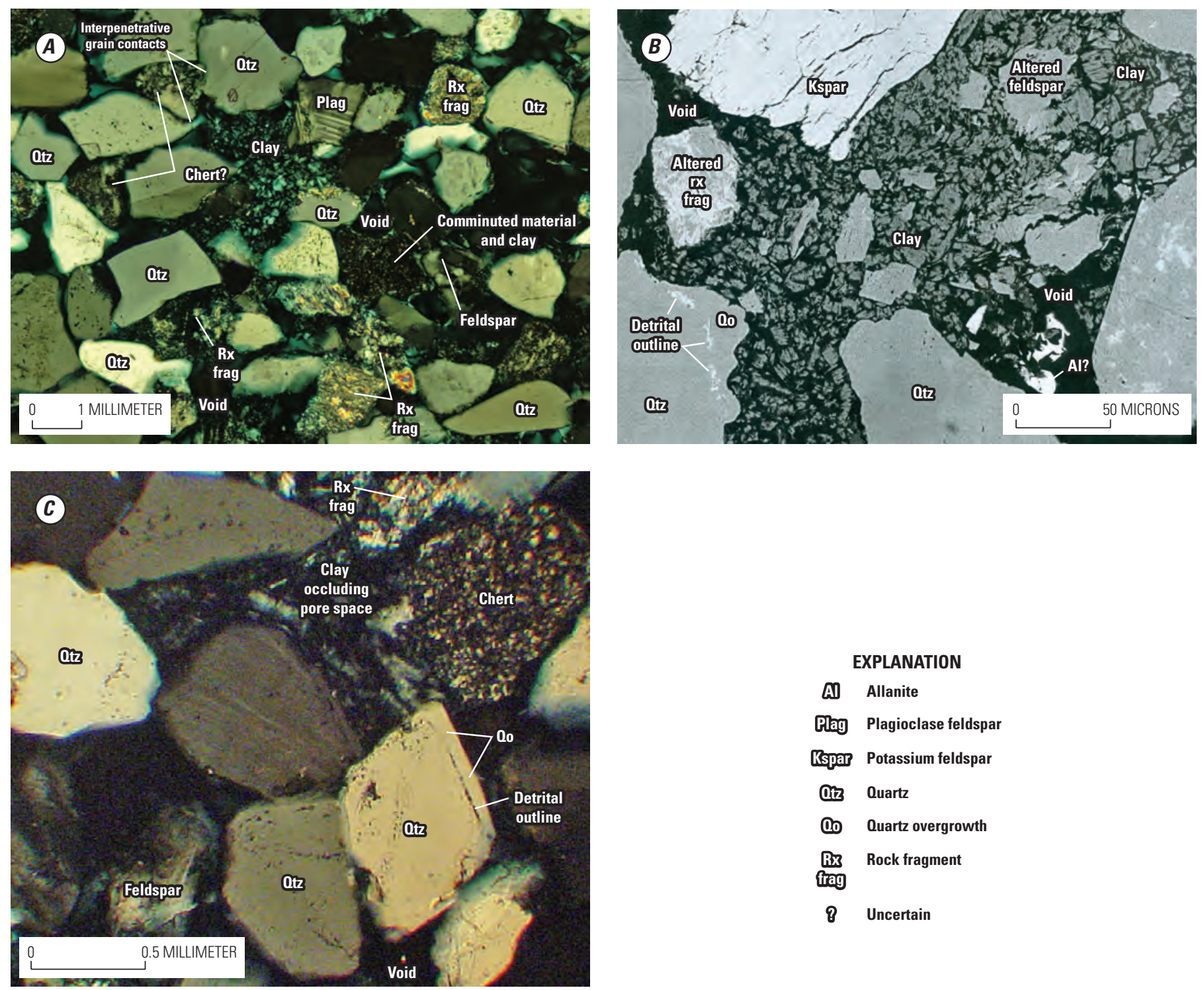

\begin{tabular}{|c|c|}
\hline \multicolumn{2}{|r|}{ EXPLANATION } \\
\hline AD & Allanite \\
\hline Plag & Plagioclase feldspa \\
\hline Kspas & Potassium feldspar \\
\hline 0 & Quartz \\
\hline c & Quartz overgrowth \\
\hline $\begin{array}{l}\text { Bx } \\
\text { frat }\end{array}$ & Rock fragment \\
\hline & Uncertain \\
\hline
\end{tabular}

Figure 23. Muddy sandstone from upper sandstone bed of the upper Fox Hills Sandstone, 781.8 to 782.0 feet below land surface, exploratory borehole LC-F1, southeastern Laramie County, Wyoming. A, crossed-nicols photomicrograph showing constituent grains of quartz, chert, plagioclase feldspar (twinned and partially crushed on left side), micaceous schistose rock fragments, and patchy areas of clay. Black areas are voids, which are partially occluded by the patchy areas of clay. Note interpenetrative grain contacts indicative of compaction in upper left corner of photomicrograph; $B$, scanning electron microscope (SEM) photomicrograph showing constituent grains of potassium feldspar, quartz with quartz overgrowths, altered rock fragments, and an accessory mineral (allanite?, in lower right corner). Black areas are voids. Pore (void) spaces are partially occluded by patchy areas of kaolinitic clays (clay); weathering of feldspar is likely the source for the kaolinite. The potassium feldspar grain has fractures and dissolution etching. Labile rock fragments and feldspar are highly altered to clays. Most constituent grains are rimmed with clays; $C$, crossed-nicols photomicrograph showing detrital outline and quartz overgrowth on angular quartz grain. Angular shape of this quartz grain may be attributable to overgrowth that was not partially dissolved, but most quartz grains with an angular shape seem to be the result of fracturing and little transport. Also note constituent grains of quartz, feldspar, and chert, and partial occlusion of pore space by clay. 

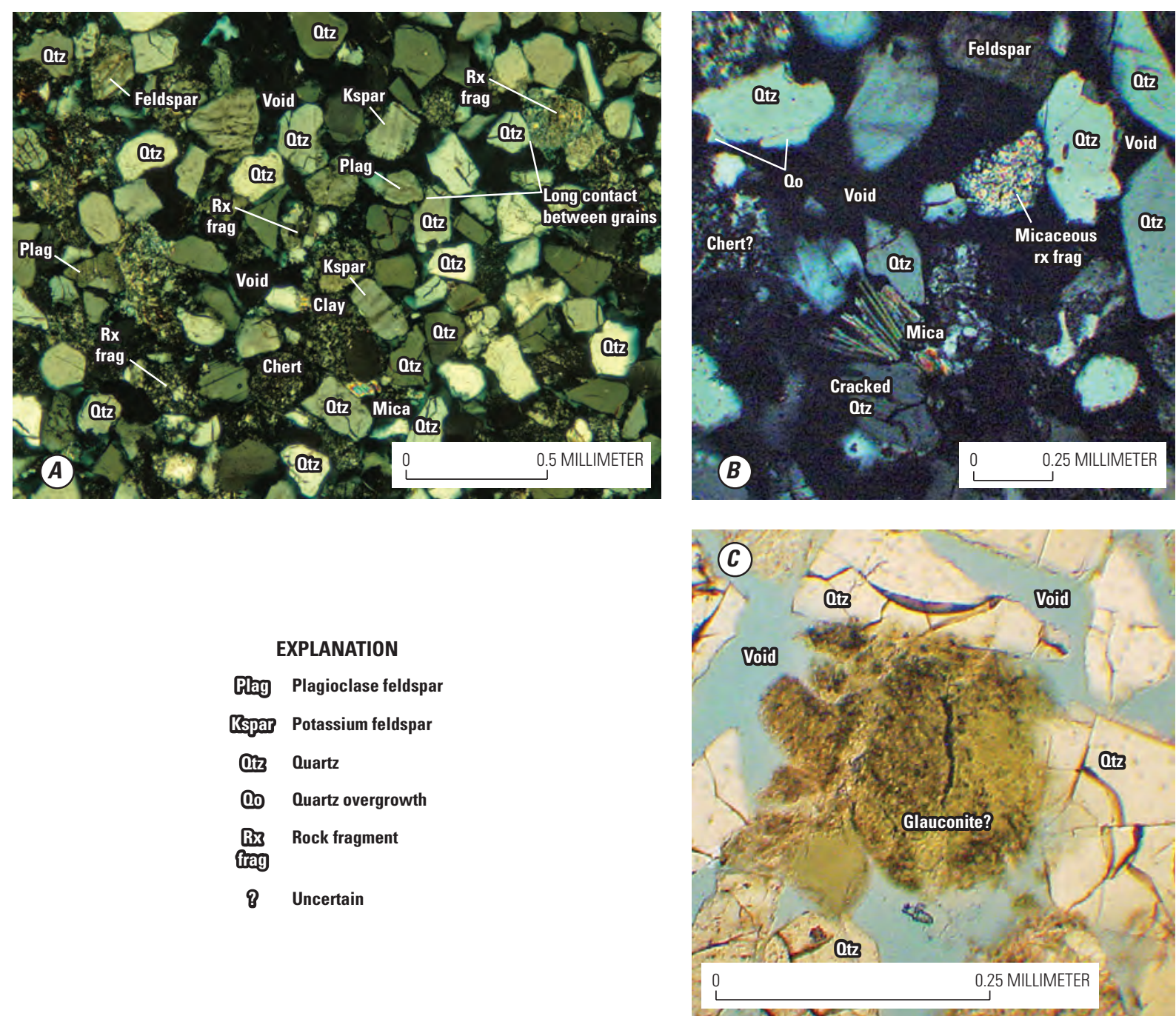

Figure 24. Muddy sandstone from upper Fox Hills Sandstone, 813.7 to 813.9 feet below land surface, exploratory borehole LC-F1, southeastern Laramie County, Wyoming. A, crossed-nicols photomicrograph showing constituent grains of quartz, chert, potassium feldspar, plagioclase feldspar, rock fragments, and mica. Black areas are voids, which are partially occluded by patchy areas of clay. Note example of long grain contacts indicative of compaction in upper right corner of photomicrograph; $B$, crossed-nicols photomicrograph showing constituent grains of quartz, feldspar, quartz with quartz overgrowths, exfoliated mica, and micaceous rock fragment. Black areas are voids. Overgrowths on quartz grains have undergone dissolution etching, creating secondary porosity. Similarly, exfoliated mica created secondary porosity because "open plates" were altered along cleavage after compaction; $C$, planelight photomicrograph showing fractured quartz grains indicating compaction and possible glauconite grain with iron oxides. 

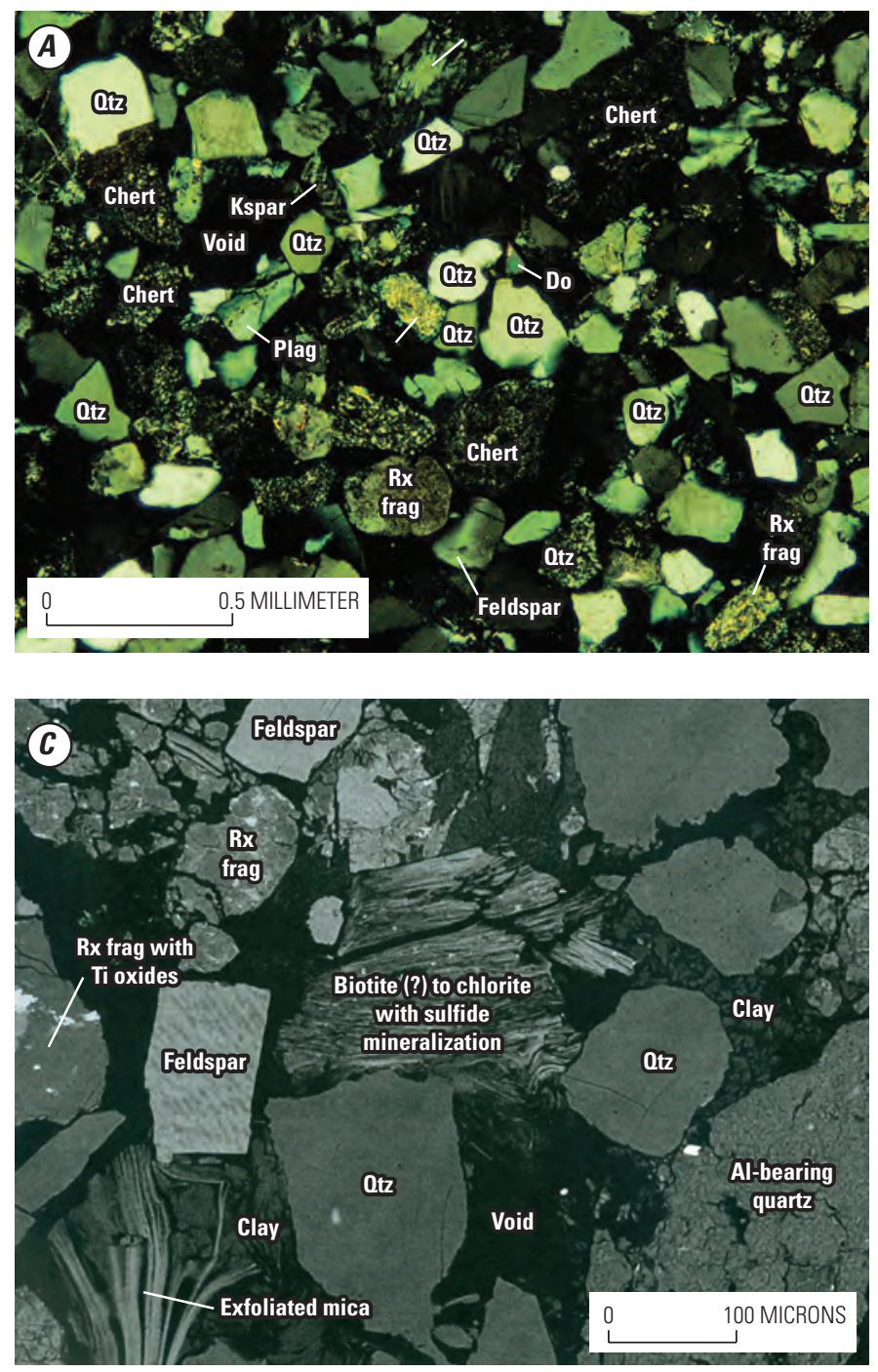

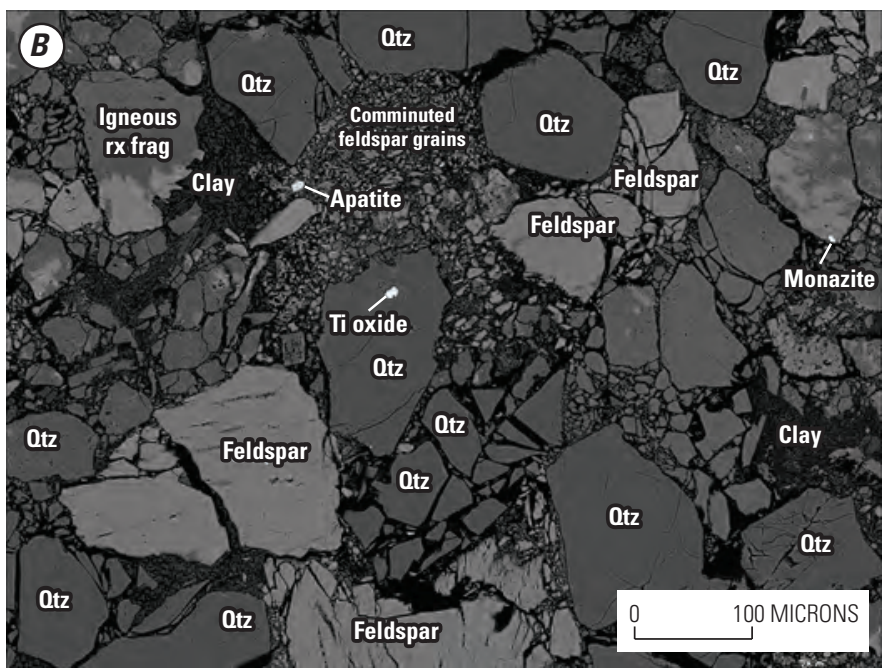

EXPLANATION

\begin{tabular}{|c|c|}
\hline AD & Aluminum \\
\hline Do & Dolomite \\
\hline Plag & Plagioclase feldspar \\
\hline Rspars & Potassium feldspar \\
\hline @ez & Quartz \\
\hline$\underset{\text { frang }}{\text { for }}$ & Rock fragment \\
\hline ד & Titanium \\
\hline 8 & Uncertain \\
\hline
\end{tabular}

Figure 25. Samples from Fox Hills Sandstone, 824.4-824.6 feet below land surface, exploratory borehole LC-F1, southeastern Laramie County, Wyoming. $A$, crossed-nicols photomicrograph showing constituent grains of quartz, chert, potassium feldspar, feldspar, and rock fragments. Black areas are voids; $B$, scanning electron microscope (SEM) photomicrograph showing constituent grains of quartz, feldspar, and igneous rock fragment. Black areas are voids. Also identified are the accessory minerals apatite, titanium oxides, and monazite. Note patchy filling of pores (void areas) by fracturing and comminution (reduction to smaller particles) of "unstable" feldspar grains (comminuted) and clay matrix; $C$, SEM photomicrograph showing constituent grains of quartz, feldspar, and rock fragment with titanium oxides. Black areas are voids. Note sulfide mineralization between the exfoliated sheets of a mica (biotite?) altered to chlorite and "punky" pitted appearance of altered aluminum-bearing quartz grain in lower right corner of image. 

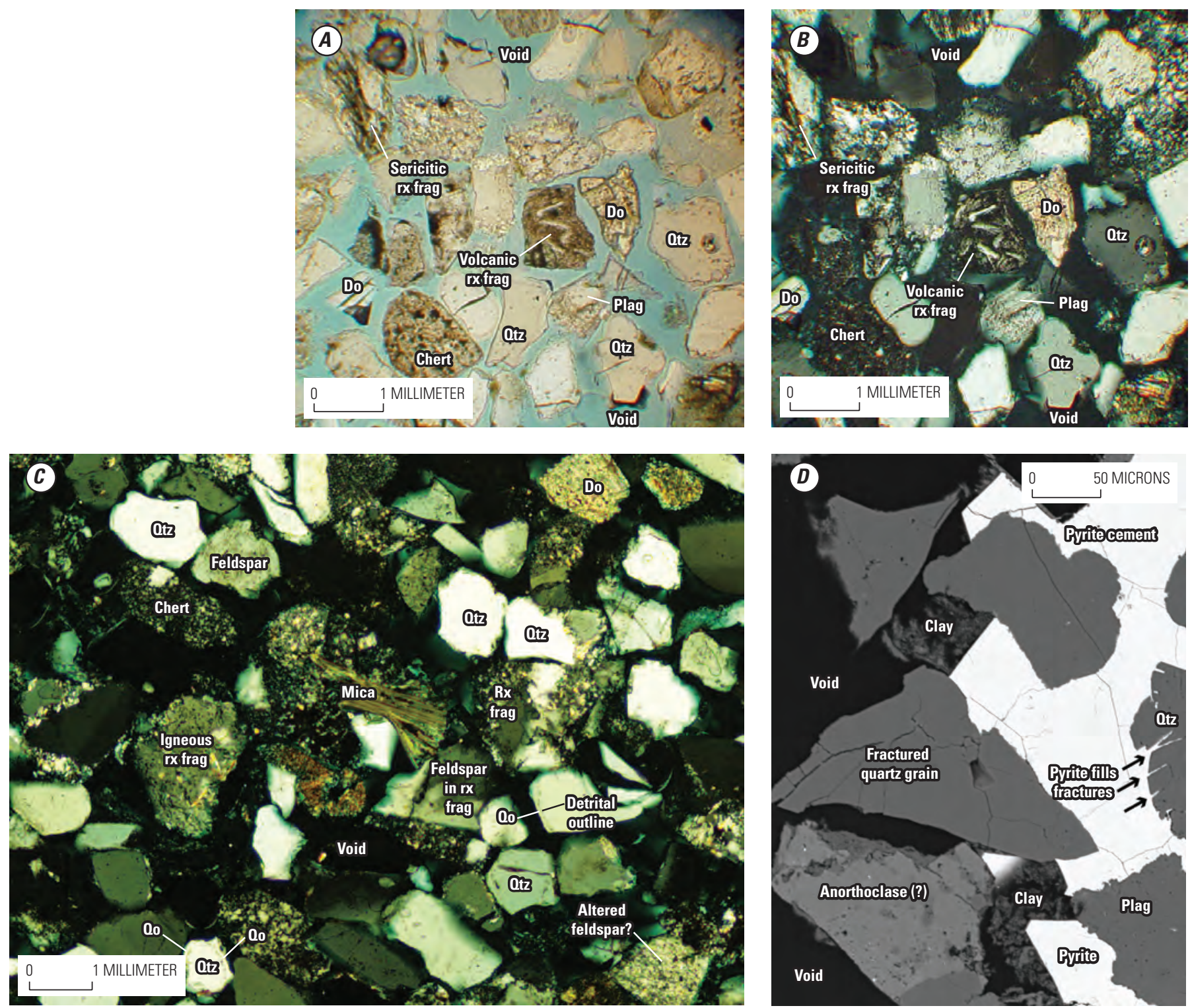

\begin{tabular}{cl}
\multicolumn{2}{c}{ EXPLANATION } \\
Do & Dolomite \\
Plag & Plagioclase feldspar \\
@izz & Quartz \\
@o & Quartz overgrowth \\
Bx & Rock fragment \\
frag & \\
8 & Uncertain
\end{tabular}

Figure 26. Samples from Fox Hills Sandstone, 839.0-839.2 feet below land surface, exploratory borehole LC-F1, southeastern Laramie County, Wyoming. $A$, plane-light photomicrograph showing constituent grains of quartz, chert, plagioclase feldspar, dolomite, and myrmekitic volcanic rock fragment. Void space between constituent grains shown in blue; $B$, crossed-nicols photomicrograph of same view as figure $26 A$; $C$, crossed-nicols photomicrograph showing constituent grains of quartz, chert, feldspar, various types of rock fragments, dolomite, and mica. Black areas are voids. Quartz overgrowths on quartz grains have undergone dissolution, creating secondary porosity. Mica grains show exfoliation and alteration along cleavage. Note mica grain is kinked and deformed because of compaction. The mica grain shows exfoliation along cleavage; $D$, scanning electron microscope photomicrograph showing constituent grains of quartz (many fractured), plagioclase feldspar, and potassium feldspar (anorthoclase?). Note how patchy pyrite cement encases constituent grains, partially replaces grains, and fills fractures in the grains. 
Geologic and Hydrogeologic Characteristics, White River Formation, Lance Formation, and Fox Hills Sandstone, Wyo.

Grain rounding ranged from subrounded to angular. The variety of grain types and rounding indicates origins from wideranging provenances. Identified feldspars included potassium feldspars (anorthoclase and orthoclase) and plagioclase. Many quartz grains indicate fracturing, which may be indicative of pressure fracturing from compaction. Some quartz grains retain original detrital outlines with partially dissolved quartz overgrowths (fig. 26C); dissolution of quartz overgrowths created secondary porosity. Chert largely is microcrystalline but also has large quartz grains; this makes it difficult to distinguish chert from some rock fragments. Mica grains show exfoliation and alteration along cleavage (fig. 26C). Muscovite grains are kinked and deformed because of compaction (fig. 26C). In places, patchy pyrite cement encases constituent grains, partially replacing grains and filling fractures in the grains (fig. 26D). The pyrite cement is euhedral and grew freely into void space.

One petrographic thin section (897.0-897.2 ft BLS; fig. 27A-E) was constructed from core collected from the upper bed (893.0-905.6 ft BLS) of the lower Fox Hills Sandstone. Primary constituent grains of this interval of muddy sandstone were quartz, chert, various types of feldspars, mica, dolomite, and rock fragments; quartz and chert were the most abundant constituent grains (fig. 27D, E). Accessory minerals include apatite, ilmenite, rare sphene, and zircon. Major clays identified using XRD are smectite, illite, kaolinite, and traces of chlorite. Rock fragments largely are igneous, composed of quartz and feldspar. One rock fragment consisted of potassium feldspar and probable barite. Micaceous rock fragments and volcanic rock fragments are rare. Mica grains largely are altered to clays (fig. 27D). Muscovite occurs within rock fragments. Identified feldspars include potassium feldspars (orthoclase and anorthoclase) and sodic plagioclase (albite). Quartz and feldspar grain rounding ranges from subrounded to angular, although most grains are subangular to angular. Overall, sorting is poor. Elongated, high-aspect ratio quartz grains show alignment along cross beds (fig. 27E). Some quartz grains have healed fractures.

Carbon-rich siderite seems to act as a cement because it encloses constituent grains; however, these cemented areas also appear fragmented and may have undergone erosive current energy, creating rip-up clasts (fig. 27A-C). Current activity is indicated by cross bedding (fig. $27 E$ ). Framboidal pyrite, an indicator of reducing conditions, is associated with the siderite cement (fig. 27F).

One petrographic thin section (920.8-921.0 ft BLS; fig. 28A-C) was constructed from core collected from the lowermost bed (919.0-929.4 ft BLS) of the lower Fox Hills Sandstone. Primary constituent grains of this interval of muddy sandstone were quartz; various types of feldspars; fresh mica (muscovite) and altered mica; amphiboles altered to clays, iron- and titanium-oxide (ilmenite) grains; and igneous rock fragments composed of quartz and feldspar (examples of quartz and feldspar grains are identified in fig. 28A). There are rare grains of probable brown chalcedonic quartz. Accessory minerals include calcite (which has replaced grains), dolomite, apatite, sphene, possible allanite, zircon, and framboidal pyrite. Dolomite rhombs indicate two generations of precipitation and micritization (very fine crystalline carbonate) of rims. Major clays identified using XRD are smectite, illite, kaolinite, and traces of chlorite. Identified feldspars include potassium feldspars (orthoclase and anorthoclase; identified using XRD) and sodic plagioclase (probably albite). Variable aluminum content in quartz grains indicates origination from various provenances. Grain rounding ranges from subrounded to angular, although many grains are angular (fig. 28A-C). As was the case with the middle sandstone bed of the lower Fox Hills Sandstone described previously, reducing conditions are indicated by the presence of framboidal pyrite grains (fig. 28A, $B$ ). Framboidal pyrite, altered micas (?), and etched constituent grains are aligned along subtle pressure-solution seams (fig. 28B, C), which indicates compaction. Dissolution etching of grains indicates development of secondary porosity (example shown in the lower left corner of fig. 28C).

Cross bedding and layering are apparent (fig. 28A, B). Despite compression indicated by the alignment of large altered mica grains (?) and pyrite, cross-bedding structure is preserved (fig. 28A, B). Elongated, high-aspect ratio quartz grains show alignment along cross beds (fig. 28A, B). Layering consists of more porous/coarser grained "open layers" interspersed with more clay-rich pore-occluding layers. Constituent grain size varies, from coarse to fine, in "faint" layers. Porosity is patchy, largely preserved along cross bedding.

\section{Occurrence in Laramie County Subsurface}

A geologic cross section was constructed to place Upper Cretaceous strata at the study site into a larger spatial context, show the character and spatial distribution of the various sandstone bodies composing the Fox Hills Sandstone, and more broadly, illustrate the stratigraphic relations between the Upper Cretaceous formations. The cross section (fig. 29) follows a generally west-east oriented line across part of southern Laramie County (fig. 30). The cross section was constructed using geophysical logs (SP and resistivity) from exploratory borehole LC-F1, 2 wellbores described previously (fig. 16), and 14 additional wellbores (logs obtained from Wyoming Oil and Gas Conservation Commission, 2018). Facies recognition and lithostratigraphic unit identification methods/principles described conceptually in the "Identification of Upper Cretaceous Lithostratigraphic Units in the Subsurface" section of the report were applied to all the geophysical logs for crosssection construction.

A distinctive geologic marker bed in the upper transition member of the Pierre Shale, known as the Pierre ash (Dechesne and others, 2011a, b), served as a common datum for cross-section construction. The Pierre ash is defined by a low-amplitude, but distinctive, deflection in SP and resistivity logs that has been identified on many logs from wells throughout the Denver and Cheyenne Basins in northeastern Colorado (Dechesne and others, 2011a, b; Jehn-Dellaport and Renninger, 2017). The Pierre ash is equivalent to the top of 

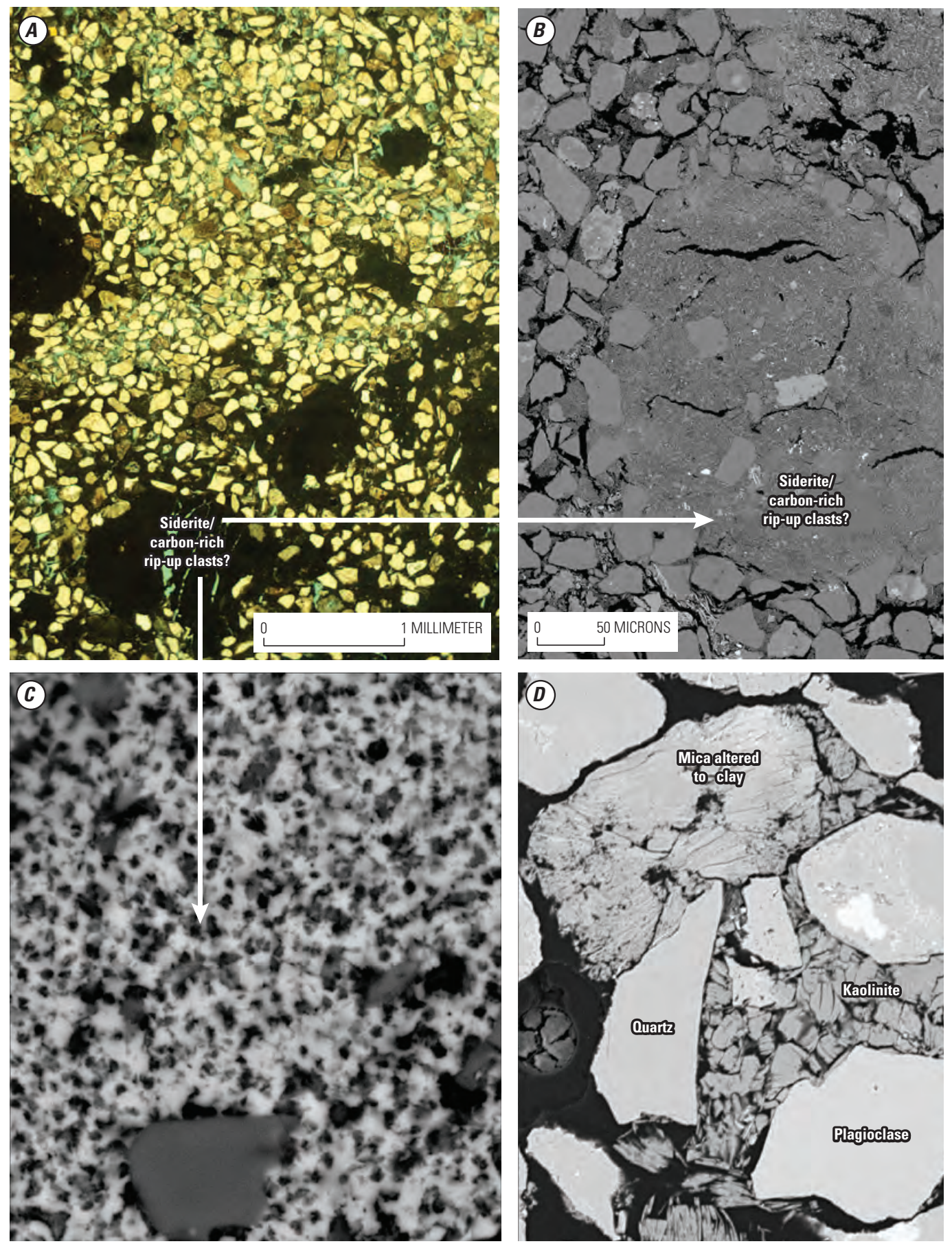

Figure 27. Samples from Fox Hills Sandstone, 897.0-897.2 feet below land surface, exploratory borehole LC-F1, southeastern Laramie County, Wyoming. A, plane-light photomicrograph showing fine-grained constituent grains and carbon-rich siderite (uncertain [?]) nodules. Void space between constituent grains shown in blue; $B$, scanning electron microscope (SEM) photomicrograph of carbonrich siderite "nodule" showing desiccation cracking. The nodules enclose constituent grains. Black areas are voids. Carbon-rich siderite appears to have acted as a cement, but the irregular nodules also look as though the cemented areas may have been subjected to erosional current activity that produced rip-up clasts of these nodules; $C$, SEM photomicrograph showing microporosity texture of carbon-rich siderite nodule and enclosed grain. Black areas are voids; $D$, SEM photomicrograph showing constituent grains of quartz (note that many grains are fractured) and plagioclase feldspar. Note occurrence of kaolinite, mica altered to clay, and booklets of clay occluding porosity. Black areas are voids; $E$, elongated angular grains show alignment across cross beds (cross beds and layering identified as white lines with arrows on ends), indicating current activity. Brighter grains are feldspars, and medium gray grains are quartz. Black areas are voids; F, SEM photomicrograph showing framboidal pyrite (bright white rounded grains), which indicates reducing conditions. 

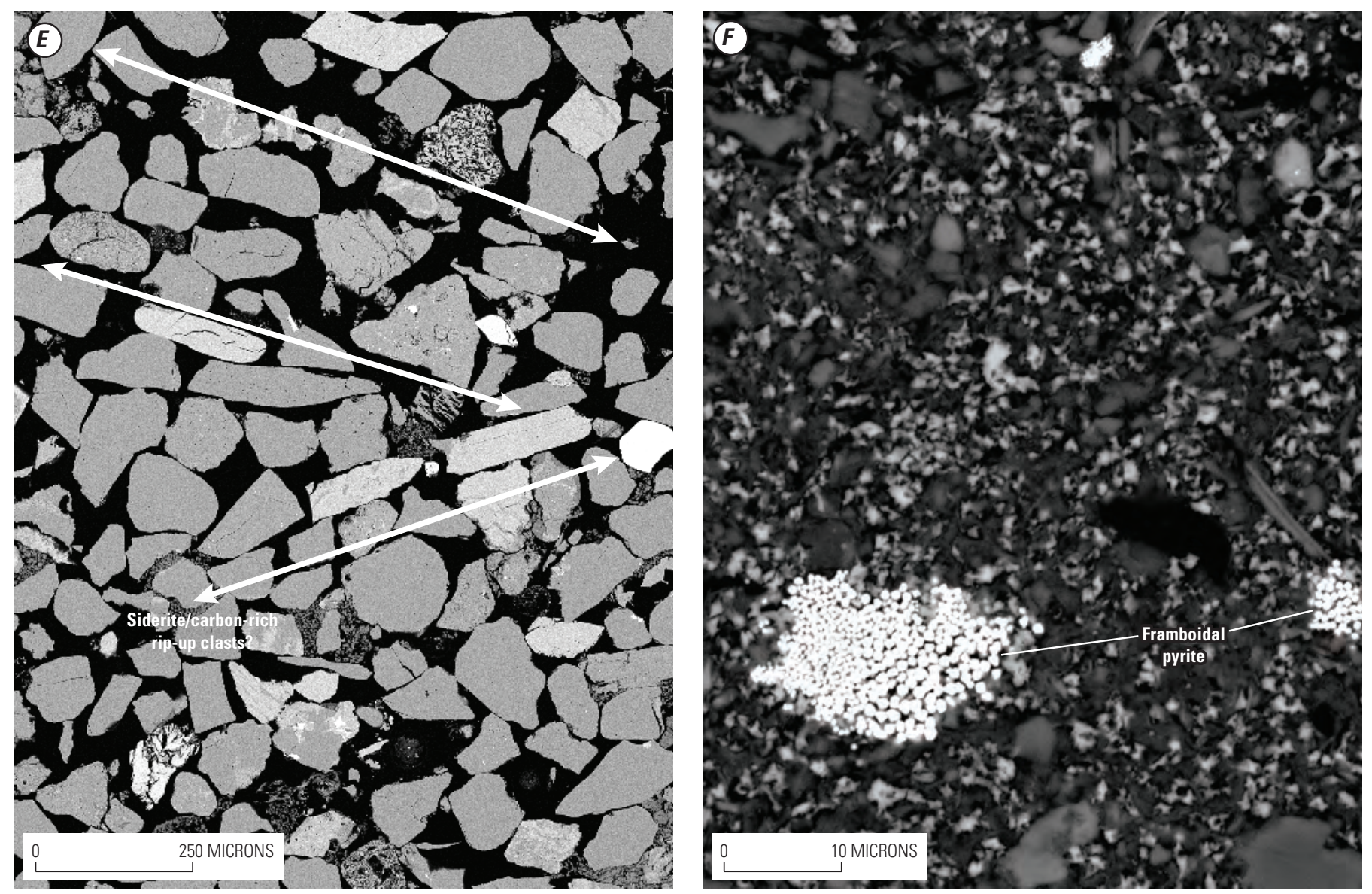

Figure 27. Samples from Fox Hills Sandstone, 897.0-897.2 feet below land surface, exploratory borehole LC-F1, southeastern Laramie County, Wyoming. $A$, plane-light photomicrograph showing fine-grained constituent grains and carbon-rich siderite (uncertain [?]) nodules. Void space between constituent grains shown in blue; $B$, scanning electron microscope (SEM) photomicrograph of carbonrich siderite "nodule" showing desiccation cracking. The nodules enclose constituent grains. Black areas are voids. Carbon-rich siderite appears to have acted as a cement, but the irregular nodules also look as though the cemented areas may have been subjected to erosional current activity that produced rip-up clasts of these nodules; $C$, SEM photomicrograph showing microporosity texture of carbon-rich siderite nodule and enclosed grain. Black areas are voids; $D$, SEM photomicrograph showing constituent grains of quartz (note that many grains are fractured) and plagioclase feldspar. Note occurrence of kaolinite, mica altered to clay, and booklets of clay occluding porosity. Black areas are voids; $E$, elongated angular grains show alignment across cross beds (cross beds and layering identified as white lines with arrows on ends), indicating current activity. Brighter grains are feldspars, and medium gray grains are quartz. Black areas are voids; F, SEM photomicrograph showing framboidal pyrite (bright white rounded grains), which indicates reducing conditions.-Continued 

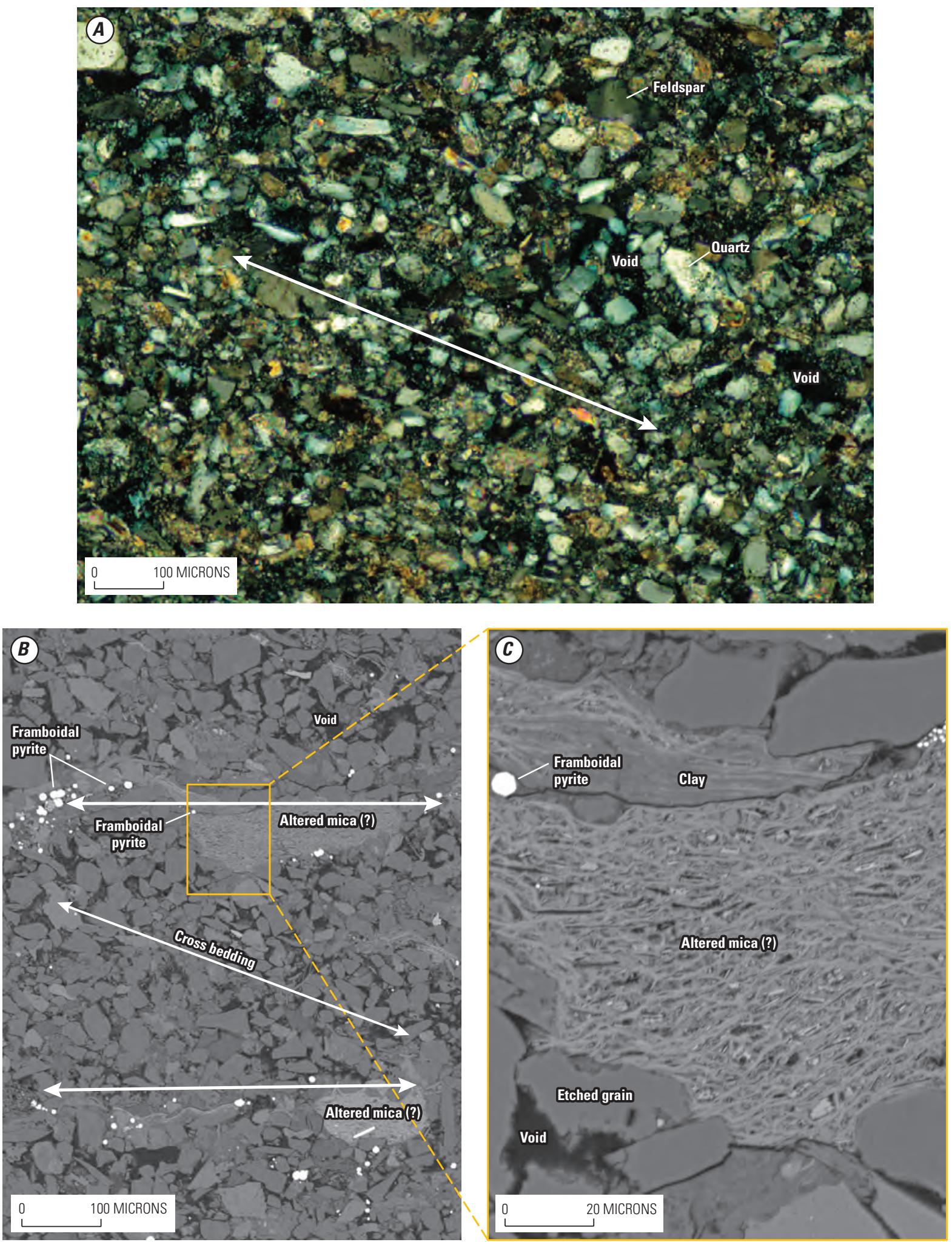

Figure 28. Samples from Fox Hills Sandstone, 920.8-921.0 feet below land surface, exploratory borehole LC-F1, southeastern Laramie County, Wyoming. $A$, cross-nicols photomicrograph showing constituent grains and cross bedding (cross beds and layering identified as white lines with arrows on ends). Black areas are voids; $B$, scanning electron microscope (SEM) photomicrograph showing poorly developed pressure-solution seams that are lined with framboidal pyrite (bright white circular grains), which indicates reducing conditions, and extensively altered large grains that likely once were micas (identified as "altered mica ([uncertain]?)"). Cross beds and layering identified as white lines with arrows on ends. Black areas are voids; $C$, SEM photomicrograph of area identified in orange rectangle in figure $28 B$ showing framboidal pyrite, alteration texture of micaceous grain (identified as "altered mica (?)"), and dissolution etching of grains, which demonstrates creation of secondary porosity (black area identified as void). 


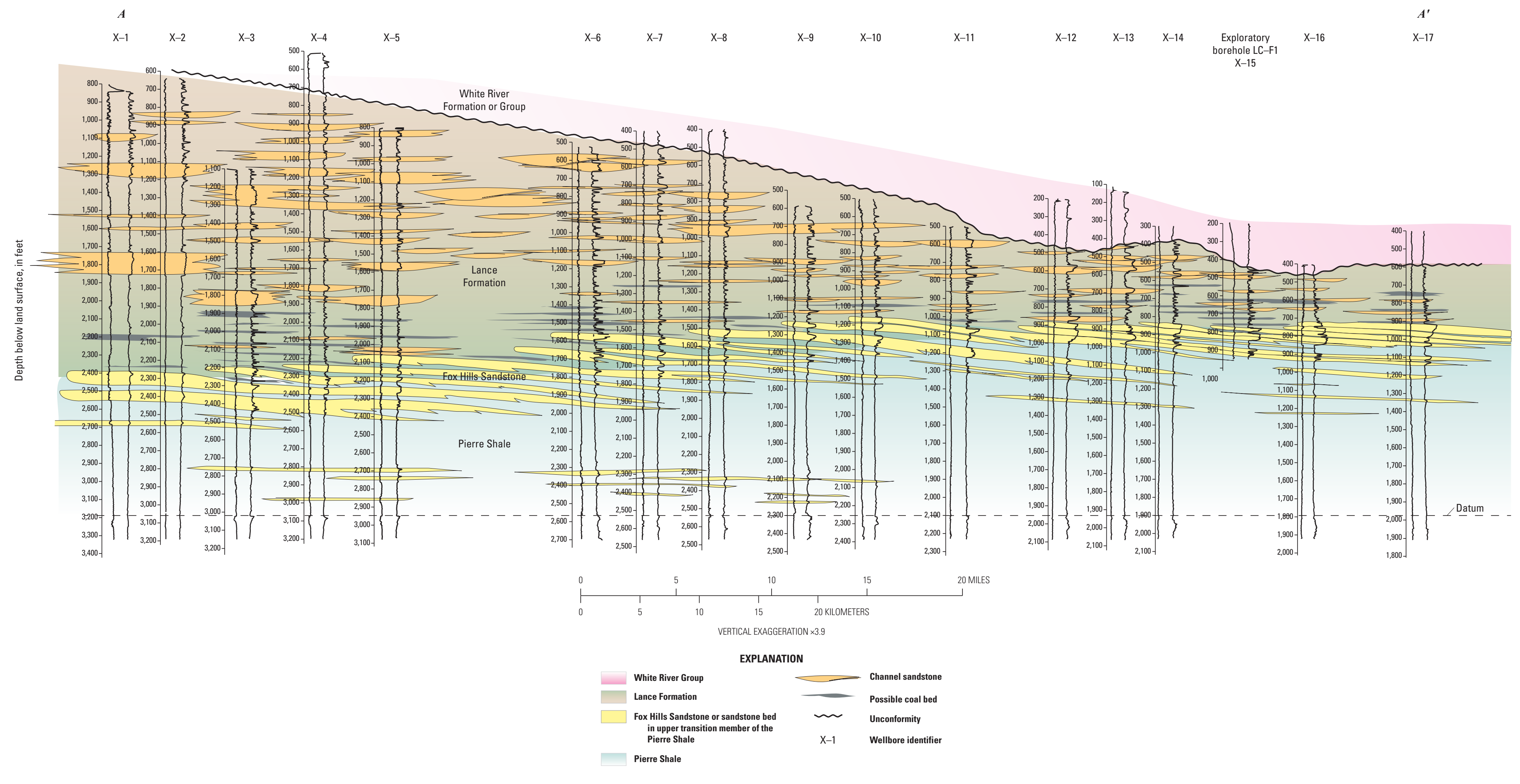




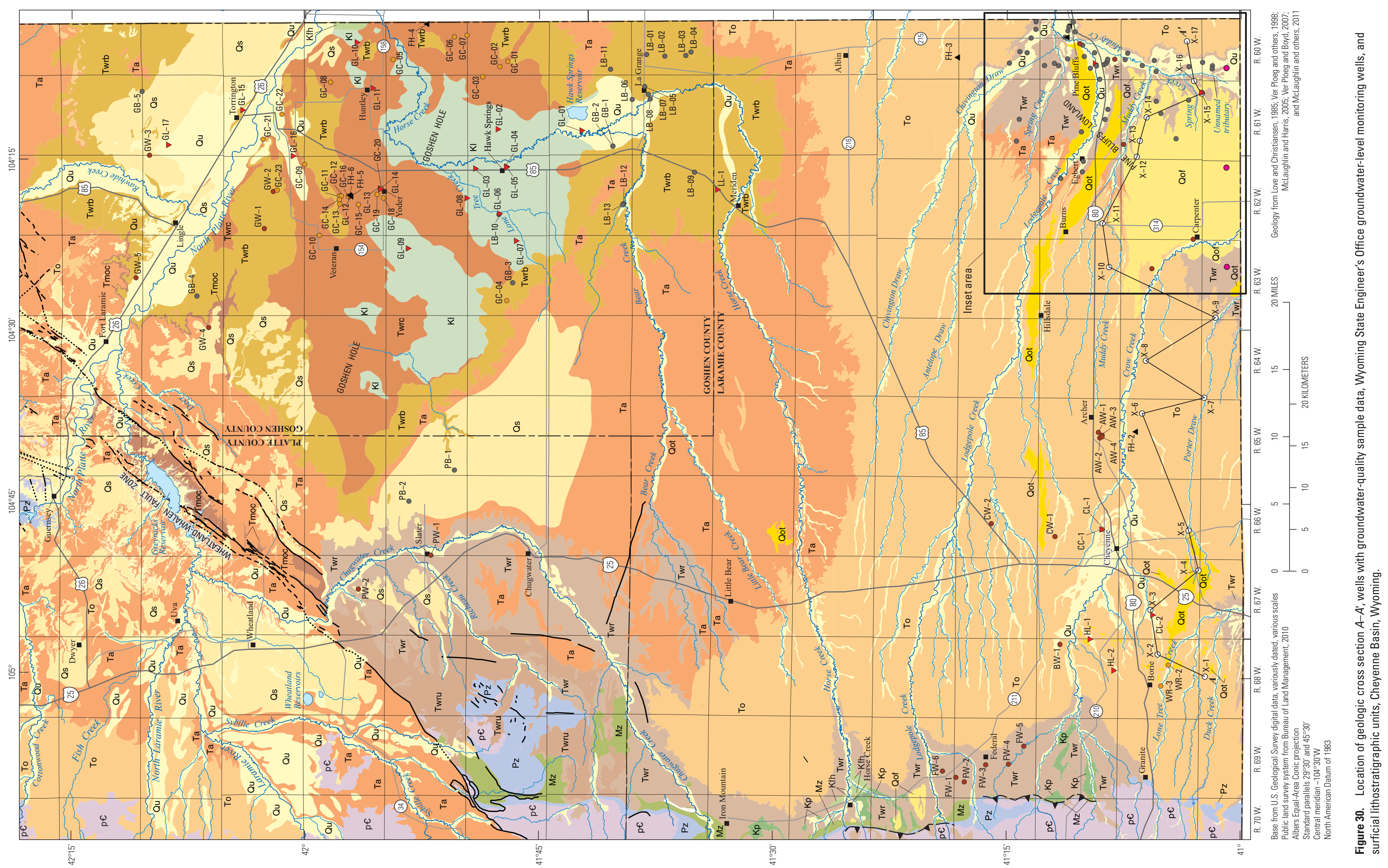




\section{EXPLANATION}

Lithostratigraphic units

\section{Quaternary unconsolidated deposits}

Holocene

Qu

Avium, terrace deposits, and colluvium

Qs

Eolian (windblown) deposits

Pleistocene

Qof Older alluvial fan deposits

Tertiary

To

Twr

Twru

White River Formation or Group (upper Eocene-Oligocene)

Twrb Brule Formation (Oligocene)

Twrc Chadron Formation (upper Eocene)

\section{Mesozoic}

KI Lance Formation (Upper Cretaceous)

Kfh Fox Hills Sandstone (Upper Cretaceous)

$\mathrm{Kp} \quad$ Pierre Shale (Upper Cretaceous)

$\mathrm{Mz}$ Mesozoic sedimentary rocks (undivided) older than Pierre Shale

\section{Paleozoic and Precambrian}

$\mathrm{Pz} \quad$ Paleozoic sedimentary rocks

pe Precambrian igneous and metamorphic rocks

Area where Quaternary older alluvial fan deposits were mapped as saturated in 1971 (Crist and Borchert, 1972)

$\underline{A \quad A_{\text {Line of section }}^{\prime}}$

- Fault

.......... Fault-Concealed

- - - - Fault-Inferred

Well with groundwater-quality sample and identifie

EW-2 White River aquifer

EB-13 Brule aquifer

GC-1॰ Chadron aquifer

$E L-1 \nabla$ Lance aquifer

$\mathrm{FH}^{-1} \triangle \quad$ Fox Hills aquifer

\section{$X-1 \cap$ Wellbore with geophysical} log used to construct geologic cross sectio

LCO1_Wyoming State Engineer's

Office High Plains aquifer

system groundwater-level

monitoring well and

identifier

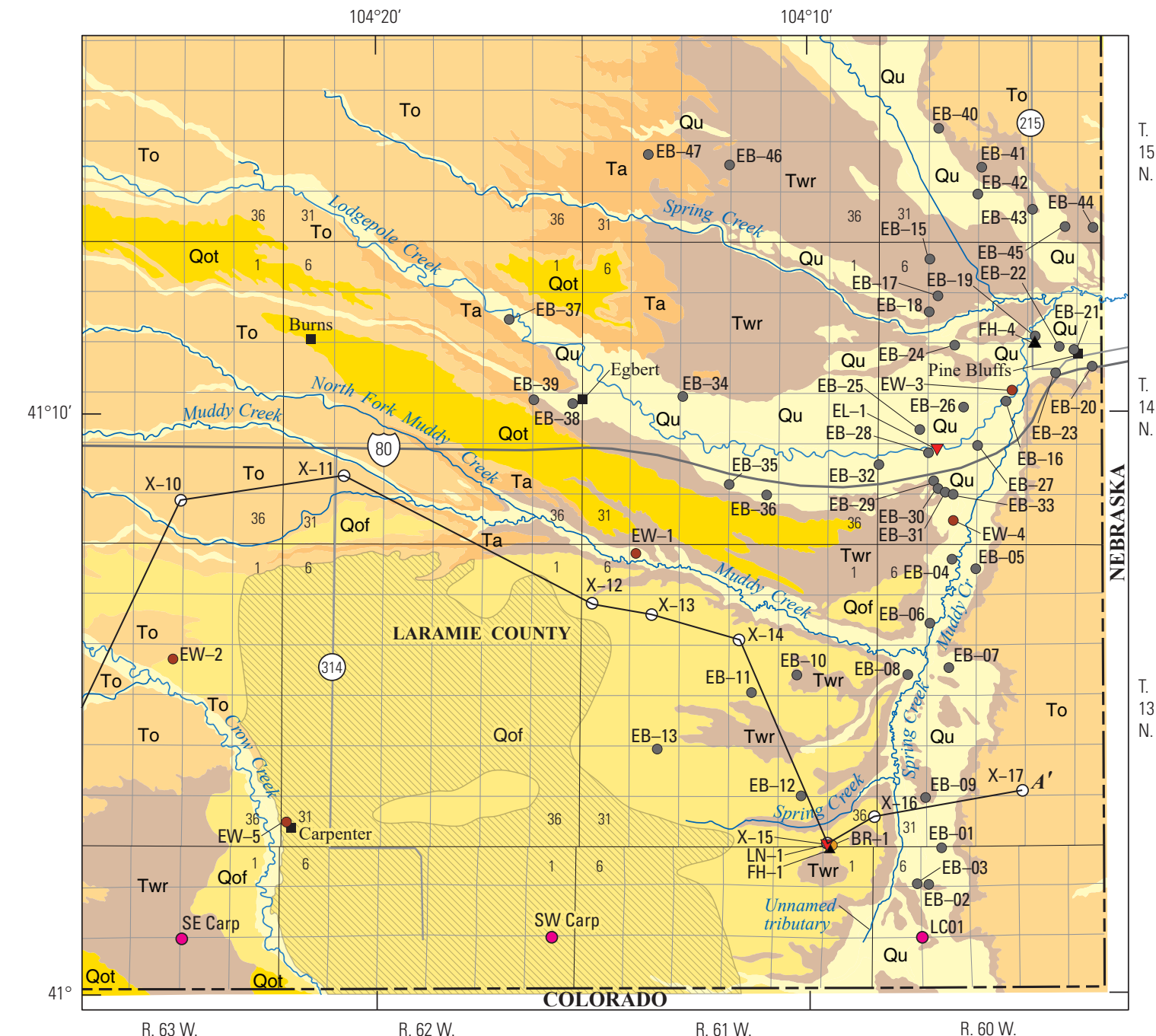

Base from U.S. Geological Survey digital data, variously dated, various scales Public land survey system from Bureau of Land Management, 2010 $\begin{array}{lll}1 & 1 & 1 \\ 2 & 4 & 6 \text { KILOMETERS }\end{array}$ Standard parallels $29^{\circ} 30^{\prime}$ and $45^{\circ} 30^{\prime \prime}$ Central meridian $-104^{\circ} 30^{\prime} \mathrm{W}$
Albers Equal-Area Conic projection North American Datum of 1983
Figure 30. Location of geologic cross section $A-A^{\prime}$ wells with groundwater-quality sample data, Wyoming State Engineer's Office groundwater-level monitoring wells, and surficial lithostratigraphic units, Cheyenne Basin, Wyoming.-Continued 
Kiteley's $(1976,1977,1978)$ member D of the Pierre Shale (fig. 6B; Jehn-Dellaport and Renninger, 2017). Petrographic examination of a thin section constructed from a sidewall core obtained from part of the Pierre ash in northeastern Colorado indicated some of the sediments were devitrified volcanic glass (Jehn-Dellaport and Renninger, 2017).

Identifying facies and recognizing the relations between lithostratigraphic units in each of the wells across the crosssection line indicate a regional pattern of eastward stepping up and progressively younger Fox Hills Sandstone bodies (fig. 29). Use of a common datum for cross-section construction allowed for illustration of the transitional nature of the contact between the Fox Hills Sandstone and upper transition member of the Pierre Shale. The cross section illustrates how the lower and upper Fox Hills sandstone beds detected in exploratory borehole LC-F1 are discrete parts/representations of several much larger sandstone bodies that are miles in length. Individual sandstone bodies extend laterally for many miles, and the overall regional pattern is similar to that observed in the Denver and Cheyenne Basins in northeastern Colorado (Raynolds and Dechesne, 2007; Dechesne and Raynolds, 2010; Dechesne and others, 2011a, b).

Collectively, the individual sandstone bodies composing the Fox Hills Sandstone form a continuous body of sandstone along the cross-section extent (fig. 29). Including intertonguing parts of the Lance Formation and (or) upper transition member of the Pierre Shale between individual Fox Hills sandstone beds, the Fox Hills Sandstone collectively spans as much as $300 \mathrm{ft}$ or more of overall stratigraphic section. In contrast, sandstone beds of the Lance Formation are slight in areal extent. Cumulative sandstone thickness of the Fox Hills Sandstone excluding intertonguing parts of the Lance Formation and (or) upper transition member of the Pierre Shale is highly variable and dependent on the number and thickness of Fox Hills sand bodies/beds present at any given location. Thickness of the Lance Formation and depth to the first Fox Hills sand bodies/beds increase substantially in a westward direction (fig. 29).

\section{Stratigraphy}

Study of the stratigraphy of the Fox Hills Sandstone in the Wyoming part of the Cheyenne Basin has been virtually nonexistent because of burial and extremely meager outcrop (fig. 30). However, as was discussed previously, studies of the Fox Hills Sandstone completed in the Colorado part of the Cheyenne Basin and the Denver Basin are directly applicable to the formation in the Wyoming part of the Cheyenne Basin. Consequently, stratigraphy of the formation discussed in this report section is derived primarily from studies completed south of the Wyoming-Colorado border.

As explained in the "Identification of Upper Cretaceous Lithostratigraphic Units in the Subsurface" report section and shown in the cross section in the previous report section, the Fox Hills Sandstone is transitional with the upper transition member of the Pierre Shale. Fossil mollusks (ammonites) collected from outcrops of the upper transition member and Fox Hills Sandstone in the Cheyenne and Denver Basins in northeastern Colorado have been used to relate the strata to the seven Maastrichtian Western Interior ammonite zones (most recent zonal table available in Merewether and others, 2011, fig. 2). The upper transition member of the Pierre Shale in the Cheyenne and Denver Basins corresponds to the Baculites clinolobatus and Hoploscaphites birkelundae Western Interior ammonite zones (fig. 6B; Kiteley, 1976, 1977, 1978; Scott and Cobban, 1986; Landman and Cobban, 2003; Cobban and others, 2006; Merewether and others, 2011). The Baculites clinolobatus zone is limited to the lower part of the upper transition member (Scott and Cobban, 1965; Kiteley, 1976; Landman and Cobban, 2003), and the zone is correlative with strata assigned to members $\mathrm{C}$ and $\mathrm{D}$ of the Pierre Shale (fig. $6 B$; Kiteley, 1976, 1977, 1978). The Baculites clinolobatus zone was dated by Cobban and others (2006) at $69.59 \pm 0.36 \mathrm{Ma}$.

The Hoploscaphites birkelundae zone is limited to the upper part of the upper transition member, including all the unnamed Pierre Shale strata above member D (fig. 6B; Kiteley, 1976, 1977, 1978; Landman and Cobban, 2003), as well as the intertonguing Fox Hills Sandstone (fig. 6B; Landman and Cobban, 2003). Older studies (for example Kiteley, 1976, fig. 5) assigned the strata to the Sphenodiscus (Coahuilites) ammonite zone, but this usage ended in the late 1980s (Cobban and others, 2006). Landman and Cobban (2003) noted that ammonites found in the Cheyenne and Denver Basins identified as Sphenodiscus (Coahuilites) in earlier studies are probably Coahuilites sheltoni. The Hoploscaphites birkelundae zone is defined by the occurrence of the ammonites Hoploscaphites birkelundae and Jeletzkytes dorfi, but other ammonites (Coahuilites sheltoni and Sphenodiscus pleurisepta) also are found in the zone in northeastern Colorado (Landman and Cobban, 2003). Coahuilites sheltoni is found in the Baculites clinolobatus and Hoploscaphites birkelundae zones. Sphenodiscus pleurisepta is only found in the Hoploscaphites birkelundae zone. Landman and Cobban (2003, p. 7) noted the Hoploscaphites birkelundae zone "represents the lower part of the upper Maastrichtian in the Western Interior [fig. 6B]" and "the presence of this zone indicates that these rocks [upper part of the upper transition member of the Pierre Shale and Fox Hills Sandstone] are equivalent in age to the Fox Hills Formation in Niobrara County, Wyoming, and older than the Fox Hills Formation in its type area in north-central South Dakota (Waage, 1968).”

\section{Hydrogeologic Characteristics of Study Site Strata}

The chemical and physical hydrogeologic characteristics of the aquifers contained in Tertiary and Upper Cretaceous hydrogeologic units at the study site are described in this section of the report. 


\section{Groundwater-Quality Characteristics}

Groundwater-quality characteristics of the five groundwater samples (fig. 30) collected during this study are described in this section of the report. In addition, groundwater-quality data collected from wells completed in the Lance and Fox Hills aquifers as part of other studies were compiled (appendixes 2, 3, fig. 30) from the USGS NWIS database (U.S. Geological Survey, 2019) and other sources (Cady, 1935; Weston Engineering, Inc., 1996a, 1999b; Lidstone and Associates, Inc., 2003; Dahlgren Consulting, Inc., and others, 2005; JR Engineering and Lidstone and Associates, Inc., 2009; Wyoming Groundwater, LLC, and others, 2011) for comparison with samples collected as part of this study and to provide a compilation of available water-quality data for these two aquifers.

\section{Physical Properties}

Physical properties measured during collection of groundwater samples included water temperature, $\mathrm{pH}$, turbidity, specific conductance, and DO (table 5). These properties tend to be unstable and are determined onsite as part of the sample collection process. DO is discussed in the next report section ("Redox Conditions").

In the monitoring wells installed for this study, water temperature was measured at 17.5 degrees Celsius $\left({ }^{\circ} \mathrm{C}\right)$ in $\mathrm{BR}-1,15.9^{\circ} \mathrm{C}$ in $\mathrm{LN}-1$, and $15.5^{\circ} \mathrm{C}$ in $\mathrm{FH}-1$ (table 5). Water temperatures measured in the two other wells sampled as part of the study, both of which were completed in the Fox Hills aquifer, were substantially warmer $\left(29.3\right.$ and $22.3{ }^{\circ} \mathrm{C}$ in wells FH-2 and FH-3, respectively).

Measured $\mathrm{pH}$ in all sampled wells ranged from 8.1 to 8.9, indicating all waters were alkaline ( $\mathrm{pH}>7.5$; table 5). Alkaline $\mathrm{pH}$ values greater than 8 are common in other groundwaterquality samples from the Lance and Fox Hills aquifers in the Cheyenne Basin (appendix 2, table 2.1; appendix 3, table 3.1). The $\mathrm{pH}$ measured in groundwater from two of three sampled wells completed in the Fox Hills aquifer was greater than 8.5 (8.9 in well FH-1 and 8.7 in well FH-3; table 5). Three of four groundwater-quality samples collected as part of other studies from wells completed in the Fox Hills aquifer (wells FH-5, FH-6, and FH-7 in Goshen County in Goshen Hole; fig. 30) had $\mathrm{pH}$ values greater than 8.5 (appendix 3, table 3.1). Values of $\mathrm{pH}$ greater than 8.5 exceed the EPA SMCL, the Wyoming Class I domestic water standard, and the Wyoming Class III livestock water standard (table 5). Waters with a $\mathrm{pH}$ greater than 8.5 may have a soda taste, feel slippery, and leave mineral deposits on plumbing fixtures (U.S. Environmental Protection Agency, 2018). Values of $\mathrm{pH}$ tend to be higher in older groundwaters, as $\mathrm{pH}$ tends to increase with increasing residence time because water-rock interactions typically consume hydrogen ions (Hem, 1985).

Because electrical conductance varies with temperature, specific-conductance measurements (in microsiemens per centimeter) are reported relative to a standard temperature $\left(25^{\circ} \mathrm{C}\right.$; table 5). Specific conductance was larger in the groundwater samples collected from the three wells completed in the Fox Hills aquifer (622-852 microsiemens per centimeter $[\mu \mathrm{S} / \mathrm{cm}])$ than in the other (shallower) wells $(540 \mu \mathrm{S} / \mathrm{cm}$ in well BR-1 completed in the White River aquifer and $457 \mu \mathrm{S} / \mathrm{cm}$ in well $\mathrm{LN}-1$ completed in the Lance aquifer; table 5).

Turbidity is an indicator of the "cloudiness" of water. The EPA SMCL for turbidity (5 nephelometric turbidity ratio units) was exceeded in one sampled well (FH-2, 57 nephelometric turbidity ratio units; table 5). Well FH-2 was sampled near the end of a 24-hour aquifer test. It is possible that the high pumping rates necessary to stress the aquifer and induce drawdown for the test increased turbidity beyond what would be expected during normal (lower) pumping rates.

\section{Redox Conditions}

The chemical quality of groundwater commonly is affected by reduction-oxidation (redox) processes. A brief description of redox processes in groundwater, largely modified from Jurgens and others (2009) and Thiros and others (2014), is provided in this paragraph. Redox processes typically are facilitated by microorganisms (bacteria), which obtain energy by transferring electrons from donors (usually organic carbon but also could be inorganic chemical species) to terminal-electron acceptors (usually inorganic chemical species). As the organic carbon or inorganic chemical species donates electrons, it is "oxidized," and the inorganic chemical species that accepts electrons is "reduced." Some terminalelectron acceptors provide more energy than others; consequently, terminal-electron acceptors that provide the most energy are used first, and acceptors that yield less energy are used in order of decreasing energy gain. If DO is present, it is the preferred terminal-electron acceptor because reduction of DO produces more energy than reduction of other commonly occurring chemical species in groundwater. DO in groundwater is obtained from the atmosphere, so the redox conditions in an aquifer near where recharge occurs typically are oxic. As groundwater moves through the aquifer, the DO in groundwater is gradually consumed by redox processes. After all the DO is consumed, other chemical species can accept electrons and become reduced. If nitrate is present, it will become the preferred terminal-electron acceptor until it is completely consumed. Then, this pattern continues along a well-known ecological sequence with manganese, iron, sulfate, and finally carbon dioxide acting as terminal-electron acceptors until they are all consumed. This order of use of terminal-electron acceptors can affect the concentration, transport, and fate of many constituents in groundwater, as well as produce undesirable constituents such as manganous manganese, ferrous iron, or dissolved gases (hydrogen sulfide and methane).

Anoxic waters (waters with little or no oxygen) have been qualitatively grouped by some investigators (Thiros and others, 2014) into three redox classification categories that broadly describe the "intensity" of reducing conditionswaters in which nitrate reduction is occurring are classified as 


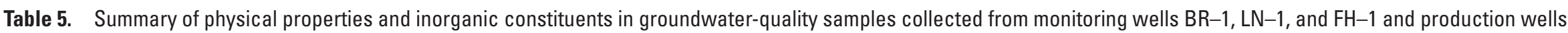
FH-2 and FH-3, southeastern Laramie County, Wyoming.

[USGS, U.S. Geological Survey; NWIS, National Water Information System; EPA, U.S. Environmental Protection Agency; --, not applicable or available; SMCL, Secondary Maximum Contaminant Level; NTRU, nephelometric turbidity ratio unit; $\mu \mathrm{S} / \mathrm{cm}$, microsiemens per centimeter at 25 degrees Celsius; mg/L, milligram per liter; L, long-term method detection limit; D, detection limit by DQCALC software; DWA, Drinking Water Advisory level, $\mathrm{CaCO}_{3}$, calcium carbonate; MCL, Maximum Contaminant Level; MRL, minimum reporting level; <, less than; HAL, lifetime Health Advisory Level; IRL, interim reporting level; $\mathrm{AL}$, Action Level; +, plus; C, carbon; pCi/L, picocuries per liter; \pm , plus or minus; CSU, 1-sigma combined standard uncertainty; SSLC, sample-specific critical level; R, radiochemical nondetect, value below sample-specific critical level; NA, not analyzed for this constituent; PMCL, proposed Maximum Contaminant Level; AMCL, proposed alternative Maximum Contaminant Level; mRem/yr, millirems per year; CE, counting error; DIC, dissolved inorganic carbon; per mil, parts per thousand]

\begin{tabular}{|c|c|c|c|c|c|c|c|c|c|c|c|}
\hline \multirow[b]{2}{*}{$\begin{array}{c}\text { Characteristic or } \\
\text { constituent }\end{array}$} & \multirow{2}{*}{$\begin{array}{c}\text { USGS } \\
\text { NWIS } \\
\text { parameter } \\
\text { code }\end{array}$} & \multirow[b]{2}{*}{$\begin{array}{l}\text { Reporting } \\
\text { level }\end{array}$} & \multirow{2}{*}{$\begin{array}{c}\text { White River } \\
\text { aquifer } \\
\text { BR-1 value } \\
\text { or concentra- } \\
\text { tion (Nov. 13, } \\
2013 \text { ) }\end{array}$} & \multirow{2}{*}{$\begin{array}{c}\begin{array}{c}\text { Lance } \\
\text { aquifer }\end{array} \\
\text { LN-1 value or } \\
\text { concentration } \\
\text { (Dec. 17, 2013) }\end{array}$} & \multicolumn{3}{|c|}{ Fox Hills aquifer } & \multirow{2}{*}{$\begin{array}{c}\text { EPA } \\
\text { drinking- } \\
\text { water } \\
\text { standards } \\
\text { or health } \\
\text { advisories }^{1}\end{array}$} & \multirow{2}{*}{$\begin{array}{l}\text { Wyoming } \\
\text { Class I } \\
\text { domestic- } \\
\text { water } \\
\text { standards² }\end{array}$} & \multirow{2}{*}{$\begin{array}{c}\text { Wyoming } \\
\text { Class II } \\
\text { agricultural } \\
\text { (irrigation)- } \\
\text { water } \\
\text { standards }^{2}\end{array}$} & \multirow{2}{*}{$\begin{array}{c}\text { Wyoming } \\
\text { Class III } \\
\text { livestock- } \\
\text { water } \\
\text { standards² }\end{array}$} \\
\hline & & & & & $\begin{array}{l}\text { FH-1 value or } \\
\text { concentration } \\
\text { (Nov. 14, 2013) }\end{array}$ & $\begin{array}{l}\text { FH-2 value or } \\
\text { concentration } \\
\text { (Dec. } 3,2014 \text { ) }\end{array}$ & $\begin{array}{l}\text { FH-3 value or } \\
\text { concentration } \\
\text { (Sept. 23, 2015) }\end{array}$ & & & & \\
\hline \multicolumn{12}{|c|}{ Physical properties } \\
\hline $\begin{array}{l}\text { Temperature } \\
\quad \text { (degrees Celsius) }\end{array}$ & 00010 & -- & 17.5 & 15.9 & 15.5 & 29.3 & 22.3 & -- & -- & -- & -- \\
\hline $\begin{array}{l}\mathrm{pH} \text {, field (standard } \\
\text { units) }\end{array}$ & 00400 & -- & 8.1 & 8.2 & 8.9 & 8.4 & 8.7 & $\begin{array}{l}6.5-8.5 \\
\text { (SMCL) }\end{array}$ & $6.5-8.5$ & $4.5-9.0$ & $6.5-8.5$ \\
\hline Turbidity (NTRU) & 63676 & -- & 1.3 & 1 & -- & 57 & 3 & 5 (SMCL) & -- & -- & -- \\
\hline $\begin{array}{l}\text { Specific conduc- } \\
\text { tance }(\mu \mathrm{S} / \mathrm{cm})\end{array}$ & 00095 & -- & 540 & 457 & 622 & 852 & 682 & -- & -- & -- & -- \\
\hline $\begin{array}{l}\text { Dissolved oxygen } \\
(\mathrm{mg} / \mathrm{L})\end{array}$ & 00300 & -- & 3.1 & 0.1 & 0.6 & 0.1 & 0.3 & -- & -- & -- & -- \\
\hline \multicolumn{12}{|c|}{ Major ions and related water-quality characteristics, in milligrams per liter unless otherwise noted, dissolved (sample filtered through 0.45-micrometer filter) } \\
\hline Calcium & 00915 & $0.022(\mathrm{~L}, \mathrm{D})$ & 26.7 & 9.05 & 2.26 & 3.08 & 1.95 & -- & -- & -- & -- \\
\hline Magnesium & 00925 & $0.011(\mathrm{~L}, \mathrm{D})$ & 6.74 & 2.46 & 0.589 & 0.617 & 0.574 & -- & -- & -- & -- \\
\hline Sodium & 00930 & $0.06(\mathrm{~L}, \mathrm{D})$ & 80.1 & 95.0 & 149 & 202 & 162 & $\begin{array}{l}20,30-60 \\
\text { (DWA) }\end{array}$ & -- & -- & -- \\
\hline Potassium & 00935 & $0.03(\mathrm{~L}, \mathrm{D})$ & 6.51 & 3.95 & 1.76 & 1.52 & 1.51 & -- & -- & -- & -- \\
\hline $\begin{array}{l}\text { Alkalinity }(\mathrm{mg} / \mathrm{L} \text { as } \\
\left.\mathrm{CaCO}_{3}\right)\end{array}$ & 39086 & Calculated & 141 & 199 & 276 & 373 & 346 & -- & -- & -- & -- \\
\hline Bicarbonate & 00453 & -- & 170 & 238 & 325 & 439 & 395 & -- & -- & -- & -- \\
\hline Carbonate & 00452 & -- & 0 & 2 & 6 & 7 & 12 & -- & -- & -- & -- \\
\hline Chloride & 00940 & $0.02(\mathrm{~L}, \mathrm{D})$ & 13.8 & 8.67 & 10.1 & 10.5 & 6.76 & $\begin{array}{c}250 \\
(\mathrm{SMCL})\end{array}$ & 250 & 100 & 2,000 \\
\hline Sulfate & 00945 & $0.02(\mathrm{~L}, \mathrm{D})$ & 93.8 & 39.6 & 26.9 & 72.9 & 18.9 & $\begin{array}{c}250 \\
(\mathrm{SMCL})\end{array}$ & 250 & 200 & 3,000 \\
\hline Fluoride & 00950 & $0.01(\mathrm{~L}, \mathrm{D})$ & 0.74 & 0.74 & 0.96 & 1.31 & 0.98 & $\begin{array}{l}2 \text { (SMCL) } \\
4 \text { (MCL) }\end{array}$ & 4 & -- & -- \\
\hline
\end{tabular}


Table 5. Summary of physical properties and inorganic constituents in groundwater-quality samples collected from monitoring wells BR-1, LN-1, and FH-1 and production wells FH-2 and FH-3, southeastern Laramie County, Wyoming.-Continued

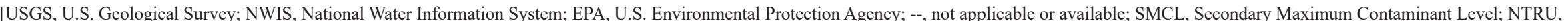
nephelometric turbidity ratio unit; $\mu \mathrm{S} / \mathrm{cm}$, microsiemens per centimeter at 25 degrees Celsius; mg/L, milligram per liter; L, long-term method detection limit; D, detection limit by DQCALC software; DWA,

Drinking Water Advisory level, $\mathrm{CaCO}_{3}$, calcium carbonate; MCL, Maximum Contaminant Level; MRL, minimum reporting level; <, less than; HAL, lifetime Health Advisory Level; IRL, interim reporting level; AL, Action Level; +, plus; C, carbon; pCi/L, picocuries per liter; \pm , plus or minus; CSU, 1-sigma combined standard uncertainty; SSLC, sample-specific critical level; R, radiochemical nondetect, value below sample-specific critical level; NA, not analyzed for this constituent; PMCL, proposed Maximum Contaminant Level; AMCL, proposed alternative Maximum Contaminant Level; mRem/yr, millirems per year; CE, counting error; DIC, dissolved inorganic carbon; per mil, parts per thousand]

\begin{tabular}{|c|c|c|c|c|c|c|c|c|c|c|c|}
\hline \multirow[b]{2}{*}{$\begin{array}{c}\text { Characteristic or } \\
\text { constituent }\end{array}$} & \multirow{2}{*}{$\begin{array}{c}\text { USGS } \\
\text { NWIS } \\
\text { parameter } \\
\text { code }\end{array}$} & \multirow[b]{2}{*}{$\begin{array}{l}\text { Reporting } \\
\text { level }\end{array}$} & \multirow{2}{*}{$\begin{array}{c}\text { White River } \\
\text { aquifer } \\
\text { BR-1 value } \\
\text { or concentra- } \\
\text { tion (Nov. 13, } \\
\text { 2013) }\end{array}$} & \multirow{2}{*}{$\begin{array}{c}\begin{array}{c}\text { Lance } \\
\text { aquifer }\end{array} \\
\text { LN-1 value or } \\
\text { concentration } \\
\text { (Dec. 17, 2013) }\end{array}$} & \multicolumn{3}{|c|}{ Fox Hills aquifer } & \multirow{2}{*}{$\begin{array}{c}\text { EPA } \\
\text { drinking- } \\
\text { water } \\
\text { standards } \\
\text { or health } \\
\text { advisories } \\
\end{array}$} & \multirow{2}{*}{$\begin{array}{l}\text { Wyoming } \\
\text { Class I } \\
\text { domestic- } \\
\text { water } \\
\text { standards }^{2}\end{array}$} & \multirow{2}{*}{$\begin{array}{l}\text { Wyoming } \\
\text { Class II } \\
\text { agricultural } \\
\text { (irrigation)- } \\
\text { water } \\
\text { standards }^{2}\end{array}$} & \multirow{2}{*}{$\begin{array}{l}\text { Wyoming } \\
\text { Class III } \\
\text { livestock- } \\
\text { water } \\
\text { standards }\end{array}$} \\
\hline & & & & & $\begin{array}{l}\text { FH-1 value or } \\
\text { concentration } \\
\text { (Nov. 14, 2013) }\end{array}$ & $\begin{array}{c}\text { FH-2 value or } \\
\text { concentration } \\
\text { (Dec. 3, 2014) }\end{array}$ & $\begin{array}{l}\text { FH-3 value or } \\
\text { concentration } \\
\text { (Sept. 23, 2015) }\end{array}$ & & & & \\
\hline \multicolumn{12}{|c|}{ Major ions and related water-quality characteristics, in milligrams per liter unless otherwise noted, dissolved (sample filtered through 0.45 -micrometer filter)—Continued } \\
\hline Silica & 00955 & $0.018(\mathrm{~L}, \mathrm{D})$ & 57.5 & 11.5 & 10.2 & 12.2 & 11.7 & -- & -- & -- & -- \\
\hline $\begin{array}{l}\text { Total dissolved } \\
\text { solids, dried } \\
\text { at } 180 \text { degrees } \\
\text { Celsius }\end{array}$ & 70300 & 20 (MRL) & 373 & 286 & 384 & 532 & 411 & $\begin{array}{c}500 \\
(\mathrm{SMCL})\end{array}$ & 500 & 2,000 & 5,000 \\
\hline $\begin{array}{l}\text { Hardness }(\mathrm{mg} / \mathrm{L} \text { as } \\
\left.\mathrm{CaCO}_{3}\right)\end{array}$ & 00900 & Calculated & 94.9 & 33.0 & 8.14 & 10.4 & 7.30 & -- & -- & -- & -- \\
\hline $\begin{array}{l}\text { Sodium adsorption } \\
\text { ratio (SAR) }\end{array}$ & 00931 & Calculated & 4 & 7 & 23 & 28 & 26 & -- & -- & 8 & -- \\
\hline \multicolumn{12}{|c|}{ Trace elements, in micrograms per liter unless otherwise noted, dissolved (sample filtered through 0.45 -micrometer filter) } \\
\hline Aluminum & 01106 & $2.2(\mathrm{~L}, \mathrm{D})$ & 3.5 & 2.6 & 33.8 & 26.2 & 45.8 & $\begin{array}{c}50-200 \\
\text { (SMCL) }\end{array}$ & -- & 5,000 & 5,000 \\
\hline Antimony & 01095 & $0.027(\mathrm{~L}, \mathrm{D})$ & 0.406 & $<0.027$ & 0.045 & 0.149 & $<0.027$ & 6 (MCL) & -- & -- & -- \\
\hline Arsenic & 01000 & $0.10(\mathrm{~L}, \mathrm{D})$ & 11.5 & 0.90 & 0.58 & 0.92 & $<0.10$ & 10 (MCL) & 50 & 100 & 200 \\
\hline Barium & 01005 & $0.25(\mathrm{~L}, \mathrm{D})$ & 21.6 & 30.4 & 12.8 & 32.6 & 20.4 & $\begin{array}{l}2,000 \\
(\mathrm{MCL})\end{array}$ & 2,000 & -- & -- \\
\hline Beryllium & 01010 & $0.02(\mathrm{~L}, \mathrm{D})$ & $<0.02$ & $<0.02$ & $<0.02$ & 0.022 & $<0.02$ & 4 (MCL) & -- & 100 & -- \\
\hline Boron & 01020 & $5.0(\mathrm{~L}, \mathrm{D})$ & 115 & 107 & 204 & 345 & 280 & $\begin{array}{l}6,000 \\
\text { (HAL) }\end{array}$ & 750 & 750 & 5,000 \\
\hline Bromide (mg/L) & 71870 & $\begin{array}{l}0.01-0.03 \\
\quad(\text { IRL })\end{array}$ & 0.210 & 0.144 & 0.151 & 0.134 & 0.126 & -- & -- & -- & -- \\
\hline Cadmium & 01025 & $0.03(\mathrm{~L}, \mathrm{D})$ & 0.034 & $<0.03$ & $<0.03$ & $<0.030$ & $<0.03$ & 5 (MCL) & 5 & 10 & 50 \\
\hline Chromium & 01030 & $0.3(\mathrm{~L}, \mathrm{D})$ & 2.9 & $<0.30$ & $<0.30$ & $<0.30$ & $<0.30$ & 100 (MCL) & 100 & 100 & 50 \\
\hline Cobalt & 01035 & $0.05(\mathrm{~L}, \mathrm{D})$ & 0.085 & $<0.05$ & 0.251 & 0.095 & $<0.05$ & -- & -- & 50 & 1,000 \\
\hline Copper & 01040 & $0.8(\mathrm{~L}, \mathrm{D})$ & 1.2 & $<0.80$ & $<0.80$ & $<0.80$ & $<0.80$ & $\begin{array}{c}1,000 \\
(\mathrm{SMCL}) \\
1,300(\mathrm{AL})\end{array}$ & 1,000 & 200 & 500 \\
\hline
\end{tabular}




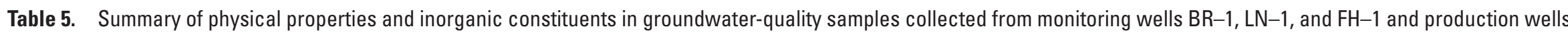
FH-2 and FH-3, southeastern Laramie County, Wyoming.-Continued

[USGS, U.S. Geological Survey; NWIS, National Water Information System; EPA, U.S. Environmental Protection Agency; --, not applicable or available; SMCL, Secondary Maximum Contaminant Level; NTRU, nephelometric turbidity ratio unit; $\mu \mathrm{S} / \mathrm{cm}$, microsiemens per centimeter at 25 degrees Celsius; mg/L, milligram per liter; L, long-term method detection limit; D, detection limit by DQCALC software; DWA,

Drinking Water Advisory level, $\mathrm{CaCO}_{3}$, calcium carbonate; MCL, Maximum Contaminant Level; MRL, minimum reporting level; <, less than; HAL, lifetime Health Advisory Level; IRL, interim reporting level; AL, Action Level; +, plus; C, carbon; pCi/L, picocuries per liter; \pm , plus or minus; CSU, 1-sigma combined standard uncertainty; SSLC, sample-specific critical level; R, radiochemical nondetect, value below sample-specific critical level; NA, not analyzed for this constituent; PMCL, proposed Maximum Contaminant Level; AMCL, proposed alternative Maximum Contaminant Level; mRem/yr, millirems per year; CE, counting error; DIC, dissolved inorganic carbon; per mil, parts per thousand]

\begin{tabular}{|c|c|c|c|c|c|c|c|c|c|c|c|}
\hline \multirow[b]{2}{*}{$\begin{array}{c}\text { Characteristic or } \\
\text { constituent }\end{array}$} & \multirow{2}{*}{$\begin{array}{c}\text { USGS } \\
\text { NWIS } \\
\text { parameter } \\
\text { code }\end{array}$} & \multirow[b]{2}{*}{$\begin{array}{l}\text { Reporting } \\
\text { level }\end{array}$} & \multirow{2}{*}{$\begin{array}{c}\text { White River } \\
\text { aquifer } \\
\text { BR-1 value } \\
\text { or concentra- } \\
\text { tion (Nov. 13, } \\
\text { 2013) }\end{array}$} & \multirow{2}{*}{$\begin{array}{c}\begin{array}{c}\text { Lance } \\
\text { aquifer }\end{array} \\
\text { LN-1 value or } \\
\text { concentration } \\
\text { (Dec. 17, 2013) }\end{array}$} & \multicolumn{3}{|c|}{ Fox Hills aquifer } & \multirow{2}{*}{$\begin{array}{c}\text { EPA } \\
\text { drinking- } \\
\text { water } \\
\text { standards } \\
\text { or health } \\
\text { advisories }\end{array}$} & \multirow{2}{*}{$\begin{array}{l}\text { Wyoming } \\
\text { Class I } \\
\text { domestic- } \\
\text { water } \\
\text { standards }^{2}\end{array}$} & \multirow{2}{*}{$\begin{array}{l}\text { Wyoming } \\
\text { Class II } \\
\text { agricultural } \\
\text { (irrigation)- } \\
\text { water } \\
\text { standards }^{2}\end{array}$} & \multirow{2}{*}{$\begin{array}{l}\text { Wyoming } \\
\text { Class III } \\
\text { livestock- } \\
\text { water } \\
\text { standards }^{2}\end{array}$} \\
\hline & & & & & $\begin{array}{l}\text { FH-1 value or } \\
\text { concentration } \\
\text { (Nov. 14, 2013) }\end{array}$ & $\begin{array}{l}\text { FH-2 value or } \\
\text { concentration } \\
\text { (Dec. 3, 2014) }\end{array}$ & $\begin{array}{l}\text { FH-3 value or } \\
\text { concentration } \\
\text { (Sept. 23, 2015) }\end{array}$ & & & & \\
\hline \multicolumn{12}{|c|}{ Trace elements, in micrograms per liter unless otherwise noted, dissolved (sample filtered through 0.45-micrometer filter)—Continued } \\
\hline Iron & 01046 & $4.0(\mathrm{~L}, \mathrm{D})$ & 8.1 & $<4.0$ & 49.8 & 184 & 19.2 & $\begin{array}{c}300 \\
(\mathrm{SMCL})\end{array}$ & 300 & 5,000 & -- \\
\hline Lead & 01049 & $0.04(\mathrm{~L}, \mathrm{D})$ & $<0.040$ & $<0.040$ & 0.051 & 0.042 & 0.045 & $15(\mathrm{AL})$ & 15 & 5,000 & 100 \\
\hline Lithium & 01130 & $0.22(\mathrm{~L}, \mathrm{D})$ & 20.3 & 15.5 & 13.1 & 23.2 & 15.5 & -- & -- & 2,500 & -- \\
\hline Manganese & 01056 & $0.40(\mathrm{~L}, \mathrm{D})$ & 4.67 & 12.4 & 12.0 & 14.4 & 8.31 & 50 (SMCL) & 50 & 200 & -- \\
\hline Molybdenum & 01060 & $0.05(\mathrm{~L}, \mathrm{D})$ & 11.8 & 4.41 & 7.63 & 3.67 & 4.84 & 40 (HAL) & -- & -- & -- \\
\hline Nickel & 01065 & $0.20(\mathrm{~L}, \mathrm{D})$ & 2.3 & $<0.20$ & $<0.20$ & 0.37 & $<0.20$ & 100 (HAL) & -- & 200 & -- \\
\hline Selenium & 01145 & $0.05(\mathrm{~L}, \mathrm{D})$ & 4.9 & $<0.05$ & $<0.05$ & $<0.05$ & $<0.05$ & 50 (MCL) & 50 & 20 & 50 \\
\hline Silver & 01075 & $0.02(\mathrm{~L}, \mathrm{D})$ & $<0.020$ & $<0.02$ & $<0.02$ & $<0.02$ & 0.03 & $\begin{array}{l}100 \text { (HAL/ } \\
\text { SMCL) }\end{array}$ & 100 & -- & -- \\
\hline Strontium & 01080 & $0.8(\mathrm{~L}, \mathrm{D})$ & 359 & 185 & 52.5 & 88.7 & 52.9 & $\begin{array}{l}4,000 \\
\text { (HAL) }\end{array}$ & -- & -- & -- \\
\hline Thallium & 01057 & 0.03 (L,D) & $<0.030$ & $<0.03$ & $<0.03$ & $<0.03$ & $<0.03$ & 2 (MCL) & -- & -- & -- \\
\hline Vanadium & 01085 & $\begin{array}{l}0.08-0.10 \\
\quad(\mathrm{~L}, \mathrm{D})\end{array}$ & 14.8 & 0.54 & 0.16 & 0.55 & $<0.10$ & -- & -- & 100 & 100 \\
\hline Zinc & 01090 & $2.0(\mathrm{~L}, \mathrm{D})$ & 6.5 & $<2.0$ & $<2.0$ & $<2.0$ & 4.0 & $\begin{array}{c}2,000 \\
\text { (HAL) } \\
5,000 \\
(\mathrm{SMCL})\end{array}$ & 5,000 & 2,000 & 25,000 \\
\hline \multicolumn{12}{|c|}{ Nutrients, in milligrams per liter, dissolved (sample filtered through 0.45 -micrometer filter), and dissolved organic carbon } \\
\hline Nitrate, as nitrogen & 00618 & Calculated & 1.91 & $<0.040$ & $<0.040$ & $<0.040$ & NA & 10 (MCL) & 10 & -- & -- \\
\hline Nitrite, as nitrogen & 00613 & $0.001(\mathrm{~L}, \mathrm{D})$ & 0.016 & $<0.001$ & $<0.001$ & $<0.001$ & $<0.001$ & 1 (MCL) & 1 & -- & 10 \\
\hline $\begin{array}{l}\text { Nitrate + nitrite, as } \\
\text { nitrogen }\end{array}$ & 00631 & $0.04(\mathrm{~L}, \mathrm{D})$ & 1.93 & $<0.040$ & $<0.040$ & $<0.040$ & $<0.04$ & 10 (MCL) & -- & -- & 100 \\
\hline $\begin{array}{l}\text { Ammonia, as } \\
\text { nitrogen }\end{array}$ & 00608 & $0.01(\mathrm{~L}, \mathrm{D})$ & 0.01 & 0.05 & 0.36 & 0.66 & 0.36 & 30 (HAL) & 0.5 & -- & -- \\
\hline
\end{tabular}


Table 5. Summary of physical properties and inorganic constituents in groundwater-quality samples collected from monitoring wells BR-1, LN-1, and FH-1 and production wells FH-2 and FH-3, southeastern Laramie County, Wyoming.-Continued

[USGS, U.S. Geological Survey; NWIS, National Water Information System; EPA, U.S. Environmental Protection Agency; --, not applicable or available; SMCL, Secondary Maximum Contaminant Level; NTRU, nephelometric turbidity ratio unit; $\mu \mathrm{S} / \mathrm{cm}$, microsiemens per centimeter at 25 degrees Celsius; mg/L, milligram per liter; L, long-term method detection limit; D, detection limit by DQCALC software; DWA,

Drinking Water Advisory level, $\mathrm{CaCO}_{3}$, calcium carbonate; MCL, Maximum Contaminant Level; MRL, minimum reporting level; <, less than; HAL, lifetime Health Advisory Level; IRL, interim reporting level; AL, Action Level; +, plus; C, carbon; pCi/L, picocuries per liter; \pm , plus or minus; CSU, 1-sigma combined standard uncertainty; SSLC, sample-specific critical level; R, radiochemical nondetect, value below sample-specific critical level; NA, not analyzed for this constituent; PMCL, proposed Maximum Contaminant Level; AMCL, proposed alternative Maximum Contaminant Level; mRem/yr, millirems per year; CE, counting error; DIC, dissolved inorganic carbon; per mil, parts per thousand]

\begin{tabular}{|c|c|c|c|c|c|c|c|c|c|c|c|}
\hline \multirow[b]{2}{*}{$\begin{array}{c}\text { Characteristic or } \\
\text { constituent }\end{array}$} & \multirow{2}{*}{$\begin{array}{l}\text { USGS } \\
\text { NWIS } \\
\text { parameter } \\
\text { code }\end{array}$} & \multirow[b]{2}{*}{$\begin{array}{l}\text { Reporting } \\
\text { level }\end{array}$} & \multirow{2}{*}{$\begin{array}{c}\text { White River } \\
\text { aquifer } \\
\text { BR-1 value } \\
\text { or concentra- } \\
\text { tion (Nov. 13, } \\
\text { 2013) }\end{array}$} & \multirow{2}{*}{$\begin{array}{c}\begin{array}{c}\text { Lance } \\
\text { aquifer }\end{array} \\
\text { LN-1 value or } \\
\text { concentration } \\
\text { (Dec. 17, 2013) }\end{array}$} & \multicolumn{3}{|c|}{ Fox Hills aquifer } & \multirow{2}{*}{$\begin{array}{c}\text { EPA } \\
\text { drinking- } \\
\text { water } \\
\text { standards } \\
\text { or health } \\
\text { advisories }\end{array}$} & \multirow{2}{*}{$\begin{array}{l}\text { Wyoming } \\
\text { Class I } \\
\text { domestic- } \\
\text { water } \\
\text { standards² }\end{array}$} & \multirow{2}{*}{$\begin{array}{l}\text { Wyoming } \\
\text { Class II } \\
\text { agricultural } \\
\text { (irrigation)- } \\
\quad \text { water } \\
\text { standards² }\end{array}$} & \multirow{2}{*}{$\begin{array}{l}\text { Wyoming } \\
\text { Class III } \\
\text { livestock- } \\
\text { water } \\
\text { standards }\end{array}$} \\
\hline & & & & & $\begin{array}{l}\text { FH-1 value or } \\
\text { concentration } \\
\text { (Nov. 14, 2013) }\end{array}$ & $\begin{array}{l}\text { FH-2 value or } \\
\text { concentration } \\
\text { (Dec. 3, 2014) }\end{array}$ & $\begin{array}{l}\text { FH-3 value or } \\
\text { concentration } \\
\text { (Sept. 23, 2015) }\end{array}$ & & & & \\
\hline \multicolumn{12}{|c|}{ Nutrients, in milligrams per liter, dissolved (sample filtered through 0.45 -micrometer filter), and dissolved organic carbon-Continued } \\
\hline Organic nitrogen & 00607 & Calculated & 0.23 & -- & $<0.08$ & $<0.04$ & NA & -- & -- & -- & -- \\
\hline $\begin{array}{l}\text { Total nitrogen } \\
\quad \text { (nitrate }+ \text { nitrite } \\
\quad+\text { ammonia }+ \\
\quad \text { organic nitrogen) }\end{array}$ & 62854 & $0.05(\mathrm{~L}, \mathrm{D})$ & 2.18 & $<0.05$ & 0.43 & 0.70 & 0.42 & -- & -- & -- & -- \\
\hline $\begin{array}{l}\text { Phosphorus, as } \\
\text { phosphorus }\end{array}$ & 00666 & $0.003(\mathrm{~L}, \mathrm{D})$ & 0.017 & 0.008 & 0.121 & 0.068 & 0.143 & -- & -- & -- & -- \\
\hline $\begin{array}{l}\text { Orthophosphate, as } \\
\text { phosphorus }\end{array}$ & 00671 & $0.004(\mathrm{~L}, \mathrm{D})$ & $<0.080$ & 0.012 & 0.117 & 0.075 & 0.143 & -- & -- & -- & -- \\
\hline $\begin{array}{l}\text { Dissolved organic } \\
\text { carbon }(\mathrm{mg} / \mathrm{L} \\
\text { as } \mathrm{C})\end{array}$ & 00681 & $0.23(\mathrm{~L}, \mathrm{D})$ & 0.39 & $<0.23$ & 1.04 & 0.72 & 0.59 & -- & -- & -- & -- \\
\hline \multicolumn{12}{|c|}{ Radiochemical constituents and environmental isotopes } \\
\hline Uranium & 22703 & $0.014(\mathrm{~L}, \mathrm{D})$ & 9.54 & 1.80 & 0.161 & 0.093 & 0.022 & 30 (MCL) & -- & -- & -- \\
\hline $\begin{array}{l}\text { Tritium } \\
\quad(\mathrm{pCi} / \mathrm{L} \pm \mathrm{CSU})\end{array}$ & 07000 & $\begin{array}{l}0.15-0.32 \\
\text { (SSLC) }\end{array}$ & $\mathrm{R} 0.26 \pm{ }^{4} 0.32$ & $\begin{array}{c}0.41 \pm{ }^{4} 0.33 \\
{ }^{6}\left(\mathrm{R} 0.00 \pm{ }^{4} 0.33\right)\end{array}$ & $\mathrm{R} 0.3 \pm{ }^{4} 0.28$ & $\begin{array}{c}{ }^{5} \mathrm{R}-0.10 \pm \\
{ }^{4} 0.29\end{array}$ & $\begin{array}{c}{ }^{5} \mathrm{R}-0.12 \pm \\
{ }^{4} 0.07\end{array}$ & -- & -- & -- & -- \\
\hline $\begin{array}{l}\text { Radon-222 } \\
\qquad(\mathrm{pCi} / \mathrm{L} \pm \mathrm{CSU})\end{array}$ & 82303 & $\begin{array}{c}10.6-11.3 \\
(\mathrm{SSLC})\end{array}$ & NA & $123 \pm{ }^{4} 11$ & $41 \pm{ }^{4} 7.8$ & $440 \pm{ }^{4} 28$ & $463 \pm{ }^{4} 29$ & $\begin{array}{c}300 \\
(\mathrm{PMCL}) \\
4,000 \\
\text { (AMCL) }\end{array}$ & -- & -- & -- \\
\hline $\begin{array}{l}\text { Radium-226 } \\
\qquad\left(\text { dissolved }^{3}\right) \\
\quad(\mathrm{pCi} / \mathrm{L} \pm \mathrm{CSU})\end{array}$ & 09511 & $\begin{array}{l}0.021-0.084 \\
\quad(\text { SSLC) }\end{array}$ & NA & $0.09 \pm{ }^{4} 0.020$ & $0.083 \pm{ }^{4} 0.019$ & $0.103 \pm{ }^{4} 0.019$ & $0.094 \pm{ }^{4} 0.053$ & 75 (MCL) & 75 & 75 & 75 \\
\hline $\begin{array}{l}\text { Radium-228 } \\
\quad\left(\text { dissolved }^{3}\right) \\
\quad(\mathrm{pCi} / \mathrm{L} \pm \mathrm{CSU})\end{array}$ & 81366 & $\begin{array}{l}0.183-0.305 \\
\quad(\text { SSLC) }\end{array}$ & NA & $0.31 \pm{ }^{4} 0.13$ & $\mathrm{R} 0.08 \pm{ }^{4} 0.13$ & $0.39 \pm{ }^{4} 0.11$ & $0.69 \pm{ }^{4} 0.18$ & 75 (MCL) & 75 & 75 & 75 \\
\hline
\end{tabular}




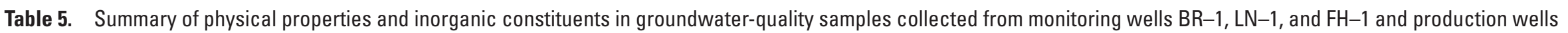
FH-2 and FH-3, southeastern Laramie County, Wyoming.-Continued

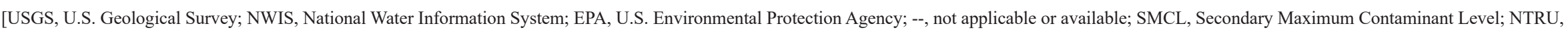

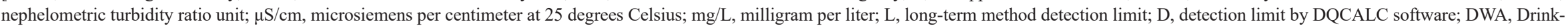
ing Water Advisory level, $\mathrm{CaCO}_{3}$, calcium carbonate; MCL, Maximum Contaminant Level; MRL, minimum reporting level; <, less than; HAL, lifetime Health Advisory Level; IRL, interim reporting level; AL, Action Level; +, plus; C, carbon; pCi/L, picocurie per liter; \pm , plus or minus; CSU, 1-sigma combined standard uncertainty; SSLC, sample-specific critical level; R, radiochemical nondetect, value below sample-

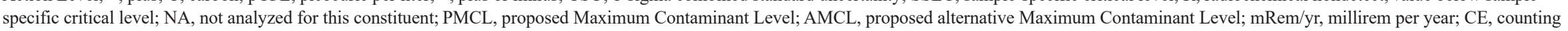
error; DIC, dissolved inorganic carbon; per mil, parts per thousand]

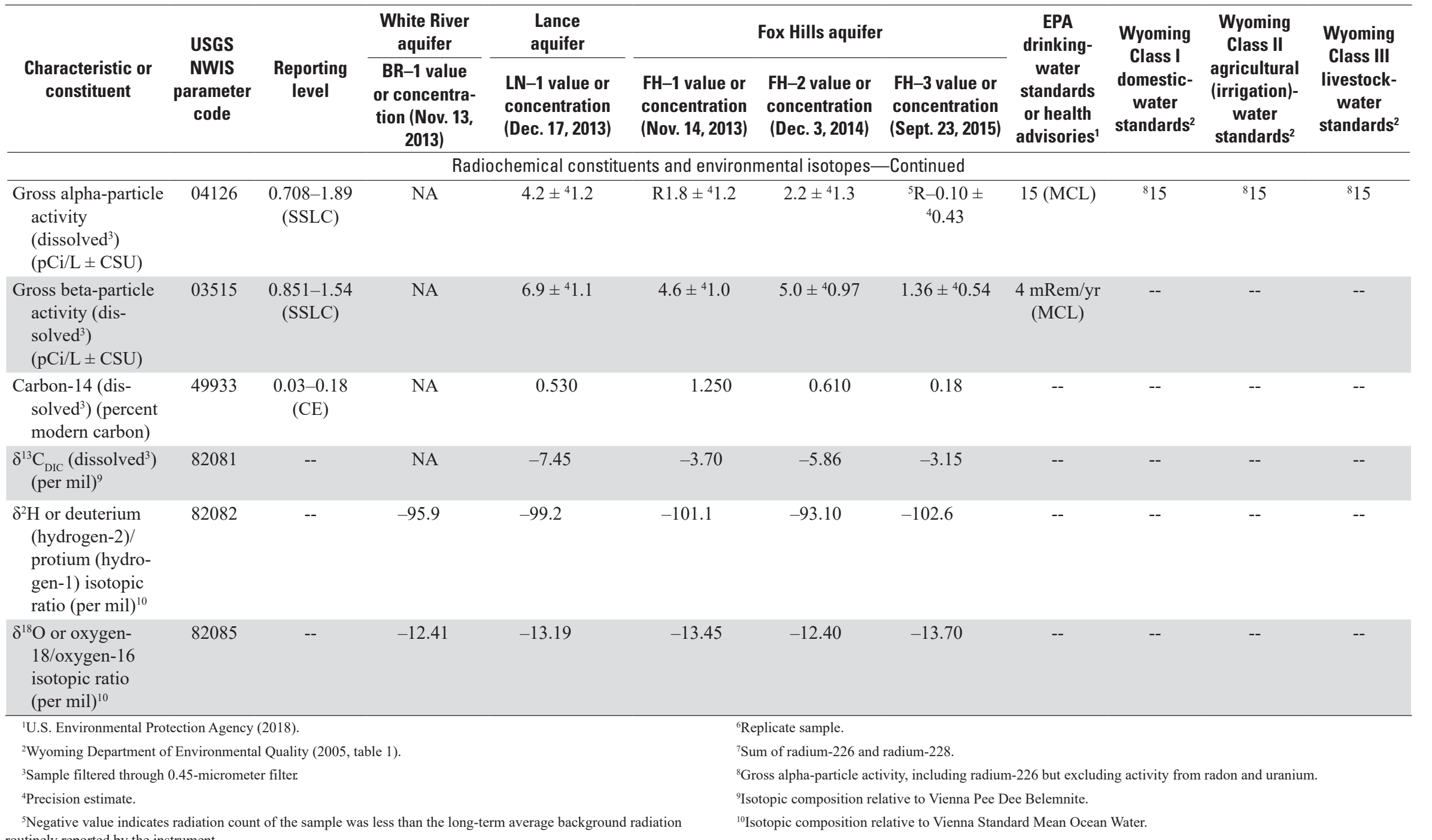


mildly reducing; waters in which manganese, iron, or sulfate reduction are occurring are classified as strongly reducing; and waters where carbon dioxide reduction is occurring are classified as very strongly reducing. Because redox reactions occur sequentially, strongly reducing conditions take a long time to develop. Consequently, anoxic groundwater typically is older than oxic groundwater, and within anoxic waters, strongly reducing groundwater typically is older than mildly reducing groundwater, and very strongly reducing groundwater typically is older than strongly reducing groundwater.

DO concentrations measured onsite using a field meter (table 5) were used as the first indication of the redox condition of water in each well. DO concentrations indicative of anoxic conditions (defined herein as having a DO concentration of less than $1 \mathrm{mg} / \mathrm{L}$ ) were measured in groundwater sampled from all wells except for BR-1. The DO measured in water from well BR-1 $(3.1 \mathrm{mg} / \mathrm{L})$ indicated groundwater from this well was oxic. Given that tritium was not detected in well BR-1, this DO measurement is higher than expected for groundwater interpreted to be recharged before the early $1950 \mathrm{~s}$ (see "Apparent Groundwater Age" report section).

To gain further insight into redox processes in anoxic waters, several redox-sensitive species, including dissolved ferrous iron, dissolved sulfide (sum of dihydrogen sulfide [aqueous dihydrogen sulfide], hydrogen sulfide, and sulfide), and a more accurate quantification of low-level DO, were analyzed onsite with a spectrophotometer in three of four wells ( $\mathrm{LN}-1, \mathrm{FH}-1$, and $\mathrm{FH}-3$; table 6). Additionally, samples for analyses of dissolved gases also were collected from these three wells and well FH-2 (table 7) to confirm reducing conditions and possibly help with identification of redox processes such as methanogenesis. The concentrations of DO determined with the spectrophotometer and (or) detected in the dissolvedgas samples (tables 6 and 7, respectively) confirmed the low field-meter readings.

Concentrations of DO and several dissolved redoxsensitive constituents determined onsite (ferrous iron and sulfide) and offsite at a laboratory (nitrate and manganese) were used to further assess the redox status of reduced waters using a modification of the classification scheme of McMahon and Chapelle (2008) and Chapelle and others (2009). The modification was that the DO threshold for separating oxic from anoxic groundwater was increased from 0.5 to $1 \mathrm{mg} / \mathrm{L}$. Because redox processes in an aquifer tend to segregate into zones dominated by a single terminal-electron accepting process (TEAP), the classification scheme uses the concentrations of redox-sensitive species to assign the dominant redox process (TEAP) to groundwater samples. A spreadsheet program that automates the classification scheme was used to assign a general redox category and predominant redox process to each sample (Jurgens and others, 2009). Low DO waters in samples from one study site well (LN-1) and well FH-3 were classified as suboxic (table 6). The suboxic classification indicated reduced redox conditions, but additional data were needed to further define the redox process. Groundwater from wells $\mathrm{FH}-1$ and $\mathrm{FH}-2$ were classified as anoxic, and iron and (or) sulfate reduction, both indicators of strongly reducing conditions, were identified as the dominant TEAPs (table 6). Dissolved methane gas was detected at low concentrations $(<0.3 \mathrm{mg} / \mathrm{L})$ in samples from all three wells completed in the Fox Hills aquifer (table 7; methane also discussed in "Dissolved Hydrocarbon Gases" report section), indicating methanogenesis had taken place near the wells. The biogenic production of methane in groundwater is facilitated by microbial reduction of carbon dioxide, and this occurs only under very strongly reducing (highly anoxic) conditions (Chapelle, 2001). This indicates that all or parts of the aquifers screened by the wells may contain waters that are very strongly reduced and, thus, "more reduced" than the redox classification indicated. Evidence of more than one TEAP in water sampled from the three wells completed in the Fox Hills aquifer could be explained by the mixing of waters from different redox zones upgradient from the well, a well screen that extends across more than one redox zone, or spatial variability in microbial activity/redox processes in the aquifer (Chapelle, 2001).

\section{Apparent Groundwater Age}

The environmental tracers tritium and carbon-14 were used to determine the apparent age of groundwater sampled from monitoring wells $\mathrm{LC}-1$ and $\mathrm{FH}-1$ and production wells FH-2 and FH-3. These environmental tracers are present in the atmosphere at trace levels and can be valuable tools for understanding groundwater-flow systems by helping to determine or estimate areas and rates of recharge and discharge, residence time, direction of flow, flow velocities, contamination potential, and the time needed to flush contaminants from groundwater systems (Plummer and others, 1993; Clark and Fritz, 1997; Kendall and McDonnell, 1998; Cook and Herczeg, 2000). Introduced to the atmosphere at activities or concentrations exceeding natural background levels after anthropogenic (human) activities, these tracers are useful for dating groundwater. The age of groundwater applies to the date of introduction of the environmental tracers to the water and not to the age of the water itself; consequently, the age refers to the time elapsed since the water recharged the aquifer and was isolated from the source (atmosphere) of the tracer. Because age dates estimated from these environmental tracers may be affected by several factors, including mixing of waters of different ages, transport processes, chemical processes, and biogeochemical processes, groundwater ages commonly are referred to as "apparent ages."

\section{Tritium}

Tritium is a radioactive hydrogen isotope that undergoes radioactive decay with a half-life of 12.32 years (Lucas and Unterweger, 2000). Tritium activities are expressed in picocuries per liter or tritium units where 1 tritium unit (TU) is equal to 1 tritium atom in $10^{18}$ atoms of hydrogen (Shapiro and others, 2012). Based on a half-life of 12.32 years, $1 \mathrm{TU}$ is equal to about 3.22 picocuries per liter ( $\mathrm{pCi} / \mathrm{L}$ ) (Shapiro and 
Table 6. Assignment of redox categories and processes for groundwater-quality samples collected from monitoring wells LN-1 and FH-1 and production wells FH-2 and FH-3, southeastern Laramie County, Wyoming.

[mg/L, milligram per liter; $\mu \mathrm{g} / \mathrm{L}$, microgram per liter; $\mathrm{H}_{2} \mathrm{~S}$, dihydrogen sulfide; $\mathrm{HS}^{-}$, hydrogen sulfide; $\mathrm{S}^{2-}$, sulfide; <, less than; --, not available]

\begin{tabular}{|c|c|c|c|c|c|c|c|c|c|c|}
\hline \multirow[b]{2}{*}{$\begin{array}{l}\text { Well identifier } \\
\text { (fig. 1) }\end{array}$} & \multicolumn{3}{|c|}{ Dissolved oxygen (mg/L), by method of analysis } & \multirow{2}{*}{$\begin{array}{c}\text { Nitrate }\left(\mathrm{NO}_{3}{ }^{-}\right) \text {, } \\
\text { as nitrogen } \\
(\mu \mathrm{g} / \mathrm{L})\end{array}$} & \multirow{2}{*}{$\begin{array}{c}\text { Manganese }{ }^{3,4} \\
(\mathrm{Mn}) \\
(\mu \mathrm{g} / \mathrm{L})\end{array}$} & \multirow{2}{*}{ 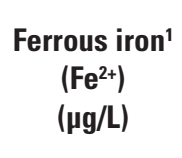 } & \multirow{2}{*}{$\begin{array}{c}\text { Sulfate }^{3} \\
\left(\mathrm{SO}_{4}{ }^{2-}\right) \\
(\mu \mathrm{g} / \mathrm{L})\end{array}$} & \multirow{2}{*}{$\begin{array}{c}\text { Sulfide }^{1} \\
\text { (sum of } \\
\left.\mathrm{H}_{2} \mathrm{~S}, \mathrm{HS}-\mathrm{S}^{2-}\right) \\
\text { (mg/L) }\end{array}$} & \multirow[b]{2}{*}{$\begin{array}{l}\text { General redox } \\
\text { category }\end{array}$} & \multirow[b]{2}{*}{ Redox process } \\
\hline & Field meter ${ }^{1}$ & $\begin{array}{c}\text { Spectro- } \\
\text { photometer }^{1}\end{array}$ & $\begin{array}{l}\text { Dissolved } \\
\text { gases }^{2}\end{array}$ & & & & & & & \\
\hline \multicolumn{11}{|c|}{ Lance aquifer } \\
\hline LN-1 & 0.1 & 0.1 & 0.2 & $<0.04$ & 12.4 & ${ }^{5} 40$ & 39.6 & 6 & Suboxic & Undetermined \\
\hline \multicolumn{11}{|c|}{ Fox Hills aquifer } \\
\hline FH-1 & -- & 0.6 & 0.2 & $<0.04$ & 12 & 1,110 & 26.9 & 200 & Anoxic (mixed) $)^{6}$ & Iron and sulfate ${ }^{6}$ \\
\hline $\mathrm{FH}-2$ & $<0.1$ & -- & 0.2 & $<0.04$ & 14.4 & ${ }^{7} 184$ & 72.9 & -- & Anoxic & $\begin{array}{l}\text { Iron and (or) } \\
\text { sulfate }^{6}\end{array}$ \\
\hline $\mathrm{FH}-3$ & 0.3 & $<0.1$ & -- & $<0.04$ & 8.31 & ${ }^{5} 40$ & 18.9 & 7 & Suboxic $^{6}$ & Undetermined $^{6}$ \\
\hline
\end{tabular}

\footnotetext{
${ }^{1}$ Analyzed onsite.

${ }^{2}$ Analyzed at U.S. Geological Survey Reston Chlorofluorocarbon Laboratory in Reston, Virginia.
}

${ }^{3}$ Analyzed at U.S. Geological Survey National Water Quality Laboratory in Denver, Colorado.

${ }^{4}$ Dissolved manganese determined at laboratory. Preference in automated spreadsheet of Jurgens and others (2009) used to assign general redox categories and determine redox processes is for manganous manganese $\left(\mathrm{Mn}^{2+}\right)$, but this form of manganese was not measured onsite so dissolved manganese determined at laboratory was used.

${ }^{5}$ Value larger than dissolved iron determined at laboratory (table 5). Use of dissolved iron value was tested in automated spreadsheet but did not change assignment of general redox category or redox process.

${ }^{6}$ Detection of low concentrations of methane indicated methanogenesis (see text).

${ }^{7}$ Value is dissolved iron from laboratory analysis because onsite determination was unavailable. 
Table 7. Analyses for dissolved gases in groundwater-quality samples collected from monitoring wells $\mathrm{LN}-1$ and $\mathrm{FH}-1$ and production wells $\mathrm{FH}-2$ and $\mathrm{FH}-3$, southeastern Laramie County, Wyoming.

[USGS, U.S. Geological Survey; <, less than; NA, not analyzed]

\begin{tabular}{|c|c|c|c|c|c|c|c|c|c|c|c|c|c|c|c|c|c|}
\hline \multirow{4}{*}{$\begin{array}{l}\text { Well } \\
\text { identifier } \\
\text { (fig. 1) }\end{array}$} & \multirow{4}{*}{$\begin{array}{c}\text { USGS } \\
\text { site-identification } \\
\text { number }\end{array}$} & \multirow{4}{*}{$\begin{array}{l}\text { Sample date } \\
\text { (month/day/ } \\
\text { year) }\end{array}$} & \multirow{4}{*}{$\begin{array}{l}\text { Sample } \\
\text { time } \\
\text { (24 hour) }\end{array}$} & \multirow{4}{*}{$\begin{array}{c}\text { Water } \\
\text { temperature, } \\
\text { field } \\
\text { (degrees } \\
\text { Celsius) }\end{array}$} & \multicolumn{13}{|c|}{ Dissolved-gas concentration (milligrams per liter) } \\
\hline & & & & & \multicolumn{4}{|c|}{ Methane $\left(\mathrm{CH}_{4}\right)$} & \multirow{2}{*}{\multicolumn{3}{|c|}{$\begin{array}{l}\text { Carbon } \\
\text { dioxide }{ }^{1} \\
\left(\mathrm{CO}_{2}\right)\end{array}$}} & \multirow{2}{*}{\multicolumn{2}{|c|}{ Nitrogen $\left(\mathbf{N}_{2}\right)^{1}$}} & \multirow{2}{*}{\multicolumn{2}{|c|}{ Oxygen $\left(0_{2}\right)^{1}$}} & \multirow{2}{*}{\multicolumn{2}{|c|}{$\operatorname{Argon}(\operatorname{Ar})^{1}$}} \\
\hline & & & & & \multicolumn{2}{|c|}{$\begin{array}{c}\text { USGS } \\
\text { laboratory }\end{array}$} & \multirow{2}{*}{$\begin{array}{l}\text { Contract } \\
\text { labora- } \\
\text { tory }^{2}\end{array}$} & \multirow{2}{*}{$\begin{array}{c}\text { Ethene }^{2,3} \\
\left(\mathrm{C}_{2} \mathrm{H}_{4}\right)\end{array}$} & & & & & & & & & \\
\hline & & & & & Vial 1 & Vial 2 & & & & Vial 1 & Vial 2 & Vial 1 & Vial 2 & Vial 1 & Vial 2 & Vial 1 & Vial 2 \\
\hline${ }^{4} \mathrm{LN}-1$ & 410233104093202 & $12 / 17 / 2013$ & 1400 & 15.9 & $<0.001$ & $<0.001$ & $<0.002$ & $<0.005$ & $<0.005$ & 2.3 & 2.3 & 24.1 & 23.7 & 0.2 & 0.2 & 0.71 & 0.71 \\
\hline${ }^{5} \mathrm{FH}-1$ & 410233104093201 & $11 / 14 / 2013$ & 1500 & 15.5 & 0.031 & 0.031 & 0.014 & $<0.005$ & $<0.005$ & 0.9 & 0.9 & 24.8 & 24.9 & 0.2 & 0.2 & 0.75 & 0.75 \\
\hline${ }^{6} \mathrm{FH}-2$ & 410651104384601 & $12 / 3 / 2014$ & 0800 & 29.3 & 0.24 & 0.25 & 0.095 & $<0.005$ & $<0.005$ & 1.8 & 1.9 & 24.7 & 25.3 & 0.3 & 0.2 & 0.72 & 0.73 \\
\hline${ }^{6} \mathrm{FH}-3$ & 411814104062601 & $09 / 23 / 15$ & 1030 & 22.3 & NA & NA & 0.092 & $<0.005$ & $<0.005$ & NA & NA & NA & NA & NA & NA & NA & NA \\
\hline
\end{tabular}

${ }^{1}$ Analyzed at U.S. Geological Survey Reston Chlorofluorocarbon Laboratory, Reston, Virginia.

${ }^{2}$ Analyzed at RTI Laboratories, Inc., Livonia, Michigan.

${ }^{3}$ Also known as ethylene.

${ }^{4}$ Monitoring well completed in the Lance Formation for this study.

${ }^{5}$ Monitoring well completed in the Fox Hills Sandstone for this study.

${ }^{6}$ Production well completed in the Fox Hills Sandstone. 
others, 2012). Unlike other radioisotopes, tritium atoms can substitute for other hydrogen atoms in the water molecule. The incorporation of tritium directly into the water molecule makes tritium a useful tool for determining apparent groundwater age. In addition, tritium is not affected by chemical reactions, microbial degradation, or other reactions that complicate the interpretation of other age-dating tracers (Clark and Fritz, 1997). Tritium is produced in small quantities naturally by cosmic radiation in the upper atmosphere, where it is incorporated into precipitation; however, large-scale atmospheric testing of thermonuclear devices beginning in the early 1950s and continuing through the early 1960s increased tritium levels by several orders of magnitude above natural levels, resulting in a global atmospheric spike in tritium concentrations measured in precipitation (Clark and Fritz, 1997). Atmospheric concentrations decreased by decay in the atmosphere and loss to the hydrologic cycle (primarily the oceans) after an international atmospheric test-ban treaty was signed in 1963 (Clark and Fritz, 1997). Before atmospheric testing of thermonuclear devices, the natural level of tritium in precipitation probably did not exceed about $26 \mathrm{pCi} / \mathrm{L}$ (8 TU) (Plummer and others, 1993). Activities probably will never completely return to lower natural levels because low levels of tritium continue to be released by other anthropogenic sources such as nuclear power plants and weapons plants (Clark and Fritz, 1997). If precipitation with tritium measured at an activity of $26 \mathrm{pCi} / \mathrm{L}$ or less recharged groundwater before 1953, those waters would have tritium present at an activity smaller than about $0.4 \mathrm{pCi} / \mathrm{L}$ (about $0.13 \mathrm{TU}$ ) in 2013 (year in which most water samples were collected for this study) because of radioactive decay. Therefore, measurement of tritium at an activity level greater than about $0.8 \mathrm{pCi} / \mathrm{L}(0.25 \mathrm{TU})$ would indicate that at least some fraction of the sampled groundwater was recharged after the early 1950s.

Tritium was not detected in water samples from monitoring wells BR-1 and FH-1 and production wells FH-2 and FH-3 (table 5). Tritium was detected at a low concentration $(0.41 \pm 0.33 \mathrm{pCi} / \mathrm{L}$, or about $0.13 \mathrm{TU}$; table 5$)$ in the environmental sample from monitoring well $\mathrm{LN}-1$ but was not detected in the associated replicate sample (table 5). The nondetections of tritium in four of the five wells sampled for this constituent, and the low concentration of less than $0.8 \mathrm{pCi} / \mathrm{L}$ $(0.25 \mathrm{TU})$ or nondetection in monitoring well $\mathrm{LN}-1$, indicated all sampled waters were recharged before the early 1950s (premodern or prebomb waters).

\section{Carbon-14}

Carbon-14 is a radioactive carbon isotope that undergoes radioactive decay with a half-life of 5,730 years (Clark and Fritz, 1997). As with tritium, carbon-14 is produced in small quantities naturally by the interaction of cosmic radiation and nitrogen atoms in the upper atmosphere, and large-scale atmospheric testing of thermonuclear devices beginning in the early 1950s and continuing through the early 1960s increased quantities greatly above natural levels. This cosmogenic carbon-14 is rapidly oxidized into carbon-14 dioxide. Carbon-14 enters the hydrologic cycle through several processes, including dissolution of atmospheric carbon dioxide into precipitation and surface water, incorporation into unsaturated-zone water as carbon dioxide by microbial oxidation of organic material in soil and plant/root respiration, and dissolution of minerals containing geologically young carbon (Kalin, 2000). Plants and water that use or react with atmospheric carbon dioxide have a carbon-14 activity equal to that in the atmosphere. DIC in precipitation has a carbon-14 activity in equilibrium with atmospheric carbon dioxide. As precipitation infiltrates the subsurface, its carbon-14 activity is modified by carbon exchange with soil-zone carbon dioxide and minerals in the unsaturated zone until it enters the saturated zone. After entering the saturated zone, interaction with soil-zone and unsaturated zone carbon ends, and the carbon-14 in DIC decays with time. The radiocarbon age of groundwater refers to the duration of radioactive decay since this water was last exposed to the carbon in the unsaturated zone. Because of its long halflife, the amount of carbon-14 in the DIC in groundwater may be used to determine apparent groundwater ages ranging from 1,000 to about 30,000-50,000 years before present (ybp; Clark and Fritz, 1997; Kalin, 2000; Bethke and Johnson, 2008).

Carbon-14 activities may be reported as percent modern or percent modern carbon. Carbon-14 values received from the analyzing laboratory were normalized for carbon isotopic fractionation based on a $\delta^{13} \mathrm{C}$ value of -25 per mil and reported in percent modern units, as is common with many radiocarbon laboratories. For groundwater studies, carbon-14 activities should be denormalized because groundwater $\delta^{13} \mathrm{C}$ values are expected to change from initial values as a result of water/rock interactions (Kalin, 2000). The percent modern carbon, not normalized for carbon-13 fractionation, is defined as the ratio of carbon-14 to carbon-12 of the sample divided by the standard carbon-14 to carbon-12 ratio of the National Bureau of Standards oxalic acid in 1950 and multiplied by 100 (Plummer and Glynn, 2013). By convention, the modern pre-1950 (before nuclear weapons testing) activity of atmosphere carbon-14 is 100 percent modern carbon (pmC). The carbon-14 activities in this study are reported as denormalized percent modern carbon. The normalized carbon-14 activities in percent modern units received from the analyzing laboratory were converted back to denormalized activities in percent modern carbon units using the following equation (Mook and van der Plicht, 1999; Plummer and others, 2004):

where

$$
{ }^{14} a^{S}={ }^{14} a_{N}\left[\frac{\left(1+{ }^{13} \delta\right)}{0.975}\right]^{2} \exp \left[\frac{-\left(t_{y}-1,950\right)}{8,267}\right]
$$

${ }^{14} a^{S} \quad$ is the carbon-14 activity ratio (expressed in percent modern carbon) of the sample at the time of sample collection,

${ }^{14} a_{N} \quad$ is the commonly reported normalized carbon-14 activity ratio (in percent modern carbon), 


\author{
${ }^{13} \delta \quad$ is the $\delta^{13} \mathrm{C}$ of the DIC (in percent modern \\ carbon), \\ $\exp$ is the natural exponential function, \\ $t_{y} \quad$ is the year of sample collection or \\ measurement, and \\ 8,267 is $1 / \lambda$ (in years), and $\lambda$ is the carbon-14 decay \\ constant ([natural logarithm (ln) 2]/5,730) \\ (per year).
}

The nonnormalized carbon-14 activities were used to calculate an unadjusted radiocarbon age $\left(t_{\text {age unadj } j}\right)$ in years before present relative to 1950 . The unadjusted radiocarbon age is determined by the following equation (modified from: Plummer and others, 2004; Plummer and Glynn, 2013):

$$
t_{\text {age_unadj }}=\left(\frac{5,568}{\ln 2}\right) \ln \left(\frac{\Lambda_{0}}{\Lambda}\right)-\left(\frac{t_{y}-1,950}{1.029}\right)
$$

where

$$
\begin{aligned}
& 5,568 \text { is the Libby half-life of carbon-14 (in years), } \\
& \Lambda_{0} \quad \text { is the initial carbon-14 activity (in percent } \\
& \text { modern carbon), } \\
& \Lambda \quad \text { is the measured carbon-14 activity (in percent } \\
& \text { modern carbon) in the sample, and } \\
& 1.029 \text { is the ratio of the modern to Libby decay } \\
& \text { constants }\left(\lambda_{5,730} / \lambda_{5,568}\right) \text {. }
\end{aligned}
$$

For this study, the radiocarbon age is reported as the unadjusted age, with the initial carbon-14 activity $\left(\Lambda_{0}\right.$, assumed be to representative of recharge water) assumed to be $100 \mathrm{pmC}$. Unadjusted ages assume that radioactive decay was the only process that reduces the radiocarbon content of DIC along groundwater-flow paths. The possible effects of geochemical reactions on initial carbon-14 activity $\left(\Lambda_{0}\right)$ measured in the groundwater samples are discussed conceptually later in this section, but the use of geochemical modeling to adjust radiocarbon ages was beyond the scope of this study.

The accuracy of radiocarbon age estimates is dependent upon the value/estimate for $\Lambda_{0}$, so understanding the various factors/complications that can result in higher or lower $\Lambda_{0}$ values is important for constraining radiocarbon ages. Before nuclear weapons testing beginning in the early 1950 s, carbon-14 in the atmospheric moisture was relatively constant at about $100 \mathrm{pmC}$ (Wang and others, 1998). Nuclear weapons testing added substantial quantities of carbon-14 in the atmosphere, which resulted in carbon-14 values in recharge waters and groundwater greater than $100 \mathrm{pmC}$. Because tritium values indicated premodern (prebomb) waters from the four wells sampled for carbon-14 (LN-1, FH-1, FH-2, FH-3), none of the water samples were considered to have $\Lambda_{0}$ values that were greater than $100 \mathrm{pmC}$ for calculation of unadjusted radiocarbon ages. Thus, use of values of $\Lambda_{0}$ equal to $100 \mathrm{pmC}$ in equation 4 results in calculation of maximum possible radiocarbon ages. There are many other possible complications in the interpretation of carbon-14 data, most of which result in unadjusted carbon-14 ages that are older than the actual age of the associated water. One of the primary complications is that DIC in groundwater can be diluted with carbon-14-free carbon (also known as dead carbon or fossil carbon) in aquifers, resulting in decreases in carbon-14 concentrations along groundwaterflow paths (also known as fossil carbon dilution) (Clark and Fritz, 1997; Wang and others, 1998; Kalin, 2000). Sources of carbon-14-free carbon in aquifers can include dissolution of carbonate minerals such as calcite and sedimentary organic material/carbon. Exchange of carbon atoms in groundwater with carbon atoms in the aquifer and diffusion of carbon-14 into underlying/overlying fine-grained confining units also can dilute carbon-14 in DIC (Bethke and Johnson, 2002, 2008). Consequently, corrections typically are required to account for these and possibly other processes such as mixing (dispersion) that affect carbon-14 values and obtain more accurate radiocarbon ages. This is typically completed using a variety of geochemical models that attempt to quantify these processes to determine the carbon-14 value of DIC derived from atmospheric carbon dioxide at the point of recharge $\left(\Lambda_{0}\right)$, after the water has moved through the unsaturated zone and before any reactions occurring within the aquifer. Use of geochemical modeling to adjust radiocarbon ages was beyond the scope of this study, so only unadjusted radiocarbon ages are described herein.

Carbon-14 was detected in all four wells ( $\mathrm{LN}-1, \mathrm{FH}-1$, FH-2, FH-3) sampled for the radioisotope but at small values ranging from $0.18 \mathrm{pmC}$ in well $\mathrm{FH}-3$ to $1.250 \mathrm{pmC}$ in well FH-1 (table 5). Assuming that the initial carbon-14 activity at the time of recharge $\left(\Lambda_{0}\right)$ is $100 \mathrm{pmC}$ (equation 4), and that no carbon mass transfers occurred as groundwater moved from the point of recharge to the aquifer locations where the water was sampled, the unadjusted radiocarbon ages calculated for waters from all four wells sampled for carbon-14 were greater than 29,000 ybp (late Pleistocene in age). Because radiocarbon ages were not adjusted through use of geochemical modeling, values of $\Lambda_{0}$ equal to $50 \mathrm{pmC}$ also were used in equation 4 to evaluate the effects on radiocarbon ages when a much lower value for $\Lambda_{0}$ was used. Use of $50 \mathrm{pmC}$ for $\Lambda_{0}$ in equation 4 still resulted in radiocarbon ages that were greater than $29,000 \mathrm{ybp}$ for waters from all four wells.

Using isotopic evidence, Dutton $(1993,1995)$ examined the sources and relative ages of groundwater in the upper unconfined aquifers composing the northern, central, and southern parts of the High Plains aquifer system and immediately underlying confined aquifers (commonly Upper Cretaceous aquifers). As part of the study of the northern High Plains aquifer-system area, the investigator sampled one well completed in the Ogallala aquifer, one well completed in the White River aquifer in the upper White River Formation (misidentified by investigator as completed in the Ogallala aquifer), and two wells completed in the Lance aquifer in Laramie County for carbon-14 and $\delta^{13} \mathrm{C}$, tritium, stable isotopes of oxygen and hydrogen, chlorine-36, and major ions. In addition, six additional wells in adjacent western Nebraska (Ogallala aquifer [four wells], White River aquifer [one well], Chadron aquifer [one well], and the upper transition member of the Pierre Shale [one well]) also were sampled for the same constituents so the investigator could examine isotopic differences 
between the shallow unconfined High Plains aquifer system (represented by wells completed in the Ogallala aquifer and one well completed in the White River aquifer in the upper White River Formation) and underlying confined aquifers (represented by deeper wells completed in various formations below the Ogallala Formation) beginning west of Cheyenne and continuing east into western Nebraska (assumed by Dutton $[1993,1995]$ to represent the generally eastward direction of groundwater flow in the northern High Plains aquifer system and underlying confined aquifers). Carbon-14 values measured in four wells completed in the Ogallala aquifer in Wyoming and Nebraska ( $34 \pm 0.5$ to $107 \pm 1 \mathrm{pmC}$; one well completed in the Ogallala aquifer in Nebraska was not measured for carbon-14) were much larger than those measured in the five wells completed in underlying confined aquifers $(<0.6$ to $3.1 \pm 0.5 \mathrm{pmC}$; Dutton, 1993, table 2; Dutton, 1995, table 1); distinct differences in chlorine-36 and tritium values between the unconfined and confined aquifers also were noted. Use of the carbon-14 data in combination with the other isotopic data led Dutton $(1993,1995)$ to conclude that groundwater in the confined aquifers was much older ( $15-35,000 \mathrm{ybp}$ ) relative to the overlying Ogallala aquifer composing the High Plains aquifer system (generally $<1,000 \mathrm{ybp}$ ). He also concluded that confined aquifers underlying the entire extent of the High Plains aquifer system (including central and southern parts) also were within the same age range (15-35,000 ybp) and that groundwaters from these confined aquifers were most likely recharged during a cool and wet regional climate regime that existed during the last Pleistocene (middle to late Wisconsinan) glaciation that differed from the later warm and dry Holocene $(<11,700 \mathrm{ybp})$ climate.

One of the "confined aquifer wells" sampled by Dutton (1993, table 2; Dutton, 1995, table 1) was well EL-1 southwest of Pine Bluffs (T. 14 N., R. 60 W., sec. 29; fig. 30). This well, known locally as the "Lodgepole Valley Potatoes well" and identified by Dutton as the "Lodgepole" well, is interpreted herein and in Dutton's studies to be completed in the Lance aquifer (see discussion in "Water Type" report section). The second sampled well completed in the Lance aquifer (identified herein as well CL- 2 and by Dutton as the "Coastal Chem" well) was southwest of Cheyenne (T. 13 N., R. 67 W.; fig. 30). Dutton (1993, table 2; 1995, table 1) reported carbon-14 and carbon- 13 values of $2.2 \pm 0.3 \mathrm{pmC}$ and -7.4 per mil, respectively, for well EL -1 and $3.1 \pm 0.5 \mathrm{pmC}$ and -12.0 per mil, respectively, for well CL-2. Assuming that the initial carbon-14 activity at the time of recharge $\left(\Lambda_{0}\right)$ is 100 pmC (eq. 4), and that no carbon mass transfers occurred as groundwater moved from the point of recharge to the aquifer locations where the water was sampled, use of Dutton's carbon-14 values in equation 4 results in unadjusted radiocarbon ages of about 30,600 ybp for water from well EL-1 and about 27,900 ybp for water from well CL-2.

Samples collected from the Lance-Fox Hills aquifer (contained in the Fox Hills Sandstone and immediately overlying lower Lance Formation sandstone beds, where present) in the Denver Basin in northeastern Colorado (basal aquifer of the Denver Basin aquifer system; fig. $6 B$ ) had old apparent groundwater ages similar to those calculated for samples collected as part of this study and the studies by Dutton (1993, 1995) described previously. The four samples were collected by Musgrove and others (2014) as part of a USGS study that examined the quality and age of groundwater in different aquifers of the Denver Basin aquifer system in northeastern Colorado (lithostratigraphic units shown on fig. $6 B$ ). Although the Lance Formation and Fox Hills Sandstone in the Denver Basin are overlain by different units than in the Cheyenne Basin (fig. 6B), burial depths and formation characteristics are similar (Dechesne and Raynolds, 2010; Dechesne and others, 2011a, b), so results from the study provide a useful comparison with this study's calculated unadjusted radiocarbon ages. Carbon-14 was measured at values ranging from 0.1 to $10.9 \mathrm{pmC}$ and from wells that ranged in depth from 590 to 1,450 ft BLS (Musgrove and others, 2014, tables 11 and 3 , respectively). Unadjusted radiocarbon ages (using an $\Lambda_{0}$ equal to $100 \mathrm{pmC}$ ) for water samples from the two wells with the highest carbon-14 activities (4.8 and $10.9 \mathrm{pmC}$ ) were 24,000 and $18,000 \mathrm{ybp}$; use of geochemical modeling and an $\Lambda_{0}$ equal to $85.5 \mathrm{pmC}$ assumed to represent recharge waters resulted in adjusted radiocarbon ages of 18,000 and $12,000 \mathrm{ybp}$ for these two samples (Musgrove and others, 2014, table 11). Unadjusted radiocarbon ages (using an $\Lambda_{0}$ equal to $100 \mathrm{pmC}$ ) for water samples from the two wells with the lowest carbon-14 activities $(0.1$ and $1.2 \mathrm{pmC}$; similar to $0.18-1.250 \mathrm{pmC}$ range measured in four wells sampled in this study) were estimated at greater than $30,000 \mathrm{ybp}$; use of geochemical modeling and an $\Lambda_{0}$ equal to $85.5 \mathrm{pmC}$ assumed to represent recharge waters resulted in adjusted radiocarbon ages still greater than 30,000 ybp for these two samples (Musgrove and others, 2014, table 11).

\section{Major lons and Related Groundwater-Quality Characteristics}

Major ions constitute most of the dissolved constituents in groundwater and generally occur naturally as a result of recharge composition and interactions between water and soil or rock. Major ions typically are present in groundwater at concentrations greater than $1.0 \mathrm{mg} / \mathrm{L}(\mathrm{Hem}, 1985)$. Groundwater samples collected for this study were analyzed for the positively charged ions (cations) calcium, magnesium, sodium, and potassium and the negatively charged ions (anions) bicarbonate (generally referred to in this report as alkalinity), chloride, sulfate, and fluoride (table 5). Alkalinity as calcium carbonate, a measure of the acid-buffering capacity of a filtered water sample, was determined onsite and in the laboratory. Bicarbonate and carbonate concentrations were calculated from alkalinity and $\mathrm{pH}$ values measured onsite (Hem, 1985). Silica, an uncharged species under typical $\mathrm{pH}$ conditions, is described with the major ions for convenience. Analytical results for major ions are shown in table 5. 


\section{Total Dissolved Solids}

Collectively, major ions compose most of the dissolved constituents composing total dissolved solids (TDS). TDS commonly is used as a quantitative measure of the salt content of water (salinity). TDS is widely used to evaluate the suitability of a water supply for a variety of uses because concentrations can be correlated with certain major ions and with specific conductance to determine water-quality characteristics such as salinity (Hem, 1985). Elevated TDS concentrations can affect aesthetic properties (color, odor, and taste), as well as the effectiveness of water for agricultural uses such as irrigation and stock watering (Hem, 1985). High TDS concentrations can cause scale buildup in pipes and boilers (Hem, 1985). In groundwater-flow systems, TDS concentrations typically increase with depth and residence time in the aquifer as interactions between water and rock dissolve minerals in the aquifer matrix.

Many classification schemes have been developed to describe waters with different TDS concentrations. Waters with TDS concentrations of less than $1,000 \mathrm{mg} / \mathrm{L}$ typically are considered fresh (Heath, 1983; Stanton and others, 2017). Drinking water is generally preferred to have less than $500 \mathrm{mg} / \mathrm{L}$ TDS because of concerns related to aesthetic effects rather than human-health effects (SMCL, U.S. Environmental Protection Agency, 2018). Waters with TDS ranging from 1,000 to less than $10,000 \mathrm{mg} / \mathrm{L}$ typically are considered brackish (Stanton and others, 2017). Brackish waters with TDS ranging from 1,000 to $2,999 \mathrm{mg} / \mathrm{L}$ are considered slightly saline, and brackish waters with TDS ranging from 3,000 to less than 10,000 are considered moderately saline in several classification schemes (Stanton and others, 2017, table 1). For regulation of underground water disposal, the EPA defines potential drinking water from underground sources (identified as "Underground Source of Drinking Water") as having TDS concentrations less than 10,000 mg/L (U.S. Environmental Protection Agency, 2018). Aquifers containing groundwater with less than $10,000 \mathrm{mg} / \mathrm{L}$ TDS may be protected as an Underground Source of Drinking Water unless exempted from protection (U.S. Code of Federal Regulations, 2016).

Groundwater from all five sampled wells was fresh (TDS $<1,000 \mathrm{mg} / \mathrm{L}$ ). TDS was larger in the groundwater samples collected from the three wells completed in the Fox Hills aquifer (384-532 $\mathrm{mg} / \mathrm{L}$ ) than in the other (shallower) wells $(373 \mathrm{mg} / \mathrm{L}$ in well BR-1 completed in the White River aquifer and $286 \mathrm{mg} / \mathrm{L}$ in well $\mathrm{LN}-1$ completed in the Lance aquifer; table 5). TDS concentrations in all but one of five sampled wells $(\mathrm{FH}-2, \mathrm{TDS}=555 \mathrm{mg} / \mathrm{L})$ were less than the $500 \mathrm{mg} / \mathrm{L}$ EPA SMCL and Wyoming Class I drinking-water standard (table 5). TDS concentrations in all five sampled wells were less than the Wyoming Class III livestock standard of 5,000 mg/L (table 5).

TDS concentrations in groundwater sampled from monitoring well LN-1 and the three wells completed in the Fox Hills aquifer are within the range reported for other wells completed in the Lance and Fox Hills aquifers in Laramie and Goshen Counties sampled as part of other studies in the Wyoming part of the Cheyenne Basin (appendix 2, table 2.1; appendix 3 , table 3.1). Including LN-1, TDS concentrations in waters from the Lance aquifer range from 264 to $1,945 \mathrm{mg} / \mathrm{L}$ (21 wells, including 4 in Laramie County and 17 in Goshen County; table 5 and appendix 2, table 2.1). TDS concentrations in groundwater from wells completed in the Lance aquifer in Laramie County (264-312 mg/L) are lower than wells in Goshen County (416-1,945 mg/L). All waters sampled from wells completed in the Lance aquifer in Laramie County and most (14 of 17) Goshen County wells were fresh (TDS $<1,000 \mathrm{mg} / \mathrm{L}$ ); waters from 3 of 17 Goshen County wells were slightly saline (TDS=1,000-2,999 mg/L). TDS concentrations in most (13 of 14) Goshen County wells completed in the Lance aquifer with waters classified as fresh were greater than the EPA SMCL of $500 \mathrm{mg} / \mathrm{L}$. Including monitoring well FH-1 and production wells FH-2 and FH-3, TDS concentrations of Fox Hills aquifer waters range from 384 to $640 \mathrm{mg} / \mathrm{L}$ (7 wells, including 4 in Laramie County and 3 in Goshen County; table 5 and appendix 3, table 3.1). Concentrations in waters from Laramie County wells $(384-532 \mathrm{mg} / \mathrm{L})$ were similar to those in Goshen County $(476-640 \mathrm{mg} / \mathrm{L})$. Although all waters from wells completed in the Fox Hills aquifer were fresh, TDS concentrations in one of three Laramie County wells and two of three Goshen County wells were greater than the EPA SMCL of $500 \mathrm{mg} / \mathrm{L}$.

\section{Water Type}

Trilinear diagrams were constructed to characterize major-ion composition by hydrogeologic unit and geographic area within the Cheyenne Basin of Wyoming (figs. 31-36). Also known as Piper diagrams, trilinear diagrams provide a convenient method to classify and compare water types based on the ionic composition of different water samples (Piper, 1944). Cation and anion concentrations for each groundwater sample are converted to milliequivalents per liter and plotted as percentages of their respective totals in two triangles. The relative percentages of cations and anions in each triangle then are projected into a quadrilateral polygon that describes a water type or hydrochemical facies. Trilinear diagrams were constructed not only to show the composition of waters from the five wells sampled as part of this study, but also to compare with composition of waters sampled from other wells completed in the White River, Brule, Chadron, Lance, and Fox Hills aquifers in the Cheyenne Basin, as documented in the USGS NWIS database and other studies (Lidstone and Anderson, Inc., and AVI Professional Corporation, 1995; BRS, Inc., and Lidstone and Anderson, Inc., 1996; Weston Engineering, Inc., 1996a, b, 1999a, b, 2000; Lidstone and Associates, Inc., 2003; Dahlgren Consulting, Inc., and others, 2005; AVI Professional Corporation and others, 2008; JR Engineering and Lidstone and Associates, Inc., 2009; Trihydro Corporation, 2009; Wyoming Groundwater, LLC, and others, 2011 [Lance aquifer and Fox Hills aquifer samples listed in tables 2.1 and 3.1, respectively]). 


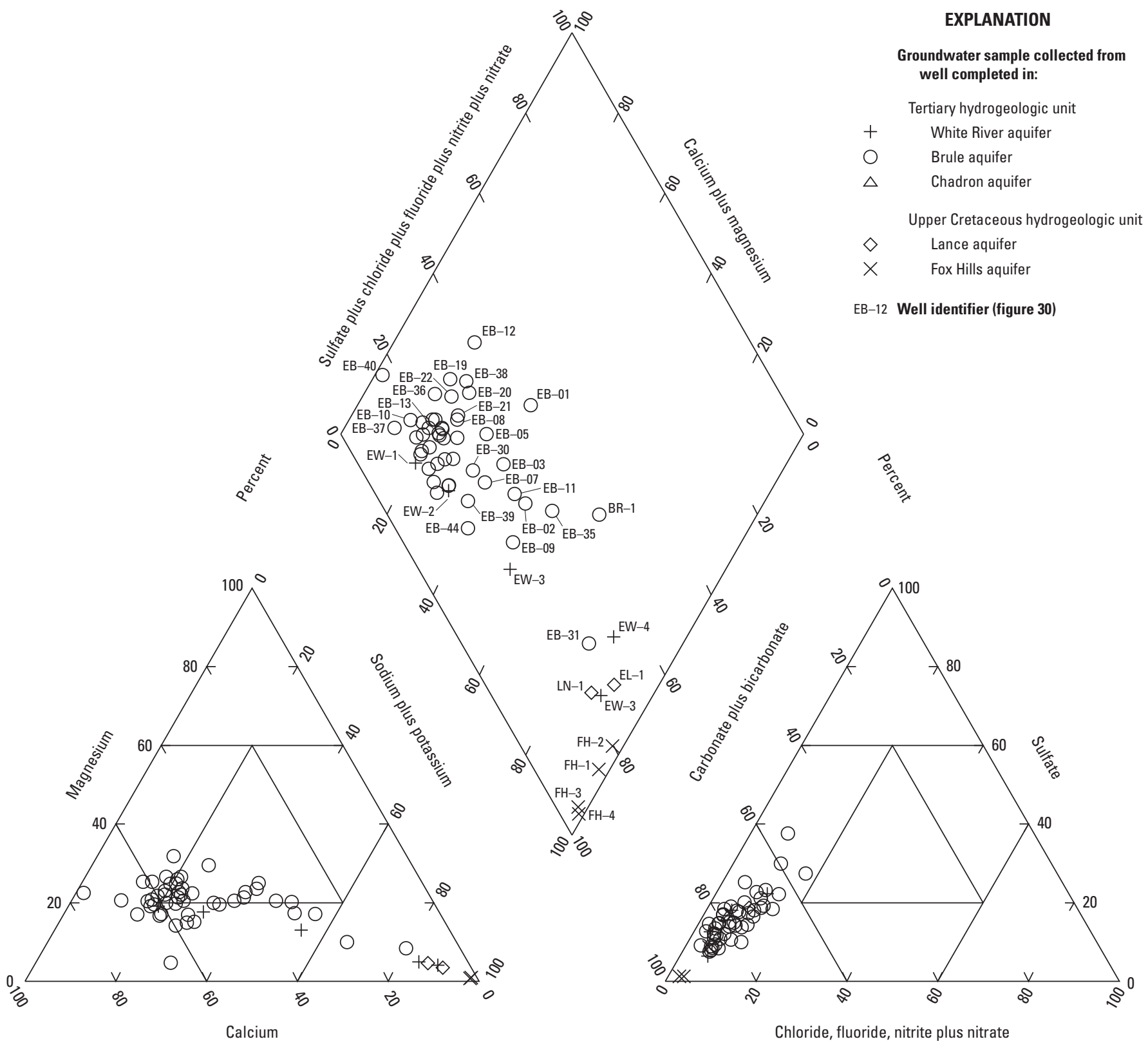

Percent

Figure 31. Major-ion composition for groundwater samples from aquifers in Tertiary and Upper Cretaceous hydrogeologic units in eastern Laramie County, Cheyenne Basin, southeastern Wyoming. Location of wells shown in figure 30. 


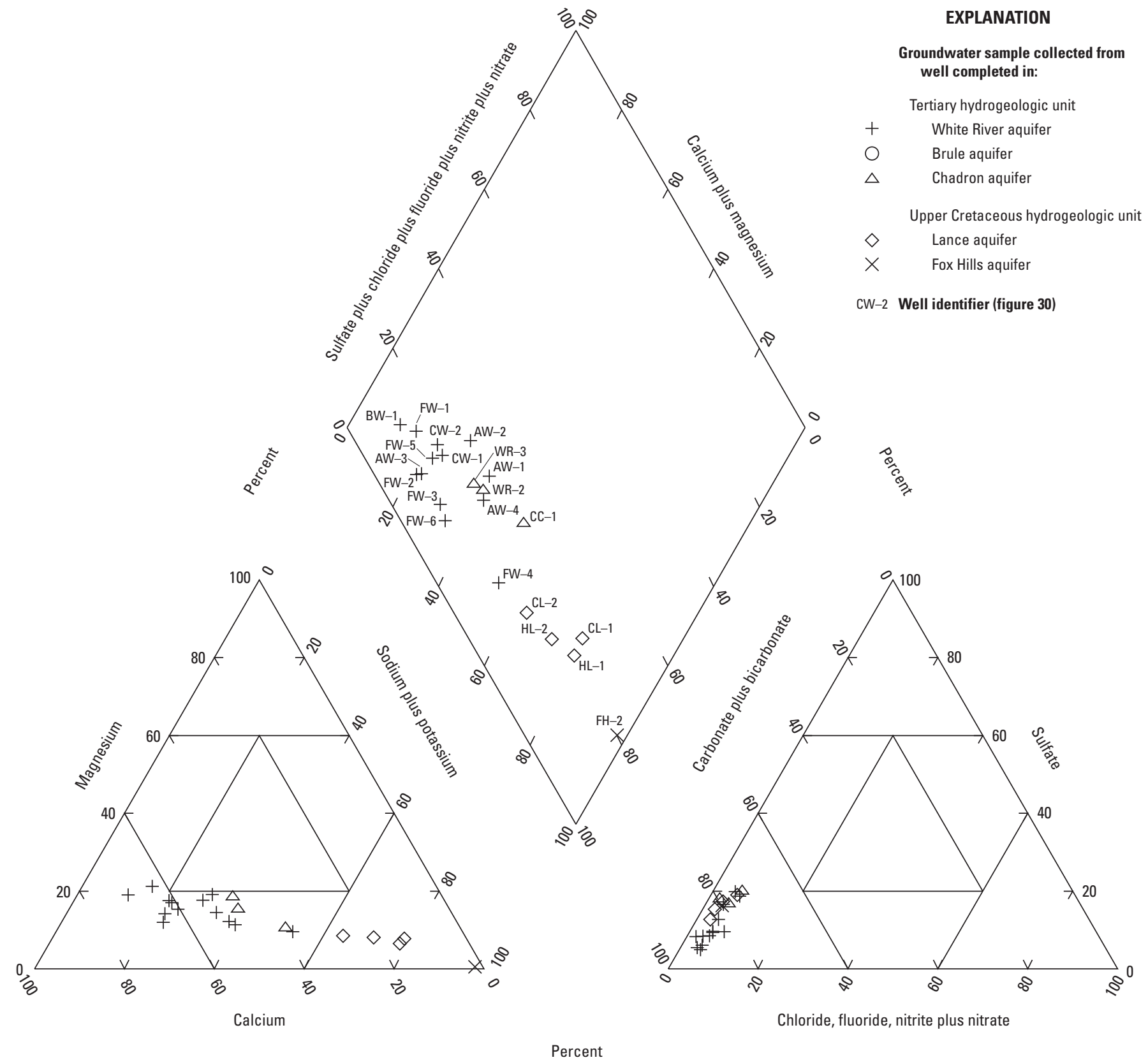

Figure 32. Major-ion composition for groundwater samples from aquifers in Tertiary and Upper Cretaceous hydrogeologic units in central and western Laramie County, Cheyenne Basin, southeastern Wyoming. Location of wells shown in figure 30. 


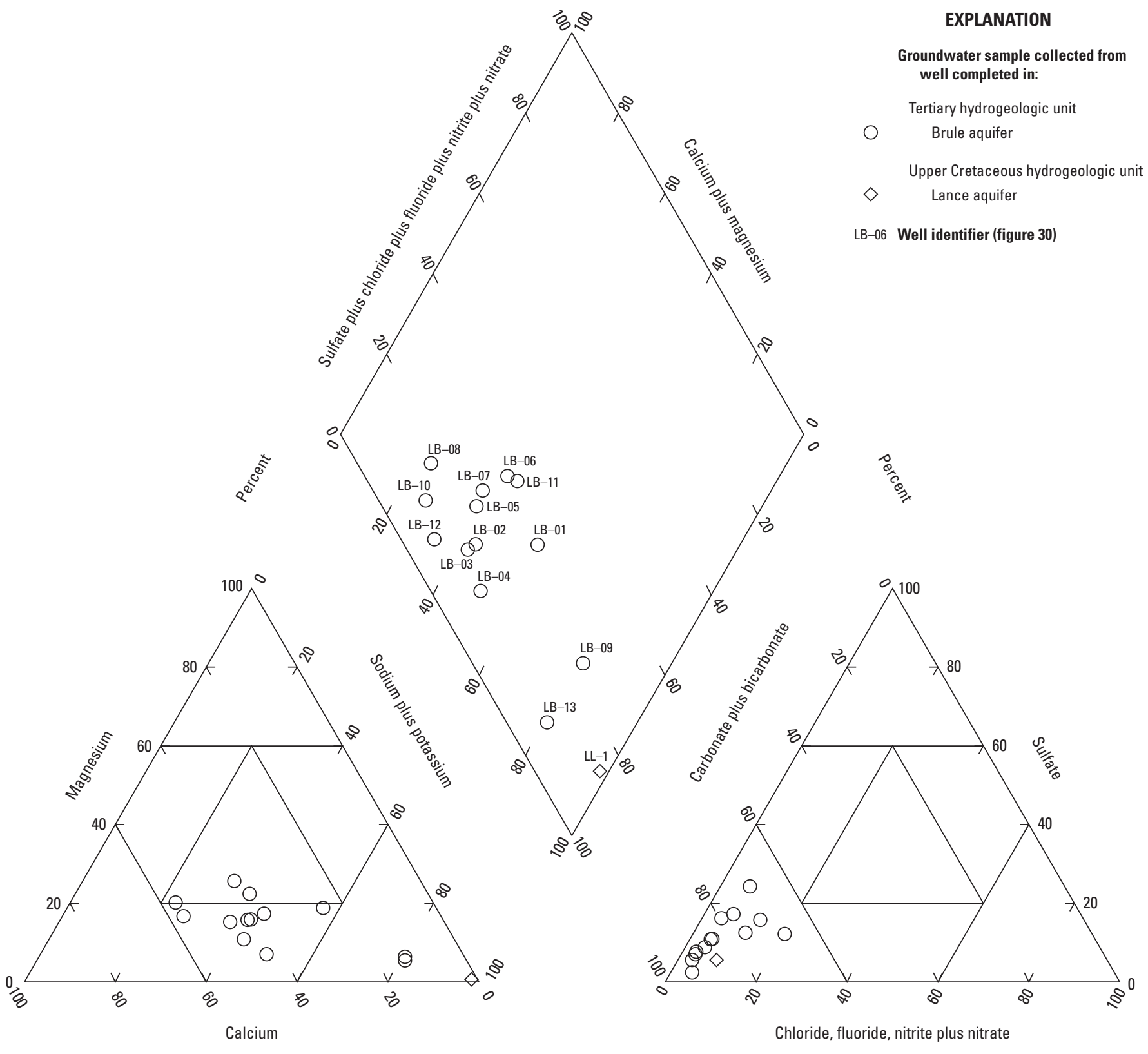

Percent

Figure 33. Major-ion composition for groundwater samples from aquifers in Tertiary and Upper Cretaceous hydrogeologic units in southern Goshen Hole, Laramie and Goshen Counties, Cheyenne Basin, southeastern Wyoming. Location of wells shown in figure 30. 


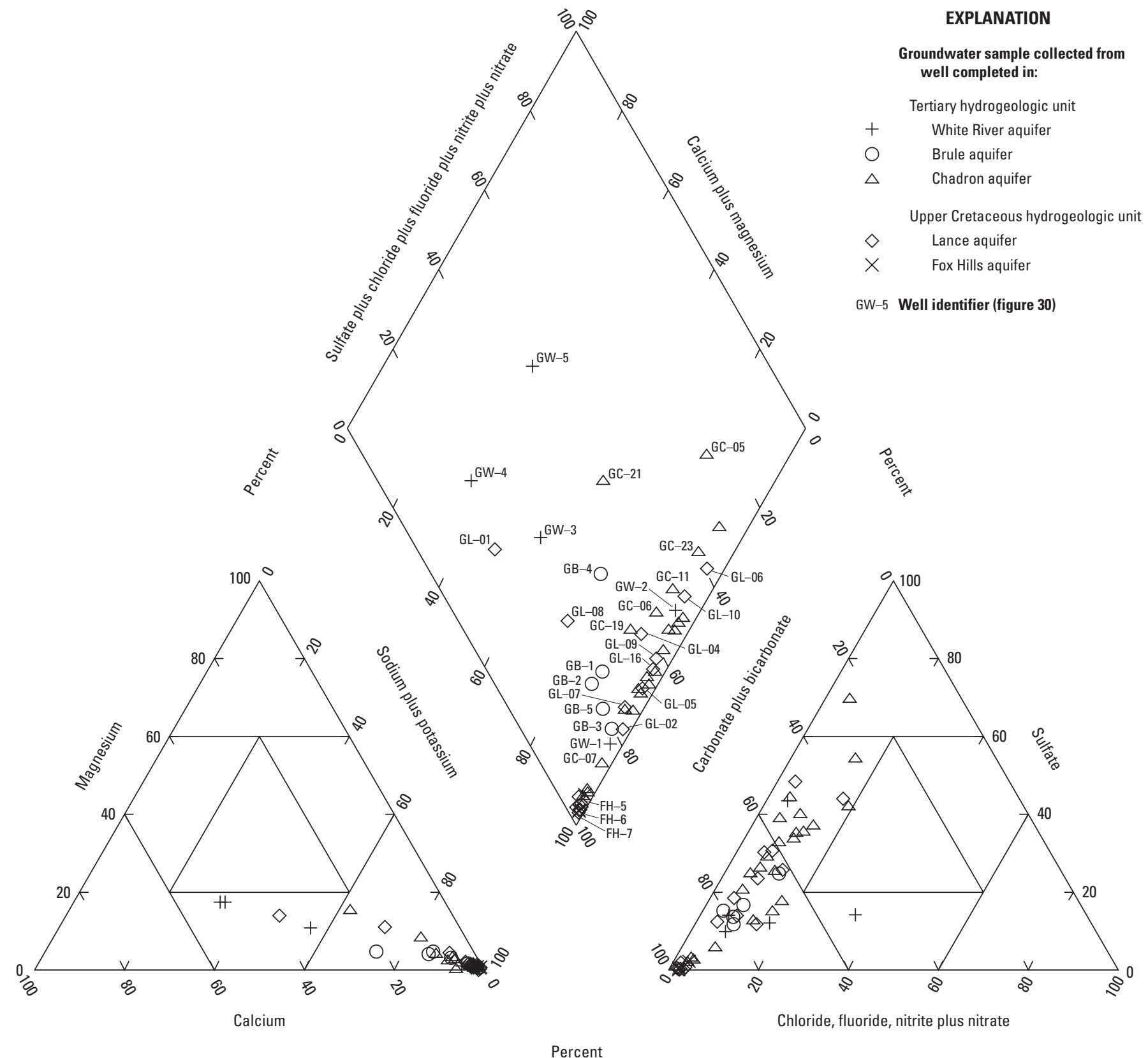

Figure 34. Major-ion composition for groundwater samples from aquifers in Tertiary and Upper Cretaceous hydrogeologic units in central and northern Goshen Hole, Goshen County, Cheyenne Basin, southeastern Wyoming. Location of wells shown in figure 30. 


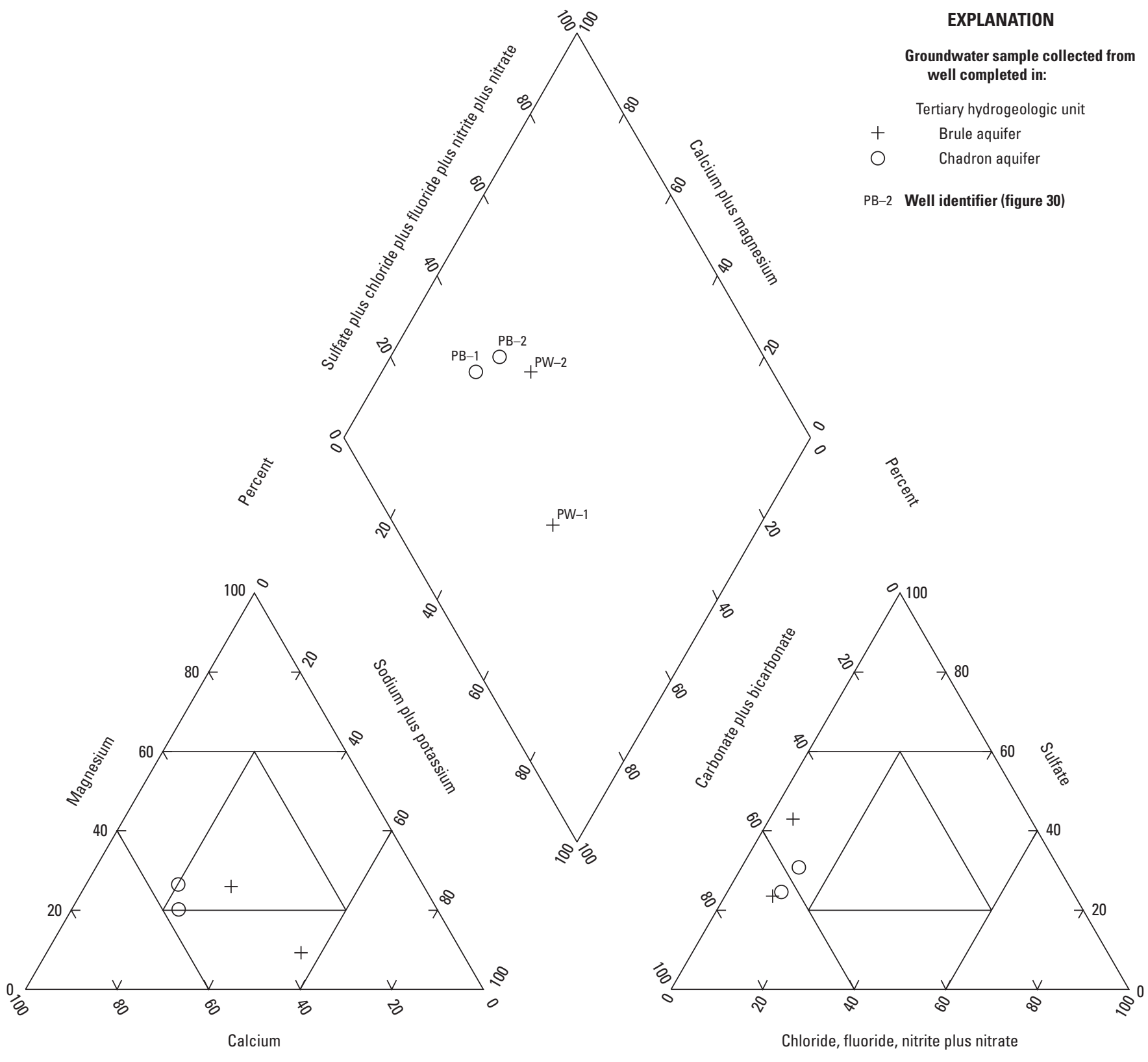

Percent

Figure 35. Major-ion composition for groundwater samples from aquifers in Tertiary hydrogeologic units in Platte County, Cheyenne Basin, southeastern Wyoming. Location of wells shown in figure 30. 


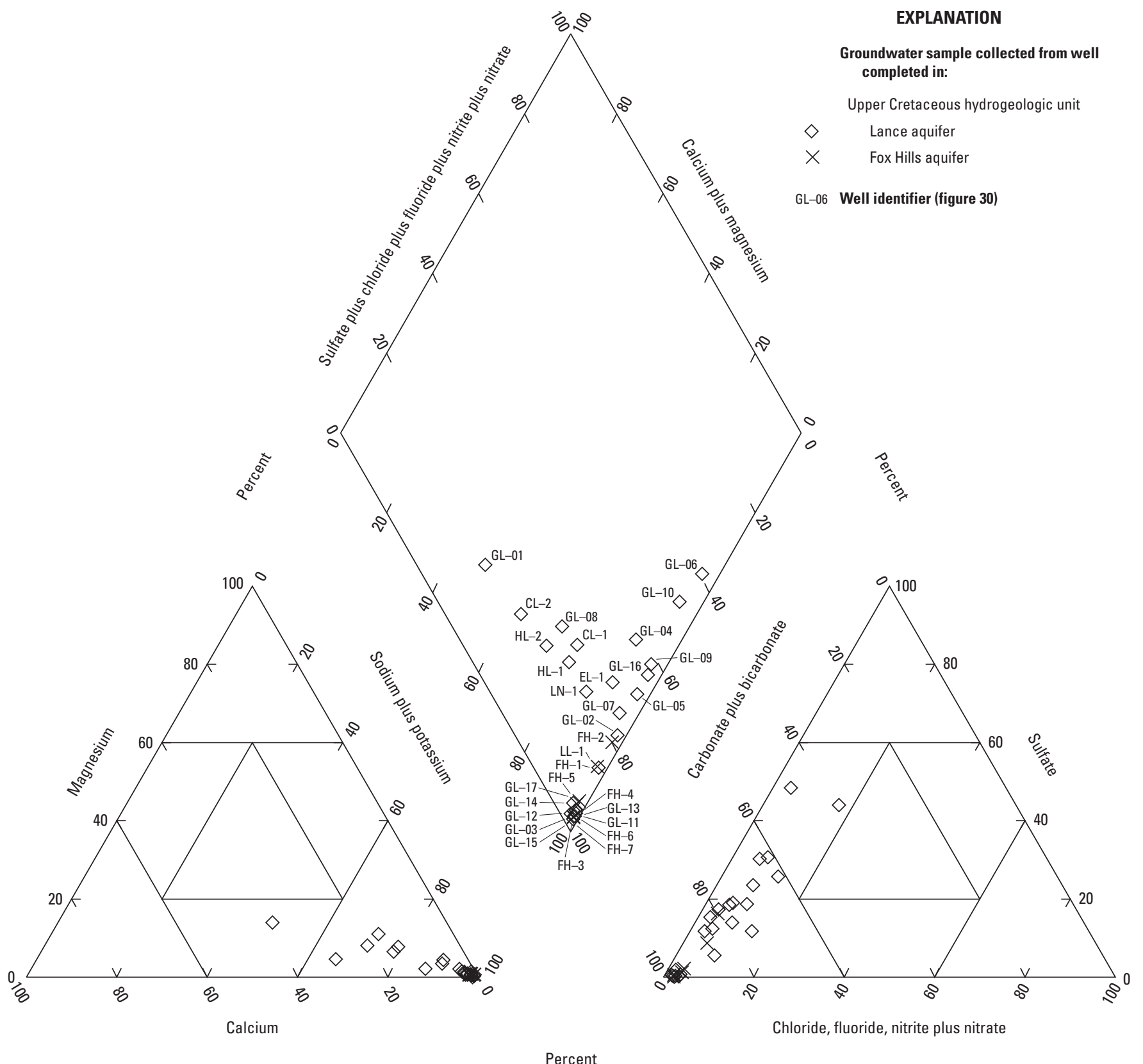

Figure 36. Major-ion composition for groundwater samples from aquifers in Upper Cretaceous hydrogeologic units in Laramie, Goshen, and Platte Counties, Cheyenne Basin, southeastern Wyoming. Location of wells shown in figure 30. 
Ionic composition of water sampled from monitoring well BR-1, a sodium-bicarbonate-sulfate type, differed from composition of most other waters from the White River or Brule aquifers in the Pine Bluffs lowland/eastern Laramie County (fig. 31) and elsewhere in the Cheyenne Basin, which mostly were calcium-bicarbonate, calcium-sodium-bicarbonate, calcium-magnesium-bicarbonate, or calcium-magnesiumsodium-bicarbonate type waters (figs. 32-35). Water samples from White River aquifer wells within a few miles of well BR-1 either were calcium-bicarbonate types (for example, EB-03 or EB-12; fig. 31), calcium-sodium-bicarbonate type (for example, EB-02; fig. 31), or sodium-calcium-bicarbonate type (well WR-3; location of wells shown in fig. 30). Only one other sample from a White River or Brule aquifer well in the Cheyenne Basin (GW-2 in Goshen Hole; fig. 30) had sodium-bicarbonate-sulfate type water (fig. 34); however, this water sample had substantially more sodium than the sample from well BR-1 (fig. 31). Waters from several wells completed in the Chadron and Lance aquifers in Goshen Hole also were sodium-bicarbonate-sulfate types (figs. 33, 34). Most of these waters contained substantially more sodium than the water from well BR-1, but water from one Chadron aquifer well in Goshen Hole (GC-21) had a composition (fig. 34) that was similar to BR-1 (fig. 31).

Water sampled from monitoring well $\mathrm{LN}-1$ at the study site was a sodium-bicarbonate type (figs. 31, 36). Except for waters from three wells in Goshen Hole (GL-01, GL-06, and GL-10), all other waters sampled from wells completed in the Lance aquifer in the Cheyenne Basin as part of other studies also were sodium-bicarbonate types (fig. 36). However, water composition varied considerably, even though sodium and bicarbonate were the dominant ions ( $>60$ percent of cation or anion equivalents, respectively) in all samples. Many Lance and Chadron aquifer wells in Goshen Hole had waters with similar water composition (figs. 33, 34).

Water sampled from well EL-1 as part of another study (Lidstone and Associates, Inc., 2003; appendix 2, table 2.1) and from monitoring well $\mathrm{LN}-1$ as part of this study plotted closely together on trilinear diagrams (figs. 31, 36), indicating similar ionic composition; waters from these two wells also had nearly identical stable isotope $\left(\delta^{18} \mathrm{O}\right.$ and $\left.\delta^{2} \mathrm{H}\right)$ composition (see "Stable Isotopes of Water" report section). As with $\mathrm{LN}-1$, water from well EL-1 is classified as a sodiumbicarbonate type. Well EL-1, near Pine Bluffs (T. 13 N., R. $60 \mathrm{~W}$., section 29; inset on fig. 30), commonly is identified as the "Lodgepole Valley Potatoes well." Data obtained from this well often are used to characterize and evaluate the physical and chemical hydrogeologic characteristics of the Lance aquifer and Fox Hills aquifer because it is one of the few water-supply wells in Laramie County known to be completed in Upper Cretaceous strata below the Tertiary strata that compose or underlie the High Plains aquifer system (Lidstone and Associates, Inc., 2003; Dahlgren Consulting, Inc., and others, 2005). Unpublished drilling logs indicate that both formations were penetrated during drilling of well EL-1; however, the open interval of the well was not recorded, and previous studies often have questioned whether the well was open to the Lance Formation, Fox Hills Sandstone, or both formations. Compositional similarity to the water sampled from monitoring well $\mathrm{LN}-1$ completed in the Lance aquifer (fig. 36), coupled with distinct compositional differences with water samples collected from wells completed in the Fox Hills aquifer in eastern Laramie County (less sulfate and more sodium in samples from $\mathrm{FH}-1, \mathrm{FH}-3$, and $\mathrm{FH}-4$; fig. 36), indicates that water sampled from this well likely was derived exclusively from or largely from the Lance aquifer rather than the Fox Hills aquifer.

Although all waters from the Lance aquifer in Laramie County were classified as sodium-bicarbonate types, waters from wells in the eastern part of the county (EL-1 and LN-1) were more sodic than waters from wells in the central and western parts of the county (CL-1, CL- $-2, \mathrm{HL}-1$, and HL -2 ; fig. 36; well locations shown on fig. 30). Waters from three of the central and western Laramie County wells (CL-1, HL-1, and HL-2) clustered together on the trilinear diagram (fig. 36), indicating relatively similar composition. Water from well CL-2 had considerably more calcium than the other central and western Laramie County wells; composition approached a sodium-calcium-bicarbonate type despite being classified as a sodium-bicarbonate type (fig. 36). The composition of water from well EL-2 (fig. 36) approached that of water from well EW-5, a sodium-calcium-bicarbonate type (fig. 31). Located in Carpenter (fig. 30), well EW-5 was interpreted to be completed in an aquifer in the lower White River Formation (identified by investigators as the "Chadron Formation") at the time of installation (AVI Professional Corporation and Lidstone and Anderson, Inc., 1996).

Waters sampled from monitoring well $\mathrm{FH}-1$ at the study site, and production wells FH-2 and FH-3 elsewhere in Laramie County, were sodium-bicarbonate types (fig. 36). Waters from other wells completed in the Fox Hills aquifer sampled as part of other studies (FH-4 near Pine Bluffs and FH-5, FH-6, and FH-7 in Goshen Hole; fig. 30; appendix 3, table 3.1) also were sodium-bicarbonate types (fig. 36).

Samples from all but two of the wells completed in the Fox Hills aquifer (wells FH-1 well FH-2) plotted closely together (fig. 36), indicating waters with principally the same compositions. Waters from monitoring well $\mathrm{FH}-1$ and production well FH-2 had more sulfate than the other wells completed in the Fox Hills aquifer, so samples from these wells plotted away from the other samples on the trilinear diagram (fig. 36). All water samples from the Fox Hills aquifer were highly sodic, as sodium composed greater than 95 percent of the cation equivalents.

\section{Hardness}

Groundwater samples herein are classified in relation to a commonly used hardness scale (Durfor and Becker, 1964), where hardness is classified into four categories as follows: 0-60 mg/L as calcium carbonate, soft; $61-120 \mathrm{mg} / \mathrm{L}$ as calcium carbonate, moderately hard; $121-180 \mathrm{mg} / \mathrm{L}$ as calcium 
carbonate, hard; and greater than $18 \mathrm{mg} / \mathrm{L}$ as calcium carbonate, very hard. Groundwater sampled from monitoring well BR-1 completed in the White River aquifer was moderately hard $(94.9 \mathrm{mg} / \mathrm{L}$ as calcium carbonate; table 5). In contrast, groundwater sampled from the four wells completed in Upper Cretaceous hydrogeologic units (Lance aquifer or Fox Hills aquifer) was soft (table 5). Although groundwater from all four wells completed in Upper Cretaceous hydrogeologic units was soft, groundwater from all three wells completed in the Fox Hills aquifer was substantially softer $(7.30-10.4 \mathrm{mg} / \mathrm{L}$ as calcium carbonate) than from monitoring well $\mathrm{LN}-1$ completed in the Lance aquifer $(33.0 \mathrm{mg} / \mathrm{L}$ as calcium carbonate; table 5). Hardness values were similar among the three sampled wells completed in the Fox Hills aquifer, ranging narrowly from 7.30 (well $\mathrm{FH}-3$ ) to $10.4 \mathrm{mg} / \mathrm{L}$ as calcium carbonate (well FH-2; table 5).

\section{Comparison to Domestic and Livestock Standards and Guidelines}

Sodium was the only major ion detected in groundwater samples at concentrations greater than any domestic or livestock water standard or guideline. Concentrations of sodium measured in water from the five sampled wells ranged from $80.1 \mathrm{mg} / \mathrm{L}$ in well BR-1 to $202 \mathrm{mg} / \mathrm{L}$ in well FH-2 (table 5). All measured concentrations exceeded the EPA DWA of $20 \mathrm{mg} / \mathrm{L}$ for individuals on sodium-restricted diets and the upper value of the EPA DWA range of 30 to $60 \mathrm{mg} / \mathrm{L}$ (table 5). According to the EPA, sodium concentrations in water less than the 30 to $60 \mathrm{mg} / \mathrm{L}$ EPA DWA range are unlikely to be perceived as salty by most individuals (U.S. Environmental Protection Agency, 2003). In contrast, the World Health Organization (2003) reports a much higher sodium concentration $(200 \mathrm{mg} / \mathrm{L})$ in water less than which most individuals are unlikely to perceive as salty.

\section{Comparison to Irrigation Standards and Guidelines}

A classification system to evaluate the suitability of water for irrigation use was developed by the U.S. Salinity Laboratory Staff (1954). The classification system is based on two characteristics, the salinity hazard and sodium (alkali) hazard of the water. Salinity hazard is divided into four classes using the specific conductance of the water. The characteristics of the salinity-hazard classes and specific-conductance ranges are shown in table $8 \mathrm{~A}$.

The sodium hazard is divided into four classes using the sodium adsorption ratio (SAR). The SAR is a dimensionless ratio that is calculated to indicate the tendency of sodium to replace calcium and magnesium in soils. The replacement of calcium and magnesium with sodium can damage the soil structure and reduce the permeability of the soil to water infiltration (Hem, 1985); however, the SAR should be used in conjunction with information about the soil characteristics and irrigation practices in the area being examined. The SAR is calculated by converting ion concentrations into milliequivalents per liter and substituting into equation 5 :

Table 8. (A) Salinity hazard and specific conductance, and $(B)$ sodium hazard and sodium adsorption ratio.

[Modified from U.S. Salinity Laboratory Staff (1954). $\mu \mathrm{S} / \mathrm{cm}$, microsiemens per centimeter at 25 degrees Celsius; >, greater than]

\begin{tabular}{|c|c|c|}
\hline \multicolumn{3}{|r|}{$\boldsymbol{A}$} \\
\hline $\begin{array}{l}\text { Salinity- } \\
\text { hazard } \\
\text { class }\end{array}$ & $\begin{array}{c}\text { Specific } \\
\text { conductance } \\
(\mu \mathrm{S} / \mathrm{cm})\end{array}$ & Characteristics \\
\hline $\begin{array}{l}\text { Low } \\
\text { (C1) }\end{array}$ & $0-250$ & $\begin{array}{l}\text { Low-salinity water can be used for } \\
\text { irrigation on most soil with mini- } \\
\text { mal likelihood that soil salinity } \\
\text { will develop. }\end{array}$ \\
\hline $\begin{array}{l}\text { Medium } \\
\text { (C2) }\end{array}$ & $251-750$ & $\begin{array}{l}\text { Medium-salinity water can be } \\
\text { used for irrigation if a moderate } \\
\text { amount of drainage occurs. }\end{array}$ \\
\hline $\begin{array}{l}\text { High } \\
\text { (C3) }\end{array}$ & $751-2,250$ & $\begin{array}{l}\text { High-salinity water is not suitable } \\
\text { for use on soil with restricted } \\
\text { drainage. Even with adequate } \\
\text { drainage, special management } \\
\text { for salinity control may be } \\
\text { required. }\end{array}$ \\
\hline $\begin{array}{l}\text { Very high } \\
\quad \text { (C4) }\end{array}$ & More than 2,250 & $\begin{array}{l}\text { Very high-salinity water is not suit- } \\
\text { able for irrigation under normal } \\
\text { conditions. }\end{array}$ \\
\hline
\end{tabular}

\begin{tabular}{|c|c|c|}
\hline \multicolumn{3}{|r|}{$B$} \\
\hline $\begin{array}{l}\text { Sodium- } \\
\text { hazard } \\
\text { class }\end{array}$ & $\begin{array}{l}\text { Sodium } \\
\text { adsorption } \\
\text { ratio }\end{array}$ & Characteristics \\
\hline $\begin{array}{l}\text { Low } \\
\text { (S1) }\end{array}$ & $0-10$ & $\begin{array}{l}\text { Low-sodium water can be used for } \\
\text { irrigation on most soil with mini- } \\
\text { mal danger of harmful levels of } \\
\text { exchangeable sodium. }\end{array}$ \\
\hline $\begin{array}{l}\text { Medium } \\
\text { (S2) }\end{array}$ & $>10-18$ & $\begin{array}{l}\text { Medium-sodium water will pres- } \\
\text { ent an appreciable sodium hazard } \\
\text { in fine-textured soil having high } \\
\text { cation-exchange capacity. }\end{array}$ \\
\hline $\begin{array}{l}\text { High } \\
\text { (S3) }\end{array}$ & $>18-26$ & $\begin{array}{l}\text { High-sodium water may produce } \\
\text { harmful levels of exchangeable } \\
\text { sodium in most soil. }\end{array}$ \\
\hline
\end{tabular}
Very high >26 Very high-sodium water is gener- (S4) ally unsatisfactory for irrigation purposes.


where

$$
S A R=\frac{\mathrm{Na}}{\sqrt{\frac{\mathrm{Ca}+\mathrm{Mg}}{2}}},
$$

$$
\begin{gathered}
\mathrm{SAR} \\
\mathrm{Na} \text { is the sodium adsorption ratio (unitless); } \\
\text { milliequivalents per liter; } \\
\mathrm{Ca} \quad \text { is the calcium concentration, in } \\
\text { milliequivalents per liter; and } \\
\mathrm{Mg} \text { is the magnesium concentration, in } \\
\text { milliequivalents per liter. }
\end{gathered}
$$

SAR values calculated using equation 5 then can be compared to characteristics of the four sodium-hazard classes shown in table $8 B$.

Typically, salinity hazard and sodium hazard are combined into a single plot to evaluate the suitability of water for irrigation (fig. 37; U.S. Salinity Laboratory Staff, 1954). Results from analyses of groundwater samples collected as part of this study, from the USGS NWIS database, and from other studies in the Cheyenne Basin in southeastern Wyoming are shown in figure 37. Groundwater sampled from monitoring well BR-1 and samples from most other wells completed in the White River and Brule aquifers in the Cheyenne Basin plotted in the range from low (S1) to medium (S2) sodiumhazard classes and medium (C2) to high (C3) salinity-hazard classes (fig. 37). Although this indicates that samples collected from wells completed in these aquifers plot in a wide range of sodium- and salinity-hazard classes, most samples clustered in or near the combined low-sodium-hazard-medium-salinityhazard (S1-C2) class, including all but one of the samples collected from wells in the Pine Bluffs lowland area.

Groundwater samples from wells completed in the Chadron and Lance aquifers in the Cheyenne Basin plotted in the range from low (S1) to very high (S4) sodium-hazard classes and medium (C2) to very high (C4) salinity-hazard classes (fig. 37). Most Chadron and Lance aquifer water samples were from the Goshen Hole area (identified with a prefix of "GC" for Chadron aquifer samples and "GL" or Lance aquifer samples on fig. 37). Except for four samples from the Chadron aquifer and two samples from the Lance aquifer, the Goshen Hole Chadron and Lance aquifer groundwater samples plotted in the very high (S4) sodium-hazard class, indicating these waters are unsuitable for irrigation use regardless of salinity-hazard classification (table $8 A$ ). Groundwater samples from Lance aquifer wells in Laramie County plotted in lower sodium-hazard and salinity-hazard classes. Samples from monitoring well LN-1 and well EL-1 (Lodgepole Valley Potatoes well), both located in the Pine Bluffs lowland (fig. 30), plotted in the combined medium-sodium-hazard-mediumsalinity-hazard (S2-C2) class (fig. 37). The SAR value calculated for the water sample from monitoring well LN-1 (7) was close to the Wyoming Class II agricultural (irrigation) SAR standard of 8 (table 5). Samples from two Lance aquifer wells (HL-1 and HL-2; appendix 2, table 2.1) west of Cheyenne (fig. 30) plotted in the combined low-sodium-hazard-mediumsalinity-hazard (S1-C2) class.
Groundwater samples from wells completed in the Fox Hills aquifer in the Cheyenne Basin, including the three wells sampled for this study (FH-1, FH-2, and FH-3) and four wells sampled as part of other studies (FH-4, FH-5, FH-6, and $\mathrm{FH}-7$ ), plotted in the very high (S4) sodium-hazard class and along the boundary between the medium (C2) to high (C3) salinity-hazard classes (fig. 37). Because all samples plotted in the very high (S4) sodium-hazard class, waters from Fox Hills aquifer wells are unsuitable for irrigation use regardless of salinity-hazard classification (table $8 A$ ). SAR values calculated for the three wells sampled for this study ( $\mathrm{FH}-1$, $\mathrm{FH}-2$, and $\mathrm{FH}-3$ ) ranged from 23 to 28 , and these values greatly exceeded the Wyoming Class II agricultural (irrigation) SAR standard of 8 (table 5) and recommended SAR levels (table 8B).

\section{Trace Elements}

Trace elements are a diverse group of constituents that typically occur naturally at small concentrations $(<1 \mathrm{mg} / \mathrm{L})$ in groundwater (Hem, 1985). Trace elements commonly are collectively referred to as metals even though some elements such as antimony, arsenic, and selenium are semimetallic elements. Geochemical conditions such as redox conditions and $\mathrm{pH}$ commonly control the occurrence and chemical speciation of trace elements in groundwater rather than the abundance of the element in the rocks and minerals composing the aquifer (Hem, 1985). Health-based regulatory standards (MCLs) have been established by the EPA for many trace elements because of toxicity to the human body. In addition, the EPA has established secondary standards (SMCLs) for some trace elements for aesthetic or cosmetic reasons.

Analytical results for trace elements are shown in table 5. Most trace elements detected at levels greater than associated reporting levels were measured at low concentrations much smaller than EPA and Wyoming drinking-water standards or health advisories, Wyoming Class II agricultural water standards, or Wyoming Class III livestock standards (table 5). Dissolved aluminum was measured in groundwater sampled from well FH-3 completed in the Fox Hills Sandstone at a concentration $(45.8 \mu \mathrm{g} / \mathrm{L})$ approaching the lower EPA SMCL limit of $50 \mu \mathrm{g} / \mathrm{L}$ (table 5).

Of the trace elements detected at concentrations greater than reporting limits, only dissolved arsenic was detected at a concentration greater than any drinking-water standard or advisory (table 5). Long-term exposure to arsenic is associated with many health problems, including various cancers, immunological impairments, cardiovascular disease, and problems with the circulatory system (U.S. Environmental Protection Agency, 2018). In 2001, the EPA lowered the MCL for arsenic in drinking water from 50 to $10 \mu \mathrm{g} / \mathrm{L}$ (U.S. Environmental Protection Agency, 2001). Dissolved arsenic was detected in the sample from well BR-1 (White River aquifer) at a concentration $(11.5 \mu \mathrm{g} / \mathrm{L})$ greater than the $10 \mu \mathrm{g} / \mathrm{L}$ EPA MCL (table 5). Concentrations of dissolved arsenic greater than the MCL have been detected infrequently in other groundwater 


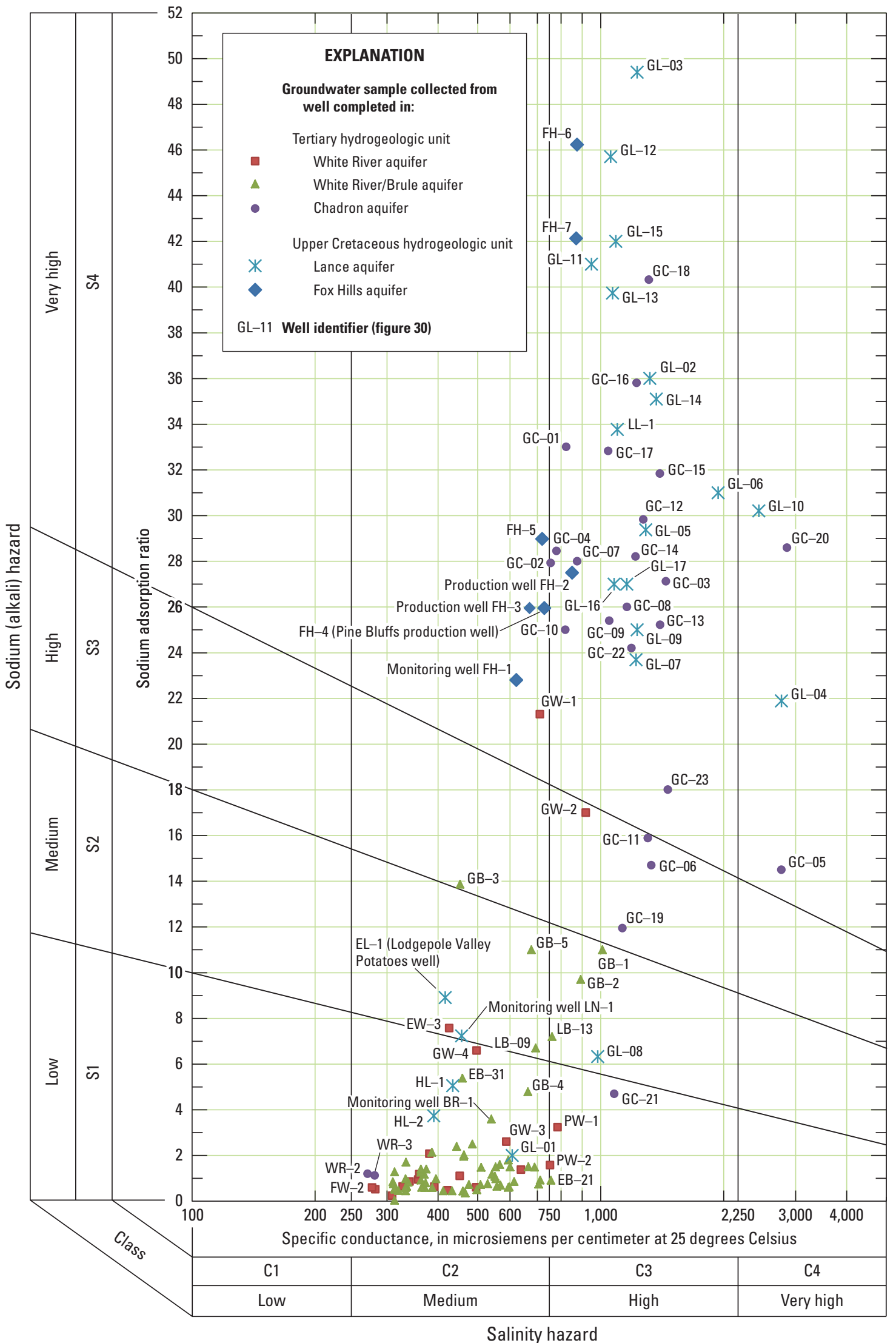

Figure 37. Suitability of water for use in irrigation based on analyses of water from wells, Cheyenne Basin, southeastern Wyoming (modified from U.S. Salinity Laboratory Staff [1954]). Location of wells shown in figure 30. 
samples collected from the White River aquifer in southeastern Wyoming (Boughton, 2014, appendix table 1-4) and adjacent western Nebraska (Verstraeten and others, 1995, fig. 16A). Studies in other parts of the country indicate the mobility and solubility of arsenic in groundwater typically is increased by low DO concentrations (anoxic conditions), high $\mathrm{pH}$, and the presence of organic carbon and iron oxides (Welch and others, 2000; Nordstrom, 2002; Kelly and others, 2005). Arsenic concentrations in groundwater greater than the MCL also have been related to the release of arsenic adsorbed to iron oxide (Welch and others, 2000) and to old groundwater (prebomb, recharged before early 1950s; Thomas, 2007). In addition, naturally occurring sulfide minerals are a major source of trace elements (Drever, 1997), and these minerals can be either a source or sink for arsenic (Welch and others, 2000).

\section{Nutrients and Dissolved Organic Carbon}

Groundwater sampled from all wells was analyzed for different species of nitrogen and phosphorus. Small concentrations of both nutrients occur naturally in groundwater, but elevated concentrations commonly are associated with anthropogenic activities. The most common anthropogenic sources of nitrogen and phosphorus in shallow groundwater are from leaching of synthetic fertilizers applied to agricultural lands, animal manure, or septic system effluent (Alley, 1993).

Nitrate (an oxidized species of nitrogen in water) and phosphorus in water are of environmental and health concern. Nitrate and phosphorus discharged to surface waters can contribute to eutrophication. Large concentrations of nitrate in drinking water have been associated with potential adverse health effects including low oxygen levels in the blood of infants ("blue baby" syndrome, also known as infantile methemoglobinemia) (Fan and Steinberg, 1996), miscarriage (Centers for Disease Control and Prevention, 1996), and increased risk of non-Hodgkin's lymphoma (Ward and others, 1996); however, the relation between nitrate in drinking water and infantile methemoglobinemia is still debated (for example, Avery, 1999).

As noted by Hem (1985, p. 124), "nitrogen occurs in water as nitrite or nitrate anions, in cationic form as ammonium, and at intermediate oxidation states as a part of organic solutes." Consequently, groundwater samples were analyzed for several species of nitrogen, including oxidized and reduced forms. Biogeochemical processes commonly control the species of nitrogen measured in groundwater (Hem, 1985). All nitrogen species concentrations presented in this report are reported as equivalent concentrations of nitrogen. Groundwater samples were analyzed for total ammonia as nitrogen (referred to as "ammonia" in this report) that included ammonium ion and un-ionized ammonia. At the $\mathrm{pH}$ values measured in groundwater samples collected during this study, un-ionized ammonia was likely a small component of total ammonia (Hem, 1985).
Analytical results for nutrients are shown in table 5 . When detected, nutrient concentrations generally were low in groundwater from all sampled wells, and all concentrations were much smaller than applicable EPA or Wyoming Class I drinking-water standards or health advisories or Wyoming Class III livestock water standards (table 5).

Oxidized and reduced forms of nitrogen were detected in groundwater sampled from monitoring well BR-1 completed in the White River aquifer (table 5). Concentrations of most nitrogen species were low $(<1 \mathrm{mg} / \mathrm{L})$ except for dissolved nitrate as nitrogen. Comparison of dissolved nitrate $(1.91 \mathrm{mg} / \mathrm{L})$ with total dissolved nitrogen $(2.18 \mathrm{mg} / \mathrm{L})$ indicated most of the nitrogen consisted of nitrate, an oxidized form of nitrogen. Concentrations of dissolved nitrate in groundwater in the conterminous United States greater than $1 \mathrm{mg} / \mathrm{L}$ have been considered indicative of contamination from anthropogenic sources (Nolan and Hitt, 2003; Dubrovsky and others, 2010). Monitoring well BR-1 is completed in an area with agricultural activities, but the absence of tritium (see "Apparent Groundwater Age" report section) indicated water sampled from the well is less likely to have been affected by agricultural or other anthropogenic activities in the area. Dissolved nitrate concentrations in groundwater sampled from the White River aquifer that are slightly larger than would be expected when affected by human activities are not surprising because nitrate concentrations in shallow groundwater beneath parts of the High Plains aquifer system can be larger than expected in other geographic regions within the United States, primarily because of the presence of large natural nitrate deposits in the soil and subsoil of some arid and semiarid areas within the regional aquifer system (McMahon and Böhlke, 2006).

Dissolved ammonia, a reduced form of nitrogen, was the only nitrogen species detected in groundwater sampled from well LN-1 completed in the Lance aquifer and all three wells completed in the Fox Hills aquifer (table 5). All measured concentrations were much smaller than the EPA MCL of $30 \mathrm{mg} / \mathrm{L}$. The detection of ammonia compared to most other species of nitrogen was expected because groundwater sampled from the Lance aquifer and Fox Hills aquifer was anoxic (see "Redox Conditions" report section); ammonia is the most common form of nitrogen in anoxic groundwater (Hem, 1985).

Dissolved phosphorus (total as phosphorus) was detected in groundwater from all sampled wells but at low concentrations ranging from $0.008 \mathrm{mg} / \mathrm{L}$ in well $\mathrm{LN}-1$ to $0.143 \mathrm{mg} / \mathrm{L}$ in well FH-3 (table 5). Dissolved orthophosphate (as phosphorus) was detected in groundwater from all sampled wells except for well BR-1 but at low concentrations ranging from $0.012 \mathrm{mg} / \mathrm{L}$ in well $\mathrm{LN}-1$ to $0.143 \mathrm{mg} / \mathrm{L}$ in well $\mathrm{FH}-3$ (table 5). Phosphorus concentrations in groundwater typically are low because of low solubility and a tendency to adsorb to organic matter or metallic oxides in the subsurface (Hem, 1985). The EPA has not established water-quality standards for phosphorus in groundwater; however, to reduce the possibility of eutrophication and resulting effects on aquatic life, the EPA recommends that total phosphorus concentrations in surface 
water should not be greater than $0.1 \mathrm{mg} / \mathrm{L}$ (as phosphorus) for flowing water not directly discharging into a lake or reservoir (U.S. Environmental Protection Agency, 1986). Phosphorus concentrations greater than $0.1 \mathrm{mg} / \mathrm{L}$ in groundwater can be a concern when groundwater discharges to surface water.

DOC occurs naturally in groundwater, but elevated concentrations are often associated with groundwater contamination from human sources (for example, septic system effluent; Appelo and Postma, 2005). DOC represents the carbon-containing fraction of dissolved organic matter, and it typically accounts for more than 90 percent of the total organic carbon detected in natural groundwater, with particulate organic carbon composing the remaining total organic carbon (Regan and others, 2017). Much of the natural DOC in groundwater is from humic and fulvic acids generated by biogeochemical degradation of organic material in the soil profile above the aquifer or by degradation of organic matter within the aquifer deposits. Percolating waters (groundwater recharge) transport DOC in the soil zone through the vadose zone to the water table. DOC in groundwater can affect numerous subsurface microbial and geochemical processes, including the redox state of groundwater (DOC is a common electron donor) and trace-element solubility (through formation of complexes; Chapelle, 2001).

DOC was detected in groundwater samples collected from all wells except for well $\mathrm{LN}-1$ (table 5). The lowest concentration $(0.39 \mathrm{mg} / \mathrm{L})$ was measured in well BR-1. Concentrations of DOC measured in groundwater samples collected from the three wells completed in the Fox Hills Sandstone ranged from $0.59 \mathrm{mg} / \mathrm{L}$ in well $\mathrm{FH}-3$ to $1.04 \mathrm{mg} / \mathrm{L}$ in well FH-1 (table 5). All concentrations measured in the five wells sampled for this study are within the range of 0.1 to about $4 \mathrm{mg} / \mathrm{L}$ reported for most natural (unpolluted) groundwaters (Drever, 1997, fig. 6-1, p. 108; Regan and others, 2017).

\section{Radiochemical Constituents}

Radiochemicals are chemical elements that undergo radioactive decay. Radioactivity is the release of energy and energetic particles by changes in certain unstable elements as they break down (decay) to form more stable elements. Radioactive energy is released as alpha radiation consisting of positively charged helium nuclei (alpha particles), beta radiation consisting of positrons and electrons (beta particles), and gamma radiation consisting of electromagnetic waves. Alpha particles do not penetrate the skin and are hazardous to internal organs only when inhaled or ingested (U.S. Environmental Protection Agency, 2018). Beta particles can penetrate the skin, and emissions from strong sources can redden or burn skin; however, exposure through inhalation or ingestion is the greatest health concern (U.S. Environmental Protection Agency, 2018).

The most commonly used measurement unit for radioactivity in water is picocuries per liter, where 1 curie is the activity of 1 gram of radium, which is equal to $3.7 \times 10^{10}$ atomic disintegrations per second, and $1 \mathrm{pCi} / \mathrm{L}$ is equal to
2.2 disintegrations per minute per liter of water (U.S. Environmental Protection Agency, 2018). Activity refers to the number of particles emitted by a radionuclide. The rate of radioactive decay is proportional to the number of atoms present and inversely proportional to its half-life. The half-life is the amount of time it takes for a radioactive element to decay to one-half of its original quantity. The activity of a single radionuclide (for example, radon-222) is considered a concentration because mass is linked directly to activity by the radioactive decay equation and half-life. Gross activity measurements (for example, gross alpha-particle activity) are considered activities and not concentrations because there is no identifiable half-life or isotope mass associated with the measurement.

In groundwater, radiochemicals are from natural sources such as rocks and minerals or from anthropogenic activities such as nuclear weapons testing, mining, or industrial/medical processes (Hem, 1985). The presence of radiochemicals in groundwater is controlled by many factors, including the distribution and concentration of radiochemicals in rock composing the aquifer, the chemical form of the radiochemicals, geochemical conditions ( $\mathrm{pH}$ and redox conditions), the presence of complexing and sorptive materials, microbial activity, and half-life (Hem, 1985). The half-life is particularly important because it determines the length of time the radiochemical can reside in groundwater.

Analyses for radioactivity and radiochemicals in groundwater samples collected from all wells except for BR-1 included gross alpha-particle activity (as thorium-230), gross beta-particle activity (as cesium-137), dissolved uranium, two radium isotopes (radium-226 and radium-228), and radon gas (radon-222). Monitoring well BR-1 was sampled only for dissolved uranium.

Gross alpha-particle and beta-particle activities are measures of alpha and beta particles produced by the decay of all radionuclides in a water sample and commonly are used as a screening tool to determine the likelihood of elevated activities of an individual radiochemical. Gross alpha-particle activities greater than associated reporting levels (SSLCs) were measured only in two of four wells (LN-1, 4.2 $\pm 1.2 \mathrm{pCi} / \mathrm{L}$, and FH-2, 2.2 $\pm 1.3 \mathrm{pCi} / \mathrm{L}$ ) sampled for the constituent (table 5). Both measured activities were smaller than the EPA MCL of $15 \mathrm{pCi} / \mathrm{L}$. Gross beta-particle activity was higher than SSLCs in all four wells sampled for the constituent, with activities that ranged from $1.36 \pm 0.54 \mathrm{pCi} / \mathrm{L}$ in $\mathrm{FH}-3$ to $6.9 \pm 1.1 \mathrm{pCi} / \mathrm{L}$ in well LN-1 (table 5). Measured activities cannot be compared directly to the EPA MCL for gross beta-particle activity (4 millirems per year) because the standard is expressed as a dose, rather than a concentration. Conversion of picocuries per liter to millirems to facilitate comparison with the MCL is not possible without identification and quantification of individual radionuclides in a given sample. The California Department of Public Health has established a drinking-water standard of $50 \mathrm{pCi} / \mathrm{L}$ (considered equivalent to 4 millirems per year) for gross beta-particle activity (California Department of Public Health, 2018). Gross beta-particle activities measured 
in all four wells were much smaller than this drinking-water standard.

Uranium is a naturally occurring element that undergoes radioactive decay into different uranium isotopes, which then decay to isotopes of other elements such as radium and lead. Groundwater samples were analyzed for total dissolved uranium, which included all three naturally occurring isotopes (uranium-234, uranium-235, and uranium-238). Elevated concentrations of uranium in drinking water can cause kidney damage and several types of cancer (U.S. Environmental Protection Agency, 2018). Uranium was detected at concentrations greater than reporting levels in all five wells sampled for this study, ranging from $0.022 \mathrm{mg} / \mathrm{L}$ in well $\mathrm{FH}-3$ to $9.54 \mathrm{mg} / \mathrm{L}$ in well BR-1 (table 5). All concentrations were smaller than the EPA MCL of $30 \mu \mathrm{g} / \mathrm{L}$. Uranium concentrations measured in samples from all three wells completed in the Fox Hills aquifer were low $(<0.25 \mathrm{mg} / \mathrm{L})$. These low concentrations may be at least partly attributable to the redox state of groundwater in these wells because uranium is much less soluble in reducing conditions.

Groundwater samples were analyzed for two of four natural radium isotopes (radium-226 and radium-228). Radium-226 is a naturally occurring product of the uranium-238 decay series, whereas radium-228 is a naturally occurring product of the thorium-232 decay series. Radium-226 was detected in all four wells sampled for the constituent, but concentrations were low $(<0.11 \mathrm{pCi} / \mathrm{L})$ and only slightly larger than SSLCs (table 5). Radium-228 was detected in three of four wells sampled for the constituent (not detected in well $\mathrm{FH}-1)$. Concentrations of radium-228 also were low $(<0.69 \pm 0.18 \mathrm{pCi} / \mathrm{L})$ and only slightly larger than SSLCs (table 5). The EPA has established an MCL for radium, which is defined as the sum of radium-226 and radium-228. No summed radium-226 and radium-228 concentrations exceeded the MCL of 5 pCi/L (U.S. Environmental Protection Agency, 2018).

Radon-222 (radon), a decay product of radium-226, is a colorless, odorless, chemically inert, naturally occurring radioactive gas that is soluble in groundwater. Ingestion of high concentrations of radon in drinking water can contribute to the risk of developing gastrointestinal cancers, but the primary hazard associated with radon is increased risk of developing lung cancer through inhalation of indoor air (Cothern and Smith, 1987; National Research Council, 1999). The main source of radon emission to indoor air is the decay of uranium in soil and rock underlying buildings (National Research Council, 1999). An additional potential source of radon to indoor air is from groundwater obtained from wells because radon gas dissolved in water can be released indoors during activities such as taking a shower; however, the amount of radon in water usually is small compared to the other sources of radon to indoor air (Hopke and others, 2000). Domestic use of water with about $10,000 \mathrm{pCi} / \mathrm{L}$ of radon contributes about $1 \mathrm{pCi} / \mathrm{L}$ of radon to indoor air (Otton, 1992). If the concentration of indoor air is greater than $4 \mathrm{pCi} / \mathrm{L}$, the EPA recommends the use of various methods to reduce the radon concentration (U.S. Environmental Protection Agency, 2016a). Because of health concerns, the EPA has proposed an MCL for radon in drinking water of $300 \mathrm{pCi} / \mathrm{L}$ and an alternative MCL of 4,000 pCi/L (U.S. Environmental Protection Agency, 1999). The lower proposed MCL for radon applies to States and public water-supply systems that do not develop programs to address health risks from radon in indoor air. The higher proposed alternative MCL applies to States and public water-supply systems that have established such programs. Radon concentrations greater than the SSLC were measured in all four wells sampled for the constituent. Concentrations measured in two of four sampled wells (FH-2, 440 $28 \mathrm{pCi} / \mathrm{L}$ and $\mathrm{FH}-3,463 \pm 29 \mathrm{pCi} / \mathrm{L}$ ) exceeded the proposed EPA MCL of $300 \mathrm{pCi} / \mathrm{L}$ (table 5 ).

\section{Organic Constituents}

Groundwater sampled from all wells except for BR-1 was analyzed for four organic constituent classes, including VOCs, GRO, DRO, and dissolved hydrocarbon gases. Although these constituents are naturally present in association with hydrocarbon (natural gas and oil) deposits, their presence in groundwater in areas outside oil and gas fields can indicate an anthropogenic source.

\section{Volatile Organic Compounds}

VOCs are anthropogenic and naturally occurring organic chemicals with low boiling points that cause them to volatilize to their gaseous form under most environmental conditions. VOCs are components in many commonly used products, such as plastics, paints, refrigerants, gasoline, fuel oils, lubricants, personal hygiene products, organic solvents, fumigants, and pesticides, as well as byproducts of chlorine disinfection of water supplies (Zogorski and others, 2006). Many VOCs are highly soluble, mobile, and persistent in groundwater. In addition, some VOCs are known or suspected carcinogens or have some type of health risk associated with exposure (Zogorski and others, 2006); therefore, EPA regulatory standards have been established for many VOCs in drinking water (U.S. Environmental Protection Agency, 2018).

VOCs were detected in only one of four wells (production well FH-2) sampled for the constituents (table 9). Three VOCs were detected in the sample from well FH-2: (1) methylene chloride (also known dichloromethane), a solvent; (2) acetone, a solvent; and (3) chloroform (also known as trichloromethane), a solvent and a common byproduct of chlorine disinfection (Zogorski and others, 2006). The concentration of methylene chloride $(5.7 \mu \mathrm{g} / \mathrm{L})$ measured in the sample is greater than the EPA MCL of $5 \mu \mathrm{g} / \mathrm{L}$. All three VOCs are widely used solvents in analytical laboratories, and all three compounds are commonly detected laboratory contaminants (U.S. Environmental Protection Agency, 2016b). The cooccurrence of three VOCs in the sample from well FH-2, all of which are known to be common laboratory contaminants, is indicative of sample contamination by laboratory activities. 
[GROs, gasoline-range organics; DROs, diesel-range organics; VOCs, volatile organic compounds; $\mu \mathrm{g} / \mathrm{L}$, microgram per liter; E, estimated concentration, indicates value measured was below laboratory reporting level (LRL), but greater than established method detection limit (MDL); $<$, less than symbol indicates the constituent was not detected and the value following the less than symbol is the laboratory reporting level; ND, VOCs not detected above compound-specific reporting levels; EPA, U.S. Environmental Protection Agency; MCL, Maximum Contaminant Level]

\begin{tabular}{|c|c|c|c|c|c|c|c|c|c|c|c|c|c|}
\hline \multirow[b]{2}{*}{ 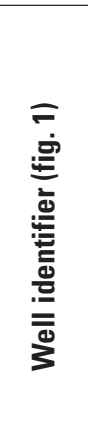 } & \multirow[b]{2}{*}{ 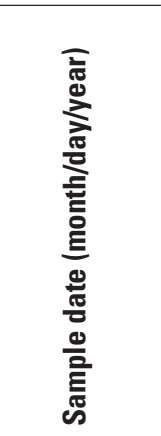 } & \multirow[b]{2}{*}{ 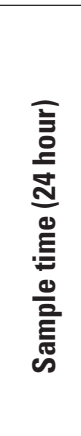 } & \multicolumn{10}{|c|}{ Organic constituent } & \multirow[b]{2}{*}{ Comments } \\
\hline & & & 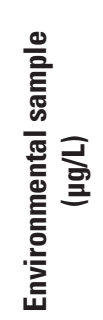 & 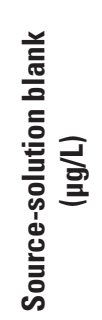 & 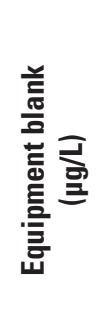 & 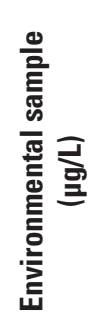 & 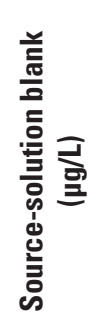 & 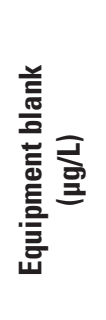 & 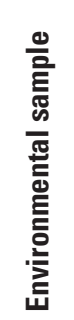 & 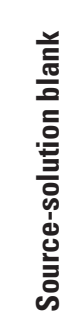 & $\begin{array}{l}\text { 兰 } \\
\text { 高 } \\
\text { 亮 }\end{array}$ & 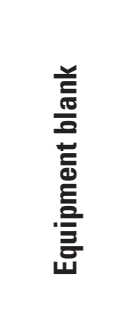 & \\
\hline \multicolumn{14}{|c|}{ Monitoring wells installed and sampled for this study } \\
\hline $\mathrm{LN}-1$ & $12 / 17 / 2013$ & 1400 & E24 & $<100$ & $<100$ & $<210$ & E25 & E36 & ND & ND & ND & $4 \mathrm{VOCs}^{3}$ & GROs detection possibly due to sample contamination. \\
\hline $\mathrm{FH}-1$ & $11 / 14 / 2013$ & 1500 & E18 & $<100$ & $<100$ & E31 & E25 & E36 & ND & ND & ND & $4 \mathrm{VOCs}^{3}$ & $\begin{array}{l}\text { DROs detection attributed to sample contamination } \\
\text { (see text). GROs detection possibly due to sample } \\
\text { contamination. }\end{array}$ \\
\hline
\end{tabular}

\begin{tabular}{lllllllllll}
\hline FH-2 & $12 / 3 / 2014$ & 0800 & E32 & $<100$ & $<100$ & E63 & E25 & E36 & 3VOCs & ND
\end{tabular}

text). Three VOCs detected in environmental sample (methylene chloride, $5.7 \mu \mathrm{g} / \mathrm{L}$; acetone, detected, but not quantified; and chloroform, $5.5 \mu \mathrm{g} / \mathrm{L}$ ) are not the same as the four VOCs detected in equipment blank

(see footnote 3). Methylene chloride value $(5.7 \mu \mathrm{g} / \mathrm{L})$ is greater than EPA MCL $(5 \mu \mathrm{g} / \mathrm{L})$. GROs detection possibly due to sample contamination.

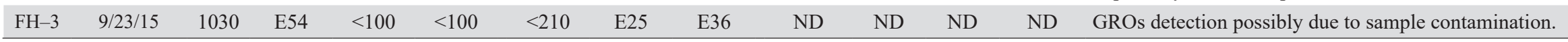

${ }^{1} \mathrm{LRL}$ for GROs was $100 \mu \mathrm{g} / \mathrm{L}$.

${ }^{2} \mathrm{LRL}$ for DROs samples from LN-1 and FH-2 was $210 \mu \mathrm{g} / \mathrm{L}$. LRLs for DROs samples from FH-1 and FH-3 were 190 and $390 \mu \mathrm{g} / \mathrm{L}$, respectively.

${ }^{3}$ Four VOCs detected in equipment blank sample were 1,2,4-trichlorobenzene (E0.4 $\mu \mathrm{g} / \mathrm{L}$ ), naphthalene (E0.3 $\left.\mu \mathrm{g} / \mathrm{L}\right), n$-butylbenzene (E0.19 $\left.\mu \mathrm{g} / \mathrm{L}\right)$, and toluene (E0.25 $\left.\mu \mathrm{g} / \mathrm{L}\right)$. None of these VOCs were detected in any environmental samples. 
Production well FH-2 is completed in the deeply buried Fox Hills Sandstone (six screen intervals within 1,702-1,916 ft BLS depth interval; table 1) and, thus, isolated from surface activities that are potential sources of groundwater contamination. In addition, well FH-2 is in a rural area with no potential sources of contamination by these solvents; therefore, all three VOC detections were interpreted to be due to sample contamination and not as detections for this study (qualified as "attributed to sample contamination" in table 9).

\section{Gasoline-Range Organics and Diesel-Range Organics}

GROs are a subset of petroleum hydrocarbons measured in the laboratory that included hydrocarbons in the C5-C10 range (5 to 10 carbon atoms). GROs were detected in all four wells sampled for the constituent, at low (estimated) concentrations ranging from $18 \mu \mathrm{g} / \mathrm{L}$ in monitoring well $\mathrm{FH}-1$ to $54 \mu \mathrm{g} / \mathrm{L}$ in production well $\mathrm{FH}-3$ (table 9). Given that all four wells sampled for GROs are completed in deeply buried aquifers (and different aquifers) isolated from any potential groundwater contamination from surface activities, the detection of GROs in water samples from these wells was surprising.

Gasoline-powered generators supplied power to the pumps used to sample these wells. GRO analyses include petroleum products such as gasoline, so it is possible that field activities related to the generators could have contaminated the environmental samples; however, GROs were not detected in the equipment or source-solution blanks. If gasoline-related compounds were introduced to environmental samples as a result of field activities, as indicated by the GRO detections, it would be expected that gasoline-related VOCs also might be detected in the source-solution or equipment blanks. In fact, four VOCs that are components of gasoline (1,2,4-trichlorobenzene, naphthalene, $n$-butylbenzene, and toluene) were detected at low (estimated) concentrations in the equipment blank sample, even though GROs were not (table 9). Another possibility is that these detections are simply the result of systematic laboratory contamination. According to the contracted analyzing laboratory, low-level organic detections qualified as "estimated" are not routinely reviewed as to their potential for being laboratory "artifacts" (laboratory-induced contaminant to environmental sample). Collectively, examination of all QC data indicated there was evidence that these detections might be attributable to contamination from field or laboratory activities and not actual detections in the environmental samples, but the existing data were not conclusive as to the source of the detections. Consequently, all GRO detections were qualified as "possibly due to sample contamination" (table 9).

DROs are a subset of petroleum hydrocarbons measured in the laboratory that included hydrocarbons in the C10-C32 range (10 to 32 carbon atoms). As described in the "Quality Assurance and Quality-Control Samples" section of the report, detections of DROs in water samples from wells FH-1 and FH-2 were attributed to sample contamination (qualified as "attributed to sample contamination" in table 9).

\section{Dissolved Hydrocarbon Gases}

Groundwater sampled from all wells but BR-1 was analyzed for three dissolved hydrocarbon gases (methane, ethene, ethane). Methane was detected in water from all three sampled wells completed in the Fox Hills aquifer (table 7). Methane is a combustible gas that can accumulate to explosive levels in confined spaces such as wellbores or buildings. Methane is produced by the microbial degradation of organic matter (biogenic) or by the thermal alteration of organic matter (thermogenic; Whiticar, 1999). Biogenic methane generally is produced at much shallower depths than thermogenic methane and can occur naturally in shallow anoxic groundwater (Chapelle, 2001). Thermogenic methane generally is produced and found at depths far below freshwater aquifers, typically at great depths (thousands of feet below land surface) associated with hydrocarbon generation and accumulation. The presence of thermogenic gas in water wells completed at shallow depths typically associated with biogenic methane production can indicate gas migration from underlying gas-bearing formations under natural conditions or possibly migration because of oil and gas extraction where these activities have occurred or are ongoing.

As was discussed briefly in the "Redox Conditions" section of the report, methane concentrations measured in the anoxic waters from monitoring well $\mathrm{FH}-1$ and production wells FH-2 and FH-3 were low $(<0.3 \mathrm{mg} / \mathrm{L}$; table 7$)$. Concentrations measured in waters from monitoring well FH-1 and production well FH-2 (unlike well FH-3, dissolved hydrocarbon gas samples collected from these two wells were sent to two laboratories; table 7) differed between the two analyzing laboratories, but these differences were not unexpected because problems with repeatability/comparability of dissolved-methane measurements in groundwater because of sampling, analytical, and hydrologic variability are well known (Gorody, 2012). Although not detected in monitoring well $\mathrm{LN}-1$, methane has been detected in groundwater sampled from other wells completed in the Lance aquifer and one well completed in the Fox Hills aquifer within the Wyoming part of the Cheyenne Basin. Boughton (2014, table 1-7) detected low $(<0.3 \mathrm{mg} / \mathrm{L})$ concentrations of methane in two of three sampled wells completed in the Lance aquifer in Goshen Hole. Wyoming Groundwater, LLC, and others (2011) noted anecdotal reports of methane in water from wells completed in the Lance aquifer in Goshen Hole, and the investigators detected methane at a concentration of about $1 \mathrm{mg} / \mathrm{L}$ in a water sample collected from a well completed in the Fox Hills aquifer installed for their study near Yoder in Goshen Hole (well identified herein as FH-7). Dissolved methane in groundwater is of safety concern because methane is flammable and can degas as groundwater is pumped from a well and flows through outdoor and household plumbing (Eltschlager and others, 2001). The low concentrations of methane measured in this study and these two other studies (less than or equal to $1 \mathrm{mg} / \mathrm{L}$ ) likely can be considered harmless from a safety perspective; all measured concentrations are substantially 
less than recommended action levels (10 and $28 \mathrm{mg} / \mathrm{L}$ ) for dissolved methane in water established by the U.S. Office of Surface Mining (Eltschlager and others, 2001). Concentrations between 10 and $28 \mathrm{mg} / \mathrm{L}$ indicate that actions should be taken to reduce the methane concentration to less than $10 \mathrm{mg} / \mathrm{L}$ and remove ignition sources from the immediate area; concentrations greater than $28 \mathrm{mg} / \mathrm{L}$ indicate potentially explosive or flammable quantities of methane are being "liberated in the well and/or...in areas of the home" (Eltschlager and others, 2001, p. 40).

No analyses were completed to determine the origin (biogenic or thermogenic) of methane detected in the water samples collected as part of this study; however, anoxic sodium-bicarbonate-type waters with low sulfate concentrations are compatible with microbial methanogenesis (Whiticar, 1999; Bates and others, 2011; also see "Redox Conditions" report section). Microbial gas generation is controlled by the quantity and bioavailability of organic carbon in the absence of alternative terminal-electron acceptors such as oxygen, iron, nitrate, and sulfate, which may cause other microbial communities to outcompete the methanogenic microbes for organic substrates (Chapelle, 2001). A recent study examined methane in groundwater of the Denver Basin aquifer system in northeastern Colorado in areas of oil and gas development (Sherwood and others, 2016). Methane (at concentrations $>1 \mathrm{mg} / \mathrm{L}$ ) detected in waters from wells completed in the Laramie-Fox Hills aquifer determined not to be the result of oil and gas development was microbial in origin (biogenic). The investigators concluded that Laramie Formation coals interbedded with the aquifer materials likely were the source of much of the microbial methane in the aquifer. Laramie Formation coals might contain economic quantities of methane (coal bed methane) in parts of the Denver Basin (Roberts, 2007).

\section{Stable Isotopes of Water}

Collection of samples for analyses of stable isotopes of oxygen (oxygen-18/oxygen-16, or $\delta^{18} \mathrm{O}$ ) and hydrogen (deuterium/protium, or $\delta^{2} \mathrm{H}$ ) in precipitation was not possible as part of this study and no local values were available; therefore, paired $\delta^{18} \mathrm{O}$ and $\delta^{2} \mathrm{H}$ values in the groundwater samples from monitoring wells $\mathrm{BR}-1, \mathrm{LN}-1$, and $\mathrm{FH}-1$ and production wells FH-2 and FH-3 (table 5) were plotted in relation to the global meteoric water line (Craig, 1961) and two local meteoric water lines (LMWLs) developed for two areas within the semiarid north-central part of the Great Plains (fig. 38; North Platte, Nebr. [fig. 2], Harvey and Welker, 2000; Pawnee National Grassland, northeastern Colorado [fig. 4], Harvey, 2005). The North Platte LMWL was developed using data collected from 1989 through 1994 (Harvey and Welker, 2000), and the Pawnee LMWL was developed using data collected from 1994 through 1998 (Harvey, 2005). In addition, paired $\delta^{18} \mathrm{O}$ and $\delta^{2} \mathrm{H}$ values obtained from the USGS NWIS database for the Ogallala, Arikaree, and White River (including Brule and Chadron, where divided) aquifers of the High Plains aquifer system (only in the Cheyenne Basin area) and for two Lance aquifer samples from Dutton (1993, 1995; wells EL-1 and CL-2) also were plotted for comparison. Many of the White River aquifer samples (grouped with Brule/Chadron aquifer samples for plotting purposes) were the same samples plotted on the various trilinear diagrams presented earlier (figs. 31-35); well-identification numbers for these samples were retained for plotting purposes, whereas other samples were simply color coded without an identification number to reflect generalized geographic locations in figure 38.

Paired $\delta^{18} \mathrm{O}$ and $\delta^{2} \mathrm{H}$ values for samples from all wells plotted below the global meteoric water line and the two LMWLs (collectively, meteoric water lines [MWLs]). Samples plotted relatively intermixed with one another, regardless of aquifer (fig. 38). Many White River and Arikaree aquifer samples from Goshen Hole and from Goshen and Platte Counties in areas outside of Goshen Hole plotted farther away from all three MWLs than many samples (fig. 38). One Lance aquifer sample (GL-08; in southern Goshen Hole area, fig. 30) plotted anomalously away from all three MWLs and all other samples (fig. 38).

Although White River aquifer samples from eastern Laramie County plotted over a relatively wide range of $\delta^{18} \mathrm{O}$ and $\delta^{2} \mathrm{H}$ values, 7 of 12 samples plotted/grouped relatively close to one another within a relatively narrow range of values $\left(\delta^{18} \mathrm{O}=-12.55\right.$ to $13.22 ; \delta^{2} \mathrm{H}=-102.2$ to 96.3 ; fig. 38$)$; three of these samples (EB-12, EB-22, and BR-1) plotted closely together. Well EB-12 is only about 1 mi northwest of well BR-1, and well EB-22 is a production well near Pine Bluffs (fig. 30). These three samples were the most enriched (least negative, or isotopically heaviest) White River aquifer samples from eastern Laramie County. Amongst these three wells, the sample from BR-1 was the most enriched; the BR-1 sample also was the second most enriched White River aquifer sample from the entire Cheyenne Basin (only the sample from well PB-2 in Platte County was more enriched; fig. 38).

Lance aquifer samples from Laramie County (three) and from Goshen Hole (three) collectively plotted over a relatively wide range of $\delta^{18} \mathrm{O}$ and $\delta^{2} \mathrm{H}$ values, but Laramie County samples (EL-1, LN-1, and CL-2) spanned a much narrower range of values (fig. 38). Samples from well EL-1 and monitoring well LN-1 (both from eastern Laramie County) plotted closely together (fig. 38), indicating nearly identical stable isotope $\left(\delta^{18} \mathrm{O}\right.$ and $\left.\delta^{2} \mathrm{H}\right)$ composition; waters from these two wells also had similar ionic composition (see "Water Type" report section).

All three samples from the Fox Hills aquifer (wells FH-1, $\mathrm{FH}-2$, and $\mathrm{FH}-3$ ) plotted approximately equidistant from the three MWLs (a line placed through these three samples would approximately parallel the three MWLs; fig. 38). Samples from wells $\mathrm{FH}-1$ and $\mathrm{FH}-3$ plotted relatively close to one another, whereas the sample from FH-2 was considerably more enriched. The FH-2 sample plotted more closely to several eastern Laramie County White River aquifer samples (including EB-12, EB-22, and BR-1) than to the FH-1 and FH-3 samples. 


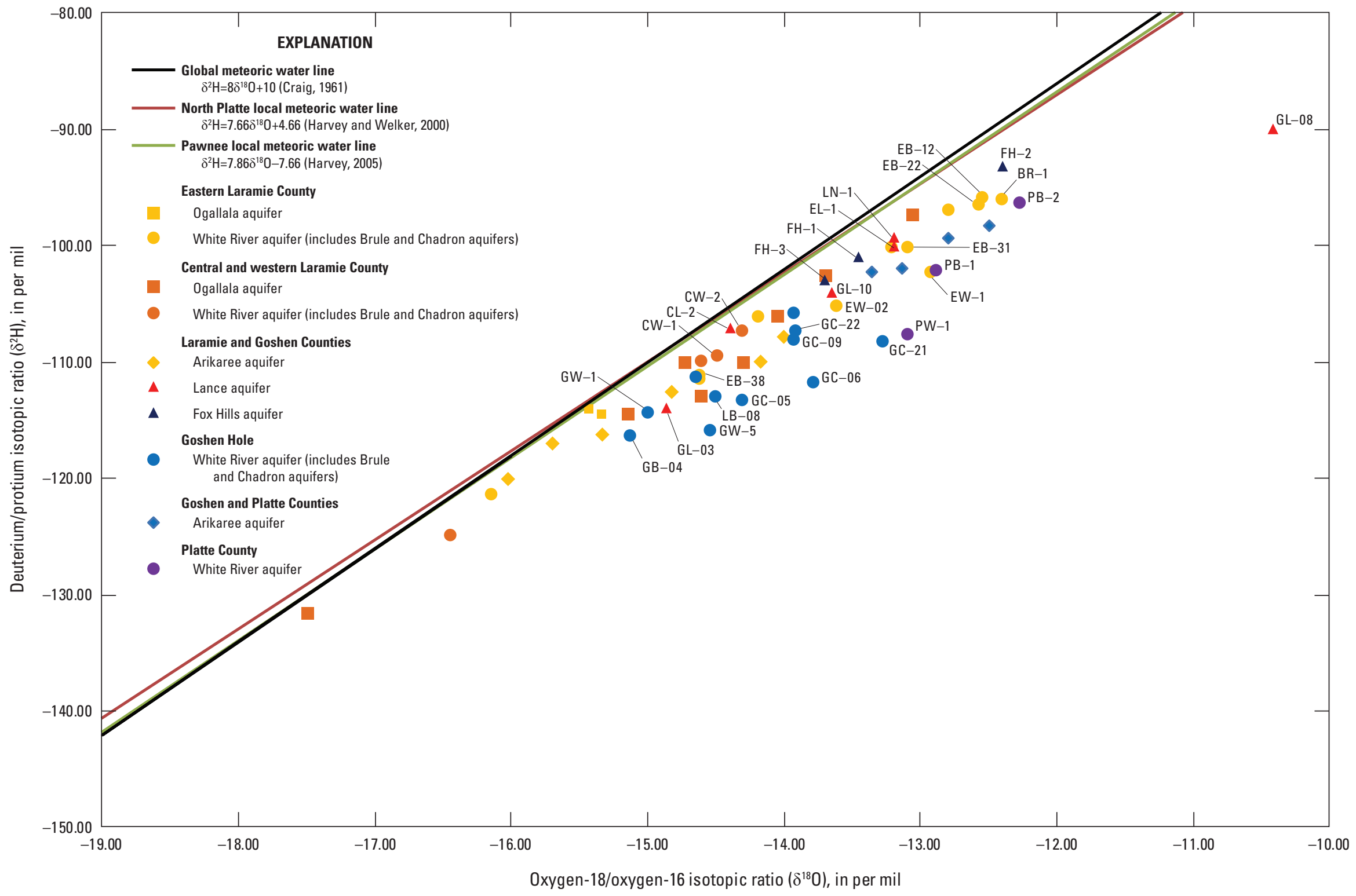

Figure 38. Relation between oxygen-18/oxygen-16 isotopic ratio and deuterium/protium isotopic ratio for groundwater samples collected from wells in the Cheyenne Basin, southeastern Wyoming. 


\section{Summary of Groundwater Levels in Study Site Monitoring Wells}

Groundwater levels in wells fluctuate and are controlled by the balance between recharge to, storage in, and discharge from an aquifer. Aquifer characteristics (for example, porosity, permeability [hydraulic conductivity], and thickness) and climatic and hydrologic factors (for example, timing and amount of recharge by precipitation; discharge to streams, springs, or wells; and evapotranspiration) also control this balance. When recharge to an aquifer exceeds the rate of discharge, groundwater levels or hydraulic heads will increase (rise); conversely, when the rate of groundwater withdrawal or discharge is greater than the rate of groundwater recharge, water is removed from aquifer storage and groundwater levels or hydraulic heads will decrease (decline). The term "groundwater level" is used herein to refer to hydraulic heads, which are groundwater-level elevations measured above a vertical datum (North American Vertical Datum of 1988 [NAVD 88]), or to depth-to-water measurements, which are depths referenced to land surface, to the standing water level in a given well.

Groundwater levels measured in monitoring wells BR-1, LN-1, and FH-1 were collected using manual (hand-measured) and instrumented methods (described in "Collection, Processing, and Storage of Groundwater-Level Measurements" report section). Manual measurements were collected intermittently (discrete data) during the study to document groundwater levels before installation of instrumentation and to periodically verify the accuracy of the groundwater levels recorded nearly continuously (generally hourly or more frequently) using instrumentation (continuously recorded data). Collection of discrete data began in June 2013, whereas collection of continuously recorded data began later, from September to December 2014 (start date differed by well). Minor gaps in continuously recorded data occurred because of infrequent lapses in power to the instrumentation used to record groundwater levels. Discrete and continuous groundwater-level measurements are available at https://waterdata.usgs. gov/wy/nwis/gw/ (U.S. Geological Survey, 2019).

Data measured and recorded in all three monitoring wells were used to summarize groundwater levels (table 10) and construct hydrographs (fig. 39) showing groundwaterlevel changes for the June 2013-September 2017 observation period. Hydrographs are presented in order from shallowest to deepest monitoring well to facilitate visual comparison of hydraulic heads between wells.

Groundwater levels in monitoring well BR-1 (White River Formation) varied during the year, with similar intraannual fluctuations and annual water-level trends during most years of the observation period (June 2013-September 2017). In general, groundwater-level elevations increased from winter to spring or early summer and declined from mid-tolate summer to fall, although the relative timing and magnitude of these intra-annual changes differed slightly among years (fig. 39). Overall, the groundwater levels in well BR-1 increased during the observation period (fig. 39; table 10).
Using the oldest and most recent groundwater levels measured or recorded and ignoring intervening fluctuations, this "net" water-level increase was $5.15 \mathrm{ft}$ for the observation period (table 10). Groundwater-level elevations at the end of most years were higher than levels earlier in or at the beginning of the same year (fig. 39; table 10). Ignoring intervening fluctuations, this net annual groundwater-level increase within the same year was similar for the 2 years with complete or nearly complete continuous groundwater-level records $(1.12 \mathrm{ft}$ in 2015 and $1.41 \mathrm{ft}$ in 2016). Differences between the lowest (lowest hydraulic head or greatest depth to water) and highest (highest hydraulic head or shallowest depth to water) groundwater levels measured or recorded in well BR-1 within the same year were small, ranging from $0.92 \mathrm{ft}$ in 2017 (partial observation record for year) to $2.27 \mathrm{ft}$ in 2013 (groundwater levels were measured only twice in 2013; table 10); however, the highest and lowest groundwater levels used to compute these differences may not represent the actual annual extremes in years with few measurements or incomplete continuously recorded data $(2013-2014,2017)$. The groundwater level measured on November 13, 2013 (57.80 ft BLS or $5,171.20 \mathrm{ft}$ above NAVD 88), was $2.27 \mathrm{ft}$ higher than measured on June 20, 2013 (60.07 ft BLS or 5,168.93 ft above NAVD 88; table 10). The June 20, 2013, groundwater level was the lowest measured or recorded in well BR-1 during the observation period. Discrete and continuously recorded data available for part of 2014 (partial observation record for year) indicated groundwater levels were highest in May and lowest in November and December, and the difference between the highest and lowest levels was $1 \mathrm{ft}$ (fig. 39; table 10). In 2015 (first complete year of continuously recorded data) and 2016, groundwater levels were lowest near the beginning of the year (January) and highest near the end of the year (December) (fig. 39; table 10). The difference between the lowest and highest groundwater levels in $2015(1.52 \mathrm{ft})$ was nearly the same as in 2016 (1.51 ft; table 10). Available continuously recorded data for 2017 (partial observation record for year) indicated groundwater levels were lowest in January and highest in May, and the difference between the lowest and highest levels was $0.06 \mathrm{ft}$ (fig. 39; table 10).

Continuously recorded groundwater-level data from monitoring well BR-1 are shown in relation to continuously recorded groundwater-level data from three WSEO monitoring wells (Wyoming State Engineer's Office, written commun., 2018) completed in the High Plains aquifer system (White River Formation and [or] Quaternary older alluvial fan deposits) in the southern part of the Pine Bluffs lowland (fig. 40; locations of three WSEO monitoring wells [SE Carp (well also completed in $20 \mathrm{ft}$ of overlying Quaternary older alluvial fan deposits), SW Carp, and LC01] shown in fig. 30). Seasonal groundwater-level fluctuations in monitoring well BR-1 are a subdued reflection of those observed in the three WSEO monitoring wells. As with BR-1, groundwater-level trends over the multiannual periods of record overall were increasing in all three WSEO monitoring wells. Similarly, like BR-1, seasonal water-level fluctuations were superimposed on the 
Table 10. Summary of discrete and continuously recorded groundwater-level data for monitoring wells BR-1, LN-1, and FH-1, June 2013-September 2017, southeastern Laramie County, Wyoming.

[ft, foot; BLS, below land surface; NAVD 88, North American Vertical Datum of 1988]

\begin{tabular}{|c|c|c|c|c|c|c|}
\hline \multirow{3}{*}{ Time period } & \multirow{3}{*}{$\begin{array}{l}\text { Highest measured or recorded } \\
\text { groundwater level, in } \mathrm{ft} \text { BLS, (and } \\
\text { corresponding groundwater-level } \\
\text { elevation, in ft above NAVD 88) }\end{array}$} & \multirow{2}{*}{$\begin{array}{l}\text { Lowest measured or recorded } \\
\text { groundwater level, in ft BLS, (and } \\
\text { corresponding groundwater-level } \\
\text { elevation, in ft above NAVD 88) }\end{array}$} & \multicolumn{2}{|c|}{ Dates of extremes } & \multirow{2}{*}{$\begin{array}{l}\text { Absolute difference between } \\
\text { highest and lowest measured } \\
\text { or recorded groundwater } \\
\text { level, in } \mathrm{ft}\end{array}$} & \multirow{2}{*}{$\begin{array}{l}\text { Net change }{ }^{3} \text { in measured } \\
\text { or recorded groundwater } \\
\text { levels between first and last } \\
\text { available observation of } \\
\text { year, in ft }\end{array}$} \\
\hline & & & Highest & Lowest & & \\
\hline & & \multicolumn{5}{|c|}{ Monitoring well BR-1 (White River Formation) } \\
\hline${ }^{4} 2013$ & $57.80(5,171.20)$ & $60.07(5,168.93)$ & $11 / 13 / 2013$ & $06 / 20 / 2013$ & 2.27 & -2.27 \\
\hline${ }^{5} 2014$ & $56.62(5,172.38)$ & $57.62(5,171.38)$ & 05/06/2014 & $11 / 12 / 2014$ & 1.00 & -0.90 \\
\hline${ }^{6} 2015$ & $56.10(5,172.90)$ & $57.62(5,171.38)$ & $12 / 22 / 2015$ & $01 / 07 / 2015$ & 1.52 & +1.12 \\
\hline 2016 & $54.88(5,174.12)$ & $56.39(5,172.61)$ & $12 / 25 / 2016$ & $01 / 01 / 2016$ & 1.51 & +1.41 \\
\hline${ }^{7} 2017$ & $54.22(5,174.78)$ & $55.14(5,173.86)$ & $05 / 24 / 2017$ & $01 / 14 / 2017$ & 0.92 & +0.06 \\
\hline Observation period ${ }^{8}$ & $54.22(5,174.78)$ & $60.07(5,168.93)$ & $05 / 24 / 2017$ & $06 / 20 / 2013$ & 5.85 & +5.15 \\
\hline \multicolumn{7}{|c|}{ Monitoring well LN-1 (Lance Formation) } \\
\hline${ }^{4} 2013$ & $120.42(5,108.58)$ & $121.64(5,107.36)$ & $06 / 20 / 2013$ & $12 / 17 / 2013$ & 1.22 & -1.22 \\
\hline${ }^{9} 2014$ & $122.21(5,106.79)$ & $124.57(5,104.43)$ & $05 / 06 / 2014$ & $12 / 16 / 2014$ & 2.36 & -2.32 \\
\hline${ }^{10} 2015$ & $124.47(5,104.53)$ & $126.04(5,102.96)$ & $05 / 15 / 2015$ & $12 / 26 / 2015$ & 1.57 & -0.88 \\
\hline 2016 & $125.42(5,103.58)$ & $126.89(5,102.11)$ & 05/09/2016 & $12 / 28 / 2016$ & 1.47 & -0.71 \\
\hline${ }^{7} 2017$ & $126.16(5,102.84)$ & $127.42(5,101.58)$ & $05 / 24 / 2017$ & $09 / 28 / 2017$ & 1.26 & -0.60 \\
\hline Observation period ${ }^{8}$ & $120.42(5,108.58)$ & $127.42(5,101.58)$ & $06 / 20 / 2013$ & $09 / 28 / 2017$ & 7.00 & -6.89 \\
\hline \multicolumn{7}{|c|}{ Monitoring well FH-1 (Fox Hills Sandstone) } \\
\hline${ }^{4} 2013$ & $431.94(4,797.06)$ & $432.04(4,796.96)$ & $06 / 20 / 2013$ & $11 / 14 / 2013$ & 0.10 & -0.10 \\
\hline${ }^{11} 2014$ & $432.45(4,796.55)$ & $434.46(4,794.54)$ & $05 / 06 / 2014$ & $12 / 30 / 2014$ & 2.01 & -1.83 \\
\hline 2015 & $434.11(4,794.89)$ & $438.63(4,792.37)$ & $01 / 02 / 2015$ & $12 / 27 / 2015$ & 2.52 & -2.31 \\
\hline${ }^{12} 2016$ & $436.29(4,792.71)$ & $438.24(4,790.76)$ & $01 / 07 / 2016$ & $12 / 29 / 2016$ & 1.95 & -1.34 \\
\hline 7,132017 & $437.83(4,791.17)$ & $439.39(4,789.61)$ & $01 / 20 / 2017$ & $09 / 28 / 2017$ & 1.56 & -1.25 \\
\hline Observation period $^{8}$ & $431.94(4,797.06)$ & $439.39(4,789.61)$ & $06 / 20 / 2013$ & $09 / 28 / 2017$ & 7.45 & -7.24 \\
\hline
\end{tabular}

${ }^{1}$ Highest groundwater level indicates shallowest depth to groundwater during observation period.

${ }^{2}$ Lowest groundwater level indicates greatest depth to groundwater during observation period.

${ }^{3}$ Negative (-) groundwater-level change value indicates a decline in observed groundwater levels with time; positive $(+)$ groundwater-level change value indicates an increase in observed groundwater levels with time.
${ }^{4}$ Only discrete groundwater-level measurements available.

${ }^{5}$ Only discrete groundwater-level measurements available until continuous recorder started in September 2014.

${ }^{6}$ Missing data September 24-October 20, 2015.

${ }^{7}$ Continuous record unavailable after September 30, 2017.

${ }^{8}$ June 2013-September 2017.
${ }^{9}$ Only discrete groundwater-level measurements available until continuous recorder started in November 2014; gap in continuous record December 18-31, 2014.

${ }^{10} \mathrm{Gap}$ in continuous record January 1-21, 2015.

${ }^{11}$ Only discrete groundwater-level measurements available until continuous recorder started in December 2014.

${ }^{12} \mathrm{Gap}$ in continuous records May 4-July 21, 2016.

${ }^{13} \mathrm{Gap}$ in continuous records June 14-August 24, 2017. 


\section{A. Well BR-1 (White River aquifer)}

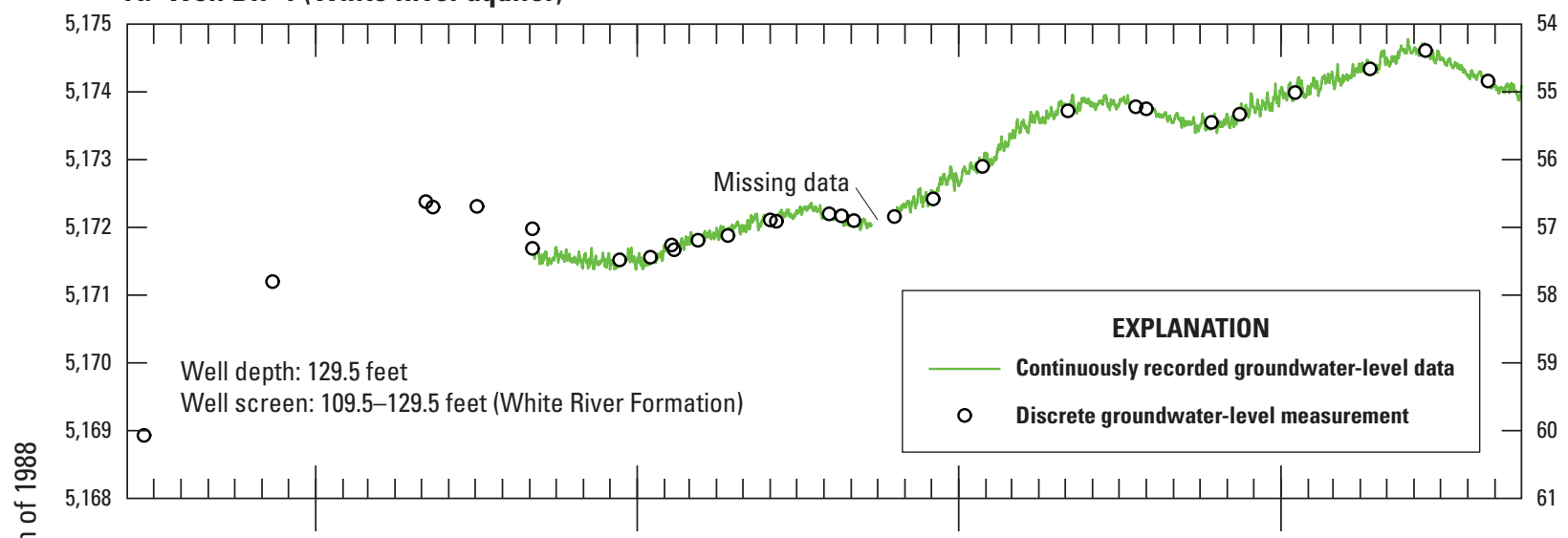

B. Well LN-1 (Lance aquifer)

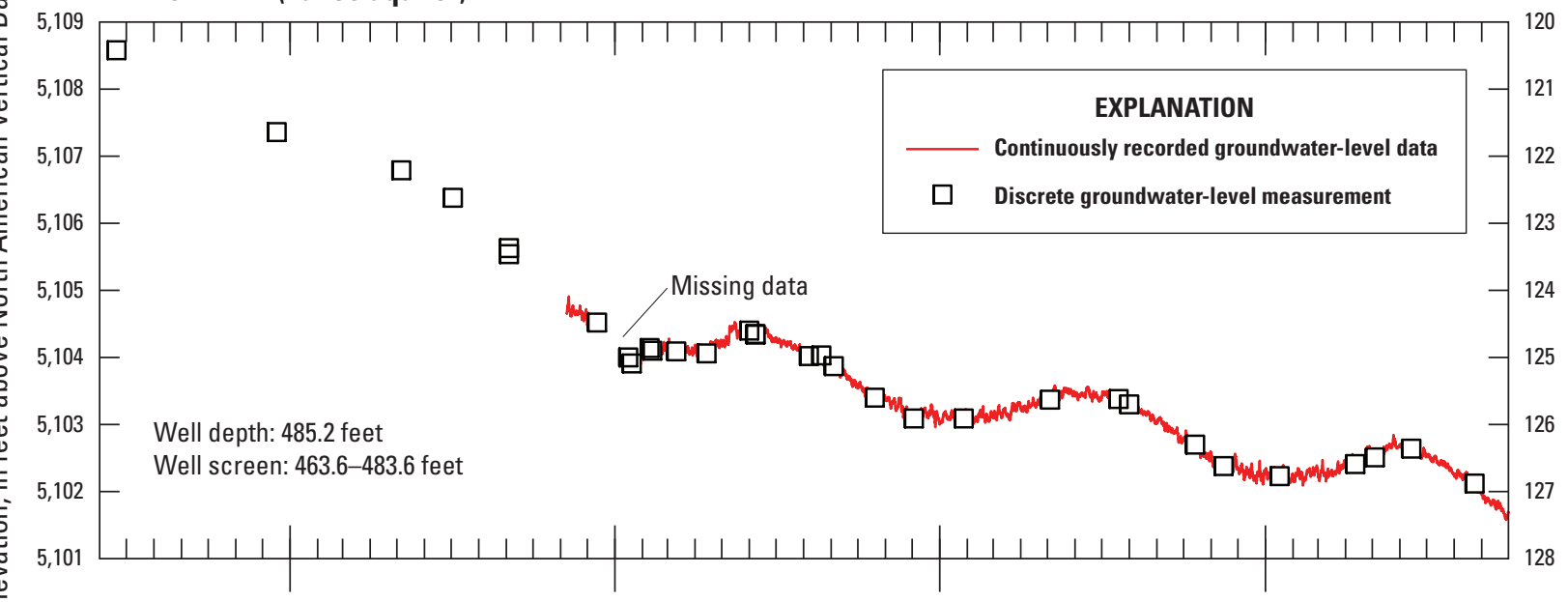

C. Well FH-1 (Fox Hills aquifer)

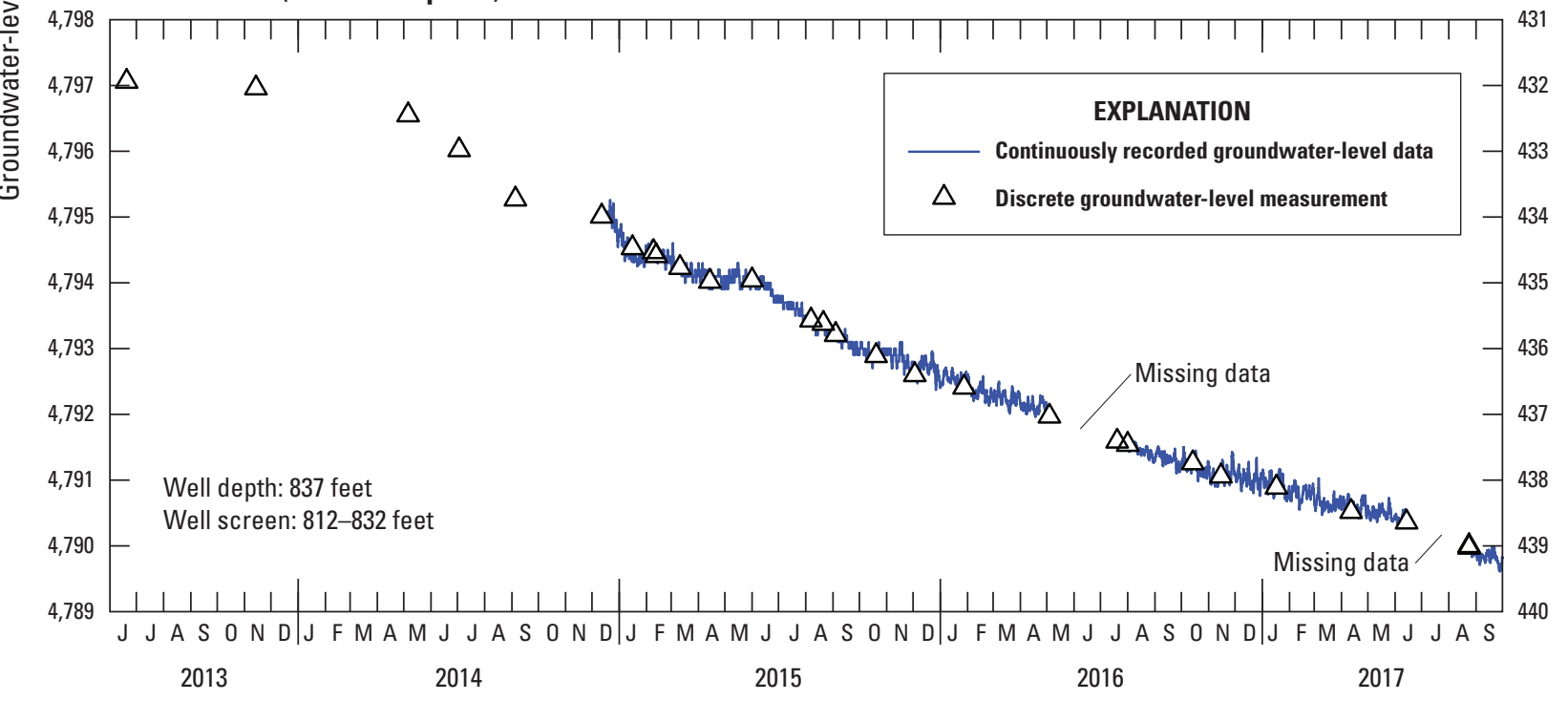

Month and year

Figure 39. Groundwater levels for June 2013-September 2017, southeastern Laramie County, Wyoming. A, monitoring well BR-1 completed in the White River aquifer; $B$, monitoring well $\mathrm{LN}-1$ completed in the Lance aquifer; $C$, monitoring well $\mathrm{FH}-1$ completed in the Fox Hills aquifer. 


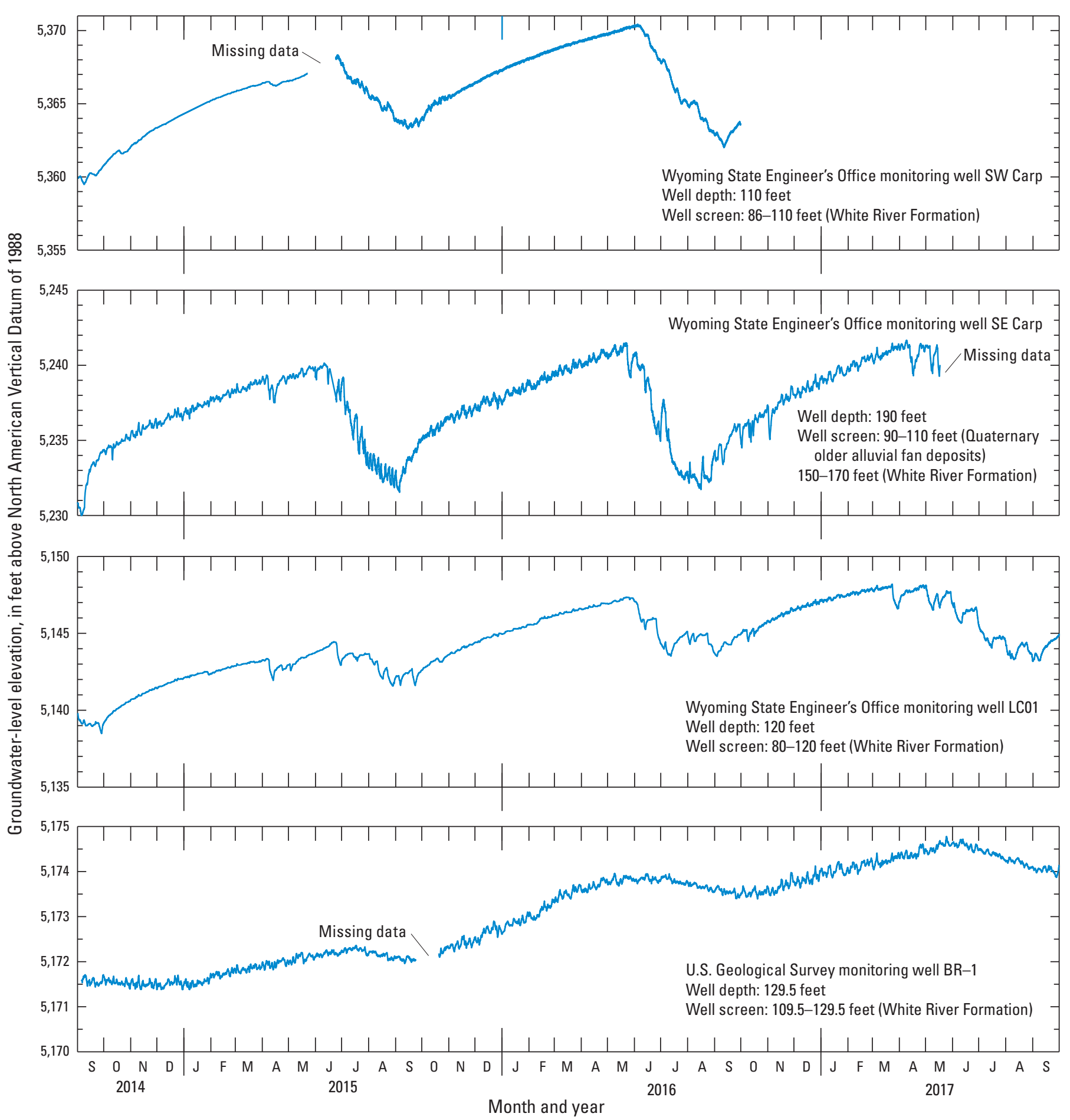

Figure 40. Hydrographs of three Wyoming State Engineer's Office groundwater-level monitoring wells in relation to hydrograph for monitoring well BR-1, September 2014-September 2017, southeastern Laramie County, Wyoming. Location of wells shown in figure 30. 
longer term upward water-level trends; however, unlike BR-1, the groundwater-level declines in the three WSEO monitoring wells beginning in the spring and continuing through the summer were much larger; these large declines are attributable to irrigation pumping in the area.

Groundwater levels in monitoring well LN-1 (Lance aquifer) varied during the year, with similar intra-annual and interannual trends during the observation period (2013-17). In general, groundwater levels increased for the period from early/midwinter (about January to February) to late spring/ early summer (about May to June) and declined for the period from late spring/early summer (about May to June) to early winter (about December to January), although the relative timing and magnitude of these intra-annual changes differed slightly among years (fig. 39). Overall, the groundwater level in well $\mathrm{LN}-1$ declined throughout the observation period (fig. 39; table 10). Using the oldest and most recent groundwater levels measured or recorded and ignoring intervening fluctuations, this net water-level decline was $6.89 \mathrm{ft}$ for the observation period (table 10); these two groundwater levels also were the highest and lowest measured or recorded in well LN-1 during the observation period (120.42 ft BLS in June 2013 and $127.42 \mathrm{ft} \mathrm{BLS}$ in September 2017; table 10). Groundwater levels at the end of all years were lower than levels earlier in or at the beginning of the same year (fig. 39; table 10). Ignoring intervening fluctuations, this net annual groundwater-level decline within the same year was similar for the two years with nearly complete annual groundwaterlevel records ( $0.88 \mathrm{ft}$ in 2015 and $0.71 \mathrm{ft}$ in 2016). Differences between the lowest and highest groundwater levels measured or recorded in well LN-1 within the same year were small, ranging from $1.22 \mathrm{ft}$ in 2013 (groundwater levels were measured only twice in 2013; table 10) to $2.36 \mathrm{ft}$ in 2014 (only partial record available for year); however, the highest and lowest groundwater levels used to compute these differences may not represent the actual annual extremes in years with few measurements/incomplete continuous annual records (2013-14, 2017). Discrete and continuous measurements available for part of 2014 (partial observation record for year) indicated groundwater levels were highest in May and lowest in December, and the difference between the lowest and highest levels was $1.22 \mathrm{ft}$ (fig. 39; table 10). In 2015 (the first complete year of continuously recorded data) and 2016, groundwater levels were highest in May and lowest near the end of the year (December) (fig. 39; table 10). The difference between the lowest and highest groundwater levels in 2015 $(1.57 \mathrm{ft})$ was nearly the same as in $2016(1.47 \mathrm{ft}$; table 10$)$. Available data for 2017 (partial observation record for year) indicated groundwater levels were lowest in May and highest in September (last month with data available during the observation period), and the difference between the lowest and highest levels was $1.26 \mathrm{ft}$ (fig. 39; table 10).

In contrast to monitoring wells BR-1 and $\mathrm{LN}-1$, monitoring well FH-1 (Fox Hills Sandstone) did not have or only had discernibly attenuated seasonal intra-annual groundwater-level fluctuations (based on available data for 2016-17; some data missing in these years). Except for parts of late 2014/early 2015, groundwater levels consistently declined throughout the observation period (fig. 39). Using the oldest and most recent groundwater levels measured or recorded and ignoring intervening fluctuations, the net water-level decline was $7.24 \mathrm{ft}$ for the observation period (table 10). Groundwater levels at the end of all years were lower than levels earlier in or at the beginning of the same year (fig. 39; table 10). Notably, years with groundwater-level data available in January (2015-17) always recorded the highest annual groundwater levels that month, and years with data available in December (2014-16) always recorded the lowest annual groundwater levels that month (fig. 39; table 10). Differences between the lowest and highest groundwater levels measured or recorded in monitoring well $\mathrm{FH}-1$ within the same year ranged from $0.10 \mathrm{ft}$ in 2013 (groundwater levels were measured only twice in 2013) to $2.52 \mathrm{ft}$ in 2015 (table 10); however, the highest and lowest groundwater levels used to compute these differences may not represent the actual annual extremes in years with few measurements or incomplete continuous annual records (2013-14, 2017).

Multiyear groundwater-level records commonly contain regular annual or seasonal fluctuations (Sophocleus and others, 2004). As described previously, these types of fluctuations were evident in groundwater-level records for monitoring wells BR-1 and $\mathrm{LN}-1$ but not well $\mathrm{FH}-1$ (fig. 39). Interestingly, seasonal fluctuations in wells $\mathrm{BR}-1$ and $\mathrm{LN}-1$ indicate some similarities, even though the overall groundwater-level trend in each well consistently diverged from the other during the observation period (upward water-level trend in well BR-1 and downward water-level trend in well LN-1). Notably, although varying year to year, the highest groundwater-level elevations (shallowest depths to groundwater) often occurred at about the same time of year (May-July) in both wells (fig. 39). In 2016 and 2017, the highest groundwater-level elevations occurred during the same time of year in wells BR-1 and LN-1 (May-June; fig. 39). In contrast, the lowest groundwater-level elevations (greatest depths to groundwater) did not occur at the same time of year during the observation periodgroundwater-level elevations in well LN-1 typically were lowest from about December to January, about 2 to 3 months after lowest groundwater-level elevations in well BR-1 (except for 2014, about September-October; fig. 39). Additionally, the duration when groundwater levels either increased or declined between the highest and lowest groundwater-level elevations differed substantially between wells. For well BR-1, the duration when groundwater levels increased from the lowest to the highest groundwater-level elevation was much longer (two or more times longer) than the duration when groundwater levels declined from the highest to lowest groundwater-level elevation (fig. 39). Conversely, for well $\mathrm{LN}-1$, the duration when groundwater levels declined between the highest and lowest groundwater-level elevations was about the same or slightly longer than the duration when groundwater levels increased from the lowest to highest groundwater-level elevation (fig. 39). This pattern was reversed in well $\mathrm{LN}-1$. 


\section{Response of Groundwater Levels to Atmospheric Loading and Earth Tides}

Groundwater-level responses to barometric-pressure variations (atmospheric loading) and solid Earth tides can be used to infer the degree to which an aquifer responds as a confined or unconfined system and, in some instances, to estimate aquifer hydraulic and mechanical properties. These responses to atmospheric loading and Earth tides can potentially mask subtle groundwater-level responses to other hydrologic stresses; therefore, often it is useful to filter these responses from the raw groundwater-level records. This section describes the development of digital filters based on analysis of the groundwater-level responses (referred to here as "water-level responses") to atmospheric loading and Earth tides for monitoring wells BR-1, $\mathrm{LN}-1$, and $\mathrm{FH}-1$. The digital filters were used to filter the water-level responses to atmospheric loading and Earth tides from time series of measured water levels in the wells.

The raw data were processed and the digital atmosphericloading and Earth-tide filters were developed using MATLAB with the MATLAB Signal Processing Toolbox software (release R2018A). For monitoring wells BR-1, LN-1, and $\mathrm{FH}-1$, water-level responses to changes in barometric pressure (BP, atmospheric loading) and the solid Earth tide were evaluated and filtered from the raw water-level record. A detailed overview of the workflow with intermediate steps is shown in figure 41. General details of the methods used to develop the digital atmospheric-loading and Earth-tide filters and the filtered water-level responses follow. The methods developed and described here generally follow those described by Howle and others (2019, appendix 2) and Galloway (2019), with some differences that include the application to water levels expressed as depth to water below "land-surface" datum in their study, compared with water levels expressed as elevations in this study. As such, the signs (positive/negative) of the water-level changes in the two approaches are opposite.

All times are reported in Mountain Standard Time (or Coordinated Universal Time minus 7 hours). To facilitate working with times in the algorithms developed to process the time series, times were converted from calendar dates (year:month:day:hour:minute) to decimal days (dd) referenced to the day-of-the-year value starting with 1 at midnight of January 1, 2014; for example, noon on January 1, 2014, was dd 1.5. The raw water-level and barometric-pressure data were processed as continuous "unpaired," variable length (accounting for data gaps) water-level and barometric-pressure time series. "Unpaired" was used to indicate that the time-series lengths (or spans) and sample times were variable. For waterlevel and barometric-pressure time series data, gaps less than or equal to 3 hours and 9 hours, respectively, were retained in the continuous time series. The time series were resampled at even (on the hour) hourly intervals, and the retained data gaps were filled using cubic spline interpolation (fig. 41, box a). The resulting unpaired, variable-length, continuous time series are referred to here as "pieces." The raw, hourly resampled water-level and barometric-pressure time-series pieces are shown in figure 42 and given in Galloway and Bartos (2021, tables 2-4), referenced in the "Filtered WaterLevel Time Series" section of this report. The individual pieces were subsequently parsed to achieve the longest length of paired (temporally coincident) barometric-pressure and water-level, continuous, hourly sampled time series (referred to as "parsed" series here, referring to breaking up or separating the input into more easily processed components) (figs. 41, box $b$, and 43 ). Pieces 1 and 2 of the barometric-pressure time series did not overlap with the water-level time series (fig. 42) and thus were not used to form the paired, parsed time series (fig. 43). For the parsed series, the units of BP were converted from inches of mercury to equivalent feet of water. The unit conversion provided a consistent set of units for water level and BP. The parsed series number was designated by the suffix “\#” appended to the well number; for example, the parsed series 8 for $\mathrm{FH}-1$ was designated as $\mathrm{FH}-1 \_8$. The parsed series $\mathrm{FH}-1 \_3$ was subdivided into $\mathrm{FH}-1 \_3 \mathrm{a}$ and $\mathrm{FH}-1 \_3 \mathrm{~b}$ to separate the beginning period of the water-level record, FH-1_3a, where the water-level measurement resolution was $0.1 \mathrm{ft}$, from the later period, $\mathrm{FH}-1 \_3 \mathrm{~b}$, where the resolution was $0.01 \mathrm{ft}$. Various time parameters for the parsed series and their derivation with respect to the originating time-series pieces are listed in table 11.

The parsed barometric-pressure series were detrended by removing a linear trend determined by least-squares regression of BP on time. The parsed water-level series were detrended using either a first-order (linear) or higher order polynomial determined by least-squares regression of water level on time, depending on the nature of the water-level trend for each parsed series (fig. 41, box c). Detrending was aimed at removing the longer period (seasonal/annual) hydrologic and barometric effects. The water-level detrending polynomial order for the parsed time series is listed in table 11. Barometric-pressure time series collected from the Cheyenne Airport barometer as "station pressure," some $35 \mathrm{mi}$ distant, were used for all the parsed series. The use of these barometric data was not ideal but necessitated by the absence of sufficient local barometric-pressure data. The station pressure data from the Cheyenne Airport barometer were corrected for the landsurface elevation differences between the Cheyenne Airport and the local wells, about $-890 \mathrm{ft}$. Selected, detrended, parsed water-level and barometric-pressure time series are given in Galloway and Bartos (2021, tables 2-4) (presented in the "Filtered Water-Level Time Series" section of this report). The detrended parsed series were used for the subsequent analyses. Shown in figure 44 is an example of the trended and detrended water levels and BP for each of three detrended, parsed series: BR-1_4 (fig. 44A, $B$ ), LN-1_5 (fig. 44C, D), and FH-1_5 (fig. $44 E, F$ ). The inverse relation between water level in wells BR-1, $\mathrm{LN}-1$, and $\mathrm{FH}-1$ and $\mathrm{BP}$ is evident in the detrended time series (fig. $44 B, D, F$ ). 


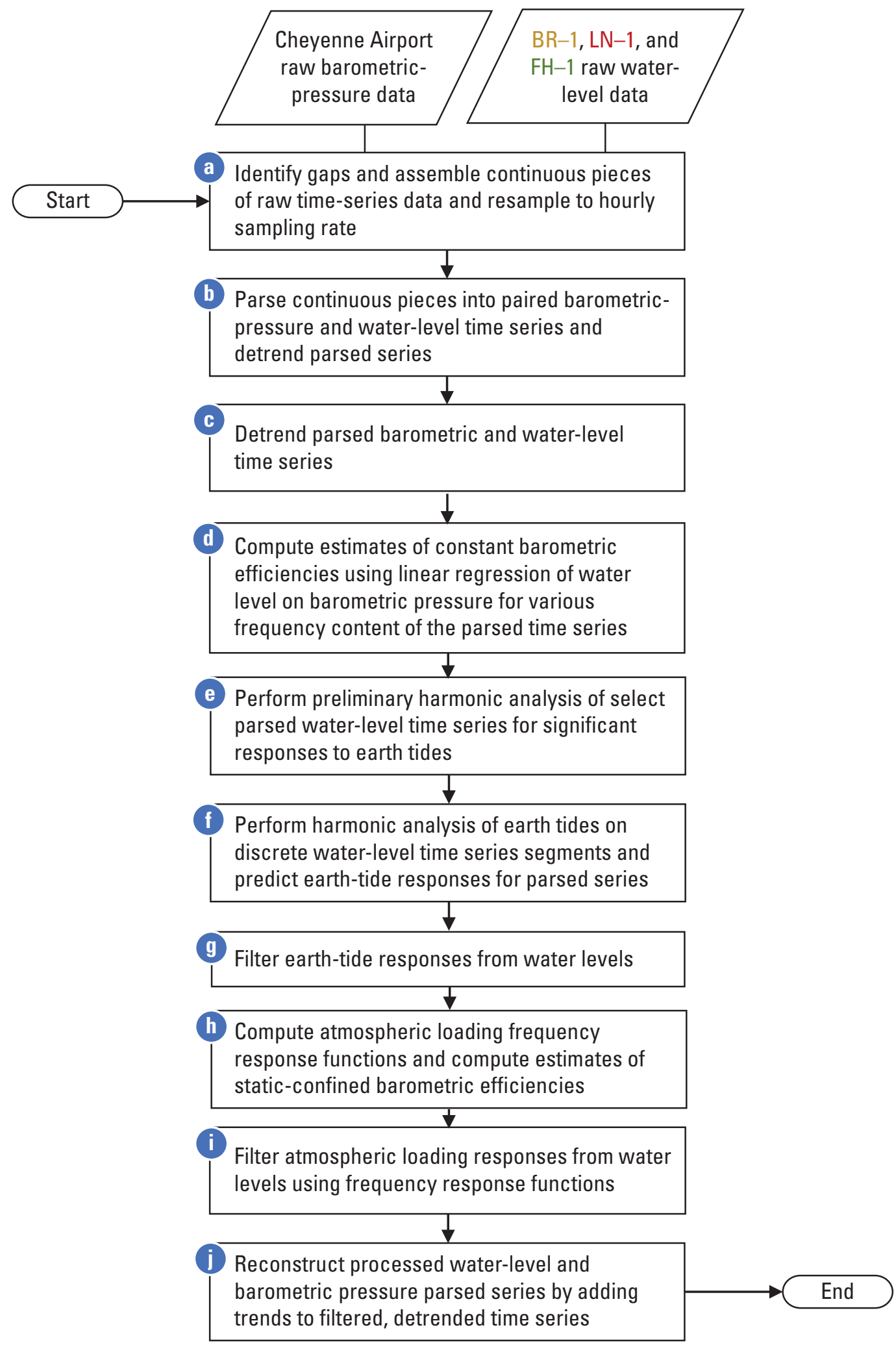

Figure 41. The workflow process used to develop the digital atmospheric-loading and Earth-tide filters for water levels from monitoring wells BR-1, LN-1, and FH-1, southeastern Laramie County, Wyoming. 
$\boldsymbol{A}$

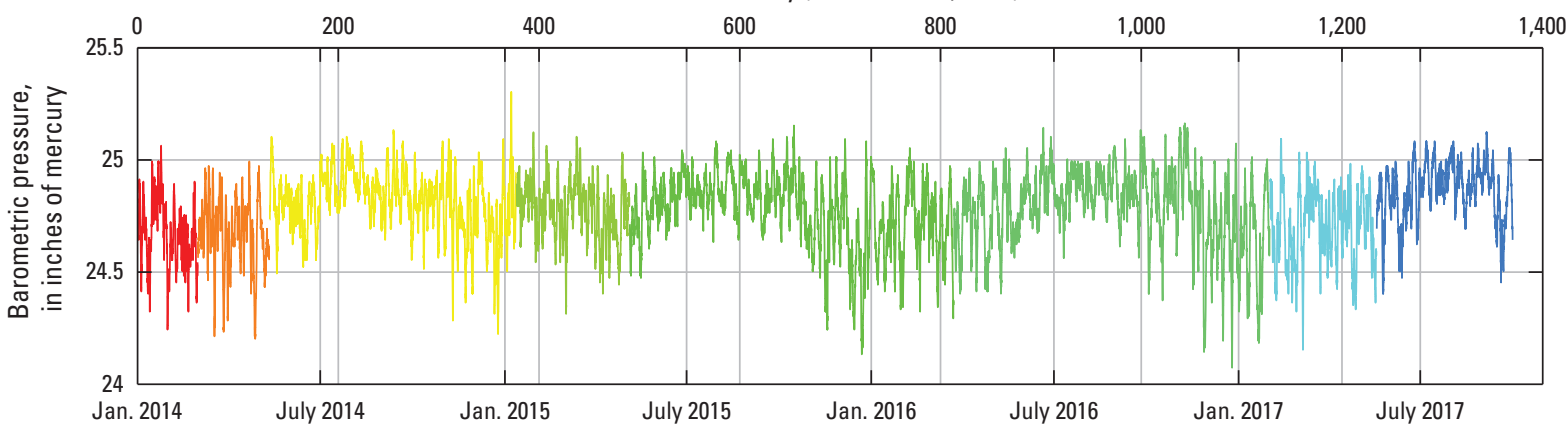

EXPLANATION

Cheyenne Airport barometer

B

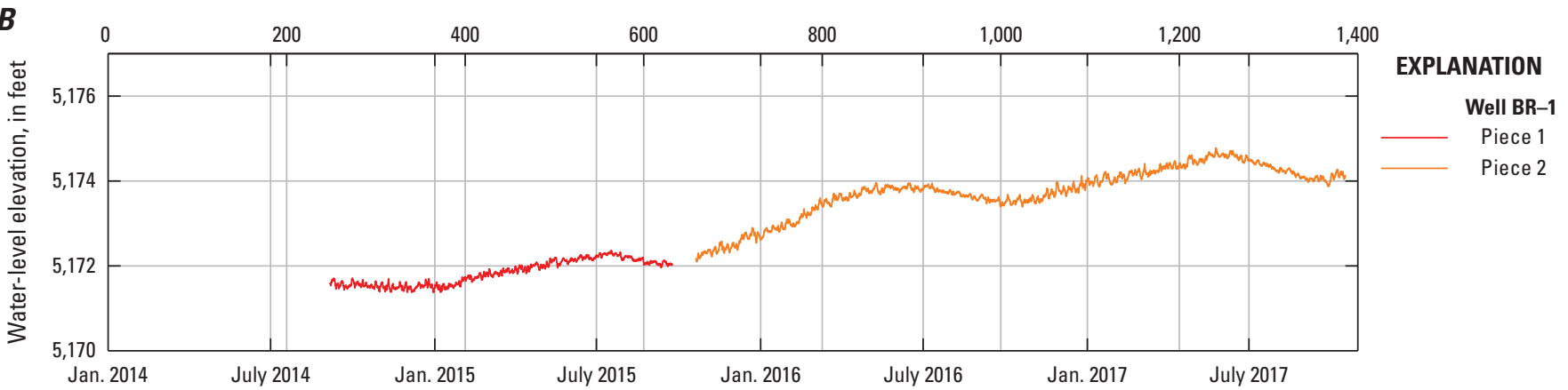

\section{C}
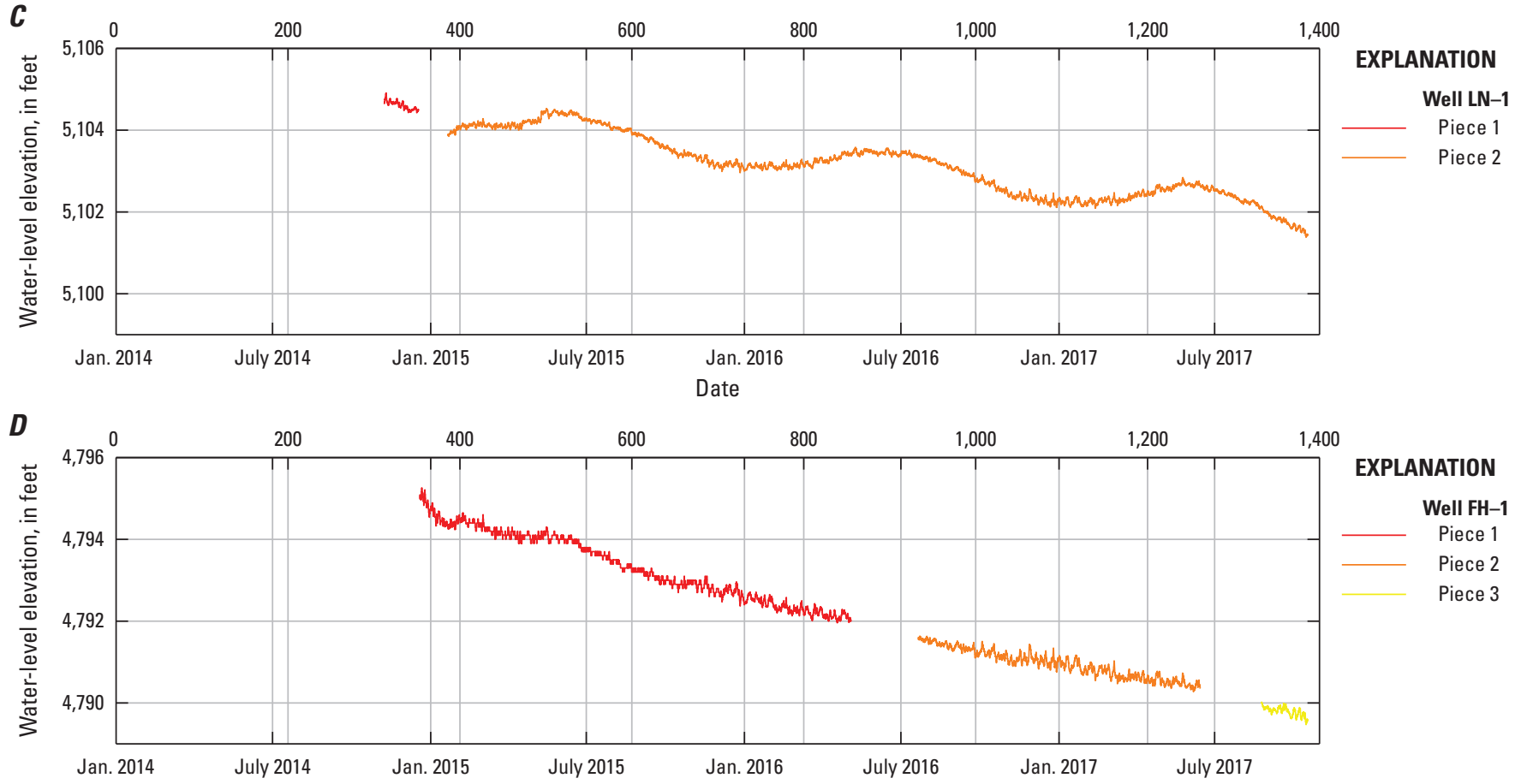

Figure 42. Continuous time-series pieces for wells $\mathrm{BR}-1, \mathrm{LN}-1$, and $\mathrm{FH}-1$, southeastern Laramie County, Wyoming. $A$, resampled, raw barometric-pressure time series for Cheyenne Airport, January 1, 2014-September 30, 2017; $B$, resampled, raw water-level time series for well BR-1, September 5, 2014-0ctober 17, 2017; C, resampled, raw water-level time series for well LN-1, November 8, 2014October 17, 2017; D, resampled, raw water-level time series for well FH-1, December 19, 2014-0ctober 17, 2017. 


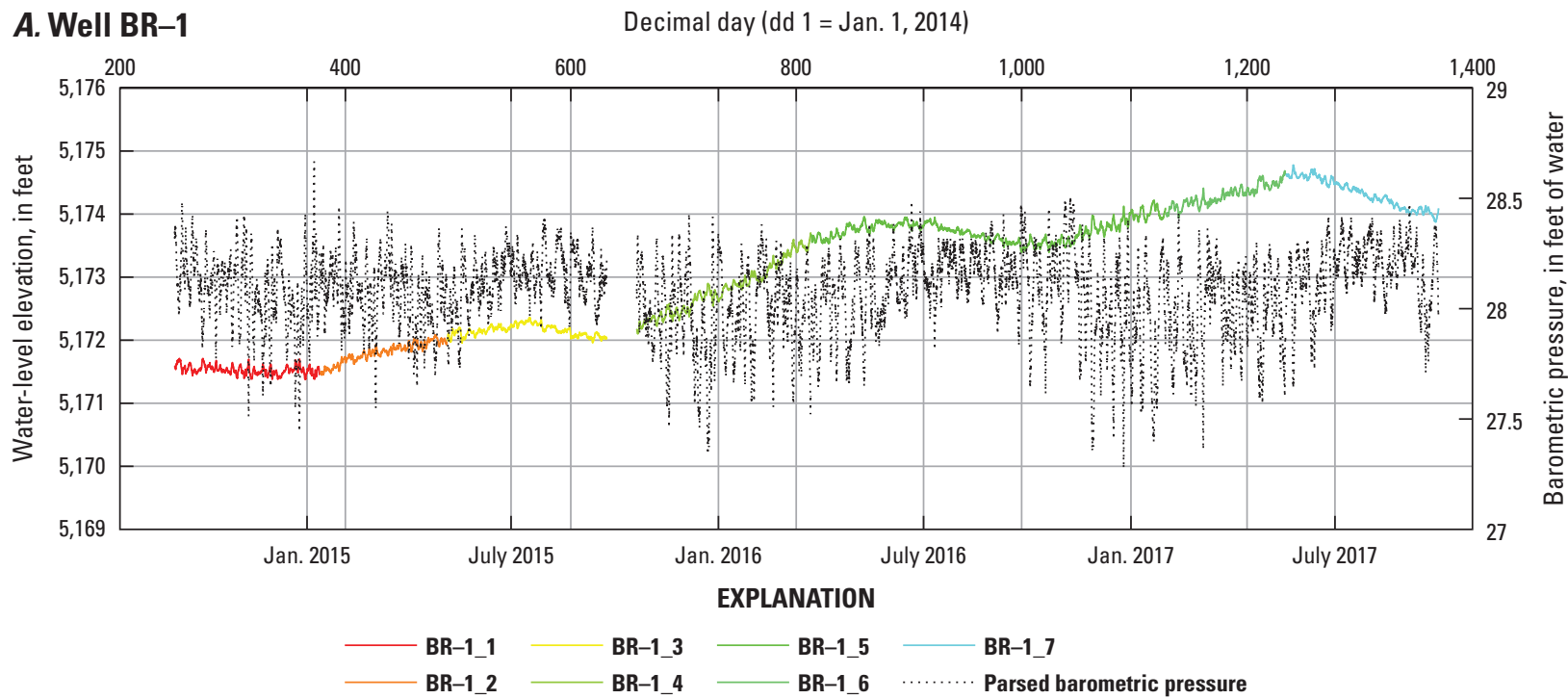

\section{B. Well LN-1}

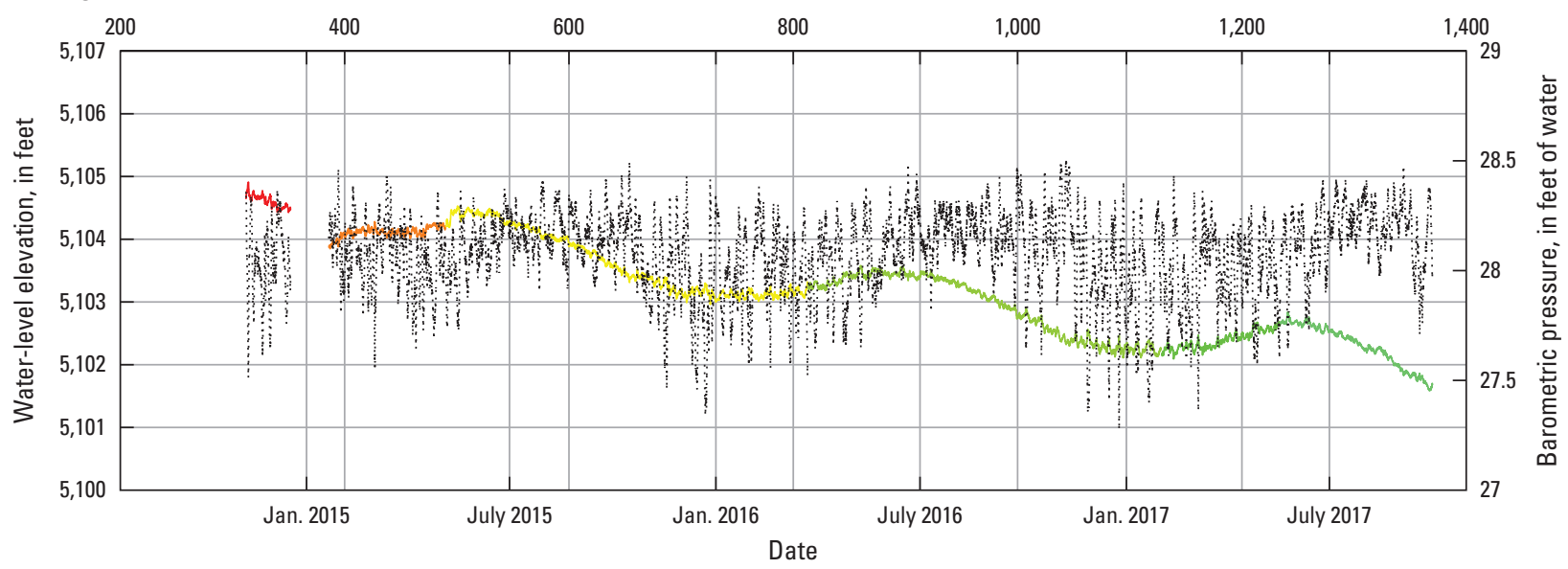

EXPLANATION

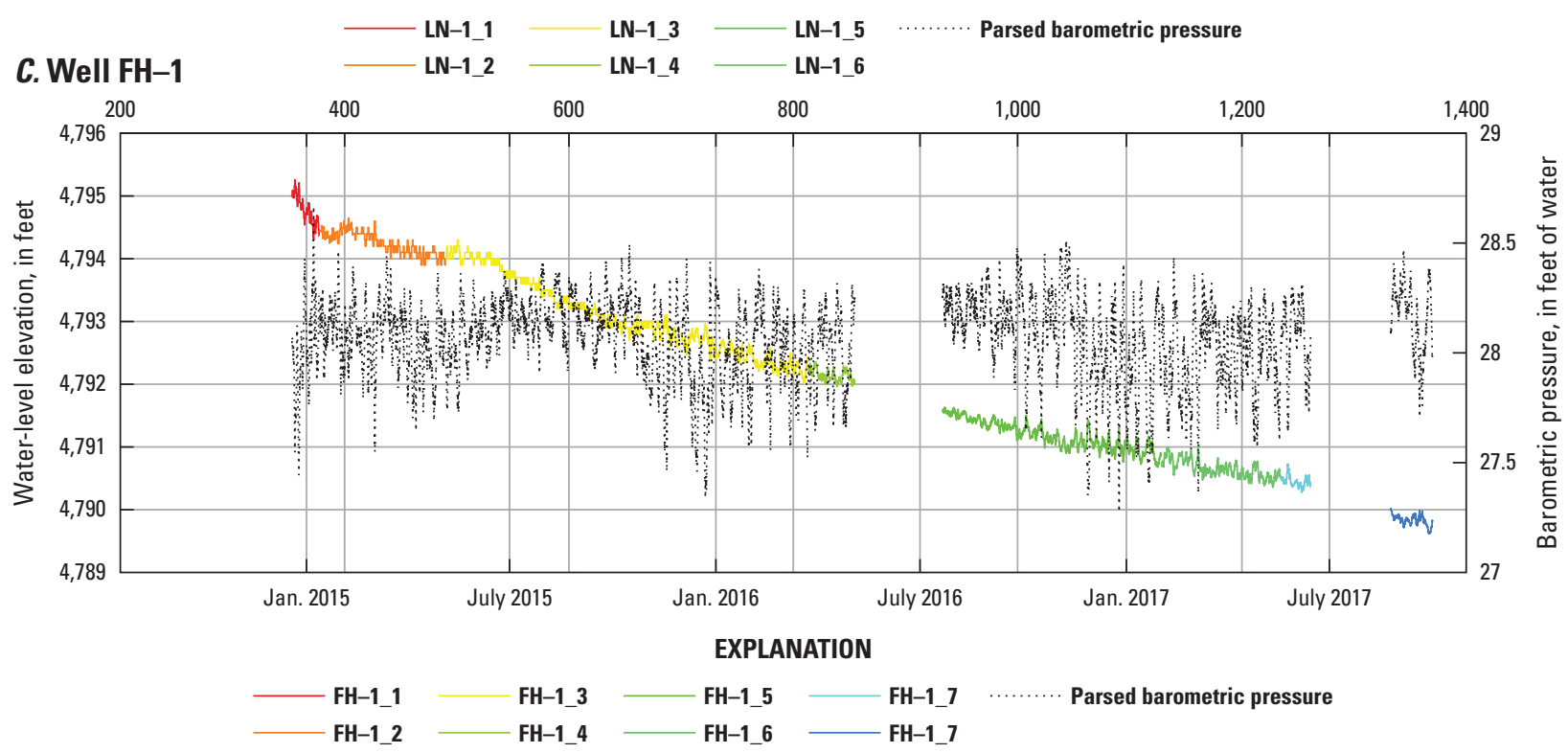

Figure 43. Parsed, coincident (paired) water-level and barometric-pressure time series for wells BR-1, LN-1, and FH-1, southeastern Laramie County, Wyoming. A, BR-1, September 5, 2014-September 30, 2017; B, LN-1, November 8, 2014September 30, 2017; C, FH-1, December 19, 2014-September 30, 2017. 
Table. 11. Parsed time-series parameters for wells BR-1, September 5, 2014-September 30, 2017; LN-1, November 8, 2014-September 30, 2017; and FH-1, December 19, 2014September 30, 2017, southeastern Laramie County, Wyoming.

[mm/dd/yyyy, month/day/year; hh:mm, hour:minute; dd, decimal day (dd 1 = Jan. 1, 2014); N, number of hourly samples in the parsed time series; WL, water level; BP, barometric pressure]

\begin{tabular}{|c|c|c|c|c|c|c|c|c|c|}
\hline $\begin{array}{l}\text { Well/parsed } \\
\text { series }\end{array}$ & $\begin{array}{l}\text { Start date and time } \\
\text { (mm/dd/yyyy hh:mm) }\end{array}$ & $\begin{array}{l}\text { End date and time } \\
\text { (mm/dd/yyyy hh:mm) }\end{array}$ & Start dd & End dd & $\begin{array}{c}N \text { samples } \\
\text { (hours) }\end{array}$ & $\begin{array}{l}\text { Time series } \\
\text { length (days) }\end{array}$ & $\begin{array}{c}\text { From WL } \\
\text { piece }\end{array}$ & $\begin{array}{c}\text { From BP } \\
\text { piece }\end{array}$ & $\begin{array}{l}\text { WL detrending } \\
\text { polynomial order }\end{array}$ \\
\hline \multicolumn{10}{|c|}{ BR-1 } \\
\hline 1 & 9/5/2014 12:00 & 1/12/2015 5:00 & 248.50000 & 377.20833 & 3,090 & 128.75000 & 1 & 3 & 1 \\
\hline 2 & 1/12/2015 18:00 & 5/4/2015 23:00 & 377.75000 & 489.95833 & 2,694 & 112.25000 & 1 & 4 & 1 \\
\hline 3 & 5/5/2015 9:00 & 9/23/2015 23:00 & 490.37500 & 631.95833 & 3,399 & 141.62500 & 1 & 5 & 3 \\
\hline 4 & 10/20/2015 11:00 & $3 / 23 / 20160: 00$ & 658.45833 & 813.00000 & 3,710 & 154.58333 & 2 & 5 & 1 \\
\hline 5 & 3/23/2016 11:00 & 1/31/2017 21:00 & 813.45833 & $1,127.87500$ & 7,547 & 314.45833 & 2 & 6 & 5 \\
\hline 6 & $2 / 1 / 201712: 00$ & 5/18/2017 4:00 & $1,128.50000$ & $1,234.16667$ & 2,537 & 105.70833 & 2 & 7 & 1 \\
\hline 7 & 5/18/2017 15:00 & 9/30/2017 23:00 & $1,234.62500$ & $1,369.95833$ & 3,249 & 135.37500 & 2 & 8 & 1 \\
\hline \multicolumn{10}{|c|}{ LN-1 } \\
\hline 1 & 11/8/2014 1:00 & $12 / 17 / 201423: 00$ & 312.04167 & 351.95833 & 959 & 39.95833 & 1 & 3 & 1 \\
\hline 2 & $1 / 21 / 20150: 00$ & 5/4/2015 23:00 & 386.00000 & 489.95833 & 2,496 & 104.00000 & 2 & 4 & 5 \\
\hline 3 & 5/5/2015 9:00 & $3 / 23 / 20160: 00$ & 490.37500 & 813.00000 & 7,744 & 322.66667 & 2 & 5 & 5 \\
\hline 4 & 3/23/2016 11:00 & 1/31/2017 21:00 & 813.45833 & $1,127.87500$ & 7,547 & 314.45833 & 2 & 6 & 5 \\
\hline 5 & 2/1/2017 12:00 & 5/18/2017 4:00 & $1,128.50000$ & $1,234.16667$ & 2,537 & 105.70833 & 2 & 7 & 1 \\
\hline 6 & 5/18/2017 15:00 & 9/30/2017 23:00 & $1,234.62500$ & $1,369.95833$ & 3,249 & 135.37500 & 2 & 8 & 2 \\
\hline \multicolumn{10}{|c|}{$\mathrm{FH}-1$} \\
\hline 1 & 12/19/2014 1:00 & 1/12/2015 5:00 & 353.04167 & 377.20833 & 581 & 24.20833 & 1 & 3 & 1 \\
\hline 2 & 1/12/2015 18:00 & 5/4/2015 23:00 & 377.75000 & 489.95833 & 2,694 & 112.25000 & 1 & 4 & 3 \\
\hline 3 & 5/5/2015 9:00 & $3 / 23 / 20160: 00$ & 490.37500 & 813.00000 & 7,744 & 322.66667 & 1 & 5 & 5 \\
\hline $3 a$ & 5/5/2015 9:00 & 12/3/2015 11:00 & 490.37500 & 702.45833 & 5,091 & 212.125 & 1 & 5 & 5 \\
\hline $3 b$ & $12 / 3 / 201512: 00$ & $3 / 23 / 20160: 00$ & 702.50000 & 813.00000 & 2,653 & 110.54167 & 1 & 5 & 1 \\
\hline 4 & $3 / 23 / 201611: 00$ & $5 / 3 / 201622: 00$ & 813.45833 & 854.91667 & 996 & 41.50000 & 1 & 6 & 1 \\
\hline 5 & 7/20/2016 23:00 & 1/31/2017 21:00 & 932.95833 & $1,127.87500$ & 4,679 & 194.95833 & 2 & 6 & 1 \\
\hline 6 & 2/1/2017 12:00 & 5/18/2017 4:00 & $1,128.50000$ & $1,234.16667$ & 2,537 & 105.70833 & 2 & 7 & 1 \\
\hline 7 & 5/18/2017 15:00 & 6/14/2017 9:00 & $1,234.62500$ & $1,261.37500$ & 643 & 26.79167 & 2 & 8 & 1 \\
\hline 8 & 8/24/2017 14:00 & 9/30/2017 23:00 & $1,332.58333$ & $1,369.95833$ & 898 & 37.41667 & 3 & 8 & 1 \\
\hline
\end{tabular}




\section{A. Well BR-1_4}

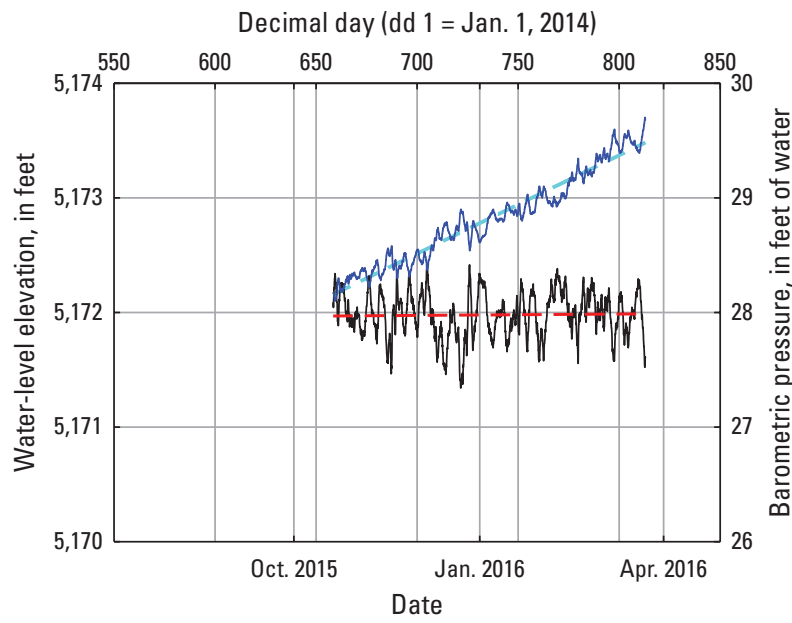

\section{Well LN-1_5}

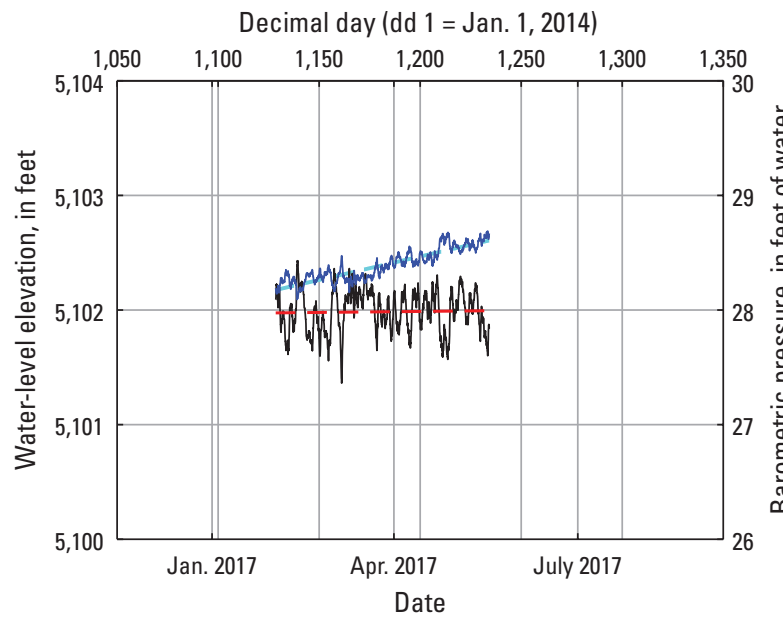

\section{E. Well FH-1_5}

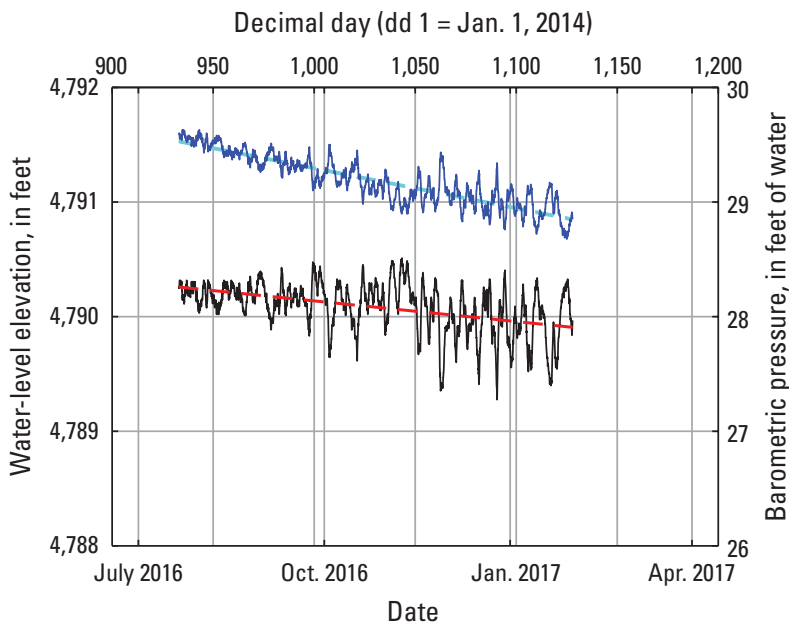

\section{B. Detrended Well BR-1_4}

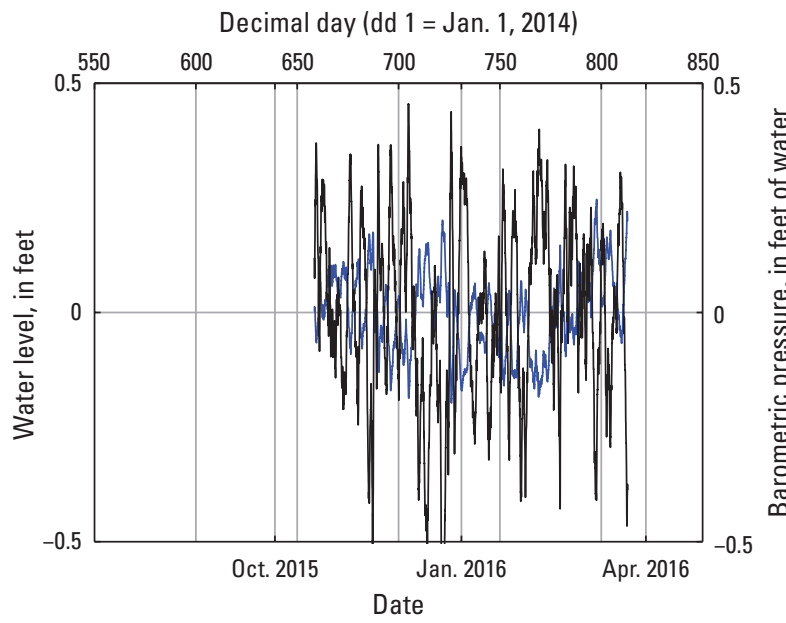

\section{Detrended Well LN-1_5}

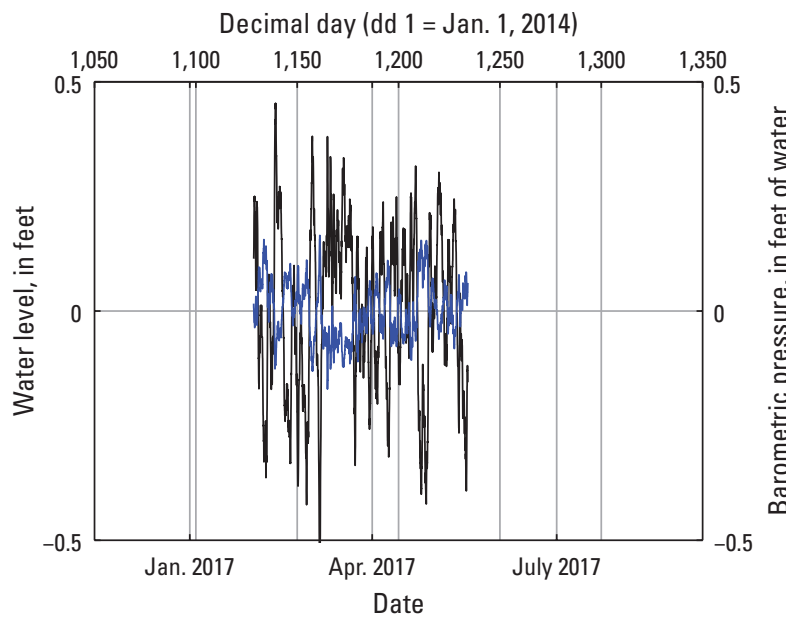

\section{F. Detrended Well FH-1_5}

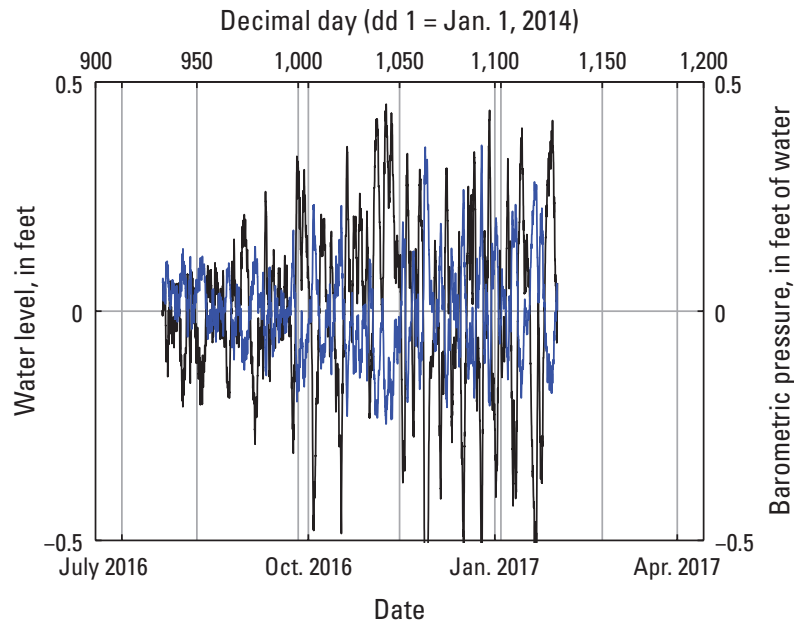

Figure 44. Trended and detrended water-level and barometric-pressure parsed time series BR-1_4, 0ctober 20, 2015-March 23, 2016; LN-1_5, February 1-May 18, 2017; and FH-1_5, July 20, 2016-January 31, 2017, from wells BR-1, LN-1, and FH-1, southeastern Laramie County, Wyoming. $A$, trended series for BR-1_4; $B$, detrended series for BR-1_4; $C$, trended series for $\mathrm{LN}-1 \_5$; $D$, detrended series for $\mathrm{LN}-1 \_5$; 


\section{Water-Level Response to Atmospheric Loading-Constant Barometric Efficiency}

The response of water level to changes in BP in a well open to the atmosphere is characterized by the barometric efficiency (BE) of the well (Jacob, 1940), as follows:

$$
B E=-\frac{\Delta y}{\Delta x},
$$

where

$\Delta y \quad$ is the change in water level and

$\Delta x \quad$ is the change in BP expressed in equivalent units of head:

$$
\Delta x=\frac{\Delta p_{x}}{\rho_{w} g},
$$

where
$\Delta p_{x} \quad$ is the change in $\mathrm{BP}$,
$\rho_{w} \quad$ is the density of water, and
$g \quad$ is the gravitational acceleration constant.

Because water levels in monitoring wells were expressed as elevation in this analysis, an increase in the level of the free-surface water level in a well (positive $\Delta y$ ) corresponded to an increase in the water-level elevation in the well.

Preliminary estimates of BE for each of the paired, detrended, parsed series are shown in table 12 (fig. 41, box d). First, using method 1, BE was estimated from a linear leastsquares regression of detrended water level $(y)$ on detrended BP $(x)$. Second, using methods $2 \mathrm{a}$ and $2 \mathrm{~b}, \mathrm{BE}$ was estimated from a least-squares linear regression of low-pass (lp) or highpass (hp) filtered detrended time series, for instance, $y_{l p}$ on $x_{l p}$ or $y_{h p}$ on $x_{h p}$, respectively, using a cutoff frequency of 0.7 cycle per day (cpd). Third, using method 3, BE was estimated from a linear least-squares regression of $\Delta y$ on $\Delta x$,

$$
\begin{aligned}
& \Delta x(t)=x_{t}-x_{t-1} \\
& \Delta y(t)=y_{t}-y_{t-1} \text { for } t=2, N,
\end{aligned}
$$

where

$$
\begin{array}{cl}
t & \text { is the index of hourly samples and } \\
N & \text { is the number of samples in the detrended, } \\
\text { parsed time series. }
\end{array}
$$

Each of the methods tested different frequency content of the water-level responses to barometric-pressure variations. Method 1 estimated an approximate mean response across the range of frequency content that was weighted more by the lower frequency content. Methods $2 \mathrm{a}$ and $2 \mathrm{~b}$ estimate approximated mean responses for frequency content below (lp) and above (hp) about $0.7 \mathrm{cpd}$, respectively. Method 3 estimated the response from hour to hour and was more representative of the highest resolvable frequency component $\left(f_{s} / 2=12 \mathrm{cpd}\right.$, where $f_{s}$ is the sampling frequency of 24 samples per day) of the response. Listed in table 12 are the BE estimates from each of methods for the selected parsed series, and figure 45 shows an example of the detrended hydrographs and regressions for parsed series FH-1_5. Note, the computed BEs were represented by the negative slope of the equation of the best-fit line determined from the linear least-squares regression, consistent with equation 6 .

The BE estimates for well BR-1 (table 12) indicated that $\mathrm{BE}$ depended on the frequency content of the barometricpressure time series $(x)$. For well BR-1, there was a notable difference between the $\mathrm{BE}$ estimates derived from the lower frequency components (methods 1 and $2 \mathrm{a}$ ) and those derived from the higher frequency components (methods $2 \mathrm{~b}$ and 3 ). The higher frequency component $\mathrm{BE}$ estimates ranged from about 0.08 to 0.19 , whereas the lower frequency component estimates ranged from about 0.27 to 0.36 . For wells $\mathrm{LN}-1$ and $\mathrm{FH}-1$, the BE estimates were markedly less frequency dependent. For well LN-1, the corresponding ranges of the highand low-frequency component estimates overlapped, ranging from about 0.18 to 0.34 and from about 0.23 to 0.30 , respectively. For well FH-1, series FH-1_3b-8, the corresponding ranges of the high- and low-frequency component estimates also overlapped, ranging from about 0.31 to 0.53 and from about 0.46 to 0.50 , respectively. The high coefficient-of-determination $\left(r^{2}\right)$ values for the FH-1_3b-8-series low-frequency component class BE estimates indicated the means (about 0.48 for methods 1 and 2a) were well estimated, whereas the low-frequency component mean BE estimates were less well determined for wells BR-1 (about 0.31 for methods 1 and $2 \mathrm{a}$ ) and $\mathrm{LN}-1$ (about 0.26 for methods 1 and 2a). Of the higher frequency component class BE estimates for $\mathrm{FH}-1$, the estimates for method 3 had substantially poorer $r^{2}$ values than those for method 2b. Generally, the high-frequency component BEs estimated using method 3 were poorly determined for each of the wells. This is attributed to the likely poor representation of the imposed high-frequency changes in BP at the well sites that were measured at the distant Cheyenne Airport, and to the generally small changes in BP at frequencies greater than $2 \mathrm{cpd}$, coupled with the estimated $0.01-\mathrm{ft}$ resolution of the water-level measurements. The water-level measurement resolution was $0.1 \mathrm{ft}$ for $\mathrm{FH}-1 \_1-3 \mathrm{a}$.

Filtered, detrended water-level estimates based on the BEs estimated using methods $1,2 \mathrm{a}$, and $2 \mathrm{~b}$ were computed using

$$
\tilde{y}_{B E}(t)=y_{t}-\hat{y}_{B E_{t}} \text { for } t=1, N \text {, }
$$

where

$\tilde{y}_{B E}(t) \quad$ is the predicted water level computed from

$$
\hat{y}_{B E_{t}}=-B E x_{t} \text {. }
$$

For method 3, $\tilde{y}_{B E}(t)$ was computed using

$$
\tilde{y}_{B E}(t)=y_{t}-\hat{y}_{B E_{t}} \text { for } t=2, N \text {, }
$$


Table 12. Estimates of constant barometric efficiency determined using methods $1,2 a, 2 b$, and 3 for each of the parsed time series shown in table 11 , for wells BR-1, LN-1, and FH-1, southeastern Laramie County, Wyoming.

[BE1, BE2a, BE2b, and BE3 refer to different methods for determining constant-valued barometric efficiency using least-squares linear regression. BE1, method 1; BE2a, method 2a; BE2b, method $2 \mathrm{~b} ; \mathrm{BE} 3$, method $3 ; r^{2} 1$, coefficient of determination from method $1 ; r^{2} 2 \mathrm{a}$, coefficient of determination from method $2 \mathrm{a} ; r^{2} 2 \mathrm{~b}$, coefficient of determination from method $2 \mathrm{~b} ; r^{2} 3$, coefficient of deter mination from method 3. --, not applicable]

\begin{tabular}{|c|c|c|c|c|c|c|c|c|}
\hline \multirow{2}{*}{ Well/parsed series } & BE1 & $r^{2} 1$ & BE2a & $r^{2} 2 a$ & BE2b & $r^{2} \mathbf{2 b}$ & BE3 & $r^{2} 3$ \\
\hline & \multicolumn{4}{|c|}{ Low-frequency component class } & \multicolumn{4}{|c|}{ High-frequency component class } \\
\hline \multicolumn{9}{|c|}{ BR-1 } \\
\hline 1 & 0.320 & 0.655 & 0.325 & 0.674 & 0.187 & 0.201 & 0.160 & 0.153 \\
\hline 2 & 0.290 & 0.541 & 0.298 & 0.558 & 0.113 & 0.136 & 0.123 & 0.118 \\
\hline 3 & 0.311 & 0.475 & 0.319 & 0.493 & 0.113 & 0.088 & 0.081 & 0.046 \\
\hline 4 & 0.341 & 0.641 & 0.344 & 0.649 & 0.153 & 0.196 & 0.140 & 0.155 \\
\hline 5 & 0.266 & 0.675 & 0.268 & 0.688 & 0.128 & 0.126 & 0.117 & 0.108 \\
\hline 6 & 0.352 & 0.901 & 0.359 & 0.925 & 0.134 & 0.186 & 0.128 & 0.135 \\
\hline 7 & 0.278 & 0.572 & 0.283 & 0.590 & 0.098 & 0.073 & 0.081 & 0.051 \\
\hline (Mean) & 0.309 & -- & 0.314 & -- & 0.132 & -- & 0.119 & -- \\
\hline \multicolumn{9}{|c|}{$\mathrm{LN}-1$} \\
\hline 1 & 0.304 & 0.926 & 0.302 & 0.954 & 0.337 & 0.514 & 0.264 & 0.333 \\
\hline 2 & 0.236 & 0.643 & 0.234 & 0.659 & 0.269 & 0.409 & 0.225 & 0.250 \\
\hline 3 & 0.232 & 0.542 & 0.230 & 0.549 & 0.311 & 0.403 & 0.226 & 0.231 \\
\hline 4 & 0.229 & 0.697 & 0.227 & 0.713 & 0.315 & 0.401 & 0.224 & 0.245 \\
\hline 5 & 0.299 & 0.809 & 0.299 & 0.823 & 0.280 & 0.437 & 0.218 & 0.256 \\
\hline 6 & 0.237 & 0.638 & 0.235 & 0.659 & 0.306 & 0.376 & 0.183 & 0.148 \\
\hline (Mean) & 0.256 & -- & 0.255 & -- & 0.303 & -- & 0.223 & -- \\
\hline \multicolumn{9}{|c|}{$\mathrm{FH}-1$} \\
\hline 1 & 0.540 & 0.890 & 0.537 & 0.973 & 0.629 & 0.339 & 0.468 & 0.088 \\
\hline 2 & 0.465 & 0.681 & 0.467 & 0.771 & 0.419 & 0.143 & 0.364 & 0.047 \\
\hline $3 a$ & 0.406 & 0.589 & 0.400 & 0.675 & 0.579 & 0.188 & 0.370 & 0.044 \\
\hline $3 b$ & 0.481 & 0.966 & 0.481 & 0.985 & 0.464 & 0.435 & 0.357 & 0.336 \\
\hline 4 & 0.463 & 0.938 & 0.464 & 0.957 & 0.447 & 0.423 & 0.353 & 0.280 \\
\hline 5 & 0.502 & 0.948 & 0.501 & 0.966 & 0.526 & 0.480 & 0.380 & 0.356 \\
\hline 6 & 0.500 & 0.957 & 0.501 & 0.977 & 0.451 & 0.490 & 0.365 & 0.346 \\
\hline 7 & 0.474 & 0.943 & 0.473 & 0.978 & 0.486 & 0.453 & 0.318 & 0.231 \\
\hline 8 & 0.476 & 0.959 & 0.474 & 0.988 & 0.523 & 0.456 & 0.304 & 0.205 \\
\hline (Mean) & 0.478 & -- & 0.477 & -- & 0.503 & -- & 0.364 & -- \\
\hline (Mean, parse 3b-8) & 0.483 & -- & 0.482 & -- & 0.483 & -- & 0.346 & -- \\
\hline
\end{tabular}



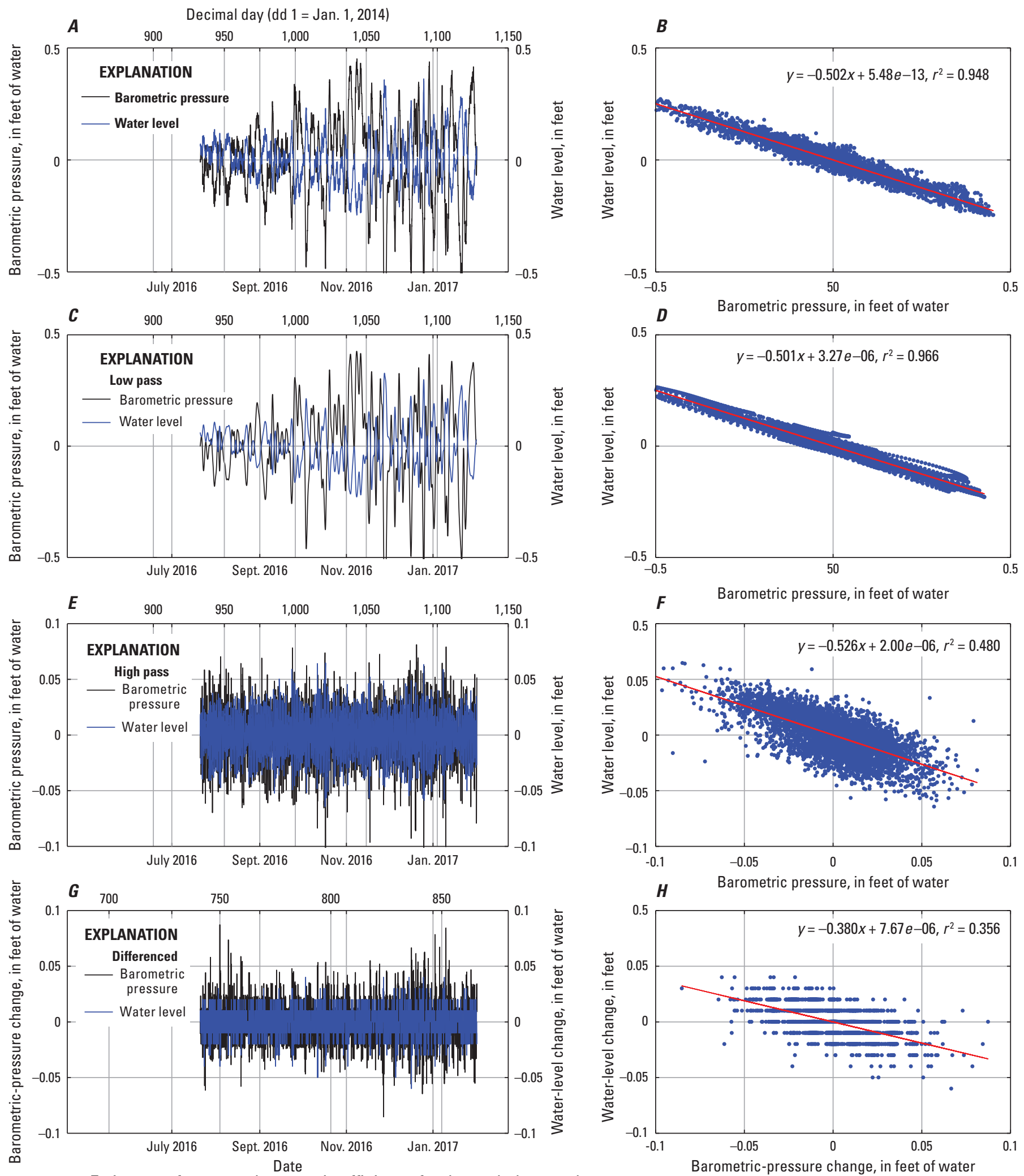

Figure 45. Estimates of constant barometric efficiency for detrended, parsed time series FH-1_5, July 20, 2016-January 31, 2017, from well FH-1, southeastern Laramie County, Wyoming, based on linear least-squares regression of water level on barometric pressure using methods $1,2 \mathrm{a}, 2 \mathrm{~b}$, and 3 . A, detrended series used for method $1 ; B$, linear regression of detrended series for method 1 ; $C$, low-pass detrended series used for method 2a; $D$, linear regression of lowpass detrended series for method 2a; $E$, high-pass detrended series used for method 2b; $F$, linear regression of high-pass detrended series for method 2b; $G$, differenced, detrended series used for method $3 ; H$, linear regression of differenced, detrended series for method 3 .

\section{EXPLANATION}

Best-fitting line determined from the linear regression, represented by the equation $y=$ slope $^{*} x+$ offset, where $y$ is water level or water-level change, $x$ is barometric pressure or barometric-pressure change, the negative of the slope is the constant barometric efficiency estimate, $e$ denotes exponentiation, and $r^{2}$ is the coefficient of determination 
where

$$
\hat{y}_{B E_{t}}=-B E \sum_{i=2}^{N}\left(\Delta x_{i}\right)+\hat{y}_{B E_{t}},
$$

where

$$
\begin{aligned}
& \sum_{i=2}^{N}\left(\Delta x_{i}\right) \quad \text { represents the cumulative sums of } \Delta x(t) \text { at } \\
& t=2, N \text { from equation } 8 \text { and } \\
& \hat{y}_{B E_{1}} \text { is } \hat{y}_{B E} \text { at } t=1 \text { computed from equation } 10 \text {. }
\end{aligned}
$$

As formulated, equations 11 and 12 are equivalent to equations 9 and 10 where BE estimated using method 3 is used in equation 10. The filtered results for the BR-1_6 detrended, parsed series using the constant BE estimates from the $\mathrm{lp}(\operatorname{method} 2 \mathrm{a})$ and $\mathrm{hp}(\operatorname{method} 2 \mathrm{~b})$ filtered time series (fig. 46A), and for all the BR-1 parsed series (table 12), indicated that a single-valued, time-invariant BE could not adequately account for the atmospheric-loading responses. Conversely, the LN-1_5 and FH-1_6 detrended, parsed series filtered using the constant BE estimates from the lp (using method $2 \mathrm{a}$ ) and hp (using method $2 \mathrm{~b}$ ) filtered time series (fig. 46B, C), and for all the parsed series for each of those wells (table 12), indicated that a single-valued, time-invariant BE could reasonably account for the atmospheric-loading responses measured in those wells.

\section{Water-Level Responses to the Solid Earth Tide}

Water-level responses in each well to the principal tides of the solid Earth tide were evaluated using harmonic analysis (for example, Hsieh and others, 1987; Galloway and Rojstaczer, 1989; Cutillo and Bredehoeft, 2011). Use of the terms "tide" and "tidal" here refer specifically to Earth tides in terms of the known frequencies of the principal constituents of the Earth tide and do not imply a more general reference that includes barometric tides. The frequencies and periods of the six principal Earth tides (Godin, 1972), which constitute about 95 percent of the tidal potential, are listed in table 13. These tides result from the relative motions of the moon, sun, and Earth. The tides are designated as lunar $\left(\mathrm{O}_{1}, \mathrm{Q}_{1}, \mathrm{M}_{2}, \mathrm{~N}_{2}\right)$, solar $\left(\mathrm{S}_{2}\right)$, or mixed $\left(\mathrm{K}_{1}\right)$ and by their mode (diurnal, ${ }_{1}$; or semidiurnal, $\left.{ }_{2}\right)$.

The detrended, parsed water-level time series were digitally filtered using an hp Butterworth filter (Butterworth, 1930) (order 7) with a cut-off frequency of $0.7 \mathrm{cpd}$ to generally separate the higher frequencies $(0.7-12 \mathrm{cpd})$ containing any diurnal and semidiurnal tidal and atmospheric-loading responses from the lower frequencies dominated by atmospheric-loading effects. At midlatitudes, fluctuations in BP at exactly 1 and 2 cpd are caused by solar heating of the atmosphere. The well responses at these frequencies, especially at $2 \mathrm{cpd}$, are dominated by atmospheric-loading effects to which the responses to Earth tides are superimposed at nearby or coincident frequencies, such as for the $\mathrm{K}_{1}$ and $\mathrm{S}_{2}$ tides; therefore, although the analysis included each of the tides in table 13, a focus was placed on the responses to the lunar tides $\left(\mathrm{M}_{2}, \mathrm{O}_{1}, \mathrm{~N}_{2}\right.$, and $\mathrm{Q}_{1}$ listed in order of decreasing tidal potential).

The theoretical tidal potential and resulting body tides of a solid Earth (oceanless) produced by the moon and sun were computed from gravitational and astronomical theory for the locations and open-interval elevations of the monitoring wells at the sample times for each of the parsed series using the Harrison (1971) model. The Earth's crust undergoes volumetric strains, $\varepsilon_{V o l}$, because of variations in the tide-generating forces:

$$
\varepsilon_{V o l}=\varepsilon_{00}+\varepsilon_{\lambda \lambda}+\varepsilon_{r r}
$$

where

$$
\begin{aligned}
& \varepsilon_{00} \text { is the component strain in the north principal } \\
& \text { axis, } \\
& \varepsilon_{\lambda \lambda} \quad \text { is the component strain in the east principal } \\
& \quad \text { axis, and } \\
& \varepsilon_{r r} \quad \text { is the component strain in the radial } \\
& \quad \text { (downward toward the center of the Earth) } \\
& \text { principal axis. }
\end{aligned}
$$

Near the Earth's surface (within the upper 10 kilometers or more), most of the stress is plane stress, and the resultant strain tide is predominantly an areal strain, $\varepsilon_{\text {Areal }}$ (Melchior, 1966; Rojstaczer and Agnew, 1989):

$$
\varepsilon_{\text {Areal }}=\varepsilon_{00}+\varepsilon_{\lambda \lambda}
$$

The areal-strain tide (positive for dilatation following the convention of Harrison, 1971) was computed in parts per billion (nanostrain) as a scaled function of the tidal potential (Munk and MacDonald, 1960; Melchior, 1966; Bredehoeft, 1967):

$$
\varepsilon_{\text {Areal }}=(2 \bar{h}-6 \bar{l}) \frac{V}{r_{e} g} \times 10^{9}
$$

where

$$
\begin{aligned}
& \bar{h} \quad \begin{array}{l}
\text { is a Love number taken to be } 0.638, \\
\bar{l}
\end{array} \quad \begin{array}{l}
\text { is a Love number taken to be } 0.088, \\
V
\end{array} \quad \begin{array}{l}
\text { is the tidal potential, } \\
r_{e} \quad \text { is the distance between the center of the Earth } \\
\text { and the observation point on or near the }
\end{array} \\
& \quad \text { Earth's surface, and } \\
& g \quad \text { is the gravitational acceleration constant. }
\end{aligned}
$$

Similar to the detrended, parsed water-level time series, the computed areal-strain tide time series were detrended and digitally filtered using an hp Butterworth filter (Butterworth, 1930) (order 7) with a cut-off frequency of $0.7 \mathrm{cpd}$. The amplitudes and phases of water level and the theoretical areal-strain tide at the principal tidal frequencies (table 13) were computed by multiple least-squares fitting for each tidal constituent of the respective time series to the following functions (after Cryer and Chan [2008, p. 34]): 

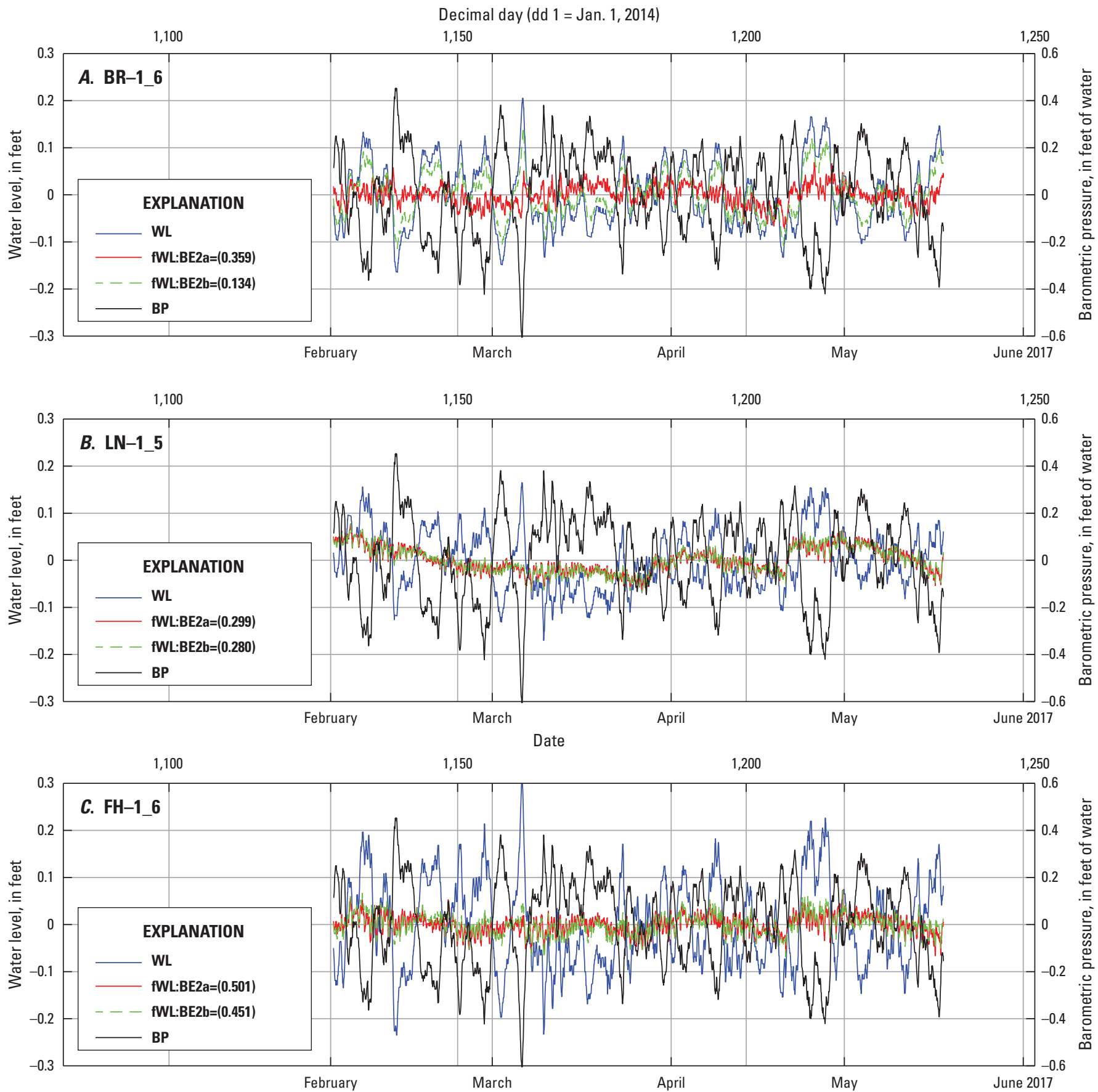

EXPLANATION

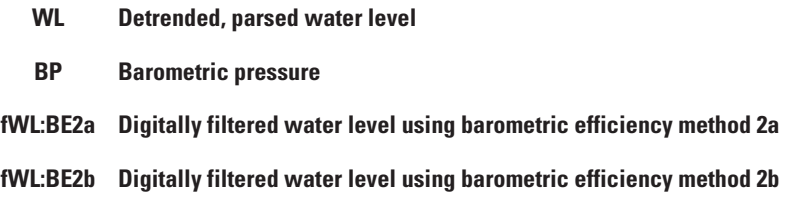

Figure 46. Digitally filtered water levels fWL:BE2a and fWL:BE2b for detrended, parsed water-level and barometric-pressure time series, February 1-May 18, 2017, from wells BR-1, LN-1, and FH-1, southeastern Laramie County, Wyoming, using the constant barometric-efficiency estimates determined from methods $2 a$ (low pass) and $2 \mathrm{~b}$ (high pass): $A, \mathrm{BR}-1$ - 6 ; $B, \mathrm{LN}-1 \_5 ; C, \mathrm{FH}-1 \_6$. Constant barometric-efficiency estimates are shown in parentheses next to the method type in the explanation. 
Table 13. Frequencies, periods, and indices used in the analysis of the six principal Earth tides (Godin, 1972).

The tides are designated as lunar $\left(\mathrm{Q}_{1}, \mathrm{O}_{1}, \mathrm{M}_{2}, \mathrm{~N}_{2}\right)$, solar $\left(\mathrm{S}_{2}\right)$, or mixed $\left(\mathrm{K}_{1}\right)$ and by their mode (diurnal, ${ }_{1}$; semidiurnal, ${ }_{2}$ ).

\begin{tabular}{cccc}
\hline Tide & $\begin{array}{c}\text { Frequency } \\
\text { (cycles per solar day) }\end{array}$ & $\begin{array}{c}\text { Period } \\
\text { (solar hours) }\end{array}$ & $\begin{array}{c}\text { Constituent } \\
\text { index }\end{array}$ \\
\hline $\mathrm{Q}_{1}$ & 0.89324 & 26.86836 & 6 \\
$\mathrm{O}_{1}$ & 0.92954 & 25.81934 & 5 \\
$\mathrm{~K}_{1}$ & 1.00274 & 23.93447 & 4 \\
$\mathrm{~N}_{2}$ & 1.89598 & 12.65835 & 3 \\
$\mathrm{M}_{2}$ & 1.93227 & 12.42060 & 2 \\
$\mathrm{~S}_{2}$ & 2.00000 & 12.00000 & 1 \\
\hline
\end{tabular}

$$
\begin{gathered}
y_{h p}\left(t_{j}\right)=\sum_{k=1}^{6}\left(a_{k} \cos \left(2 \pi f_{k} t_{j}\right)+b_{k} \sin \left(2 \pi f_{k} t_{j}\right)\right)+R y_{h p_{j}}, \\
\varepsilon_{\text {Areal hp }}\left(t_{j}\right)=\sum_{k=1}^{6}\left(c_{k} \cos \left(2 \pi f_{k} t_{j}\right)+d_{k} \sin \left(2 \pi f_{k} t_{j}\right)\right)+R_{\mathcal{E}_{\text {Arral } h p_{j}}},
\end{gathered}
$$

where

$$
\begin{aligned}
& y_{h p} \quad \text { is the hp detrended water-level series, } \\
& t_{j} \text { is time in decimal days (for } j=1 \text { to the number } \\
& \text { of samples, } N \text { ), } \\
& a_{k}, b_{k} \quad \text { are the coefficients of the regression for the hp } \\
& \text { water-level series, } \\
& f_{k} \quad \text { is the frequency in cycles per day of } \\
& \text { the } k \text { th tidal constituent (for } k=1 \text { to } 6 \\
& \text { corresponding to the six tides in table 13), } \\
& R y_{h p_{j}} \quad \text { are the residuals for the hp water-level series, } \\
& \varepsilon_{\text {arral } h p} \quad \text { is the hp areal-strain tide series, } \\
& c_{k}, d_{k} \quad \text { are the coefficients of the regression for the } \mathrm{hp} \\
& \text { areal-strain tide time series, and } \\
& R_{\mathcal{E}_{\text {Areal } h p_{j}}} \quad \text { are the residuals for the hp areal-strain tide } \\
& \text { series. }
\end{aligned}
$$

The summation terms in equations 16 and 17 represent the predicted values of the regressions, $\hat{y}_{\text {hpet }}$ and $\hat{\varepsilon}_{\text {Areal }}$, respectively. The predicted fits to the hp detrended water level and theoretical areal-strain tide for parsed series $\mathrm{FH}-1 \_8$ are shown in figure 47. Predicted fits to the theoretical areal-strain tide (fig. $47 B$ ) were much better than the predicted fits to water level (fig. 47A), reflecting that the six principal Earth tides accounted for almost all the variation in the theoretical arealstrain tide and a much smaller proportion of the hp detrended water-level variation.

The amplitudes $\left(A y_{k}, A \varepsilon_{\text {Araal }_{k}}\right)$ and phases $\left(\phi_{y_{k}}\right.$ and $\phi_{\varepsilon_{\text {Arral }} k}$, expressed in degrees) referenced to the starting time of the individual parsed series were computed for each tidal constituent $(k)$ in each time series $\left(y_{h p}, \boldsymbol{\varepsilon}_{\text {Araal hp }}\right)$ using the following equations:

$$
\begin{aligned}
& A y_{k}=\sqrt{a_{k}{ }^{2}+b_{k}{ }^{2}} ; A \varepsilon_{\text {Areal }_{k}}=\sqrt{c_{k}{ }^{2}+d_{k}{ }^{2}} \\
& \phi_{y_{k}}=\operatorname{atan} 2\left(b_{k}, a_{k}\right) ; \phi_{\varepsilon_{\text {Areal } k}}=\operatorname{atan} 2\left(d_{k}, c_{k}\right) \text { ' }
\end{aligned}
$$

where

$A y_{k}$ and $A \varepsilon_{\text {Araal }}$ are the positive roots of the arguments and atan2 is the two-argument arctangent.

The phase shift, $\eta_{k}$, of the water-level response to each tidal constituent ( $k=1$ to 6$)$ in the forcing theoretical strain tide was computed using the following equation:

$$
\eta_{k}=\phi_{y_{k}}-\phi_{\mathcal{E}_{\text {Araal }},},-360^{\circ} \leq \eta_{k} \leq 0^{\circ} .
$$

Because tidal dilation was defined as positive, an increasing tidal dilatation would cause a decreasing absolute water level, and the ideal water-level response would be antiphase (for example, $-180^{\circ}$ ) with respect to the tidal dilatation. The phases and phase shifts were mapped in the interval -360 to $0^{\circ}$ (eq. 19); thus, for the conventions used here to compute phases and phase shifts, phase shifts greater than $-180^{\circ}$ (for example, $-160^{\circ}$ ) represented a phase lag of the water-level response to the tidal dilatation.

\section{Preliminary Earth-Tide Analysis of Detrended, Parsed Water-Level Time Series}

A preliminary analysis was done for each of the parsed series in table 11 to determine if water levels responded to Earth tides (fig. 41, box e). The preliminary analysis consisted of computing the amplitude, phase, and phase shift using equations 18-19 for each tidal constituent for each of the parsed series for wells BR-1, LN-1, and FH-1 (table 14).

Because at the exact frequencies of the lunar Earth tides $\left(\mathrm{M}_{2}, \mathrm{~N}_{2}, \mathrm{O}_{1}\right.$, and $\left.\mathrm{Q}_{1}\right)$ there is little power in the BP signal, the presence of discernable water-level amplitudes at the frequencies of the principal lunar tides $\left(\mathrm{M}_{2}\right.$ and $\left.\mathrm{O}_{1}\right)$ is an indication that a water-level response at these frequencies may be due to Earth tides. The estimated tidal constituent parameters in table 14 indicate that the $\mathrm{S}_{2}$ (solar), $\mathrm{K}_{1}$ (mixed), and $\mathrm{M}_{2}$ and $\mathrm{O}_{1}$ (principal lunar) tides dominated the water-level amplitude responses at these tidal frequencies in each of the wells. The computed $\mathrm{M}_{2}$ water-level amplitudes of about $0.011 \mathrm{ft}$, $0.007 \mathrm{ft}$, and $0.004 \mathrm{ft}$ for wells $\mathrm{FH}-1, \mathrm{LN}-1$, and $\mathrm{BR}-1$, respectively, are shown in table 14 . All the lesser lunar $\left(\mathrm{N}_{2}\right.$ and $\mathrm{Q}_{1}$ ) tidal amplitude responses in each of the wells were relatively weak with large uncertainties as indicated by the large standard deviations with respect to the means. Note that the means and standard deviations listed in table 14 do not represent the true population means and variances because the length (number of samples) for each parsed series (table 1) varied widely. Because the principal lunar tidal responses were potentially important in each well, and to compute relevant population statistics, the detrended, parsed water-level time series were further analyzed for tidal responses. 

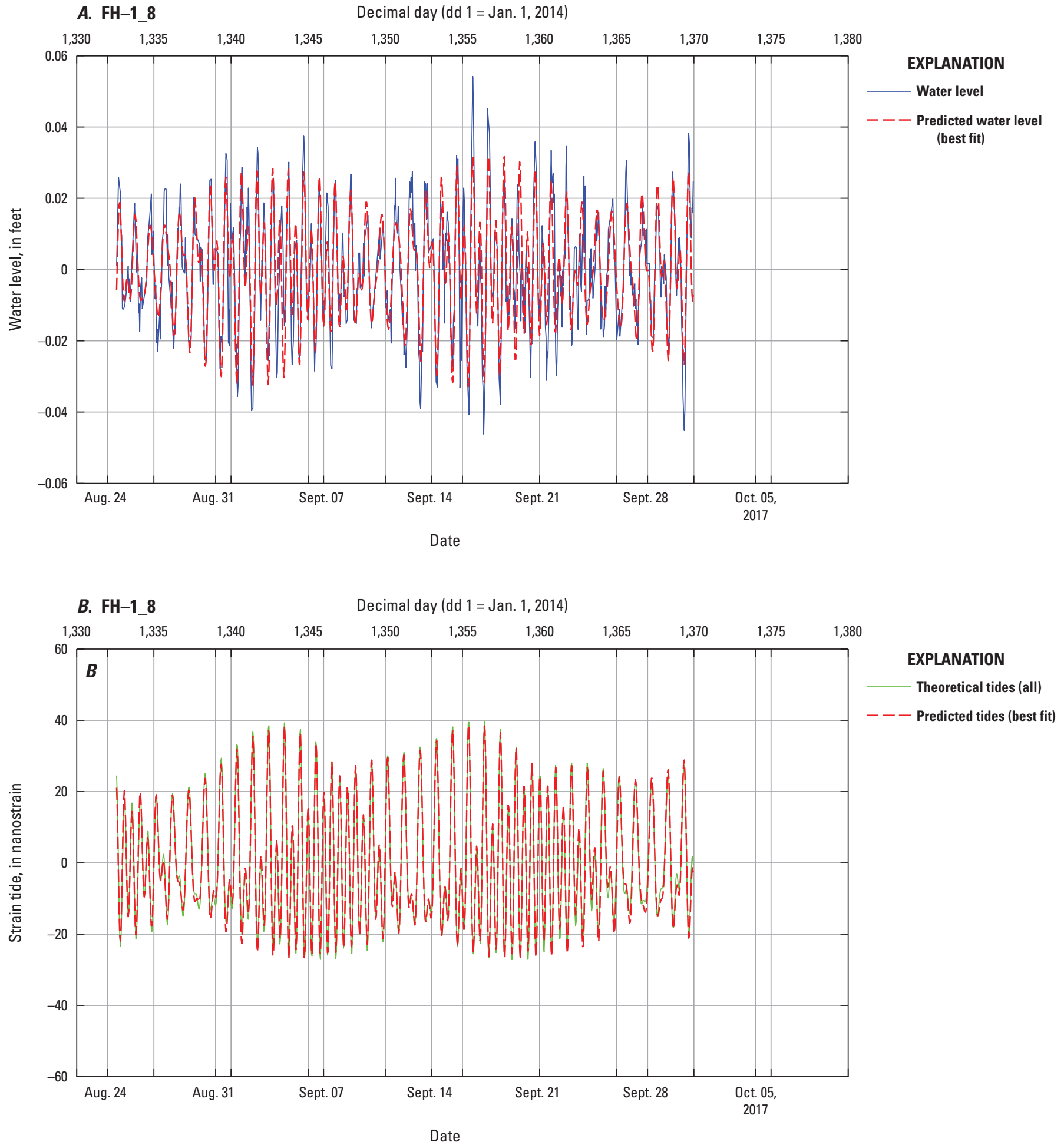

Figure 47. Predicted fits for predicted water level and predicted tides to the high-pass, detrended, parsed water-level and theoretical areal-strain tide time series, respectively, for parsed series FH-1_8 for August 24-September 30, 2017, from well FH-1, southeastern Laramie County, Wyoming. $A$, water level and predicted water level; $B$, theoretical tides and predicted tides. 


\section{Geologic and Hydrogeologic Characteristics, White River Formation, Lance Formation, and Fox Hills Sandstone, Wyo.}

Table 14. Results of tidal harmonic analysis of detrended, parsed time series for wells BR-1, September 5, 2014-September 30, 2017; LN-1, November 8, 2014-September 30, 2017; and FH-1, December 19, 2014-September 30, 2017, southeastern Laramie County, Wyoming.

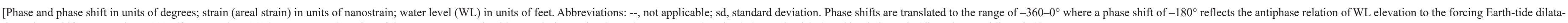
tion; Phase shifts greater than $-180^{\circ}$ (for example, $\left.-160^{\circ}\right)$ represent a phase lag of the $\mathrm{WL}$ response. The tides are designated as lunar $\left(\mathrm{Q}_{1}, \mathrm{O}_{1}, \mathrm{M}_{2}, \mathrm{~N}_{2}\right.$ ), solar $\left(\mathrm{S}_{2}\right)$, or mixed $\left(\mathrm{K}_{1}\right)$ ) and by their mode (diurnal, $;$; semidiurnal, 2$\left.)\right]$

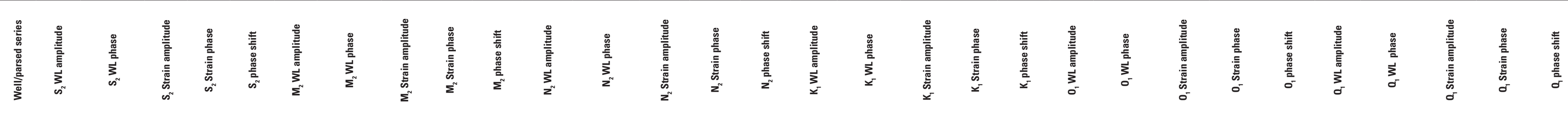

\begin{tabular}{|c|c|c|c|c|c|c|c|c|c|c|c|c|c|c|c|c|c|c|c|c|c|c|c|c|c|c|c|c|c|c|}
\hline \multicolumn{31}{|c|}{ BR-1 } \\
\hline 4 & 0.0041 & -155.8 & 7.7003 & 21.2 & -177.0 & 0.0046 & 166.2 & 17.0845 & -60.8 & -133.0 & 0.0009 & 137.4 & 2.9235 & -84.3 & -138.2 & 0.0090 & 146.6 & 15.1795 & -71.5 & -141.9 & 0.0031 & -148.1 & 9.5141 & 3.2 & -151.3 & 0.0010 & 103.7 & 1.6673 & -17.6 & -238.7 \\
\hline 2 & 0.0047 & 32.0 & 8.4676 & -146.8 & -181.2 & 0.0042 & -102.3 & 16.9860 & 29.9 & -132.3 & 0.0008 & 131.6 & 3.6211 & -104.4 & -124.0 & 0.0010 & 72.2 & 12.2487 & 84.8 & -12.7 & 0.0021 & 146.2 & 9.3706 & -48.3 & -165.5 & 0.0010 & -32.3 & 1.8139 & 178.6 & -210.9 \\
\hline 3 & 0.0042 & -56.3 & 7.0627 & 120.5 & -176.9 & 0.0040 & 36.3 & 16.8857 & 166.5 & -130.2 & 0.0005 & -88.3 & 3.0669 & 66.4 & -154.7 & 0.0068 & -64.3 & 15.3097 & 109.5 & -173.8 & 0.0026 & -96.0 & 9.0726 & 60.7 & -156.7 & 0.0012 & -165.5 & 1.7062 & -40.0 & -125.5 \\
\hline 4 & 0.0044 & -126.0 & 7.5936 & 59.5 & -185.5 & 0.0041 & 111.8 & 17.0286 & -114.8 & -133.4 & 0.0004 & 47.3 & 3.1436 & 178.0 & -130.8 & 0.0038 & 154.1 & 15.4316 & -87.1 & -118.8 & 0.0024 & -143.5 & 9.2852 & -25.2 & -118.2 & 0.0002 & 97.3 & 1.6243 & -93.3 & -169.5 \\
\hline 5 & 0.0040 & -119.0 & 7.4097 & 56.3 & -175.2 & 0.004 & -67.9 & 16.9663 & 64.6 & -132.5 & 0.0006 & 100.8 & 3.4130 & -137.9 & -121.3 & 0.0053 & -48.7 & 15.0574 & 118.3 & -167.0 & 0.0039 & 151.2 & 9.4738 & -58.0 & -150.8 & 0.0008 & -40.2 & 1.8350 & 103.2 & -143.4 \\
\hline 6 & 0.0042 & -150.1 & 8.5579 & 31.5 & -181.6 & 0.0040 & 20.1 & 16.9083 & 155.8 & -135.7 & 0.0005 & -9.5 & 3.1413 & 115.6 & -125.1 & 0.0011 & 86.6 & 11.9464 & 155.1 & -68.5 & 0.0032 & -175.6 & 9.5548 & -3.2 & -172.4 & 0.0020 & 162.6 & 1.6902 & -37.5 & -159.9 \\
\hline 7 & 0.0039 & 129.7 & 7.0260 & -59.4 & -170.8 & 0.0039 & 5.1 & 16.8630 & 133.8 & -128.7 & 0.0010 & -104.7 & 3.4132 & 31.6 & -136.3 & 0.0062 & -164.7 & 15.6094 & 14.1 & -178.8 & 0.0034 & -36.7 & 9.7739 & 123.0 & -159.7 & 0.0008 & -92.7 & 1.8477 & 20.3 & -113.0 \\
\hline (Man) & 0.0042 & - & 7.6882 & - & -178.3 & 0.0041 & - & 16.9603 & $\because$ & -132.2 & 0.0007 & - & 3.2461 & - & -132.9 & 0.0047 & - & 14.3975 & - & -123.1 & 0.0030 & -- & 9.4350 & - & -153.5 & 0.0010 & - & 1.7406 & $\cdots$ & -165.8 \\
\hline (sd) & 0.0003 & - & 0.5708 & -- & 4.5 & 0.0002 & -- & 0.0742 & -- & 2.1 & 0.0002 & - & 0.2249 & - & 10.7 & 0.0028 & -- & 1.4659 & -- & 57.5 & 0.0006 & -- & 0.2053 & -- & 16.1 & 0.0005 & -- & 0.0831 & - & 41.9 \\
\hline \multicolumn{31}{|c|}{ LN-1 } \\
\hline 1 & 0.0065 & 111.6 & 6.8527 & -13.1 & -235.4 & 0.0073 & -165.0 & 16.8509 & 17.3 & -182.2 & 0.0010 & -48.7 & 2.3825 & 108.9 & -157.6 & 0.0098 & -152.9 & 17.9306 & 26.2 & -179.1 & 0.0024 & 157.5 & 8.8824 & -22.4 & -180.1 & 0.0007 & -55.6 & 0.9263 & 75.0 & -130.6 \\
\hline 2 & 0.0081 & 158.7 & 8.5268 & 32.2 & -233.5 & 0.0075 & -132.5 & 16.9810 & 51.3 & -183.7 & 0.0015 & -143.3 & 3.5226 & 23.7 & -167.0 & 0.0013 & -66.4 & 11.7117 & -15.4 & -51.0 & 0.0022 & -129.8 & 8.8736 & 70.6 & -200.4 & 0.0012 & -171.6 & 1.5462 & 38.3 & -210.0 \\
\hline 3 & 0.0072 & -114.1 & 7.4715 & 118.9 & -233.0 & 0.0073 & -16.5 & 16.9664 & 166.9 & -183.4 & 0.0009 & -116.6 & 3.1719 & 65.0 & -181.5 & 0.0061 & -78.5 & 14.9180 & 108.0 & -186.6 & 0.0030 & -111.1 & 9.2066 & 60.6 & -171.8 & 0.0010 & 153.9 & $\begin{array}{l}1.7320 \\
0\end{array}$ & -41.2 & -164.9 \\
\hline 4 & 0.0069 & -170.6 & 7.4095 & 56.3 & -226.9 & 0.0074 & -118.2 & 16.96600 & 64.6 & -182.8 & 0.0012 & 50.4 & 3.4129 & -137.9 & -171.8 & 0.0068 & -80.9 & 15.0571 & 118.3 & -199.2 & 0.0048 & 115.3 & 9.4736 & -58.0 & -186.8 & 0.0010 & -68.9 & 1.8350 & 103.2 & -172.1 \\
\hline 5 & 0.0074 & 159.0 & 8.5577 & 31.5 & -232.4 & 0.0074 & -32.6 & 16.9080 & 155.8 & -188.4 & 0.0010 & -67.6 & 3.1413 & 115.6 & -183.2 & 0.0022 & 24.9 & 11.9462 & 155.1 & -130.1 & 0.0037 & 150.9 & 9.5546 & -3.2 & -205.9 & 0.0024 & 127.6 & 1.6902 & -37.5 & -194.9 \\
\hline 6 & 0.0067 & 77.0 & 7.0258 & -59.4 & -223.6 & 0.0072 & -47.6 & 16.8028 & 133.8 & -181.3 & 0.0018 & -148.4 & 3.4131 & 31.6 & -180.0 & 0.0074 & 158.0 & 15.6091 & 14.1 & -216.1 & 0.0043 & -70.5 & 9.7738 & 123.0 & -193.5 & 0.0010 & -127.3 & 1.8476 & 20.3 & -147.6 \\
\hline (Mean) & 0.0071 & -- & 7.6407 & -- & -230.8 & 0.0073 & -- & 2225 & - & -183.6 & 012 & $\ldots$ & 3.1 & -- & -173.5 & 0.0056 & - & 5288 & -- & -160.3 & 0.0034 & -- & 2941 & - & -189.8 & 0012 & -- & 1.5962 & - & -170.0 \\
\hline (sd) & 0.0005 & -- & 0.6717 & - & 4.2 & 0.0001 & -- & 0.0519 & - & 2.3 & 0.0003 & -- & 0.3793 & -- & 9.1 & 0.0030 & - & 2.1516 & - & 55.6 & .0010 & -- & 0.3377 & -- & 11.6 & 0.0006 & -- & 0.3159 & $\ldots$ & 26.8 \\
\hline
\end{tabular}

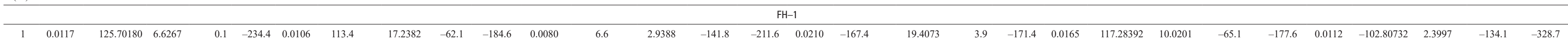

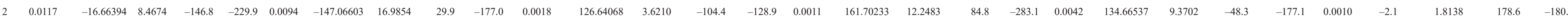

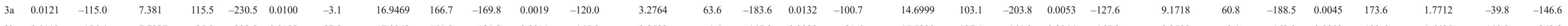

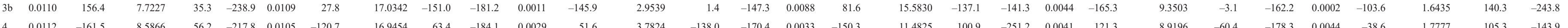

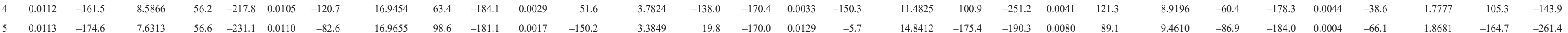

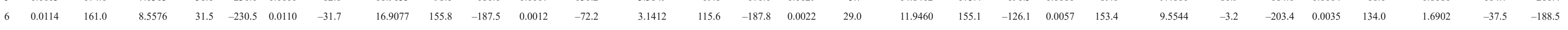

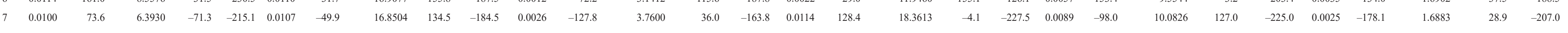

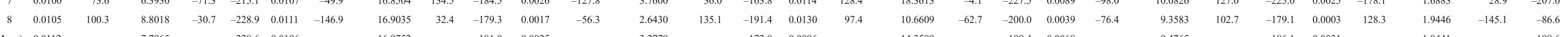

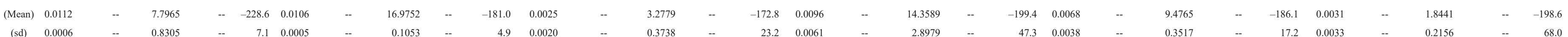




\section{Earth-Tide Analysis of Discrete Segments of Select Detrended, Parsed Water-Level Time Series}

For this analysis, parsed series FH-1_1-3a were omitted because of the $0.1-\mathrm{ft}$ estimated water-level measurement resolution for those series compared to the preliminary estimate of about $0.01-\mathrm{ft}$ water-level response to the $\mathrm{M}_{2}$ tide (table 14). The detrended parsed series selected for further tidal analysis (fig. 41, box f) were divided into multiple, 32-day discrete (nonoverlapping) segments, and as such, series FH-1_7 was omitted because of its less than 32-day length. This resulted in 31,30 , and 14 segments for tidal analysis of BR-1, LN-1, and FH-1 water levels, respectively. A segment length of 32 days was chosen primarily because it is sufficiently longer than one lunar month and preserves a maximum total number of discrete segments obtainable from the parsed water-level time series. A constant segment length simplified the computation of population statistics for the tidal responses. The water-level and strain amplitudes, phases and phase shifts ( $\eta_{k}$, eq. 19), and the ratio of the water-level amplitude to the theoretical areal-strain amplitude computed for each of the principal tidal constituents are listed in table 15 . The ratio of the water-level amplitude to the theoretical areal-strain amplitude $\left(A_{k}\right.$, in units of feet per nanostrain) was computed using equation 20 :

$$
A_{k}=\frac{A y_{k}}{A \varepsilon_{\text {Areal }}} .
$$

The responses (table 15) indicated similar results as those obtained in the preliminary tidal analysis (table 14) described previously with some differences. Focusing on the principal lunar tides $\left(\mathrm{M}_{2}\right.$ and $\left.\mathrm{O}_{1}\right)$, for all wells, both analyses indicated demonstrably larger uncertainties for the mean $\mathrm{O}_{1}$ water-level amplitudes and phase shifts compared with those for the $M_{2}$ tides. This may be attributed in part to contamination of the $\mathrm{O}$ tidal responses with atmospheric loading effects. For all wells, the mean water-level amplitudes and phase shifts for the principal lunar tides were only slightly different from those computed in the preliminary analysis. For wells BR-1 and $\mathrm{LN}-1$, the uncertainties (as indicated by the standard deviations) in the $\mathrm{M}_{2}$ and $\mathrm{O}_{1}$ water-level amplitudes and phase shifts were substantially greater than those computed in the preliminary analysis. For well $\mathrm{FH}-1$, the uncertainties in the $\mathrm{M}_{2}$ water-level amplitudes and phase shifts were similar for both analyses and, in contrast to wells BR-1 and LN-1, were higher for the preliminary analysis. The greater uncertainties in the $\mathrm{M}_{2}$ and $\mathrm{O}_{1}$ water-level amplitudes and phase shifts in wells BR-1 and LN-1 for the more robust, discrete-segment analysis (table 15) compared with those from the preliminary analysis (table 14) might simply be due in part to most of the data being broken into shorter segments than for the preliminary analysis. For the preliminary analysis, the mean lengths of the data series for wells BR-1, LN-1, and FH-1 were about 156, 170, and 96 days, respectively, compared to 32 days for the discrete tidal analysis (table 15). Results from longer series are expected to be less variable than results from shorter series, especially for lower frequency constituents (for example, $\mathrm{O}_{1}$ ). Another factor that may in part explain the lower uncertainties for the well $\mathrm{FH}-1$ responses to the principal lunar tides is the larger responses in well FH-1 and the fact that the magnitude of the responses to the principal lunar tide $\left(\mathrm{M}_{2}\right)$ in all wells is near (for well FH-1) or less than (for wells BR-1 and LN-1) the estimated 0.01-ft water-level measurement resolution. Note, however, that the amplitude of the "measured" and "predicted" water-level responses to the solid Earth tide were greater than $0.01 \mathrm{ft}$ for each of the wells (for example, for series $\mathrm{FH}-1$ _ 8, see the peak periodic responses in fig. 47A). The computed values of $A_{k}$ (eq. 20) indicated that the water-level responses for each tide were not due solely to the theoretical areal-strain tide. This was especially true for tidal frequencies other than the principal lunar tides $\left(\mathrm{M}_{2}\right.$ and $\mathrm{O}_{1}$ ) for which water-level responses likely contained barometric-pressure inputs. For $\mathrm{M}_{2}$ and $\mathrm{O}_{1}, A_{k}$ may represent the areal-strain sensitivity of water-level response to the theoretical areal strain at these tidal frequencies.

The computed mean ratios of the water-level amplitudes to the theoretical areal-strain amplitudes in units of feet per nanostrain for $\mathrm{M}_{2}\left(\bar{A}_{2}\right)$ and $\mathrm{O}_{1}\left(\bar{A}_{5}\right)$ and their standard deviations (table 15) were $2.42 \times 10^{-4} \pm 2.37 \times 10^{-5}$ and $3.53 \times 10^{-4} \pm 1.34 \times 10^{-4}$ for well BR-1, $14.33 \times 10^{-4} \pm 2.39 \times 10^{-5}$ and $4.13 \times 10^{-4} \pm 1.60 \times 10^{-4}$ for well $\mathrm{LN}-1$, and $6.39 \times 10^{-4} \pm 3.61 \times 10^{-5}$ and $6.50 \times 10^{-4} \pm 2.71 \times 10^{-4}$ for well $\mathrm{FH}-1$. Within one standard deviation, the values for $\bar{A}_{2}$ and $\bar{A}_{5}$ can be considered equivalent. Thus, there was no evidence for a heterogeneous response to the $\mathrm{M}_{2}$ and $\mathrm{O}_{1}$ tide that may result from differences in the physical setting because of topographic effects (Berger and Beaumont, 1976) and (or) the presence of local faults or fracture networks in the formations penetrated by the wells. For example, because of the orthogonality of the principal directions of $\mathrm{M}_{2}$ and $\mathrm{O}_{1}$ theoretical areal-strain tensors, a particular orientation of a compliant fault or fracture network that is in hydraulic connection with the aquifer penetrated by the well could generate an anisotropic water-level response to the two principal lunar tides (Hanson and Owen, 1982; Hanson, 1984). However, without more information and no evidence for a heterogenous response, the following analysis assumed a homogenous tidal response that could be characterized by the response computed here for the $\mathrm{M}_{2}$ tide with respect to $\bar{A}_{2}$. Under this assumption, the estimated homogenous tidal response $\left(\overline{A_{2}}\right)$ in each well was used to filter Earth tides from the hp detrended, parsed water-level time series in each well to improve the subsequent analysis of the frequency response of the tidally filtered time series to atmospheric loading.

\section{Digital Earth-Tide Filters for Wells BR-1, LN-1, and FH-1 Detrended, Parsed Water-Level Time Series}

The predicted water-level responses at the six principal Earth-tide frequencies (from eq. 16) contained mixed atmospheric-loading and Earth-tide responses at some of the frequencies, especially at the frequencies of the solar and lunisolar tides, $\mathrm{S}_{2}$ and $\mathrm{K}_{1}$, respectively. Because the water-level 


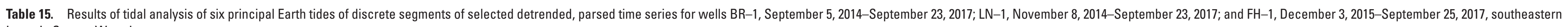
Laramie County, Wyoming.

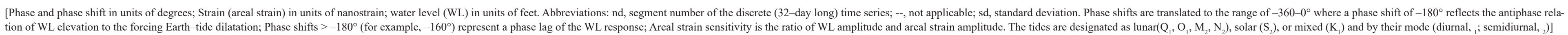
111111111111111111111111111111

\begin{tabular}{|c|c|c|c|c|c|c|c|c|c|c|c|c|c|c|c|c|c|c|c|c|c|c|c|c|c|c|c|c|c|c|c|c|c|c|}
\hline \multicolumn{35}{|c|}{ BR-1 } \\
\hline 1 & 0.0048 & 39.4 & 9.0229 & 24.0 & -163.40 .0005 & 0.0049 & 161.0 & 16.9359 & -60.4 & $\begin{array}{ll}-138.6 & 0.0003 \\
\end{array}$ & 0.0015 & 126.6 & 3.4010 & -91.4 & -142.0 & 0.0004 & 0.0102 & 154.4 & 9.8749 & -64.2 & -141.4 & 0.0010 & 0.0030 & -134.6 & 9.2045 & 2.8 & -137.5 & 0.0003 & 0.0023 & 70.3 & 1.8737 & -28.1 & -261.6 & 0.0012 \\
\hline 2 & 0.0050 & -158.9 & 8.4214 & 15.5 & -174.40 .0006 & 048 & -133.1 & 16.9878 & -0.4 & $\begin{array}{l}-132.6 \\
0.0003\end{array}$ & 0.0006 & -136.0 & 2.9166 & 27.0 & -163.0 & 0.0002 & 0.0074 & 113.1 & 13.5701 & -117.1 & -129.8 & 0.0 & 0.0041 & -71 & 9.2382 & 98.2 & -1 & 0.0004 & 0.0012 & -50.2 & 1.6531 & 9.3 & -179.5 & 0.0007 \\
\hline 3 & 0.0036 & -172.8 & 6.9843 & 16.6 & - 189.4 0.0005 & 049 & -69.5 & 16.9357 & 59.9 & $\begin{array}{ll}-129.5 & 0.0003\end{array}$ & 0.0002 & 94.5 & 2.5667 & 154.2 & -59.7 & 0.0001 & 0.0080 & 77.5 & 18.4804 & -140.7 & -141.7 & 0.0004 & 0.0014 & 17.6 & 9.5418 & -169.8 & -172.6 & 0.00011 & .0012 & 131.5 & 1.5361 & -74.6 & -153.9 & 0.0008 \\
\hline 4 & 033 & -159.8 & 6.5101 & 30.9 & - 190.70 .0005 & 0.0039 & -7.5 & 17.0790 & 120.2 & $\begin{array}{lll}-127.7 & 0.0002\end{array}$ & 111 & 142.1 & 2.8278 & -77.2 & -140.7 & 0.0004 & 0.0105 & 47.9 & 192 & -154.4 & -157.6 & os & 0.0033 & 133.8 & 9.9897 & -79.4 & -146.8 & 005 & 018 & 116.7 & 1.5794 & 81.7 & -323.0 & 0.0012 \\
\hline 5 & 0.0040 & 26.6 & 029 & -139.2 & - 194.2 0.0005 & 39 & -102.4 & 16.7961 & 30.2 & $\begin{array}{ll}-132.6 & 0.0002\end{array}$ & 0009 & 144.8 & 3.5608 & -95.9 & -119.3 & 0.0 & 0.0028 & -28.9 & 16.7044 & 99.3 & -128.1 & 0.0002 & 0.0007 & -142.8 & 7580 & -50 . & -92. & 0.0001 & 024 & -43.5 & 7793 & -171.8 & -231.7 & 0.0011 \\
\hline 6 & 0.0053 & 34.2. & 9.0405 & -142.8 & -183.00 .0006 & 0.0047 & -45.5 & 16.7731 & 90.4 & $\begin{array}{ll}-135.9 & 0.0003\end{array}$ & 0.0008 & -126.8 & 3.7944 & 13.1 & -140.0 & 0.0002 & 0.0034 & -3.4 & 11.2195 & 65.8 & -69.2 & 0.0003 & 0.0043 & -142.4 & 9.3321 & 39.5 & -181.9 & 0.0005 & 0.0012 & 34.7 & 2.2447 & -35.0 & -290.2 & 0.0005 \\
\hline 7 & 0.0051 & 29.3 & 106 & -152.7 & $\begin{array}{ll}-178.0 & 0.0006\end{array}$ & 339 & 14.8 & 17.0703 & 150.6 & $\begin{array}{ll}-135.8 & 0.0002\end{array}$ & 0.0009 & -5.8 & 3.6444 & 124.9 & -130.7 & 0.0003 & 0.0039 & 70.5 & 10.6410 & $3.7-7>3$ & -293.2 & 0.0004 & 0.0023 & -63.2 & 8.8540 & 133.6 & -196.8 & 0.0003 & 0019 & -25.9 & 1.8471 & 109.6 & -135.5 & 0.00 \\
\hline 8 & 0.0039 & -60.2 & 6.6577 & 110.5 & $\begin{array}{lll}-170.7 & 0.0006\end{array}$ & 0.0034 & 33.3 & 16.9242 & 165.7 & $\begin{array}{ll}-132.5 & 0.0002\end{array}$ & 0.0002 & -112.8 & 2.8621 & 53.1 & -165.9 & 0.0001 & 0.0048 & -93.2 & 17.5959 & 89.7 & -182.9 & 0.0003 & 0.0028 & -103.0 & 9.5152 & 63.5 & -166.6 & 0.0003 & 0.0010 & -170.0 & 1.6382 & -46.5 & -123.5 & 0.0006 \\
\hline 9 & 0.0042 & -56.1 & 5.7845 & 119.9 & -176.00 .0007 & 0.0040 & 101.9 & 06 & -133.3 & $\begin{array}{ll}-124.8 & 0.0002\end{array}$ & 7 & 22.3 & 2.6629 & 175.5 & -162.2 & 0.0002 & 84 & -103.2 & 19.3676 _ & 74.2 & -177.4 & 0.0004 & 0.0023 & -33.0 & 9.7010 & 153.6 & -186.6 & 0. & & 37.3 & 26 & .2 & -73.0 & c \\
\hline 10 & 0.0035 & -47.8 & 6.7892 & 128.0 & -175.70 .0005 & 040 & 153.6 & 16.9549 & -72.7 & $\begin{array}{l}-133.7 \\
0.0002\end{array}$ & 005 & -139.3 & 3.1159 & -47.2 & -92.1 & 0.0002 & 0.0075 & -124.3 & 17.2679 & 58.1 & -182.4 & 0.0004 & 30 & 86.7 & 9.6266 & -115.8 & -157.5 & 0.0003 & 0023 & 104.0 & 1.7585 & -86.7 & -169.3 & 0.0013 \\
\hline 11 & 0.0047 & -56.1 & 749 & 123.7 & -179.80 .0006 & 0.0045 & -141.3 & 41 & -12.1 & $\begin{array}{ll}-129.2 & 0.0003\end{array}$ & 0.0009 & 17.4 & 3.6 & 67.7 & -185.1 & 0.0 & 0. & -139.8 & & 32 & -171.9 & 0.0 & & 176.0 & & -24 & -159.2 & & & -108 & 56 & 3 & -167.0 & 0.0 \\
\hline 12 & 0.0044 & -133.3 & 8.0248 & 45.0 & -178.40 .0005 & 0.0047 & 109.8 & 16.9293 & -114.9 & $\begin{array}{ll}-135.2 & 0.0003\end{array}$ & 34 & -21.1 & 3.5 & 168.1 & -189.3 & 0.0001 & 0.0072 & 109.1 & 15.5607 & -110.2 & -140.7 & ( & 0.0040 & -124.8 & 9.4665 & -26 & -98.6 & 0.0004 & 021 & 129.7 & 738 & -101.9 & -128.4 & 0.0010 \\
\hline 13 & 0.0 & .8 & 571 & 49.7 & 1.50 .0006 & 0043 & 175.8 & 59 & -54.9 & $\begin{array}{ll}-129.4 & 0.0003\end{array}$ & 0.0008 & 98.5 & 2.9 & -72.6 & -188.9 & 0.0003 & 0.0 & 88.4 & & -12 & -142.8 & te & & -6 & & 65 & -131.8 & 0.0 & & -123.3 & 1.6408 & 2.9 & -176.2 & 0.0010 \\
\hline 14 & 0.0040 & -124.8 & 839 & 65.4 & -190.20 .0006 & 038 & -130.1 & 16.9312 & 5.9 & $\begin{array}{ll}-136.0 & 0.0002\end{array}$ & 004 & -33.5 & 2.7008 & 56.6 & -90.1 & 0.0002 & 0.0038 & 72.9 & 19.4242 & -142.0 & -145.2 & 0.000 & 0.0030 & 15 & 9.3598 & 156.2 & -141.2 & 0.0003 & 0002 & -145.8 & 1.5484 & -151.5 & -354.3 & 0.0001 \\
\hline & & & 8 & & 20 & & -65.9 & 1 & 66 & $\begin{array}{lll}-132.1 & 0.0\end{array}$ & & 105.3 & 2.98 & -177.0 & -77.7 & 0.0002 & 0.0 & 103 & & -16 & -34.1 & 0.00 & & -15 & & -111 & -4 & 0.0 & & 6.6 & 1.6107 & 3.9 & -35 & $0 . c$ \\
\hline 16 & 0.0043 & -109.4 & 384 & 56.7 & $\begin{array}{lll}-166.1 & 0.0005\end{array}$ & 0.0040 & -71.5 & 17.1240 & 63.8 & $\begin{array}{ll}-135.2 & 0.0002\end{array}$ & 008 & 108.3 & 3.7965 & -135.3 & -116.4 & 0.0002 & 0.0024 & -135.2 & 10.8856 & 101.2 & -236.4 & 0002 & 0.0022 & 131. & 9.27 & -55 . & -172.8 & 0.0002 & 031 & -15.1 & 2255 & 108.7 & -123.8 & 0.0016 \\
\hline 1 & 0.0040 & 4 & 104 & & 40. & & -12.5 & 2 & 124.3 & -136.80 .00 & 0.0012 & -146.7 & 3.7 & -25.7 & -121.0 & 0.0 & 0.8 & -1 & & 68.8 & -210.9 & 0.000 & 0.00 & -124 & 9.40 & 37.3 & -1 & 0 & & 178.7 & 2.1131 & -113.1 & -67.6 & 0 \\
\hline 18 & 0.0034 & 3.4 & 308 & 54.3 & -167.70 .0006 & 0.0041 & 52.7 & 16.9579 & -175.3 & $\begin{array}{ll}-131.9 & 0.0002\end{array}$ & 507 & -58.4 & 3.3521 & 87.7 & -146.1 & 0.0002 & 0.0074 & -139.8 & 19.1543 & 51.8 & -191.6 & 0.0004 & 0.0047 & -21 & 9.7 & 127 & -148 & 0.000 & 0.0026 & -80.1 & 3880 & 30.0 & -110.1 & 0.0014 \\
\hline & 0.0042 & 6.4 & 439 & 66 & -172.50 .0007 & 0.0040 & 120.8 & 17.0169 & -115.0 & $\begin{array}{l}-124.2 \quad 0.0002 \\
\end{array}$ & 006 & 59.9 & 2.8386 & -147.8 & -152.2 & 0.0002 & 0.0074 & -149.6 & (10.00 & 36.5 & -186.1 & 0.00 & 0.003 & 争 & 9.80 & -142.5 & -126.1 & 0.00 & 0.0021 & 19.7 & 1.5480 & -1711.1 & -169.2 & 0.0013 \\
\hline 20 & 0.0040 & -117.2 & 057 & 66.7 & $\begin{array}{ll}-183.9 & 0.0005\end{array}$ & 0038 & 176.1 & 16.9571 & -53.7 & $\begin{array}{ll}-130.2 & 0.0002\end{array}$ & 0003 & -140.1 & 2.8771 & -15.8 & -124.4 & 0.0001 & 0.0065 & -170.6 & 14.4345 & 15.6 & -186.2 & .0005 & 1.0029 & 170.6 & 9.5198 & -51.8 & -137.6 & 0.0003 & 0005 & -59.7 & 1.6092 & -11.2 & -48.4 & 0.0003 \\
\hline & $0.004 / 1 / 2-3$ & 0.0 & 8.9365 & 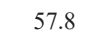 & -177.80 .0 & 0.0045 & -127.5 & 17.1570 & 6.5 & $\begin{array}{ll}-134.0 & 0.0\end{array}$ & 0.0008 & -63.3 & 3.29 & 106.3 & $-1 / 1.1 / 2 y$ & 0.0003 & 0.0 & 160.8 & 9.81 & -28 & $-1 / 1.1$ & 0.00 & 0.002 & -108 & 9.35: & 41.3 & -150.2 & 0.0 & 0.0012 & 1605.9 & 1.1916 & 140.6 & -334.8 & 0.0007 \\
\hline 22 & 0.0046 & -133.4 & 8.8488 & 48.4 & $\begin{array}{ll}-181.8 & 0.0005\end{array}$ & 043 & -61.2 & 17.1111 & 66.3 & $\begin{array}{ll}-127.6 & 0.0003\end{array}$ & 007 & 97.0 & 3.7376 & -138.7 & -124.3 & 0.0002 & 0.0072 & 126.6 & 11.8257 & -88.7 & -144.7 & 0.0006 & 0.0061 & -29.9 & 9.4314 & 133.8 & -163.7 & 0.0006 & 019 & 86.7 & 416 & -67.7 & -205.6 & 0.0009 \\
\hline & 0.0038 & 35.8 & 1.5186 & 44 & 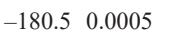 & 0.004 & -5.4 & 10.9143 & 126.8 & $\begin{array}{l}-132.2 \\
0.0002\end{array}$ & 0.0011 & -143.2 & 3.955 & -29.4 & -115.9 & 0.0003 & 0.0065 & 105.8 & $1 / .427$. & -117.2 & -136.9 & 0.0004 & 0.00 & 76.1 & 9.0260 & -133.2 & -150.7 & 0.0006 & 0013 & -131.7 & 2.2618 & 68.4 & -200.1 & 0.0006 \\
\hline 24 & 0.0036 & -127.8 & 22 & 55 & $\begin{array}{ll}-183.0 & 0.0006\end{array}$ & 0.0038 & 49.1 & 16.9584 & -173.5 & $\begin{array}{ll}-137.5 & 0.0002\end{array}$ & 08 & 10.0 & 3.7 & 80.2 & -70.1 & 0.0002 & 0.0071 & 96.4 & 246 & -131.9 & -131.7 & 0.0003 & 0.0054 & 178.0 & 10.0280 & -44.1 & -137.9 & 005 & 029 & -46.7 & 8840 & -150.7 & -256.1 & 0014 \\
\hline & 0.0040 & -151.7 & 8.4805 & 40 & -192.30 .0005 & 0.00 & 16.4 & $17.0285 \mathrm{~s}$ & 155.6 & $-139.2 \quad 0.0002$ & 0.00 & -43.9 & 2.777 & 108.7 & -152.6 & 0.0003 & $0.0 x$ & 89.3 & 14.053 & 178.3 & -88.9 & 0.0003 & 0.00 & 161 & 9.93 & -3. & -195.2 & 0.0004 & 0015 & -158.4 & 1.5383 & -48.9 & -109.5 & 0.0010 \\
\hline 26 & 0.0045 & 15.9 & 9.2085 & 32.7 & .0005 & 0.003 & 77.8 & 531 & -143.6 & $\begin{array}{ll}-138.6 & 0.0002\end{array}$ & 0.0007 & 84.2 & 3 & -121.0 & -154.8 & 02 & 0.0 & 58.8 & 9.8418 & 126.4 & -67.6 & & 0.0046 & -62 & 9.9079 & 88.0 & -150.5 & 0.0005 & 0.0030 & -73.2 & 548 & 112.0 & -185.3 & 17 \\
\hline & 0.0044 & -159.0 & 8 & 22 & $\begin{array}{l}-181.80 .0005 \\
0\end{array}$ & 0.00 & 140.4 & 17. $\mathrm{Y}>\mathrm{c}$ & -83.7 & $\begin{array}{l}-135.9 \\
\end{array} 0.0002$ & 0.0005 & -56.1 & 3.60 & -3.5 & -52.6 & 0.0001 & 0. & 171 & 13.177: & 72.9 & $-261.22>>$ & 0.0001 & 0.0013 & 63. & 9.8922 & 179.5 & -116.4 & 001 & 0013 & 75.8 & 0433 & -100.3 & -183.9 & 0.0006 \\
\hline 8 & 0.0037 & 126.6 & .3378 & -68.8 & 06 & 0.0043 & 2.8 & 16.7743 & 133.5 & $\begin{array}{ll}-130.7 & 0.0003\end{array}$ & 0.0011 & -72 & $.96 \mathrm{C}$ & 34.3 & -106.7 & .0003 & .0059 & 159.1 & $18.8728 \mathrm{r}$ & & -199.3 & & 0.0048 & -5 & 10.0693 & 122.9 & -177 & 0.0005 & 0.0009 & -107.4 & 2.2556 & 23.7 & -131.2 & 04 \\
\hline & 0.0 & 134.3 & 5.7843 & -57 & 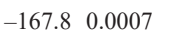 & 0.06 & 65.8 & 16.7825 & -166.3 & $\begin{array}{lll}-127.9 & 0.0002\end{array}$ & & 19.3 & 3.7 & 14 & -127.2 & 0.0004 & 0.0 & 149.8 & 19.4178 & -17.3 & .9 & 0.0 & & $69.7 \mathrm{C}$ & 10.1415 & -146 & -144.0 & 003 & 009 & 32.8 & 81 & 70.4 & 137.6 & 004 \\
\hline 30 & 0.004 & 13 & 45 & -51.4 & 06 & 0.0040 & 124.0 & 09 & -104.8 & -131.2 & 12 & 128 & 3.2411 & -93 & -137.8 & .0004 & 068 & 1414 & $16.2806 \mathrm{~s}$ & -35.8 & -182.8 & 0004 & 0.0036 & 142 & 9.8849 & -55.1 & -162.6 & 0.0004 & 16 & 142.5 & 581 & -45.4 & -97.1 & 09 \\
\hline & 0.0038 & 120.1 & 列 & -58.5 & 0.0004 & & -174.5 & 6.9940 & -44.8 & 0.0002 & & -161. & 2.8 & 30. & 2.0 & 0.0002 & 0.0 & 123 & 11.2290 & -76 & -165.7 & & & -91 & 9.7928 & 38. & 0.3 & & 0006 & -152.7 & 5878 & 113.7 & 66.3 & 04 \\
\hline & 0042 & - & 094 & $x^{2}+2$ & 0.00055 & 411 & - & 9672 & - & 024 & 008 & - & 3.2846 & - & -132.7 & & 0062 & - & 170 & & 63.0 & & & - & & $\ldots$ & -148.7 & 00035 & 017 & - & & - & -185.6 & \\
\hline & 002 & $\ldots$ & . & -- & 0.00006 & 640 & -- & . 1012 & -- & & 003 & -- & 0.4269 & -- & 37.1 & & 0.0022 & & 1888 & & 49.0 & & 0132 & & 3013 & -- & 31.4 & & 0008 & -- & 464 & -- & & \\
\hline
\end{tabular}




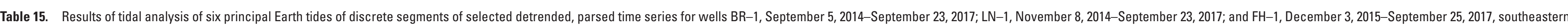
Laramie County, Wyoming.-Continued

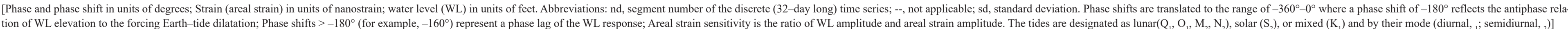

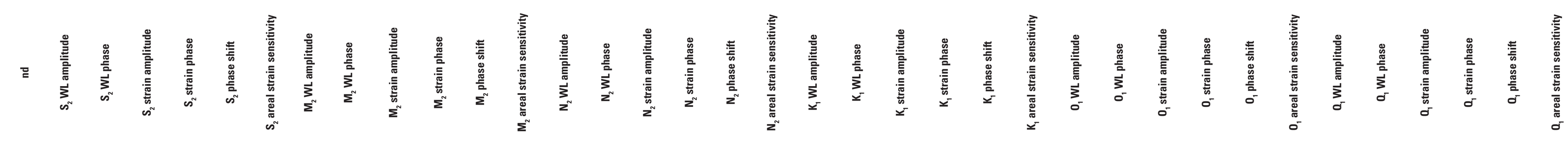

\begin{tabular}{|c|c|c|c|c|c|c|c|c|c|c|c|c|c|c|c|c|c|c|c|c|c|c|c|c|c|c|c|c|c|c|c|c|c|c|c|c|}
\hline \multicolumn{37}{|c|}{$L N-1$} \\
\hline & & & & & & & & & & & & & & & & & & 0.00 & & & & & & & & & & & & & & & & & & \\
\hline 2 & 772 & 152.6 & 017 & 1.5 & 9.0 & 0.0009 & 070 & 28.1 & & 51.7 & .8 & 0.0004 & 020 & -123.4 & 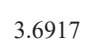 & 32.4 & -155.8 & 0005 & 0.0060 & -155.7 & 530. & 3.0 & 158.7 & 0.0004 & & 54. & 1477 & 69. & -15.4 & 0002 & D023 & 144. & 1.9647 & 49.4 & 265. & \\
\hline 3 & & 2.3 & & & & & & & & & & & & & & & & & & & & & & & & -3 & & & & & & & & & & \\
\hline 4 & 84 & 3.7 & 66 & .4 & & & & -16.4 & & & & 0.0005 & & & & -108.7 & -193.6 & 04 & & 67.5 & & -99.9 & 2275 & & & 41 & & -105 & -200.1 & & & 178.5 & & -24.5 & -154. & 011 \\
\hline 5 & & & & & & & & & & & & & & & & & & & & & & & & & & & & & & & & & & & 1.5 & \\
\hline 6 & & & & & & & & & & & & & & & & & & & & & & & & & & & & & & & & & & & -111 & \\
\hline 7 & & & & & & & & & & & & & & 161.5 & & 2 & -151.2 & & & & & & & & & & 265 & 5.8 & -180.9 & 0.0004 & & 68.4 & & 86.7 & 0.0 & \\
\hline 8 & & & & & & & & & & & & & & 6 & & & & & & & & & & & & & & & & & & & & & 92. & 1007 \\
\hline 9 & & & & & & & & -135.6 & & & & 0.00 & & 1 & & 188.0 & -187.1 & 04 & & 142.0 & 9.3573 & -24.1 & 9 & 0.0009 & & 122.6 & 488 & & -19 & 0003 & & -50.5 & 1.9865 & .1 & 32.8 & 006 \\
\hline 10 & & & & & & & & & & & & 0.8 & & & & & & & & & 85 & & & & & & & & & & & & & & & 026 \\
\hline 11 & & & & & & & & -14 & & & & 0.0 & & .7 & & & -2 & 004 & & 75 & 8597 & & & & & 135 & 114 & -16 & 4 & 0.0002 & & .0 & 1.773 & 127.4 & 37.4 & 10 \\
\hline 12 & & & & & & & & & & & & & & & & & & & & & & & & & & & & & & & & & & & & 005 \\
\hline 13 & & & & & & & & 101. & & & & 0 & & 168.3 & & & -1 & 04 & & 75 & & & 60.0 & & & & & & 9.9 & 0.001 & & (4.5) & & 86.4 & -12.2 & 18 \\
\hline 14 & & & & & & & & & & & & & & & & & & & & & & & & & & & & & & & & & & & & \\
\hline 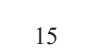 & & & & & & & & - & & 63.8 & & 0.0004 & & 75.7 & & 55.3 & -1 & & & 151.6 & 8854 & & & & & & & & & 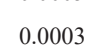 & & 50.6 & & 108.7 & -159.3 & .0018 \\
\hline 16 & & & & & & & & & & & & & & & & & & & & & & & & & & & & & & & & & & & & \\
\hline 17 & & 8 & $\approx$ & 54 & & & & -0.8 & & 5.3 & 4 & 0. & & 5.7 & 520 & & -193.4 & 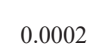 & & $\pi$ & 15 & & & & & -60 & 7942 & 27 & -188.0 & 000 & & 101.5 & & 30.0 & -131.5 & 119 \\
\hline 18 & & & & & & & & & & & & & & & & & & & & & & & & & & & & & & & & & & & & \\
\hline 19 & & .3 & & & & & & 126.5 & & -53.7 & 7 & 0 . & & 50 & & 3 & 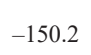 & 04 & & 9 & 434 & & & & & 131. & 5197 & -51 & & 0002 & & 104.2 & & -11.2 & -93.0 & 005 \\
\hline 20 & & & & & & & & & & & & & & & & & & & & & & & & & & & & & & & & & & & & 008 \\
\hline 21 & & & & & & & & 8.1 & & & & 0. & & 3 & & -138.7 & 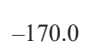 & & & & & & & & & & & & & & & & & -67.7 & -235.7 & 0013 \\
\hline 22 & & & & & & & & & & & & & & & & & & & & & & & & & & & & & & & & & & & & 005 \\
\hline 23 & & & & & & & & 1.1 & & & & & & 2 & & & 9.4 & & & & & & & & & & & & & & & & & 150.7 & 289.9 & 015 \\
\hline 24 & & & & & & & & & & & & & & -10 & & & & & & & & & & & & & & & & & & & & & & 013 \\
\hline 25 & & 2.7 & & & & & & & & & & & & & & -12 & 7 & & & & & & & & & & & & & & & -107.9 & & & 9 & \\
\hline 26 & & 152 & & & & & & & & & & & & & & & & & & & & & & & & & & & & & & & & & & \\
\hline 27 & & 73. & & & & & & & & & -186.4 & 0.8 & & -132.3 & & & 5 & & & & & & & & & -8 & 10.6 & & 10.4 & & 015 & -157.8 & 2556 & 23.7 & .6 & 0007 \\
\hline 28 & & & & & & & & & & & & & & & & & & & & & & & & & & & & & & & & & & & & \\
\hline 29 & & 83.7 & & & & & & & & 4.8 & -185.4 & & & & & -9 & & & & & & & & & & & & & & & & 157.7 & & & 12.3 & 208 \\
\hline 30 & & 70.0 & & -8. & & & & & & -4 & & & & -16 & & & & & & & & & & & & -12 & & & & & & -166 & & 13. & 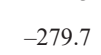 & \\
\hline & & -. & & - & -230.5 & & & -- & & -. & 18. & & & & & & & & & & & & & & & & & & & & & & & & -178.4 & \\
\hline & & $\ldots$ & & & & & & & & & & & & & & & & & & & & & & & & & & & & & & & 364 & & & \\
\hline
\end{tabular}


144 Geologic and Hydrogeologic Characteristics, White River Formation, Lance Formation, and Fox Hills Sandstone, Wyo.

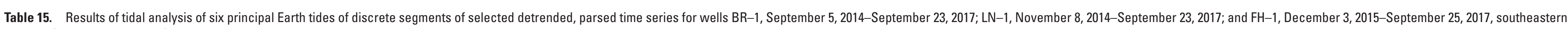
Laramie County, Wyoming.-Continued

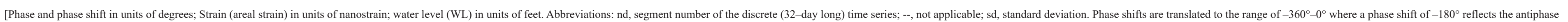

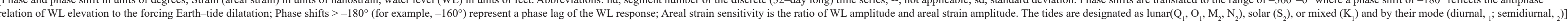

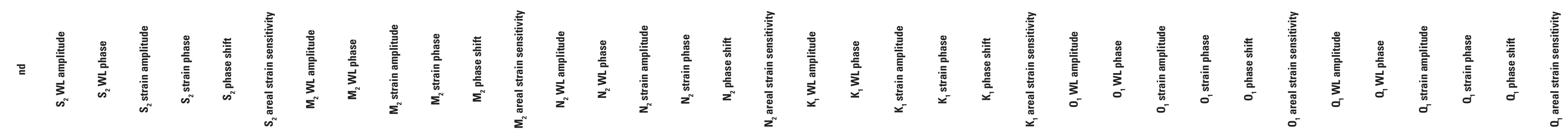

\begin{tabular}{|c|c|c|c|c|c|c|c|c|c|c|c|c|c|c|c|c|c|c|c|c|c|c|c|c|c|c|c|c|c|c|c|c|c|c|c|c|}
\hline & & & & & & & & & & & & & & & & 9.9 & & & 0.0 & & & & & & 061 & 69. & & & 64. & 00 & 003 & 5. & 407. & 38.6 & 03.5 & 0.0022 \\
\hline 2 & 092 & 151.8 & 725 & 4 & & 0.0013 & & & 16.9046 & -91.5 & -181.5 & & & -27.6 & & 120.3 & 7.9 & 0.6 & & 7.3 & 604 & -162.8 & -169.9 & 0.0006 & 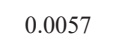 & -103.7 & & 84.1 & -187.8 & 006 & & 3.0 & & -59.0 & -304. & 017 \\
\hline 3 & 138 & 3.2 & 866 & 9.3 & 5.1 & 16 & & 148.0 & 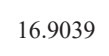 & -31.0 & -181.0 & 006 & 023 & 124.2 & & 17.4 & 18.4 & 0. & & 57.6 & .8958 & 171 & -114.2 & & .0019 & 105.7 & 9.1011 & 17 & -69.6 & & & 23.7 & 1.86 & 0.3 & -6 & 1023 \\
\hline 4 & & 61.0 & & 56.7 & & 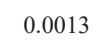 & & & & 8 & -1 & & & 2 & & 5.3 & .5 & 0 & & -161.6 & 52 & 16 & -262.8 & 0.0004 & 0.004 & 5.0 & 9.2154 & -55.7 & 9.2 & 0.0005 & 0.0055 & -50.0 & 2.0254 & 8.7 & -158.7 & 0027 \\
\hline & & & & & & & & & & & & & & & & & & & & & & & & & & & & & & & & & & & & \\
\hline 6 & 0.0123 & -168.6 & 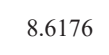 & 60. & 29.0 & 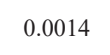 & & 2 & 1 & 8.7 & -18 & 0.0007 & 0.0011 & -48.5 & 3.1715 & 8.3 & 8 & 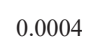 & 0.0145 & -41.1 & 10.9782 & 16 & 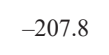 & 0.0013 & 0.0054 & 1.3 & 9.5542 & 6.9 & -168.2 & 0.0006 & 0.0005 & -154.6 & 1.7453 & -2.1 & -152.6 & 0.0003 \\
\hline & & & & & & & & & & & & & & & & & & & & & & & & & & & & & & & & & & & & \\
\hline 8 & 0.0121 & 175.0 & 7 & 44.2 & 29.2 & 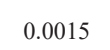 & & 97.5 & 1 & .2 & 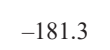 & 0.0006 & 0.0026 & -141.3 & 3.9714 & 14.1 & 4.4 & 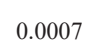 & 0.0131 & -96.0 & 16.0724 & 68.2 & -164.2 & 0.0008 & 0.0097 & 7.9 & 9.8563 & -172.0 & -180.1 & .0010 & 0.000 & 66.1 & 2.1859 & -77.1 & -216.8 & 0004 \\
\hline 9 & & & & & & & & 4 & & -21.4 & & & & -12.0 & & 8.1 & 17 & & & -120 & & & 4 & & & 100.0 & 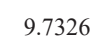 & -8 & $-1 / 7.3$ & & & 134.7 & 2.0164 & & -293.0 & 027 \\
\hline 10 & 0.0091 & -17 & 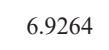 & 67. & & 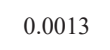 & & 2.0 & 16 & 39.2 & -18 & & & 4 & & 21.2 & 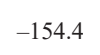 & . & & -1 & & 38.1 & 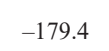 & & 8006 & 74.8 & & 104 & -195.6 & & 1007 & 97.0 & 1.8224 & -150.3 & -112. & 0011 \\
\hline & 0.0 & 160.4 & & 40 & & 12 & & -37.3 & & 155.6 & -193.0 & & 0.0024 & -100.1 & & 108.7 & 8.9 & 0.0009 & & 41 & 1528 & 178.3 & -131.0 & & 0.04 & 120.5 & & - & 28.3 & 100 & .0 & $1 / 2.0$ & 1.5882 & -48.9 & -156 & 1021 \\
\hline & & & & & & & & & & -143.6 & - & & & & & -121.0 & & & & 12. & & & 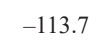 & & & & & & & & & & & & 5 & \\
\hline & 126 & 153.8 & 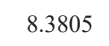 & 22 & 9.1 & 015 & & 91.1 & 1 & -83.7 & -185.2 & 006 & 10 & -140.7 & 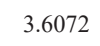 & -3 & 37.3 & 003 & 0.0030 & 159.1 & 768 & 72.9 & -273.8 & 002 & 0032 & 24.2 & 9.8916 & 1799.5 & 55.3 & 003 & .0027 & 56.4 & 432 & 00.3 & -203.3 & 0.0013 \\
\hline & & & & -29.2 & & & & -146.2 & & 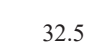 & -178.7 & & & -61.2 & & & & & & & & -59.1 & & & & -7 & & & 76.9 & & & -109 & & -155 & & \\
\hline & 0.01 & $\ldots$ & 8.0 & $\ldots$ & -232.5 & 0.0014 & & $\ldots$ & 17.0003 & $\ldots$ & -182.49 & 00064 & & $\cdots$ & & - & -172.7 & 005 & & . & 1554 & & -184.11 & 008 & 0.00631 & & & & -176.3 & 006 & & & 1.8004 & & -192.9 & 0016 \\
\hline & & & & & & & & & & & & & & & & & & & & & & & & & & & & & & & & & & & & \\
\hline
\end{tabular}


response at the frequency of the $\mathrm{M}_{2}$ tide likely represented a purely Earth-tide response, the water-level response to the $\mathrm{M}_{2}$ tide was used to scale water-level responses to the other five principal Earth tides to estimate water-level responses to Earth tides for the hp detrended, parsed water-level series (table 14). The $\mathrm{M}_{2}$-scaled responses were computed from the unscaled water-level responses to the tides based on the water-level amplitude and the theoretical areal-strain amplitude for the $\mathrm{M}_{2}$ tide $\left(\overline{A_{2}}\right)$, the computed areal-strain amplitudes for each of the Earth tides $\left(A \varepsilon_{\text {Arral }_{k}}\right)$, and the mean phase shift of the waterlevel response for the $\mathrm{M}_{2}$ tide $\left(\bar{\eta}_{2}\right)$. The equation used to compute the $\mathrm{M}_{2}$-scaled water-level responses was developed as follows:

1. The predicted, unscaled water-level response for the hp detrended water levels at the frequencies of the six principal Earth tides from equation 16 is

$$
\hat{y}_{\text {hpet }}\left(t_{j}\right)=\sum_{k=1}^{6}\left(a_{k} \cos \left(2 \pi f_{k} t_{j}\right)+b_{k} \sin \left(2 \pi f_{k} t_{j}\right)\right) .
$$

Using $a_{k}=A_{y_{k}} \cos \left(\phi_{y_{k}}\right)$ and $b_{k}=A_{y_{k}} \sin \left(\phi_{y_{k}}\right)$, and the trigonometric identity for the expansion of the cosine sum of differences between two angles, equation 21 can be rewritten as

$$
\begin{aligned}
\hat{y}_{\text {hpet }}\left(t_{j}\right) & =\sum_{k=1}^{6} A_{y_{k}} \cos \left(\phi y_{k}\right) \cos \left(2 \pi f_{k} t_{j}\right) \\
& +A_{y_{k}} \sin \left(\phi y_{k}\right) \sin \left(2 \pi f_{k} t_{j}\right) \\
& =\sum_{k=1}^{6} A_{y_{k}} \cos \left(2 \pi f_{k} t_{j}-\phi y_{k}\right)
\end{aligned}
$$

2. Applying $\mathrm{M}_{2}$ scaling is done in two steps:

A. First, multiplying the argument of summation by the ratio of $\bar{A}_{2}$ to $A_{k}$ gives:

$$
\hat{y}_{\text {hpetM } 2}\left(t_{j}\right)=\sum_{k=1}^{6} \frac{\bar{A}_{2}}{A_{k}} A_{y_{k}} \cos \left(2 \pi f_{k} t_{j}-\phi_{y_{k}}\right),
$$

where

$$
\hat{y}_{\text {hpetM2 }} \text { is the predicted value of the } \mathrm{M}_{2} \text {-scaled water- }
$$
level response.

B. Next, expressing $\phi_{y_{k}}$ in terms of the mean $\mathrm{M}_{2}$ phase $\operatorname{shift}\left(\bar{\eta}_{2}\right)$, where $\phi y_{k}=\phi \varepsilon_{\text {Aral }_{k}}+\bar{\eta}_{2}$, gives

$$
\hat{y}_{\text {hpetM } 2}\left(t_{j}\right)=\sum_{k=1}^{6} \frac{\bar{A}_{2}}{A_{k}} A_{y_{k}} \cos \left(2 \pi f_{k} t_{j}-\phi_{\mathcal{E}_{\text {Areal }}}-\bar{\eta}_{2}\right)
$$

3. Finally, substituting 20 into 24 and moving $\bar{A}_{2}$ outside the summation gives:

$$
\hat{y}_{\text {hpetM } 2}\left(t_{j}\right)=\bar{A}_{2} \sum_{k=1}^{6} A_{\varepsilon_{\text {Areal }}} \cos \left(2 \pi f_{k} t_{j}-\phi_{\mathcal{E}_{\text {Areal }}}-\bar{\eta}_{2}\right) .
$$

The summation term is a function of the amplitude and phase of the theoretical tidal strain signal and the mean phase shift of the water-level response at the $\mathrm{M}_{2}$ tidal frequency. The $\mathrm{M}_{2}$-scaled water-level response is a constant factor multiplied by this term. The uses of $\bar{A}_{2}$ for this constant factor and of $\bar{\eta}_{2}$ to modify the phase of the response are reasonable because $\mathrm{M}_{2}$ is the principal lunar tide for which power at principally solar frequencies in the BP signal is least among the other principal Earth tide frequencies. Values for $A \varepsilon_{\text {Arral }_{k}}$ and $\phi_{\varepsilon_{\text {arral }}}$ for each parsed series analyzed are available in table 14 , and the values for $\bar{A}_{2}$ and $\bar{\eta}_{2}$ are available in table 15 . This resulted in $\hat{y}_{\text {hpet } M 2}$ with $\mathrm{M}_{2}$-scaled amplitude and phase responses to Earth tides computed for each of the analyzed hp detrended parsed waterlevel series. The predicted, discrete amplitudes for the six principal tides (table 13) for (1) the theoretical areal-strain tide and (2) the unscaled $\left(\hat{y}_{\text {hpet }}\right.$ indicated by WL:ET) and $\mathrm{M}_{2}$-scaled $\left(\hat{y}_{\text {hpetM } 2}\right.$, indicated by WL:ETM2) water-level responses, computed using the hp detrended areal-strain tide and water-level time series, respectively, for parsed series FH-1_8 (fig. 41, box f) are shown in figure 48. Filtered water-level responses at tidal frequencies for each hp detrended parsed water-level time series analyzed (table 14) were computed (fig. 41, box g) using the following:

$$
\begin{gathered}
\tilde{y}_{\text {hpet }}\left(t_{j}\right)=y_{h p}\left(t_{j}\right)-\hat{y}_{\text {hpet }}\left(t_{j}\right), \\
\tilde{y}_{\text {hpetM } 2}\left(t_{j}\right)=y_{h p}\left(t_{j}\right)-\hat{y}_{\text {hpetM } 2}\left(t_{j}\right) .
\end{gathered}
$$

Here, $y_{h p}$ is the hp detrended water level used in equation 16. The predicted, unscaled ( $\hat{y}_{\text {hpet }}$, or WL:ET) and the $\mathrm{M}_{2}$-scaled $\left(\hat{y}_{\text {hpetM2 } 2}\right.$, or WL:ETM2), hp water-level responses to the six principal Earth tides compared to the hp water levels $\left(y_{h p}\right.$, or $\mathrm{WL})$ and the resulting tidally filtered, unscaled $\left(\hat{y}_{\text {hpet }}\right.$, indicated by fWL:ET) and $\mathrm{M}_{2}$-scaled ( $\hat{y}_{\text {hpet } M 2}$, indicated by fWL:ETM2), hp water levels for the detrended series FH-1_8 are shown in figure 49. The filtered results from the $\mathrm{M}_{2}$-scaled water-level responses (eq. 27) retained slightly more atmospheric-loading effects than did those from the unscaled water-level responses at the frequencies of the six principal Earth tides (eq. 26).

Unscaled and $\mathrm{M}_{2}$-scaled, tidally filtered water-level responses for each of the detrended parsed water-level series in table 14 were computed as follows:

$$
\begin{gathered}
\tilde{y}_{e t}(t)=\tilde{y}_{\text {hpet }}(t)+y_{l p}(t), \\
\tilde{y}_{e t M 2}(t)=\tilde{y}_{\text {hpetM } 2}(t)+y_{l p}(t),
\end{gathered}
$$

where

$$
\begin{aligned}
& \tilde{y}_{e t}(t) \quad \text { is the unscaled tidally filtered water-level } \\
& \tilde{y}_{e t M 2}(t) \quad \text { is the } \mathrm{M}_{2} \text {-scaled tidally filtered water-level } \\
& \text { series, } \\
& y_{l p}(t) \quad \text { is the lp detrended water-level series, and } \\
& y_{h p}(t) \quad \text { is the hp detrended water-level series used in } \\
& \text { equation } 16 .
\end{aligned}
$$



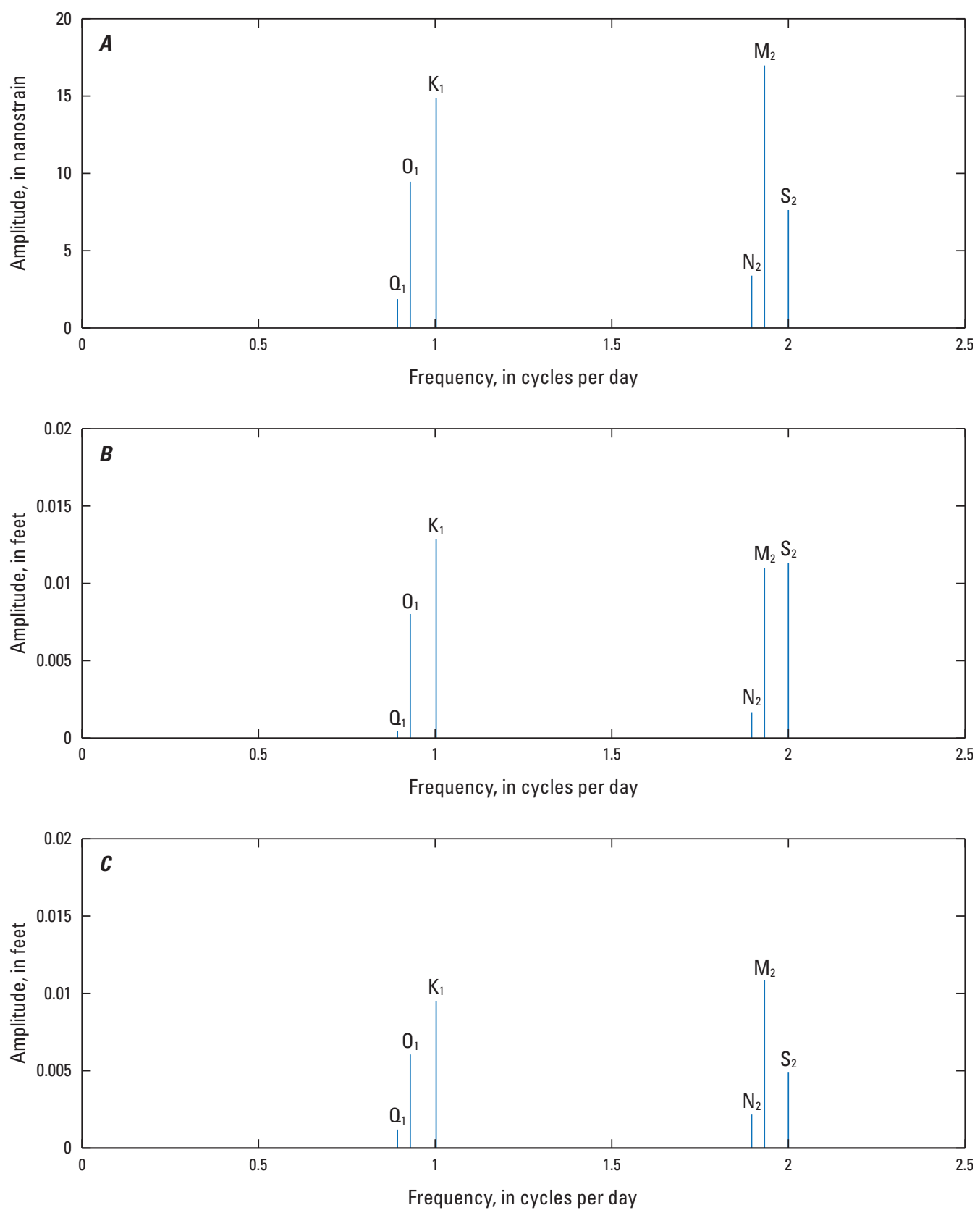

EXPLANATION

The tides are designated as lunar $\left(\mathbf{O}_{1}, \mathbf{O}_{1}, \mathrm{M}_{2}, \mathbf{N}_{2}\right)$, solar $\left(\mathrm{S}_{2}\right)$, or mixed $\left(\mathrm{K}_{1}\right)$ and by their mode (diurnal, ; semidiurnal, $\left.{ }_{2}\right)$

Figure 48. Predicted discrete amplitudes of the six principal Earth tides shown in table 13 computed for the high-pass (greater than 0.7 cycle per day), detrended theoretical areal-strain tide and unscaled (WL:ET) and $\mathrm{M}_{2}$-scaled (WL:ETM2) water levels for parsed series FH-1_8, August 24-September 30, 2017, from well FH-1, southeastern Laramie County, Wyoming. $A$, theoretical areal-strain tide amplitudes; $B$, WL:ET amplitudes; $C$, WL:ETM2 amplitudes. 
A. FH-1_8 Decimal day (dd 1 = Jan. 1, 2014)

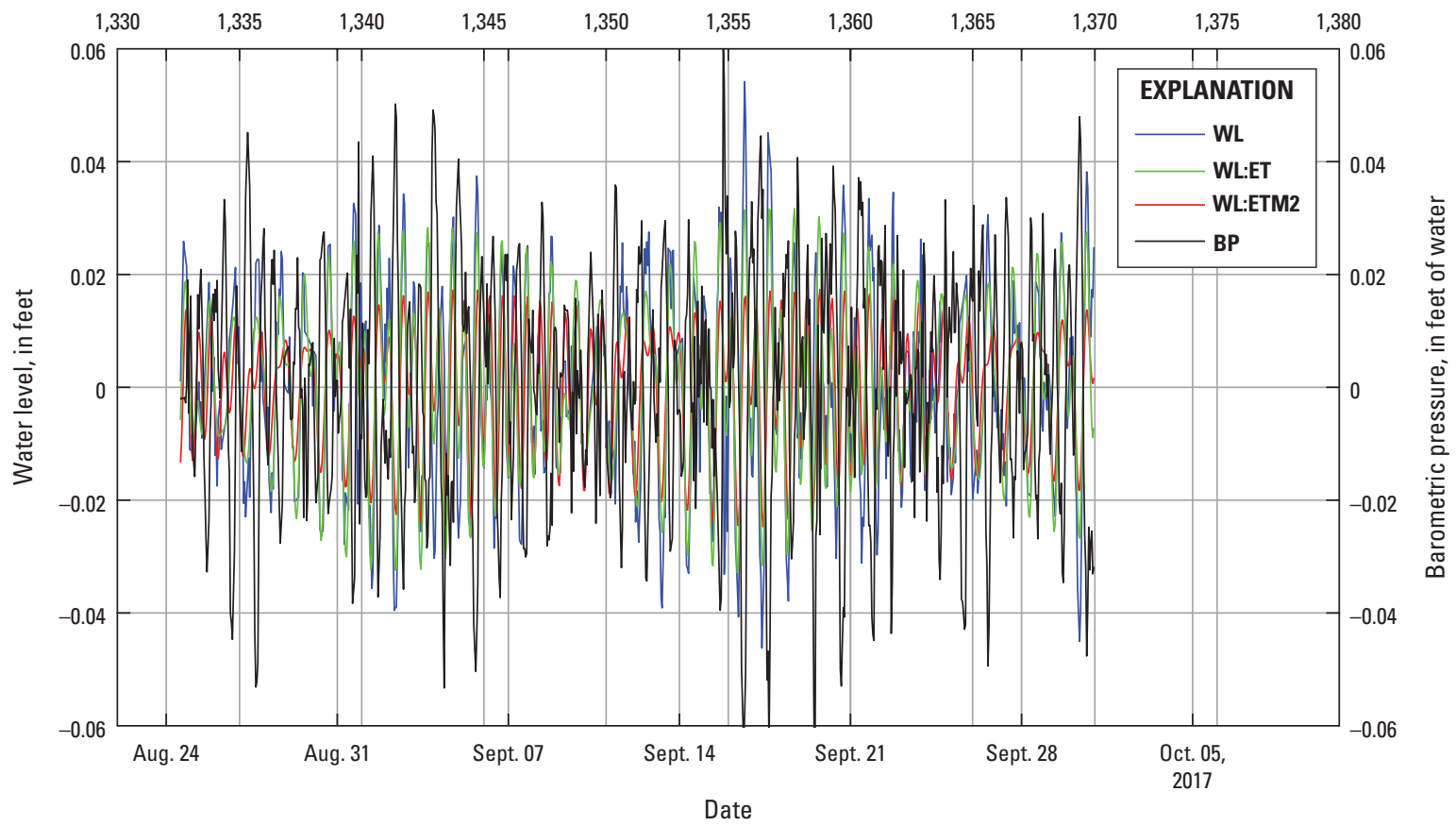

B. FH-1_8

Decimal day (dd 1 = Jan. 1, 2014)

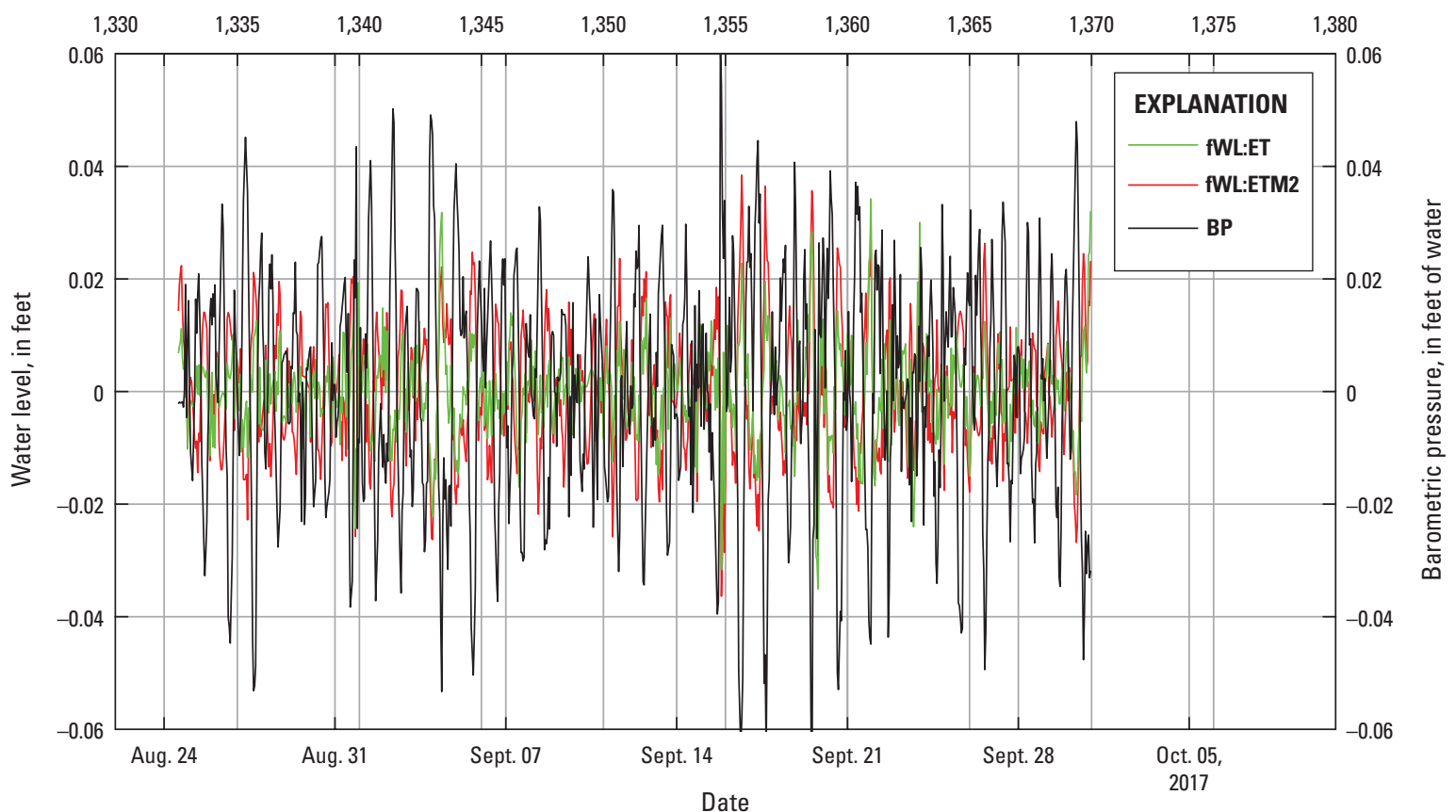

EXPLANATION

WL High-pass, detrended water level
BP High-pass, detrended barometric pressure

WL:ET Unscaled water-level response to principal Earth tides
WL:ETM2 $M_{2}$-scaled water-level response to principal Earth tides

fWL:ET Tidally filtered, unscaled high-pass water-level response to principal Earth tides

fWL:ETM2 Tidally filtered, $M_{2}$-scaled high-pass water-level response to principal Earth tides

Figure 49. Predicted unscaled (WL:ET) and $\mathrm{M}_{2}$-scaled (WL:ETM2) water-level responses to the six principal Earth tides shown in table 13 for the high-pass (greater than 0.7 cycle per day [cpd]), detrended water levels (WL); and the tidally filtered, unscaled (fWL:ET) and $\mathrm{M}_{2}$-scaled (fWL:ETM2), high-pass water levels for parsed series FH-1_8, August 24September 30, 2017, from well FH-1, southeastern Laramie County, Wyoming. $A$, WL, WL:ET, and WL:ETM2 shown with high-pass (greater than $0.7 \mathrm{cpd}$ ), detrended barometric pressure (BP); $B$, fWL:ET and fWL:ETM2 shown with high-pass (greater than $0.7 \mathrm{cpd}$ ), detrended BP. 
The unscaled and $\mathrm{M}_{2}$-scaled tidally filtered detrended water levels, equations 28 and 29, respectively, for parsed series $\mathrm{FH}-1 \_8$ are shown in figure 50 . The effects of filtering Earth tides from the water levels were small compared to the effects of atmospheric loading on the water levels.

\section{Frequency Responses of Water Levels to Atmospheric Loading}

Although the primary purpose here was to develop filters to remove the effects of atmospheric loading from the waterlevel time series, it is also useful to describe the physical effects of atmospheric loading on ideal wells and aquifers to understand the computed frequency responses that were used to filter the water levels. Physically, a frequency-dependent water-level response to atmospheric loading can be indicative of vertical fluid-flow effects induced by the loading, such as flow within the aquifers penetrated by and open to the wells, flow between a shallower unconfined aquifer overlying the monitored aquifer with some impedance to vertical flow between the two aquifers, and lateral flow between the well and the aquifer. The physical interpretation of the characteristics of a frequency-dependent response to atmospheric loading has been well described by others (for example, Weeks, 1979; Rojstaczer, 1988a; Rojstaczer and Agnew, 1989).

\section{Idealized Well/Aquifer Response to Atmospheric Loading}

Because aquifers are commonly imperfectly confined, and their transmissivity $(T)$ can range over many orders of magnitude, the water-level response of a well and aquifer to atmospheric loading may not always reflect the coupled hydraulic and mechanical response of the well and aquifer in the absence of fluid-flow effects, referred to as the undrained or static-confined response. Shown in figure 51 are four idealized responses of water levels in wells that are open to the atmosphere and screened below the water table to loads imposed by BP at the land surface. The BE for a well tapping a perfectly confined aquifer of infinite extent with large $T$ and no drainage effects (fig. 51A) represents the equilibrated balance between the air pressure imposed directly on the freesurface water level in the well and the mechanical response of the aquifer to the change in load (pressure) imposed on

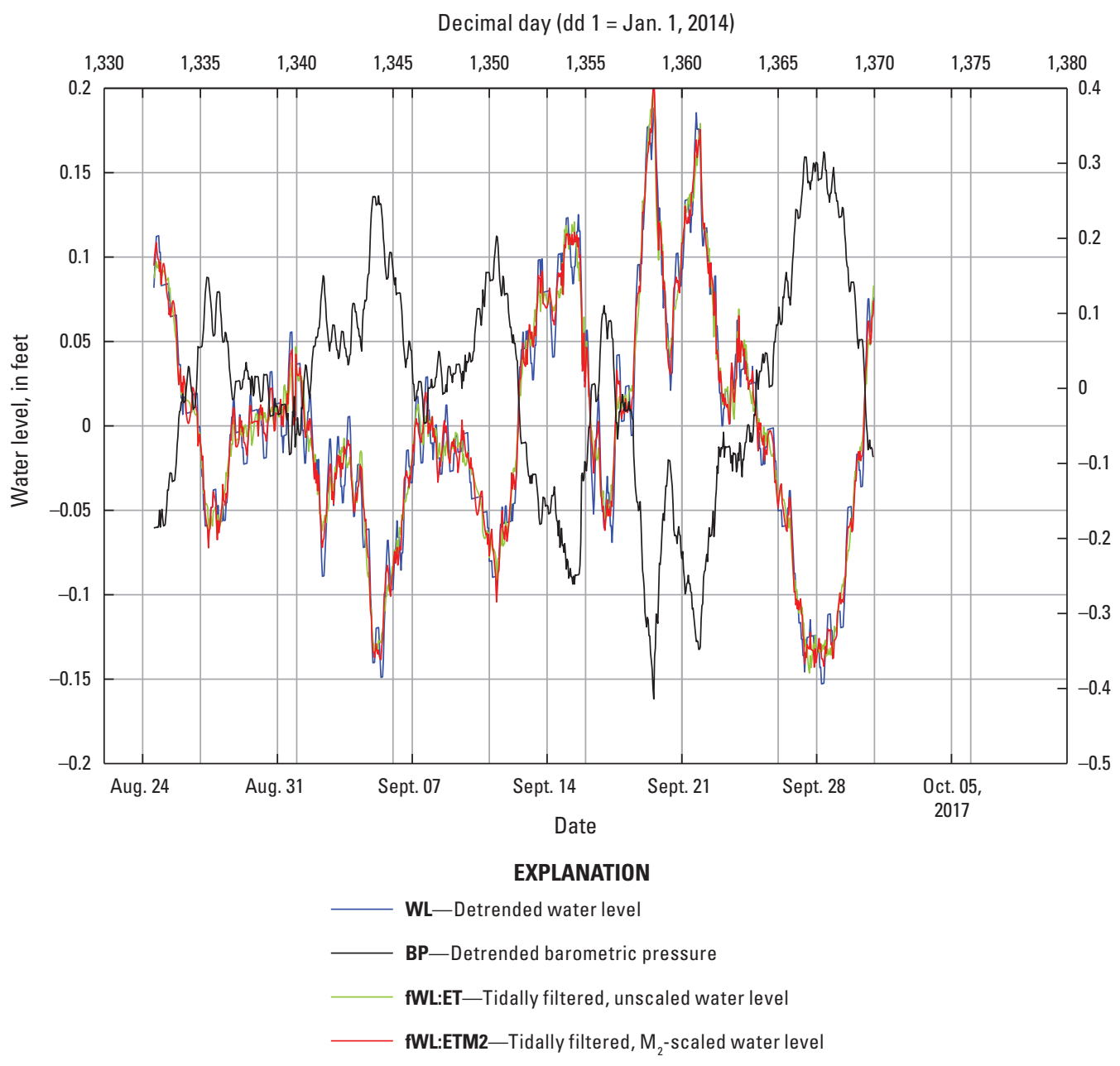

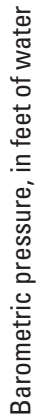

Figure 50. Tidally filtered unscaled and $\mathrm{M}_{2}$-scaled water levels for the detrended, parsed time series FH-1_8, August 24September 30, 2017, from well FH-1, southeastern Laramie County, Wyoming, shown with detrended water levels and barometric pressure. 

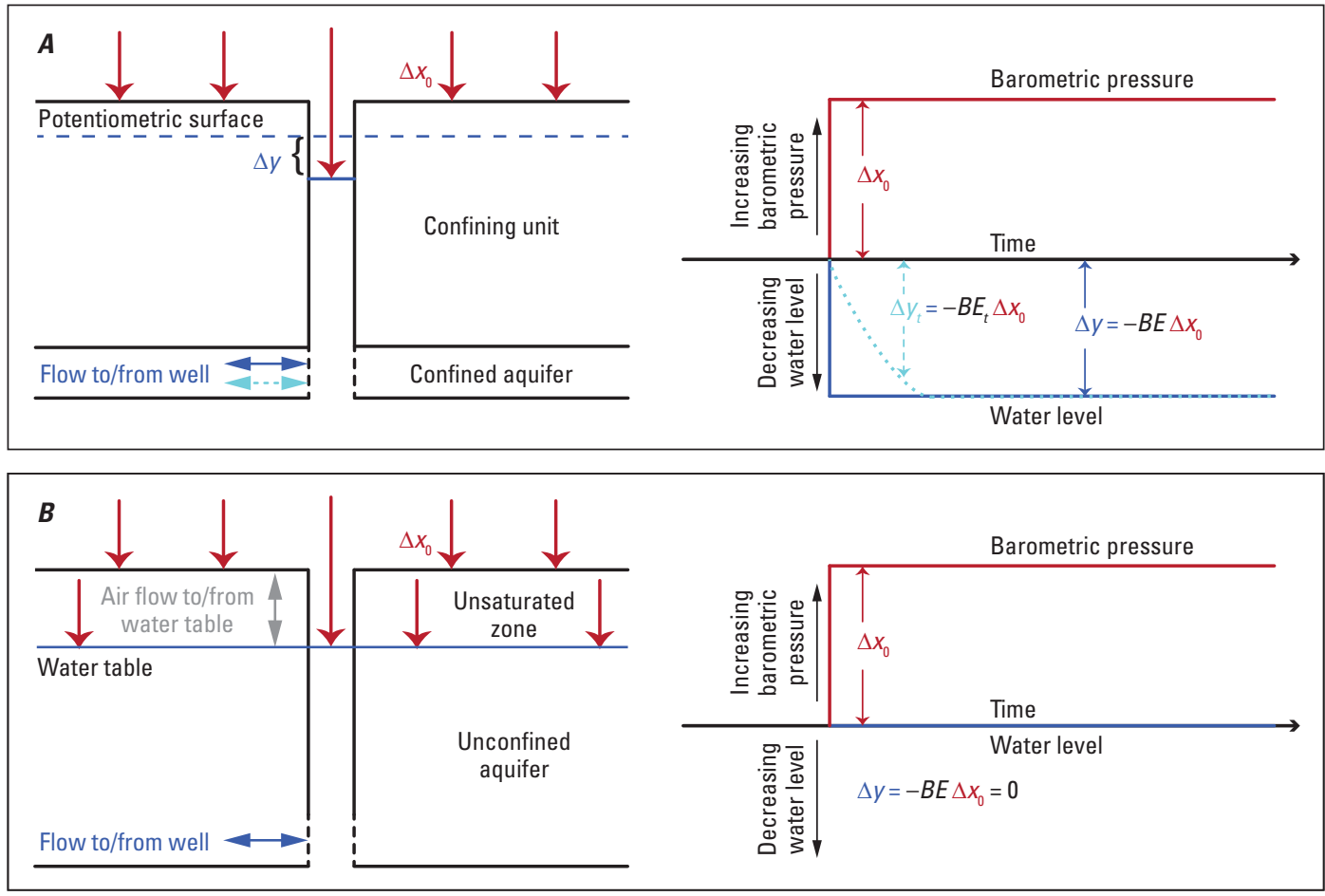

\author{
EXPLANATION \\ $\Delta h \quad$ Change in hydraulic head of \\ partially confined aquifer \\ $\Delta h_{p c u}$ Change in hydraulic head of \\ partial confining unit \\ $\Delta x_{0} \quad$ Instantaneous step change in \\ barometric pressure \\ $\Delta x_{t} \quad$ Change in barometric pressure \\ at time $t$

\section{$\Delta y \quad$ Resultant change in water} \\ level
}

$\Delta y_{t} \quad$ Change in water level at time $t$

$B E \quad$ Barometric efficiency
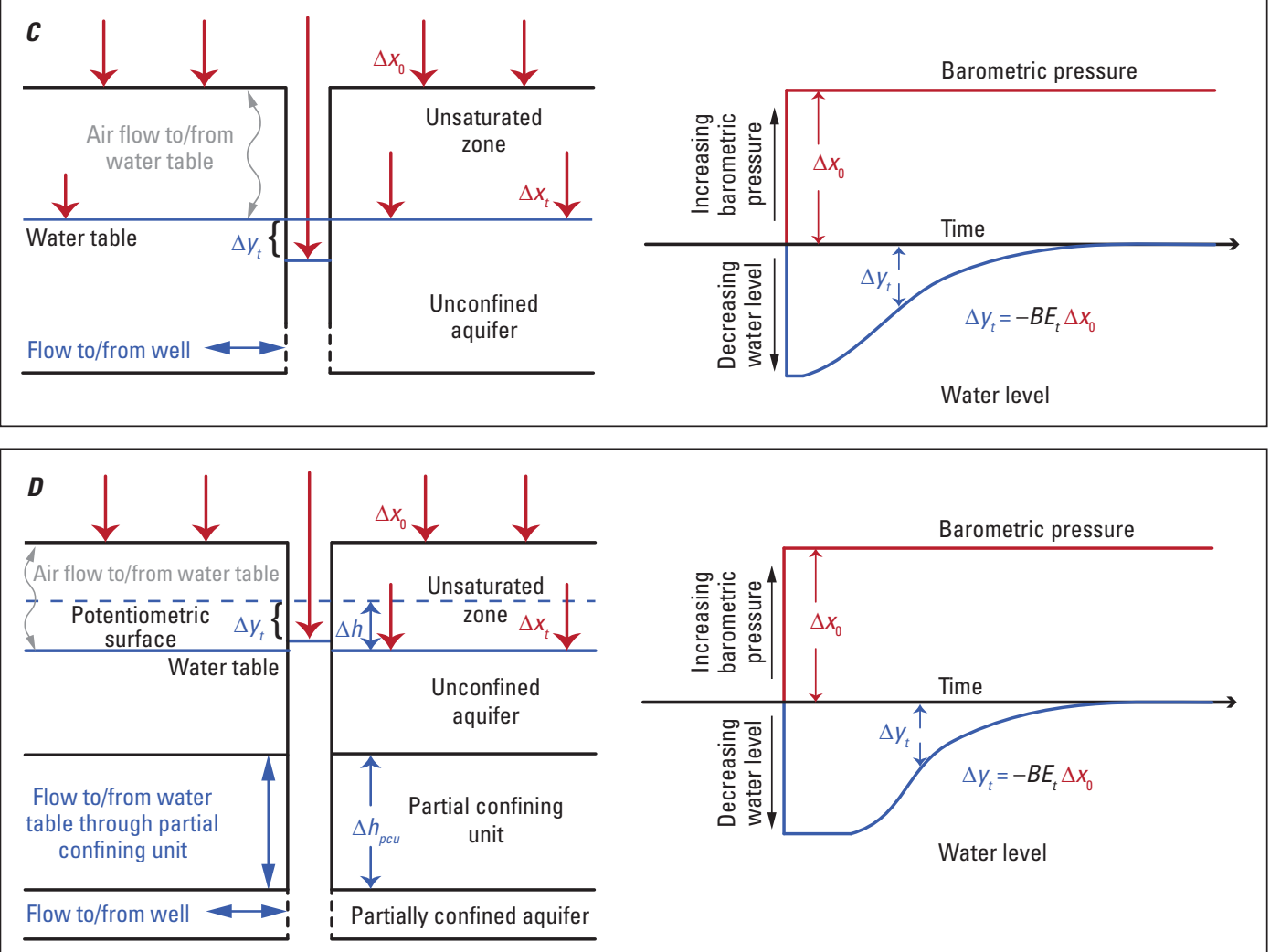

Figure 51. Cross sections of idealized aquifers showing idealized well responses to atmospheric loading with principal sources of attenuation caused by drainage (flow) effects and idealized water-level responses to a step increase in barometric pressure or load (right plots) (modified from Howle and others, 2019). $A$, confined aquifer, showing static-confined response (solid blue line) and the response caused by drainage attributed to wellbore-storage effects (dashed cyan line); $B$, unconfined aquifer (shallow or with large unsaturated-

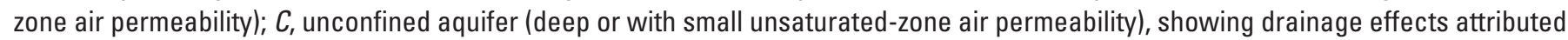
to a delayed equilibration between the aquifer fluid pressure (equivalent hydraulic head), caused by loading of the aquifer skeleton, and the water table because of delayed equilibration between an overlying unconfined aquifer and the barometric pressure change at land surface; $D$, partially confined aquifer overlain by unconfined aquifer (shallow or with small unsaturated-zone air permeability), showing drainage effects attributed to a delayed equilibration of aquifer hydraulic head because of a vertical hydraulic communication between the aquifer and an overlying unconfined aquifer. 
the land surface and translated to the saturated rock matrix (aquifer matrix or skeleton). For example, for a step increase in $\mathrm{BP}\left(\Delta x_{0}\right)$, initially, water level in the well would be forced downward an amount equal to the change in BP (in equivalent units of head) and water would flow from the well to the aquifer. This response, shown by the solid blue line in the rightmost plot of figure $51 \mathrm{~A}$, would be balanced by the increased load on the saturated aquifer matrix, which would compress, reduce porosity slightly, and increase heads in the aquifer and, in turn, cause water to flow from the aquifer to the well and water level in the well to increase, recovering a part of the initial water-level decrease. If the $T$ of the aquifer is sufficiently large, and the hydraulic connection between the well and aquifer does not impede flow, these effects would occur nearly simultaneously, and the resultant water level in the well $\left(\Delta y_{0}\right)$ would represent the balanced response of the well and aquifer to the step increase in BP. As such, this ideal response in the ideal well tapping the ideal confined aquifer occurs under conditions absent of fluid-flow (drainage) effects such as those related to the degree of confinement of the aquifer (discussed later in this section and in the "Frequency Dependent Barometric Efficiency" section) and represents the static-confined response of the well and aquifer to atmospheric loading. This response can be modified if aquifer $T$ is small enough (for the given wellbore storage) to sufficiently impede groundwater flow between the aquifer and the borehole. In this case, as time since the imposition of the step increase in BP increases, the transient water-level response (cyan dashed line in rightmost part of fig. 51A) asymptotically approaches the static-confined response (Rojstaczer, 1988a). These responses occurring at early times or high frequencies of BP fluctuations can create substantial attenuation and lag in the response of water level in the well to atmospheric loading. For each of the idealized responses that follow (fig. 51B-D), flow exchanged between the well and the aquifer is shown on the plots for completeness, but for purposes of the following discussions, it is assumed that the aquifer transmissivities are large enough (for the given wellbore storage) that these effects, termed "wellbore-storage effects," are assumed negligible.

Shown in figure $51 B$ is the response of an ideal unconfined aquifer to a step increase in $\operatorname{BP}\left(\Delta x_{0}\right)$ where the water table is shallow or the air permeability of the unsaturated zone is large. In this case, the air pressure at the water table equilibrates rapidly with the BP change at land surface. As such, because there is no pressure imbalance between the water level in the open well and the water table, there is no change in water level in the well $\left(\Delta y_{0}=0\right)$ and $\mathrm{BE}$ is zero. There is a negligible mechanical response to loading because any small decrease in storage because of compression of the aquifer matrix is accommodated by the relatively large storage capacity provided by the available porosity in these unconfined systems, resulting in negligible change in aquifer hydraulic head. By contrast, figure $51 C$ shows the response of an unconfined aquifer to a step increase in $\operatorname{BP}\left(\Delta x_{0}\right)$ where the water table is deep or the air permeability in the unsaturated zone is sufficiently small to delay equilibration of air pressure at the water table $\left(\Delta x_{t=0}<\Delta x_{0}\right)$ with BP at land surface. Here, there is an initial pressure imbalance between the water level and the water table. Initially, the change in water level in the well $\left(\Delta y_{t=0}\right)$ is equal to $-B E \Delta x_{0}$, approximating a confinedaquifer response. With time, however, as the air pressure at the water table equilibrates with the step increase in $\mathrm{BP}$ at land surface $\left(\Delta x_{t>0} \rightarrow \Delta x_{0}\right)$, the change in water level in the well approaches zero $\left(\Delta y_{t>0} \rightarrow 0\right)$. For this case, described in detail by Weeks (1979) and Rojstaczer and Riley (1990), the computed $\mathrm{BE}\left(B E_{t}=-\Delta y_{t} / \Delta x_{t}\right)$ is time dependent, a function of the transient diffusion of air pressure through the unsaturated zone.

Shown in figure $51 D$ is the response of a partially confined aquifer overlain by an unconfined aquifer to a step increase in BP. Here, the unconfined aquifer is shallow or the air permeability in the unsaturated zone is sufficiently large enough to facilitate rapid equilibration of air pressure at the water table with BP at land surface. There is a background head difference $(\Delta h)$ between the water table and the confined aquifer equal to the background head difference across the partial confining unit $\left(\Delta h_{p c u_{t<0}}\right)$, indicating upward flow from the confined aquifer through the partial confining unit to the unconfined aquifer. Similar to the response described previously for a deep unconfined aquifer, initially, the change in water level in the well $\left(\Delta y_{t=0}\right)$ is equal to $-B E \Delta x_{0}$, approximating an undrained confined-aquifer response. Because of the increased head in the confined aquifer caused by the mechanical loading of the aquifer, approximately equal to $(1-B E) \Delta x_{0}$, $\Delta h_{p c u_{t=0}}$ is increased by that amount. Increased groundwater flow from the confined aquifer through the partial confining unit to the unconfined aquifer is induced by the increased head gradient across the partial confining unit until this drainage dissipates the head increases in the partially confined aquifer as $\Delta h_{p c u_{t \gg 0}} \rightarrow \Delta h$. The resulting water-level change in the well reequilibrates with the background head in the confined aquifer $\left(\Delta y_{t>0} \rightarrow 0\right)$ that has reequilibrated with the unconfined aquifer having a BE of zero. For this case, described in more detail by Rojstaczer (1988a), the computed BE, $B E_{t}$ $=-\Delta y_{t} / \Delta_{x t}$, is time dependent, a function of transient fluidpressure diffusion through the partial confining unit.

The time-dependent responses associated with a deep unconfined aquifer and drainage of a partially confined aquifer through a partial confining unit may exist in combination and further complicate the characterization of the time dependence of $\mathrm{BE}$ for a well affected by both governing processes. As a result of these time-dependent water-level responses, the $\mathrm{BE}$ of a well is a function of the length of time or width of frequency band over which the BP (atmospheric load) change takes place. Analytical approaches to resolving the effects of these processes in terms of the frequency response of water levels in wells to atmospheric loading are presented by Rojstaczer (1988a, b). 


\section{Computed Frequency Responses}

The frequency response of water level to atmospheric loading is defined by the relation

$$
Y(\omega)=H(\omega) X(\omega)
$$

where

$\omega \quad$ is the angular frequency that is equal to the frequency $(f)$ by $f=\omega /(2 \pi)$,

$Y(\omega) \quad$ is the discrete Fourier transform of the detrended water-level responses to $\mathrm{BP}$,

$H(\omega) \quad$ is the frequency response function (Rojstaczer 1988a, b; Quilty and Roeloffs, 1991), which represents the $\mathrm{BE}$ in the frequency domain, and

$X(\omega) \quad$ is the discrete Fourier transform of the detrended BP time series.

The frequency response function was computed using equation 31:

$$
H(\omega)=\frac{G_{x y}(\omega)}{G_{x x}(\omega)},
$$

where

$$
\begin{gathered}
G_{x y}(\omega) \quad \begin{array}{l}
\text { is the cross-spectral density of the paired } \\
\text { detrended barometric-pressure and water- } \\
\text { level time series and }
\end{array} \\
G_{x x}(\omega) \quad \begin{array}{l}
\text { is the autospectral density of the barometric- } \\
\text { pressure time series (fig. } 41 \text {, box h). }
\end{array}
\end{gathered}
$$

The cross- and autospectral densities were computed using the Welch (1967) method. The gain (amplitude) and phase shift of the frequency response function were calculated using

$$
\begin{aligned}
& A(\omega)=|H(\omega)| \\
& \phi_{s}(\omega)=\operatorname{atan} 2(H(\omega))
\end{aligned}
$$

where

$A(\omega)$ is the amplitude or gain,

$|H(\omega)| \quad$ is the magnitude of the complex valued $(a+b i)$

frequency response function computed using $|a+b i|=\sqrt{a^{2}+b^{2}}$, and

$\phi_{s}(\omega) \quad$ is the phase shift of the water-level response relative to the forcing atmospheric load computed using $\operatorname{atan} 2(b, a)$.

The squared coherence at each frequency $\left(\gamma^{2}[\omega]\right)$ was computed using equation 33 (Bendat and Piersol, 1986):

$$
\gamma^{2}(\omega)=\frac{\left|G_{x y}(\omega)\right|^{2}}{G_{x x}(\omega) G_{y y}(\omega)} .
$$

The amplitude of the frequency response represents the gain or BE of the response at the evaluated angular frequencies $(\omega=2 \pi f)$. The phase shift represents the phase of the measured water-level response relative to the phase of the forcing atmospheric load. For water levels measured in terms of elevation, the ideal water-level responses to atmospheric loading are antiphase and computed relative to the forcing load with a phase of $0^{\circ}$. Phase shifts were computed in the interval -360 to $0^{\circ}$ to represent the sense of phase lags and advances in a manner consistent with the portrayal of phase shifts computed for the water-level responses to Earth tides; thus, angles greater than $-180^{\circ}$ (for example, $-140^{\circ}$ ) represented phase lags, and angles less than $-180^{\circ}$ represented phase advances. Note, this convention for representing phase shifts of the water-level response to atmospheric loading is opposite that presented by Rojstaczer (1988a), and Howle and others (2019, appendix 2).

Frequency response functions were computed for each of the detrended, parsed series for wells BR-1, LN-1, and $\mathrm{FH}-1$. The frequency responses to atmospheric loading were computed using the $\mathrm{M}_{2}$-scaled tidally filtered, detrended water

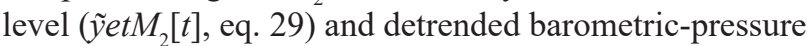
parsed time series $(x[t])$. For purposes of comparing the effects of tidal filtering on the computed frequency-response functions, the frequency responses were also computed for the detrended water-level series without tidal filtering $(y[t])$ (see accompanying discussion later in this section).

To compute $H(\omega)$, the lengths or spans in hours (the sample rate or interval) were specified for the number of discrete Fourier transform points ( $n f f t$ ), window, and overlap parameters in the computations of the power spectra. A Hamming window was used to reduce spectral leakage of the computed spectral estimates. Values for $n f f t$, window, and overlap were specified to preserve frequency resolution in the subtidal frequencies $(<0.7 \mathrm{cpd})$. The specified values were determined by trial and error to minimize the ratio of variances of filtered to detrended water levels (discussed later). For each $H(\omega)$ computed using the specified values of $n f f t$, window, and overlap, a second $H(\omega)$ was computed by resampling the original $H(\omega)$ at a specified resampling rate. The resampled $H(\omega)$ was designated $\mathrm{reH}(\omega)$. The resampling rate was specified as a multiple of the original rate. The resampling factor (ref) was computed to ensure the period associated with the minimum resampled frequency was less than the span in hours of the parsed time series $(N)$. Resampling was achieved using an antialiasing finite-impulse response lp filter (order $=20 \times[N-10]$; Kaiser window shape factor, $\beta=5)$. The original sampling and resampling frequencies ranged from $24 /(r e f \times n f f t)$ to $12 \mathrm{cpd}$, which is equal to the Nyquist frequency, where $n f f t$ is in hours and $r e f=1$ for the original sampling rate. The use of relatively large $n f f t$ values to enhance resolution in the low-frequency range limited computed values of ref, which ranged from 1.85 to 3.89. In most cases, resampling improved the frequency response function estimates and the filtered results, especially in the important subtidal frequency range where most of the cross-spectral power resides. The parameters used to compute the power spectra for each parsed series analyzed are listed in table 16. The auto- and cross-spectral density power spectra computed for the detrended parsed series BR-1_4, LN-1_6, and FH-1_6 are shown in figure 52. For each time series, much of the spectral power was concentrated at lower 
Table 16. Parameters used to compute atmospheric loading frequency-response functions for the parsed water-level and barometric-pressure time series from wells BR-1, September 5 , 2014-September 30, 2017; LN-1, November 8, 2014-September 30, 2017; and FH-1, December 19, 2014-September 30, 2017, southeastern Laramie County, Wyoming.

[hrs, hours; $N$, number of hourly samples in the parsed time series; $n f f t$, number of discrete Fourier transform points]

\begin{tabular}{|c|c|c|c|c|c|}
\hline $\begin{array}{l}\text { Well/ } \\
\text { parsed } \\
\text { series }\end{array}$ & $\begin{array}{c}\text { N samples } \\
\text { (hrs) }\end{array}$ & $\begin{array}{c}n f f t \\
\text { (hrs) }\end{array}$ & $\begin{array}{l}\text { Window } \\
\text { (hrs) }\end{array}$ & $\begin{array}{c}\text { Overlap } \\
\text { (hrs) }\end{array}$ & $\begin{array}{l}\text { Resampling } \\
\text { factor }\end{array}$ \\
\hline \multicolumn{6}{|c|}{ BR-1 } \\
\hline 1 & 3,090 & 1,440 & 960 & 96 & 2.139 \\
\hline 2 & 2,694 & 1,320 & 768 & 96 & 2.033 \\
\hline 3 & 3,399 & 1,680 & 960 & 96 & 2.017 \\
\hline 4 & 3,710 & 1,680 & 960 & 96 & 2.202 \\
\hline 5 & 7,547 & 2,160 & 1,200 & 120 & 3.489 \\
\hline 6 & 2,537 & 1,200 & 720 & 96 & 2.106 \\
\hline 7 & 3,249 & 1,440 & 840 & 96 & 2.249 \\
\hline \multicolumn{6}{|c|}{ LN-1 } \\
\hline 1 & 959 & 480 & 288 & 48 & 1.977 \\
\hline 2 & 2,496 & 1,200 & 720 & 96 & 2.072 \\
\hline 3 & 7,744 & 2,160 & 1,200 & 120 & 3.581 \\
\hline 4 & 7,547 & 2,160 & 1,200 & 120 & 3.489 \\
\hline 5 & 2,537 & 1,200 & 720 & 96 & 2.106 \\
\hline 6 & 3,249 & 1,440 & 840 & 96 & 2.249 \\
\hline \multicolumn{6}{|c|}{$\mathrm{FH}-1$} \\
\hline 1 & 581 & 288 & 168 & 48 & 1.983 \\
\hline 2 & 2,694 & 1,320 & 768 & 96 & 2.033 \\
\hline $3 a$ & 5,091 & 1,800 & 1,080 & 144 & 2.823 \\
\hline $3 b$ & 2,653 & 1,200 & 720 & 96 & 2.203 \\
\hline 4 & 996 & 432 & 240 & 48 & 2.282 \\
\hline 5 & 4,679 & 1,200 & 720 & 96 & 3.891 \\
\hline 6 & 2,537 & 1,200 & 720 & 96 & 2.106 \\
\hline 7 & 643 & 288 & 168 & 48 & 2.198 \\
\hline 8 & 898 & 480 & 288 & 48 & 1.850 \\
\hline
\end{tabular}

frequencies (less than about $0.3 \mathrm{cpd}$ ) with notable peaks at the semidiurnal frequency $(2 \mathrm{cpd})$ and with a relatively substantial peak at the diurnal frequency $(1 \mathrm{cpd})$ in parsed series $\mathrm{LN}-1 \_6$. The peaks at $3 \mathrm{cpd}$ in each of the plots and $4 \mathrm{cpd}$ in figure $52 \mathrm{~A}$ were harmonics (integer multiples of the fundamental frequency) that arose with the Fourier transform of the imperfect sinusoid of the fundamental frequency at $1 \mathrm{cpd}$. No attempt was made to remove these harmonics from the time series before computing the frequency-response functions.

The computed frequency responses in terms of amplitude (BE) and phase shift for parsed series BR-1_4, LN-1_6, and FH-1_6 are shown in figure 53. Five responses are shown for each parsed series in terms of gain and phase: four responses based on the original sampling rate and one based on the resampled rate. At the original sampling rate, frequency responses are shown for the $H_{f f t b p}(\omega)$ (indicated by FRF) without tidal filtering (unscaled) and $H_{\text {frtbp:et } M 2}(\omega)$ (indicated by FRF:ETM2) with prior $\mathrm{M}_{2}$-scaled tidal filtering, and for each of those, frequency responses at frequencies with squared coherences greater than or equal to 0.85 , FRF:Coh2 and FRF:Coh2:ETM2, respectively. At the resampled rate, the frequency response for $H_{\text {refritb:et } M 2}(\omega)$ (indicated by reFRF:ETM2), the resampled response function with prior $\mathrm{M}_{2}$-scaled tidal filtering, is shown. Also shown on the phase plots (fig. 53B, $D$, $F)$ are the squared coherence values Coh2 and Coh2:ETM2 at each frequency for FRF and FRF:ETM2, respectively.

Generally, the signal-to-noise ratios of the computed frequency responses as indicated by the power spectral densities (for example, fig. 52) were low for frequencies higher than about $2.5 \mathrm{cpd}$, and the squared coherences were highly variable and generally small. Spuriously high correlations are possible when the signal-to-noise ratios are small; thus, including frequencies beyond the tidal frequencies, greater than about $2.5 \mathrm{cpd}$, was not useful for demonstrating and analyzing the frequency responses of water levels to atmospheric loading because most of the signal power resided at frequencies less than about $2.5 \mathrm{cpd}$. Computed responses for frequencies greater than $5 \mathrm{cpd}$ are not shown here; however, the computed frequency responses for the full frequency range to as much as $12 \mathrm{cpd}$ were used in the analysis.

The frequency responses for the series with prior $\mathrm{M}_{2}$-scaled tidal filtering (FRF:ETM2 and reFRF:ETM2) improved the computed frequency responses in the tidal bands near the semidiurnal and diurnal frequencies. This was indicated by the larger squared coherence (Coh2:ETM2) values and, more generally, by the reduced peaks and troughs in the gains and phases in these frequency bands. The effects of resampling FRF $\left(H_{f f i: e t M 2}[\omega]\right)$ at the higher rates indicated by the resampling factor (ref) in table 16 had minimal effects on the character of the gains and phases of the computed frequency responses.

The frequency responses, FRF:Coh2:ETM2, for all the detrended, parsed series analyzed for each well are shown in figure 54 . The frequency responses for BR-1 showed a strong frequency dependence in gain and phase shift (fig. 54A, $B$ ). The dependence was more evident in the phase shifts that deviate substantially from the antiphase $\left(-180^{\circ}\right)$ response at frequencies higher than about $0.2 \mathrm{cpd}$. The gains were fairly constant or flat (about \pm 0.1 ) throughout the frequency band of $0.02-0.8 \mathrm{cpd}$. At higher frequencies beyond the upper band limits of $0.8 \mathrm{cpd}$ for gains and $0.2 \mathrm{cpd}$ for phase shifts, the responses followed downward and upward trends, respectively, that indicated an attenuation of the gains and phase lags. Qualitatively, drainage effects attributed to wellbore storage described previously with respect to figure $51 \mathrm{~A}$ could explain this type of response. An estimate of the staticconfined response was made based on the gain and phase responses using the more limited bandwidth, $0.02-0.2 \mathrm{cpd}$ of 


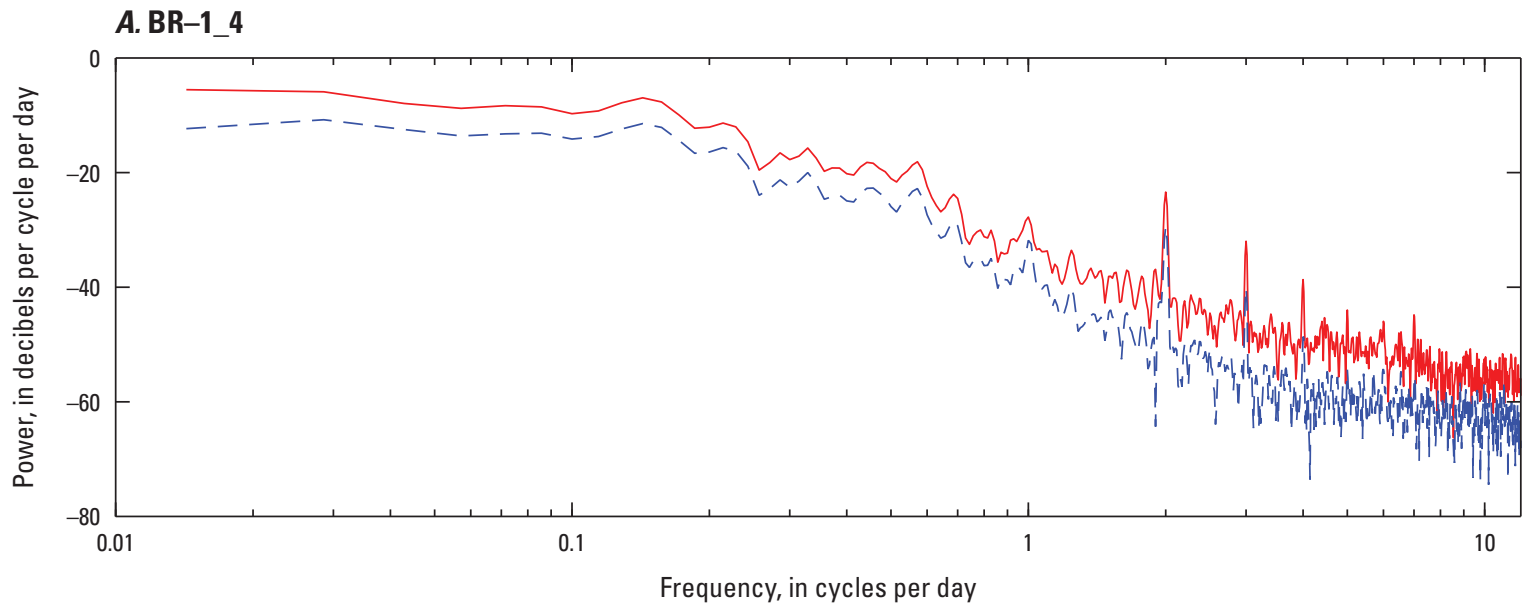

B. LN-1_6

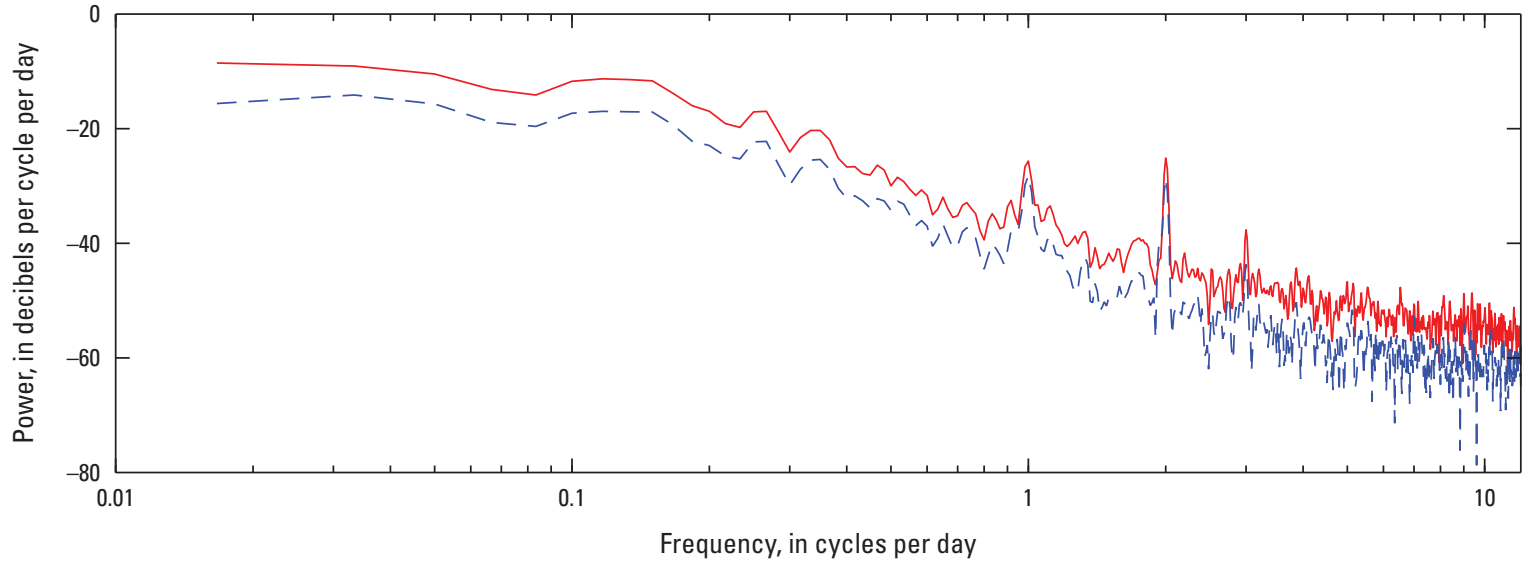

C. FH-1_6

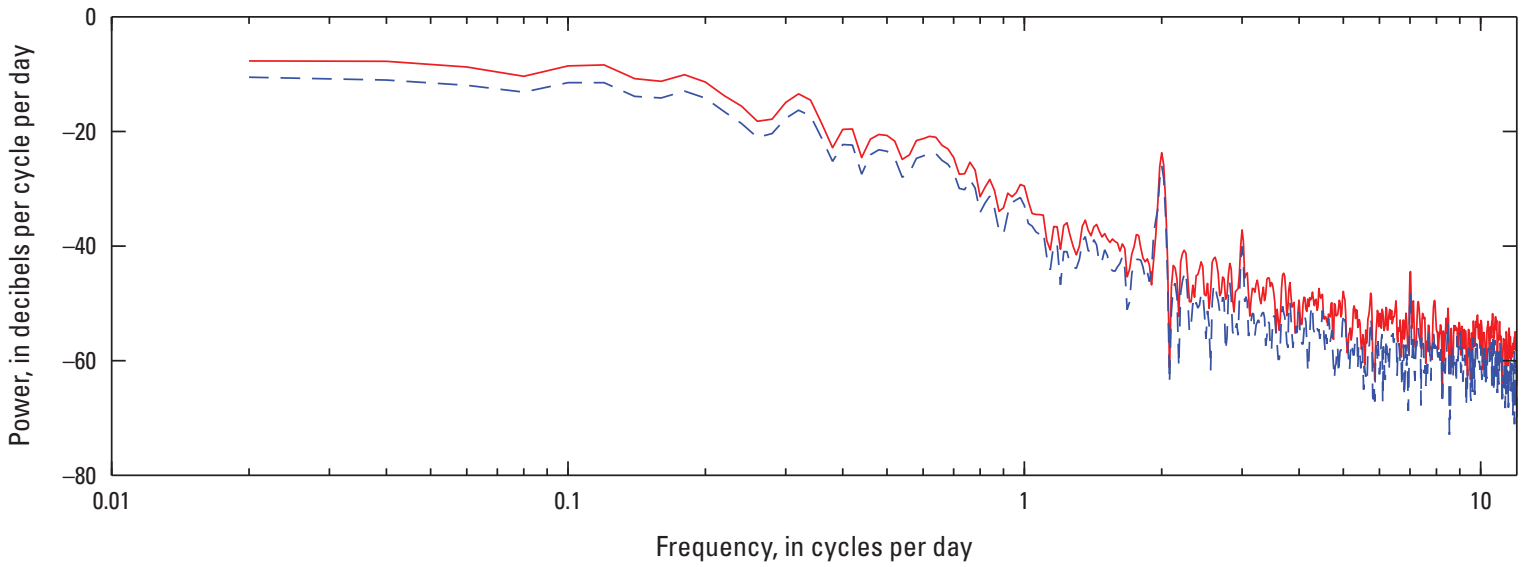

EXPLANATION

$\boldsymbol{G}_{X X}$-Autospectral density

$---G_{x y}-$ Cross-spectral density

Figure 52. Power spectral densities $\left(G_{x x^{\prime}} G_{x y}\right.$ from eq. 31$)$ computed for the parameters listed in table 16 for the nontidally filtered, detrended, parsed series BR-1_4, October 20, 2015-March 23, 2016; LN-1_6, May 18September 30, 2017; and FH-1_6, February 15-May 24, 2017, from wells BR-1, LN-1, and FH-1, respectively, southeastern Laramie County, Wyoming. A, BR-1_4; $B$, LN-1_6; C, FH-1_6. 
A. BR-1_4

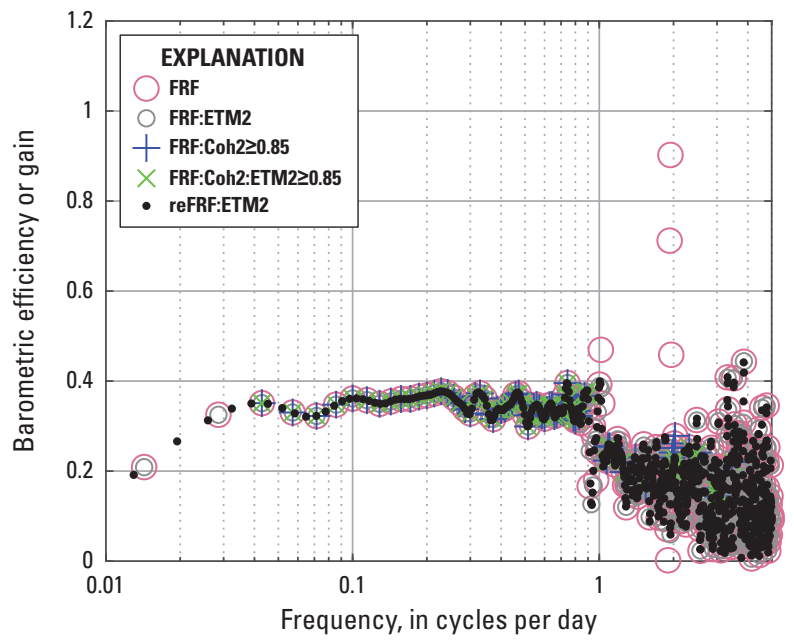

C. $\mathrm{LN}-1 \_6$

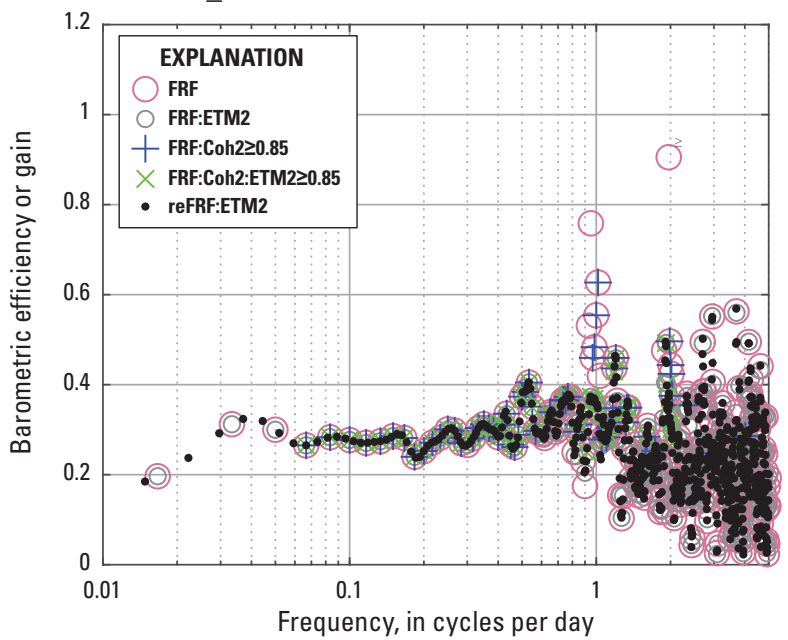

\section{B. BR-1_4}

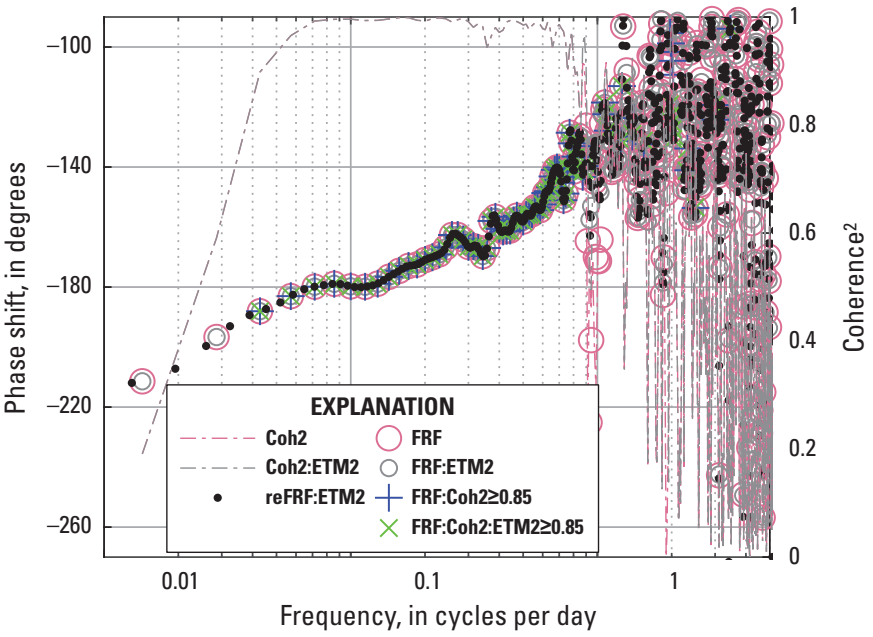

D. LN-1_6

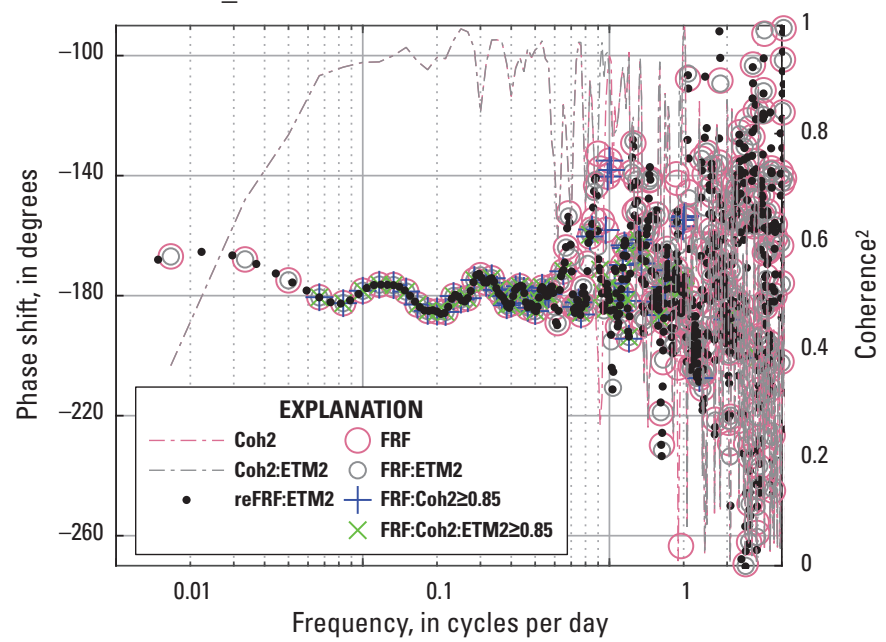

EXPLANATION

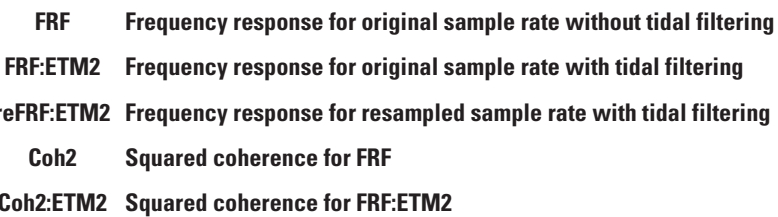

Figure 53. Computed atmospheric-loading frequency responses: frequency response for original sample rate without tidal filtering (FRF), frequency response for original sample rate with tidal filtering (FRF:ETM2), and frequency response for resampled sample rate with tidal filtering (reFRF:ETM2) of water levels in terms of barometric efficiency (BE) or gain, phase shift, and squared coherences (squared coherence for FRF [Coh2] and squared coherence for FRF:ETM2 [Coh2:ETM2]) for parsed time series BR-1_4, October 20, 2015-March 23, 2016; LN-1_6, May 18-September 30, 2017; and FH-1_6, February 15-May 24, 2017, from wells BR-1, LN-1, and FH-1, respectively, southeastern Laramie County, Wyoming. BEs or gains and phase shifts for FRF and FRF:ETM2 at frequencies in which Coh2 and Coh2:ETM2, respectively, were greater than or equal to 0.85 are shown as FRF:Coh2 and FRF:Coh2:ETM2. A, BR-1_4 BEs or gains of the frequency response functions; $B, B R-1 \_4$ phase shifts of the frequency response functions shown with Coh2 and Coh2:ETM2; $C$, LN-1_6 BEs or gains of the frequency response functions; $D$, LN-1_6 phase shifts of the frequency response functions shown with Coh2 and Coh2:ETM2; E, FH-1_6 BEs or gains of the frequency response functions; F, FH-1_6 phase shifts of the frequency response functions shown with Coh2 and Coh2:ETM2. 
E. FH-1_6

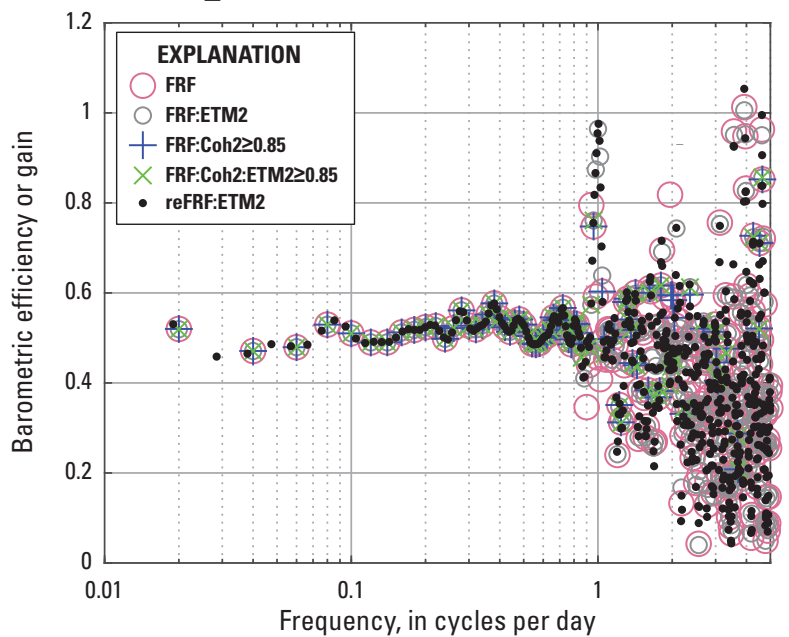

\section{F. FH-1_6}

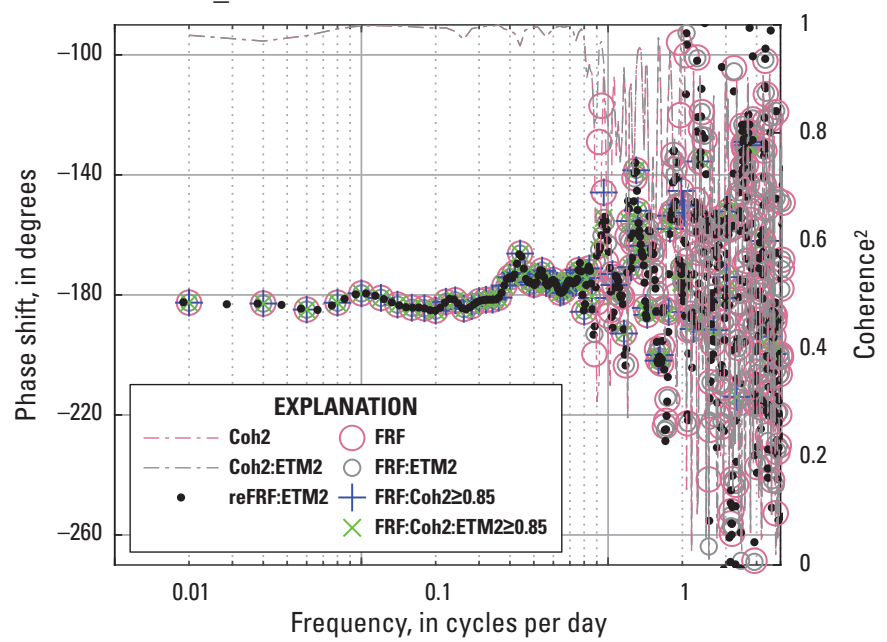

EXPLANATION

\author{
FRF Frequency response for original sample rate without tidal filtering \\ FRF:ETM2 Frequency response for original sample rate with tidal filtering \\ reFRF:ETM2 Frequency response for resampled sample rate with tidal filtering \\ Coh2 Squared coherence for FRF \\ Coh2:ETM2 Squared coherence for FRF:ETM2
}

Figure 53. Computed atmospheric-loading frequency responses: frequency response for original sample rate without tidal filtering (FRF), frequency response for original sample rate with tidal filtering (FRF:ETM2), and frequency response for resampled sample rate with tidal filtering (reFRF:ETM2) of water levels in terms of barometric efficiency (BE) or gain, phase shift, and squared coherences (squared coherence for FRF [Coh2] and squared coherence for FRF:ETM2 [Coh2:ETM2]) for parsed time series BR-1_4, October 20, 2015-March 23, 2016; LN-1_6, May 18-September 30, 2017; and FH-1_6, February 15-May 24, 2017, from wells BR-1, LN-1, and FH-1, respectively, southeastern Laramie County, Wyoming. BEs or gains and phase shifts for FRF and FRF:ETM2 at frequencies in which Coh2 and Coh2:ETM2, respectively, were greater than or equal to 0.85 are shown as FRF:Coh2 and FRF:Coh2:ETM2. $A, B R-1 \_4$ BEs or gains of the frequency response functions; $B, B R-1 \_4$ phase shifts of the frequency response functions shown with Coh2 and Coh2:ETM2; $C$, LN-1_6 BEs or gains of the frequency response functions; $D$, LN-1_6 phase shifts of the frequency response functions shown with Coh2 and Coh2:ETM2; E, FH-1_6 BEs or gains of the frequency response functions; F, FH-1_6 phase shifts of the frequency response functions shown with Coh2 and Coh2:ETM2._Continued 
A. BR-1

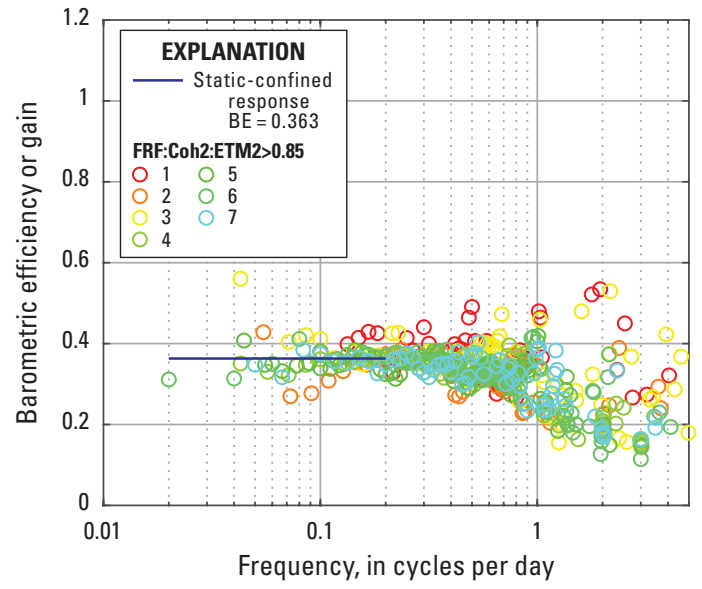

C. $\mathrm{LN}-1$

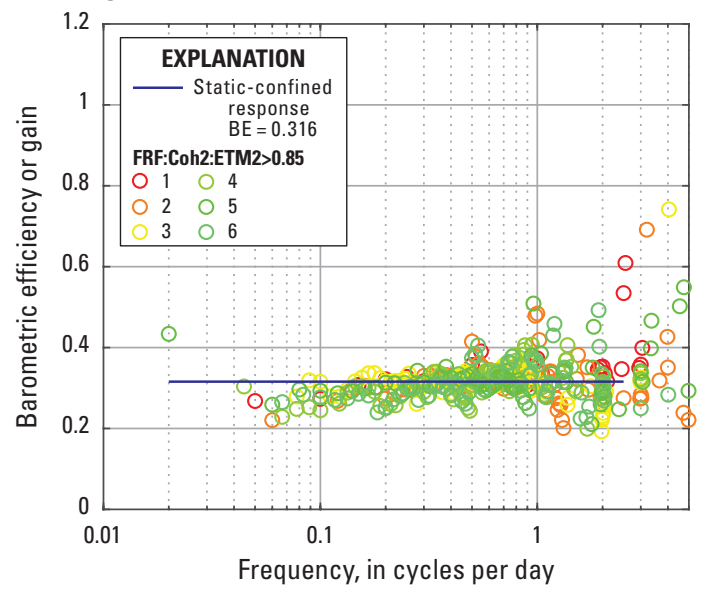

E. FH-1

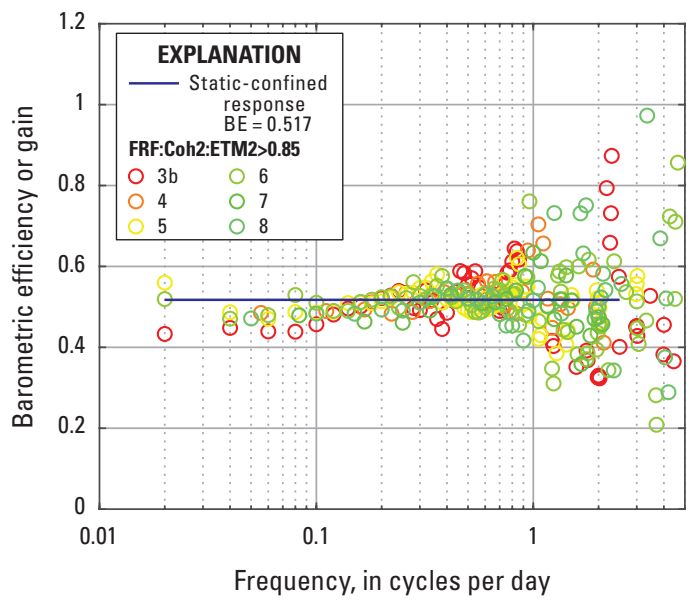

BE Barometric efficiency

\section{B. BR-1}

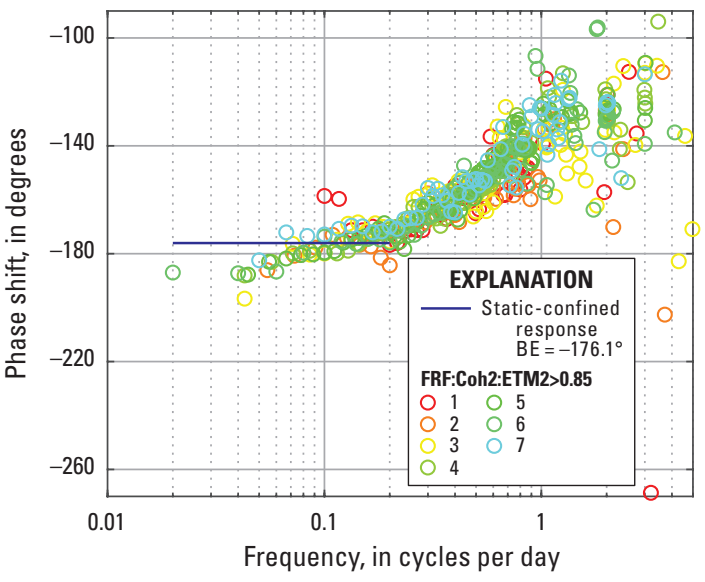

D. LN-1

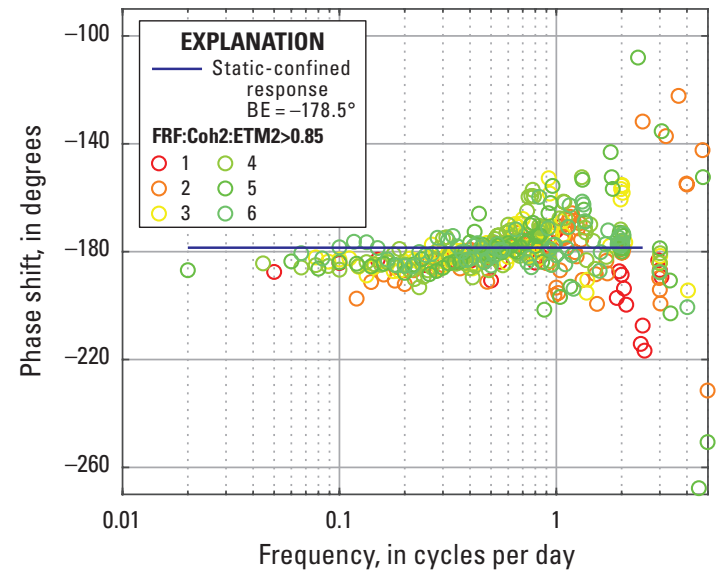

F. FH-1

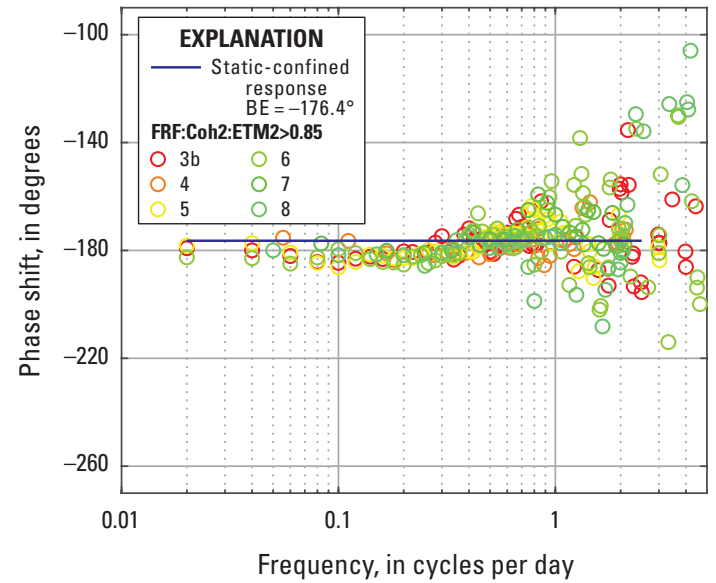

EXPLANATION

FRF:Coh2:ETM2>0.85 Frequency response with prior $\mathbf{M}_{2}$-scaled filtered water levels in terms of gain (BE) and phase shift at frequencies in which squared coherences were greater than or equal to 0.85

Figure 54. Computed, atmospheric-loading frequency responses with prior, $\mathrm{M}_{2}$-scaled filtered water levels (FRF:ETM2), in terms of gain (barometric efficiency [BE]) and phase shift, at frequencies in which squared coherences (Coh2:ETM2) were greater than or equal to 0.85, shown as FRF:Coh2:ETM2 for each of the detrended, parsed series for wells $\mathrm{BR}-1, \mathrm{LN}-1$, and $\mathrm{FH}-1$, southeastern Laramie County, Wyoming. $A, \mathrm{BR}-1, \mathrm{BE}$ or gain; $B, \mathrm{BR}-1$, phase shift; $C_{,} \mathrm{LN}-1, \mathrm{BE}$ or gain; $D, \mathrm{LN}-1$, phase shift; $E, \mathrm{FH}-1, \mathrm{BE}$ or gain; $F, \mathrm{FH}-1$, phase shift. 
the flat part of the phase responses. The mean gain or BE and mean phase shift for responses in this frequency band, 0.363 and $-176.1^{\circ}$, respectively, represented the estimated staticconfined response and are shown as the solid black lines in figure $54 A, B$.

The frequency responses for well $\mathrm{LN}-1$ (fig. $54 C, D$ ) and well FH-1 (fig. 54E, F) were qualitatively similar and showed little discernible frequency dependence throughout the frequency band of $0.02-2.5 \mathrm{cpd}$. These responses where gains and phase shifts are fairly constant over a broad range of frequencies are indicative of the static-confined response in these wells and represent the classic concept of $\mathrm{BE}$ in terms of a simple loading response that is related to the load by a constant BE, without the effect of fluid-flow effects. Estimates of the static-confined responses for wells $\mathrm{LN}-1$ and $\mathrm{FH}-1$ were made based on the gain and phase responses in the 0.02 $2.5 \mathrm{cpd}$ frequency band. The mean gain or $\mathrm{BE}$ and mean phase shift for the well $\mathrm{LN}-1$ responses were 0.316 and $-178.5^{\circ}$, respectively, and for the well FH-1, responses were 0.517 and $-176.4^{\circ}$, respectively. These represent the estimated staticconfined responses and are shown as the solid black lines in figure $54 C-F$. The computed frequency responses analyzed for each well in the full frequency range $(0-12 \mathrm{cpd})$ for the original and resampled frequencies without tidal filtering, FRF and reFRF, respectively, and with prior $\mathrm{M}_{2}$-scaled tidal filtering, FRF:ETM2, and reFRF:ETM2, respectively, are given in Galloway and Bartos (2021, table 1).

The predicted time-domain responses of water levels to atmospheric loading were computed using the three frequency response function models FRF, FRF:ETM2, and reFRF:ETM2 for each detrended, parsed series analyzed for each well by taking the inverse discrete Fourier transform of $Y(\omega)$ in equation 30 for the different frequency response functions using

$$
\begin{aligned}
& \hat{y}_{f i f b p}(t)=\operatorname{Re}\left(i f f t\left(Y_{f i f b p}(\omega)\right)\right) \\
& \hat{y}_{\text {frtbpet:etM } 2}(t)=\operatorname{Re}\left(\operatorname{ifft}\left(Y_{\text {frtbpet:etM } 2}(\omega)\right)\right) \text {, } \\
& \hat{y}_{\text {refffbpet:etM } 2}(t)=\operatorname{Re}\left(\operatorname{ifft}\left(Y_{\text {refiffppet:etM } 2}(\omega)\right)\right)
\end{aligned}
$$

where

$$
\begin{aligned}
& \hat{y}_{f t r b p}(t) \quad \text { is the predicted time-domain water-level } \\
& \text { response for the FRF model, } \\
& \operatorname{Re} \quad \text { is the real part of the complex-valued } \\
& \text { argument, } \\
& \text { ifft is the inverse Fourier transform operator, } \\
& Y_{f i f b p}(\omega) \quad \text { is the transformed water-level response } \\
& \text { from the FRF model, } \\
& \hat{y}_{\text {fitbpet:etM2 }}(t) \\
& Y_{\text {fiftbet:et } M 2}(\omega) \\
& \hat{y}_{\text {refiftopet:etM2 } 2}(t) \\
& Y_{\text {refiffpet: }: \text { M } M}(\omega) \\
& \text { is the predicted time-domain water-level } \\
& \text { response for the FRF:ETM2 model, } \\
& \text { is the transformed water-level response from } \\
& \text { the FRF:ETM2 model, } \\
& \text { is the predicted time-domain water-level } \\
& \text { response for the reFRF:ETM2 model, and } \\
& \text { is the transformed water-level response from } \\
& \text { the reFRF:ETM2 model. }
\end{aligned}
$$

measure of the goodness of fit of the predicted to "observed" values for predictions from the FRF, FRF:ETM2, and reFRF:ETM2 models and the constant BE method 1 (BE1) linear regression model. The "observed" values were the detrended water-level series $(y[t])$ for the FRF and BE1 models, and the $\mathrm{M}_{2}$-scaled, tidally filtered water-level series $\left(\tilde{y}_{e t M 2}[t]\right)$ for the FRF:ETM2 and reFRF:ETM2 models. The RMSEs, in feet, for each of the detrended parsed series analyzed for each well are shown in table 17. Predictions computed using the reFRF:ETM2 models had lower RMSEs than predictions computed using the FRF:ETM2 models, except for series BR-1_1, BR-1_3, and LN-1_4. Generally, the RMSEs for the predicted water-level responses to atmospheric loading computed using the reFRF:ETM2 model were lowest among the prediction models. For well $\mathrm{FH}-1$, the RMSEs for FH-1_1-3a were notably higher than RMSEs for the other FH-1 parsed series. This is attributed to the 0.1 -ft water-level measurement resolution for the $\mathrm{FH}-1 \_1-3 \mathrm{a}$ series compared with the $0.01-\mathrm{ft}$ measurement resolution for the other FH-1 water-level series. For the BR-1_2-7 parsed series and each of the LN-1 and FH-1 parsed series, RMSEs for predictions computed using the reFRF:ETM2 model were lowest or second lowest (BR-1_3 and LN-1_4) among RMSEs for all the prediction models. For BR-1_1, RMSEs for predictions computed using the reFRF:ETM 2 model were the highest $(0.0502 \mathrm{ft})$ among the four models shown for this parsed series. For the FH-1 parsed series, RMSEs for predictions computed using the BE1 model FH-1 were the second or third lowest (FH-1_7-8). Shown in figure 55 are the predicted water levels for the detrended parsed series BR-1_4, $\mathrm{LN}-1 \_6$, and $\mathrm{FH}-1 \_6$, computed from equation 34 for reFRF:ETM2 and from equation 10 for BE1, and the respective "observed" water levels - with prior $\mathrm{M}_{2}$-scaled tidal filtering for the reFRF:ETM2 predictions and without tidal filtering for the BE1 predictions. A comparison of the predicted fits to the "observed" values for these three parsed series revealed some generalities of the fits for all parsed series analyzed. Excluding the series FH-1_1-3a, which were compromised by the relatively poor resolution of the water-level measurement, generally, the predictions were close to the "observed" values and better for well FH-1. For FH-1_6 (fig. $55 E, F$ ), reFRF:ETM2 and BE1 predictions performed well with the lowest RMSEs of the predictions for the three parsed series shown in figure 55. The predictions for BR-1_4 (fig. 55A, $B$ ) performed less well with higher RMSEs than for FH-1_6 for reFRF:ETM 2 and BE1 predictions by factors of about $\overline{3}$ and 2.6 , respectively. The predictions for $\mathrm{LN}-1 \_6$ (fig. $55 C, D$ ) were better than those for BR-1_4 but poorer than those for FH-1_6 with higher RMSEs than for FH-1_6 by a factor of about 1.3 for reFRF:ETM2 and BE1 predictions. One interval of relatively poor fits for $\mathrm{LN}-1$ - 6 that occurred during August 11-16, 2017 (fig. 55C, D), likely could be attributed to a water-level response to precipitation loading from about 0.74 in. of rain (measured at the Cheyenne Airport) occurring August 11-12. The response was not discernible in well BR-1, 
Table 17. Root mean square errors for the fit of predicted waterlevel responses to atmospheric loading using the FRF, FRF:ETM2, and reFRF:ETM2 frequency response function models and the constant BE method 1 (BE1) linear least-squares regression model of detrended water level on detrended barometric pressure, to the observed detrended water levels, for the detrended, parsed time series analyzed for wells BR-1, September 5, 2014-September 30, 2017; LN-1, November 8, 2014-September 30, 2017; and FH-1, December 19, 2014-September 30, 2017, southeastern Laramie County, Wyoming.

[BE1, refers to method 1 for determining constant-valued barometric efficiency using least-squares linear regression; FRF, FRF:ETM2, and reFRF:ETM2 refer to the different frequency response functions models of the same name. Bold italic font indicates smallest root mean square error (RMSE), gray shaded cell indicates second lowest RMSE, italic font indicates third lowest RMSE; border line between FH-1_3a and 3b separates low measurement resolution series above for $\mathrm{FH}-1$ from those below with high measurement resolution]

\begin{tabular}{|c|c|c|c|c|}
\hline $\begin{array}{l}\text { Well/ } \\
\text { parsed } \\
\text { series }\end{array}$ & FRF & FRF:ETM2 & reFRF:ETM2 & BE1 \\
\hline \multicolumn{5}{|c|}{ BR-1 } \\
\hline 1 & 0.04816 & 0.04669 & 0.05016 & 0.03881 \\
\hline 2 & 0.04184 & 0.04130 & 0.03816 & 0.03817 \\
\hline 3 & 0.03433 & 0.03352 & 0.03413 & 0.03754 \\
\hline 4 & 0.04740 & 0.04704 & 0.04579 & 0.05107 \\
\hline 5 & 0.03273 & 0.03108 & 0.01902 & 0.03654 \\
\hline 6 & 0.02327 & 0.02230 & 0.01650 & 0.02141 \\
\hline 7 & 0.03029 & 0.02930 & 0.02442 & 0.03452 \\
\hline \multicolumn{5}{|c|}{$\mathrm{LN}-1$} \\
\hline 1 & 0.01811 & 0.01542 & 0.01189 & 0.01471 \\
\hline 2 & 0.02410 & 0.02288 & 0.02029 & 0.02574 \\
\hline 3 & 0.03891 & 0.03731 & 0.03201 & 0.03688 \\
\hline 4 & 0.02808 & 0.02082 & 0.02194 & 0.02983 \\
\hline 5 & 0.02847 & 0.02656 & 0.02178 & 0.02672 \\
\hline 6 & 0.02539 & 0.02318 & 0.02013 & 0.02563 \\
\hline \multicolumn{5}{|c|}{$\mathrm{FH}-1$} \\
\hline 1 & 0.06547 & 0.05735 & 0.03215 & 0.03662 \\
\hline 2 & 0.08624 & 0.08305 & 0.04332 & 0.04540 \\
\hline $3 a$ & 0.05853 & 0.05708 & 0.04002 & 0.04880 \\
\hline $3 b$ & 0.02545 & 0.02114 & 0.01435 & 0.01836 \\
\hline 4 & 0.02496 & 0.02209 & 0.01679 & 0.02033 \\
\hline 5 & 0.03362 & 0.02737 & 0.01917 & 0.02286 \\
\hline 6 & 0.02793 & 0.02282 & 0.01538 & 0.01936 \\
\hline 7 & 0.02714 & 0.01620 & 0.01609 & 0.01835 \\
\hline 8 & 0.01711 & 0.01320 & 0.01028 & 0.01423 \\
\hline
\end{tabular}

and no data were available for well FH-1 during this time. Responses to two larger precipitation loading episodes measured in all three wells for one episode and BR-1 and LN-1 for another episode are discussed later in the section "Surface Loading."

\section{Filtered Water-Level Time Series}

The predicted water-level responses (eq. 34) computed using the reFRF:ETM2 model were used to filter atmosphericloading responses from the detrended water levels (fig. 41, box i). The filtered detrended water level was computed using equation 35 :

$$
\tilde{y}_{\text {refrfbpet:etM } 2}(t)=\tilde{y}_{\text {etM2 }}(t)-\hat{y}_{\text {refifbpet:etM2 }}(t) .
$$

Examples of the filtered results $\tilde{y}_{\text {refirfbet:etM2 }}$ (indicated by fWL:reFRF:ETM2) computed using equation 35 for the $\mathrm{M}_{2}$-scaled tidally filtered, detrended water-level time series $\tilde{y}_{e t M 2}$ and barometric-pressure (BP) time series for the detrended, parsed series BR-1_4, LN-1_6, and FH-1_6 are shown in figure 56 . Also shown are the filtered result $\bar{y}_{B E}$ (indicated by fWL:BE1) computed using equation 9 for BE1 for the same detrended parsed series. Generally, variability in fWL:reFRF:ETM2 was demonstrably reduced compared to fWL:BE1. The frequency response filters generally performed worse at the ends ("heads" and "tails") of the parsed series than did the constant BE filters, because of spectral leakage occurring at the boundaries of the finite time series in the modeled frequency domain. This was evident at the beginning of parsed series BR-1_4 (fig. 56A) and the end of parsed series FH-1_6 (fig. 56C) for fWL:reFRF:ETM2 compared to fWL:BE1; nevertheless, the "heads" and "tails" of the filtered results for each parsed time series were retained. The filtered results, fWLf:BE1 and fWL:reFRF:ETM2, for all the detrended series for which frequency response functions were computed (table 16) are given in Galloway and Bartos (2021, tables 2-4).

The trends removed to create the detrended time series were restored (added back) to the detrended, filtered waterlevel time series computed using the reFRF:ETM2 frequency response function model to produce reconstructed filtered water-level time series trfWL:reFRF:ETM2 (fig. 41, box j). An example of the reconstructed time series for each of the wells (parsed series BR-1_4, LN-1_6, and FH-1_6) is shown in figure 57 . The reconstructed filtered water-level time series, trfWL:BE1, computed using the linear regression model BE1 is also shown in figure 57. Note, "tr" prepended to fWL:reFRF:ETM2 and fWL:BE1 denotes the trend restored to the detrended filtered series computed using the reFRF:ETM2 frequency response and the BE1 linear regression models, respectively. The reconstructed time series for all the parsed series analyzed for each of the wells are shown in figure 58. Water levels filtered to remove the effects of atmospheric loading and Earth tides indicated an upward trend of $+1.13 \mathrm{ft} / \mathrm{yr}$ in well BR-1 and downward trends of -0.86 and $-1.74 \mathrm{ft} / \mathrm{yr}$ in 
Decimal day (dd 1 = Jan. 1, 2014)

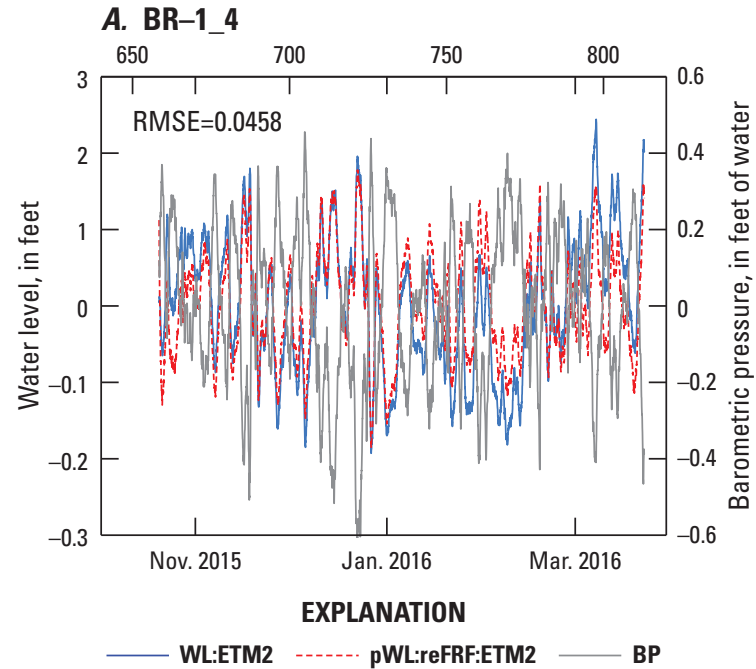

C. $\mathrm{LN}-16$

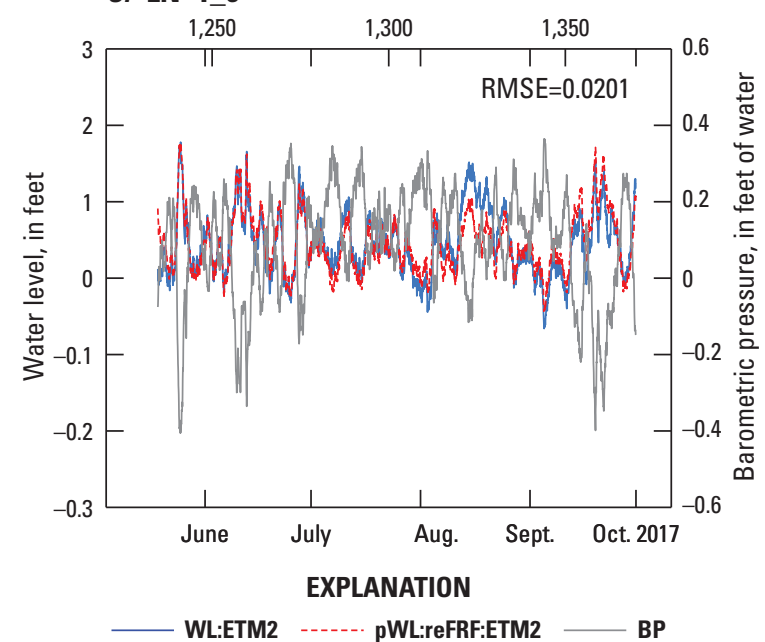

$\begin{array}{cl}\text { RMSE } & \text { Root mean square error } \\ \text { WL:ETM2 } & \text { "Observed" water level for the reFRF:ETM2 model }\end{array}$

pWL:reFRF:ETM2 Predicted water level computed using the reFRF:ETM2 model
Decimal day (dd $1=$ Jan. 1, 2014)

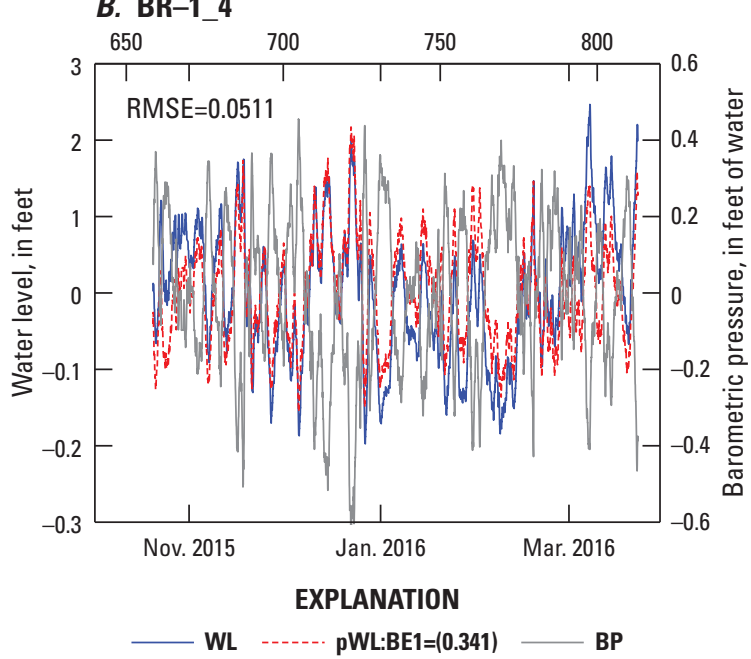

D. $\mathrm{LN}-16$

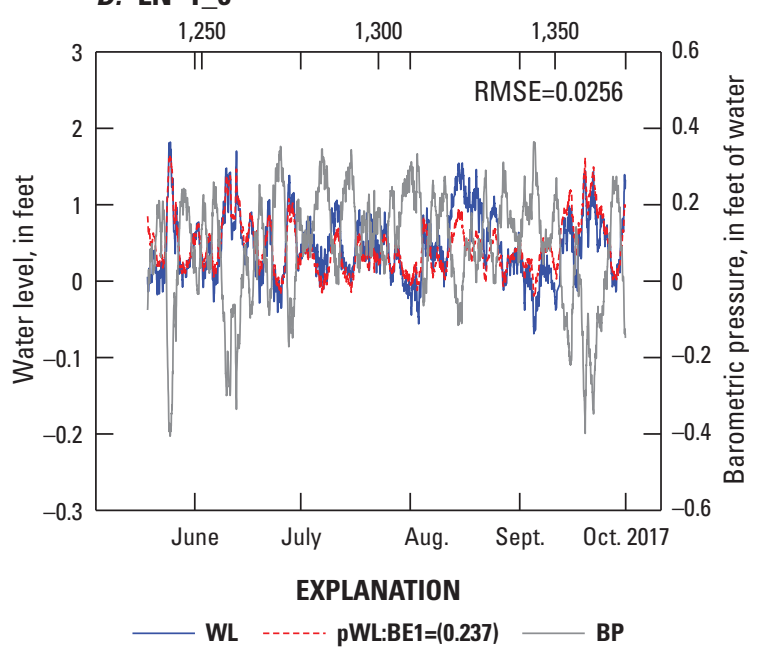

WL "Observed" water level for barometric efficiency method 1

BP Barometric pressure

pWL:BE1 $=(x)$ Predicted water level computed using barometric efficiency method 1 with barometric efficiency shown in parentheses

Figure 55. Predicted water levels computed using the reFRF:ETM2 (pWL:reFRF:ETM2) and barometric efficiency method 1 (BE1) (pWL:BE1; with barometric efficiency shown in parentheses) models, and the respective "observed" water levels (WL:ETM2 for the reFRF:ETM2 model, and WL for the BE1 model), for the detrended, parsed series BR-1_4, October 20, 2015-March 23, 2016; LN-1_6, May 18-September 30, 2017; and FH-1_6, February 15-May 24, 2017, shown with the detrended, parsed barometric pressure, for wells $B R-1, \mathrm{LN}-1$, and FH-1, respectively, southeastern Laramie County, Wyoming. $A$, BR-1_4, reFRF:ETM2 model; $B$, BR-1_4, BE1 model; $C$, LN-1_6, reFRF:ETM2 model; D, LN-1_6, BE1 model; E, FH-1_6, reFRF:ETM2 model; $F$, FH-1_6, BE1 model. 


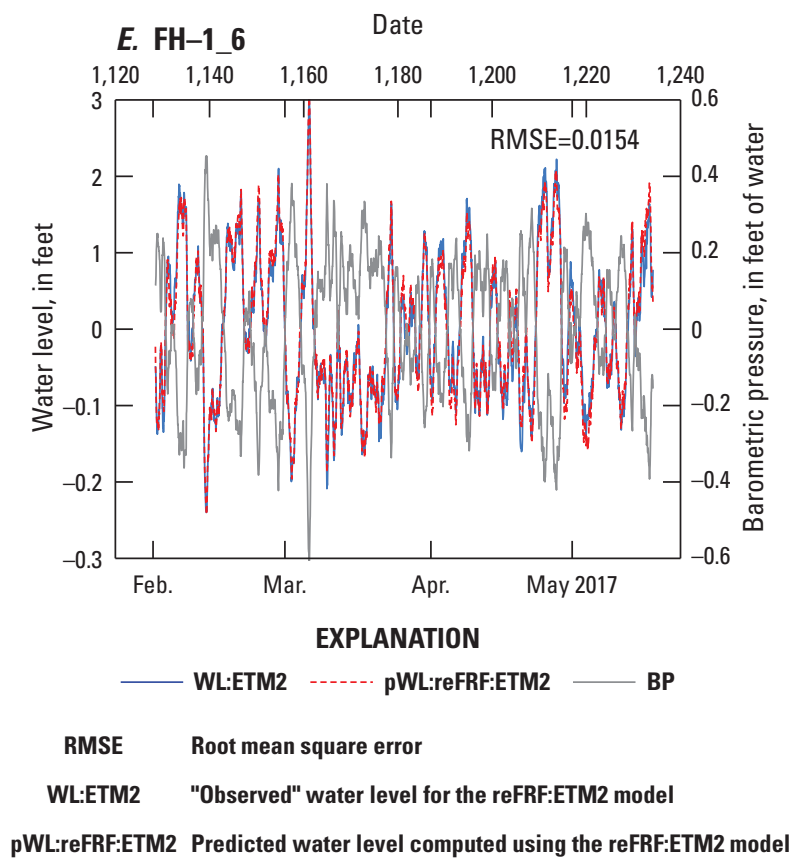

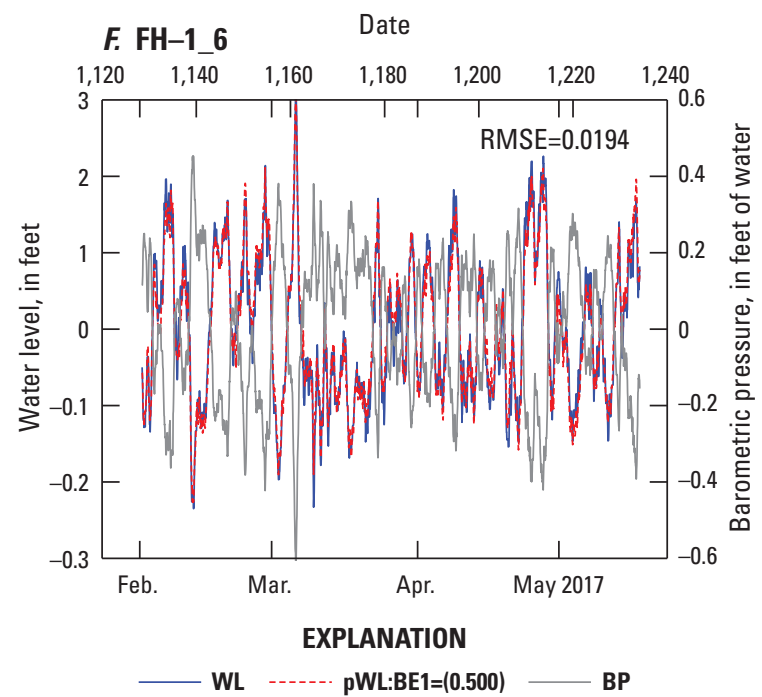

$\begin{array}{cc}\text { WL } & \text { "Observed" water level for barometric efficiency method } 1 \\ \text { BP } & \text { Barometric pressure }\end{array}$

Figure 55. Predicted water levels computed using the reFRF:ETM2 (pWL:reFRF:ETM2) and barometric efficiency method 1 (BE1) (pWL:BE1; with barometric efficiency shown in parentheses) models, and the respective "observed" water levels (WL:ETM2 for the reFRF:ETM2 model, and WL for the BE1 model), for the detrended, parsed series BR-1_4, October 20, 2015-March 23, 2016; LN-1_6, May 18-September 30, 2017; and FH-1_6, February 15-May 24, 2017, shown with the detrended, parsed barometric pressure, for wells $B R-1, \mathrm{LN}-1$, and $\mathrm{FH}-1$, respectively, southeastern Laramie County, Wyoming. $A$, BR-1_4, reFRF:ETM2 model; $B$, BR-1_4, BE1 model; $C$, LN-1_6, reFRF:ETM2 model; D, LN-1_6, BE1 model; $E$, FH-1_6, reFRF:ETM2 model; $F$, FH-1_6, BE1 model._Continued 
A. BR-1_4

Decimal day (dd 1 = Jan. 1, 2014)

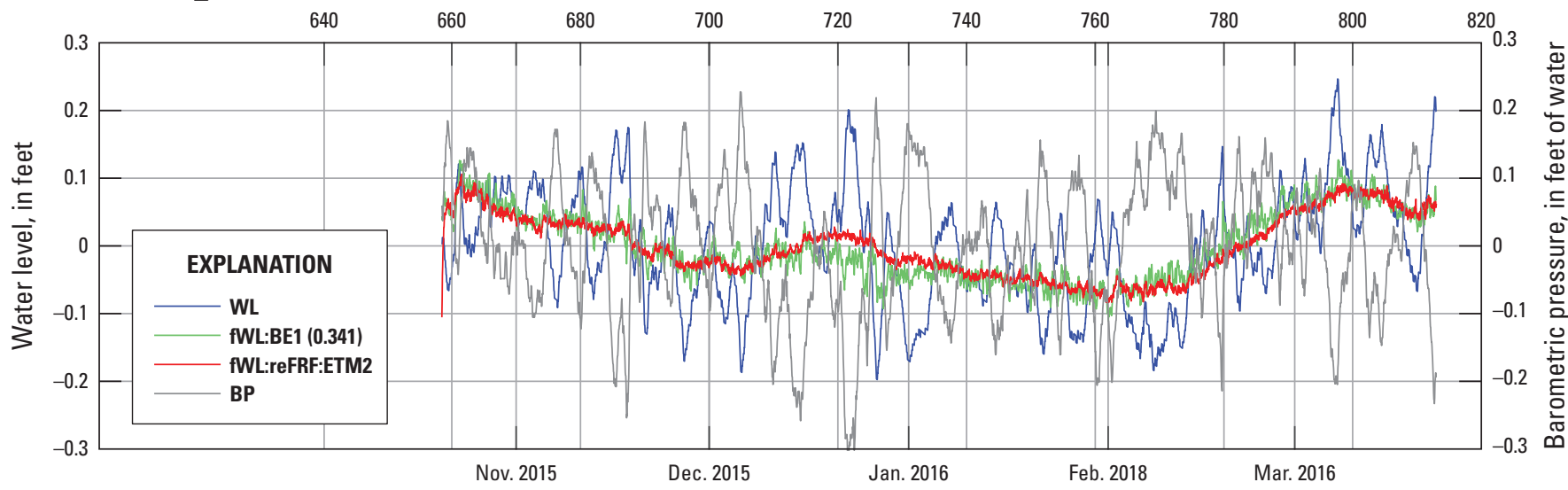

B. $\mathrm{LN}-1 \_6$

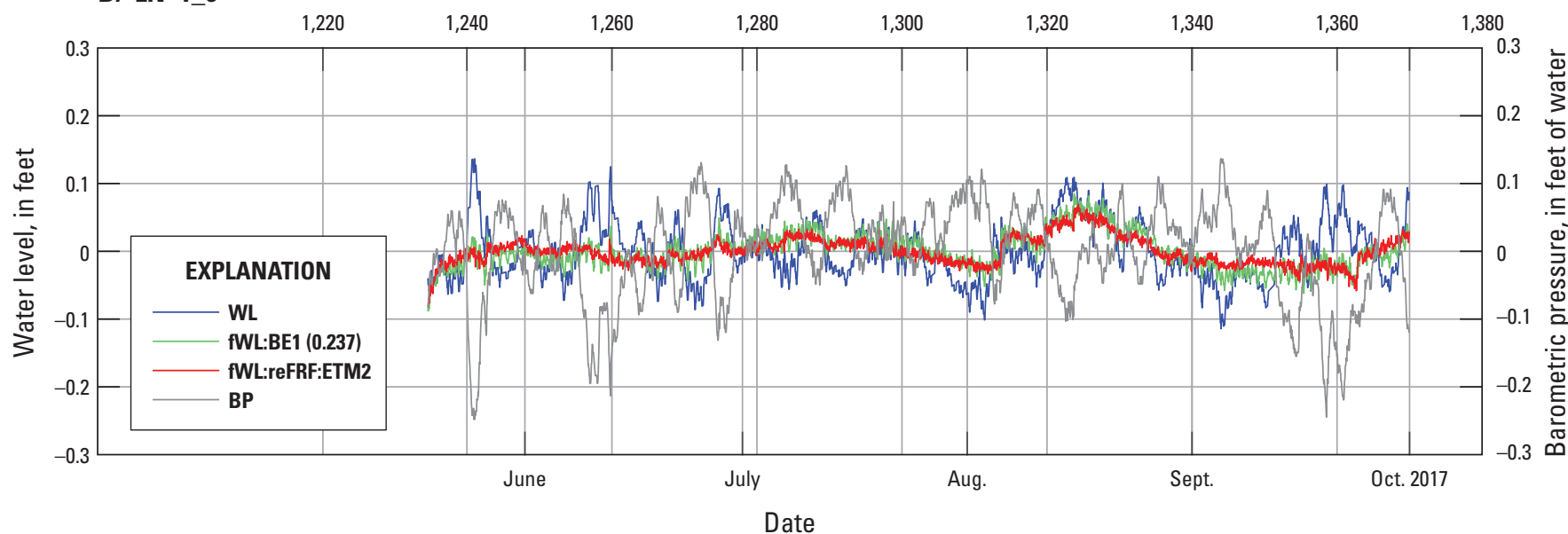

C. FH-1_6

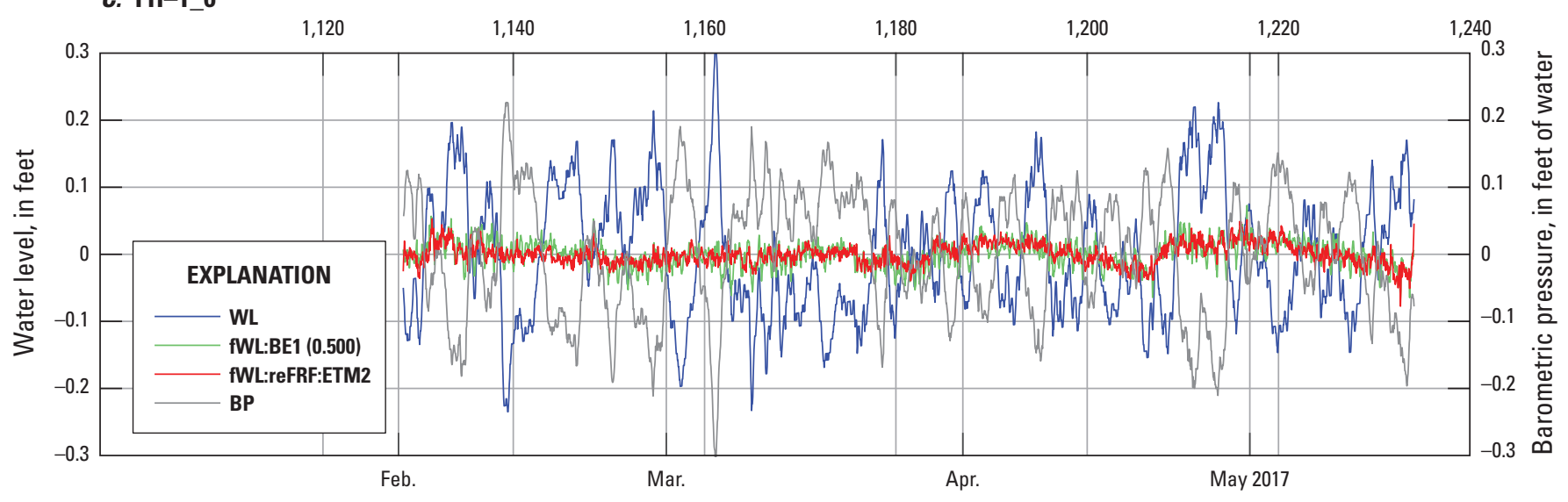

EXPLANATION

WL Detrended water level
BP Barometric pressure
fWL:reFRF:ETM2 Filtered, detrended, parsed water-level time series computed using the frequency response function reFRF:ETM2

fWL:BE1(x)
Filtered, detrended, parsed water-level time series computed using the linear regression model for barometric efficiency method 1 with barometric efficiency shown in parentheses

Figure 56. Filtered, detrended, parsed water-level time series fWL:reFRF:ETM2 and fWL:BE1 (barometric efficiency shown in parentheses), computed using the frequency response function model, reFRF:ETM2, and the linear regression model, BE1, respectively, shown with detrended water level and barometric pressure for parsed series BR-1_4, October 20, 2015-March 23, 2016; LN-1_6, May 18-September 30, 2017; and FH-1_6, February 15-May 24, 2017, from wells BR-1, LN-1, and FH-1, southeastern Laramie County, Wyoming. $A$, BR-1_4; $B, \mathrm{LN}-1 \_6$; $C$, FH-1_6. 
A. BR-1_4 Decimal day (dd 1 = Jan. 1, 2014)

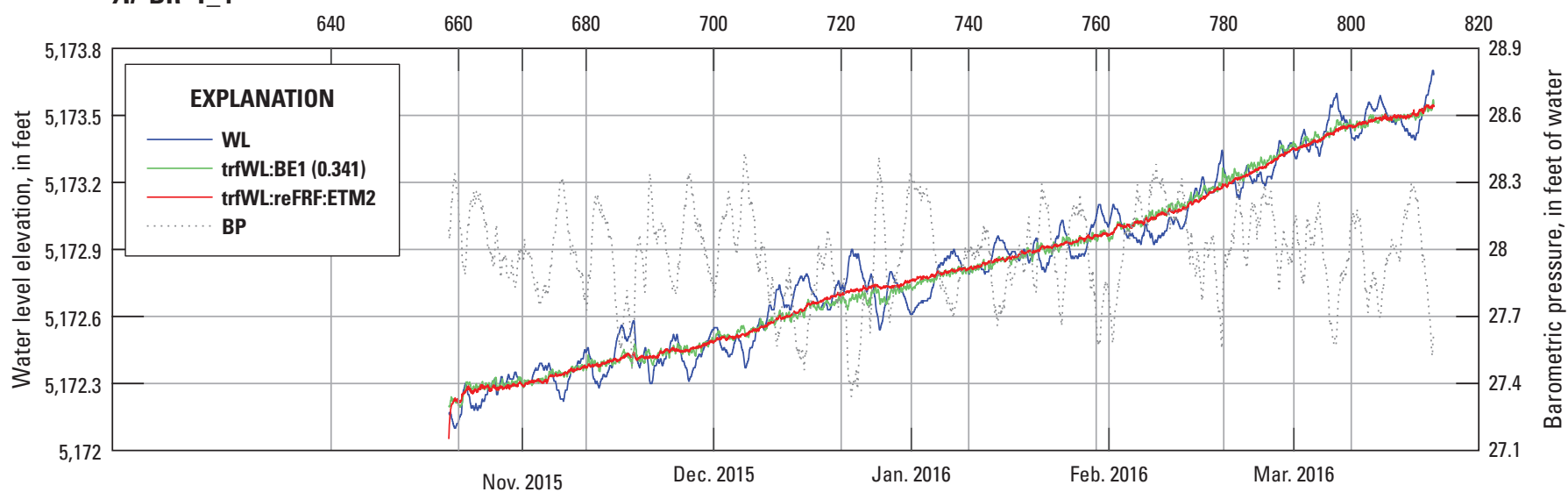

B. $\mathrm{LN}-1$

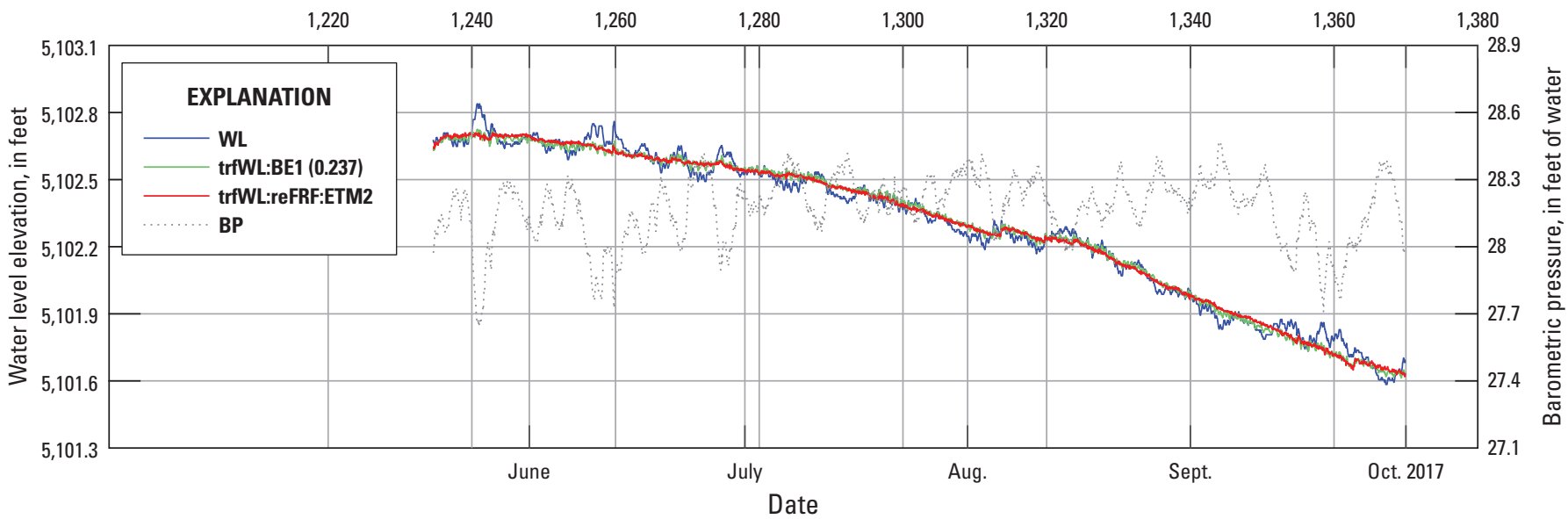

\section{FH-1_6}

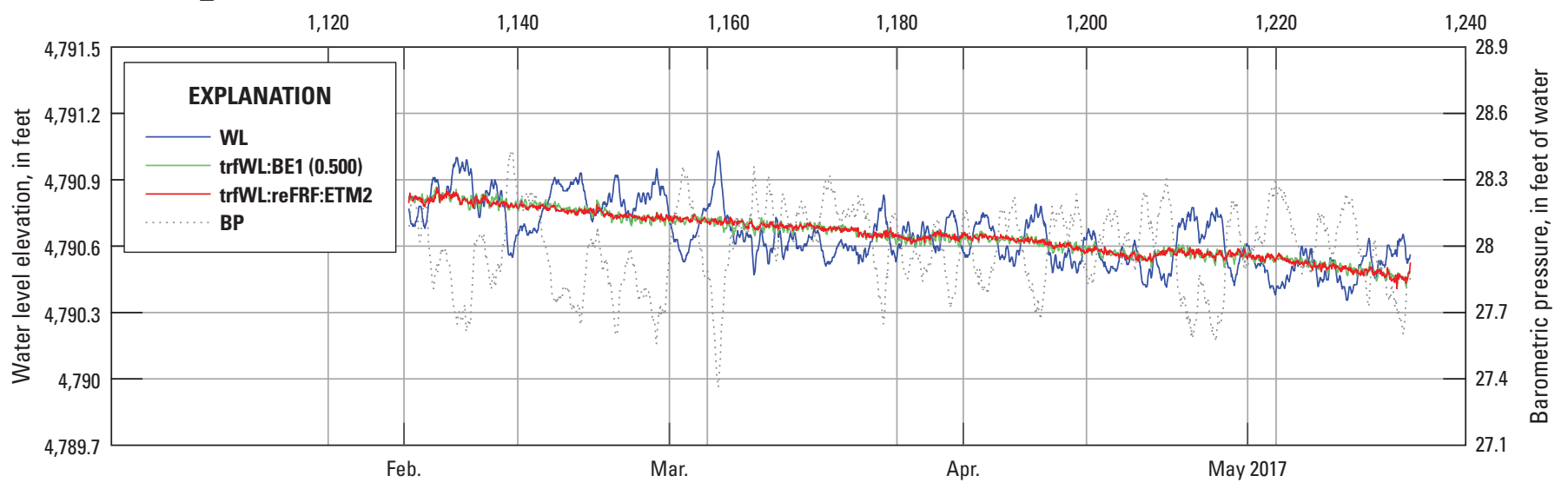

EXPLANATION

WL Water level
BP Barometric pressure

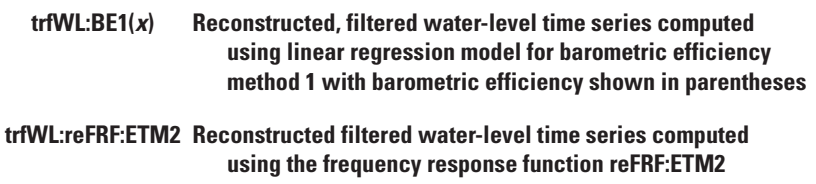

Figure 57. Reconstructed (trends restored), filtered water-levels trfWL:reFRF:ETM2 and trfWL:BE1 (barometric efficiency shown in parentheses) shown with water level and barometric pressure for the detrended, parsed time series BR-1_4, 0ctober 20, 2015March 23, 2016; LN-1_6, May 18-September 30, 2017; and FH-1_6, February 15-May 24, 2017, from wells BR-1, LN-1, and FH-1, southeastern Laramie County, Wyoming. $A$, BR-1_4; $B, \mathrm{LN}-1 \_6$; $C$, FH-1_6. 
Decimal day (dd 1 = Jan. 1, 2014)
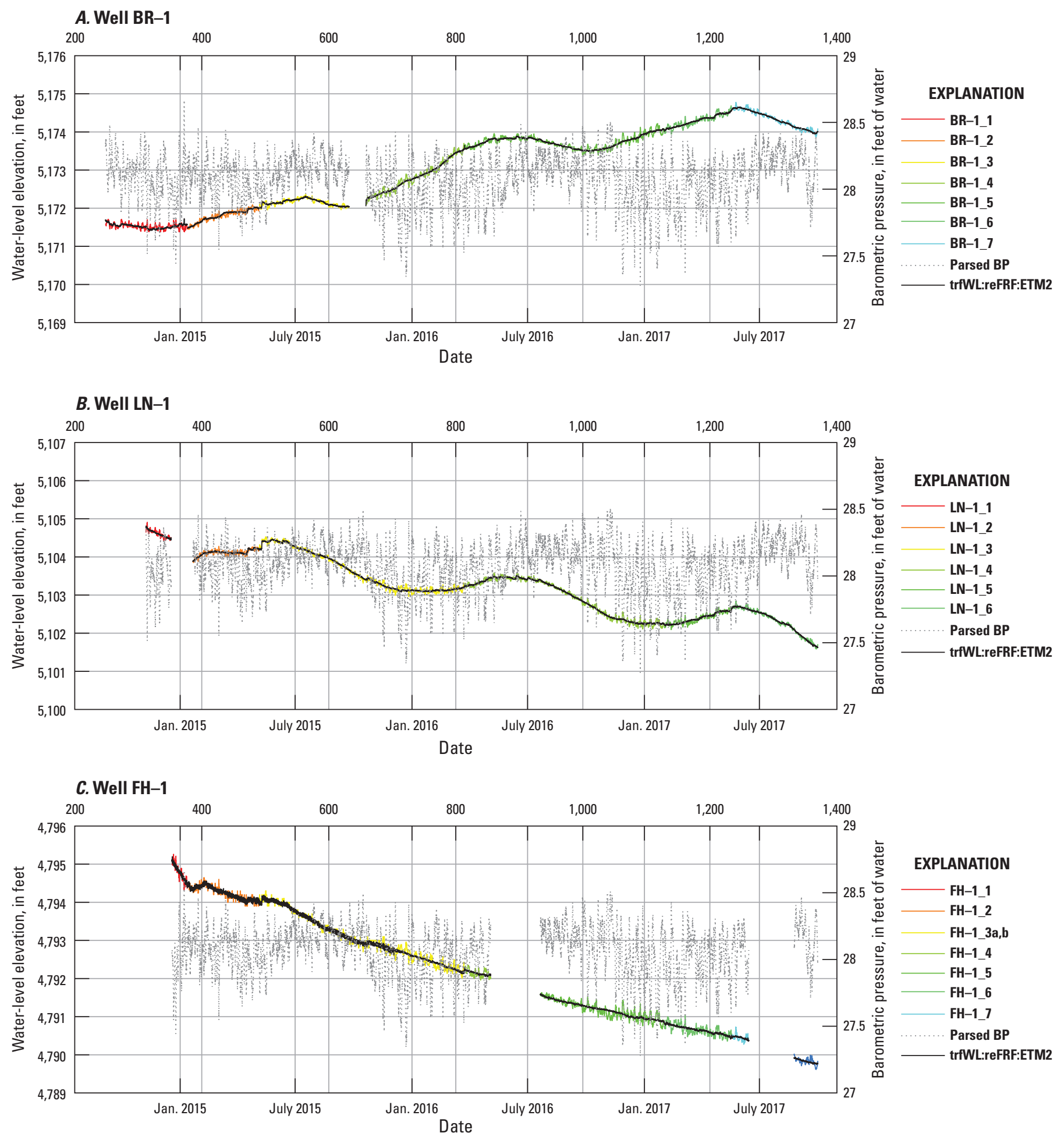

EXPLANATION

BP Barometric pressure

trfWL:reFRF:ETM2 Reconstructed, filtered water-level time series computed using the frequency response function reFRF:ETM2

Figure 58. Reconstructed (trends restored), filtered water-levels trfWL:reFRF:ETM2 shown with water level and barometric pressure for parsed time series from wells BR-1, LN-1, and FH-1, southeastern Laramie County, Wyoming. A, BR-1, September 5, 2014-September 30 , 2017; B, LN-1, November 8, 2014-September 30, 2017; C, FH-1, December 19, 2014-September 30, 2017. 
wells $\mathrm{LN}-1$ and $\mathrm{FH}-1$, respectively, for the periods analyzed during 2014-17. The reconstructed filtered water-level time series, trfWL:reFRF:ETM2, computed using the reFRF:ETM2 frequency response function model for each of the parsed series analyzed in this section for each of the wells are given in Galloway and Bartos (2021, tables 2-4).

\section{Interpretations and Summary of Results of the Water-Level Responses to Earth Tides and Atmospheric Loading, Filtered Water-Level Responses to Other Hydrologic Stresses and Computed Vertical Hydraulic Gradients}

This section describes interpretations and summarizes results of the water-level responses in wells BR-1, $\mathrm{LN}-1$, and FH-1 to Earth tides, atmospheric loading, and other hydrologic stresses retained in the filtered water levels (Earth-tide and atmospheric-loading effects removed) presented previously. The responses to Earth tides and atmospheric loading are used to estimate aquifer/well hydraulic properties. The estimated hydraulic properties are compared to hydraulic properties estimated from other studies. Filtered water-level responses to other hydrologic stresses such as recharge to and discharge from the aquifers, and surface loading are presented and analyzed. Filtered water levels are used to compute and interpret time series of vertical hydraulic gradients between the aquifers penetrated by wells BR-1, $\mathrm{LN}-1$, and $\mathrm{FH}-1$.

\section{Earth Tides}

Water levels in wells $\mathrm{BR}-1, \mathrm{LN}-1$, and $\mathrm{FH}-1$ respond moderately to weakly to the two principal lunar tides $\left(\mathrm{M}_{2}\right.$ and $\mathrm{O}_{1}$ ) of the solid Earth tide, especially the $\mathrm{M}_{2}$ tide that has the largest tidal potential and areal strain of the principal lunar tides. The mean amplitudes of the water-level responses for BR-1, LN-1, and FH-1 were about $0.004,0.007$, and $0.011 \mathrm{ft}$, respectively, for $\mathrm{M}_{2}$ and about $0.003,0.004$, and $0.006 \mathrm{ft}$, respectively, for $\mathrm{O}_{1}$ (table 15). The mean phase shifts of the responses for wells BR-1, $\mathrm{LN}-1$, and $\mathrm{FH}-1$ were about -133 , -184 , and $-182^{\circ}$, respectively, for $\mathrm{M}_{2}$ and about $-149,-176$, and $-176^{\circ}$, respectively, for $\mathrm{O}_{1}$ (table 15 ). The amplitudes and phase shifts of the water-level responses for both tides, with respect to the expected antiphase $\left(-180^{\circ}\right)$ responses for an ideal (undrained) water-level response to a homogeneous areal dilatation of the Earth tides, were close to ideal (antiphase). The mean phase shifts determined for the well BR -1 responses were lagged and were about -133 and $-149^{\circ}$ for $\mathrm{M}_{2}$ and $\mathrm{O}_{1}$, respectively. The mean ratios of the waterlevel amplitudes to the areal-strain amplitudes for the BR-1 responses, $2.42 \times 10^{-4}$ and $3.53 \times 10^{-4}$ feet per nanostrain for $\mathrm{M}_{2}$ and $\mathrm{O}_{1}$, respectively, differed by about 31 percent with respect to the $\mathrm{O}_{1}$ ratio (table 15). In contrast to well $\mathrm{BR}-1$, the mean ratios for wells $\mathrm{LN}-1$ and $\mathrm{FH}-1$ were similar: $4.33 \times 10^{-4}$ and $4.13 \times 10^{-4}$ and $6.39 \times 10^{-4}$ and $6.50 \times 10^{-4}$ feet per nanostrain, for $\mathrm{M}_{2}$ and $\mathrm{O}_{1}$, respectively (table 15 ). The larger mean phase lag and reduced mean ratio of water-level amplitude to areal-strain amplitude for the BR-1 water-level responses to the $\mathrm{M}_{2}$ tidal dilatation can be explained by drainage effects occurring at the higher frequency of the $\mathrm{M}_{2}$ tide that are consistent with wellbore-storage effects in BR-1. These effects are manifest by low hydraulic conductivity $(K)$ of either the formation penetrated by, and in hydraulic communication with, the open interval in BR-1 or a zone in the borehole (skin effect) in this interval or both. The similar values for the mean ratios of water-level amplitudes to areal-strain amplitudes for the $\mathrm{M}_{2}$ and $\mathrm{O}_{1}$ tides in $\mathrm{LN}-1$ and in $\mathrm{FH}-1$ are consistent with an undrained response to a homogeneous solid earth tide.

\section{Atmospheric Loading}

The water-level responses to changes in BP (atmospheric loading) were examined to determine if a constant $\mathrm{BE}$ could adequately explain the well/aquifer responses to atmospheric loading. The frequency dependence of BE was also examined and was used to determine quantitative and qualitative information regarding fluid-flow effects affecting the well/aquifer responses to atmospheric loading.

\section{Constant Barometric Efficiency}

Estimates of a constant-valued BE for each well using four linear regression methods revealed that the lp (cut-off frequency of $0.7 \mathrm{cpd}$ ) method (BE2a) explained more variation in the regression for each well than the other methods, although BE1 was a close second in each well (table 12). The BE1 and BE2a methods were weighted more by the generally larger atmospheric loading stresses occurring at frequencies below the diurnal and semidiurnal loading of Earth tides and BP. Estimates of the mean BEs determined from BE1 and BE2a differed (absolute value of the differences) by less than 0.01 for each well and were about $0.31,0.26$, and 0.48 for wells BR $-1, \mathrm{LN}-1$, and $\mathrm{FH}-1$, respectively. Note that parsed series FH-1_1-3a were omitted from these comparisons.

Estimates of BE from methods BE2b and 3 considered the generally smaller atmospheric loading stresses occurring at frequencies that included the diurnal loading of earth tides and BP and higher frequencies. Much less variation in the water-level responses to atmospheric loading for each well was explained by the regressions using these methods than for methods 1 and 2a. The least variation was explained by the regressions using method 3 for each well. For methods $2 \mathrm{~b}$ and 3 , the mean BE estimates were about 0.13 and $0.12,0.30$ and 0.22 , and 0.48 and 0.35 for wells $\mathrm{BR}-1, \mathrm{LN}-1$, and $\mathrm{FH}-1$, respectively. The mean estimated BEs determined using method $2 \mathrm{~b}$ compared with those using methods 1 or $2 \mathrm{a}$ were about 0.18 lower, 0.05 higher, and nearly equivalent for wells BR-1, LN-1, and FH-1, respectively. The differences for well BR-1 indicated that the higher frequency water-level responses to atmospheric loading were substantially less than the lower frequency water-level responses. 


\section{Frequency Dependent Barometric Efficiency}

The frequency response functions computed for each parsed series for each well provided quantitative and qualitative information regarding the frequency dependence of the water-level responses to atmospheric loading. Quantitatively, useful estimates of BE in terms of the gain and phase shift of the water-level responses were provided at discrete frequencies in the range of about $0.02-2.5 \mathrm{cpd}$. Qualitatively, the frequency responses provided useful information regarding the degree of confinement of the aquifers in hydraulic communication with the wells and related information regarding the presence or absence of discernible drainage effects affecting the responses. Of the three frequency response functions computed for each well (FRF, FRF:ETM2, and reFRF:ETM2), the resampled, with prior $\mathrm{M}_{2}$-scaled tidal filtering, reFRF:ETM2 generally provided the best estimates of the frequency dependence of the water-level responses to atmospheric loading (fig. 53 and table 17). For frequency responses with high values of squared coherence (greater than or equal to 0.85 ), $\mathrm{M}_{2}$-scaled tidal filtering of the water levels before computation of the frequency response function (FRF:ETM2) and resampling of that function (reFRF:ETM2) tended to reduce interference between water-level responses to Earth tides and BP at the critical frequencies of 1 and $2 \mathrm{cpd}$ (fig. 53). The gains and phase shifts of the water-level responses in wells LN-1 and FH-1 were generally flat (independent of frequency) throughout the range of frequencies analyzed, whereas those for well BR-1 indicated a frequency dependence for frequencies higher than about $0.2 \mathrm{cpd}$, Progressive changes in the gains and phase shifts occurred for increasing frequencies greater than $0.2 \mathrm{cpd}$. Gains were gradually attenuated, and phase shifts were continually increased, indicating a progressively lagged response with respect to the atmospheric loadings.

The responses for wells LN-1 and FH-1 were consistent with a confined-aquifer response (for example, solid blue line in rightmost plot in fig. 51A), absent drainage effects. The responses for well BR-1 were consistent with a confinedaquifer response with drainage effects at frequencies higher than about $0.2 \mathrm{cpd}$ that could be explained by wellbore-storage effects (for example, dashed cyan lines in rightmost plots fig. 51A). This response in well BR-1 is consistent with the differences in the mean estimates of constant BE determined using BE1 or BE2a and those determined using BE2b and 3 . The BR-1 phase responses at about 1 and 2 cpd are generally consistent with the phase shifts (lags) determined for waterlevel responses to the $\mathrm{O}_{1}$ and $\mathrm{M}_{2}$ Earth tides. The mean phases computed from the frequency responses (with respect to the expected antiphase relation of BP and water level) for each of the parsed series analyzed for well BR-1 indicated phase lags at 1 and 2 cpd of about -126 and $-124^{\circ}$, respectively (as can be generally inferred from fig. 54B).

Static-confined barometric efficiencies were estimated from the mean gains and phase shifts of the frequency responses in the frequency bands representing the flat part responses (fig. 54). The estimated static-confined BEs for
BR-1, LN-1, and FH- 1 were about $0.36,0.32$, and 0.52 , respectively. These estimates were slightly higher by 0.04 0.07 than the BEs estimated using either constant BE methods, $\mathrm{BE} 1$ or BE2a, and are considered to have a higher degree of uncertainty than the BE1 and BE2a estimates.

\section{Estimates of Hydraulic Properties Based on Well Responses to Atmospheric Loading and Earth Tides}

Estimates of aquifer storage properties, specific storage $(S s)$, porosity $(n)$, and matrix compressibility $(\alpha)$, were made for the aquifers monitored in wells BR-1 (White River aquifer), $\mathrm{LN}-1$ (Lance aquifer), and $\mathrm{FH}-1$ (Fox Hills aquifer) based on the static-confined water-level responses to atmospheric loading and Earth tides. These estimates were made using the method presented by Bredehoeft (1967). Because the static-confined water-level responses to atmospheric loading and Earth tides were observed in wells $\mathrm{LN}-1$ and $\mathrm{FH}-1$, it was possible to estimate $S s, n$, and $\alpha$ directly from the observed responses in those wells. Because fluid flow attributed to wellbore-storage effects affected the observed water-level responses at diurnal and semidiurnal frequencies in well BR-1, the static-confined responses to atmospheric loading and Earth tides at these frequencies were not observed. Thus, before estimating $S s, n$, and $\alpha$ using the Bredehoeft (1967) method, it was necessary to estimate the static-confined water-level responses at these frequencies in BR-1. The static-confined water-level response to atmospheric loading was observed at lower frequencies (less than about $0.2 \mathrm{cpd}$ ) in BR-1, and this response was used to represent the static-confined response to atmospheric loading at the diurnal and semidiurnal frequencies. The static-confined water-level response to Earth tides in BR-1 was estimated by correcting the observed areal-strain sensitivity (or areal dilatational efficiency) of the water-level responses to Earth tides. The correction technique used was based on the lagged water-level response to the forcing $\mathrm{M}_{2}$ Earth tide observed in well BR-1. The lagged response is attributed to wellbore-storage effects. The technique used the theoretical development and method presented by Hsieh and others (1987) for estimating $T$ from lagged water-level responses to Earth tides. Because lagged responses to the Earth tides attributable to fluid-flow effects were not evident in wells $\mathrm{LN}-1$ and $\mathrm{FH}-1$, it was not possible to estimate $T$ using this method for the hydrogeologic units monitored in these wells. Nonetheless, it is possible to estimate a lower bound for $T$ in wells $\mathrm{LN}-1$ and $\mathrm{FH}-1$.

The formulations of Bredehoeft (1967) for computing Ss, $n$, and $\alpha$ based on the static-confined water-level response to atmospheric loading and Earth tides are presented in the following section. Next, in a subsequent section, the estimates are presented for wells $\mathrm{LN}-1$ and $\mathrm{FH}-1$. Next, in a following section, the technique for estimating $T$ (and $K$ from the estimated $T)$ and the static-confined areal dilatational efficiency based on Hsieh and others (1987), and estimates of $K, S s, n$, and $\alpha$ are presented for well BR-1. Lastly, in a subsequent section, 
lower bounding estimates of $K$ made using the Hsieh and others (1987) method are presented for wells LN-1 and FH-1.

\section{Specific Storage, Porosity, and Matrix Compressibility} Formulations

In the standard groundwater-flow theory (Jacob, 1940), the elastic storage coefficient, generally referred to as the storage coefficient $(S)$ of a confined aquifer is related to the aquifer specific storage $(S s)$ by

$$
S=S_{s} b
$$

where

$$
\begin{gathered}
b \quad \text { is the thickness of the aquifer and } \\
S s \quad \text { is the aquifer specific storage, defined as }
\end{gathered}
$$

$$
S_{s}=\rho_{w} g\left(a+n \beta_{f}\right)
$$

where

$$
\begin{array}{ll}
a & \text { is the matrix compressibility, } \\
n & \text { is porosity, and } \\
\beta_{f} & \text { is the fluid (water) compressibility. }
\end{array}
$$

The specific storage $(S s)$ represents the volume of water that an aquifer releases or takes into storage per unit volume of aquifer-system material per unit change in head. Inherent in the definition are three assumptions: (1) vertical total stress remains constant, (2) there is no horizontal deformation, and (3) the solid grains of the rock constituting the rock matrix of the aquifer material are incompressible. The matrix compressibility, $a$, used in the standard theory of groundwater flow represents the drained vertical compressibility and characterizes compression of the porous medium without lateral deformation. In the absence of fluid-flow effects (the static-confined condition), the sensitivity of the well response to atmospheric loading and Earth tides can be used to compute the elastic material properties, $S s, a$, and $n$ of an aquifer (Bredehoeft, 1967). See Hsieh and others (1988) for further discussion on the applicability of the Bredehoeft (1967) formulations for estimating $S s$ from water-level responses to atmospheric loading and Earth tides.

In the following formulations, known values for Poisson's ratio $(v=0.25)$ and fluid (water) compressibility $\left(\beta_{f}=4.4 \times 10^{-10}\right.$ pascals $^{-1}$, or about $2.107 \times 10^{-8}$ pounds per square foot) were assumed. Calculations were done using parameter values expressed in International System of Units, and the computed and assumed parameter values are expressed in U.S. customary units of feet, pounds, and days in later sections; computed values for $a$ presented in table 18 are presented in International System of Units and U.S. customary units for purposes of comparison with results from other studies.

Bredehoeft (1967) determined that for the assumptions in the standard formulation of $S s$, if a value for Poisson's ratio can be assumed, $S s$ can be computed using
Table 18. Groundwater-storage-related property values computed for wells BR-1, LN-1, and FH-1, southeastern Laramie County, Wyoming.

$\left[D E_{a}\right.$ is dilatational efficiency in units of feet per nanostrain; $S_{s}$ is specific storage computed using Bredehoeft (1967) formulation in units of per feet; $n$ is porosity computed using Bredehoeft (1967) formulation; $\alpha$ is matrix compressibility computed using Bredehoeft (1967) formulation in units of per pounds per square feet and per Pascals. Abbreviations: $\mathrm{ft}$, foot; psf, pound per square foot; $\mathrm{Pa}$, pascal]

\begin{tabular}{lccc}
\hline \multirow{2}{*}{$\begin{array}{c}\text { Groundwater-storage } \\
\text { related property values }\end{array}$} & BR-1 & LN-1 & FH-1 \\
\cline { 2 - 4 } \multicolumn{4}{c}{ Measured or inferred } \\
\hline${ }^{\mathrm{a} D E_{a} \times 10^{-4} \mathrm{ft}^{1} \text { nanostrain }}{ }^{-1}$ & 4.26 & 4.30 & 6.40 \\
\hline \multicolumn{4}{c}{ Calculated } \\
\hline$S_{s} \times 10^{-6} \mathrm{ft}^{-1}$ & 1.56 & 1.55 & 1.04 \\
$n$ & 0.43 & 0.38 & 0.41 \\
$\alpha \times 10^{-8} \mathrm{psf}^{-1}$ & 1.60 & 1.69 & 0.80 \\
$\alpha \times 10^{-10} \mathrm{~Pa}^{-1}$ & 3.35 & 3.53 & 1.67 \\
\hline
\end{tabular}

${ }^{a}$ Value for well BR-1 inferred using analytical solution of Hsieh and others (1987); values for wells $\mathrm{LN}-1$ and $\mathrm{FH}-1$ are the measured static-confined responses.

$$
S_{s}=\frac{(1-2 v)}{D E_{a}(1-v)}
$$

where

$$
\begin{array}{cl}
v & \text { is Poisson's ratio and } \\
D E_{\alpha} & \text { is the areal dilatational efficiency of the well } \\
& \text { response to Earth tides. }
\end{array}
$$

If the BE is known, Bredehoeft (1967) determined that porosity can be computed using

$$
n=\frac{(B E) S_{s}}{\rho_{w} g \beta_{f}} .
$$

Once $S s$ and $n$ are determined, the matrix compressibility can be computed from equation 37 using

$$
\alpha=\frac{S_{s}}{\rho_{w} g}-n \beta_{f} .
$$

Estimates of Specific Storage, Porosity, and Matrix Compressibility for Wells $\mathrm{LN}-1$ and $\mathrm{FH}-1$

The Bredehoeft (1967) formulations were used to compute $S s, n$, and $\alpha$ based on the water-level responses to atmospheric loading and Earth tides in wells LN-1 and FH-1 (table 18). For both wells, the static-confined BE determined from the frequency responses to atmospheric loading (see fig. 54C, E) were used for $B E$ (eq. 39), and the mean arealstrain sensitivities computed for the $\mathrm{M}_{2}$ tide (table 15) were interpreted to be representative static-confined responses and were used for $D E_{a}$ (eq. 38). 
Estimates of Transmissivity, Hydraulic Conductivity, Specific Storage, Porosity, and Matrix Compressibility for Well BR-1

For well BR-1, the static-confined response to atmospheric loading was not observed at diurnal and semidiurnal frequencies. This was attributed to lateral drainage effects associated with wellbore storage. The static-confined BE was computed from the estimated static-confined BE (about 0.36) based on the frequency response of water levels to atmospheric loading for the frequencies less than about $0.2 \mathrm{cpd}$ (fig. 54A, B). Water-level responses greater than about $0.2 \mathrm{cpd}$ were affected by wellbore-storage effects; thus, to estimate hydraulic properties using the Bredehoeft (1967) formulations, it was necessary to infer a static-confined $D E_{\alpha}$. This was done using the method of Hsieh and others (1987) based on the mean phase shift $\left(-132.5^{\circ}\right)$ and mean areal-strain sensitivity (about $2.4 \times 10^{-4} \mathrm{ft} /$ nanostrain) computed for the $\mathrm{M}_{2}$ tide (table 15).

Hsieh and others (1987) developed an analytical method (referred to as the "Hsieh method" hereafter) for estimating $T$ based on a periodic solution (Hsieh and others, 1987, eq. 11) for drawdown (in the absence of inertial effects) in a well completed in a confined aquifer with a periodic discharge, where a pressure-head disturbance in the aquifer produces a discharge from the aquifer to the well. The water-level fluctuation in the well is assumed to occur within the well casing. The periodic solution is expressed in terms of the amplitude and phase of the ratio of the response of water level in the well to the aquifer pressure head (expressed in terms of equivalent head) (Hsieh and others, 1987, eqs. 12-18) as a function of two dimensionless parameters:

$$
\begin{aligned}
& \frac{T \tau}{r_{c}{ }^{2}}, \\
& \frac{S r_{w}{ }^{2}}{r_{c}{ }^{2}},
\end{aligned}
$$

where

$$
\begin{array}{cl}
T & \text { is the aquifer transmissivity, } \\
\tau & \text { is the period of the water-level fluctuation, } \\
r_{c} & \text { is the radius of the well casing, } \\
S & \text { is the aquifer elastic storage coefficient, and } \\
r_{w} & \text { is the radius of the well bore in the screened } \\
& \text { or open interval of the well. }
\end{array}
$$

The amplitude and phase of the Hsieh and others (1987) solution (referred to as the "Hsieh solution" hereafter) as a function of the dimensionless parameter $T \tau / r_{c}^{2}$ for values of the dimensionless parameter $S r_{w}{ }^{2} / r_{c}{ }^{2}$ are shown in figure 59. The amplitude represents an attenuation factor whereby an amplitude of 0 represents a fully attenuated or no well water-level response to an aquifer pressure-head disturbance, and a value of 1 represents no attenuation of the water-level response. Similarly, for phase shift, $-90^{\circ}$ represents a lagged, fully attenuated water-level response and $0^{\circ}$ represents an in-phase (no attenuation) water-level response. In terms of wellbore-storage effects on the water-level response, no attenuation of the response indicates no wellbore-storage effects.

The Hsieh method can be used where wellbore-storage effects affect water-level responses to Earth tides (for example, Merritt, 2004; Fuentes-Arreazola and others, 2018). Merritt (2004) determined that the method was not applicable in aquifers with high $T$ for wells in which water-level responses to Earth tides were not substantially affected by wellbore-storage effects. The method estimates $T$ of the monitored hydrogeologic unit and the amplitude attenuation of the water-level response to a particular Earth tide based on known values of the frequency of the tide, phase lag of the water-level response to the tide, well-casing and borehole radii, and an a priori estimate of $S$. Because dilatation is defined as positive in this report and negative in the development of the Hsieh solution, it is necessary to translate the phase shifts determined here to equivalent phases as defined in the Hsieh solution. The phase shifts that lag the tidal dilation in this report represent positively shifted values with respect to an expected antiphase $\left(-180^{\circ}\right)$ response of water level to tidal dilatation; thus, to translate the phase shifts measured in well BR-1 to equivalent phases computed in the Hsieh solution, the measured phase shifts here need to be subtracted from $-180^{\circ}$. For example, the mean measured $\mathrm{M}_{2}$ water-level phase shift of $-132.5^{\circ}$ for well BR-1 (table 15) represents a phase lag that translates to a phase shift (lag) of $-47.5^{\circ}\left(-180^{\circ}--132.5^{\circ}\right)$ in the reference frame used in the Hsieh solution.

The procedure used in this report is an iterative process based on trial values of $S$ to estimate the amplitude attenuation and $T$, based on the mean measured phase lag of the well BR-1 water-level response to the $\mathrm{M}_{2}$ tide. Known values of phase lag $\left(-47.5^{\circ}\right)$, radius of casing $(0.1578 \mathrm{ft}$; from 4-in. internal diameter of schedule 80 PVC casing), radius of well $(0.3594 \mathrm{ft}$; based on drilled 8.6250-in. diameter borehole), and $\tau$ ( 0.51752505 day; period of the $\mathrm{M}_{2}$ tide) were used in the calculation. The procedure was implemented using a simple algorithm described in the following steps. (1) The procedure began by computing a range of specified values of $T \tau / r_{c}{ }_{c}^{2}$ between 1 and 100 at increments of 0.001 (for example, fig. 59) for reference purposes and by computing an initial $S s$ estimate using the Bredehoeft (1967) formulation (eq. 38) with the mean measured (uncorrected) $\mathrm{M}_{2}$ areal-strain sensitivity (table 15) for $D E_{a}$ in the formulation. (2) $S$ was computed using equation 36 for $b$ equal to $10.4 \mathrm{ft}$, the thickness of the "sandy unit" in the open interval of well BR-1, and the parameter value $S r_{w}{ }^{2} / r_{c}{ }_{c}^{2}$ was calculated and used to compute and plot the Hsieh solution in terms of amplitude and phase shift. (3) A match point $\left(T \tau / r_{c}^{2},-47.5^{\circ}\right)$ on the phase-shift plot representing the intersection of the translated $\mathrm{M}_{2}$ phase lag $\left(-47.5^{\circ}\right)$ and the computed $\mathrm{Sr}_{w}{ }^{2} / r_{c}{ }^{2}$ curve was computed using linear interpolation to determine the match point of the measured phase lag between computed values of phase lag from the $S r_{w}{ }^{2} / r_{c}{ }^{2}$ curve and the corresponding interpolated value of $T \tau / r_{c}^{2}$ between the specified values of $T \tau / r_{c}^{2}$. (4) The amplitude corresponding to the match-point value of $T \tau / r_{c}^{2}$ on the $S r_{w}{ }^{2} / r_{c}{ }^{2}$ curve was determined from the amplitude plot 

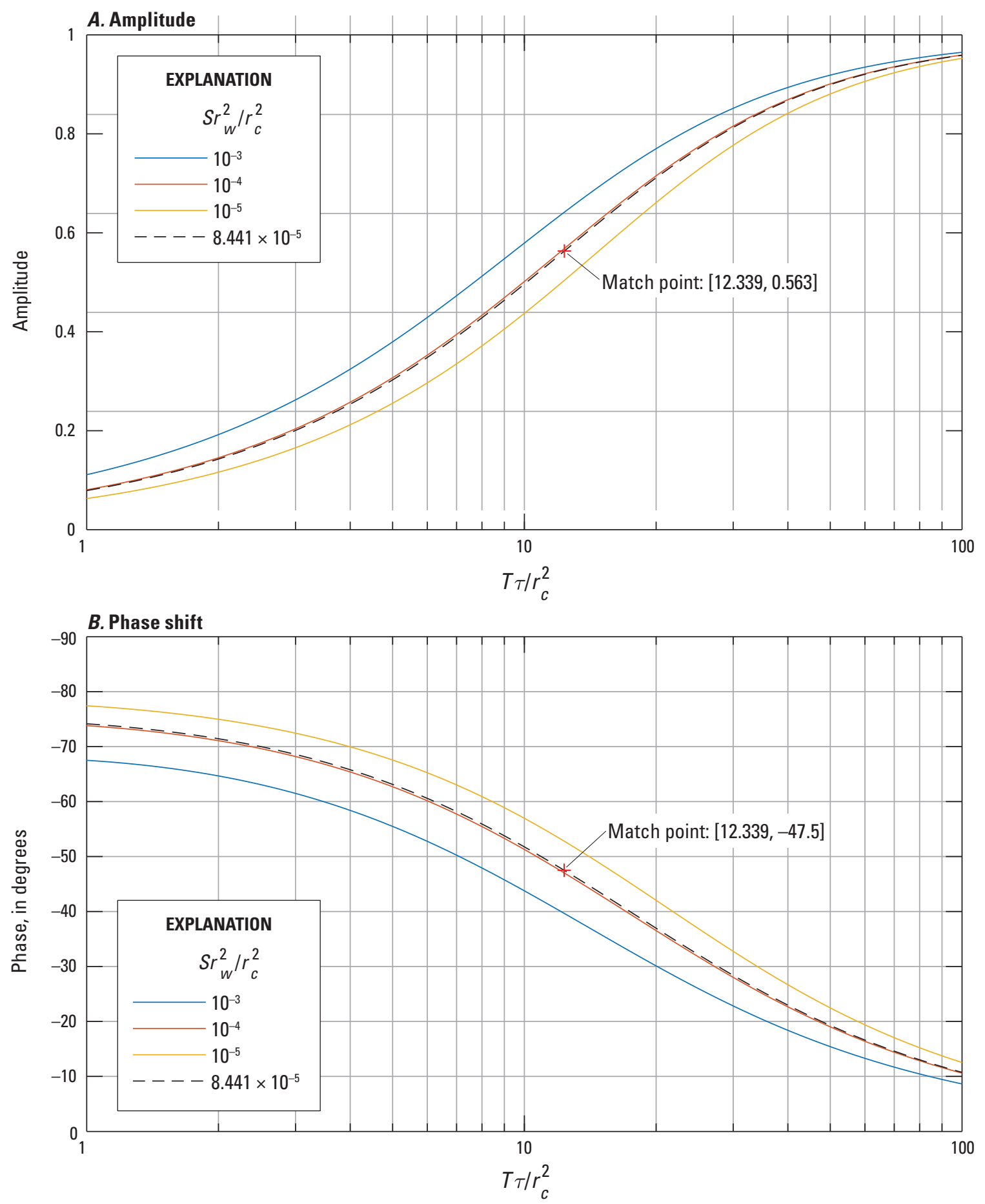

EXPLANATION

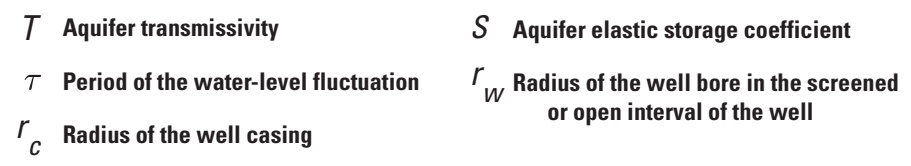

Figure 59. Amplitude (amplitude attenuation factor) and phase shift computed using the Hsieh solution (Hsieh and others, 1987) for the response of water level in an open well completed in a confined aquifer to the head disturbance in the aquifer caused by Earth tide dilatation (areal) of the aquifer. Also shown are the match-point values for the computed response for well BR-1, southeastern Laramie County, Wyoming. $A$, amplitude; $B$, phase shift. 
using a similar linear interpolation process as described in step 3. (5) A corrected $D E_{a}$ value was calculated by dividing the mean measured $M_{2}$ areal-strain sensitivity by the amplitude determined in step 4. (6) A new Ss was computed from the Bredehoeft (1967) formulation (eq. 38) using the corrected $D E_{a}$ value from step 5. Steps 2-6 were repeated until the differences in computed sequential $S s$ values and differences in computed sequential amplitude values differed by less than 0.05 percent, which occurred after three iterations. The final iteration value of the corrected $D E_{a}$ (step 5) was assumed to represent the inferred static-confined areal dilatational efficiency, $D E_{a}$ (table 18). The analysis revealed that the measured areal-strain sensitivity (table 15) of the water-level response to the $\mathrm{M}_{2}$ tide was reduced by a factor of about 0.563 (final iteration value for amplitude) from that of the inferred $D E_{a}$. Using the final match point value for $T \tau / r_{c}^{2}$, a $T$ of $0.59 \mathrm{ft}^{2} / \mathrm{d}$ was computed. Using the $10.4-\mathrm{ft}$ thickness $(b)$ of the aquifer monitored in well BR-1, this equates to a horizontal hydraulic conductivity $(K=T / b)$ estimate of about $0.057 \mathrm{ft} / \mathrm{d}$ for that unit.

Using the inferred $D E_{a}$ computed from the preceding analysis using the Hsieh method, the Bredehoeft (1967) formulations were used to compute $S s, n$, and $\alpha$ for the monitored aquifer in well BR-1. The computed values are close to those computed for well LN-1 (table 18).

\section{Lower Bounding Estimates of Transmissivity and Hydraulic} Conductivity for Wells $\mathrm{LN}-1$ and $\mathrm{FH}-1$

Though no discernible drainage effects were evident in the water-level responses to Earth tides in wells $\mathrm{LN}-1$ and FH-1, lower bounding $T$ and $K$ estimates of the aquifers measured in wells $\mathrm{LN}-1$ and $\mathrm{FH}-1$ were made using the Hsieh method, assuming possible phase shifts equal to the measured phase shifts minus two standard deviations of the water-level responses to the $\mathrm{M}_{2}$ tide for each well (table 15). The mean measured LN-1 and FH-1 $\mathrm{M}_{2}$ water-level phase shifts of -183.6 and $-182.5^{\circ}$ (table 15 ), respectively, represent small phase advances of $+3.6^{\circ}\left(-180^{\circ}--183.6^{\circ}\right)$ and $+2.5^{\circ}$ $\left(-180^{\circ}--182.5^{\circ}\right)$ in the Hsieh solution reference frame. Assuming that the actual phase shifts were two standard deviations $\left(2\right.$ times $4.3^{\circ}$ for $\mathrm{LN}-1$ and -2 times $3.9^{\circ}$ for $\mathrm{FH}-1$ [table 15]) less gives phase shifts (lags) of -5.0 and $-5.3^{\circ}$ for wells $\mathrm{LN}-1$ and $\mathrm{FH}-1$ in the Hsieh solution reference frame, respectively. The lower bounding estimates of $T$ and $K$ were computed by implementing steps 2-4 (with no iterations) described previously using the following parameter values: $S s$ (table 18), $r_{c}$, and $r_{w}$ equivalent to those for well BR-1; aquifer thicknesses $(b)$ of 18 and $37.9 \mathrm{ft}$ monitored in wells LN-1 and $\mathrm{FH}-1$, respectively; and the assumed phase lags of -5.0 and $-5.3^{\circ}$ for wells $\mathrm{LN}-1$ and $\mathrm{FH}-1$, respectively. Because of the small assumed phase lags, the computed amplitudes were $0.98-0.99$ for wells $\mathrm{LN}-1$ and $\mathrm{FH}-1$, reflecting negligible amplitude attenuation; thus, the corrected $D E_{a}, S s, n$, and $\alpha$ values differed negligibly from the static-confined values shown in table 18. The computed lower bounding estimates for $T$ and $K$ are $10.8 \mathrm{ft}^{2} / \mathrm{d}$ and $0.60 \mathrm{ft} / \mathrm{d}$ for well $\mathrm{LN}-1$ and
$10.0 \mathrm{ft}^{2} / \mathrm{d}$ and $0.26 \mathrm{ft} / \mathrm{d}$ for well $\mathrm{FH}-1$. Compared to $T$ and $K$ estimates for well BR-1, the lower bounding $T$ estimates for wells $\mathrm{LN}-1$ and $\mathrm{FH}-1$ are about 17-18 times greater, and the lower bounding $K$ estimates are about 11 and 5 times greater for wells $\mathrm{LN}-1$ and $\mathrm{FH}-1$, respectively. The actual $K$ values likely are higher than these lower bounding $K$ estimates for wells $\mathrm{LN}-1$ and $\mathrm{FH}-1$.

\section{Comparison of Hydraulic Properties Estimated for Wells BR-1,} $\mathrm{LN}-1$, and $\mathrm{FH}-1$ with Properties Determined in Other Studies

Hydraulic properties have been determined in other studies for the aquifers monitored in this study or for aquifers with similar lithologic properties to those included in this study. This section of the report compared the hydraulic properties for wells BR-1 (White River aquifer), $\mathrm{LN}-1$ (Lance aquifer), and FH-1 (Fox Hills aquifer) determined in this report with properties determined in other studies.

Well BR-1.-After an exhaustive search, no reported results from aquifer tests completed in isolated sandstones in the White River Formation in southeastern Wyoming were discovered. Most of the tests that have been done focused on permeable zones that can substantially increase the waterbearing capacity of the units, either in parts of the formation where secondary permeability has developed in mudrocks or in localized sandy gravel/conglomerate deposits (for example, Morris and Babcock, 1960; Lowry and Crist, 1967; Crist and Borchert, 1972; Borchert, 1976; Trihydro Corporation, 1990, 2009; AVI Professional Corporation and Lidstone and Anderson, Inc., 1994; Lidstone and Associates, Inc., 2003; AVI Professional Corporation and others, 2008).

The estimated $K$ for well BR-1 $(0.057 \mathrm{ft} / \mathrm{d})$ falls in the middle of the range of values for sandstone, silt, loess, and unconsolidated deposits summarized in Freeze and Cherry (1979). Laboratory tests of $K$ on core samples from siltstones in the White River Formation in Goshen County, Wyo., yielded estimates from "too small to be measured accurately" to $0.027 \mathrm{ft} / \mathrm{d}$ (Lowry and Crist, 1967, p. 25, $0.027 \mathrm{ft} / \mathrm{d}$ reported as 0.2 gallon per day per square foot). The upper range value is about a factor of two smaller than the $K$ estimated in the present study for well BR-1. A calibrated groundwater-flow model of Laramie County developed for the WSEO determined final calibrated values of $K$ ranging from about 0.20 to $0.33 \mathrm{ft} / \mathrm{d}$ for the model unit comprising the lower permeability parts of the White River Formation in the present study area (AMEC Environment and Infrastructure, Inc., and others, 2014, reported as 0.06-0.1 meter per day for model layer 3, fig. 6.4). These values are about 3.5-5.8 times greater than the $K$ estimated in the present study for well BR-1.

Wells $L N-1$ and $F H-1$.- Comparisons of the lower bounding $K$ estimates for wells $\mathrm{LN}-1$ (Lance aquifer) and $\mathrm{FH}-1$ (Fox Hills aquifer) with other estimates made in the Denver Basin indicate that the lower bounding estimates fall at about the 50th and between the 10th and 25th percentile values, respectively, compiled by Paschke and others (2011, fig. A36) for the Laramie-Fox Hills aquifer in the Denver Basin. More locally, in the Cheyenne Basin, a nearly 3-day single-well, airlift 
"pumping" and recovery test in a test/production well (identified herein as well FH-4) near Pine Bluffs, Wyo., about $11 \mathrm{mi}$ from the study site (fig. 30) yielded $T$ estimates of $123.2 \mathrm{ft}^{2} / \mathrm{d}$ (pumping phase) and $80.2 \mathrm{ft}^{2} / \mathrm{d}$ (recovery phase), representative of a composite response from two intervals open to the well (Dahlgren Consulting, Inc., and others, 2005). The tested intervals were a 40 -ft-thick sandstone in the Fox Hills Sandstone and a 420 -ft-thick shale with occasional thin sand stringers in the Pierre Shale. Specific-capacity tests in the composite interval and in the interval open to the Pierre Shale indicated that the specific capacity of the composite interval was about 10 times that of the Pierre Shale interval. Thus, to account for the flow contributed by the Pierre Shale interval during the composite-interval test, assuming $T$ is directly proportional to specific capacity (Theis and others, 1954), the estimated $T$ values from the composite-interval test were adjusted downward by 10 percent to yield estimated $K$ values for the Fox Hills Sandstone of 1.8-2.8 ft/d (using the monitored sandstone thickness of $40 \mathrm{ft}$ ). These values are about 3-11 times greater than the lower bounding $K$ estimates determined for the sandstones monitored in wells $\mathrm{LN}-1$ and $\mathrm{FH}-1$.

Near Yoder, Wyo., about 60 mi north of the study site in Goshen Hole, single-well, airlift "pumping" tests in a test hole/well (identified in their study as "Yoder Test Hole \#1," and herein as "well FH-6") yielded $T$ and $K$ estimates of the Lance and Fox Hills aquifers contained in sandstone beds in the Lance Formation and Fox Hills Sandstone (inflatable packers used to isolate different intervals within FH-6 for testing; Wyoming Groundwater, LLC, and others, 2011). The estimated $T$ values were $119 \mathrm{ft}^{2} / \mathrm{d}$ for the Fox Hills aquifer and $21-47 \mathrm{ft}^{2} / \mathrm{d}$ for the Lance aquifer. The resulting estimated $K$ values were $2.2 \mathrm{ft} / \mathrm{d}$ for the Fox Hills aquifer (sandstone thickness of $55 \mathrm{ft}$ ) and $0.5-0.7 \mathrm{ft} / \mathrm{d}$ for the Lance aquifer (cumulative sandstone thickness of 32-94 ft). These $K$ estimates from well FH-6 for the Lance aquifer are nearly equal to the lower bounding $K$ estimated for well $\mathrm{LN}-1$; for the Fox Hills aquifer, the $K$ estimates from well FH-6 are about eight times greater than the lower bounding $K$ estimated for well FH-1. Subsequently, a nearby well completed in the Fox Hills aquifer (similarly named by Wyoming Groundwater, LLC, and others (2011) as "Yoder Test Well \#1," and identified herein as "well FH-7") was drilled and completed. A 5-day single-well pumping test of well FH-7 yielded a $T$ estimate of $102 \mathrm{ft}^{2} / \mathrm{d}$. Using a sandstone thickness of $48 \mathrm{ft}, K$ was estimated to be about $2.1 \mathrm{ft} / \mathrm{d}$, which is about eight times greater than the lower bounding $K$ estimated for well $\mathrm{FH}-1$.

Two pumping tests and one airlift "pumping" test were done in wells open to individual sandstone beds of the Fox Hills Sandstone near Nunn, Colo. (fig. 4), about $40 \mathrm{mi}$ southwest of the study site as part of the Centennial project - proposed solution mining of uranium from roll-front deposits in the Fox Hills Sandstone (SRK Consulting, 2010). Analysis of the tests completed in 2007 and 2008 yielded $K$ estimates of about 0.8 and $1.7 \mathrm{ft} / \mathrm{d}$ for two tests in the same well and $1.1 \mathrm{ft} / \mathrm{d}$ for one test in a different well in the project area. These $K$ values generally are less than a factor of seven larger than the lower bounding $K$ estimates computed in the present study for wells $\mathrm{LN}-1$ and $\mathrm{FH}-1$. SRK Consulting (2010) also report on intrinsic permeability, $K$, and $n$ estimates of various sandstone beds of the Fox Hills Sandstone derived from laboratory tests (although not indicated, it is possible that some of these are sandstone beds in the Laramie Formation). The intrinsic permeability and $K$ values are reported in units of millidarcy and feet per day, respectively. Values of intrinsic permeability and $K$ reported for core samples from 11 drill holes in the project area ( 7 and 4 from the north and south project areas, respectively) ranged from 800 to 3,500 millidarcys (md) and from 1.8 to $280 \mathrm{ft} / \mathrm{d}$, respectively. Assuming that the reported intrinsic permeability values were measured and converted to $K$, the $K$ values as reported are apparently inconsistent with the intrinsic permeability values. Corrected $K$ values were computed using 1 darcy is equal to about $3.17 \times 10^{-5}$ feet per second (ft/s; Freeze and Cherry, 1979, table 2.3 , p. 29), or $1 \mathrm{md}$ is about $2.74 \times 10^{-3} \mathrm{ft} / \mathrm{d}$. A corrected range of $K$ values corresponding to the reported intrinsic permeability values would be about $2.2-9.6 \mathrm{ft} / \mathrm{d}$. The range of $n$ values was $0.26-0.48$ for the 11 core samples. Comparatively, the corrected $K$ values estimated from the Centennial core samples are about 4-16 times greater and 8-37 greater than the lower bounding $K$ estimates computed in the present study for wells $\mathrm{LN}-1$ and $\mathrm{FH}-1$, respectively. The $n$ estimates computed in the present study for wells $\mathrm{LN}-1$ and $\mathrm{FH}-1$ fall within the range of $n$ values estimated from the Centennial core samples.

Weist (1965) reported on results from three aquifer (pumping) tests completed in three wells (B8-63-24bda, B10-66-36dda, and B11-61-4cdb) open to the Laramie Formation in Weld County, Colo. The tests were done by various entities and analyzed by the USGS. For these tests, saturated thickness of the perforated intervals in the wells was available, which enabled the estimation of $K$ from $T$ determined directly from the analyses of the tests. Two of those tests (wells B10-66-36dda and B11-61-4cdb) were multiple-well tests (included an observation well in addition to the pumping well), which allowed for a reliable determination of $S$. Weist (1965) reported values of saturated thickness, $T, K$, and $S$. The reported $K$ values ranged from 0.4 to $0.8 \mathrm{ft} / \mathrm{d}$. For both multiple-well tests, an $S$ of $2.0 \times 10^{-4}$ was reported. Estimates of $S s$ computed using the different saturated thicknesses for the two multiple-well tests $(160$ and $85 \mathrm{ft})$ are $1.3 \times 10^{-6}$ and $2.4 \times 10^{-6} \mathrm{ft}^{-1}$. The reported $K$ values are near the lower bounding $K$ estimated for well $\mathrm{LN}-1(0.60 \mathrm{ft} / \mathrm{d})$ in the present study. The computed $S s$ values from Weist's (1965) reported $S$ value agree well with the estimated $S s$ for well LN-1 $\left(1.55 \times 10^{-6} \mathrm{ft}^{-1}\right)$ in the present study.

Laboratory measurements of $K$ and $n$ made on sandstone core from the Laramie-Fox Hills aquifer (individual formation not specified) from the Kiowa core on the Elbert County Fairgrounds in the town of Kiowa, Colo., about $115 \mathrm{mi}$ southsouthwest of the study site (fig. 4), ranged from $9.7 \times 10^{-4}$ to $2.4 \mathrm{ft} / \mathrm{d}$ and from 0.23 to 0.43 , respectively (Raynolds and others, 2001, tables 4 and 5; range includes samples 42A-45A 
and $47 \mathrm{~A}-51 \mathrm{~A}$ for $K$ and samples $42 \mathrm{~A}-45 \mathrm{~A}$ and $47 \mathrm{~A}-48 \mathrm{~A}$ for $n$ ). Comparatively, the lower bounding $K$ and the $n$ estimates obtained from the present study for the Lance aquifer for well LN-1 $(0.60 \mathrm{ft} / \mathrm{d}$ and 0.38 , respectively) and the Fox Hills aquifer for well FH-1 ( $0.26 \mathrm{ft} / \mathrm{d}$ and 0.41 , respectively) fall near the upper range of the laboratory $K$ values and at the upper range of $n$ values measured in the Kiowa Laramie-Fox Hills aquifer core samples.

Wacinski (1979) analyzed $K$ and $n$ in four core samples of upper Laramie Formation sandstones collected from a well (T. 10 N., R. 62 W, section 24) in north-central Weld County, Colo., about $25 \mathrm{mi}$ from the study site. Four reported $K$ and $n$ values ranged from 3.2 to $3.5 \mathrm{ft} / \mathrm{d}$ and about $0.29-0.35$, respectively. These estimated $K$ values are about five to six times greater than the lower bounding $K(0.60 \mathrm{ft} / \mathrm{d})$ estimated in the present study for well $\mathrm{LN}-1$. The estimated $n$ for well $\mathrm{LN}-1$ $(0.38)$ in the present study is larger, by about $0.03-0.09$, than Wacinski's (1979) $n$ estimates.

Wade (1981) estimated $K$ from sieve analyses and $n$ from bulk density and thin-section analyses of samples from an areally extensive sandstone bed in the Laramie Formation (locally known as the "Grover Sandstone") collected in the Grover/ Keota area of Weld County, Colo. (fig. 4), about 15 mi south of the study site. The reported $n$ estimates ranged from 0.28 to 0.33 , and a $K$ of $10.3 \mathrm{ft} / \mathrm{d}(3,760 \mathrm{ft} / \mathrm{yr})$ was reported. The estimated $K$ is about 17 times greater than the lower bounding $K(0.60 \mathrm{ft} / \mathrm{d})$ estimated in the present study for well $\mathrm{LN}-1$, and the estimated $n$ for well $\mathrm{LN}-1(0.38)$ is larger, by about 0.05 , than the maximum estimated $n$ by Wade (1981). The investigator also noted that another study (identified as "Wyoming Mineral Corporation, 1976" in Wade [1981]; however, a copy of the 1976 report could not be obtained) determined that $n$ averaged 0.38 (14 core samples), which agrees well with the estimated $n$ for $\mathrm{LN}-1(0.38)$ in the present study.

Nibbelink (1983, fig. 78) determined intrinsic permeability and $n$ values for a sandstone bed in the Fox Hills Sandstone (identified as the "A $\mathrm{A}_{2}$ sandstone of the upper Fox Hills Sandstone") cored near the western flank of the formation in the Cheyenne Basin in northeastern Colorado (exact location not specified). The reported intrinsic permeability values were about 1-3 darcys, or the equivalent $K$ values were about $2.7-8.2 \mathrm{ft} / \mathrm{d}$ (converted using 1 darcy is equal to about $3.17 \times 10^{-5} \mathrm{ft} / \mathrm{s}$ [Freeze and Cherry, 1979, table 2.3, p. 29]; values herein are summarized for Nibbelink's "foreshore and upper shoreface" facies of this sandstone bed). The reported $n$ values were about $0.32-0.38$. Compared to the lower bounding $K$ estimates computed in the present study for wells $\mathrm{LN}-1$ and FH-1, Nibbelink's (1983) $K$ estimates are 4.5-14 times and 10-32 times larger, respectively, and their estimated $n$ values are as much as 0.09 smaller than those estimated for wells LN-1 and FH-1 in the present study.

Paschke and others (2011, fig. A36, table A5) compiled $K$ estimates from 147 pumping tests for the Laramie-Fox Hills aquifer in the Denver Basin. Those estimates ranged from 0.003 to $7.2 \mathrm{ft} / \mathrm{d}$. The estimated lower bounding $K$ values for wells $\mathrm{LN}-1(0.60 \mathrm{ft} / \mathrm{d})$ and $\mathrm{FH}-1(0.26 \mathrm{ft} / \mathrm{d})$ fall near the geometric mean $(0.40 \mathrm{ft} / \mathrm{d})$ of the compiled values. The estimated lower bounding $K$ values for wells $\mathrm{LN}-1$ and $\mathrm{FH}-1$ fall near the median $(0.50 \mathrm{ft} / \mathrm{d})$ of the compiled 39 laboratoryderived $K$ values (Paschke and others, 2011, fig. A36, table 5).

The $\mathrm{Ss}$ estimates computed for wells $\mathrm{LN}-1$ $\left(1.55 \times 10^{-6} \mathrm{ft}^{-1}\right)$ and FH-1 $\left(1.04 \times 10^{-6} \mathrm{ft}^{-1}\right)$ in the present study compare well with the value used by Banta and others (2011) for confining units $\left(1.7 \times 10^{-6} \mathrm{ft}^{-1}\right)$ in their regional groundwater-flow model of the Denver Basin aquifer system that included the Laramie-Fox Hills aquifer. Robson and Banta (1990) computed $S s$ ranging from $8.04 \times 10^{-7}$ to $1.22 \times 10^{-6} \mathrm{ft}^{-1}$ for a sandstone aquifer in the Arapahoe Formation in the Denver Basin based on three measurement techniques: pumping tests, $\mathrm{BE}$, and vertical compression of the aquifer. The estimates determined here for wells $\mathrm{LN}-1$ and $\mathrm{FH}-1$ are about a factor of 0.9-1.9 times those computed by Robson and Banta (1990) and about two to three times greater than the $S s$ values used by Banta and others (2011) for aquifers $\left(5.2 \times 10^{-7} \mathrm{ft}^{-1}\right)$ in the Denver Basin groundwater-flow model. The computed $n$ values determined for wells $\mathrm{LN}-1$ and $\mathrm{FH}-1$ in the present study are greater by $0.06-0.09$ than mean porosity values of about 0.32 measured in the Laramie-Fox Hills aquifer in the Denver Basin using laboratory and geophysical techniques (Robson, 1987).

\section{Responses to Other Hydrologic Stresses Retained in the Filtered Water Levels}

Predicted water levels reflected the water-level responses to atmospheric loading and Earth tides. The filtered water levels were the residuals of the measured and the predicted water levels and ideally reflected the removal of atmospheric loading and effects and the retention of water-level responses to other stresses on the monitored aquifers. These "other" stresses were dominated by hydrologic stresses such as recharge to and discharge from the systems, but other stresses such as surface loading and earthquakes may have caused waterlevel responses. An examination of the filtered water levels revealed no discernible responses that could be attributed to earthquakes. Several small (less than about $0.2 \mathrm{ft}$ ) water-level responses attributed to surface loading from precipitation were observed and are discussed later.

\section{Recharge and Discharge}

Water levels in each of the wells responded predominantly to changes in groundwater storage resulting from temporal variations in recharge to and discharge from the monitored aquifers. Water-level trends over the periods of record analyzed during 2014-17 were upward in well BR-1 $(+1.13 \mathrm{ft} / \mathrm{yr})$ and downward in wells $\mathrm{LN}-1(-0.86 \mathrm{ft} / \mathrm{yr})$ and FH-1 (-1.74 ft/yr).

The downward water-level trends in wells $\mathrm{LN}-1$ and FH-1 could have been responses to decreases in the annual, natural recharge amounts during the monitored period relative to the longer term mean, natural annual recharge, and (or) responses to sustained discharge from the monitored aquifers 
during the monitored period. The converse conditions could explain the upward water-level trend in well BR-1; however, the coincidence of decreased natural recharge in the recharge source areas for wells $\mathrm{LN}-1$ and $\mathrm{FH}-1$ and increased natural recharge for well BR-1 is unlikely. Lags in the water-level responses in wells $\mathrm{LN}-1$ and $\mathrm{FH}-1$ to variable annual recharge in their source areas (discussed more later in this section) compared with the responses in well BR-1 could also explain the differences. The responses observed in well FH-1 could represent responses to recharge conditions from many years previous; nevertheless, it is useful to examine if the occurrence of discharge in excess of natural recharge could plausibly explain the trends.

Annual recharge in recharge source areas of aquifers can cause annual (cyclic or sinusoidal) water-level fluctuations in wells tapping the aquifers. The water-level responses in wells located at great distances (for example, tens of miles) from the recharge source areas can manifest as annual cyclical variations in the well hydrographs and can be used to infer characteristics of the well's response to recharge and to estimate hydraulic properties of the aquifers that govern the water-level responses to the distant, annual recharge pulses (for example, Townley, 1995; Dickinson and others, 2004).

Three annual fluctuations of water level attributed to annual recharge were superimposed on the longer term waterlevel trends in wells BR-1 and $\mathrm{LN}-1$ (fig. $58 A, B$ ) and were largely absent or discernably attenuated for $\mathrm{FH}-1$ (fig. $58 \mathrm{C}$ ). The magnitude and timing of the annual fluctuations in the filtered water levels were examined. To facilitate comparisons while preserving the most content of the continuously sampled parsed series, a common start date corresponding to the start date of parsed series LN-1_2 was chosen. For each well, the reconstructed (trends restored), hourly sampled, filtered parsed series (trfWL:reFRF:ETM2) shown in figure 58 were reassembled as a single time series, resampled at a daily rate, and detrended by removing the best straight-line fit to the time series. Gaps (missing daily data) between individual parsed series in the reassembled time series were filled using linear interpolation. An equation of the form of equation 16 for a single frequency of one cycle per year (representing an ideal cyclical, annual recharge pulse) was fit (least-squares regression) to the data. The detrended, daily sampled, reassembled, filtered time series described previously from wells BR- $-1, \mathrm{LN}-1$, and $\mathrm{FH}-1$ and the predicted (best-fitting) annual recharge response are shown in figure 60 . The fit to reassembled series for well $\mathrm{LN}-1$ was quite good (fig. $60 B$; RMSE $=0.074 \mathrm{ft}$ ). The fitted amplitude was $0.376 \mathrm{ft}$, with a phase corresponding to an annual peak response on June 21 each year. The fit to the reassembled series for well BR-1 was fair to poor (fig. $60 \mathrm{~A}$; RMSE $=0.217 \mathrm{ft}$ ). The fitted amplitude was $0.286 \mathrm{ft}$, with a phase corresponding to an annual peak response on April 22 each year. The fit to the reassembled series for well FH-1 was poor (fig. $60 C$; RMSE $=0.115 \mathrm{ft}$ ). The fitted amplitude was $0.098 \mathrm{ft}, 85$ percent of the RMSE, with a phase corresponding to an annual peak response on May 11 each year.
As expected for variable annual recharge, the observed responses to annual recharge in each well, compared to the fitted responses, varied from year to year. The variations were more pronounced in wells BR-1 and FH-1 than in well $\mathrm{LN}-1$. Year-to-year variations in the timing of the peak observed recharge response were as much as 1-2 months in wells BR-1 and FH-1, compared with 2-3 weeks in well $\mathrm{LN}-1$. Year-to-year variations in the peak magnitude of the observed responses were as much as $0.4 \mathrm{ft}$ in well $\mathrm{BR}-1$ and $0.3 \mathrm{ft}$ in well FH-1, compared with less than $0.1 \mathrm{ft}$ in well $\mathrm{LN}-1$. The good fit to the observations in well $\mathrm{LN}-1$ indicates a stable recharge pulse and consistent response, albeit only three responses were observed. The fits for wells BR-1 and FH-1 indicate that the observed water-level responses to annual recharge were quite variable compared with the responses for well LN-1. The more highly variable response in well BR-1 compared with that for well $\mathrm{LN}-1$ could be explained by variable recharge inputs to the two aquifers. However, for regional flow systems, despite the expected annual variability in recharge at the recharge source area, annual responses appreciably downgradient from the source area tend to be less variable as the responses to the annually variable recharge inputs are averaged out and attenuated with distance along the flow path. The amplitude of the response is attenuated, and the phase of the response is lagged as a function of the square root of hydraulic diffusivity $(T / S)$ and the characteristic flow-path length. Long flow-path lengths and low hydraulic diffusivities favor higher amplitude attenuation and phase lag, with higher sensitivity to path length. At some distance, the cyclical response is considered to be in a dynamic equilibrium or periodic steady state with some longer term mean annual recharge.

The water-level responses to recharge in well BR-1 could indicate that the recharge was derived from a different, perhaps more local source than possibly more regional-scale systems monitored by wells $\mathrm{LN}-1$ and $\mathrm{FH}-1$. The well $\mathrm{BR}-1$ hydrograph is similar to, albeit a subdued expression of, hydrographs from other distant wells in the vicinity (Wyoming State Engineer's Office monitoring wells SE Carp, SW Carp, and LC01; fig. 40) during 2014-17, also completed in the White River aquifer (well SE Carp also is completed in $20 \mathrm{ft}$ of overlying Quaternary older alluvial fan deposits), which forms part of or the base of the High Plains aquifer in southeastern Wyoming (see "Relation of Cenozoic Hydrogeologic Units in Pine Bluffs Lowland to High Plains Aquifer System" report section). These wells were affected by nearby groundwater pumping for irrigation purposes and likely affected by local recharge from infiltration of excess applied irrigation water. The steadily increasing water level in well BR-1 (fig. 58A) during the period analyzed in this report is consistent with increased local recharge occurring in this hydrogeologic unit. The lack of a well-defined pulse in well FH-1 could result from nearly complete attenuation of the recharge pulse because of (1) a long flow path and (or) low hydraulic diffusivity and (or) (2) the effects of discharge from the aquifer monitored by well $\mathrm{FH}-1$. 
Decimal day (dd 1 = Jan. 1, 2014)

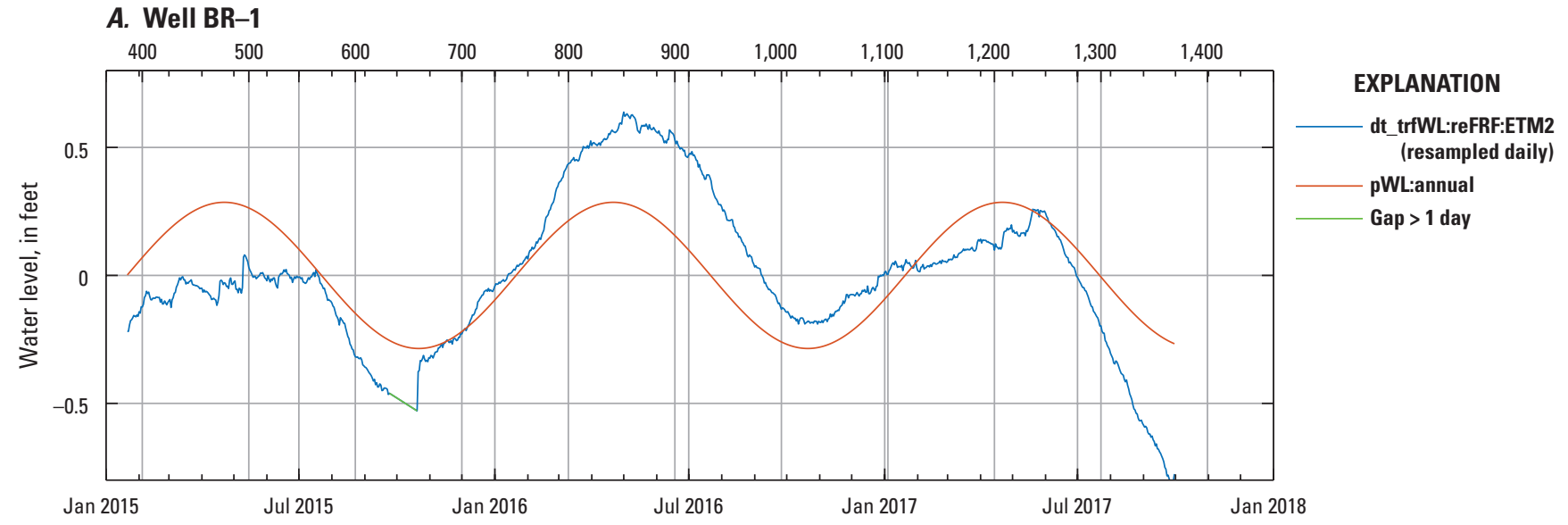

B. Well LN-1

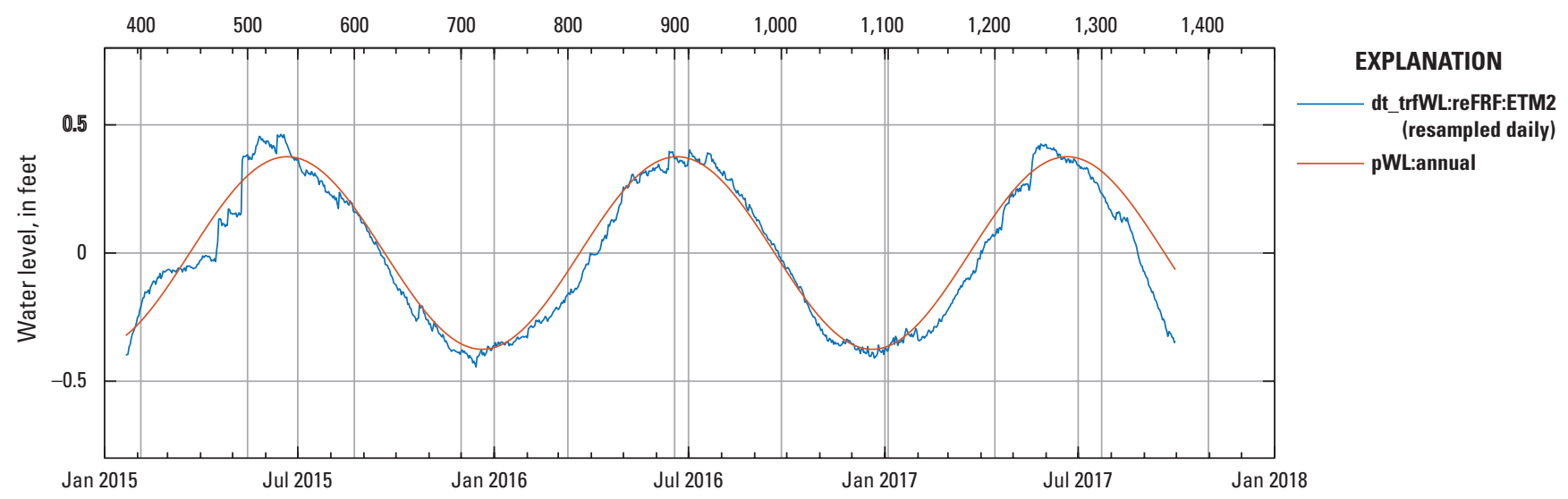

\section{Well FH-1}

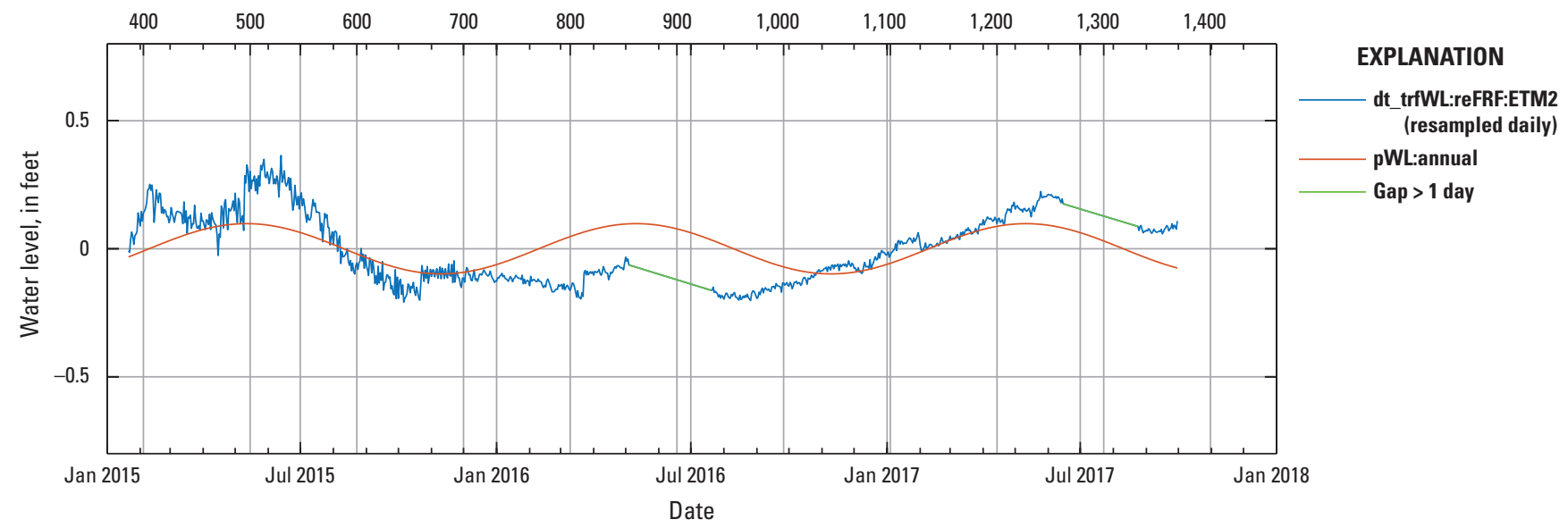

EXPLANATION

dt_trfWL:reFRF:ETM2 Detrended, daily sampled, reassembled, filtered time series computed using the frequency response function reFRF:ETM2

pWL Predicted annual water-level responses to annual recharge pulses

Figure 60. Predicted annual water-level responses to annual recharge pulses computed using the detrended, daily sampled, reassembled, filtered time series for wells BR-1, LN-1, and FH-1, January 21, 2015, to September 30, 2017, southeastern Laramie County, Wyoming. $A, \mathrm{BR}-1 ; B, \mathrm{LN}-1 ; C, \mathrm{FH}-1$. 


\section{Surface Loading}

Small water-level responses (step increases), measured in multiple wells, that were attributed to surface loading from two precipitation episodes are shown in figure 61. The two precipitation episodes occurred May 8-9, 2015 (2.67 in. of rain and 2.2 in. of snow measured at the Cheyenne Airport), and June 12, 2016 (1.44 in. of rain measured at the Cheyenne Airport). In response to the first episode, step increases in water levels of about $0.14,0.2$, and $0.2 \mathrm{ft}$ that began in the morning of May 9 and peaked the morning of May 10 were measured in parsed series BR-1_3, $\mathrm{LN}-1 \_3$, and $\mathrm{FH}-1 \_3 \mathrm{a}$, respectively (fig. $61 A, C$, and $E$ ). Because of the poor measurement resolution $(0.1 \mathrm{ft})$ for parsed series $\mathrm{FH}-1$ _3a during this period, a corrected response for $\mathrm{FH}-1 \_3 \mathrm{a}$ of $0.12 \mathrm{ft}$ was estimated based on the filtered water-level response; filtered and measured step responses in parsed series BR-1_3 and LN-1_3 were nearly the same as the measured values. In response to the second episode, step increases in water levels of about 0.05 and $0.08 \mathrm{ft}$ that began in the early afternoon of June 12 and peaked around midnight that day were measured in parsed series BR-1_5 and LN-1_4, respectively (fig. 61B, $D$ ); data for well $\mathrm{FH}-1$ were not available during this period. For each episode, the increased water levels gradually recovered during the following 5-7 days as the hydraulic heads in the monitored aquifers equilibrated with the surface loads. The maximum water-level response for each loading episode was measured in well $\mathrm{LN}-1$. This was consistent with the relatively larger loading efficiency (1-BE; based on the mean $\mathrm{BE}$ estimated using method 1 from table 12) for well $\mathrm{LN}-1$ of about 0.74 , compared with 0.69 for well BR-1 and 0.52 for well FH-1. For well LN-1, based on ratios of the water-level responses to the loading efficiency, the estimated equivalent loads (expressed as equivalent heights of water, or head) for the two episodes were about 0.27 and $0.11 \mathrm{in}$. Assuming no extensive pooling of water near the well and a snow-water equivalent of about 10 percent for a 0.2 -in. water equivalent derived from the $2.2 \mathrm{in}$. of snow during the first episode, the estimated equivalent loads represented about 8-9 percent of the precipitation totals for each event.

\section{Vertical Hydraulic Gradients}

Vertical hydraulic gradients were computed using the reassembled, reconstructed (trends restored) filtered waterlevel elevations (above NAVD 88) (trfWL:reFRF:ETM2 resampled at a daily rate) and the elevations (above NAVD 88) of the open-interval midpoints in wells BR-1, $\mathrm{LN}-1$, and $\mathrm{FH}-1$ of 5,109.51, 4,755.41, and 4,406.99 ft, respectively. Time series of vertical hydraulic gradients between wells BR-1 and $\mathrm{LN}-1$, and between wells $\mathrm{LN}-1$ and $\mathrm{FH}-1$, were computed using

$$
v g(t)=\frac{\left(h_{2}(t)-h_{1}(t)\right)}{z_{2}-z_{1}}, \text { for } t=1, N
$$

where

$$
\begin{array}{cc}
v g(t) \quad \text { is the vertical hydraulic gradient at time, } t \\
h_{2}(t) \quad \text { is the hydraulic head (water-level elevation, } \\
\text { above NAVD 88) at well LN-1 for } \\
\text { computing the gradient between wells } \\
\text { BR-1 and LN-1 and the hydraulic head } \\
\text { at well FH-1 for computing the gradient } \\
\text { between wells LN-1 and FH-1; } \\
\text { is the hydraulic head (water-level elevation, } \\
\text { above NAVD 88) at well BR-1 for } \\
\text { computing the gradient between wells } \\
\text { BR-1 and LN-1 and the hydraulic head } \\
\text { at well LN-1 for computing the gradient } \\
\text { between wells LN-1 and FH-1; } \\
\text { is the elevation (above NAVD 88) of the } \\
\text { open-interval midpoint in well LN-1 for } \\
\text { computing the gradient between wells } \\
\text { BR-1 and LN-1 and the elevation (above } \\
\text { NAVD 88) of the open-interval midpoint } \\
\text { in well FH-1 for computing the gradient } \\
\text { between wells LN-1 and FH-1; } \\
\text { is the elevation (above NAVD } 88 \text { ) of the } \\
\text { open-interval midpoint in well BR-1 for } \\
\text { computing the gradient between wells } \\
\text { BR-1 and LN-1 and the elevation (above } \\
\text { NAVD 88) of the open-interval midpoint } \\
\text { in well LN-1 for computing the gradient } \\
\text { between wells LN-1 and FH-1; and } \\
\text { is the number of daily head (water-level) } \\
\text { values in the water-level time series. }
\end{array}
$$

The computed vertical hydraulic gradients were positive, indicating downward flow from higher water level (hydraulic head) to lower water level (from the White River aquifer monitored in well BR-1 to the Lance aquifer monitored in well $\mathrm{LN}-1$ and from the Lance aquifer monitored in well $\mathrm{LN}-1$ to the Fox Hills aquifer monitored in well $\mathrm{FH}-1$ ). The gradients varied throughout the period of record analyzed (January 21,2015 , to September 30,2017 ), principally because of the water-level trends during the period (upward for well BR-1 and downward for wells $\mathrm{LN}-1$ and $\mathrm{FH}-1$; see fig. 58). The mean vertical hydraulic gradients were 0.19801 foot per foot (ft/ft) between wells BR-1 and $\mathrm{LN}-1$ and a factor of 4.5 greater between wells LN-1 and FH-1, $0.89295 \mathrm{ft} / \mathrm{ft}$. The vertical gradients were increasing throughout the period of record. The RMSEs of the best-fit line (linear least-squares regressions) to the vertical hydraulic gradient time series were small, $0.00089 \mathrm{ft} / \mathrm{ft}$ between wells BR-1 and LN-1 and $0.000727 \mathrm{ft} / \mathrm{ft}$ between wells $\mathrm{LN}-1$ and $\mathrm{FH}-1$, compared to the respective mean gradients. Variances in the gradients were principally due to the different magnitudes and timing of the annual periodic water-level fluctuations for each well, analyzed previously with respect to evaluating water-level responses to annual recharge pulses (fig. 60). The mean rates of change (increases) in the vertical gradients (computed based on the slopes of the best-fit lines to the vertical hydraulic gradient time series) were 0.00561 and 0.00253 foot per foot per 
Decimal day (dd 1 = Jan. 1, 2014)

\section{A. BR-1 3}

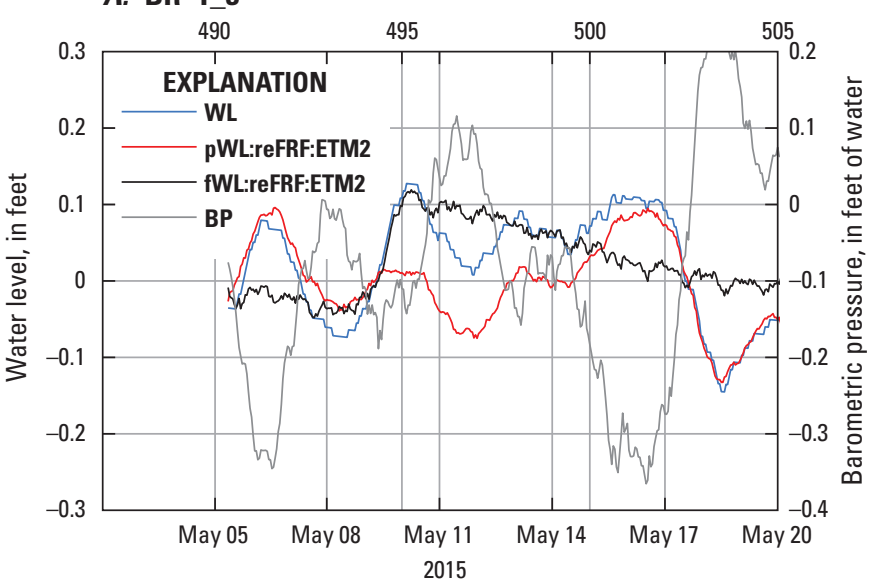

C. FH-1_3a

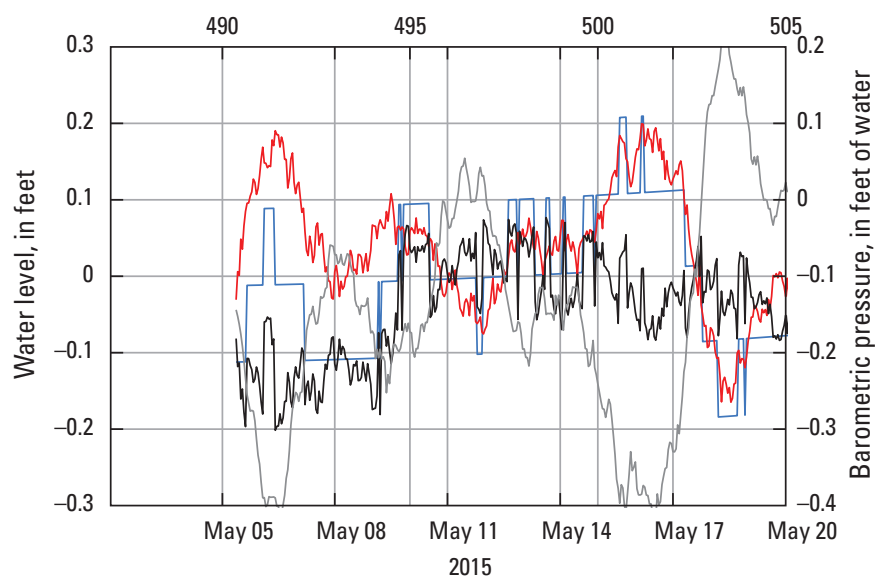

D. BR-1_5

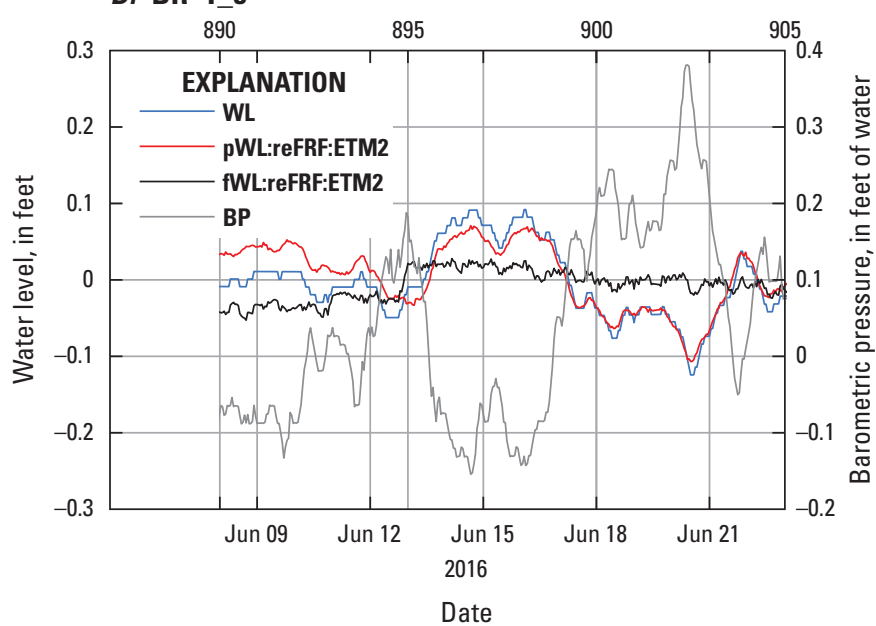

EXPLANATION

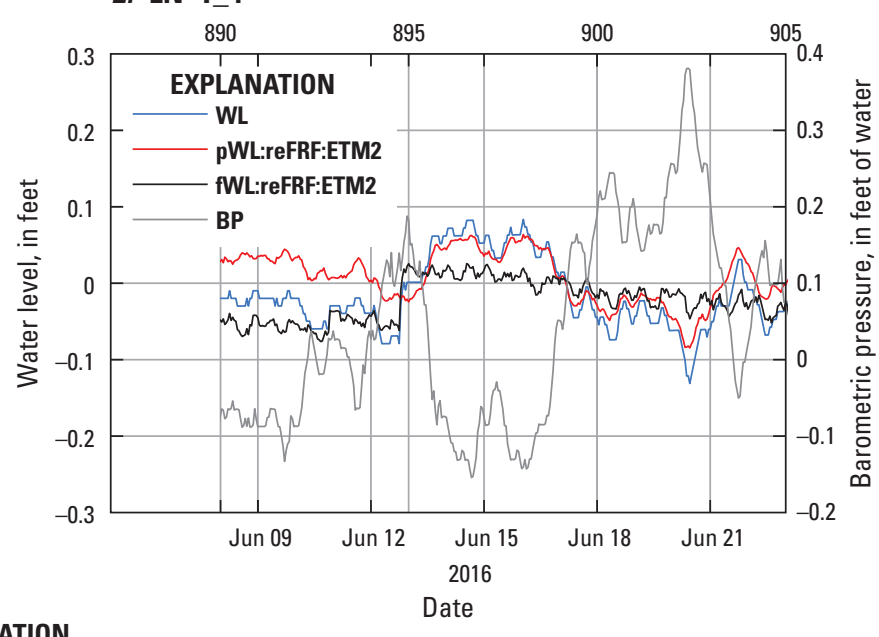

WL Measured detrended water-level response

BP Barometric pressure

pWL:reFRF:ETM2 Predicted detrended water-level response computed using the frequency response function reFRF:ETM2

fWL:reFRF:ETM2 Filtered detrended water-level response computed using the frequency response function reFRF:ETM2

Figure 61. Measured, predicted, and filtered detrended water-level responses to two precipitation loading episodes, May 8-9, 2015, and June 12, 2016, in parsed series for wells BR-1, LN-1, and FH-1, southeastern Laramie County, Wyoming, shown with detrended barometric pressure. A, BR-1_3, May 5-20, 2015; B, LN-1_3, May 5-20, 2015; C, FH-1_3a, May 5-20, 2015; D, BR-1_5, June 8-23, 2016; E, LN-1_4, June 8-23, 2016. 
year between wells BR-1 and $\mathrm{LN}-1$ and between wells $\mathrm{LN}-1$ and $\mathrm{FH}-1$, respectively.

The vertical flow of groundwater between the aquifers monitored by wells BR-1 and $\mathrm{LN}-1$ was downward toward the aquifer monitored by well FH-1. Based on Darcy's law, this flow is controlled by the magnitude of vertical gradients between the aquifers and by the vertical hydraulic conductivity $\left(K_{v}\right)$ of the monitored aquifers and any intervening units/strata. The computed vertical hydraulic gradients indicated a strong potential for downward flow that increased slightly during the period of record analyzed in this report. However, the large hydraulic-head differences between wells BR-1 and LN-1 (about $70 \mathrm{ft}$ ) and between wells $\mathrm{LN}-1$ and FH-1 (about $310 \mathrm{ft}$ ) indicate that a high impedance (low $K_{v}$ ) to flow exists between the aquifers monitored by these wells. Coupled with the dissimilarities between groundwater-level fluctuations and trends in groundwater levels measured during the period of record analyzed in this report (for example, figs. 58 and 60), vertical downward flow between wells BR-1 and $\mathrm{LN}-1$ and between wells $\mathrm{LN}-1$ and $\mathrm{FH}-1$ likely was small.

\section{Interpretation of the Groundwater System at the Study Site}

A groundwater system at any given location is defined by the aquifers and confining units that underlie the area (Heath, 1983). Physical and chemical characteristics collected from the various hydrogeologic units as part of this study are summarized and synthesized and, in some cases, selectively evaluated in relation to characteristics described in previous studies. Combined, these characteristics were used to interpret the groundwater system at the study site, including definition of lithostratigraphic units (lithostratigraphy) or parts of lithostratigraphic units as hydrogeologic units (hydrostratigraphy).

\section{Quaternary Older Alluvial Fan Deposits}

Water-bearing characteristics of the Quaternary older alluvial fan deposits (0-40 ft BLS) at the study site were not assessed as part of this study. Mapping of the saturated thickness of these deposits and associated aquifer ("fan aquifer" herein) in southeastern Laramie County revealed no saturated thickness of these deposits at the study site (area of fan deposits mapped by Crist and Borchert [1972] as saturated reproduced on fig. 30). The drilling and coring techniques used in the present study (use of heavy mud while coring and subsequent installation of steel surface casing to seal the Quaternary older alluvial fan deposits) precluded evaluation of deposit saturation at the study site.

\section{White River Hydrogeologic Unit}

The White River hydrogeologic unit, consisting of all $407.3 \mathrm{ft}$ of the White River Formation at the study site
(40-447.3 ft BLS), was relatively homogenous and composed almost entirely of mudrocks except for a few thin beds of sandstone, muddy gravel, and conglomerate. Water-bearing zones/aquifers in the White River hydrogeologic unit typically are localized, consisting primarily of either (1) zones of secondary porosity/permeability development in the mudrocks that compose most of the formation or (2) coarse-grained rocks (for example, sandstone and conglomerate) of sufficient thickness and permeability to compose an aquifer. Detailed descriptions of core collected from the entire thickness of the White River hydrogeologic unit indicated no substantial secondary permeability features except for a few minor voids in one depth interval ("Lithology" report section). Only one coarse-grained depth interval (117-127.4 ft BLS; muddy sandstone) is of sufficient thickness and permeability to contain an aquifer. Monitoring well BR-1 was completed with the $20-\mathrm{ft}$ well screen open to the entire thickness of the muddy sandstone in this interval and partly open to overlying/underlying mudrocks, many of which were sandy.

Well development, well purging for groundwater sampling, and calculated aquifer properties indicated the sandstone aquifer screened by monitoring well BR-1 was not very productive. A low pumping rate of less than about $0.2 \mathrm{gal} /$ min was necessary to prevent substantial groundwater-level decline during purging. Calculation of $T$ and $K$ (see "Estimates of Transmissivity, Hydraulic Conductivity, Specific Storage, Porosity, and Matrix Compressibility for Well BR-1" and "Lower Bounding Estimates of Transmissivity and Hydraulic Conductivity for Wells $\mathrm{LN}-1$ and $\mathrm{FH}-1$ " report sections) resulted in low estimates of both properties ( $T$ of $0.59 \mathrm{ft}^{2} / \mathrm{d}$ and $K$ of $0.057 \mathrm{ft} / \mathrm{d}$ ). A $T$ of less than about $1 \mathrm{ft}^{2} / \mathrm{d}$ would not qualify as an aquifer or a feasible water supply in some classification schemes used to evaluate water-supply or well potential (Kasenow, 2001, table 6.3, and Bureau of Reclamation, 1985, fig. 2-4, respectively).

The computed frequency response of groundwater levels in well BR-1 to atmospheric loading was consistent with a confined-aquifer response with wellbore drainage effects (see "Frequency Dependent Barometric Efficiency" subsection under the "Atmospheric Loading" report section). Given that the sandstone aquifer screened in well BR-1 is overlain and underlain by thick sequences of low-permeability mudrocks (fig. 11; appendix 1, table 1.1; plate 1), the confined nature of this aquifer is not surprising. Large hydraulic-head differences between well BR-1 and well LN-1 completed in a deeper sandstone subaquifer in the upper Lance Formation/hydrogeologic unit indicated the intervening mudrocks (almost all of which are part of the White River Formation/ hydrogeologic unit) had low $K_{v}$ and downward flow (including recharge) through the intervening strata (primarily mudrocks) between wells BR-1 and LN-1 (and vertical hydraulic connection between these aquifers) likely was small (see "Vertical Hydraulic Gradients" report section and next report section, "Lance Hydrogeologic Unit").

Some amount of hydraulic connection between the sandstone aquifer screened by well BR-1 and the upper part 
of the White River hydrogeologic unit at the study site and more broadly in the area underlain by the terrace was evident, but collected physical and chemical data indicated differing and somewhat contradictory amounts of hydraulic connection. Recharge responses in well BR-1 indicated that recharge likely was locally derived, possibly because of, at least in part, infiltration of excess applied irrigation water; this indicates at least some degree of downward movement of waters through the overlying part of the unit to the sandstone aquifer. The BR-1 hydrograph was similar to, albeit a subdued expression of, hydrographs from other distant wells completed in the White River aquifer in the vicinity (Wyoming State Engineer's Office monitoring wells SE Carp [well also completed in $20 \mathrm{ft}$ of overlying Quaternary older alluvial fan deposits], SW Carp, and LC01), indicating some degree of connection throughout the hydrogeologic unit. However, the well BR-1 hydrograph did not show the large groundwater-level declines from pumping of nearby irrigation wells observed in these other hydrographs, indicating a more limited hydraulic connection throughout the upper part of the White River hydrogeologic unit. Ionic composition of water from well BR-1 was different from waters from nearby and more distant wells completed in the White River aquifer, indicating some degree of isolation from the rest of the unit. However, the stable isotope composition of water from well BR-1 was similar to waters from some nearby eastern Laramie County wells completed in the White River aquifer, indicating waters from well BR-1 likely were subject to similar recharge and evolutional paths, despite differing water types. The presence of oxic water (DO $>1 \mathrm{mg} / \mathrm{L}$ ) in well BR-1 is indicative of active movement of waters through the upper part of the hydrogeologic unit, but the absence of tritium indicating older (premodern, or prebomb) water contradicted this interpretation, though tritium was analyzed in only a single groundwater sample. DO can be unintentionally introduced during sampling into waters that otherwise are naturally anoxic; however, the detection of nitrate in water sampled from well BR-1, a species of nitrogen stable in oxic waters, indicated the field DO measurement was indicative of oxic waters in the White River aquifer.

\section{Lance Hydrogeologic Unit}

Because no sandstone beds were present in the lowermost/basal part of the Lance Formation immediately above or intertonguing with the Fox Hills Sandstone (Lance-Fox Hills aquifer), all the strata comprising the defined Lance hydrogeologic unit at the study site were interpreted to be Lance Formation strata. As is the case throughout much of the Cheyenne Basin in Wyoming and northeastern Colorado (see previous "Lance Formation" report section under "Upper Cretaceous Strata" section and "Lance Hydrogeologic Unit" report section under "Upper Cretaceous Hydrogeologic Units" section), lithologic characteristics of the Lance hydrogeologic unit at the study site indicated only a small amount of total unit thickness (all of which was water saturated) had the potential to yield useful quantities of water (and thus be considered water-bearing or potential aquifer material). Including thin coal beds, fine-grained mudrocks composed about 80 percent of unit thickness, and only about 20 percent of the unit consisted of coarser grained sedimentary rocks (very fine- to medium-grained muddy or silty sandstone). The water-bearing potential of the coal beds was not evaluated, but most beds were less than 1-ft thick and cumulatively represented little of total unit thickness. Most sandstone beds were in the upper part of the formation, from about 457 to $517 \mathrm{ft} \mathrm{BLS}$. Below this 60 -ft-thick "sandy" interval, most of the Lance Formation consisted of fine-grained mudrocks interbedded with sparse thin sandstone beds (most $<2.5 \mathrm{ft}$ thick) and thin coal beds (see the "Lithology" report section under "Lance Formation" under "Upper Cretaceous Strata" sections). Thus, at the study site below the "sandy" interval, most of the Lance hydrogeologic unit consists of various low-permeability lithologies (various types of mudrocks) unlikely to yield substantial quantities of water to wells. Based on lithology and other information (discussed in this section), this part of the Lance hydrogeologic unit below the "sandy" interval largely functions as a confining unit separating the underlying Lance-Fox Hills aquifer and the overlying "sandy" interval in the upper part of the Lance hydrogeologic unit. Examination of the geologic cross section constructed for this study indicated fine-grained sediments also composed a substantial part of the Lance Formation/ hydrogeologic unit throughout southern Laramie County along the line of section (fig. 29), a characteristic of the hydrogeologic unit that likely applies throughout the Wyoming and Colorado parts of the Cheyenne Basin.

Completion and subsequent development of monitoring well $\mathrm{LN}-1$ indicated sandstone beds can form moderately productive confined subaquifers within the uppermost part of the Lance hydrogeologic unit at the study site. Despite being composed largely of very fine- to medium-grained muddy sandstone and only partial penetration by the well, the sandstone subaquifer penetrated by monitoring well $\mathrm{LN}-1$ produced about 7,000 gallons of water during well development over a period of about 5 hours (mean of about $23 \mathrm{gal} / \mathrm{min}$; airlifting started and stopped several times during development, and airlift volume rates were varied during development); no attempt was made to determine a maximum production rate from the monitoring well. Larger water volumes likely could be produced by a well constructed for use as a source of supply, including a well screen open to the entire thickness of the aquifer, because only about $13.5 \mathrm{ft}$ of the 18.0 -ft-thick aquifer was open to the screened interval of monitoring well $\mathrm{LN}-1$. Much of the productivity of this fine-grained aquifer likely is attributable to the largely unconsolidated or poorly consolidated (friable) sediments composing the subaquifer, a result of the development of secondary porosity/permeability (see "Petrography" report section under "Lance Formation" under "Upper Cretaceous Strata" sections). Larger volumes of water also could be obtained at the study site by completing a well with the well screen open not only to this subaquifer, but also to the overlying and underlying very fine- to fine-grained sandstone beds/subaquifers within the upper "sandy" interval 
(5.4-ft-thick bed at 457.5-462.9 ft BLS and 11.7-ft-thick bed at $497-508.7 \mathrm{ft}$ BLS, respectively; appendix 1, table 1.1; plate 1).

The frequency response of water levels in well $\mathrm{LN}-1$ to atmospheric loading indicated a confined-aquifer response absent of drainage effects - the static-confined response (see "Frequency Dependent Barometric Efficiency" subsection under the "Atmospheric Loading" report section). The staticconfined response further indicated that the sandstone unit monitored in well $\mathrm{LN}-1$ was relatively hydraulically isolated from the sandstone units monitored in wells BR -1 and $\mathrm{FH}-1$. A lower bounding estimate of $K(0.60 \mathrm{ft} / \mathrm{d})$ for this sandstone unit monitored in well $\mathrm{LN}-1$ was about 11 times greater than the estimated $K$ for the sandstone unit monitored in well BR-1, and based on comparisons with $K$ values estimated for sandstones in the Lance Formation or equivalent stratigraphic units in the Cheyenne and Denver Basins, it is likely that the $K$ of the sandstone monitored in well $\mathrm{LN}-1$ is greater than the lower bounding estimate by as much as $1-1.5$ orders of magnitude. This supports the potential utility of this sandstone unit as a limited source of groundwater supply.

Computed vertical hydraulic gradients ("Vertical Hydraulic Gradients" report section) indicated a strong potential for downward flow throughout the groundwater system at the study site, including from the low-yielding "aquifer" in the upper White River Formation/hydrogeologic unit (monitoring well BR-1) to the sandstone subaquifer in the Lance Formation/hydrogeologic unit (monitoring well LN-1). Large hydraulic-head differences indicated high resistance to vertical flow attributable to the low $K_{v}$ of intervening strata, which consisted almost entirely of low-permeability mudrocks in the White River Formation (see "Lance Formation" report section under "Upper Cretaceous Strata," under "Geologic Characteristics of Study Site Strata" section). Coupled with the highly confined nature of the sandstone aquifer (staticconfined-aquifer response) monitored by well $\mathrm{LN}-1$ and dissimilarities between groundwater-level fluctuations and trends in groundwater levels measured in well BR-1 during the period of record analyzed in this report (see various subsections within "Response of Groundwater Levels to Atmospheric Loading and Earth Tides" report section), downward flow (including recharge) through the intervening strata (primarily) mudrocks between wells BR-1 and LN-1 (and vertical hydraulic connection between these aquifers) likely was small. Nevertheless, consistent annual groundwater-level fluctuations attributable to consistent/stable annual groundwater recharge were observed in well LN-1 during the water-level observation period (see "Recharge and Discharge" report section); these annual fluctuations were superimposed on a longer term downward groundwater-level trend. Given the calculated unadjusted carbon-14 ages indicating the Lance subaquifer likely contained old water that largely may be pre-Holocene $(>11,800 \mathrm{ybp}) /$ late Pleistocene in age and the confining nature of the overlying sediments at the study site, a stable annual recharge pulse is somewhat surprising. One possible explanation for the chemically older waters in the Lance subaquifer could be mixing of older water supplied to the subaquifer by leakage from the adjacent fine-grained, low-permeability hydrogeologic units (for example, from the overlying mudrocks of the White River Formation/White River hydrogeologic unit). This stable recharge pulse and a consistent water-level response may possibly reflect some degree of a more regional (basinwide) flow system in the Lance hydrogeologic unit, with a distant source area(s) of current (modern) recharge (see "Recharge and Discharge" report section). In regional flow systems, annual water-level responses appreciably downgradient from the source area(s) of recharge tend to be less variable as the responses to the annually variable recharge inputs are averaged out and attenuated with distance along the groundwater-flow path. The degree of attenuation is a function of the square root of hydraulic diffusivity and the characteristic flow-path length. Long flow-path lengths and low hydraulic diffusivities favor higher attenuation. At some distance from the source areas of recharge, the consistent annual water-level responses observed in well $\mathrm{LN}-1$ may be reflective of dynamic equilibrium or periodic steady state with some longer term mean annual recharge.

Study of the source area(s) and amount of recharge to Upper Cretaceous lithostratigraphic/hydrogeologic units below the Tertiary hydrogeologic units composing or underlying the High Plains aquifer system, including the Lance hydrogeologic unit (and sandstone subaquifers within the unit) and underlying Lance-Fox Hills aquifer, has been scanty in the Wyoming or Colorado parts of the Cheyenne Basin. Upon initial examination, likely source(s) of recharge to the Lance hydrogeologic unit and the various sandstone subaquifers contained therein would seem to include (1) diffuse and focused recharge to the Lance Formation/hydrogeologic unit outcrop area in Goshen Hole (fig. 30) and subsequent horizontal flow of waters to other parts of the basin, including the study site; (2) downward vertical flow/leakage from/ through overlying Cenozoic lithostratigraphic/hydrogeologic units composing or underlying the High Plains aquifer system (cross-formational/interaquifer flow) at locations throughout the unit's extent in the basin or in specific parts of the basin; or (3) some combination of 1 and 2. No potentiometric-surface maps have been created for the Lance Formation/hydrogeologic unit in the Wyoming part of the Cheyenne Basin, but a comparison between Lance Formation outcrop elevations in the Goshen Hole and the elevation of the top of the sandstone bed monitored in well $\mathrm{LN}-1$ indicates it is unlikely the direction of groundwater flow is southward from the Goshen Hole area to the study site. The discontinuous and lenticular characteristics of the sandstone subaquifers within the Lance hydrogeologic unit would likely make it difficult to create and interpret such maps even if data were available, whether at the local or more basinwide scale. In addition, the sandstone subaquifers are interbedded with substantial quantities of fine-grained mudrocks, so the amount of hydraulic connection between individual sandstone aquifers likely is highly spatially variable and difficult to assess. Combined, these characteristics indicate the Lance hydrogeologic unit at the study site, 
southern Laramie County (cross section $A-A^{\prime}$; fig. 29), and likely throughout the Cheyenne Basin, consists of a system of numerous sandstone subaquifers/aquifers of varying thickness and extent separated and confined by fine-grained low-permeability mudrocks that vary areally and vertically at any given location. Because mudrocks dominate the unit and horizontally and vertically separate/surround the lenticular estuarine and fluvial channel sandstone beds that compose the subaquifers, hydraulic interconnection between subaquifers, although highly variable, overall likely is meager in the Lance hydrogeologic unit, a conclusion also reached for the equivalent Laramie Formation in parts of the Cheyenne Basin of northeastern Colorado (for example, Wade, 1981; SRK Consulting, 2010; Yoshino, 2011). Consequently, the discontinuous sandstone subaquifers in the Lance hydrogeologic unit could be considered as individual aquifers, with available recharge limited to vertical and (or) horizontal leakage through the surrounding confining mudrocks and with each sandstone subaquifer/aquifer potentially having a different potentiometric surface.

\section{Lance-Fox Hills Aquifer}

Because of the absence of any overlying or intertonguing sandstone beds belonging to the lower/basal part of the Lance Formation, the Lance-Fox Hills aquifer at the study site was interpreted to consist only of the five sandstone beds of the Fox Hills Sandstone (see previous report section). Absence of these lower Lance Formation sandstone beds in the Cheyenne Basin is common, as can be seen in the cross section constructed for this study (fig. 29) and other studies (for example, upper Crow Creek drainage within part of the Cheyenne Basin in Wyoming and Colorado, Kirkham and Rold, 1986). In addition, use of the methods presented in the "Identification of Upper Cretaceous Lithostratigraphic Units in the Subsurface" report section likely would result in many of the sandstone beds identified in other studies as part of the lower Lance/ Laramie Formation being alternatively identified as sandstone beds of the upper Fox Hills Sandstone (see Dechesne and others, 2011a). Estuarine and amalgamated fluvial channel deposits of the lowermost Lance/Laramie Formation are difficult to distinguish from the Fox Hills Sandstone, especially on well logs where they have a similar pattern and, from an aquifer perspective, similar hydrogeologic characteristics. Correspondingly, it is likely that many of the sandstone beds identified in other studies as part of the upper Pierre Shale (upper transition member of the Pierre Shale) would be identified as distal sandstone beds of the lower Fox Hills Sandstone, which are the offshore ("more marine") equivalents of older Fox Hills Sandstone beds at the same location. Thus, the multilayered Lance-Fox Hills (Laramie-Fox Hills) aquifer in many parts of the Cheyenne Basin likely consists only of the beds of the Fox Hills Sandstone, the number of which varies by location. This was confirmed to be the case along the southern Laramie County cross section constructed for this study because there are few lower/basal Lance Formation sandstone beds immediately overlying the Fox Hills Sandstone (fig. 29). The cross section (fig. 29) illustrates how the Fox Hills Sandstone, and thus, the part of the Lance-Fox Hills aquifer (most of the aquifer) composed by the formation, consists of a series of sandstone bodies that overlap (shingle) upward to the east across southern Laramie County. These bodies collectively form a relatively continuous body of sandstone, thus forming an areally extensive aquifer across southern Laramie County, and by extension, likely most of the formation's extent in the Wyoming part of the Cheyenne Basin (fig. 4), as is the case in the Colorado part of the basin (Kirkham and Rold, 1986; Dechesne and Raynolds, 2010; Topper and others, 2017).

Completion and subsequent development of monitoring well FH-1 indicated the thickest of five sandstone beds of the Fox Hills Sandstone (37.9 ft thick; 808.4-846.3 ft BLS) composing the Lance-Fox Hills aquifer at the study site was moderately to highly productive. After airlift development, well FH-1, which was completed in a very fine- to mediumgrained muddy and silty sandstone bed (fig. 11; plate 1), easily produced 25 to $30 \mathrm{gal} / \mathrm{min}$; no attempt was made to determine a maximum production rate from the monitoring well. Substantially larger water production rates likely are possible because only $20 \mathrm{ft}$ (entire length of FH-1 well screen) of the 37.9-ft-thick bed (about one-half of thickness) was open to the well and the well was constructed for monitoring, rather than production purposes. A production well completed in this sandstone bed likely could obtain much larger yield. For example, well FH-4 near Pine Bluffs is completed in a 40-ft-thick sandstone bed similar to the bed open to well FH-1; well FH-4 was determined to "safely" yield about $230 \mathrm{gal} / \mathrm{min}$ (conservative estimate of pumping rate that will maintain a minimum of $25 \mathrm{ft}$ of water above the pump intake after 2.5 months of continuous pumping; a small part of this well yield at the time of testing was attributable to thin Pierre Shale sandstones [see "Comparison of Hydraulic Properties Estimated for Wells BR-1, LN-1, and FH-1 with Properties Determined in Other Studies" report section]; Dahlgren Consulting, Inc., and others, 2005).

As was the case with the sandstone subaquifer in the Lance hydrogeologic unit open to monitoring well $\mathrm{LN}-1$, much of the productivity of this fine-grained aquifer likely is attributable to the largely unconsolidated or poorly consolidated (friable) sediments composing the bed, a result of the development of secondary porosity/permeability (see "Petrography" report section under "Fox Hills Sandstone and Upper Transition Member of the Pierre Shale," under "Upper Cretaceous Strata" section). Larger volumes of water also could be obtained from the Lance-Fox Hills aquifer at the study site by completing a well open not only to this bed, but also to the other upper Fox Hills Sandstone bed (overlying 14.7-ft-thick muddy sandstone bed, 779.7-794.4 ft BLS) and some or all three of the underlying distal very fine- to fine-grained muddy and silty sandstone beds composing the lower Fox Hills Sandstone. However, water production from the distal sandstone beds in the lower Fox Hills Sandstone at the study site and elsewhere is expected to be substantially less than production 
from sandstone beds in the upper Fox Hills Sandstone because these beds typically are thinner and overall finer grained because of the predominant offshore depositional environment from which they are derived ("Lithology" and "Petrography" report sections within "Fox Hills Sandstone and Upper Transition Member of the Pierre Shale" part of the report). To improve well yields, completion of wells with one or more screen intervals open to the various sandstone beds of the Fox Hills Sandstone (and overlying lower Laramie Formation, where present) is common practice for establishing water-supply wells in the multilayered Laramie-Fox Hills aquifer in the Cheyenne and Denver Basins of northeastern Colorado (Weist, 1965; Romero, 1976; Wacinski, 1979; Kirkham and Rold, 1986; Robson and Banta, 1990). For example, this method was used for construction of production well FH-2, which is open to multiple sandstone beds of the Fox Hills Sandstone (table 1).

The frequency response of water-levels in FH-1 to atmospheric loading was similar to that of well LN-1 and indicated a confined-aquifer response absent of drainage effects - the static-confined response (see "Frequency Dependent Barometric Efficiency" subsection under the "Atmospheric Loading" report section). The static-confined response further indicated that the sandstone bed monitored in well $\mathrm{FH}-1$ was relatively hydraulically isolated from the sandstone beds monitored in wells BR-1 and LN-1. A lower bounding estimate of $K$ $(0.26 \mathrm{ft} / \mathrm{d})$ for this sandstone bed monitored in well $\mathrm{FH}-1$ was about five times greater than the estimated $K$ for the sandstone bed monitored in well BR-1, and based on comparisons with $K$ values estimated for sandstones in the Lance-Fox Hills and equivalent Laramie-Fox Hills aquifers in the Cheyenne and Denver Basins, it is likely that the $K$ of the sandstone monitored in well FH-1 is greater than the lower bounding estimate by as much as 1-1.5 orders of magnitude. This supports the potential utility of this sandstone bed as a limited source of groundwater supply and, when combined with other sandstone beds in these aquifers, a substantial source of groundwater supply.

Computed vertical hydraulic gradients (see "Vertical Hydraulic Gradients" report section) indicated a strong potential for downward flow from the sandstone subaquifer in the Lance hydrogeologic unit (monitoring well LN-1) to the sandstone bed/aquifer (808.4-846.3 ft BLS) that composes much of the Lance-Fox Hills aquifer thickness at the study site (monitoring well FH-1). However, large hydraulic-head differences (about $310 \mathrm{ft}$ ) indicated high resistance to vertical flow. This high resistance to vertical flow is attributable to the low $K_{v}$ of intervening confining strata, which consisted almost entirely of low-permeability mudrocks in the Lance Formation/hydrogeologic unit (see "Geologic Characteristics of Study Site Strata" report section). Coupled with the highly confined nature of the sandstone aquifer (static-confinedaquifer response without drainage effects) monitored by well FH-1 (various subsections within "Response of Groundwater Levels to Atmospheric Loading and Earth Tides" report section), downward flow (including recharge) and vertical hydraulic connection between these aquifers through the intervening strata (primarily mudrocks) likely was small. Unlike wells BR-1 and LN-1, annual groundwater-level fluctuations largely were absent or discernably attenuated for well FH-1 (fig. 60C). The lack of a well-defined annual recharge pulse in well FH-1 could result from nearly complete attenuation of the recharge pulse because of (1) a long flow path and (or) low hydraulic diffusivity and (or) (2) the effects of discharge from the aquifer system monitored by well $\mathrm{FH}-1$. As was explained in the previous report section ("Lance Hydrogeologic Unit"), recharge to the Lance-Fox Hills aquifer throughout the Wyoming part of the Cheyenne Basin likely is limited primarily to areas where vertical cross-formational recharge occurs because of slight outcrop extent (fig. 30) and burial by overlying Tertiary lithostratigraphic units. Areas for potential diffuse and (or) focused recharge directly to Fox Hills Sandstone outcrops in the Wyoming part of the Cheyenne Basin are limited almost entirely to the upper Horse Creek drainage in western Laramie County (T. 17 N., Rs. 69 and 70 W; fig. 30). In this area, the Fox Hills Sandstone dips about 5 to $8^{\circ}$ eastward (basinward) from the Laramie Mountains (Blackstone, 1996). Any recharge waters successfully entering the aquifer outcrops at this location likely would be able to flow only about $6 \mathrm{mi}$ downdip/eastward into the Cheyenne Basin before meeting the Horse Creek anticline (scaled from Blackstone, 1996, fig. 10, cross section $G-G^{\prime}$ ). Lateral continuity of the Fox Hills Sandstone (and correspondingly, Lance-Fox Hills aquifer) is severed by erosion along the crest of the anticline (Blackstone, 1996, fig. 10, cross section $G-G^{\prime}$ ), preventing downdip (eastward) movement of water deeper into the Cheyenne Basin beyond the anticline extent. If the anticline extent fully parallels the extent of the Fox Hills Sandstone outcrop (unknown if full extent of structure is shown in Blackstone, 1996), there likely is little opportunity for downdip movement of recharge waters deeper into the basin anywhere along the outcrop.

Some insight into the low $K_{v}$ (and thus, highly confining nature) of Lance Formation mudrocks overlying the Lance-Fox Hills aquifer at the study site (and elsewhere in the Cheyenne Basin) is provided by comparison with direct measurements of $K_{v}$ from cores of mudrocks in the equivalent Laramie Formation at two locations in the Denver Basin (Saint Vrain and Kiowa cores in the northern and central Denver Basin, respectively; fig. 4). These measurements are from cored Laramie Formation mudrocks located between the various sandstone beds composing the Laramie-Fox Hills aquifer of the Denver Basin aquifer system. In the Saint Vrain core, $K_{v}$ values determined for five plug samples collected from cored mudrocks (all identified as shale) at depths ranging from 357 to $890 \mathrm{ft}$ BLS were small, ranging from $2.67 \times 10^{-4}$ to $2.27 \mathrm{ft} / \mathrm{d}$ (reported as $9.43 \times 10^{-8}$ to $8.02 \times 10^{-4}$ centimeters per second $[\mathrm{cm} / \mathrm{s}]$; analyzed using air and water as saturating media; Barkmann, 2004, table 3 [converted by Barkmann from original reported intrinsic permeability measurements reported in Major and others, 1983]). The $K_{v}$ values measured in three Kiowa core samples (Barkmann, 2004, table 3) also were small and within a similar range, but the samples were 
collected from greater depths $(1,846.3$ to $2,046.4 \mathrm{ft}$ BLS). In the Kiowa core, $K_{v}$ values (using water as saturating media) determined for two silty mudstone samples were $5.61 \times 10^{-4}$ and $9.95 \mathrm{ft} / \mathrm{d}$ (reported as $1.98 \times 10^{-7}$ and $1.65 \times 10^{-5} \mathrm{~cm} / \mathrm{s} ; 2,242$ and $1,846.3 \mathrm{ft}$ BLS, respectively) and one sandy mudstone was $1.89 \times 10^{-2} \mathrm{ft} / \mathrm{d}$ (reported as $6.68 \times 10^{-6} \mathrm{~cm} / \mathrm{s} ; 2,046.4 \mathrm{ft}$ BLS). Measurements from both sites span a wide range. Some of this variability may be attributable to differences in sample handling and analytical methods, but it also likely reflects differences in mudrock characteristics such as grain size, clay mineralogy, and compaction, and some of these characteristics may vary in relation to geographic location in the Denver Basin (Barkmann, 2004).

\section{Summary}

The geologic and hydrogeologic characteristics of Cenozoic and Upper Cretaceous strata were described physically and chemically and evaluated at a location ("study site") in southeastern Laramie County within the Wyoming part of the Cheyenne Basin, the northern subbasin of the greater Denver Basin. This study, completed by the U.S. Geological Survey in cooperation with the Wyoming State Engineer's Office, was begun to improve understanding of the aquifers/aquifer systems in these strata, motivated in part by declining groundwater levels and interest in exploring future groundwater supplies. Based on detailed geologic characterization using visual descriptions and thin-section petrography of core, as well as geophysical logs obtained from a 960-foot (ft)-deep exploratory borehole (LC-F1), and comparisons with previously published descriptions of equivalent strata in southeastern Wyoming and adjacent northeastern Colorado, two Cenozoic and three Upper Cretaceous lithostratigraphic units were identified at the study site. From shallowest to deepest, identified Cenozoic lithostratigraphic units included Quaternary older alluvial fan deposits and the late Eocene-Oligocene White River Formation; identified Upper Cretaceous lithostratigraphic units included the Lance Formation, Fox Hills Sandstone, and upper transition member of the Pierre Shale. Sediments composing the 40-ft-thick Quaternary unconsolidated older alluvial fan deposits consisted of mixtures of silt, clay, sand, and gravel, with the sand- and gravel-sized sediments overall composing a much larger percentage of the unit than mud-sized sediments (silt and clay). The following summarizes the lithostratigraphic units and hydrogeologic units below these unconsolidated deposits including some hydrogeologic characteristics (hydraulic properties and waterlevel variations) at the study site, in the context of the present regional geologic and hydrogeologic characterization.

Except for a few thin sandstone, muddy gravel, and conglomeratic beds, composition of the 407.3-ft-thick White River Formation was relatively homogenous and consisted almost entirely of mudrocks with varying proportions of mud-sized sediments (clay and silt). The formation was informally divided into three "parts" that generally contained similar lithologic characteristics - an overall coarser upper part ("upper White River") consisting of mudrocks and sandy mudrocks, the underlying middle to lower part of the formation ("middle to lower White River") consisting of a homogenous sequence of mudstone and claystone, and the lowermost part of the formation ("lowermost White River") consisting mostly of mudstone with varying amounts of gravel, including slightly conglomeratic mudstone, conglomeratic mudstone, and conglomeratic sandy mudstone. Four sandstone beds were present in the formation, all of which were in the upper White River Formation; the thickest of these beds was a 10.4-ft-thick muddy (silty and clayey) sandstone. This sandstone bed was water saturated, and a monitoring well (BR-1) was completed with the well screen open to the bed (and partly open to overlying/underlying mudrocks, many of which were sandy).

Present as a "main body" and as a tongue between two sandstone beds of the upper Fox Hills Sandstone, the Lance Formation consisted of $351.6 \mathrm{ft}$ of many types of terrestrial sedimentary rocks that varied with depth, commonly over relatively short depth intervals. Lance Formation sedimentary rocks at the study site included interbedded muddy shale and silty and sandy shale, siltstone, claystone, and mudstone; interbedded very fine- to medium-grained, muddy and silty sandstone; and coal. The upper part of the Lance Formation consisted largely of a unique sequence of mudrocks, identified informally in this study as the "weathered Lance Formation"; the upper part of this varicolored rock sequence represents a zone of ancient pedogenic modification (paleosol zone) that developed on the top of the Lance Formation before deposition of the White River Formation. Including the weathered zone, rocks in the upper part of the Lance Formation generally reflected an increasing abundance of carbonaceous material with depth, including coal. Sandstone beds composed only about 20 percent or less of total formation thickness, and muddy shale and other mudrocks such as sandy siltstone and mudstone composed most of the rest. Thickness of sandstone beds in the Lance Formation ranged from less than 1 to $18 \mathrm{ft}$, but most beds were thin (less than $2.5 \mathrm{ft}$ ). Only five sandstone beds were greater than $2.5 \mathrm{ft}$ in thickness - three were less than $10 \mathrm{ft}$ and two were between 10 and $20 \mathrm{ft}$. Three of the five sandstone beds, including the two thickest, were in the upper Lance Formation that overall was coarser grained than the rest of the formation. A monitoring well ( $\mathrm{LN}-1)$ was completed with the well screen open to $13.5 \mathrm{ft}$ of the thickest sandstone bed $(18.0 \mathrm{ft})$ in the Lance Formation. Sandstones throughout the formation mostly were unconsolidated or poorly consolidated (collectively, friable). Sandstone grain size mostly ranged from very fine to fine in size. The Lance Formation sandstones were classified as either muddy or silty sandstones. All sandstone beds appeared to be water saturated.

The Fox Hills Sandstone at the study site consisted of a sequence of five sandstone beds ( $79.6 \mathrm{ft}$ total thickness) separated by generally much finer grained rocks attributable to either the Lance Formation or the 86.7-ft-thick upper transition member of the Pierre Shale. The sandstone beds largely 
were unconsolidated or very poorly/poorly consolidated (friable), attributable at least in part to substantial secondary porosity development. The upper part of the Fox Hills Sandstone consisted of two upward-coarsening muddy sandstone beds separated by a 14-ft-thick Lance Formation tongue. A monitoring well (FH-1) was completed with the well screen open to $20 \mathrm{ft}$ of the thicker lower bed (37.9 ft). The lower part of the Fox Hills Sandstone is separated from the upper Fox Hills Sandstone by $46.7 \mathrm{ft}$ of intertonguing rocks belonging to the upper transition member of the Pierre Shale. The lower Fox Hills Sandstone consisted of three sandstone beds, including a 12.6-ft-thick muddy sandstone bed and 4- and 10.4-ft-thick silty sandstone beds. The three sandstone beds of the lower Fox Hills Sandstone were separated by intertonguing parts of the upper transition member of the Pierre Shale, which continued below the lowermost sandstone bed. A cross section constructed along southern Laramie County for this study illustrated how these three sandstone beds are offshore equivalents of older Fox Hills Sandstone bodies/beds farther to the east. Including all five sandstone beds and intervening strata of the Lance Formation and upper transition member of the Pierre Shale, the Fox Hills Sandstone spanned $149.7 \mathrm{ft}$ of total stratigraphic section at the study site.

The White River hydrogeologic unit consisted of the entire White River Formation at the study site. No substantial secondary permeability features were observed, except for a few minor voids in one depth interval. A monitoring well (BR-1) was completed with the well screen open to the only coarse-grained unit (muddy sandstone) that had sufficient thickness and permeability to be considered as an aquifer. Sampling of the well for a broad suite of constituents indicated groundwater generally was of excellent quality except for one constituent (dissolved arsenic) exceeding a health-based regulatory drinking-water standard and one constituent (dissolved sodium) exceeding a recommended health/aesthetic drinking-water standard. Dissolved arsenic was detected at a concentration (11.5 milligrams per liter $[\mathrm{mg} / \mathrm{L}])$ greater than the U.S. Environmental Protection Agency (EPA) Maximum Contaminant Level of $10 \mathrm{mg} / \mathrm{L}$. The measured dissolved sodium concentration $(80.1 \mathrm{mg} / \mathrm{L})$ exceeded the EPA Drinking Water Advisory Level (DWA) of $20 \mathrm{mg} / \mathrm{L}$ and the upper value of the EPA DWA range of 30 to $60 \mathrm{mg} / \mathrm{L}$.

Well development, well purging for groundwater sampling, and calculated aquifer properties indicated the sandstone aquifer screened by monitoring well BR-1 was not very productive. Analysis of the well water-level responses in well BR-1 to atmospheric loading and Earth tides for the period September 5, 2014, to September 30, 2017, indicated the responses were consistent with a confined-aquifer response with wellbore-storage effects. Hydraulic properties estimated based on these responses yielded values of hydraulic conductivity $(K, 0.057$ foot per day [ft/d]), specific storage ( $S s$, $\left.1.6 \times 10^{-6} \mathrm{ft}^{-1}\right)$, and porosity $(n, 0.43)$. Water levels filtered to remove the effects of atmospheric loading and Earth tides indicated an upward trend $(+1.13$ feet per year $[\mathrm{ft} / \mathrm{yr}])$ during the period analyzed.
Large hydraulic-head differences between well BR-1 and well LN-1 completed in a deeper sandstone subaquifer in the underlying upper Lance Formation/hydrogeologic unit indicated the intervening mudrocks had low vertical hydraulic conductivity and that downward flow through the intervening strata between wells BR-1 and LN-1 likely was small. Some amount of hydraulic connection between the sandstone aquifer screened by well BR-1 and the upper part of the White River hydrogeologic unit at the study site and, more broadly, in the area underlain by the terrace was evident, but the collected physical and chemical data indicated differing and somewhat contradictory amounts of hydraulic connection.

Lithologic characteristics of the Lance hydrogeologic unit at the study site indicated only a small amount of total unit thickness (all of which was water saturated) had the potential to yield useful quantities of water (and thus, be considered water-bearing/potential aquifer material). At the study site below the "sandy" interval (composing the three sandstone beds in the upper Lance Formation), most of the Lance hydrogeologic unit consists of various low-permeability lithologies unlikely to yield substantial quantities of water. This part of the Lance hydrogeologic unit below the "sandy" interval largely functions as a confining unit separating the underlying Lance-Fox Hills aquifer and the overlying "sandy" interval in the upper part of the Lance hydrogeologic unit. Examination of the geologic cross section constructed for this study indicated fine-grained sediments composed a substantial part of the Lance Formation/hydrogeologic unit not only at the study site, but also throughout southern Laramie County along the line of section, a characteristic of the hydrogeologic unit that likely applies throughout the Wyoming and Colorado parts of the Cheyenne Basin. Completion and subsequent development of monitoring well LN-1 indicated sandstone beds can form moderately productive confined subaquifers within the uppermost part of the Lance hydrogeologic unit at the study site. The sandstone subaquifer screened by monitoring well $\mathrm{LN}-1$ produced a mean of about 23 gallons per minute (gal $/ \mathrm{min}$ ) during well development. Larger water volumes likely could be produced by a well constructed for use as a source of supply, including a well screen open to the overlying and underlying very fine- to fine-grained sandstone beds/subaquifers within the upper "sandy" interval. Sampling of well LN-1 for a broad suite of constituents indicated groundwater generally was of excellent quality, although the measured dissolved sodium concentration $(95 \mathrm{mg} / \mathrm{L})$ exceeded the EPA DWA level of $20 \mathrm{mg} / \mathrm{L}$ and the upper value of the EPA DWA range of 30 to $60 \mathrm{mg} / \mathrm{L}$.

Analysis of the well water-level responses in $\mathrm{LN}-1$ to atmospheric loading and Earth tides for the period November 8, 2014, to September 30, 2017, indicated the responses were consistent with a confined-aquifer response. Hydraulic properties estimated based on these responses yielded values for a lower bounding $K$ of $0.60 \mathrm{ft} / \mathrm{d}$, Ss of $1.6 \times 10^{-6} \mathrm{ft}^{-1}$, and $n$ of 0.38 . Water levels filtered to remove the effects of atmospheric loading and Earth tides indicated a downward trend $(-0.86 \mathrm{ft} / \mathrm{yr})$ during the period analyzed. 
Computed vertical hydraulic gradients indicated a strong potential for downward flow throughout the groundwater system at the study site, including from the low-yielding aquifer in the upper White River Formation/hydrogeologic unit (monitoring well BR-1) to the sandstone subaquifer in the Lance Formation/hydrogeologic unit (monitoring well LN-1). Large hydraulic-head differences indicated high resistance to vertical flow attributable to the low vertical hydraulic conductivity of intervening strata, which consisted almost entirely of low-permeability mudrocks in the White River Formation. The confined nature of the sandstone aquifer monitored by well $\mathrm{LN}-1$ coupled with dissimilarities between groundwaterlevel fluctuations and trends in groundwater levels measured during the period of record analyzed in this report indicate downward flow through the intervening strata (primarily) mudrocks between wells BR-1 and LN-1 likely was small. Nevertheless, consistent annual groundwater-level fluctuations attributable to consistent/stable annual groundwater recharge were observed in well $\mathrm{LN}-1$ during the water-level observation period; these annual fluctuations were superimposed on a longer term downward groundwater-level trend. Given that calculated unadjusted carbon-14 ages indicated the aquifer likely contained old water that largely may be pre-Holocene (greater than 11,800 years before present)/late Pleistocene in age and the confining nature of the overlying sediments at the study site, a stable annual recharge pulse is surprising. One possible explanation for the chemically older waters in the Lance sandstone subaquifer could be mixing of older water supplied to the subaquifer by leakage from the adjacent finegrained, low-permeability hydrogeologic units (for example, from the overlying mudrocks of the White River Formation/ White River hydrogeologic unit). This stable recharge pulse and a consistent water-level response may possibly reflect some degree of a more regional (basinwide) flow system in the Lance hydrogeologic unit, with a distant source area(s) of current (modern) recharge.

Because of the absence of any overlying or intertonguing sandstone beds belonging to the lower/basal part of the Lance Formation, the Lance-Fox Hills aquifer at the study site consisted only of the five sandstone beds of the Fox Hills Sandstone. The multilayered Lance-Fox Hills (Laramie-Fox Hills in northeastern Colorado) aquifer at the study site and in many parts of the Cheyenne Basin (confirmed by the southern Laramie County cross section constructed for this study) likely consists only of the beds of the Fox Hills Sandstone, the number of which varies by location. The cross section also illustrated how the Fox Hills Sandstone, and thus, the part of the Lance-Fox Hills aquifer (most of the aquifer composed by the formation), consists of a series of sandstone bodies that overlap (shingle) upward to the east across southern Laramie County. These bodies collectively form a relatively continuous body of sandstone, thus potentially forming an areally extensive aquifer across southern Laramie County, and by extension, throughout most of the formation's extent in the Wyoming part of the Cheyenne Basin, as is the case in the Colorado part of the basin.
Completion and subsequent development of monitoring well FH-1 indicated the thickest sandstone bed of the Fox Hills Sandstone (37.9 ft) composing the Lance-Fox Hills aquifer at the study site was moderately to highly productive. After airlift development, well FH-1 easily produced 25 to $30 \mathrm{gal} / \mathrm{min}$. Substantially larger water production rates likely are possible because only $20 \mathrm{ft}$ of the $37.9-\mathrm{ft}$-thick bed was open to the well and the well was constructed for monitoring, rather than production purposes. A production well completed into this sandstone bed likely could obtain much larger yield because a production well near Pine Bluffs completed in a 40-ft-thick sandstone bed comparable to the bed open to well FH-1 "safely" yields about $230 \mathrm{gal} / \mathrm{min}$. Much of the productivity of this fine-grained aquifer likely is attributable to the largely unconsolidated or poorly consolidated (friable) nature of the sediments composing the bed, a result of the development of secondary porosity/permeability. Larger volumes of water likely also could be obtained from the Lance-Fox Hills aquifer at the study site by completing a well open not only to this bed, but also to the other upper Fox Hills Sandstone bed (overlying a 14.4-ft-thick muddy sandstone bed).

Analysis of the well water-level responses in well FH-1 to atmospheric loading and Earth tides for the period December 19, 2014, to September 30, 2017, indicated the responses were consistent with a confined-aquifer response. Hydraulic properties estimated based on these responses yielded values for a lower bounding $K$ of $0.26 \mathrm{ft} / \mathrm{d}$, Ss of $1.0 \times 10^{-6} \mathrm{ft}^{-1}$, and $n$ of 0.41 . Water levels filtered to remove the effects of atmospheric loading and Earth tides indicated a downward trend $(-1.74 \mathrm{ft} / \mathrm{yr})$ during the period analyzed.

Sampling of monitoring well $\mathrm{FH}-1$ and production wells FH-2 and FH-3 for a broad suite of constituents indicated groundwater of the Fox Hills aquifer generally is of excellent quality, although $\mathrm{pH}$, total dissolved solids, and dissolved sodium measured in some wells exceeded some recommended standards. The $\mathrm{pH}$ measured in wells $\mathrm{FH}-1$ and $\mathrm{FH}-3$ (8.9 and 8.7, respectively) was greater than the EPA Secondary Maximum Contaminant Level of 8.5. The total dissolved solids concentration measured in well FH-2 (532 mg/L) exceeded the EPA Secondary Maximum Contaminant Level of $500 \mathrm{mg} / \mathrm{L}$. Measured dissolved sodium concentrations in all three sampled wells (FH-1, $149 \mathrm{mg} / \mathrm{L}$; FH-2, $202 \mathrm{mg} / \mathrm{L}$; FH-3, $162 \mathrm{mg} / \mathrm{L}$ ) completed in the Fox Hills aquifer exceeded the EPA DWA level of $20 \mathrm{mg} / \mathrm{L}$ and the upper value of the EPA DWA range of 30 to $60 \mathrm{mg} / \mathrm{L}$. The Wyoming Class II agricultural (irrigation) sodium adsorption ratio standard of 8 also was exceeded in all three sampled wells (FH-1, 23; FH-2, 28; FH-3, 26), indicating waters from these wells completed in the Fox Hills aquifer are not suitable for irrigation use.

Computed vertical hydraulic gradients indicated a strong potential for downward flow from the sandstone subaquifer in the Lance hydrogeologic unit (monitoring well LN-1) to the sandstone bed/aquifer that composes much of the LanceFox Hills aquifer thickness at the study site (monitoring well FH-1). However, large hydraulic-head differences (about 
$310 \mathrm{ft}$ ) indicated high resistance to vertical flow attributable to the low vertical hydraulic conductivity of intervening confining strata, which consisted almost entirely of lowpermeability mudrocks in the Lance Formation/hydrogeologic unit. Coupled with the highly confined nature of the sandstone aquifer monitored by well FH-1, downward flow and vertical hydraulic connection between these aquifers through the intervening strata (primarily mudrocks) likely was small. Unlike wells BR-1 and LN-1, annual groundwater-level fluctuations largely were absent or discernably attenuated for well FH-1. The lack of a well-defined annual recharge pulse in well FH-1 could result from nearly complete attenuation of the recharge pulse because of (1) a long flow path and (or) low hydraulic diffusivity and (or) (2) the effects of discharge from the aquifer system monitored by well FH-1. Because of meager outcrop extent and burial by overlying Tertiary lithostratigraphic units, recharge to the Lance-Fox Hills aquifer throughout the Wyoming part of the Cheyenne Basin likely is limited primarily to areas where vertical cross-formational recharge occurs.

\section{References Cited}

Alley, W.M., ed., 1993, Regional ground-water quality: New York, Van Nostrand Reinhold, 634 p.

AMEC Environment and Infrastructure, Inc., Hinckley Consulting, and HDR Engineering, Inc., 2014, Hydrogeologic study of the Laramie County Control Area (corrected July 10, 2014): report prepared for Wyoming State Engineer's Office [variously paged].

American Society for Testing and Materials, 1996, Annual book of ASTM standards, section 11-Water and environmental technology: ASTM D5072-92, v. 11.02, p. 674-676.

Anderman, G.G., and Ackman, E.J., 1963, Structure of the Denver-Julesburg Basin and surrounding areas, in Bolyard, D.W., and Katich, P.J., eds., Geology of the northern Denver Basin and adjacent uplifts: Denver, Colo., Rocky Mountain Association of Geologists, p. 170-175.

Anderson, J.A., Morin, R.H., Cannia, J.C., and Williams, J.H., 2009, Geophysical log analysis of selected test holes and wells in the High Plains aquifer, Central Platte River Basin, Nebraska: U.S. Geological Survey Scientific Investigations Report 2009-5033, 16 p. [Also available at https://doi.org/10.3133/sir20095033.]

Appelo, C.A.J., and Postma, D., 2005, Geochemistry, groundwater and pollution ( $2 \mathrm{~d}$ ed.): Leiden, Netherlands, A.A. Balkema Publishers, 649 p.
ASTM International, 2007, Standard practice for $99 \% / 95 \%$ interlaboratory detection estimate (IDE) for analytical methods with negligible calibration error: ASTM D6091-07, 13 p., accessed June 13, 2020, at https://www.astm.org/ Standards/D6091.htm.

ASTM International, 2010, Standard practice for performing detection and quantitation estimation and data assessment utilizing DQCALC software, based on ASTM practices D6091 and D6512 of Committee D19 on water: ASTM D7510-10, 2 p., accessed June 13, 2020, at https://www.astm.org/Standards/D7510.htm.

Avery, A.A., 1999, Infantile methemoglobinemia-Reexamining the role of drinking water nitrate: Environmental Health Perspectives, v. 107, no. 7, p. 583-586. [Also available at https://doi.org/10.1289/ehp.99107583.]

Avery, C.F., and Pettijohn, R.A., 1984, Generalized potentiometric-surface map of the High Plains aquifer in Wyoming, 1981: U.S. Geological Survey Water-Resources Investigations Report 84-4033, 1 sheet, scale 1:250,000. [Also available at https://doi.org/10.3133/wri844033.]

AVI Professional Corporation, Black and Veatch, Dahlgren Consulting, Inc., Short Elliott Hendrickson, Inc., and Stockdale Consulting, 2008, Cheyenne/Laramie County water service area level II study, v. I, Archer Special Use District water master plan: report prepared for the Wyoming Water Development Commission [variously paged].

AVI Professional Corporation and Lidstone and Anderson, Inc., 1994, Pine Bluffs level I water study: report prepared for the Wyoming Water Development Commission [variously paged].

AVI Professional Corporation and Lidstone and Anderson, Inc., 1996, Final report for town of Carpenter water supply project: report prepared for the Wyoming Water Development Commission [variously paged].

Babcock, H.M., and Bjorklund, L.J., 1956, Ground-water geology of parts of Laramie and Albany Counties, Wyoming, and Weld County, Colorado with a section on Chemical quality of the ground water, by L.R. Kister: U.S. Geological Survey Water-Supply Paper 1367, 61 p., 1 pl. [Also available at https://doi.org/10.3133/wsp1367.]

Babcock, H.M., and Rapp, J.R., 1952, Reconnaissance of the geology and ground-water resources of the Horse CreekBear Creek area, Laramie and Goshen Counties, Wyoming with a section on Chemical quality of the water, by W.H. Durum: U.S. Geological Survey Circular 162, 28 p., $1 \mathrm{pl}$. [Also available at https://doi.org/10.3133/cir162.] 
Banta, E.R., Paschke, S.S., and Litke, D.W., 2011, Groundwater flow simulations of the Denver Basin aquifer system, Colorado, chap. C of Paschke, S.S., ed., Groundwater availability of the Denver Basin aquifer system, Colorado: U.S. Geological Survey Professional Paper 1770, p. 181269. [Also available at https://doi.org/10.3133/pp1770.]

Barkmann, P.E., 2004, Vertical hydraulic conductivity measurements in the Denver Basin, Colorado: Mountain Geologist, v. 41, no. 4, p. 169-183.

Barrash, W., and Morin, R.H., 1987, Hydrostratigraphy and distribution of secondary permeability in the Brule Formation, Cheyenne County, Nebraska: Geological Society of America Bulletin, v. 99, no. 4, p. 445-462. [Also available at https://doi.org/10.1130/0016-7606(1987)99\%3C445:HA DOSP\%3E2.0.CO;2.]

Bart, H.A., 1974, A sedimentologic and petrographic study of the Miocene Arikaree Group of southeastern Wyoming and west-central Nebraska: Lincoln, University of Nebraska, Ph.D. dissertation, $106 \mathrm{p}$.

Bart, H.A., 1975, Miocene sediment dispersal for western Nebraska and southeastern Wyoming: Laramie, Wyo., University of Wyoming, Contributions to Geology, v. 14, no. 1, p. 27-39.

Bartos, T.T., Diehl, S.F., Hallberg, L.L., and Webster, D.M., 2014, Geologic and hydrogeologic characteristics of the Ogallala Formation and White River Group, Belvoir Ranch near Cheyenne, Laramie County, Wyoming: U.S. Geological Survey Scientific Investigations Report 20135242, 100 p. [Also available at https://doi.org/10.3133/ sir20135242.]

Bartos, T.T., and Hallberg, L.L., 2011, Generalized potentiometric surface, estimated depth to water, and estimated saturated thickness of the High Plains aquifer system, MarchJune 2009, Laramie County, Wyoming: U.S. Geological Survey Scientific Investigations Map 3180, 1 sheet. [Also available at https://doi.org/10.3133/sim3180.]

Bartos, T.T., Hallberg, L.L., and Clark, M.L., 2013, Platte River Basin hydrogeologic units-Physical and chemical characteristics, chap. 7 of Taboga, K.G., ed., Available groundwater determination technical memorandum, WWDC [Wyoming Water Development Commission] Platte River Basin water plan update, Groundwater study level 1 (2009-2013): Laramie, Wyo., report prepared by the Wyoming State Geological Survey for the Wyoming Water Development Commission, p. 7-127-7-289. [Also available at https://waterplan.state.wy.us/plan/platte/2013/ gw-finalrept/gw_toc.html.]
Bates, B.L., McIntosh, J.C., Lohse, K.A., and Brooks, P.D., 2011, Influence of groundwater flowpaths, residence times, and nutrients on the extent of microbial methanogenesis in coal beds-Powder River Basin, USA: Chemical Geology, v. 284, no. 1-2, p. 45-61. [Also available at https://doi.org/10.1016/j.chemgeo.2011.02.004.]

Belitz, K., and Bredehoeft, J.D., 1988, Hydrodynamics of the Denver Basin -Explanation of subnormal fluid pressures: The American Association of Petroleum Geologists Bulletin, v. 72, no. 11, p. 1334-1359.

Bendat, J.S., and Piersol, A.G., 1986, Random data analysis and measurement procedures: New York, Wiley, 566 p.

Berger, J., and Beaumont, C., 1976, An analysis of tidal strain observations from the United States of America II-The inhomogeneous tide: Bulletin of the Seismological Society of America, v. 66, no. 6, p. 1821-1846.

Berggren, W.A., Kent, D.V., Obradovich, J.A., and Swisher, C.C., III, 1992, Toward a revised Paleogene geochronology, in Prothero, D.R., and Berggren, W.A., eds., EoceneOligocene climatic and biotic evolution: Princeton, N.J., Princeton University Press, p. 29-45.

Berggren, W.A., and Prothero, D.R., 1992, Eocene and Oligocene climatic and biotic evolution-An overview, in Prothero, D.R., and Berggren, W.A., eds., Eocene-Oligocene climatic and biotic evolution: Princeton, N.J., Princeton University Press, p. 1-28.

Bethke, C.M., and Johnson, T.M., 2002, Groundwater age: Ground Water, v. 40, no. 4, p. 337-339.

Bethke, C.M., and Johnson, T.M., 2008, Groundwater age and groundwater age dating: Annual Review of Earth and Planetary Sciences, v. 36, p. 121-152.

Bjorklund, L.J., 1957a, Geology and ground-water resources of the lower Lodgepole Creek drainage basin, Nebraska, with a section on Chemical quality of the water, by E.R. Jochens: U.S. Geological Survey Water-Supply Paper 1410, 76 p. [Also available at https://doi.org/10.3133/wsp1410.]

Bjorklund, L.J., 1957b, Ground-water resources of parts of Weld, Logan, and Morgan Counties, Colorado, with a section on Chemical quality of the ground water, by F.H. Rainwater: U.S. Geological Survey Hydrologic Investigations Atlas 9, 1 pl. [Also available at https://doi.org/10.3133/ha9.]

Bjorklund, L.J., 1959, Geology and ground-water resources of the upper Lodgepole Creek drainage basin, Wyoming, with a section on Chemical quality of the water, by R.A. Krieger and E.R. Jochens: U.S. Geological Survey Water-Supply Paper 1483, 40 p., 2 pls. [Also available at https://doi.org/10.3133/wsp1483.] 
Blackstone, D.L., Jr., 1996, Structural geology of the Laramie Mountains, southeastern Wyoming and northeastern Colorado: Wyoming State Geological Survey Report of Investigations no. 51,28 p., 3 pls.

Borchert, W.B., 1976, Geohydrology of the Albin and LaGrange areas, southeastern Wyoming: U.S. Geological Survey Water-Resources Investigations Report 76-118, 72 p., 6 pls. [Also available at https://doi.org/10.3133/ wri76118.]

Borchert, W.B., 1981, Water-level contours near LaGrange, southeastern Wyoming and an adjacent part of Nebraska, April 30, 1980: U.S. Geological Survey Open-File Report 81-422, 1 pl. [Also available at https://doi.org/10.3133/ ofr81422.]

Borchert, W.B., 1985, The ground-water system in the LaGrange aquifer near LaGrange, southeastern Wyoming: U.S. Geological Survey Water-Resources Investigations Report 83-4024, 56 p., 4 pls. [Also available at https://doi.org/10.3133/wri834024.]

Boughton, G.K., 2014, Groundwater-quality characteristics for the Wyoming Groundwater-Quality Monitoring Network, November 2009 through September 2012 (ver. 1.1, October 2014): U.S. Geological Survey Scientific Investigations Report 2014-5130, 80 p., appendix. [Also available at https://doi.org/10.3133/sir20145130.]

Boughton, G.K., Remley, K.R., and Bartos, T.T., 2006, Estimated water use in Wyoming during 2000: U.S. Geological Survey Fact Sheet 2006-3099, 4 p. [Also available at https://doi.org/10.3133/fs20063099.]

Boyd, H.A., 1999, Younger Tertiary (Late Eocene-Early Pliocene) stratigraphic succession and the geologic history of the western United States: 1-The High Plains classical area, in Miller, W.R., ed., Coalbed methane and the Tertiary geology of the Powder River Basin, Wyoming and Montana: Wyoming Geological Association Guidebook, 50th Annual Field Conference, 1999, p. 167-210.

Braddock, W.A., and Cole, J.C., 1978, Preliminary geologic map of the Greeley 1 degree by two degrees quadrangle, Colorado and Wyoming: U.S. Geological Survey OpenFile Report 78-532, 1 pl., scale 1:250,000, accompanying pamphlet 10 p. [Also available at https://doi.org/10.3133/ ofr78532.]

Brady, R.T., 1949, Geology of the east flank of the Laramie Range in the vicinity of Federal and Hecla, Laramie County, Wyoming: Laramie, University of Wyoming, Department of Geology, master's thesis, 41 p., 13 pls. [All figures in text identified as plates but most are page sized.]
Bredehoeft, J.D., 1967, Response of well-aquifer systems to Earth tides: Journal of Geophysical Research, v. 72, no. 12, p. 3075-3087. [Also available at https://doi.org/10.1029/ JZ072i012p03075.]

Brenton, R.W., and Arnett, T.L., 1993, Methods of analysis by the U.S. Geological Survey National Water Quality Laboratory-Determination of dissolved organic carbon by UV-promoted persulfate oxidation and infrared spectrometry: U.S. Geological Survey Open-File Report 92-480, 12 p. [Also available at https://doi.org/10.3133/ofr92480.]

BRS, Inc., and Lidstone and Anderson, Inc., 1996, Hawk Springs water supply project, final report: report prepared for the Wyoming Water Development Commission [variously paged].

Bureau of Reclamation, 1985, Ground water manual, a water resources technical publication ( $3 \mathrm{~d}$ printing): Washington, D.C., U.S. Government Printing Office, 480 p.

Burleigh, H.P., Gwillim, E.C., Dunewald, T.J., and Pearson, H.V., 1938, Report on irrigation by recovery of ground waters in the Egbert-Pine Bluffs area: Wyoming, U.S. Department of Agriculture, Bureau of Agricultural Economics, Open-File Report, 54 p.

Busenberg, E., and Plummer, L.N., 1992, Use of chlorofluorocarbons as hydrologic tracers and age-dating tools-The alluvium and terrace system of central Oklahoma: Water Resources Research, v. 28, no. 9, p. 2257-2283.

Busenberg, E., Plummer, L.N., and Bartholomay, R.C., 2001, Estimated age and source of the young fraction of groundwater at the Idaho National Engineering and Environmental Laboratory: U.S. Geological Survey Water-Resources Investigations Report 01-4265 (DOE/ID-22177), 144 p.

Butterworth, S., 1930, On the theory of filter amplifiers: Experimental Wireless and the Wireless Engineer, v. 7, p. 536-541.

Cady, R.C., 1935, Report on the test well at the Veterans' Administration facility, Cheyenne, Wyoming: U.S. Geological Survey unnumbered open-file report, $38 \mathrm{p}$.

California Department of Public Health, 2018, Maximum contaminant levels and regulatory dates for drinking water, U.S. EPA [U.S. Environmental Protection Agency] vs California, October 2018, 4 p., accessed April 26, 2019, at https://www.waterboards.ca.gov/drinking_water/certlic/ drinkingwater/documents/ccr/mcls_epa_vs_dwp.pdf.

Cant, D.J., 1992, Subsurface facies analysis, in Walker, R.G., and James, N.P., eds., Facies models — Response to sea level change ( $2 \mathrm{~d}$ ed.): Geological Association of Canada, p. 27-45. 
Carpenter, K., 1979, Vertebrate fauna of the Laramie Formation (Maastrichtian), Weld County, Colorado: Contributions to Geology (Laramie), v. 17, p. 37-49.

Carpenter, K., and Young, D.B., 2002, Late Cretaceous dinosaurs from the Denver Basin, Colorado: Rocky Mountain Geology, v. 37, no. 2, p. 237-254. [Also available at https://doi.org/10.2113/gsrocky.37.2.237.]

Cassiliano, M.L., 1980, Stratigraphy and vertebrate paleontology of the Horse Creek-Trail Creek area, Laramie County, Wyoming: Laramie, Wyo., Contributions to Geology, v. 19, no. 1, p. 25-68.

Cather, S.M., Chapin, C.E., and Kelly, S.A., 2012, Diachronous episodes of Cenozoic erosion in southwestern North America and their relationship to surface uplift, paleoclimate, paleodrainage, and paleoaltimetry: Geosphere, v. 8, no. 6, p. 1177-1206. [Also available at https://doi.org/10.1130/GES00801.1.]

Centers for Disease Control and Prevention, 1996, Spontaneous abortions possibly related to ingestion of nitratecontaminated well water, LaGrange County, Indiana, 1991-1994: Morbidity and Mortality Weekly Report, v. 45, no. 26 , p. 569-572.

Chapelle, F.H., 2001, Ground-water microbiology and geochemistry ( $2 \mathrm{~d}$ ed.): New York, Wiley, $477 \mathrm{p}$.

Chapelle, F.H., Bradley, P.M., Thomas, M.A., and McMahon, P.B., 2009, Distinguishing iron-reducing from sulfatereducing conditions: Ground Water, v. 47, no. 2, p. 300305. [Also available at https://doi.org/10.1111/j.17456584.2008.00536.x.]

Chapin, C.E., 2008, Interplay of oceanographic and paleoclimate events with tectonism during middle to late Miocene sedimentation across the southwestern USA: Geosphere, v. 4 , no. 6, p. 976-991.

Chapin, C.E., and Kelley, S.A., 1997, The Rocky Mountain erosion surface in the Front Range of Colorado, in Bolyard, D.W., and Sonnenberg, S.A., eds., Colorado Front Range guidebook: Denver, Colo., Rocky Mountain Association of Geologists, p. 101-114.

Clark, J., 1975, Controls of sedimentation and provenance of sediments in the Oligocene of the central Rocky Mountains, in Curtis, B.F., ed., Cenozoic history of the southern Rocky Mountains: Geological Society of America Memoir 144, p. $95-117$.

Clark, I.D., and Fritz, P., 1997, Environmental isotopes in hydrogeology: New York, Lewis Publishers, 328 p.

Clesceri, L.S., Greenberg, A.E., and Franson, M.A.H., eds., 1998, Standard methods for the examination of water and wastewater (20th ed.): Washington, D.C., American Public Health Association, 1,325 p.
Cobban, W.A., Walaszczyk, I., Obradovich, J.D., and McKinney, K.C., 2006, A USGS zonal table for the Upper Cretaceous middle Cenomanian-Maastrichtian of the Western Interior of the United States based on ammonites, inoceramids, and radiometric ages: U.S. Geological Survey Open-File Report 2006-1250, 46 p., accessed November 24, 2020, at https://doi.org/10.3133/ofr20061250.

Cohen, K.M., Finney, S.C., Gibbard, P.L., and Fan, J., 2018, International chronostratigraphic chart (ver. 2018/08): International Commission on Stratigraphy, 1 p., accessed March 19, 2019, at https://stratigraphy.org/icschart/ ChronostratChart2018-08.pdf.

Colorado Division of Water Resources, 1985, Geology of the Denver Basin aquifers: Colorado Division of Water Resources, $38 \mathrm{p}$.

Condon, S.M., 2005, Geologic studies of the Platte River, south-central Nebraska and adjacent areas-Geologic maps, subsurface study, and geologic history: U.S. Geological Survey Professional Paper 1706, 63 p. [Also available at https://doi.org/10.3133/pp1706.]

Cook, P.G., and Herczeg, A.L., 2000, Environmental tracers in subsurface hydrology: Boston, Mass., Kluwer Academic Publishers, $529 \mathrm{p}$.

Cooley, M.E., 1991, The Cheyenne tableland, in Wayne, W.J., and others, Quaternary geology of the northern Great Plains, chap. 15 of Quaternary nonglacial geology-Conterminous U.S.: Boulder, Colo., Geological Society of America, The geology of North America, v. K-2, p. 453-455.

Cooley, M.E., and Crist, M.A., 1981, Generalized fence diagram showing stratigraphy and potentiometric surface of the Tertiary formations in southeastern Wyoming and an adjacent part of Colorado: U.S. Geological Survey Miscellaneous Investigations Series Map I-1308, 1 sheet. [Also available at https://doi.org/10.3133/i1308.]

Cooley, M.E., and Crist, M.A., 1994, Geohydrology of the High Plains aquifer system, Cheyenne urban area, Wyoming: U.S. Geological Survey Water-Resources Investigations Report 92-4047, 4 sheets. [Also available at https://doi.org/10.3133/wri924047.]

Copland, J.R., 1984, Laramide structural deformation at the interface between the Laramie range and the DenverJulesburg Basin, southeastern Wyoming: Laramie, University of Wyoming, Department of Geology and Geophysics, master's thesis, 49 p., 2 pls.

Coplen, T.B., 1994, Reporting of stable hydrogen, carbon, and oxygen isotopic abundances: Pure and Applied Chemistry, v. 66, no. 2, p. 273-276. [Also available at https://doi.org/10.1351/pac199466020273.] 
Coplen, T.B., Wildman, J.D., and Chen, J., 1991, Improvements in the gaseous hydrogen-water equilibration technique for hydrogen isotope ratio analysis: Analytical Chemistry, v. 63, no. 9, p. 910-912. [Also available at https://doi.org/10.1021/ac00009a014.]

Cothern, C.R., and Smith, J.E., eds., 1987, Environmental radon: New York, Plenum Publishing Corp., 363 p.

Courtright, T.R., and Braddock, W.A., 1989, Geologic map of the Table Mountain quadrangle and adjacent parts of the Round Butte and Buckeye quadrangles, Larimer County, Colorado, and Laramie County, Wyoming: U.S. Geological Survey Miscellaneous Investigations Series Map I-1805, 1 sheet, scale 1:24,000. [Also available at https://doi.org/10.3133/i1805.]

Craig, H., 1961, Isotopic variations in meteoric waters: Science, v. 133, no. 3465, p. 1702-1703. [Also available at https://doi.org/10.1126/science.133.3465.1702.]

Crist, M.A., 1977, Hydrologic evaluation of the Arikaree Formation near Lusk, Niobrara and Goshen Counties, Wyoming: U.S. Geological Survey Water-Resources Investigations/Open-File Report 77-111, 23 p., 3 pls. [Also available at https://doi.org/10.3133/wri77111.]

Crist, M.A., 1980, Effect of pumpage on ground-water levels as modeled in Laramie County, Wyoming: U.S. Geological Survey Water-Resources Investigations/OpenFile Report 80-1104, 26 p., 4 pls. [Also available at https://doi.org/10.3133/ofr801104.]

Crist, M.A., 1983, Hydrologic conditions in the Wheatland Flats area, Platte County, Wyoming: U.S. Geological Survey Water-Resources Investigations Report 83-4047, 36 p., 3 pls. [Also available at https://doi.org/10.3133/wri834047.]

Crist, M.A., and Borchert, W.B., 1972, The ground-water system in southeastern Laramie County, Wyoming: U.S. Geological Survey Open-File Report 72-80, 53 p., 7 pls. [Also available at https://doi.org/10.3133/ofr7280.]

Cryer, J.D., and Chan, K.S., 2008, Time series analysis-With applications in R (2d ed.): New York, Springer, 491 p.

Cunningham, W.L., and Schalk, C.W., comps., 2011, Groundwater technical procedures of the U.S. Geological Survey: U.S. Geological Survey Techniques and Methods, book 1, chap. A1, 151 p., accessed January 25, 2013, at https://doi.org/10.3133/tm1A1.

Curtis, B.F., 1988, Sedimentary rocks of the Denver Basin, in Sloss, L.L., ed., Sedimentary cover-North American craton: Geological Society of America, The geology of North America, v. D-2, p. 182-196. [Also available at https://doi.org/10.1130/DNAG-GNA-D2.109.]
Cutillo, P.A., and Bredehoeft, J.D., 2011, Estimating aquifer properties from the water level response to Earth tides: Ground Water, v. 49, no. 4, p. 600-610. [Also available at https://doi.org/10.1111/j.1745-6584.2010.00778.x.]

Dahlgren Consulting, Inc., Natural Resources Consulting Engineers, Hydrokinetics, and ECI, 2001, Lodgepole aquifer storage and retrieval level I study, final report: report prepared for the Wyoming Water Development Commission [variously paged].

Dahlgren Consulting, Inc., Stockdale Consulting, Inc., SRK Consulting, Inc., Benchmark Engineers, P.C., and Greystone Environmental, 2005, Pine Bluffs Lance/Fox Hills well level II study, final report: report prepared for the Wyoming Water Development Commission [variously paged], accessed June 28, 2019, at http://library.wrds.uwyo.edu/ wwdcrept/Pine_Bluffs/Pine_Bluffs-Lance_Fox_Hills_WellLevel_II-Final_Report-2005.pdf.

Dahlgren Consulting, Inc., WWC Engineering, Ayres Associates, InfoMaption, Inc., Neirbo Hydrogeology, McGrane Water Engineering, LLC, and Ecosystem Management, Inc., 2018, South Platte River watershed level I study: report prepared for the Wyoming Water Development Commission, Laramie County Conservation District, and Laramie Rivers Conservation District [variously paged].

Darton, N.H., 1899, Relations of Tertiary formations in the western Nebraska region: American Geologist, v. 23, p. 94.

Darton, N.H., 1903, Preliminary report on the geology and water resources of Nebraska west of the 103rd meridian: U.S. Geological Survey Professional Paper 17, 69 p. [reproduced with minor revisions from 19th Annual Report of the U.S. Geological Survey for 1897-98, 1899, p. 719-785].

Darton, N.H., 1905, Preliminary report on the geology and underground water resources of the central Great Plains: U.S. Geological Survey Professional Paper 32, 433 p., 2 pls. [Also available at https://doi.org/10.3133/pp32.]

Darton, N.H., Blackwelder, E., and Siebenthal, C.E., 1910, Laramie-Sherman folio, Wyoming: Washington, D.C., U.S. Geological Survey, Folios of the Geologic Atlas 173, 34 p., 8 pls. [Also available at https://doi.org/10.3133/ gf173.]

Dechesne, M., and Raynolds, R.G., 2005, Reservoir geometry of the regressive Fox Hills Sandstone-Control on aquifer quality: Annual meeting of the American Association of Petroleum Geologists, Rocky Mountain Section, Jackson, Wyo., September 24-26, 2005.

Dechesne, M., and Raynolds, R.G., 2010, Coastlines of the Cretaceous Fox Hills Sandstone in the Denver Basin, Colorado: Geological Society of America Abstracts with Programs, v. 42, no. 5, p. 509 [abstract]. 
Dechesne, M., Raynolds, R.G., Barkmann, P.E., and Johnson, K.R., 2011a, Notes on the Denver Basin geologic mapsBedrock geology, structure, and isopach maps of the Upper Cretaceous to Paleogene strata between Greeley and Colorado Springs, Colorado: Denver, Colo., Colorado Geological Survey, Division of Minerals and Geology, Department of Natural Resources, $35 \mathrm{p}$.

Dechesne, M., Raynolds, R.G., Barkmann, P.E., and Johnson, K.R., 2011b, Structure and isopach maps of the Denver Basin with sand distribution maps for the Denver Basin Group (sheet 1), and cross sections of the Denver Basin (sheet 2): Denver, Colo., Denver Museum of Nature and Science and Colorado Geological Survey, 2 sheets [both sheets included in pocket in Dechesne and others, 2011a].

Denson, N.M., and Bergendahl, M.H., 1961, Middle and upper Tertiary rocks of southeastern Wyoming and adjoining areas, in Short papers in the geologic and hydrologic sciences: U.S. Geological Survey Professional Paper 424-C, p. C168-C172. [Also available at https://doi.org/10.3133/ pp424C.]

Denson, N.M., and Chisholm, W.A., 1971, Summary of mineralogic and lithologic characteristics of Tertiary sedimentary rocks in the middle Rocky Mountains and the northern Great Plains, in Geological Survey Research 1971: U.S. Geological Survey Professional Paper 750-C, p. C117-C126. [Also available at https://doi.org/10.3133/ pp750C.]

Derstler, K., 1994, Dinosaurs of the Lance Formation in eastern Wyoming, in Nelson, G.E., ed., The dinosaurs of Wyoming: Wyoming Geological Association Guidebook, 44th Annual Field Conference, p. 125-146.

Dickinson, J.E., Hanson, R.T., Ferré, T.P.A., and Leake, S.A., 2004, Inferring time-varying recharge from inverse analysis of long-term water levels: Water Resources Research, v. 40, no. 7, art. W07403. [Also available at https://doi.org/10.1029/2003WR002650.]

Dickinson, W.R., Klute, M.A., Hayes, M.J., Janecke, S.U., Lundin, E.R., McKittrick, M.A., and Olivares, M.D., 1988, Paleogeographic and paleotectonic setting of Laramide sedimentary basins in the central Rocky Mountain region: Geological Society of America Bulletin, v. 100, no. 7, p. 1023-1039. [Also available at https://doi.org/10.1130/0016-7606(1988)100\%3C1023:PAP SOL\%3E2.3.CO;2.]

Diffendal, R.F., Jr., 1982, Regional implications of the geology of the Ogallala Group (upper Tertiary) of southwestern Morrill County, Nebraska, and adjacent areas: Geological Society of America Bulletin, v. 93, no. 10, p. 964-976.
Diffendal, R.F., Jr., 1984, Comments on the geologic history of the Ogallala Formation in the southern panhandle of Nebraska, in Whetstone, G.A., ed., Proceedings of the Ogallala aquifer symposium II: Lubbock, Texas Tech University, June 1984, p. 194-216.

Divine, D., and Sibray, S.S., 2017, An overview of secondary aquifers in Nebraska: University of Nebraska-Lincoln, School of Natural Resources, Conservation and Survey Division, Educational Circular no. 26, 40 p.

Dockery, W.L., 1940, Underground water resources of Horse Creek and Bear Creek valleys, southeastern Wyoming: Laramie, University of Wyoming, Wyoming Geological Survey Bulletin no. 30, 32 p., 3 pls.

Drever, J.I., 1997, The geochemistry of natural waters (3d ed.): Upper Saddle River, N.J., Prentice Hall, 437 p.

Driscoll, F.G., 1986, Groundwater and wells (2d ed.): St. Paul, Minn., Johnson Division, 1,089 p.

Droullard, E.K., 1963, Tectonics of the southeast flank of the Hartville uplift, Wyoming, in Bolyard, D.W., and Katich, P.J., eds., Geology of the northern Denver Basin and adjacent uplifts: Denver, Colo., Rocky Mountain Association of Geologists, p. 176-179.

Dubrovsky, N.M., Burow, K.R., Clark, G.M., Gronberg, J.M., Hamilton, P.A., Hitt, K.J., Mueller, D.K., Munn, M.D., Nolan, B.T., Puckett, L.J., Rupert, M.G., Short, T.M., Spahr, N.E., Sprague, L.A., and Wilber, W.G., 2010, The quality of our Nation's waters-Nutrients in the Nation's streams and groundwater, 1992-2004: U.S. Geological Survey Circular 1350, 174 p. [Also available at https://doi.org/10.3133/ cir1350.]

Duller, R.A., Whittaker, A.C., Swinehart, J.B., Armitage, J.J., Sinclair, H.D., Bair, A., and Allen, P.A., 2012, Abrupt landscape change post- $6 \mathrm{Ma}$ on the central Great Plains, USA: Geology, v. 40, no. 10, p. 871-874. [Also available at https://doi.org/10.1130/G32919.1.]

Durfor, C.N., and Becker, E., 1964, Public water supplies of the 100 largest cities in the United States, 1962: U.S. Geological Survey Water-Supply Paper 1812, 364 p. [Also available at https://doi.org/10.3133/wsp1812.]

Dutton, A.R., 1993, Sources and ages of groundwater in unconfined and confined aquifers beneath the U.S. High Plains: Austin, Tex., Bureau of Economic Geology, University of Texas at Austin [final technical report prepared for U.S. Geological Survey under award number 14-08-0001G1885], October 1993, 43 p.

Dutton, A.R., 1995, Groundwater isotopic evidence for paleorecharge in U.S. High Plains aquifers: Quaternary Research, v. 43, no. 2, p. 221-231. [Also available at https://doi.org/10.1006/qres.1995.1022.] 
Eltschlager, K.K., Hawkins, J.W., Ehler, W.C., and Baldassare, F., 2001, Technical measures for the investigation and mitigation of fugitive methane hazards in areas of coal mining: Pittsburgh, Pa., Office of Surface Mining Reclamation and Enforcement, 124 p., accessed May 11, 2019, at https://ntrl.ntis.gov/NTRL/dashboard/searchResults/ titleDetail/PB2002106133.xhtml.

Emry, R.J., 1973, Stratigraphy and preliminary biostratigraphy of the Flagstaff Rim area, Natrona County, Wyoming: Washington, D.C., Smithsonian Institution Press, Smithsonian Contributions to Paleobiology, no. 18, p. 1-43.

Emry, R.J., 1992, Mammalian range zones in the Chadronian White River Formation at Flagstaff Rim, Wyoming, in Prothero, D.R., and Berggren, W.A., eds., Eocene-Oligocene climatic and biotic evolution: Princeton, N.J., Princeton University Press, p. 106-115.

Emry, R.J., Bjork, P.R., and Russell, L.S., 1987, The Chadronian, Orellan, and Whitneyan land mammal ages, in Woodburne, M.O., ed., Cenozoic mammals of North America - Geochronology and biostratigraphy: Berkeley, Calif., University of California Press, p. 116-130.

Epis, R.C., and Chapin, C.E., 1975, Geomorphic and tectonic implications of the post-Laramide, late Eocene erosion surface in the southern Rocky Mountains, in Curtis, F.B., ed., Cenozoic history of the southern Rocky Mountains: Geological Society of America Memoir 144, p. 1023-1039.

Epstein, S., and Mayeda, T., 1953, Variation in $\delta^{18} \mathrm{O}$ content of water from natural sources: Geochimica et Cosmochimica Acta, v. 4, no. 5, p. 213-224.

Ethridge, F.G., Tyler, N., and Thompson, T.B., 1979, The uranium-bearing Fox Hills and Laramie aquifers, Cheyenne Basin, Colorado - Structure, depositional systems, and groundwater, part I, structure and depositional systems: Fort Collins, Colorado State University, Department of Earth Resources, College of Forestry and Natural Resources, $40 \mathrm{p}$.

Evanoff, E., 1990a, Early Oligocene paleovalleys in southern and central Wyoming-Evidence of high local relief on the late Eocene unconformity: Geology, v. 18, no. 5, p. 443-446. [Also available at https://doi.org/10.1130/00917613(1990)018\%3C0443:EOPISA\%3E2.3.CO;2.]

Evanoff, E., 1990b, Late Eocene and early Oligocene paleoclimates as indicated by the sedimentology and nonmarine gastropods of the White River Formation near Douglas, Wyoming: Boulder, University of Colorado, master's thesis, $440 \mathrm{p}$.

Evanoff, E., 1993, Stratigraphy of the White River Formation, Converse County, Wyoming: Boulder, University of Colorado, Ph.D. dissertation, 298 p.
Evanoff, E., and Chapin, C.E., 1994, Composite nature of the "late Eocene surface" of the Front Range and adjacent regions, Colorado and Wyoming: Geological Society of America Abstracts with Programs, v. 26, no. 6, p. 12 [abstract].

Evanoff, E., Prothero, D.R., and Lander, R.H., 1992, Eocene and Oligocene climatic change in North America-The White River Formation near Douglas, east-central Wyoming, in Prothero, D.R., and Berggren, W.A., eds., EoceneOligocene climatic and biotic evolution: Princeton, N.J., Princeton University Press, p. 116-130.

Faires, L.M., 1993, Methods of analysis by U.S. Geological Survey National Water Quality Laboratory-Determination of metals in water by inductively coupled plasma-mass spectrometry: U.S. Geological Survey Open-File Report 92-634, 28 p. [Also available at https://doi.org/10.3133/ ofr92634.]

Fan, M., Heller, P., Allen, S.D., and Hough, B.G., 2014a, Middle Cenozoic uplift and concomitant drying in the central Rocky Mountains and adjacent Great Plains: Geology, v. 42, no. 6, p. 547-550. [Also available at https://doi.org/10.1130/ G35444.1.]

Fan, M., Hough, B.G., and Passey, B.H., 2014b, Middle to late Cenozoic cooling and high topography in the central Rocky Mountains - Constraints from clumped isotope geochemistry: Earth and Planetary Science Letters, v. 408, p. 35-47. [Also available at https://doi.org/10.1016/j.eps1.2014.09.050.]

Fan, A.M., and Steinberg, V.E., 1996, Health implications of nitrate and nitrite in drinking water-An update on methemoglobinemia occurrence and reproductive and developmental toxicity: Regulatory Toxicology and Pharmacology, v. 23, p. 35-43. [Also available at https://doi.org/10.1006/ rtph.1996.0006.]

Fenneman, N.M., and Johnson, D.W., 1946, Physical divisions of the United States: U.S. Geological Survey map, 1 sheet, scale $1: 7,000,000$.

Fischer, R.V., 1966, Rocks composed of volcanic fragments and their classification: Earth-Science Reviews, v. 1, no. 4, p. 287-298. [Also available at https://doi.org/10.1016/0012-8252(66)90010-9.]

Fishman, M.J., 1993, Methods of analysis by the U.S. Geological Survey National Water Quality Laboratory-Determination of inorganic and organic constituents in water and fluvial sediments: U.S. Geological Survey Open-File Report 93-125, 217 p. [Also available at https://doi.org/10.3133/ ofr93125.] 
Fishman, M.J., and Friedman, L.C., 1989, Methods for determination of inorganic substances in water and fluvial sediments: U.S. Geological Survey Techniques of WaterResources Investigations, book 5, chap. A1, 545 p. [Also available at https://doi.org/10.3133/twri05A1.]

Flanagan, K.M., and Montagne, J., 1993, Neogene stratigraphy and tectonics of Wyoming, in Snoke, A.W., Steidtmann, J.R., and Roberts, S.M., eds., Geology of Wyoming: Geological Survey of Wyoming Memoir no. 5, p. 572-607.

Foley, F.C., 1942, Progress report on geology and groundwater resources of the Cheyenne area, Wyoming: Cheyenne, Wyo., U.S. Geological Survey Open-File Report (unnumbered) prepared with the cooperation of the Wyoming State Planning and Conservation Board and the City of Cheyenne, 95 p., 4 pls.

Folk, R.L., 1954, The distinction between grain size and mineral composition and sedimentary-rock nomenclature: The Journal of Geology, v. 62, no. 4, p. 344-359.

Folk, R.L., 1980, Petrology of sedimentary rocks: Austin, Tex., Hemphill Publishing Company, 185 p.

Freeze, R.A., and Cherry, J.A., 1979, Groundwater: Englewood Cliffs, N.J., Prentice-Hall, Inc., 604 p.

Fuentes-Arreazola, M.A., Ramírez-Hernández, J., and Vázquez-González, R., 2018, Hydrogeological properties estimation from groundwater level natural fluctuations analysis as a low-cost tool for the Mexicali Valley aquifer: Water (Basel), v. 10, no. 5, p. 586.

Galbreath, E.C., 1953, A contribution to the Tertiary geology and paleontology of northeastern Colorado: Topeka, University of Kansas Paleontological Contributions, art. 13, Vertebrata 4, 120 p., 2 pls.

Galloway, D.L., 2019, Atmospheric-loading frequency response functions and groundwater levels filtered for the effects of atmospheric loading and solid Earth tides for three monitoring wells near Mammoth Lakes, California, 2015-2017: U.S. Geological Survey data release, accessed November 24, 2020, at https://doi.org/10.5066/P9ON8U5U.

Galloway, D.L., and Bartos, T.T., 2021, Atmospheric-loading frequency response functions and groundwater levels filtered for the effects of atmospheric loading and solid Earth tides for three USGS monitoring wells, southeastern Laramie County, Wyoming, 2014-2017: U.S. Geological Survey data release, https://doi.org/10.5066/P9PPLA74.
Galloway, D.L., and Rojstaczer, S.A., 1989, Inferences about formation elastic and fluid flow properties from the frequency response of water levels to atmospheric loads and Earth tides: 4th Canadian/American Conference on Hydrogeology_Fluid flow, heat transfer and mass transport in fractured rocks, Banff, Alberta, Canada, June 21-24, 1988, p. 100-113.

Gao, M., 2017, Tectonic processes and continental hydroclimate during the Laramide deformation in the central Rocky Mountains: Arlington, University of Texas, Ph.D. dissertation, 171 p., accessed April 17, 2018, at https:/uta-ir.tdl.org/ uta-ir/bitstream/handle/10106/26818/GAO-DISSERTATION-2017.pdf? sequence $=1$ \&isAllowed $=\mathrm{y}$.

Garbarino, J.R., 1999, Methods of analysis by the U.S. Geological Survey National Water Quality Laboratory-Determination of dissolved arsenic, boron, lithium, selenium, strontium, thallium, and vanadium using inductively coupled plasma-mass spectrometry: U.S. Geological Survey Open-File Report 99-93, 31 p. [Also available at https://doi.org/10.3133/ofr9993.]

Godin, G., 1972, The analysis of tides: Toronto, Buffalo, University of Toronto Press, 264 p.

Gorody, A.W., 2012, Factors affecting the variability of stray gas concentration in composition in groundwater: Environmental Geoscience, v. 19, no. 1, p. 17-31.

Gray, L.O., Jr., 1947, Geology of the east flank of the Laramie Range in the vicinity of Horse Creek, Laramie County, Wyoming: Laramie, University of Wyoming, Department of Geology, master's thesis, 25 p., 3 pls.

Gutentag, E.D., Heimes, F.J., Krothe, N.C., Luckey, R.R., and Weeks, J.B., 1984, Geohydrology of the High Plains aquifer in parts of Colorado, Kansas, Nebraska, New Mexico, Oklahoma, South Dakota, Texas, and Wyoming: U.S. Geological Survey Professional Paper 1400-B, 63 p. [Also available at https://doi.org/10.3133/pp1400B.]

Gutentag, E.D., and Weeks, J.B., 1980, Water table in the High Plains aquifer in 1978 in parts of Colorado, Kansas, Nebraska, New Mexico, Oklahoma, South Dakota, Texas, and Wyoming: U.S. Geological Survey Hydrologic Investigations Atlas HA-642, 1 sheet, scale 1:2,500,000. [Also available at https://doi.org/10.3133/ha642.]

HACH, 2007, DR 2800 Spectrophotometer procedures manual (2d ed.): Germany, HACH Company, 814 p., accessed November 24, 2020, at https:/www.hach.com/ asset-get.download.jsa?id=7639982436. 
Hallberg, L.L., and Case, J.C., 1998, Preliminary digital surficial geologic map of the Cheyenne $30^{\prime} \times 60^{\prime}$ quadrangle, southeastern Wyoming, western Nebraska, and northern Colorado: Laramie, Wyo., Wyoming State Geological Survey Geologic Hazards Section Digital Map 98-4, scale $1: 100,000$.

Hammond, C.R., 1949, Geology of the south flank of the Laramie Range in the vicinity of Iron Mountain, Laramie County, Wyoming: Laramie, University of Wyoming, Department of Geology, master's thesis, 63 p., 2 pls.

Hanson, J.M., 1984, Evaluation of subsurface fracture geometry using fluid pressure response to solid Earth tidal strain: Lawrence Livermore National Laboratory UCID-20156, $135 \mathrm{p}$.

Hanson, J.M., and Owen, L.B., 1982, Fracture orientation analysis by the solid Earth tidal strain method: Society of Petroleum Engineers, Annual Technical Conference and Exhibition, New Orleans, La., September 26-29, 1982, 18 p. [Also available at https://doi.org/10.2118/11070-MS.]

Harrison, J.C., 1971, New computer programs for the calculation of Earth tides: Cooperative Institute for Research in Environmental Sciences, National Oceanic and Atmospheric Administration, University of Colorado, $30 \mathrm{p}$.

Harvey, F.E., 2005, Stable hydrogen and oxygen isotope composition of precipitation in northeastern Colorado: Journal of the American Water Resources Association, v. 41, no. 2, p. 447-459. [Also available at https://doi.org/10.1111/j.1752-1688.2005.tb03748.x.]

Harvey, F.E., and Welker, J.M., 2000, Stable isotopic composition of precipitation in the semi-arid north-central portion of the U.S. Great Plains: Journal of Hydrology (Amsterdam), v. 238, no. 1-2, p. 90-109. [Also available at https://doi.org/10.1016/S0022-1694(00)00316-4.]

Haun, J.D., 1949, Geology of a portion of the east flank of the Laramie Range: Laramie, University of Wyoming, Department of Geology, master's thesis, 40 p., 3 pls.

Hearst, J.R., Nelson, P.H., and Paillet, F.L., 2000, Well logging for physical properties ( $2 \mathrm{~d}$ ed.): New York, Wiley, $442 \mathrm{p}$.

Heath, R.C., 1983, Basic ground-water hydrology: U.S. Geological Survey Water-Supply Paper 2220, 84 p. [Also available at https://doi.org/10.3133/wsp2220.]

Heller, P.L., Dueker, K., and McMillan, M.E., 2003, PostPaleozoic alluvial gravel transport as evidence of continental tilting in the U.S. Cordillera: Geological Society of America Bulletin, v. 115, no. 9, p. 1122-1132.

Hem, J.D., 1985, Study and interpretation of the chemical characteristics of natural water (3d ed.): U.S. Geological Survey Water-Supply Paper 2254, 263 p. [Also available at https://doi.org/10.3133/wsp2254.]
Hembree, D.I., and Hasiotis, S.T., 2007, Paleosols and ichnofossils of the White River Formation of Colorado-Insight into soil ecosystems of the North American midcontinent during the Eocene-Oligocene transition: Palaios, v. 22, no. 2 , p. $123-142$.

Herrmann, R., 1972, Shallow aquifers relative to surface waters, North Platte River valley, Goshen County, Wyoming: Laramie, University of Wyoming, Department of Geology, Ph.D. dissertation, 195 p.

Higley, D.K., and Cox, D.O., 2007, Oil and gas exploration and development along the Front Range in the Denver Basin of Colorado, Nebraska, and Wyoming, chap. 2 of Higley, D.K., comp., Petroleum systems and assessment of undiscovered oil and gas in the Denver Basin Province, Colorado, Kansas, Nebraska, South Dakota, and Wyoming-USGS Province 39: U.S. Geological Survey Digital Data Series DDS-69-P, 41 p.

Hinckley Consulting, 2009, Lusk area groundwater level I study final report: report prepared for Wyoming Water Development Commission [variously paged], $1 \mathrm{pl}$.

Hopke, P.K., Borak, T.B., Doull, J., Cleaver, J.E., Eckerman, K.F., Gundersen, L.C.S., Harley, N.H., Hess, C.T., Kinner, N.E., Kopecky, K.J., McKone, T.E., Sextro, R.G., and Simon, S.L., 2000, Health risks due to radon in drinking water: Environmental Science \& Technology, v. 34, no. 6, p. 921-926. [Also available at https://doi.org/10.1021/ es9904134.]

Howle, J.F., Evans, W.C., Galloway, D.L., Hsieh, P.A., Hurwitz, S., Smith, G.A., and Nawikas, J., 2019, Hydraulic, geochemical, and thermal monitoring of an aquifer system in the vicinity of Mammoth Lakes, Mono County, California, 2015-17: U.S. Geological Survey Open-File Report 2019-1063, 90 p., accessed November 24, 2020, at https://doi.org/10.3133/ofr20191063.

Hoxie, D.T., 1977, Digital model of the Arikaree aquifer near Wheatland, southeastern Wyoming: U.S. Geological Survey Open-File Report 77-676, 54 p. [Also available at https://doi.org/10.3133/ofr77676.]

Hoxie, D.T., 1979, Results of transient simulations of a digital model of the Arikaree aquifer near Wheatland, southeastern Wyoming: U.S. Geological Survey Open-File Report 79-1280, 17 p. [Also available at https://doi.org/10.3133/ ofr791280.]

Hoxie, D.T., 1983, Hydrologic evaluation of proposed groundwater withdrawals in Muleshoe Flat near Wheatland, southeastern Wyoming: U.S. Geological Survey Water-Resources Investigations Report 83-4150, 16 p. [Also available at https://doi.org/10.3133/wri834150.] 
Hsieh, P.A., Bredehoeft, J.D., and Farr, J.M., 1987, Determination of aquifer transmissivity from Earth tide analysis: Water Resources Research, v. 23, no. 10, p. 1824-1832. [Also available at https://doi.org/10.1029/ WR023i010p01824.]

Hsieh, P.A., Bredehoeft, J.D., and Rojstaczer, S.A., 1988, Response of well aquifer systems to Earth tides-Problem revisited: Water Resources Research, v. 24, no. 3, p. 468-472. [Also available at https://doi.org/10.1029/ WR024i003p00468.]

Hudson, F., 2004, Standard operating procedure-Sample preparation and calculations for dissolved gas analysis in water samples using a GC [gas chromatograph] headspace equilibration technique: U.S. Environmental Protection Agency, RSKSOP-175 Revision No. 2, May 2004, accessed November 24, 2020, at https://archive.epa.gov/region1/info/ testmethods/web/pdf/rsksop175v2.pdf.

Hunt, R.M., Jr., 1985, Arikaree rocks (lower Miocene) of the Hartville Table, Nebraska and Wyoming, in Martin, J.E., ed., Fossiliferous Cenozoic deposits of western South Dakota and northwestern Nebraska: Dakoterra, v. 2, no. 2, p. 155-204.

Hunt, R.M., Jr., 1990, Taphonomy and sedimentology of Arikaree (lower Miocene) fluvial, eolian, and lacustrine paleoenvironments, Nebraska and Wyoming - A paleobiota entombed in fine-grained volcaniclastic rocks, in Lockley, M.G., and Rice, A., eds., Volcanism and fossil biotas: Boulder, Colo., Geological Society of America, Special Paper 244, p. 69-111.

Hunt, R.M., Jr., 2002, New amphicyonid carnivorans (Mammalia, Daphoeninae) from the early Miocene of southeastern Wyoming: American Museum Novitates, no. 3385, 41 p.

Ingram, R.L., and Johnson, M., 2006, Grain-size scales, in Walker, J.D., and Cohen, H.A., comps., The geoscience handbook-AGI [American Geological Institute] data sheets (4th ed.): Alexandria, Va., American Geological Institute, p. 161.

Izett, G.A., 1975, Late Cenozoic sedimentation and deformation in northern Colorado and adjoining areas, in Curtis, B.F., ed., Cenozoic history of the southern Rocky Mountains: Geological Survey of America Memoir 144, p. 179209.

Jacob, C.E., 1940, On the flow of water in an elastic artesian aquifer: Eos (Washington, D.C.), v. 21, no. 2, p. 574-586. [Also available at https://doi.org/10.1029/ TR021i002p00574.]

Jehn-Dellaport, T., and Renninger, T., 2017, The Pawnee aquifer, Denver-Julesburg Basin, northeastern Colorado: The Mountain Geologist, v. 54, no. 1, p. 15-32.
Johnson, R.A., and Smithson, S.B., 1985, Thrust faulting in the Laramie Mountains, Wyoming, from reanalysis of COCORP data: Geology, v. 13, no. 8, p. 534-546. [Also available at https://doi.org/10.1130/00917613(1985)13\%3C534:TFITLM\%3E2.0.CO;2.]

Jones, S.R., and Garbarino, J.R., 1999, Methods of analysis by the U.S. Geological Survey National Water Quality Laboratory-Determination of arsenic and selenium in water and sediment by graphite furnace-atomic absorption spectrometry: U.S. Geological Survey Open-File Report 98-639, 39 p. [Also available at https://doi.org/10.3133/ofr98639.]

Jordan, B.J., 1998, Wellhead protection for the Cheyenne municipal well fields: Laramie, University of Wyoming, Department of Geology and Geophysics, master's thesis, $132 \mathrm{p}$.

Jorgensen, D.G., Helgesen, J.O., Signor, D.C., Leonard, R.B., Imes, J.L., and Christenson, S.C., 1996, Analysis of regional aquifers in the central Midwest of the United States in Kansas, Nebraska, and parts of Arkansas, Colorado, Missouri, New Mexico, Oklahoma, South Dakota, Texas, and Wyoming - Summary: U.S. Geological Survey Professional Paper 1414-A, 67 p. [Also available at https://doi.org/10.3133/pp1414A.]

JR Engineering and Lidstone and Associates, Inc., 2009, Master plan, level I study for the town of Pine Bluffs, Wyoming: report prepared for the Wyoming Water Development Commission [variously paged].

JR Engineering, Lidstone and Associates, Inc., and HDR, 2008, Water resource atlas of Laramie County, Wyoming: report prepared for Wyoming Water Development Commission and Laramie County, Wyo. [variously paged].

Jurgens, B.C., McMahon, P.B., Chapelle, F.H., and Eberts, S.M., 2009, An Excel workbook for identifying redox processes in groundwater: U.S. Geological Survey Open-File Report 2009-1004, 8 p., accessed November 24, 2020, at https://doi.org/10.3133/ofr20091004.

Kalin, R.M., 2000, Radiocarbon dating of groundwater systems, in Cook, P.G., and Herczeg, A.L., eds., Environmental tracers in subsurface hydrology: Boston, Mass., Kluwer Academic Publishers, p. 111-144.

Karlstrom, K.E., Coblentz, D., Dueker, K., Ouimet, W., Kirby, E., Van Wijk, J., Schmandt, B., Kelley, S., Lazear, G., Crossey, L.J., Crow, R., Aslan, A., Darling, A., Aster, R., MacCarthy, J., Hansen, S.M., Stachnik, J., Stockli, D.F., Garcia, R.V., Hoffman, M., McKeon, R., Feldman, J., Heizler, M., Donahue, M.S., and the CREST Working Group, 2012, Mantle-driven dynamic uplift of the Rocky Mountains and Colorado Plateau and a surface response-Toward a unified hypothesis: Lithosphere, v. 4, no. 1, p. 3-22. [Also available at https://doi.org/10.1130/L150.1.] 
Karlstrom, K.E., Whitmeyer, S.J., Dueker, K., Williams, M.L., Bowring, S.A., Levander, A., Humphreys, E.D., and Keller, G.R., 2005, Synthesis of results from the CD-ROM experiment - 4-D image of the lithosphere beneath the Rocky Mountains and implications for understanding the evolution of continental lithosphere, in Karlstrom, K.E., and Keller, G.R., eds., The Rocky Mountain region-An evolving lithosphere-Tectonics, geophysics, and geochemistry: Washington, D.C, American Geophysical Union, Geophysical Monograph 154, p. 421-441.

Kasenow, M., 2001, Applied ground-water hydrology and well hydraulics ( $2 \mathrm{~d}$ ed.): Highlands Ranch, Colo., Water Resources Publications, LLC, 835 p.

Kelly, W.R., Holm, T.R., Wilson, S.D., and Roadcap, G.S., 2005, Arsenic in glacial aquifers-Sources and geochemical controls: Ground Water, v. 43, no. 4, p. 500-510.

Kendall, C., and McDonnell, J.J., eds., 1998, Isotope tracers in catchment hydrology: Amsterdam, Elsevier Science B.V., $839 \mathrm{p}$.

Keys, W.S., 1990, Borehole geophysics applied to groundwater investigations: U.S. Geological Survey Techniques of Water-Resources Investigations, book 2, chap. E2, 150 p. [Also available at https://doi.org/10.3133/twri02E2.]

Keys, W.S., 1997, A practical guide to borehole geophysics in environmental investigations: Boca Raton, Fla., CRC/Lewis Publishers, $176 \mathrm{p}$.

Kihm, A.J., 1987, Mammalian paleontology and geology of the Yoder Member, Chadron Formation, east-central Wyoming: Dakoterra, v. 3, p. 28-45.

Kirkham, R.M., and Ladwig, L.R., 1979, Coal resources of Denver and Cheyenne Basins, Colorado: Denver, Colorado Geological Survey Resource Series no. 5, 70 p.

Kirkham, R.M., and Ladwig, L.R., 1980, Energy resources of Denver and Cheyenne Basins, Colorado-Resource characteristics, development potential, and environmental problems: Denver, Colorado Geological Survey Environmental Series EG-12, 258 p.

Kirkham, R.M., O’Leary, W., and Warner, J.W., 1980, Hydrogeologic and stratigraphic data pertinent to uranium mining, Cheyenne Basin, Colorado: Denver, Colorado Geological Survey Information Series no. 12, $31 \mathrm{p}$.

Kirkham, R.M., and Rold, J.W., 1986, Water resources of upper Crow Creek, Colorado: Denver, Colorado Geological Survey Special Publication no. 29, 102 p., 7 pls.

Kiteley, L.W., 1976, Marine shales and sandstones in the Upper Cretaceous Pierre Shale at the Francis Ranch, Laramie County, Wyoming: The Mountain Geologist, v. 13, no. 1, p. 1-19.
Kiteley, L.W., 1977, Shallow marine deposits in the Upper Cretaceous Pierre Shale of the northern Denver Basin and their relation to hydrocarbon accumulation: Exploration frontiers of the Central and Southern Rockies, Rocky Mountain Association of Geologists-1977 symposium, p. 197-211.

Kiteley, L.W., 1978, Stratigraphic sections of Cretaceous rocks of the northern Denver Basin, northeastern Colorado and southeastern Wyoming: U.S. Geological Survey Oil and Gas Investigations Chart OC-78, 3 sheets.

Knight, S.H., and Morgan, A.M., 1937, Report on the underground water resources of Crow Creek Valley, Laramie County, Wyoming: Laramie, Geological Survey of Wyoming, University of Wyoming, 16 p., 1 pl.

Knowlton, F.H., 1922, The Laramie flora of the Denver Basin, with a review of the Laramie problem: U.S. Geological Survey Professional Paper 130, 175 p. [Also available at https://doi.org/10.3133/pp130.]

Koterba, M.T., Wilde, F.D., and Lapham, W.W., 1995, Ground-water data-collection protocols and procedures for the National Water-Quality Assessment Program-Collection and documentation of water-quality samples and related data: U.S. Geological Survey Open-File Report 95-399, 113 p. [Also available at https://doi.org/10.3133/ofr95399.]

LaGarry, H.E., 1998, Lithostratigraphic revision and redescription of the Brule Formation (White River Group) of northwestern Nebraska, in Terry, D.O., LaGarry, H.E., and Hunt, R.M., Jr., eds., Depositional environments, lithostratigraphy, and biostratigraphy of the White River and Arikaree Groups (late Eocene to early Miocene, North America): Boulder, Colo., Geological Society of America Special Paper 325, p. 63-91.

Landman, N.H., and Cobban, W.A., 2003, Ammonites from the upper part of the Pierre Shale and Fox Hills Formation of Colorado: American Museum Novitates no. 3388, 45 p.

Lapham, W.W., Wilde, F.D., and Koterba, M.T., 1995, Ground-water data-collection protocols and procedures for the National Water-Quality Assessment Program-Selection, installation, and documentation of wells and collection of related data: U.S. Geological Survey Open-File Report 95-398, 69 p. [Also available at https://doi.org/10.3133/ ofr95398.]

Larson, E.E., and Evanoff, E., 1998, Tephrostratigraphy and source of the tuffs of the White River sequence, in Terry, D.O., LaGarry, H.E., and Hunt, R.M., Jr., eds., Depositional environments, lithostratigraphy, and biostratigraphy of the White River and Arikaree Groups (late Eocene to early Miocene, North America): Boulder, Colo., Geological Society of America Special Paper 325, p. 1-14. 
Lavington, C.S., 1933, Montana Group in eastern Colorado: Bulletin of the American Association of Petroleum Geologists, v. 17, no. 4, p. 397-410.

LeRoy, L.W., 1946, Stratigraphy of the Golden-Morrison area, Jefferson County, Colorado: Quarterly of the Colorado School of Mines, v. 41, no. 2, 115 p.

Libra, R.D., Collentine, M., and Feathers, K.R., 1981, Occurrence and characteristics of ground water in the Denver-Julesburg Basin, Wyoming: Laramie, University of Wyoming, Water Resources Research Institute, v. VIIA-B [variously paged].

Lidstone and Anderson, Inc., and AVI Professional Corporation, 1995, Final report for Town of Pine Bluffs water supply investigation, level II: report prepared for the Wyoming Water Development Commission [variously paged].

Lidstone and Associates, Inc., 2003, Town of Pine Bluffs groundwater exploration grant final report: report prepared for the Wyoming Water Development Commission [variously paged].

Lidstone and Associates, Inc., 2005, Cheyenne Belvoir Ranch environmental report, level II: report prepared for the Wyoming State Revolving Fund [variously paged].

Lidstone and Associates, Inc., 2012, Cheyenne Belvoir Ranch groundwater level II: report prepared for the Wyoming Water Development Commission [variously paged].

Lillegraven, J.A., 1993, Correlation of Paleogene strata across Wyoming-A user's guide, in Snoke, A.W., Steidtmann, J.R., and Roberts, S.M., eds., Geology of Wyoming: Geological Survey of Wyoming Memoir no. 5 p. 414-477.

Lillegraven, J.A., and Ostresh, L.M., 1988, Evolution of Wyoming's early Cenozoic topography and drainage patterns: National Geographic Research, v. 4, p. 303-327.

Lillegraven, J.A., and Ostresh, L.M., 1990, Late Cretaceous (earliest Campanian/Maastrichtian) evolution of western shorelines of the North American Western Interior Seaway in relation to known mammalian faunas, in Bown, T.M., and Rose, K.D., eds., Dawn of the age of mammals in the northern part of the Rocky Mountain interior, North America: Boulder, Colo., Geological Society of America, Special Paper 243, p. 1-30.

Lines, G.C., 1976, Digital model to predict effects of pumping from the Arikaree aquifer in the Dwyer area, southeastern Wyoming: U.S. Geological Survey Water-Resources Investigations/Open-File Report 76-8 [identified as WRI/ OFR 8-76 on report], 24 p., 7 separate figs. [Also available at https://doi.org/10.3133/wri768.]
Liu, L., 2015, The ups and downs of North America-Evaluating the role of mantle dynamic topography since the Mesozoic: Reviews of Geophysics, v. 53, no. 3, p. 1022-1049.

[Also available at https://doi.org/10.1002/2015RG000489.]

Love, J.D., and Christiansen, A.C., comps., 1985, Geologic map of Wyoming: U.S. Geological Survey, 3 sheets, scale 1:500,000. [Also available at https://doi.org/10.3133/70046739.]

Love, J.D., Christiansen, A.C., and Ver Ploeg, A.J., 1993, Stratigraphic chart showing Phanerozoic nomenclature for the state of Wyoming: Geological Survey of Wyoming Map Series 41,1 sheet.

Love, J.D., Weitz, J.L., and Hose, R.K., 1955, Geologic map of Wyoming: U.S. Geological Survey, 1 sheet, scale 1:500,000.

Lovering, T.S., Aurand, H.A., Lavington, C.S., and Wilson, J.H., 1932, Fox Hills Formation, northeastern Colorado: Bulletin of the American Association of Petroleum Geologists, v. 16, p. 702-703.

Lowry, M.E., 1966, The White River Formation as an aquifer in southeastern Wyoming and adjacent parts of Nebraska and Colorado, in Geological Survey Research 1966: U.S. Geological Survey Professional Paper 550-D, p. D217-D222. [Also available at https://doi.org/10.3133/ pp550D.]

Lowry, M.E., and Crist, M.A., 1967, Geology and groundwater resources of Laramie County, Wyoming, with a section on Chemical quality of ground water and of surface water, by J.R. Tilstra: U.S. Geological Survey Water-Supply Paper 1834, 71 p., 2 pls. [Also available at https://doi.org/10.3133/ wsp1834.]

Lucas, L.L., and Unterweger, M.P., 2000, Comprehensive review and critical evaluation of the half-life of tritium: Journal of Research of the National Institute of Standards and Technology, v. 105, no. 4, p. 541-549.

Lugn, A.L., 1939, Classification of the Tertiary system in Nebraska: Geological Society of America Bulletin, v. 50, p. 1245-1276.

Major, T.J., Robson, S.G., Romero, J.C., and Zawistowski, S., 1983, Hydrogeologic data from parts of the Denver Basin, Colorado: U.S. Geological Survey Open-File Report 83-274, 425 p. [Also available at https://doi.org/10.3133/ ofr83274.]

Martin, C.A., 1965, Denver Basin: Bulletin of the American Association of Petroleum Geologists, v. 49, no. 11, p. 1908 1925.

Mather, K.F., Gilluly, J., and Lusk, R.G., 1928, Geology and oil and gas prospects of northeastern Colorado: U.S. Geological Survey Bulletin 796-B, p. 65-118. 
Matuszczak, R.A., 1973, Wattenberg field, Denver Basin, Colorado: The Mountain Geologist, v. 10, p. 99-105.

McCurdy, D.E., Garbarino, J.R., and Mullin, A.H., 2008, Interpreting and reporting radiological water-quality data: U.S. Geological Survey Techniques and Methods, book 5, chap. B6, 33 p. [Also available at https://doi.org/10.3133/ tm5B6.]

McGrew, P.O., 1953, Tertiary deposits of southeastern Wyoming, in Eighth Annual Field Conference, Laramie Basin, Wyoming and North Park, Colorado: Laramie, Wyoming Geological Association and University of Wyoming, p. $61-64$.

McGrew, L.W., 1963, Geology of the Fort Laramie area, Platte and Goshen Counties, Wyoming: U.S. Geological Survey Bulletin 1141-F, 39 p. [Also available at https://doi.org/10.3133/b1141F.]

McGuire, V.L., 2017, Water level and recoverable water in storage changes, High Plains aquifer, predevelopment to 2015 and 2013-2015: U.S. Geological Survey Scientific Investigations Report 2017-5040, 14 p., accessed November 24, 2020, at https://doi.org/10.3133/sir20175040.

McGuire, V.L., Johnson, M.R., Schieffer, R.L., Stanton, J.S., Sebree, S.K., and Verstraeten, I.M., 2003, Water in storage and approaches to ground-water management, High Plains aquifer, 2000: U.S. Geological Survey Circular 1243, 51 p. [Also available at https://doi.org/10.3133/cir1243.]

McLain, B.J., 1993, Methods of analysis by the U.S. Geological Survey National Water Quality Laboratory-Determination of chromium in water by graphite furnace atomic absorption spectrophotometry: U.S. Geological Survey Open-File Report 93-449, 16 p. [Also available at https://doi.org/10.3133/ofr93449.]

McLaughlin, J.F., and Harris, R.E., 2005, Geologic map of the Torrington $30^{\prime} \times 60^{\prime}$ quadrangle, Goshen and Platte Counties, Wyoming, and Sioux and Scotts Bluff Counties, Nebraska: Wyoming State Geological Survey Map Series 66,1 sheet, scale 1:100,000.

McLaughlin, J.F., Stafford, J.E., and Harris, R.E., 2011, Geologic map of the Lusk $30^{\prime} \times 60^{\prime}$ quadrangle, Niobrara, Goshen, Converse, and Platte Counties, Wyoming, and Sioux County, Nebraska: Wyoming State Geological Survey Map Series 82, 1 sheet, scale 1:100,000.

McMahon, P.B., and Böhlke, J.K., 2006, Regional patterns in the isotopic composition of natural and anthropogenic nitrate in ground water, High Plains, USA: Environmental Science \& Technology, v. 40, no. 9, p. 2965-2970.
McMahon, P.B., and Chapelle, F.H., 2008, Redox processes and water quality of selected principal aquifer systems: Ground Water, v. 46, p. 259-271. [Also available at https://doi.org/10.1021/es052229q.]

McMillan, M.E., Angevine, C.L., and Heller, P.L., 2002, Postdepositional tilt of the Miocene-Pliocene Ogallala Group on the western Great Plains-Evidence of late Cenozoic uplift of the Rocky Mountains: Geology, v. 30, no. 1, p. 63-66. [Also available at https://doi.org/10.1130/00917613(2002)030\%3C0063:PTOTMP\%3E2.0.CO;2.]

McMillan, M.E., Heller, P.L., and Wing, S.L., 2006, History and causes of post-Laramide relief in the Rocky Mountain orogenic plateau: Geological Society of America Bulletin, v. 118 , no. $3 / 4$, p. $393-405$.

Mears, B., Jr., 1991, The Cheyenne tableland, in Morrison, R.B., ed., Quaternary nonglacial geology-Conterminous U.S.: Boulder, Colo., Geological Society of America, The geology of North America, v. K-2, p. 453-455.

Meek, F.B., and Hayden, F.V., 1857, Descriptions of new species and genera of fossils, collected by Dr. F.V. Hayden in Nebraska Territory, under the direction of Lieutenant G.K. Warren, U.S. topographical engineer, with some remarks on the Tertiary and Cretaceous formations of the northwest, and the parallelism of the latter with those of other portions of the United States and Territories: Proceedings of the Academy of Natural Sciences of Philadelphia, May 26, 1857, v. 9, p. 117-148, accessed December 10, 2020, at https://www.jstor.org/stable/4059198?seq=1\#metadata info_tab_contents.

Meek, F.B., and Hayden, F.V., 1861, Descriptions of new lower Silurian (primordial), Jurassic, Cretaceous, and Tertiary fossils, collected in Nebraska, by the exploring expedition under the command of Capt. Wm. F. Raynolds, U.S. topographical engineer, with some remarks on the rocks from which they were obtained: Proceedings of the Academy of Natural Sciences of Philadelphia, December 31, 1861, v. 13, p. 415-447, accessed December 10, 2020, at https://www.jstor.org/stable/4059571?seq=1\#metadata info_tab_contents.

Meinzer, O.E., 1917, Groundwater for irrigation in Lodgepole Valley, Wyoming and Nebraska: U.S. Geological Survey Water-Supply Paper 425-B, p. 37-69. [Also available at https://doi.org/10.3133/wsp425B.]

Melchior, P., 1966, The Earth Tides: London, Pergamon Press, $458 \mathrm{p}$.

Merewether, E.A., Cobban, W.A., and Obradovich, J.D., 2011, Biostratigraphic data from Upper Cretaceous formationseastern Wyoming, central Colorado, and northeastern New Mexico: U.S. Geological Survey Scientific Investigations Map 3175, 2 sheets, pamphlet, 10 p. [Also available at https://doi.org/10.3133/sim3175.] 
Merritt, M.L., 2004, Estimating hydraulic properties of the Floridan aquifer system by analysis of Earth-tide, oceantide, and barometric effects, Collier and Hendry Counties, Florida: U.S. Geological Survey Water-Resources Investigations Report 2003-4267, 70 p. [Also available at https://doi.org/10.3133/wri034267.]

Minick, J.N., 1951, Tertiary stratigraphy of southeastern Wyoming and northeastern Colorado: Laramie, University of Wyoming, Department of Geology, master's thesis, 53 p., $1 \mathrm{pl}$.

Mook, W.G., and van der Plicht, J., 1999, Reporting ${ }^{14} \mathrm{C}$ activities and concentrations: Radiocarbon, v. 41, no. 3 , p. 227-239. [Also available at https://doi.org/10.1017/ S0033822200057106.]

Moore, F.E., 1959, The geomorphic evolution of the east flank of the Laramie Range, Colorado and Wyoming: Laramie, University of Wyoming, Department of Geology, Ph.D. dissertation, 123 p., 6 pls.

Moore, F.E., 1963, Tertiary stratigraphy of the High Plains, in Bolyard, D.W., and Katich, P.J., eds., Geology of the northern Denver Basin and adjacent uplifts: Denver, Colo., Rocky Mountain Association of Geologists, p. 162-166.

Morgan, A.M., 1946, Progress report on the geology and ground-water resources of the Cheyenne area, Wyoming: U.S. Geological Survey Open-File Report 49-95 [number assigned retroactively], 55 p., 7 pls. [Also available at https://doi.org/10.3133/ofr4995.]

Morris, D.A., and Babcock, H.M., 1960, Geology and groundwater resources of Platte County, Wyoming, with a section on Chemical quality of the water, by R.H. Langford: U.S. Geological Survey Water-Supply Paper 1490, 195 p., 4 pls. [Also available at https://doi.org/10.3133/wsp1490.]

Munk, W.H., and MacDonald, G.J.F., 1960, The rotation of the Earth-A geophysical discussion: London, Cambridge University Press, $323 \mathrm{p}$.

Munsell, 2000, Munsell soil color charts-Year 2000 revised washable edition: New Windsor, N.Y., Gretag Macbeth, $10 \mathrm{p}$.

Musgrove, M., Beck, J.A., Paschke, S.S., Bauch, N.J., and Mashburn, S.L., 2014, Quality of groundwater in the Denver Basin aquifer system, Colorado, 2003-5: U.S. Geological Survey Scientific Investigations Report 2014-5051, 107 p., accessed May 23, 2019, at https://doi.org/10.3133/ $\operatorname{sir} 20145051$.

Nace, R.L., 1936, Summary of the Late Cretaceous and early Tertiary stratigraphy of Wyoming: Geological Survey of Wyoming Bulletin no. 26, 271 p.
National Research Council, 1999, Risk assessment of radon in drinking water: Washington, D.C., National Academy Press, $296 \mathrm{p}$.

Nelson, P.H., Gianoutsos, N.J., and Drake, R.M., 2015, Underpressure in Mesozoic and Paleozoic rock units in the midcontinent of the United States: The American Association of Petroleum Geologists Bulletin, v. 99, no. 10, p. 1861-1892.

Nibbelink, K.A., 1983, Depositional environments of the Fox Hills Sandstone (Upper Cretaceous), Cheyenne Basin, Colorado: Fort Collins, Colorado State University, Department of Earth Resources, master's thesis, 226 p., 8 pls.

Nolan, B.T., and Hitt, K.J., 2003, Nutrients in shallow ground waters beneath relatively undeveloped areas in the conterminous United States: U.S. Geological Survey WaterResources Investigations Report 2002-4289, 17 p. [Also available at https://doi.org/10.3133/wri20024289.]

Nordstrom, D.K., 2002, Worldwide occurrences of arsenic in groundwater: Science, v. 296, no. 5576, p. 2143-2145.

Oblinger Childress, C.J., Foreman, W.T., Connor, B.F., and Maloney, T.J., 1999, New reporting procedures based on long-term method detection levels and some considerations for interpretations of water-quality data provided by the U.S. Geological Survey National Water Quality Laboratory: U.S. Geological Survey Open-File Report 99-193, 20 p. [Also available at https://doi.org/10.3133/ofr99193.]

Obradovich, J.A., Evanoff, E., and Larson, E.E., 1995, Revised single-crystal laser-fusion ${ }^{40} \mathrm{Ar} /{ }^{39} \mathrm{Ar}$ ages of Chadronian tuffs in the White River Formation of Wyoming: Geological Society of America Abstracts with Programs, v. 27 , no. 3 , p. $77-78$.

Ostlund, H.G., and Dorsey, H.G., 1977, Rapid electrolytic enrichment of hydrogen gas proportional counting of tritium: High Tatras, Czechoslovakia, Proceedings of International Conference on Low Radioactivity Measurement and Applications, October 1975, 6 p.

Otton, J.K., 1992, The geology of radon: U.S. Geological Survey General Interest Publication, 29 p.

Paschke, S.S., ed., 2011, Groundwater availability of the Denver Basin aquifer system, Colorado: U.S. Geological Survey Professional Paper 1770, 274 p. [Also available at https://doi.org/10.3133/pp1770.]

Paschke, S.S., Banta, E.R., Dupree, J.A., and Capesius, J.P., 2011, Introduction, conceptual model, hydrogeologic framework, and predevelopment groundwater availability of the Denver Basin aquifer system, Colorado, chap. A of Paschke, S.S., ed., Groundwater availability of the Denver Basin aquifer system, Colorado: U.S. Geological Survey Professional Paper 1770, p. 1-93. [Also available at https://doi.org/10.3133/pp1770.] 
Pettyjohn, W.A., 1966, Eocene paleosol in the northern Great Plains, in U.S. Geological Survey, ed., Geological Survey Research 1966, chap. C: U.S. Geological Survey Professional Paper 550-C, p. 61-65.

Piper, A.M., 1944, A graphic procedure in the geochemical interpretation of water analyses: American Geophysical Union Transactions, v. 25, no. 6, p. 914-923. [Also available at https://doi.org/10.1029/TR025i006p00914.]

Plummer, N., Bexfield, L.M., Anderholm, S.K., Sanford, W.E., and Busenberg, E., 2004, Geochemical characterization of groundwater flow in the Santa Fe Group aquifer system, Middle Rio Grande basin, New Mexico: U.S. Geological Survey Water-Resources Investigation Report 20034131, 395 p. [Also available at https://doi.org/10.3133/ wri034131.]

Plummer, L.N., and Glynn, P.D., 2013, Radiocarbon dating in groundwater systems, chap. 4 of International Atomic Energy Agency, ed., Isotope methods for dating old groundwater: Vienna, Austria, International Atomic Energy Agency, p. 33-89.

Plummer, L.N., Michel, R.L., Thurman, E.M., and Glynn, P.D., 1993, Environmental tracers for age-dating young groundwater, in Alley, W.M., ed., Regional ground-water quality: New York, Van Nostrand Reinhold, p. 181-198.

Powers, M.C., and Johnson, M., 2006, Comparison charts for estimating roundness and sphericity, in Walker, J.D., and Cohen, H.A., comps., 2006, The geoscience handbookAGI [American Geological Institute] data sheets (4th ed.): Alexandria, Va., American Geological Institute, p. 161.

Prothero, D.R., 1996a, Magnetic stratigraphy of the White River Group in the High Plains, in Prothero, D.R., and Emry, R.J., eds., The terrestrial Eocene-Oligocene transition in North America: Cambridge University Press, p. 262-277.

Prothero, D.R., 1996b, Camelidae, in Prothero, D.R., and Emry, R.J., eds., The terrestrial Eocene-Oligocene transition in North America: Cambridge University Press, p. 609-651.

Prothero, D.R., and Emry, R.J., 2004, The Chadronian, Orellan, and Whitneyan North American land mammal ages, in Woodburne, M.O., ed., Late Cretaceous and Cenozoic mammals of North America-Biostratigraphy and geochronology: New York, Columbia University Press, p. 156-168.

Prothero, D.R., and Swisher, C.C., III, 1992, Magnetostratigraphy and geochronology of the terrestrial Eocene-Oligocene transition in North America, in Prothero, D.R., and Berggren, W.A., eds., Eocene-Oligocene climatic and biotic evolution: Princeton, N.J., Princeton University Press, p. 46-73.
Prothero, D.R., and Whittlesey, K.E., 1998, Magnetic stratigraphy and biostratigraphy of the Orellan, and Whitneyan land-mammal ages in the White River Group in Terry, D.O., Jr., LaGarry, H.E., and Hunt, R.M., Jr., eds., Depositional environments, lithostratigraphy, and biostratigraphy of the White River and Arikaree Groups (late Eocene to early Miocene, North America): Boulder, Colo., Geological Society of America Special Paper 325, p. 39-61.

Qi, S.L., 2010, Digital map of aquifer boundary for the High Plains aquifer in parts of Colorado, Kansas, Nebraska, New Mexico, Oklahoma, South Dakota, Texas, and Wyoming: U.S. Geological Survey Data Series 543, accessed November 24, 2020, at https://doi.org/10.3133/ds543.

Quilty, E.G., and Roeloffs, E.A., 1991, Removal of barometric pressure response from water level data: Journal of Geophysical Research, v. 96, no. B6, p. 10209-10218. [Also available at https://doi.org/10.1029/91JB00429.]

Rapp, J.R., Visher, F.N., and Littleton, R.T., 1957, Geology and ground-water resources of Goshen County, Wyoming, with a section on Chemical quality of the ground water, by W.H. Durum: U.S. Geological Survey Water-Supply Paper 1377, 145 p., 4 pls. [Also available at https://doi.org/10.3133/wsp1377.]

Rapp, J.R., Warner, D.A., and Morgan, A.M., 1953, Geology and ground-water resources of the Egbert-Pine BluffsCarpenter area, Laramie County, Wyoming: U.S. Geological Survey Water-Supply Paper 1140, 67 p., 3 pls. [Also available at https://doi.org/10.3133/wsp1140.]

Raynolds, R.G., 1997, Synorogenic and post-orogenic strata in the central Front Range, Colorado, in Bolyard, D.W., and Sonnenberg, S.A., eds., Geologic history of the Colorado Front Range: Denver, Colo., Rocky Mountain Association of Geologists, 1997 American Association of Petroleum Geologists, Rocky Mountain Section Field Trip Guide no. 7, p. 43-47.

Raynolds, R.G., 2002, Upper Cretaceous and Tertiary stratigraphy of the Denver Basin, Colorado: Rocky Mountain Geology, v. 37, no. 2, p. 111-134. [Also available at https://doi.org/10.2113/gsrocky.37.2.111.]

Raynolds, R.G., 2003, Laramide synorogenic strata bounding the Front Range, Colorado, in Raynolds, R.G., and Flores, R.M., eds., Cenozoic systems of the Rocky Mountain region: Society of Economic Paleontologists and Mineralogists, Rocky Mountain Section, p. 355-368.

Raynolds, R.G., and Dechesne, M., 2007, Fox Hills Sandstone shingle stratigraphy in the Denver Basin, Colorado: Geological Society of America Abstracts with Programs, v. 39, no. 6, p. 151 [abstract]. 
Raynolds, R.G., and Hagadorn, J.W., 2016, Colorado stratigraphy chart: Denver, Colo., chart prepared jointly by Colorado Geological Survey and the Denver Museum of Nature and Science, Colorado Geological Survey Map Series MS-53, $1 \mathrm{pl}$.

Raynolds, R.G., and Johnson, K.R., 2003, Synopsis of the stratigraphy and paleontology of the uppermost Cretaceous and lower Tertiary strata in the Denver Basin, Colorado: Rocky Mountain Geology, v. 38, no. 1, p. 171-181. [Also available at https://doi.org/10.2113/gsrocky.38.1.171.]

Raynolds, R.G., Johnson, K.R., Arnold, L.R., Farnham, T.M., Fleming, R.F., Hicks, J.F., Kelley, S.A., Lapey, L.A., Nichols, D.J., Obradovich, J.D., and Wilson, M.D., 2001, The Kiowa core, a continuous drill core through the Denver Basin bedrock aquifers at Kiowa, Elbert County, Colorado: U.S. Geological Survey Open-File Report 2001-185, 127 p., 2 pls. [Also available at https://doi.org/10.3133/ ofr01185.]

Reade, H.L., Jr., 1976, Grover uranium deposit—A case history of uranium exploration in the Denver Basin, Colorado: The Mountain Geologist, v. 13, no. 1, p. 21-31.

Regan, S., Hynds, P., and Flynn, R., 2017, An overview of dissolved organic carbon in groundwater and implications for drinking water safety: Hydrogeology Journal, v. 25, p. 959-967.

Retallack, G.J., 1983, Late Eocene and Oligocene paleosols from Badlands National Park, South Dakota: Geological Society of America Special Paper 193, 82 p. [Also available at https://doi.org/10.1130/SPE193.]

Révész, K., and Coplen, T.B., 2008a, Determination of the delta $\left({ }^{2} \mathrm{H} /{ }^{1} \mathrm{H}\right)$ of water: RSIL lab code 1574 : U.S. Geological Survey Techniques and Methods, book 10, chap. C1, 27 p. [Also available at https://doi.org/10.3133/tm10C1.]

Révész, K., and Coplen, T.B., 2008b, Determination of the delta $\left({ }^{18} \mathrm{O} /{ }^{16} \mathrm{O}\right)$ of water: U.S. Geological Survey Techniques and Methods, book 10, chap. C2, 28 p. [Also available at https://doi.org/10.3133/tm10C2.]

Roberts, S.B., 2007, Coal in the Front Range urban corridor-An overview of coal geology, coal production, and coal-bed methane potential in selected areas of the Denver Basin, Colorado, and the potential effects of historical coal mining on development and land-use planning, chap. 3 of Higley, D.K., comp., Petroleum systems and assessment of undiscovered oil and gas in the Denver Basin Province, Colorado, Kansas, Nebraska, South Dakota, and Wyoming-USGS Province 39: U.S. Geological Survey Digital Data Series DDS-69-P, 45 p.
Roberts, L.N.R., and Kirschbaum, M.A., 1995, Paleogeography of the Late Cretaceous of the western interior of middle North America-Coal distribution and sediment accumulation: U.S. Geological Survey Professional Paper 1561, 115 p. [Also available at https://doi.org/10.3133/pp1561.]

Robson, S.G., 1987, Bedrock aquifers in the Denver Basin, Colorado-A quantitative water-resources appraisal: U.S. Geological Survey Professional Paper 1257, 73 p., 5 pls. [Also available at https://doi.org/10.3133/pp1257.]

Robson, S.G., 1989, Alluvial and bedrock aquifers in the Denver Basin, eastern Colorado's groundwater resourceA quantitative water-resources appraisal: U.S. Geological Survey Water-Supply Paper 2302, 40 p.

Robson, S.G., Arnold, L.R., and Heiny, J.S., 2000a, Geohydrology of the Greeley-Nunn area, Colorado: U.S. Geological Survey Hydrologic Investigations Atlas HA-746-A, 5 sheets, scale 1:50,000. [Also available at https://doi.org/10.3133/ha746A.]

Robson, S.G., Arnold, L.R., and Heiny, J.S., 2000b, Geohydrology of the shallow aquifers in the Fort Collins-Loveland area, Colorado: U.S. Geological Survey Hydrologic Investigations Atlas HA-746-B, 5 sheets, scale 1:50,000. [Also available at https://doi.org/10.3133/ha746B.]

Robson, S.G., and Banta, E.R., 1987, Geology and hydrology of the deep bedrock aquifers in eastern Colorado: U.S. Geological Survey Water-Resources Investigations Report 85-4240, 6 pls. [Also available at https://doi.org/10.3133/ wri854240.]

Robson, S.G., and Banta, E.R., 1990, Determination of specific storage by measurement of aquifer compression near a pumping well: Ground Water, v. 28, no. 6, p. 868-874.

Robson, S.G., Van Slyke, G.D., and Graham, G., 1998, Structure, outcrop, and subcrop of the bedrock aquifers along the western margin of the Denver Basin, Colorado: U.S. Geological Survey Hydrologic Investigations Atlas HA-742, 5 sheets, scale 1:50,000. [Also available at https://doi.org/10.3133/ha742.]

Robson, S.G., Wacinski, A., Zawistowski, S., Romero, J.C., 1981, Geologic structure, hydrology, and water quality of the Laramie-Fox Hills aquifer in the Denver Basin, Colorado: U.S. Geological Survey Hydrologic Investigations Atlas HA-650, 3 sheets. [Also available at https://doi.org/10.3133/ha650.]

Rojstaczer, S., 1988a, Determination of fluid flow properties from the response of water levels in wells to atmospheric loading: Water Resources Research, v. 24, no. 11, p. 1927-1938. [Also available at https://doi.org/10.1029/ JB093iB11p13619.] 
Rojstaczer, S., 1988b, Intermediate period response of water levels in wells to crustal strain-Sensitivity and noise level: Journal of Geophysical Research, v. 93, no. B11, p. 13619-13634. [Also available at https://doi.org/10.1029/ JB093iB11p13619.]

Rojstaczer, S., and Agnew, D.C., 1989, The influence of formation material properties on the response of water levels in wells to Earth tides and atmospheric loading: Journal of Geophysical Research, v. 94, no. B9, p. 12403-12411. [Also available at https://doi.org/10.1029/JB094iB09p12403.]

Rojstaczer, S., and Riley, F.S., 1990, Response of the water level in a well to Earth tides and atmospheric loading under unconfined conditions: Water Resources Research, v. 26, no. 8, p. 1803-1817. [Also available at https://doi.org/10.1029/WR026i008p01803.]

Romero, J.C., 1976, Ground-water resources of the bedrock aquifers of the Denver Basin: Colorado, Colorado Division of Water Resources, $109 \mathrm{p}$.

Romero, J.C., and Hampton, E.R., 1972, Maps showing the approximate configuration and depth to the top of the Laramie-Fox Hills aquifer, Denver Basin, Colorado: U.S. Geological Survey Miscellaneous Investigations Series Map I-791, 1 sheet, scale 1:500,000. [Also available at https://doi.org/10.3133/i791.]

Rowley, J., and Fan, M., 2016, Middle Cenozoic diachronous shift to eolian deposition in the central Rocky MountainsTiming, provenance, and significance for paleoclimate, tectonics, and paleogeography: Geosphere, v. 12, no. 6, p. 1795-1812. [Also available at https://doi.org/10.1130/ GES01218.1.]

Sato, Y., and Denson, N.M., 1967, Volcanism and tectonism as reflected by the distribution of nonopaque heavy minerals in some Tertiary rocks of Wyoming and adjacent states, in Geological Survey Research 1967: U.S. Geological Survey Professional Paper 575-C, p. C42-C54. [Also available at https://doi.org/10.3133/pp575C.]

Scannella, J.B., Fowler, D.W., Goodwin, M.B., and Horner, J.R., 2014, Evolutionary trends in Triceratops from the Hell Creek Formation, Montana: Proceedings of the National Academy of Sciences of the United States of America, v. 111 , no. 28 , p. $10245-10250$. [Also available at https://doi.org/10.1073/pnas.1313334111.]

Schlaikjer, E.M., 1935a, A new basal Oligocene formation, in Contributions to the stratigraphy and paleontology of the Goshen Hole area, Wyoming: Cambridge, Mass., Harvard College, Bulletin of the Museum of Comparative Zoology, v. 76, no. 3, p. 71-93, accessed November 24, 2020, at https://www.biodiversitylibrary.org/item/91610\#page/126/ mode/2up.
Schlaikjer, E.M., 1935b, New vertebrates and the stratigraphy of the Oligocene and early Miocene, in Contributions to the stratigraphy and paleontology of the Goshen Hole area, Wyoming: Cambridge, Mass., Harvard College, Bulletin of the Museum of Comparative Zoology, v. 76, no. 4, p. 97-187, 41 pls., accessed November 24, 2020, at https://www.biodiversitylibrary.org/item/91610\#page/190/ mode/2up.

Schlaikjer, E.M., 1935c, The Torrington Member of the Lance Formation and the study of a new Triceratops, in Contributions to the stratigraphy and paleontology of the Goshen Hole area, Wyoming: Cambridge, Mass., Harvard College, Bulletin of the Museum of Comparative Zoology, v. 76, no. 2, p. 31-68, 6 pls., accessed November 24, 2020, at https://www.biodiversitylibrary.org/item/91610\#page/54/ mode/2up.

Schneider, P.A., Jr., 1980, Water-supply assessment of the Laramie-Fox Hills aquifer in parts of Adams, Boulder, Jefferson, and Weld Counties, Colorado: U.S. Geological Survey Open-File Report 80-327, 21 p. [Also available at https://doi.org/10.3133/ofr80327.]

Schultz, C.B., and Stout, T.M., 1938, Preliminary remarks on the Oligocene of Nebraska (abstract): Bulletin of the Geological Society of America, v. 49, p. 1921.

Schultz, C.B., and Stout, T.M., 1955, Classification of Oligocene sediments in Nebraska: Bulletin of the University of Nebraska State Museum, v. 4, p. 17-52.

Scott, G.R., 1975, Cenozoic surfaces and deposits in the southern Rocky Mountains, in Curtis, B.F., ed., Cenozoic history of the southern Rocky Mountains: Geological Society of America Memoir 144, p. 227-248.

Scott, G.R., 1978, Map showing geology, structure, and oil and gas fields in the Sterling $1^{\circ} \times 2^{\circ}$ quadrangle, Colorado, Nebraska, and Kansas: U.S. Geological Survey Miscellaneous Investigations Series Map I-1092, scale 1:250,000. [Also available at https://doi.org/10.3133/i1092.]

Scott, G.R., 1982, Paleovalley and geologic map of northeastern Colorado: U.S. Geological Survey Miscellaneous Investigations Series Map I-1378, 1 sheet, scale 1:250,000, pamphlet $12 \mathrm{p}$. [Also available at https://doi.org/10.3133/ i1378.]

Scott, G.R., and Cobban, W.A., 1965, Geologic and biostratigraphic map of the Pierre Shale between Jarre Creek and Loveland, Colorado: U.S. Geological Survey Miscellaneous Geological Investigations Series Map I-439, 1 sheet, scale 1:48,000, pamphlet $4 \mathrm{p}$. [Also available at https://doi.org/10.3133/i439.] 
Scott, G.R., and Cobban, W.A., 1986, Geologic, biostratigraphic, and structure map of the Pierre Shale between Loveland and Round Butte, Colorado: U.S. Geological Survey Miscellaneous Geological Investigations Series Map I-1700, 1 sheet, scale 1:50,000. [Also available at https://doi.org/10.3133/i1700.]

Seeland, D., 1985, Oligocene paleogeography of the northern Great Plains and adjacent mountains, in Flores, R.M., and Kaplan, S.S., eds., Cenozoic paleogeography of the westcentral United States: Denver, Colo., Society of Economic Paleontologists and Mineralogists, Rocky Mountain Section, p. 187-205.

Shapiro, S.D., Plummer, L.N., Busenberg, E., Widman, P.K., Casile, G.C., Wayland, J.E., and Runkle, D.L., 2012, Estimates of tracer-based piston-flow ages of groundwater from selected sites-National Water-Quality Assessment Program, 2006-10: U.S. Geological Survey Scientific Investigations Report 2012-5141, 100 p., accessed November 24, 2020, at https://doi.org/10.3133/sir20125141.

Shepherd, R.G., and Summer, R.M., 1979, Depositional environments and processes, Laramie and Fox Hills Formations northeast of Wellington, Colorado, in Ethridge, F.G., ed., Field guide to the northern Front Range and northwest Denver Basin, Colorado - Guidebook for postmeeting field trips, 32nd annual meeting of the Rocky Mountain section of the Geological Society of America, Colorado State University, May 26-27, 1979: Fort Collins, Colorado State University, p. 87-102.

Sherwood, O.A., Rogers, J.D., Lackey, G., Burke, T.L., Osborn, S.G., and Ryan, J.N., 2016, Groundwater methane in relation to oil and gas development and shallow coal seams in the Denver-Julesburg Basin of Colorado: Proceedings of the National Academy of Sciences of the United States of America, v. 113, no. 30, p. 8391-8396. [Also available at https://doi.org/10.1073/pnas.1523267113.]

Sibray, S.S., 2011, White River Group paleosols as source rocks for uranium mineralization in western Nebraska: The Mountain Geologist, v. 48, no. 1, p. 9-21.

Singler, C.R., and Picard, M.D., 1979a, Petrography of White River Group (Oligocene) in northwest Nebraska and adjacent Wyoming: Contributions to Geology (Laramie), v. 18, no. 1, p. 51-67.

Singler, C.R., and Picard, M.D., 1979b, Stratigraphic review of Oligocene beds in northern Great Plains: Earth Science Bulletin, v. 13, no. 1, p. 1-18.

Snoke, A.W., 1993, Geologic history of Wyoming within the tectonic framework of the North American Cordillera, in Snoke, A.W., Steidtmann, J.R., and Roberts, S.M., eds., Geology of Wyoming: Geological Survey of Wyoming Memoir 5, p. 2-56.
Sonnenberg, S.A., 1985, Northwest Denver Basin/southeast Hartville uplift, in Gries, R.R., and Dyer, R.C., eds., Seismic exploration of the Rocky Mountain region: Rocky Mountain Association of Geologists and Denver Geophysical Society, p. 213-217.

Sonnenberg, S.A., 2011, Petroleum geology of Silo Field, Wyoming: American Association of Petroleum Geologists, Rocky Mountain Section meeting, Cheyenne, Wyo., June 25-29, 2011, 32 unnumbered pages.

Sonnenberg, S.A., and Weimer, R.J., 1981, Tectonics, sedimentation, and petroleum potential, northern Denver Basin, Colorado, Wyoming, and Nebraska: Colorado School of Mines Quarterly, v. 76, p. 1-45.

Sonnenberg, S.A., and Weimer, R.J., 1993, Oil production from the Niobrara Formation, Silo field, Wyoming - Fracturing associated with a possible wrench fault system: The Mountain Geologist, v. 30, p. 39-53.

Sophocleus, M., Bardsley, E., Healey, J., and Engard, B., 2004, Can precipitation loading be detected at 300-meter depth or greater?: Lawrence, Kansas Geological Survey Open-File Report 2004-4615, 15 p.

SRK Consulting, 2010, NI 43-101 Preliminary assessment, Powertech Uranium Corporation Centennial uranium project, Weld County, Colorado: Lakewood, Colo., report prepared for Powertech Uranium Corporation [variously paged], accessed November 24, 2020, at http://azargauranium.com/wp-content/uploads/report/ technical/Centennial_PA_Rev3.pdf.

Stanley, K.O., 1971, Tectonic implications of Tertiary sediment dispersal on the Great Plains east of the Laramie Range, in Renfroe, A.R., Madison, L.V., and Bradley, W.A., eds., Symposium on Wyoming tectonics and their economic significance: Casper, Wyoming Geological Association Guidebook, 23rd Annual Field Conference, September 1971, p. 65-70.

Stanley, K.O., 1976, Sandstone petrofacies in the Cenozoic High Plains sequence, eastern Wyoming and Nebraska: Geological Society of America Bulletin, v. 87, no. 2, p. 297-309. [Also available at https://doi.org/10.1130/00167606(1976)87\%3C297:SPITCH\%3E2.0.CO;2.]

Stanley, K.O., and Benson, L.V., 1979, Early diagenesis of High Plains Tertiary vitric and arkosic sandstone, Wyoming and Nebraska: Society of Economic Paleontologists and Mineralogists, Special publication no. 26, p. 401-423. [Also available at https://doi.org/10.2110/pec.79.26.] 
Stanton, J.S., Anning, D.W., Brown, C.J., Moore, R.B., McGuire, V.L., Qi, S.L., Harris, A.C., Dennehy, K.F., McMahon, P.B., Degnan, J.R., and Böhlke, J.K., 2017, Brackish groundwater in the United States: U.S. Geological Survey Professional Paper 1833, 185 p. [Also available at https://doi.org/10.3133/pp1833.]

States West Water Resources Corporation and ESA Consultants, 1990, Crow Creek groundwater recharge project, level II-Evaluation: report prepared for the Wyoming Water Development Commission [variously paged].

Steven, T.A., Evanoff, E., and Yuhas, R.H., 1997, Middle and late Cenozoic tectonic and geomorphic development of the Front Range of Colorado, in Bolyard, D.W., and Sonnenberg, S.A., eds., Geologic history of the Colorado Front Range: Denver, Colo., Rocky Mountain Association of Geologists, 1997 American Association of Petroleum Geologists, Rocky Mountain Section Field Trip Guide no. 7, p. 115-123.

Stoeser, D.B., Green, G.N., Morath, L.C., Heran, W.D., Wilson, A.B., Moore, D.W., and Van Gosen, B.S., 2005, Preliminary integrated geologic map databases for the United States - Central States-Montana, Wyoming, Colorado, New Mexico, North Dakota, South Dakota, Nebraska, Kansas, Oklahoma, Texas, Iowa, Missouri, Arkansas, and Louisiana (ver. 1.2, December 2007): U.S. Geological Survey Open-File Report 2005-1351, accessed November 24, 2020, at https://doi.org/10.3133/ofr20051351.

Swinehart, J.B., and Diffendal, R.F., Jr., 1997, Geologic map of the Scottsbluff $1^{\circ} \times 2^{\circ}$ quadrangle, Nebraska and Colorado: U.S. Geological Survey Geologic Investigations Series Map I-2545, 1 sheet, scale 1:250,000. [Also available at https://doi.org/10.3133/i2545.]

Swinehart, J.B., Souders, V.L., DeGraw, H.M., and Diffendal, R.F., Jr., 1985, Cenozoic paleogeography of western Nebraska, in Flores, R.M., and Kaplan, S.S., eds., Cenozoic paleogeography of west-central United States: Denver, Colo., Rocky Mountain Section, Society of Economic Paleontologists and Mineralogists, p. 209-229.

Taboga, K.G., Bartos, T.T., Hallberg, L.L., Clark, M.L., Stafford, J.E., and Loveland, A.M., 2019, Powder/Tongue/ Northeast river basins water plan update, groundwater study, level I (2002-2016)_Available groundwater determination: Wyoming State Geological Survey Technical Memorandum 8, 479 p., 3 pls., accessed November 24, 2020, at http://waterplan.state.wy.us/plan/newy/2016/ gw-finalrept/gw_toc.html.
Taucher, P., Bartos, T.T., Taboga, K.G., Hallberg, L.L., Clark, M.L., Stafford, J., Gracias, T., Hinckley, B., Worman, B., Clarey, K., Lindemann, L., Quillinan, S.A., Copeland, D., Hays, R., and Thompson, M., 2013, Available groundwater determination technical memorandum, WWDC [Wyoming Water Development Commission] Platte River Basin water plan update, Groundwater study level 1 (2009-2013): Laramie, Wyo., report prepared by the Wyoming State Geological Survey for the Wyoming Water Development Commission [variously paged], accessed November 24, 2020, at http://waterplan.state.wy.us/plan/platte/2013/gw-finalrept/ gw_toc.html.

Terry, D.O., Jr., 1998, Lithostratigraphic revision and correlation of the lower part of the White River Group-South Dakota to Nebraska, in Terry, D.O., Jr., LaGarry, H.E., and Hunt, R.M., Jr., eds., Depositional environments, lithostratigraphy, and biostratigraphy of the White River and Arikaree Groups (late Eocene to early Miocene, North America): Boulder, Colo., Geological Society of America Special Paper 325, p. 15-37.

Terry, D.O., Jr., LaGarry, H.E., and Wells, W.B., 1995, The White River Group revisited-Vertebrate trackways, ecosystems, and lithostratigraphic revision, redefinition, and redescription, field trip no. 4 , in Flowerday, C.A., ed., Geologic field trips in Nebraska and adjacent parts of Kansas and South Dakota - Guidebook no. 10: Lincoln, University of Nebraska, Conservation and Survey Division, p. 43-57.

Theis, C.V., Brown, R.H., and Meyer, R.R., 1954, Estimating transmissibility from specific capacity: U.S. Geological Survey Open-File Report 54-310, 11 p.

Thiros, S.A., Paul, A.P., Bexfield, L.M., and Anning, D.W., 2014, The quality of our Nation's waters - Water quality in basin-fill aquifers of the southwestern United StatesArizona, California, Colorado, Nevada, New Mexico, and Utah, 1993-2009: U.S. Geological Survey Circular 1358, 113 p. [Also available at https://doi.org/10.3133/cir1358.]

Thomas, M.A., 2007, The association of arsenic with redox conditions, depth, and ground-water age in the glacial aquifer system of the northern United States: U.S. Geological Survey Scientific Investigations Report 2007-5036, 26 p. [Also available at https://doi.org/10.3133/sir20075036.]

Thompson, T.B., Wade, K., and Ethridge, F.G., 1980, The uranium-bearing Fox Hills and Laramie aquifers, Cheyenne Basin, Colorado-Structure, depositional systems, and groundwater, an interim report, part II, groundwater: Fort Collins, Colorado State University, Department of Earth Resources, College of Forestry and Natural Resources, 23 p.

Timme, P.J., 1995, National Water Quality Laboratory, 1995 services catalog: U.S. Geological Survey Open-File Report 95-352, p. 120. [Also available at https://doi.org/10.3133/ ofr95352.] 
Toner, R.N., and Campbell, E.A., 2017, Codell Sandstone oil production trends, northern Denver Basin, Laramie County, Wyoming: Wyoming State Geological Survey Open File Report 2017-2, $40 \mathrm{p}$.

Toner, R.N., Lynds, R.M., and Stafford, J.E., 2016, Oil and gas map of Wyoming: Wyoming State Geological Survey Map Series 103, scale 1:500,000.

Topper, R., Meyer, C.D., Haworth, M., Donegan, K.C., Banks, H., Bandler, A., Flor, A., and Sares, M.A., 2017, The Upper Pierre aquifer of the Cheyenne Basin, northeastern Colorado, geologic cross sections: Colorado Division of Water Resources, Water Resources Investigation 2017-1a.

Townley, L.R., 1995, The response of aquifers to periodic forcing: Advances in Water Resources, v. 18 , no. 3, p. 125-146. [Also available at https://doi.org/10.1016/0309-1708(95)00008-7.]

Trihydro Corporation, 1990, Construction and testing report, Yoder no. 2 production well, Yoder, Wyoming: report prepared for Wells Engineering [variously paged].

Trihydro Corporation, 1996, Well construction and aquifer testing level II water supply project, Lusk, Wyoming, final report: report prepared for the Wyoming Water Development Commission and Centennial Civil Engineers, Inc. [variously paged].

Trihydro Corporation, 2006, Platte River Basin final report: report prepared in cooperation with Lidstone and Associates, Harvey Economics, and Water Rights Services, LLC, for the Wyoming Water Development Commission [variously paged].

Trihydro Corporation, 2009, Project report, Belvoir Ranch High Plains aquifer-White River study: report prepared for Cheyenne Board of Public Utilities and Wyoming Water Development Commission [variously paged].

Trimble, D.E., 1980, Cenozoic tectonic history of the Great Plains contrasted with that of the southern Rocky Mountains-A synthesis: The Mountain Geologist, v. 17, no. 3, p. 59-69.

Tweto, O., 1975, Laramide (Late Cretaceous/early Tertiary) orogeny in the southern Rocky Mountains, in Curtis, B.F., ed., Cenozoic history of the southern Rocky Mountains: Geological Society of America Memoir 144, p. 1-44.

Tweto, O., 1979, Geologic map of Colorado: U.S. Geological Survey Special Geologic Map, 1 sheet, scale 1:500,000.

Tweto, O., 1980, Summary of Laramide orogeny in Colorado, in Kent, H.C., and Porter, J.W., eds., Colorado geology: Rocky Mountain Association of Geologists, p. 129-134.
Umari, A.M.J., Nelson, P.H., Fridrich, C., and LeCain, G.D., 2018, Simulating the evolution of fluid under pressures in the Great Plains, by incorporation of tectonic uplift and tilting, with a groundwater flow model: Geofluids, v. 2018, article $3765743,30 \mathrm{p}$.

U.S. Census Bureau, 2020, Explore Census Data (queryable online database), accessed November 24, 2020, at https://data.census.gov/cedsci/.

U.S. Code of Federal Regulations, 2016, Title 40-Protection of environment (40 CFR): U.S. Government Printing Office, accessed March 22, 2017, at https://www.gpo.gov/fdsys/ browse/collectionCfr.action?selectedYearFrom=2016\&go $=$ Go.

U.S. Department of Agriculture, 1943, A wartime water facilities plan for the Carpenter area, Crow Creek drainage basin, Laramie County, Wyoming: U.S. Department of Agriculture Bureau of Agricultural Economics [Water Utilization Planning Service under the provisions of the Water Facilities Act], March 1943, 23 p., unnumbered appendix, charts, and 2 maps.

U.S. Department of Agriculture, 2015, CropScape-Cropland data layer for the year 2014: U.S. Department of Agriculture, National Agricultural Statistics Service web page, accessed July 6, 2015, at http://nassgeodata.gmu.edu/ CropScape/.

U.S. Environmental Protection Agency, 1980, Prescribed procedures for measurement of radioactivity in drinking water: Cincinnati, Ohio, U.S. Environmental Protection Agency, Radiochemical Methods Section, Physical and Chemical Methods Branch, Environmental Monitoring and Support Laboratory, EPA 600/4-80-032, 133 p.

U.S. Environmental Protection Agency, 1986, Quality criteria for water 1986: Washington, D.C., U.S. Environmental Protection Agency, Office of Water Regulations and Standards, EPA 440/5-86-001, 395 p.

U.S. Environmental Protection Agency, 1996a, Test methods for evaluating solid waste, physical/chemical methods, SW-846, (3d ed.), update IV-Method 8015B nonhalogenated organics using GC/FID, rev. 2: Washington, D.C., U.S. Environmental Protection Agency [variously paged].

U.S. Environmental Protection Agency, 1996b, Test methods for evaluating solid waste, physical/chemical methods, SW-846, (3d ed.), update IV-Method 8021B aromatic and halogenated volatiles by gas chromatography using photoionization and/or electrolytic conductivity detectors, rev. 2: Washington, D.C., U.S. Environmental Protection Agency [variously paged]. 
U.S. Environmental Protection Agency, 1999, 40 CFR parts 141 and 142 - National primary drinking water regulations, radon-222, proposed rule: Washington, D.C: Federal Register, v. 64 , no. 211 , p. 59245-59378.

U.S. Environmental Protection Agency, 2001, Drinking water standard for arsenic: U.S. Environmental Protection Agency Fact Sheet EPA 815-F-00-015, 2 p., accessed April 25, 2019, at https://nepis.epa.gov/Exe/ ZyPdf.cgi?Dockey=20001XXC.txt.

U.S. Environmental Protection Agency, 2003, Drinking water advisory - Consumer acceptability advice and health effects analysis on sodium: U.S. Environmental Protection Agency, EPA 822-R-03-006, February 2003, 29 p., accessed April 27, 2019, at https://www.epa.gov/sites/production/ files/2014-09/documents/support_cc1_sodium_dwreport. pdf.

U.S. Environmental Protection Agency, 2006, Test methods for evaluating solid waste, physical/chemical methods, SW-846-Method 8260C volatile organic compounds by gas chromatography/mass spectrometry (GC/MS), rev. 3: Washington, D.C., U.S. Environmental Protection Agency [variously paged].

U.S. Environmental Protection Agency, 2016a, Consumer's guide to radon reduction-How to fix your home: U.S. Environmental Protection Agency, EPA 402/K-10/005, 17 p., accessed April 27, 2019, at https://www.epa.gov/ sites/production/files/2016-12/documents/2016_consumers_guide_to_radon_reduction.pdf.

U.S. Environmental Protection Agency, 2016b, Data validation standard operating procedures for contract laboratory program organic data using gas chromatograph/mass spectrometer and gas chromatograph/electron capture detector: Athens, Ga., U.S. Environmental Protection Agency, Region IV, SOP no. QAS-SOP-0025, 44 p., accessed May 13, 2019, at https://www.epa.gov/sites/production/files/2018-01/documents/qas-sop-0025_data_validation_for_clp_organics.pdf.

U.S. Environmental Protection Agency, 2018, 2018 Edition of the drinking water standards and health advisories: Washington, D.C., U.S. Environmental Protection Agency, Office of Water, EPA 822-F-18-001, March 2018, 12 p., accessed November 20, 2018, at https://www.epa.gov/sites/production/files/2018-03/documents/dwtable2018.pdf.

U.S. Geological Survey, 2015, Dissolved gas $\mathrm{N}_{2} /$ Ar sample collection procedure: U.S. Geological Survey, Reston Groundwater Dating Laboratory web page, accessed November 12, 2013, at https://water.usgs.gov/lab/ dissolved-gas/sampling/.
U.S. Geological Survey, 2019, USGS groundwater data for Wyoming, in USGS water data for the Nation: U.S. Geological Survey National Water Information System database, accessed August 12, 2019, at https://doi.org/10.5066/ F7P55KJN. [Site data are directly accessible at https://waterdata.usgs.gov/wy/nwis/gw/.]

U.S. Geological Survey, [variously dated], National field manual for the collection of water-quality data: U.S. Geological Survey Techniques of Water-Resources Investigations, book 9, chaps. A1-A9, 2 v. [variously paged], accessed November 26, 2020, at https://water.usgs.gov/owq/ FieldManual/.

U.S. Salinity Laboratory Staff, 1954, Diagnosis and improvement of saline and alkali soils: Washington, D.C., U.S. Department of Agriculture Handbook 60, 160 p.

Van Houten, F.B., 1964, Tertiary geology of the Beaver Rim area, Fremont, and Natrona Counties, Wyoming: U.S. Geological Survey Bulletin 1164, 99 p. [Also available at https://doi.org/10.3133/b1164.]

Ver Ploeg, A.J., 1995, Geologic map of the Cheyenne $30^{\prime} \times 60^{\prime}$ quadrangle, southeastern Wyoming, western Nebraska, and northern Colorado: Wyoming State Geological Survey Map Series 46, 1 sheet, scale 1:100,000, 1 pamphlet.

Ver Ploeg, A.J., and Boyd, C.S., 2007, Geologic map of the Laramie $30^{\prime} \times 60^{\prime}$ quadrangle, Albany and Laramie Counties, southeastern Wyoming: Wyoming State Geological Survey Map Series 77, 1 sheet, scale 1:100,000.

Ver Ploeg, A.J., Jessen, C.A., and Case, J.C., 1998, Digital geologic map of the Cheyenne $30^{\prime} \times 60^{\prime}$ quadrangle, southeastern Wyoming, western Nebraska, and northern Colorado: Wyoming State Geological Survey Geologic Hazards Section Digital Map 98-2 (HSDM 98-2).

Verstraeten, I.M., Sibray, S.S., Cannia, J.C., and Tanner, D.Q., 1995, Reconnaissance of ground-water quality in the North Platte Natural Resources District, western Nebraska, June-July 1991: U.S. Geological Survey Water-Resources Investigation Report 94-4057, 114 p. [Also available at https://doi.org/10.3133/wri944057.]

Visher, F.N., and Babcock, H.M., 1953, Ground-water conditions in the soil and moisture conservation demonstration area near Torrington, Goshen County, Wyoming, with a section on Chemical quality of the ground water, by W.H. Durum and R.A. Krieger: U.S. Geological Survey Circular 238, 51 p., 3 pls. [Also available at https://doi.org/10.3133/cir238.] 
Visher, F.N., Rapp, J.R., and Babcock, H.M., 1954, Geology and ground-water resources of the North Platte irrigation project area in Goshen County, Wyoming, with a section on Chemical quality of ground water, by W.H. Durum: U.S. Geological Survey Open-File Report 54-322, 177 p. [Also available at https://doi.org/10.3133/ofr54322.]

Voorhies, M.R., 1965, The carnivora of the Trail Creek fauna: Laramie, University of Wyoming, Contributions to Geology (Laramie), v. 4, no. 1, p. 21-25.

Waage, K.M., 1968, The type Fox Hills Formation, Cretaceous (Maastrichtian), South Dakota, part 1-Stratigraphy and paleoenvironments: Yale University, Peabody Museum of Natural History Bulletin no. 27, p. 1-175.

Waage, K.M., 1975, Deciphering the basic sedimentary structure of the Cretaceous system in the Western Interior: Geological Association of Canada Special Paper 13, p. 55-81.

Wacinski, A., 1979, A hydrogeologic investigation of the Crow Creek drainage basin in north-central Weld County, Colorado: Denver, Colo., State of Colorado Division of Water Resources, Office of the State Engineer, unnumbered openfile report, 28 p., 9 pls.

Wade, K.S., 1981, Uranium in situ solution mining and groundwater quality at the Grover test site, Weld County, Colorado: Fort Collins, Colorado State University, Department of Earth Resources, 85 p.

Wang, Y., Huntington, T.G., Osher, L.J., Wassenaar, L.I., Trumbore, S.E., Amundson, R.G., Harden, J.W., McKnight, D.M., Schiff, S.L., Aiken, G.R., Lyons, W.B., Aravena, R.O., and Baron, J.S., 1998, Carbon cycling in terrestrial environments, in Kendall, C., and McDonnell, J.J., eds., Isotope tracers in catchment hydrology: Amsterdam, Elsevier Science B.V., p. 577-610.

Ward, M.H., Mark, S.D., Cantor, K.P., Weisenburger, D.D., Correa-Villaseñor, A., and Zahm, S.H., 1996, Drinking water nitrate and the risk of non-Hodgkin's lymphoma: Cambridge, Mass., Epidemiology, v. 7, no. 5, p. 465-471.

Warner, D.A., 1947, Geology and ground-water resources of the Glendo area, Wyoming: U.S. Geological Survey OpenFile Report, 9 p.

Weeks, E.P., 1960, Hydrologic conditions in the Horseshoe Creek valley near Glendo, Platte County, Wyoming: U.S. Geological Survey Open-File Report 60-152, 10 p.

Weeks, E.P., 1964, Hydrologic conditions in the Wheatland Flats area, Platte County, Wyoming: U.S. Geological Survey Water-Supply Paper 1783, 79 p., 8 pls.

Weeks, E.P., 1979, Barometric fluctuations in wells tapping deep unconfined aquifers: Water Resources Research, v. 15, no. 5, p. 1167-1176. [Also available at https://doi.org/10.3133/wsp1783.]
Weeks, J.B., and Gutentag, E.D., 1981, Bedrock geology, altitude of base, and 1980 saturated thickness of High Plains aquifer in parts of Colorado, Kansas, Nebraska, New Mexico, Oklahoma, South Dakota, Texas, and Wyoming: U.S. Geological Survey Hydrologic Investigations Atlas HA-648, 2 sheets, scale 1:2,500,000. [Also available at https://doi.org/10.3133/ha648.]

Weeks, J.B., Gutentag, E.D., Heimes, F.J., and Luckey, R.R., 1988, Summary of the High Plains Regional Aquifer-System Analysis in parts of Colorado, Kansas, Nebraska, New Mexico, Oklahoma, South Dakota, Texas, and Wyoming: U.S. Geological Survey Professional Paper 1400-A, 30 p. [Also available at https://doi.org/10.3133/pp1400A.]

Weimer, R.J., 1977, Stratigraphy and tectonics of western coals, in Murray, D.K., ed., Geology of Rocky Mountain coal: Colorado Geological Survey Resources Series 1, p. 9-27.

Weimer, R.J., 1996, Guide to the petroleum geology and Laramide Orogeny, Denver Basin and Front Range, Colorado: Colorado Geological Survey Bulletin 51, 127 p.

Weist, W.G., Jr., 1964, Hydrogeologic data from parts of Larimer, Logan, Morgan, Sedgwick, and Weld Counties, Colorado: Colorado Water Conservation Board Basic Data Report no. 16, $30 \mathrm{p}$.

Weist, W.G., Jr., 1965, Reconnaissance of the ground-water resources in parts of Larimer, Logan, Morgan, Sedgwick, and Weld Counties with a section on Chemical quality of the water, by R. Brennan: U.S. Geological Survey WaterSupply Paper 1809-L, 24 p., 1 pl. [Also available at https://doi.org/10.3133/wsp1809L.]

Welch, P.D., 1967, The use of fast Fourier transform for the estimation of power spectra-A method based on time averaging over short, modified periodograms: IEEE Transactions on Audio and Electroacoustics, v. 15, no. 2, p. 70-73. [Also available at https://doi.org/10.1109/ TAU.1967.1161901.]

Welch, A.H., Westjohn, D.B., Helsel, D.R., and Wanty, R.B., 2000, Arsenic in ground water of the United States-Occurrence and geochemistry: Ground Water, v. 38, no. 4, p. 589-604. [Also available at https://doi.org/10.1111/j.1745-6584.2000.tb00251.x.]

Welder, G.E., and Weeks, E.P., 1965, Hydrologic conditions near Glendo, Platte County, Wyoming: U.S. Geological Survey Water-Supply Paper 1791, 82 p., 3 pls. [Also available at https://doi.org/10.3133/wsp1791.] 
Western Regional Climate Center, 2019, National Oceanic and Atmospheric Administration National Climate Data Center (NCDC) 1981-2010 monthly normals for Carpenter, Wyo.: Western Regional Climate Center web page, accessed July 5, 2019, at https://wrcc.dri.edu/cgi-bin/ cliMAIN.pl?wycarp.

Weston Engineering, Inc., 1996a, Cheyenne 10 well rehabilitation report: Cheyenne, Wyo., report prepared for the Cheyenne Board of Public Utilities, 258 p., 2 pls, 15 geophysical logs.

Weston Engineering, Inc., 1996b, Cheyenne water well rehabilitation and exploration project report: prepared for the city of Cheyenne [variously paged].

Weston Engineering, Inc., 1999a, Cheyenne fiscal year 1999 well rehabilitation project final report: prepared for the city of Cheyenne [variously paged].

Weston Engineering, Inc., 1999b, Cheyenne water well rehabilitation and exploration project report: prepared for the city of Cheyenne [variously paged].

Weston Engineering, Inc., 2000, Project report Cheyenne fiscal year 2000 well rehabilitation project—Laramie and Upton, Wyoming: report prepared for the city of Cheyenne [variously paged].

Whitcomb, H.A., 1965, Ground-water resources and geology of Niobrara County, Wyoming, with a section on Chemical quality of the ground water, by T.R. Cummings: U.S. Geological Survey Water-Supply Paper 1788, 101 p., 3 pls. [Also available at https://doi.org/10.3133/wsp1788.]

Whiticar, M.J., 1999, Carbon and hydrogen isotope systematics of bacterial formation and oxidation of methane: Chemical Geology, v. 161, no. 1-3, p. 291-314. [Also available at https://doi.org/10.1016/S0009-2541(99)00092-3.]

Wiersma, U.M., 1989, Structural obstruction of recharge to the Paleozoic aquifer in the Denver-Julesburg Basin along the Laramie Range, Wyoming: Laramie, University of Wyoming, Department of Geology and Geophysics, master's thesis, 56 p., 5 pls.

Williams, T., and Foreman, W., 2015, Changes to National Water Quality Laboratory (NWQL) procedures used to establish and verify laboratory detection and reporting limits: National Water Quality Laboratory technical memorandum 15.02, 21 p., accessed June 13, 2020, at https://nwql.usgs.gov/Public/tech_memos/ nwql.2015-02.pdf.

Willmarth, M.G., 1957, Lexicon of geologic names of the United States, part 1, A-L: U.S. Geological Survey Bulletin 896, 1,244 p. [Also available at https://doi.org/10.3133/ b896.]
Wilson, G.P., Dechesne, M., and Anderson, I.R., 2010, New latest Cretaceous mammals from northeastern Colorado with biochronologic and biogeographic implications: Journal of Vertebrate Paleontology, v. 30, no. 2, p. 499-520. [Also available at https://doi.org/10.1080/02724631003620955.]

Wood, H.E., II, Chaney, R.W., Clark, J., Colbert, E.H., Jepsen, G.L., Reeside, J.B., Jr., and Stock, C., 1941, Nomenclature and correlation of the North American Continental Tertiary: Bulletin of the Geological Society of America, v. 52, no. 1, p. 1-48. [Also available at https://doi.org/10.1130/ GSAB-52-1.]

Wood, G.H., Jr., Kehn, T.M., Devereux Carter, M., and Culbertson, W.C., 1983, Coal resource classification system of the U.S. Geological Survey: U.S. Geological Survey Circular 891, p. 46-65. [Also available at https://doi.org/10.3133/ cir891.]

Woods Hole Oceanographic Institute, 2015, National Ocean Sciences Accelerator Mass Spectrometry Facility: Woods Hole Oceanographic Institute web page, accessed September 4, 2015, at http://www.whoi.edu/nosams/ general-statement-of-14c-procedures.

World Health Organization, 2003, Sodium in drinking water, background document for development of WHO guidelines for drinking-water quality: World Health Organization, $\mathrm{WHO} / \mathrm{SDE} / \mathrm{WSH} / 03.04 / 15,6$ p., accessed April 27, 2019, at https://www.who.int/water_sanitation_health/dwq/ chemicals/sodium.pdf.

WWC Engineering, Hinckley Consulting, Collins Planning Associates, Greenwood Mapping, Inc., and States West Water Resources Corporation, 2007, Wyoming Framework Water Plan, v. I: report prepared for Wyoming Water Development Commission [variously paged].

Wyoming Department of Environmental Quality, 2005, Water quality rules and regulations, chapter 8 , quality standards for Wyoming groundwaters: Cheyenne, Wyoming Department of Environmental Quality, 13 p.

Wyoming Geological Association, 1969, Symposium on Tertiary rocks of Wyoming: Wyoming Geological Association Guidebook, 21st Annual Field Conference, 233 p.

Wyoming Geological Association, 2014, Wyoming stratigraphic nomenclature chart: Casper, Wyoming Geological Association, Stratigraphic Nomenclature Committee, $1 \mathrm{pl}$.

Wyoming Groundwater, LLC, Camp Creek Engineering, and Marlatt, G., 2011, Yoder groundwater level II study, final report: report prepared for Wyoming Water Development Commission [variously paged], accessed June 29, 2019, at http://library.wrds.uwyo.edu/wwdcrept/Yoder/YoderGroundwater_Level_II_Study-Final_Report-2011.html. 
Wyoming Mineral Corporation, 1976, Grover uranium solution mining test site-Appendix of technical support for subsurface disposal system permit application: Lakewood, Colo., Wyoming Mineral Corporation [unknown number of pages because report could not be located].

Wyoming Oil and Gas Conservation Commission, 2018, Finding your information: Wyoming Oil and Gas Conservation Commission database, accessed November 26, 2020, at http://pipeline.wyo.gov/rnewuserspage.html.

Wyoming State Engineer's Office, 2008, Investigation of a complaint of interference to the Cheyenne no. 57 (Weber no. 1) water well (well registration U.W. no. 13), Laramie County, Wyoming: Cheyenne, Wyo., Groundwater Division, Wyoming State Engineer's Office, June 2008, 298 p.
Wyoming State Engineer's Office, 2015, Order of the State Engineer-Laramie County Control Area: Wyoming State Engineer's Office web page, accessed June 23, 2019, at http://seo.wyo.gov/ground-water/state-engineer-s-orders.

Yoshino, M., 2011, Groundwater flow of a proposed uranium in-situ recovery mine site and surrounding areas, Weld County, Colorado: University of Colorado at Boulder, master's thesis, 135 p., accessed June 6, 2019, at https://scholar.colorado.edu/concern/graduate_thesis_or dissertations/4x51hj32t.

Zogorski, J.S., Carter, J.M., Ivahnenko, T., Lapham, W.W., Moran, M.J., Rowe, B.L., Squillace, P.J., and Toccalino, P.L., 2006, The quality of our Nation's water-Volatile organic compounds in the Nation's ground water and drinking-water supply wells: U.S. Geological Survey Circular 1292, 101 p., accessed November 26, 2020, at https://doi.org/10.3133/cir1292. 

Appendixes 1-3 


\section{Appendix 1}

Table 1.1. Description of core collected from exploratory borehole LC-F1, southeastern Laramie County, Wyoming

[available for download at https://doi.org/10.3133/sir20215020]. 


\section{Appendix 2}




\section{Geologic and Hydrogeologic Characteristics, White River Formation, Lance Formation, and Fox Hills Sandstone, Wyo.}

Table 2.1. Summary of groundwater-quality samples collected from the Lance aquifer as part of other studies, 1935-2011, Laramie and Goshen Counties, southeastern Wyoming.

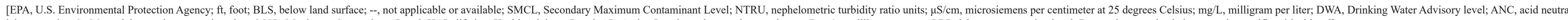
izing capacity; $\mathrm{CaCO}_{3}$, calcium carbonate; $<$ less than; MCL, Maximum Contaminant Level; HAL, lifetime Health Advisory Level; AL, Action Level; +, plus; +, plus or minus; mRem/yr, millirem per year; LRL, laboratory reporting level; R, non-detect, value below sample-specific critical level]

\begin{tabular}{|c|c|c|c|c|c|c|c|c|c|c|c|c|c|c|c|c|c|c|c|c|c|c|c|c|c|c|}
\hline \multicolumn{23}{|c|}{ Lance aquifer } & \multirow{3}{*}{ 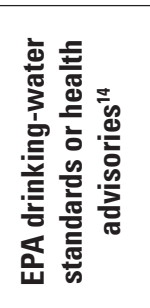 } & \multirow{3}{*}{ 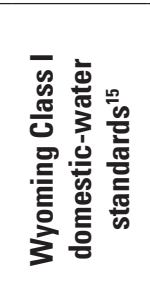 } & \multirow{3}{*}{ 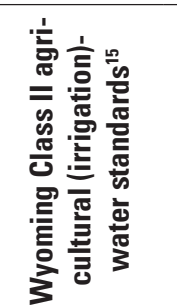 } & \multirow{3}{*}{ 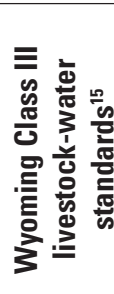 } \\
\hline \multirow{2}{*}{$\begin{array}{l}\text { Characteristic } \\
\text { or constituent }\end{array}$} & \multicolumn{5}{|c|}{ Laramie County } & \multicolumn{17}{|c|}{ Goshen County } & & & & \\
\hline & 'EL-1 & ${ }^{2} \mathrm{CL}-1$ & ${ }^{3} \mathrm{HL}-1$ & ${ }^{4} \mathrm{HL}-2$ & ${ }^{5 L L-1}$ & ${ }^{6} \mathrm{GL}-01$ & ${ }^{5} \mathrm{GL}-02$ & ${ }^{\top} \mathrm{GL}-03$ & ${ }^{5} \mathrm{GL}-04$ & ${ }^{8} \mathrm{GL}-05$ & ${ }^{7} \mathbf{G L}-06$ & ${ }^{9} \mathrm{GL}-07$ & ${ }^{7} \mathrm{GL}-08$ & ${ }^{5} \mathrm{GL}-09$ & ${ }^{\prime}$ GL-10 & ${ }^{10} \mathrm{GL}-11$ & "GL-12 & ${ }^{12} \mathrm{GL}-13$ & ${ }^{12} \mathrm{GL}-14$ & ${ }^{13} \mathrm{GL}-15$ & ${ }^{7} \mathrm{GL}-16$ & 'GL-17 & & & & \\
\hline
\end{tabular}

\begin{tabular}{|c|c|c|c|c|c|c|c|c|c|c|c|c|c|c|c|c|c|c|c|c|c|c|c|c|c|c|}
\hline \multicolumn{27}{|c|}{ Well information } \\
\hline $\begin{array}{l}\text { Depth of well } \\
\text { (ft BLS) }\end{array}$ & 910 & 1,070 & $1,040.5$ & 810 & 704 & -- & 85 & 100 & 156 & 135 & 117 & 150 & 100 & 157 & 88 & 275 & 540 & 420 & 350 & 470 & 160 & 787 & -- & -- & -- & -- \\
\hline $\begin{array}{l}\text { Depth to water level } \\
\text { (ft BLS) }\end{array}$ & -- & -- & -- & -- & -- & -- & -- & -- & -- & -- & -- & -- & 26.73 & -- & -- & -- & 107 & 22 & -- & -- & -- & -- & -- & -- & -- & -- \\
\hline \multicolumn{27}{|c|}{ Physical properties } \\
\hline $\begin{array}{l}\text { Temperature } \\
\text { (degrees Celsius) }\end{array}$ & -- & -- & -- & -- & 11.1 & 13.3 & 12.2 & 13.9 & 16 & 17 & 12.2 & 16.5 & 16.3 & -- & 13.5 & 10 & 23.2 & -- & -- & 15.6 & 15 & 18 & -- & -- & -- & -- \\
\hline $\begin{array}{l}\mathrm{pH} \text {, unfiltered } \\
\text { (standard units) }^{16}\end{array}$ & 8.3 & -- & 8.2 & 8 & 8.5 & 7.7 & 8.8 & 8.7 & 7.2 & 7.7 & 8.6 & 7.7 & 7.6 & 8.6 & 8.1 & 8.7 & 8.8 & 8.1 & 8.4 & 8.5 & 8.3 & 9.8 & $\begin{array}{l}6.5-8.5 \\
\text { (SMCL) }\end{array}$ & $6.5-8.5$ & $4.5-9.0$ & $6.5-8.5$ \\
\hline $\begin{array}{l}\text { Turbidity, unfiltered } \\
\text { (NTRU) }\end{array}$ & -- & -- & 400 & -- & -- & -- & -- & 1.1 & 0.63 & 74.5 & -- & 1.42 & 0.4 & -- & 0.3 & -- & -- & -- & -- & -- & -- & -- & 5 (SMCL) & -- & -- & -- \\
\hline $\begin{array}{l}\text { Specific conduc- } \\
\text { tance, unfiltered } \\
(\mu \mathrm{S} / \mathrm{cm})^{16}\end{array}$ & 417 & -- & 435 & 391 & 1,100 & 608 & 1,320 & 1,230 & 2,771 & 1,290 & 1,940 & 1,222 & 984 & 1,230 & 2,440 & 951 & 1,059 & 1,070 & 1,370 & 1,090 & 1,080 & 1,160 & -- & -- & -- & -- \\
\hline $\begin{array}{l}\text { Dissolved oxygen, } \\
\text { unfiltered }(\mathrm{mg} / \mathrm{L})\end{array}$ & -- & -- & -- & -- & -- & -- & -- & 0.1 & -- & -- & -- & -- & 3.5 & -- & 6.3 & -- & -- & -- & -- & -- & -- & -- & -- & -- & -- & -- \\
\hline \multicolumn{27}{|c|}{ Major ions and related water-quality characteristics, in milligrams per liter } \\
\hline Calcium, filtered & 6.1 & 14 & 13.4 & 17.1 & 3.2 & 50 & 3.5 & 2.18 & 33.2 & 5.6 & 9.5 & 7.8 & 37.3 & 6 & 17.4 & 1.7 & 2 & 3.8 & 2.5 & 3.2 & 4.3 & 6.2 & -- & -- & -- & -- \\
\hline Magnesium, filtered & 2.1 & 3.6 & 4.6 & 4.1 & 1 & 11 & 1.3 & 0.6 & 16.3 & 1.4 & 3.3 & 2.4 & 15.1 & 1.7 & 7.03 & 0.5 & $<1$ & 0.83 & 2.8 & 0.1 & 1.4 & 1.1 & -- & -- & -- & -- \\
\hline Sodium, filtered ${ }^{17}$ & 100 & 81 & 84 & 66.1 & 270 & 60 & 310 & 319 & 616 & 300 & 429 & 295 & 181 & 273 & 591 & 237 & 317 & 328 & 340 & 282 & 250 & 282 & $\begin{array}{l}20,30-60 \\
\text { (DWA) }\end{array}$ & -- & -- & -- \\
\hline Potassium, filtered & 3.1 & -- & 5.6 & 3.9 & -- & 18 & 6.3 & 4.16 & 12.9 & 5.1 & 7 & 5.4 & 9.23 & 5.4 & 12.3 & 2.6 & 4 & 4 & 4.5 & 2.4 & 5.1 & 3.3 & -- & -- & -- & -- \\
\hline $\begin{array}{l}\text { Alkalinity, filtered, } \\
\text { or ANC, unfiltered } \\
\left(\mathrm{mg} / \mathrm{L} \text { as } \mathrm{CaCO}_{3}\right)^{18}\end{array}$ & 162 & 169 & 177 & 167 & 516 & 272 & 555 & 716 & 916 & 468 & 375 & 505 & 395 & 386 & 630 & 519 & 700 & 740 & 720 & 599 & 350 & 596 & -- & -- & -- & -- \\
\hline Chloride, filtered & 13.2 & 7.5 & 3.6 & 3.9 & 31 & 10 & 37 & 3.8 & 130 & 35 & 113 & 64 & 18.3 & 34 & 36.6 & 9.5 & 5 & 4.37 & 3.3 & 6 & 23 & 8.3 & $\begin{array}{c}250 \\
\text { (SMCL) }\end{array}$ & 250 & 100 & 2,000 \\
\hline Fluoride, filtered & 0.7 & 1 & 1.09 & -- & 2.8 & 0.4 & 2.4 & 2.3 & 0.93 & 2.2 & 0.5 & 0.87 & -- & 0.3 & 0.5 & 1.6 & 2.7 & 2.95 & 3.6 & 2.2 & 0.6 & 3.4 & $\begin{array}{l}2 \text { (SMCL) } \\
4 \text { (MCL) }\end{array}$ & 4 & -- & -- \\
\hline $\begin{array}{l}\text { Silica, filtered } \\
(\mathrm{mg} / \mathrm{L})\end{array}$ & 10.3 & -- & 29.3 & -- & 13 & 53 & 11 & 7.56 & 15.3 & 16.4 & 17 & 33.4 & 22.1 & 11 & 7.79 & 11 & -- & -- & -- & 11 & 11 & 13 & -- & -- & -- & -- \\
\hline $\begin{array}{l}\text { Total dissolved } \\
\text { solids, filtered }\end{array}$ & 267 & -- & 312 & 264 & -- & 416 & 833 & 777 & 1,945 & 820 & 1,250 & 776 & 641 & 790 & 1,650 & 592 & 709 & 848 & 812 & 664 & 667 & 699 & $\begin{array}{c}500 \\
\text { (SMCL) }\end{array}$ & 500 & 2,000 & 5,000 \\
\hline $\begin{array}{l}\text { Hardness } \\
\quad\left(\mathrm{mg} / \mathrm{L} \text { as } \mathrm{CaCO}_{3}\right)\end{array}$ & -- & 50 & 52.4 & -- & 12 & 170 & 14 & 8.02 & -- & -- & 37 & -- & 156 & 22 & 73.1 & 6 & -- & -- & 18 & 8 & 17 & 20 & -- & -- & -- & -- \\
\hline $\begin{array}{l}\text { Sodium adsorption } \\
\text { ratio (SAR) }\end{array}$ & 9 & 5 & 5 & 4 & 34 & 2 & 36 & 49 & 22 & 29 & 31 & 24 & 6 & 25 & 30 & 41 & 45 & 40 & 35 & 42 & 27 & 27 & -- & -- & 8 & -- \\
\hline \multicolumn{27}{|c|}{ Trace elements, in micrograms per liter } \\
\hline Aluminum, filtered & -- & -- & -- & -- & -- & -- & -- & $<100$ & $<100$ & 1,520 & -- & $<100$ & $<100$ & -- & $<100$ & -- & -- & -- & -- & -- & -- & -- & $\begin{array}{l}50-200 \\
\text { (SMCL) }\end{array}$ & -- & 5,000 & 5,000 \\
\hline $\begin{array}{l}\text { Aluminum, } \\
\text { unfiltered }\end{array}$ & $<100$ & -- & -- & -- & -- & -- & -- & 600 & -- & -- & -- & -- & $<100$ & -- & $<100$ & -- & -- & -- & -- & -- & -- & -- & $\begin{array}{l}50-200 \\
(\mathrm{SMCL})\end{array}$ & -- & 5,000 & 5,000 \\
\hline non & -- & -- & $<1$ & $<5$ & - & -- & -- & $<1$ & -- & - & -- & -- & $<1$ & -- & $<1$ & -- & -- & -- & -- & - & -- & -- & $6(\mathrm{MCL})$ & -- & -- & -- \\
\hline
\end{tabular}




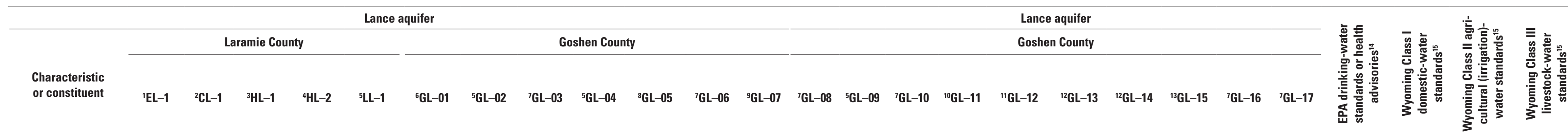

\begin{tabular}{|c|c|c|c|c|c|c|c|c|c|c|c|c|c|c|c|c|c|c|c|c|c|c|c|c|c|c|}
\hline \multicolumn{27}{|c|}{ Trace elements, in micrograms per liter-Continued } \\
\hline Antimony, unfiltered & -- & -- & -- & -- & -- & -- & -- & $<1$ & -- & -- & -- & -- & $<1$ & -- & $<1$ & -- & $<1$ & -- & -- & -- & -- & -- & $6(\mathrm{MCL})$ & -- & -- & -- \\
\hline Arsenic, filtered & -- & -- & 21 & $<5$ & -- & -- & -- & $<4$ & $<1$ & $<1$ & -- & 2 & $<4$ & -- & $<4$ & -- & -- & -- & -- & -- & -- & -- & $10(\mathrm{MCL})$ & 50 & 100 & 200 \\
\hline Arsenic, unfiltered & 2 & -- & -- & -- & -- & -- & -- & $<4$ & -- & -- & -- & -- & $<4$ & -- & $<4$ & -- & $<5$ & -- & -- & -- & -- & -- & $10(\mathrm{MCL})$ & 50 & 100 & 200 \\
\hline Barium, filtered & -- & -- & $<100$ & $<100$ & -- & -- & -- & 51.8 & $<100$ & $<100$ & -- & $<100$ & 34.2 & -- & 31.5 & -- & -- & -- & -- & -- & -- & -- & $\begin{array}{l}2,000 \\
\text { (MCL) }\end{array}$ & 2,000 & -- & -- \\
\hline Barium, unfiltered & $<100$ & -- & -- & -- & -- & -- & -- & 59.4 & -- & -- & -- & -- & 35.4 & -- & 34.1 & -- & $<100$ & -- & -- & -- & -- & -- & $\begin{array}{l}2,000 \\
\text { (MCL) }\end{array}$ & 2,000 & -- & -- \\
\hline Beryllium, filtered & -- & -- & $<5$ & $<1$ & -- & -- & -- & $<1$ & -- & -- & -- & -- & $<1$ & -- & $<1$ & -- & -- & -- & -- & -- & -- & -- & 4 (MCL) & -- & 100 & -- \\
\hline Beryllium, unfiltered & -- & -- & -- & -- & -- & -- & -- & $<1$ & -- & -- & -- & -- & $<1$ & -- & $<1$ & -- & $<0.5$ & -- & -- & -- & -- & -- & 4 (MCL) & -- & 100 & -- \\
\hline Boron, filtered & -- & -- & 100 & -- & -- & 200 & 770 & 500 & 1,230 & 860 & 210 & 200 & 310 & 180 & 270 & 360 & -- & -- & -- & -- & 140 & 440 & $\begin{array}{c}6,000 \\
\text { (HAL) }\end{array}$ & 750 & 750 & 5,000 \\
\hline Boron, unfiltered & 100 & -- & -- & -- & -- & -- & -- & 510 & -- & -- & -- & -- & 320 & -- & 270 & -- & -- & -- & -- & -- & -- & -- & $\begin{array}{l}6,000 \\
\text { (HAL) }\end{array}$ & 750 & 750 & 5,000 \\
\hline Cadmium, filtered & -- & -- & $<0.5$ & $<5$ & -- & -- & -- & $<0.2$ & $<10$ & $<10$ & -- & $<10$ & $<0.2$ & -- & $<0.2$ & -- & -- & -- & -- & -- & -- & -- & $5(\mathrm{MCL})$ & 5 & 10 & 50 \\
\hline Cadmium, unfiltered & $<5$ & -- & -- & -- & -- & -- & -- & $<0.2$ & -- & -- & -- & -- & $<0.2$ & -- & $<0.2$ & -- & $<0.5$ & -- & -- & -- & -- & -- & 5 (MCL) & 5 & 10 & 50 \\
\hline Chromium, filtered & -- & -- & $<50$ & $<50$ & -- & -- & -- & $<5$ & $<50$ & $<50$ & -- & $<50$ & $<5$ & -- & $<5$ & -- & -- & -- & -- & -- & -- & -- & $100(\mathrm{MCL})$ & 100 & 100 & 50 \\
\hline Chromium, unfiltered & $<50$ & -- & -- & -- & -- & -- & -- & $<5$ & -- & -- & -- & -- & $<5$ & -- & $<5$ & -- & $<50$ & -- & -- & -- & -- & -- & 100 (MCL) & 100 & 100 & 50 \\
\hline Cobalt, filtered & -- & -- & -- & -- & -- & -- & -- & $<2$ & -- & -- & -- & -- & $<2$ & -- & $<2$ & -- & -- & -- & -- & -- & -- & -- & -- & -- & 50 & 1,000 \\
\hline Cobalt, unfiltered & -- & -- & -- & -- & -- & -- & -- & $<2$ & -- & -- & -- & -- & $<2$ & -- & $<2$ & -- & -- & -- & -- & -- & -- & -- & -- & -- & 50 & 1,000 \\
\hline Copper, filtered & -- & -- & $<10$ & $<10$ & -- & -- & -- & $<5$ & $<10$ & $<10$ & -- & 10 & $<5$ & -- & $<5$ & -- & -- & -- & -- & -- & -- & -- & $\begin{array}{c}1,000 \\
\text { (SMCL) } \\
1,300(\mathrm{AL})\end{array}$ & 1,000 & 200 & 500 \\
\hline Copper, unfiltered & $<10$ & -- & -- & -- & -- & -- & -- & 10 & -- & -- & -- & -- & $<5$ & -- & $<5$ & -- & $<10$ & -- & -- & -- & -- & -- & $\begin{array}{c}1,000 \\
\text { (SMCL) } \\
1,300(\mathrm{AL})\end{array}$ & 1,000 & 200 & 500 \\
\hline Lead, filtered & -- & -- & 11 & $<1$ & -- & -- & -- & $<1$ & $<50$ & $<50$ & -- & $<50$ & $<1$ & -- & $<1$ & -- & -- & -- & -- & -- & -- & -- & $15(\mathrm{AL})$ & 15 & 5,000 & 100 \\
\hline Lead, unfiltered & $<50$ & -- & -- & -- & -- & -- & -- & 1.8 & -- & -- & -- & -- & $<1$ & -- & $<1$ & -- & $<1$ & -- & -- & -- & -- & -- & $15(\mathrm{AL})$ & 15 & 5,000 & 100 \\
\hline Manganese, filtered & -- & -- & 160 & -- & -- & -- & -- & 2.5 & $<10$ & 20 & -- & $<10$ & $<2$ & -- & $<2$ & -- & -- & -- & -- & -- & -- & -- & 50 (SMCL) & 50 & 200 & -- \\
\hline $\begin{array}{c}\text { Manganese, } \\
\text { unfiltered }\end{array}$ & $<10$ & -- & -- & -- & -- & -- & -- & 6.2 & -- & -- & -- & -- & $<2$ & -- & $<2$ & -- & 30 & -- & -- & -- & -- & -- & 50 (SMCL) & 50 & 200 & -- \\
\hline Mercury, filtered & -- & -- & $<0.2$ & $<0.5$ & -- & -- & -- & -- & $<1$ & $<1$ & -- & $<1$ & -- & -- & -- & -- & -- & -- & -- & -- & -- & -- & 2 (MCL) & 2 & -- & 0.05 \\
\hline Mercury, unfiltered & $<1$ & -- & -- & -- & -- & -- & -- & -- & -- & -- & -- & -- & -- & -- & -- & -- & $<0.2$ & -- & -- & -- & -- & -- & 2 (MCL) & 2 & -- & 0.05 \\
\hline Molybdenum, filtered & -- & -- & -- & -- & -- & -- & -- & 11 & $<100$ & $<100$ & -- & $<100$ & 11 & -- & $<5$ & -- & -- & -- & -- & -- & -- & -- & 40 (HAL) & -- & -- & -- \\
\hline $\begin{array}{l}\text { Molybdenum, } \\
\text { unfiltered }\end{array}$ & $<100$ & -- & -- & -- & -- & -- & -- & 7 & -- & -- & -- & -- & 10 & -- & $<5$ & -- & -- & -- & -- & -- & -- & -- & 40 (HAL) & -- & -- & -- \\
\hline Nickel, filtered & -- & -- & $<20$ & $<20$ & -- & -- & -- & $<4$ & $<50$ & $<50$ & -- & $<50$ & $<4$ & -- & $<4$ & -- & -- & -- & -- & -- & -- & -- & $100(\mathrm{HAL})$ & -- & 200 & -- \\
\hline Nickel, unfiltered & $<50$ & -- & -- & -- & -- & -- & -- & $<4$ & -- & -- & -- & -- & $<4$ & -- & $<4$ & -- & $<20$ & -- & -- & -- & -- & -- & 100 (HAL) & -- & 200 & -- \\
\hline Selenium, filtered & -- & -- & $<1$ & $<5$ & -- & -- & -- & $<1$ & 50 & 6 & -- & 4 & 13 & -- & 69 & -- & -- & -- & -- & -- & -- & -- & 50 (MCL) & 50 & 20 & 50 \\
\hline Selenium, unfiltered & $<1$ & -- & -- & -- & -- & -- & -- & $<1$ & -- & -- & -- & -- & 8 & -- & 46 & -- & $<5$ & -- & -- & -- & -- & -- & $50(\mathrm{MCL})$ & 50 & 20 & 50 \\
\hline
\end{tabular}


Table 2.1. Summary of groundwater-quality samples collected from the Lance aquifer as part of other studies, 1935-2011, Laramie and Goshen Counties, southeastern Wyoming.-Continued

\section{Lance aquifer}

Laramie County $\quad$ Goshen County

Characteristic

\begin{tabular}{|c|c|c|c|c|c|c|c|c|c|c|c|c|c|c|c|c|c|c|c|c|c|c|c|c|c|c|}
\hline \multicolumn{27}{|c|}{ Trace elements, in micrograms per liter-Continued } \\
\hline Silver, filtered & -- & -- & -- & -- & -- & -- & -- & $<0.5$ & -- & -- & -- & -- & $<0.5$ & -- & $<0.5$ & -- & -- & -- & -- & -- & -- & -- & $\begin{array}{l}100(\mathrm{HAL} / \\
\mathrm{SMCL})\end{array}$ & 100 & -- & -- \\
\hline Silver, unfiltered & - & -- & -- & -- & -- & -- & -- & $<0.5$ & -- & -- & -- & -- & $<0.5$ & -- & $<0.5$ & -- & -- & -- & -- & -- & -- & -- & $\begin{array}{l}100(\mathrm{HAL} / \\
\mathrm{SMCL})\end{array}$ & 100 & -- & -- \\
\hline Strontium, filtered & -- & -- & -- & -- & -- & -- & -- & 70 & -- & -- & -- & -- & 930 & -- & 610 & -- & -- & -- & -- & -- & -- & -- & 4,000 (HAL) & -- & -- & -- \\
\hline Strontium, unfiltered & -- & -- & -- & -- & -- & -- & -- & 70 & -- & -- & -- & -- & 900 & -- & 640 & -- & -- & -- & -- & -- & -- & -- & 4,000 (HAL) & -- & -- & -- \\
\hline Thallium, filtered & -- & -- & $<0.4$ & $<2$ & -- & -- & -- & $<0.3$ & -- & -- & -- & -- & $<0.3$ & -- & $<0.3$ & -- & -- & -- & -- & -- & -- & -- & 2 (MCL) & -- & -- & -- \\
\hline Thallium, unfiltered & -- & -- & -- & -- & -- & -- & -- & $<0.3$ & -- & -- & -- & -- & $<0.3$ & -- & $<0.3$ & -- & $<0.4$ & -- & -- & -- & -- & -- & $2(\mathrm{MCL})$ & -- & -- & -- \\
\hline Uranium, filtered & 1.6 & -- & 4 & -- & -- & -- & -- & $<0.2$ & 151 & 37 & -- & 62 & 63.1 & -- & 0.9 & -- & 0.3 & -- & -- & -- & -- & -- & 30 (MCL) & -- & -- & -- \\
\hline Uranium, unfiltered & -- & -- & -- & -- & -- & -- & -- & $<0.1$ & -- & -- & -- & -- & 64.8 & -- & 1 & -- & -- & -- & -- & -- & -- & -- & 30 (MCL) & -- & -- & -- \\
\hline Vanadium, filtered & $<100$ & -- & -- & -- & -- & -- & -- & $<10$ & $<100$ & $<100$ & -- & $<100$ & 13.6 & -- & $<10$ & -- & -- & -- & -- & -- & -- & -- & -- & -- & 100 & 100 \\
\hline Vanadium, unfiltered & -- & -- & -- & -- & -- & -- & -- & $<10$ & -- & -- & -- & -- & 10 & -- & $<10$ & -- & -- & -- & -- & -- & -- & -- & -- & -- & 100 & 100 \\
\hline Zinc, filtered & - & -- & $<10$ & -- & -- & -- & -- & $<50$ & 40 & 1,150 & -- & 40 & $<50$ & -- & $<50$ & -- & -- & -- & -- & -- & -- & -- & $\begin{array}{c}2,000 \text { (HAL) } \\
5,000 \text { (SMCL) }\end{array}$ & 5,000 & 2,000 & 25,000 \\
\hline Zinc, unfiltered & $<10$ & -- & -- & -- & -- & -- & -- & $<50$ & -- & -- & -- & -- & $<50$ & -- & $<50$ & -- & -- & -- & -- & -- & -- & -- & $\begin{array}{c}2,000 \text { (HAL) } \\
5,000 \text { (SMCL) }\end{array}$ & 5,000 & 2,000 & 25,000 \\
\hline
\end{tabular}

\begin{tabular}{|llllllllllll} 
Nitrate, filtered & -- & 0.02 & -- & -- & $<0.01$ & 0.52 & 2 & $<0.01$ & -- & & \multicolumn{3}{c}{ Nutrients, in milligrams per liter as nitrogen } \\
\hline
\end{tabular}

$\begin{array}{lcccccccc}\text { Nitrate, filtered } & -- & 0.02 & -- & -- & <0.01 & 0.52 & 2 & <0.01 \\ \text { Nitrite, filtered } & <0.1 & -- & -- & <0.1 & -- & -- & -- & <0.005\end{array}$

Nitrite, filtered

Nitrate + nitrice,
filtered $\begin{array}{cccccccc}<0.1 & -- & -- & <0.1 & - & -- & - & <0.005 \\ <0.1 & -- & -- & <0.1 & -- & -- & -- & --\end{array}$

\begin{tabular}{ccccccccc} 
filtered & & & & & & & & \\
Ammonia, filtered & 0.07 & -- & - & -- & - & -- & - & 0.09 \\
\hline
\end{tabular} Gross alpha-paty

Gross beta-particle

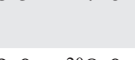
$\begin{array}{cccccccccccc}1.37 & 0.27 & - & 0.25 & - & 0.09 & - & - & 10(\mathrm{MCL}) & 10 & -- & - \\ 0.005 & -- & -- & -- & - & -- & - & - & 1(\mathrm{MCL}) & 1 & -- & 10 \\ & -- & <0.1 & -- & 0 & -- & 0.2 & 4.2 & 10(\mathrm{MCL}) & -- & -- & 100\end{array}$

Radium -22

\begin{tabular}{llllll|lll} 
Radium-226, filtered & $<0.2$ & - & $0.9 \pm{ }^{20} 0.3$ & -- & - & - & -- & -- \\
\hline
\end{tabular}

\begin{tabular}{lllllllll} 
Radium-228, filtered & $<1.0$ & - & $<1.0$ & - & - & - & - & - \\
\hline
\end{tabular} 'Industrial water-supply well (Lidstone and Associates, Inc., 2003). Also known informally as Lodgepole Valley
Potatoes well.

${ }^{2}$ Test well near Veterans Administration, Cheyenne, Wyo. (Cady, 1935).

3Production well near Cheyenne, Wyo. (Weston Engineering, Inc., 1996a).

${ }^{4}$ Test well near Cheyenne, Wyo. Well completed with 20 feet of screen in the Chadron Formation above static (ic water level (Weston Enginering, inc., SDomestic water-supply well (BRS, Inc., and Lidstone and Anderson, Inc., 1996; U.S. Geological Survey,
2019).

${ }^{6}$ Spring (U.S. Geological Survey, 2019).

'Domestic and stock water-supply well (U.S. Geological Survey, 2019).

${ }^{8}$ Commercial water-supply well (BRS, Inc., and Lidstone and Anderson, Inc., 1996). $\begin{array}{lllllllll}0.091 & -- & - & - & - & - & <0.05 & - & <0.05\end{array}$

\section{$05 \quad-$}

$-0.2-4.2-10(\mathrm{MCI}$

\begin{tabular}{cccccc}
-- & -- & -- & - & -- & -- \\
\hline${ }^{21} \mathrm{R}-0.5 \pm{ }^{203.4}$ & 4.24 & -- & - & -- & --
\end{tabular}

${ }^{21} \mathrm{R}-0.2 \pm{ }^{20} 0.1$

Stock water-supply well (BRS, Inc., and Lidstone and Anderson, Inc., 1996). 'PProduction well near Huntley, Wyo. (U.S. Geological Survey, 2019). "Test hole near Yoder, Wyo. (Wyoming Groundwater, LLC, and others, 2011). (2Production well near Yoder, Wyo. (Wyoming Groundwater, LLC, and others, 2011). ${ }^{13}$ Well at former Goshen County Memorial Hospital (U.S. Geological Survey 2019). ${ }^{14}$ U.S. Environmental Protection Agency (2018).

${ }^{15}$ Wyoming Department of Environmental Quality (2005, table 1). IFField measurements are the preferred values. Laboratory measurements were used if field values were not

"Purple value indicates a combined sodium and potassium value.
30 (HAL) $\quad 0.5 \quad--\quad--$ $15(\mathrm{MCL}) \quad{ }^{22} 15 \quad{ }^{2215} \quad{ }^{2215}$ $4 \mathrm{mRem} / \mathrm{yr}$

Is Field alkalinities are the preferred values. Laboratory alkalinities were used if field values were not available (blue text). Acid neutralizing capacity, unfiltered, fixed endpoint ( $\mathrm{pH} 4.5)$ titration, field, $\mathrm{mg} / \mathrm{Las}$ calciu

${ }^{19}$ If the residue on evaporation at 180 degrees Celsius was not available, the sum of constituents was used

on estimate.

${ }^{2}$ Negative value indicates radiation count of the sample was less than the long-term average background

dium-226 but excluding activity from radon and uranium.

Sum of radium-226 and radium-228. 


\section{References Cited}

BRS, Inc., and Lidstone and Anderson, Inc., 1996, Hawk Springs water supply project, final report: report prepared for the Wyoming Water Development Commission [variously paged].

Cady, R.C., 1935, Report on the test well at the Veterans' Administration facility, Cheyenne, Wyoming: U.S. Geological Survey unnumbered open-file report, $38 \mathrm{p}$.

Lidstone and Associates, Inc., 2003, Town of Pine Bluffs groundwater exploration grant final report: report prepared for the Wyoming Water Development Commission [variously paged].

U.S. Environmental Protection Agency, 2018, 2018 Edition of the drinking water standards and health advisories: Washington, D.C., U.S. Environmental Protection Agency, Office of Water, EPA 822-F-18-001, March 2018, 12 p., accessed November 20, 2018, at https://www.epa.gov/sites/production/files/2018-03/documents/dwtable2018.pdf.
U.S. Geological Survey, 2019, USGS groundwater data for Wyoming, in USGS water data for the Nation: U.S. Geological Survey National Water Information System database, accessed August 12, 2019, at https://doi.org/10.5066/ F7P55KJN. [Site data are directly accessible at https://waterdata.usgs.gov/wy/nwis/gw/.]

Weston Engineering, Inc., 1996a, Cheyenne 10 well rehabilitation report: Cheyenne, Wyo., report prepared for the Cheyenne Board of Public Utilities, 258 p., 2 pls., 15 geophysical logs.

Weston Engineering, Inc., 1996b, Cheyenne water well rehabilitation and exploration project report: prepared for the city of Cheyenne [variously paged].

Wyoming Department of Environmental Quality, 2005, Water quality rules and regulations, chapter 8 , quality standards for Wyoming groundwaters: Cheyenne, Wyoming Department of Environmental Quality, 13 p.

Wyoming Groundwater, LLC, Camp Creek Engineering, and Marlatt, G., 2011, Yoder groundwater level II study, final report: report prepared for Wyoming Water Development Commission [variously paged], accessed June 29, 2019, at http://library.wrds.uwyo.edu/wwdcrept/Yoder/YoderGroundwater_Level_II_Study-Final_Report-2011.html. 


\section{Appendix 3}


Table 3.1. Summary of groundwater-quality samples collected from the Fox Hills aquifer as part of other studies, 2005-14, Laramie and Goshen Counties, southeastern Wyoming.

[EPA, U.S. Environmental Protection Agency; ft, foot; BLS, below land surface; --, not applicable or available; SMCL, Secondary Maximum Contaminant Level; NTRU, nephelometric turbidity ratio units; $\mu \mathrm{S} / \mathrm{cm}$, microsiemens per centimeter at 25 degrees Celsius; <, less than; DWA, Drinking Water Advisory level; mg/L, milligram per liter; CaCO ${ }_{3}$, calcium carbonate; MCL, Maximum Contaminant Level; HAL, lifetime Health Advisory Level; AL, Action Level; +, plus; \pm , plus or minus; mRem/yr, millirem per year]

\begin{tabular}{|c|c|c|c|c|c|c|c|c|}
\hline \multirow{3}{*}{ Characteristic or constituent } & \multicolumn{4}{|c|}{ Fox Hills aquifer } & \multirow{3}{*}{$\begin{array}{l}\text { EPA drinking- } \\
\text { water standards or } \\
\text { health advisories }\end{array}$} & \multirow{3}{*}{$\begin{array}{l}\text { Wyoming Class I } \\
\text { domestic-water } \\
\text { standards }^{6}\end{array}$} & \multirow{3}{*}{$\begin{array}{l}\text { Wyoming Class II } \\
\text { agricultural } \\
\text { (irrigation)- } \\
\text { water standards }^{6}\end{array}$} & \multirow{3}{*}{$\begin{array}{c}\text { Wyoming Class II } \\
\text { livestock-water } \\
\text { standards }^{6}\end{array}$} \\
\hline & \multirow{2}{*}{$\begin{array}{c}\text { Laramie County } \\
{ }^{1} \mathrm{FH}-4\end{array}$} & \multicolumn{3}{|c|}{ Goshen County } & & & & \\
\hline & & ${ }^{2} \mathrm{FH}-5$ & ${ }^{3} \mathrm{FH}-6$ & ${ }^{4} \mathrm{FH}-7$ & & & & \\
\hline \multicolumn{9}{|c|}{ Well information } \\
\hline Depth of well (ft bls) & 1,780 & -- & 1,130 & 1,104 & -- & -- & -- & -- \\
\hline Depth to water level (ft bls) & -- & -- & 65 & 67 & -- & -- & -- & -- \\
\hline \multicolumn{9}{|c|}{ Physical properties } \\
\hline Temperature (degrees Celsius) & -- & -- & 11.8 & 21.3 & -- & -- & -- & -- \\
\hline $\mathrm{pH}$, unfiltered (standard units) $)^{7}$ & 8.4 & 8.8 & 8.8 & 8.9 & $6.5-8.5(\mathrm{SMCL})$ & $6.5-8.5$ & $4.5-9.0$ & $6.5-8.5$ \\
\hline Turbidity, unfiltered (NTRU) & 0.55 & -- & -- & 0.7 & 5 (SMCL) & -- & -- & -- \\
\hline $\begin{array}{l}\text { Specific conductance, unfiltered } \\
(\mu \mathrm{S} / \mathrm{cm})^{7}\end{array}$ & 729 & 720 & 876 & 872 & -- & -- & -- & -- \\
\hline
\end{tabular}

\begin{tabular}{|c|c|c|c|c|c|c|c|c|}
\hline \multicolumn{9}{|c|}{ Major ions and related water-quality characteristics, in milligrams per liter unless otherwise noted } \\
\hline Calcium, filtered & 2 & 2 & 1 & $<1$ & -- & -- & -- & -- \\
\hline Magnesium, filtered & $<1$ & $<1$ & $<1$ & $<1$ & -- & -- & -- & -- \\
\hline Sodium, filtered & 180 & 201 & 264 & 249 & $\begin{array}{c}20,30-60 \\
\text { (DWA) }\end{array}$ & -- & -- & -- \\
\hline Potassium, filtered & 2 & 5 & 1 & $<1$ & -- & -- & -- & -- \\
\hline Alkalinity, filtered $\left(\mathrm{mg} / \mathrm{L} \text { as } \mathrm{CaCO}_{3}\right)^{7}$ & 390 & 430 & 538 & 555 & -- & -- & -- & -- \\
\hline Chloride, filtered & 8 & 8 & 6 & 6 & 250 (SMCL) & 250 & 100 & 2,000 \\
\hline Sulfate, filtered & 5 & 10 & $<2$ & $<1$ & 250 (SMCL) & 250 & 200 & 3,000 \\
\hline Fluoride, filtered & 1.2 & 1.7 & 2 & 1.6 & 2 (SMCL) 4 (MCL) & 4 & -- & -- \\
\hline Silica, filtered & 10 & -- & -- & 12.2 & -- & -- & -- & -- \\
\hline Total dissolved solids, filtered & 423 & 476 & 640 & 561 & 500 (SMCL) & 500 & 2,000 & 5,000 \\
\hline Hardness $\left(\mathrm{mg} / \mathrm{L}\right.$ as $\left.\mathrm{CaCO}_{3}\right)$ & 8.2 & -- & -- & 3 & -- & -- & -- & -- \\
\hline Sodium adsorption ratio (SAR) & 26 & 29 & 46 & 42 & 8 & -- & 8 & -- \\
\hline \multicolumn{9}{|c|}{ Trace elements, in micrograms per liter } \\
\hline Aluminum, unfiltered & $<100$ & -- & -- & $<100$ & 50-200 (SMCL) & -- & 5,000 & 5,000 \\
\hline Antimony, unfiltered & $<1$ & -- & $<1$ & $<1$ & $6(\mathrm{MCL})$ & -- & -- & -- \\
\hline Arsenic, unfiltered & $<5$ & 25 & $<5$ & $<1$ & 10 (MCL) & 50 & 100 & 200 \\
\hline Barium, unfiltered & $<100$ & -- & $<100$ & $<100$ & 2,000 (MCL) & 2,000 & -- & -- \\
\hline Beryllium, unfiltered & $<0.5$ & -- & $<0.5$ & $<1$ & 4 (MCL) & -- & 100 & -- \\
\hline Boron, unfiltered & 300 & -- & -- & 300 & 6,000 (HAL) & 750 & 750 & 5,000 \\
\hline Cadmium, unfiltered & $<0.5$ & -- & $<0.5$ & $<1$ & 5 (MCL) & 5 & 10 & 50 \\
\hline Chromium, unfiltered & $<50$ & -- & $<50$ & $<50$ & 100 (MCL) & 100 & 100 & 50 \\
\hline
\end{tabular}


Table 3.1. Summary of groundwater-quality samples collected from the Fox Hills aquifer as part of other studies, 2005-14, Laramie and Goshen Counties, southeastern Wyoming.-Continued

\begin{tabular}{|c|c|c|c|c|c|c|c|c|}
\hline \multirow{3}{*}{ Characteristic or constituent } & \multicolumn{4}{|c|}{ Fox Hills aquifer } & \multirow{3}{*}{$\begin{array}{c}\text { EPA drinking- } \\
\text { water standards or } \\
\text { health advisories }^{5}\end{array}$} & \multirow{3}{*}{$\begin{array}{l}\text { Wyoming Class I } \\
\text { domestic-water } \\
\text { standards }^{6}\end{array}$} & \multirow{3}{*}{$\begin{array}{l}\text { Wyoming Class II } \\
\text { agricultural } \\
\text { (irrigation)- } \\
\text { water standards }^{6}\end{array}$} & \multirow{3}{*}{$\begin{array}{c}\text { Wyoming Class II } \\
\text { livestock-water } \\
\text { standards }^{6}\end{array}$} \\
\hline & Laramie County & & Goshen County & & & & & \\
\hline & ${ }^{1} \mathrm{FH}-4$ & ${ }^{2} \mathrm{FH}-\mathbf{5}$ & ${ }^{3} \mathrm{FH}-6$ & ${ }^{4} \mathrm{FH}-7$ & & & & \\
\hline \multicolumn{9}{|c|}{ Trace elements, in micrograms per liter-Continued } \\
\hline Copper, unfiltered & $<10$ & -- & $<10$ & $<10$ & $\begin{array}{c}1,000(\mathrm{SMCL}) \\
1,300(\mathrm{AL})\end{array}$ & 1,000 & 200 & 500 \\
\hline Iron, filtered & -- & -- & 440 & -- & 300 (SMCL) & 300 & 5,000 & -- \\
\hline Iron, unfiltered & 120 & -- & 1,600 & 70 & $300(\mathrm{SMCL})$ & 300 & 5,000 & -- \\
\hline Lead, unfiltered & $<1$ & -- & 2 & $<1$ & $15(\mathrm{AL})$ & 15 & 5,000 & 100 \\
\hline Manganese, unfiltered & $<10$ & -- & 50 & $<10$ & $50(\mathrm{SMCL})$ & 50 & 200 & -- \\
\hline Mercury, unfiltered & $<0.5$ & -- & $<0.2$ & $<0.2$ & 2 (MCL) & 2 & -- & 0.05 \\
\hline Nickel, unfiltered & $<20$ & -- & $<20$ & $<50$ & 100 (HAL) & -- & 200 & -- \\
\hline Selenium, unfiltered & $<5$ & -- & $<5$ & $<1$ & 50 (MCL) & 50 & 20 & 50 \\
\hline Silver, unfiltered & $<10$ & -- & -- & $<10$ & 100 (HAL/SMCL) & 100 & -- & -- \\
\hline Thallium, filtered & $<0.4$ & -- & -- & -- & 2 (MCL) & -- & -- & -- \\
\hline Thallium, unfiltered & -- & -- & $<0.4$ & $<0.4$ & 2 (MCL) & -- & -- & -- \\
\hline Uranium, filtered & $<0.3$ & $<0.3$ & 0.4 & 1.1 & 30 (MCL) & -- & -- & -- \\
\hline Zinc, unfiltered & $<10$ & -- & -- & $<10$ & $\begin{array}{c}2,000 \text { (HAL) } \\
5,000 \text { (SMCL) }\end{array}$ & 5,000 & 2,000 & 25,000 \\
\hline \multicolumn{9}{|c|}{ Nutrients, in milligrams per liter as nitrogen } \\
\hline Nitrite, filtered & $<0.1$ & -- & -- & $<0.1$ & $1(\mathrm{MCL})$ & 1 & -- & 10 \\
\hline Nitrate + nitrite, filtered & $<0.1$ & -- & $<0.1$ & $<0.1$ & 10 (MCL) & -- & -- & 100 \\
\hline \multicolumn{9}{|c|}{ Radiochemical constituents, in picocuries per liter } \\
\hline Gross alpha-particle activity & $1.6 \pm{ }^{8} 1.0$ & $11 \pm{ }^{8} 2.4$ & $1.8 \pm{ }^{8} 3.5$ & ${ }^{9}-6 \pm{ }^{8} 2.4$ & 15 (MCL) & ${ }^{10} 15$ & ${ }^{10} 15$ & ${ }^{10} 15$ \\
\hline Gross beta-particle activity & $<2.0$ & -- & -- & $0.4 \pm{ }^{8} 1.9$ & 4 mRem/yr (MCL) & -- & -- & -- \\
\hline Radium-226, filtered & $<0.2$ & -- & $0.29 \pm{ }^{8} 0.11$ & $0.02 \pm{ }^{8} 0.1$ & ${ }^{11} 5$ (MCL) & ${ }^{11} 5$ & ${ }^{11} 5$ & ${ }^{11} 5$ \\
\hline Radium-228, filtered & $<1.0$ & -- & $0.007 \pm{ }^{8} 0.74$ & $0.5 \pm{ }^{8} 0.7$ & ${ }^{11} 5$ (MCL) & ${ }^{11} 5$ & ${ }^{11} 5$ & ${ }^{11} 5$ \\
\hline
\end{tabular}

${ }^{1}$ Test/production well near Pine Bluffs, Wyo. Upper screen interval is open to the Fox Hills aquifer. At time of groundwater-quality sample collection, well also included a lower screened interval (thin sandstone beds in Pierre Shale) that did not produce much water (Dahlgren Consulting, Inc., and others, 2005; JR Engineering and Lidstone and Associates, Inc., 2009). This lower screened interval subsequently was cemented in when well was converted into a production well.

${ }^{2}$ Domestic water-supply well (Wyoming Groundwater, LLC, and others, 2011)

${ }^{3}$ Identified as "Yoder Test Hole \#1" (Wyoming Groundwater, LLC, and others, 2011).

${ }^{4}$ Identified as "Yoder Test Well \#1" (Wyoming Groundwater, LLC, and others, 2011).

${ }^{5}$ U.S. Environmental Protection Agency (2018).

${ }^{6}$ Wyoming Department of Environmental Quality (2005, table 1).
${ }^{7}$ Field measurements are the preferred values. Laboratory measurements were used if field values were not available (blue text).

${ }^{8}$ Precision estimate.

${ }^{9}$ Negative value indicates radiation count of the sample was less than the long-term average background radiation routinely reported by the instrument.

${ }^{10} \mathrm{Gross}$ alpha-particle activity, including radium-226 but excluding activity from radon and uranium.

${ }^{11}$ Sum of radium-226 and radium-228. 


\section{References Cited}

Dahlgren Consulting, Inc., Stockdale Consulting, Inc., SRK Consulting, Inc., Benchmark Engineers, P.C., and Greystone Environmental, 2005, Pine Bluffs Lance/Fox Hills well level II study, final report: report prepared for the Wyoming Water Development Commission [variously paged], accessed June 28, 2019, at http://library.wrds.uwyo.edu/ wwdcrept/Pine_Bluffs/Pine_Bluffs-Lance_Fox_Hills_WellLevel_II-Final_Report-2005.pdf.

JR Engineering and Lidstone and Associates, Inc., 2009, Master plan, level I study for the town of Pine Bluffs, Wyoming: report prepared for the Wyoming Water Development Commission [variously paged].
U.S. Environmental Protection Agency, 2018, 2018 Edition of the drinking water standards and health advisories: Washington, D.C., U.S. Environmental Protection Agency, Office of Water, EPA 822-F-18-001, March 2018, 12 p., accessed November 20, 2018, at https://www.epa.gov/sites/production/files/2018-03/documents/dwtable2018.pdf.

Wyoming Department of Environmental Quality, 2005, Water quality rules and regulations, chapter 8 , quality standards for Wyoming groundwaters: Cheyenne, Wyoming Department of Environmental Quality, $13 \mathrm{p}$.

Wyoming Groundwater, LLC, Camp Creek Engineering, and Marlatt, G., 2011, Yoder groundwater level II study, final report: report prepared for Wyoming Water Development Commission [variously paged], accessed June 29, 2019, at http://library.wrds.uwyo.edu/wwdcrept/Yoder/YoderGroundwater_Level_II_Study-Final_Report-2011.html. 
For more information about this publication, contact:

Director, USGS Wyoming-Montana Water Science Center 3162 Bozeman Avenue

Helena, MT 59601

406-457-5900

For additional information, visit:

https://www.usgs.gov/centers/wy-mt-water/

Publishing support provided by the

Pembroke and Rolla Publishing Service Centers 



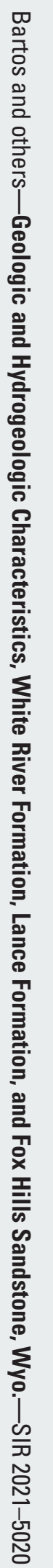

